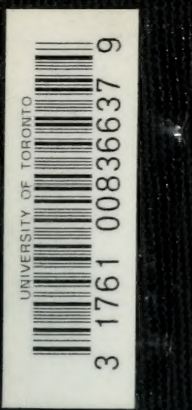

Univ. of

Tonome

LIBRARY 




68.03 



\title{
REAL SOCIEDAD ESPAÑOLA DE HISTORIA NATURAL
}

\author{
TOMO EXTRAORDINARIO
}

PUBLICADO CON MOTIVO DEL 50. ANIVERSARIO DE SU FUNDACIÓN

1921

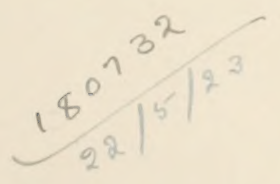

MADRID

MUSEO NACIONAL DE CIENCIAS NATURALES Hípódromo. - Teléfono S-443. 


$$
\begin{aligned}
& \text { QH } \\
& 7 \\
& \text { S64 }
\end{aligned}
$$


ACTA Y DISCURSOS 



\section{F}

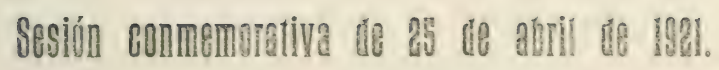

(Celebrada en la Real Academia de Medicina.)

\section{Presidencia de S. M. el Rey Don Alfonso Xlll.}

Constitución de la mesa. - Tiegnen asiento en la mesa presidencial, a la derecha de S. M. el Rey, el Excmo. Sr. D. Manuel Allendesalazar, presidente del Consejo de Ministros y socio protector de la Sociedad; D. Ignacio Bolivar y Urrutia, director del Museo Nacional de Ciencias Naturales y presidente honorario de la Sociedad, y D. Luis Octavio de Toledo, decano de la Facultad de Ciencias de Madrid, en representación de la Universidad Central; y a la izquierda de S. M., el Excmo. Sr. D. Angel Fernández Caro, vicepresidente de la Real Academia de Medicina; D. Mantel Aulló y Costilla, presidente de la Sociedad, y D. Ricardo Garcia Mercet, vicepresidente de la misma.

Asisten representaciones de la Real Academia de Ciencias, Real Academia de Medicina, Facultad de Ciencias de Madrid, Museo Nacional de Ciencias Naturales, Jardin Botánico y el director del Instituto Geológico de España; los ex presidentes de la Sociedad D. José Rodriguez Mourelo, D. Juan M. Diaz del Villar, D. José Madrid Moreno, D. Antonio Martinez y Fernández Castillo y don Romualdo Gonzailez Fragoso; D. Luis Pardo, secretario de la Sección de Valencia, en representación de la misma, y el socio correspondiente extranjero profesor Lewis Knudson, de la Universidad Cornell, de Ithaca (Estados Unidos).

Recibense adhesiones de las Secciones de provincias y de numerosos socios ausentes. 
Concedida por S. M. el Rey la venia a los señores que han de hacer uso de la palabra, el señor Secretario lee la siguiente Memoria histórica de los cincuenta años de vida de la Sociedad:

\section{SEÑOR :}

\section{SEÑORAS y SEÑORES :}

A pocas cosas de este mundo puede aplicarse la parábola del grano de mostaza convertido en frondosísima planta, mejor que a la Sociedad que en estos momentos celebra el quincuagésimo aniversario de su fundación, acontecimiento científico cuya conmemoración ha sido forzoso aplazar a consecuencia del doloroso suceso que todos lamentaremos largo tiempo.

La Real Sociedad Española de Historia Natural, que hoy cuenta con más de medio millar de socios, que lleva una vida próspera, que mantiene relaciones con todas las entidades similares del extranjero, y cuyas publicaciones son estimadas en todo el mundo científico, nació hace ahora medio siglo en una simple tertulia de amigos, en lo que hoy llamariamos una peña de amantes de las Ciencias naturales.

Un ilustre catedrático de la Universidad Central, autor de un texto de Zoología no superado en su época, e iniciador en dicha ciencia de varias generaciones de médicos, de farmacéuticos y de naturalistas, el maestro D. Laureano Pérez Arcas, acostumbraba reunir por entonces en su casa, un día a la semana, a algunos compañeros de afición para conversar con ellos, principalmente de Historia Natural, mostrarse unos a otros las nuevas adquisiciones de sus respectivas colecciones de insectos y proyectar excursiones, que realizaban, generalmente, a la vecina Sierra de Guadarrama. Pero tened en cuenta que aquellas excursiones se hacian en época en que no sólo no se pensaba en clubs alpinos, ni mucho menos en funiculares y hoteles elegantes, sino que ni aun había línea férrea a Segovia, de modo que la mayor parte del trayecto y la más penosa habian de hacerla a pie o en malas diligencias, sin pensar que 
habrian de ser los precursores del actual movimiento en pro del amor a las montañas.

De aquel grupo de amigos sólo dos quedan : el eminente conquiliólogo y sabio médico D. Joaquín González Hidalgo, y el entomólogo ilustre, maestro de muchos de los que me escuchan y alma de la Sociedad durante buena parte de su existencia, Dr. D. Ignacio Bolivar y Urrutia. Los que ya pasaron eran, además del dueño de la casa, el célebre botánico Colmeiro; el antropólogo Dr. Velasco, que legó a la Ciencia y a la nación el Museo de su nombre; el docto naturalista y americanista incomparable Jiménez de la Espada; el notabilísimo médico Martínez Molina; el zoólogo bondadoso y pulcro Martínez y Sáez; el entusiasta malacólogo Paz y Membiela; el laborioso catedrático Pereda; el cultísimo y caballeroso geólogo Solano y Eulate; el también geólogo y paleontólogo Vilanova, de fama europea, y el P. Zapater, sacerdote de vasta cultura y de profundos conocimientos en Historia Natural.

Ocurrióles un buen día-qué bueno hubo de ser para la Ciencia patria-, ocurrióles, digo, a aquellos enamorados de la Naturaleza, que en sus conversaciones, en sus colecciones, en sus excursiones pudiera haber algo de interés más general, algo que mereciese ser publicado, y empezaron a pensar en la fundación de una Revista consagrada a las Ciencias naturales. A dar más fuerza a esta idea vino el hecho de que Jiménez de la Espada, que había tomado parte en aquella larga y accidentada expedición que se conoce como «el viaje al Pacífico», habiendo hecho en la América del Sur importantes estudios y descubrimientos, iba a verse obligado a publicarlos en el extranjero por no existir en España un periódico profesional. Convino, pues, aquel grupo de hombres de ciencia en publicar una Revista consagrada exclusivamente a esta clase de estudios, empezando para ello por fundar una Sociedad, que acordaron llamar Española de Historia Natural, y comprometiéndose a entregar cada uno de ellos mil reales para sufragar los gastos de impresión del primer volumen.

No fué necesario cumplir este compromiso. La idea de aquel 
grupo de amigos fué tan bien recibida por cuantos sentian alguna inclinación a las Ciencias naturales, que las adhesiones a la nueva Sociedad afluyeron de todas las provincias de España y aun de naciones extranjeras, y el importe de las cuotas fué suficiente para convertir el proyecto en hermosa realidad. Baste decir que habiendo empezado a funcionar la Sociedad en marzo de 1871, en diciembre del mismo año contaba ya con doscientos cuarenta socios, y hoy, a los cincuenta años, cuenta con más de setecientos. No negaréis que en un pais como el nuestro, donde las Ciencias naturales no han llegado a gozar todavia de popularidad, y donde aún se considera al naturalista como un ser estrafalario, constituye esto un verdadero éxito.

Pero no es el número de socios lo que mejor idea puede dar de la vida de una Asociación. Hay que mirar cuál ha sido su labor dentro de su esfera de actividad. Por lo que a nuestra Sociedad toca, esta labor está bien patente en sus Anales, primero, y luego en sus Memorias y su Boletin, publicaciones que actualmente constituyen ya setenta volúmenes. Repasadlos y alli veréis trabajos biológicos tan interesantes como el de Jiménez de la Espada sobre la reproducción del Rhinoderma darwini, ese diminuto sapo americano que cría a sus hijos en la boca o, hablando con más exactitud, en los sacos aéreos bucales; estudios de Sistemática zoológica tan valiosos como la "Enumeración de los peces de Cuba», por Poey, o la «Revisión de los ortópteros de España y Portugal», por Bolivar; investigaciones botánicas de tanta importancia como el estudio micrográfico de las maderas de las coníferas, por Castellarnau, y las observaciones de Masferrer sobre la flora canaria; notas y memorias geológicas, en fin, tan dignas de mención como las de Mac-Pherson acerca de la estructura de la Península Ibérica, las de Calderón sobre la evolución terrestre de los lagos de Nicaragua, y la de este mismo, Fernández Navarro y Cazurro sobre los volcanes extinguidos de Olot, o las de Botella sobre la Ciudad Encantada.

En nuestros Anales, allá por los años de 1892 a 96, aparecieron muchos de esos admirables trabajos de investigación histológica 
que han dado fama imperecedera al maestro Cajal. En nuestras publicaciones también, Vilanova, Jiménez de la Espada y González de Linares, tres figuras gigantescas de la Ciencia española, defendieron paladinamente la autenticidad de las famosas pinturas de Altamira contra la opinión de otros sabios de nuestro pais y de todos los extranjeros, que entonces la negaban y ridiculizaban. Los resultados científicos de los viajes de Ossorio y de Quiroga al África, en nuestras publicaciones aparecieron, y no debemos dejar de consignar que si en la Comisión demarcadora de límites que fué a la Guinea española iba un naturalista, Martinez Escalera, se debió a gestiones de esta Sociedad, que consagró un volumen completo de sus Memorias al estudio histórico-natural de aquella región.

Si toda esta labor es poco conocida débese a que la Sociedad de Historia Natural ha seguido trabajando siempre como se fundó: modestamente, sin ruido, buscando siempre con seriedad el progreso de la Ciencia patria, huyendo de la exhibición. Tal vez sea ésa, después de todo, nuestra gran falta; mas no olvidemos cuánto ha influido en todas las religiones la labor ignorada de los ermitaños.

Si queréis tener una idea más exacta de sus efectos en el adelanto científico de nuestro país, considerad por un momento que aquella docena de amigos que hace media centuria se aventuraba, no sin temor, a publicar una Revista científica, se ha convertido en una falange tal de cultivadores de la Ciencia, que ahora, al publicarse el tomo extraordinario conmemorativo cie esta fecha, figuran en él trabajos de cincuenta autores, a pesar de no haber colaborado en él sino una minoría de nuestros naturalistas.

Puede decirse que esta Sociedad sólo se ha revelado al mundo desde hace unos veinte años próximamente, desde que S. M. el Rey; que Dios guarde, a propuesta del entonces ministro de Instrucción pública y hoy presidente del Consejo de Ministros, D. Hanuel Allendesalazar, tuvo a bien honrarla con el titulo de Real Sociedaci, no siendo ésta la única prueba de distinción que tan ilustre hombre público ha dado a esta entidad, a la que pertenece desde su primera época, y cuya Comisión de Estudio del Noroeste de Africa preside: 
y se ha revelado con una labor que, a la vez que sus entusiasmos cientificos, demuestra su acendrado patriotismo, ese patriotismo que las Asociaciones culturales no deben olvidar jamás, por alejadas que vivan del mundo de la política. Quiero referirme a la gestión de nuestra Sociedad en Marruecos, gestión que señala una de las épocas más brillantes de su historia, la época en que el celo, el entusiasmo y la actividad de mi sabio antecesor en este puesto, D. Ricardo Garcia Mercet, comunicaron a la Sociedad nuevos alientos y nuevos brios.

Mientras en otras entidades y en ciertos partidos surgia la duda o la vacilación, la Sociedad de Historia Natural, que por algo se apellida Española, tuvo siempre plena conciencia de los derechos y los deberes de España al otro lado del Estrecho, de esos derechos y deberes que, como ha dicho hace poco un ilustre escritor, «sólo pueden desconocer los mentecatos, los ignorantes y los enemigos de la patria». La Real Sociedad Española de Historia Natural puede envanecerse de no haberse hecho acreedora a ninguno de estos dictados. Antes, mucho antes de la ocupación hispano-francesa de Marruecos, ella enviaba ya sus naturalistas a Marraquex, a Mogador, al Atlas y al Rif, y una vez establecido el Protectorado, gracias al apoyo constante que ha recibido del Ministerio de Estado y de la Alta Comisaria, ha podido hacer con mayor detenimiento el estudio de la gea, flora y fauna de nuestra zona.

A más de esto, en la primera mitad de 1913, recién ocupadas Arcila, Alcázar y Tetuán, una nutrida Comisión de la Sociedad recorría aquella región con la laboriosidad de siempre, y resultado de aquel viaje es ese libro, Yebala y el bajo Lucus, que constituye el primer trabajo de conjunto acerca de las producciones naturales de Marruecos que se ha publicado con carácter vulgarizador.

Además de esta obra, hemos consagrado a los resultados de aquella y de las demás expediciones un tomo completo de $M$ emorias, y otro en publicación, siendo hoy imposible hacer ningún estudio serio sobre Zoología, Botánica o Geología marroquies sin consultar nuestros trabajos sobre la materia; y careciendo nuestra 
Sociedad de colecciones propias, los ejemplares obtenidos en e'stns viajes han enriquecido las del Museo Nacional de Ciencias Naturales, resultando así el Estado doblemente beneficiado.

Tal ha sido, señores, descrita a grandes rasgos y huyendo de toda prolijidad, la labor de la Real Sociedad Española de Historia Natural en medio siglo de existencia; tales son, vistos en conjunto, sus frutos. El mundo podrá juzgarla como tenga por conveniente, pero nosotros tendremos siempre la tranquilidad de conciencia que da el haber trabajado con perseverancia, con fe, con desinterés y con buena voluntad.

$\mathrm{Y}$ si a alguien de los que escuchan sonasen mis palabras a vanidad de miembro de la entidad elogiada, no se piense que he de llevarlo a mal; que hay tal prosperidad en la marcha de nuestra Sociedad, tal corrección y seriedad en su vida, tal intensidad y fervor en sus trabajos, que cuantos a ella pertenecemos, en momentos como el presente tenemos derecho a decirlo con aquel orgullo con que e! súbdito de los Césares decía : "Civis romanus sum.»

A continuación el Presidente efectivo de la Sociedad leyó el siguiente discurso :

\section{SEÑOR :}

La fortuna, que tantas ocasiones encuentra para favorecer a quien menos la espera o la merece, no solamente ha permitido que el menos calificado de los naturalistas españoles prcsida la Real Sociedad Española de Historia Natural, sino que le confiere, en ocasion de la fecha que hoy se conmemora, el encargo de dirigirse a V.M. con tan honrosa investidura.

Son, pues, mis primeras palabras para rendir, en nombre de la Real Sociedad Española de Historia Natural, priblico testimonio de adhesion y de gratitud a V. M., egregio Socio 
Protector, que da con su asistencia extraordinaria y augusta solemnidad a muestra fiesta jubilar.

\section{SEÑORAS Y SEÑORES:}

La Memoria que acaba de leer nuestro distinguido secretario Sr. Cabrera, os ha permitido recordar los progresos realizados por los naturalistas españoles durante los últimos cincuenta años.

Mi intervención sería innecesaria, si no hubiera de exponer a vuestra benevolencia algunas consideraciones que a mi ánimo sugiere la labor realizada para obtener de ella un máximo rendimiento en lo porvenir.

No será difícil la generalización de cuanto diga a las variadas ramas del saber humano que integran la labor de nuestra Sociedad; mas se hace forzoso que, para concretar mi pensamiento, haya de referirme a una de aquellas en que por mi profesión de ingeniero de Montes, si bien modestamente, figuro como cultivador de sus estudios. Me refiero a la Entomología aplicada a las Ciencias agricola y forestal.

La intensa y meritísima labor realizada por la Real Sociedad Española de Historia Natural en el vasto dominio de la Sistemática, tiene carácter fundamental y da las bases que son indispensables a los trabajos de Entomología aplicada. Es innegable que en muchos casos la presencia sobre plantas valiosas de insectos que hasta entonces no causaron sensible daño o vivieron sobre otras sin valor, obliga a la Entomología aplicada a buscar el apoyo de la Sistemática; al entomólogo, profesionalmente ligado a los estudios de característica económica, le es forzoso recurrir a la benevolencia de nuestros colegas en la Sociedad para obtener la documentación necesaria.

Pero, además de los grupos hasta aqui más principalmente estudiados, hay otros uitiles en particular para el progreso de la Entomologia aplicada. La lucha biológica contra los insectos perjudiciales, que tan intensamente se desarrolla en Norte-América, ha 
demostrado los beneficios incalculables que se pueden obtener cंe la aclimatación c'e auxiliares exóticos; en otros paises, y por fortuna también en el nuestro, se ha despertado la atención hacia algu!nos grupos de interés esencial: los himenópteros parásitos y los dipteros taquinarios. Mas se precisa la intensificación de esos estt:dios, donde culminan trabajos de los nuestros. Y es uirgente la más amplia exploración sistemática, porque ésta ha de impulsar los estudios biológicos, que al fin y al cabo darán los fundamentos de la técnica en la más adecuada aplicación de los remedios.

Esos estudios biológicos, tanto en relación con los insectos elitomófagos como con los fitófagos, no pueden limitarse para aquéllos al estudio del parásito y de su huésped, ni para los segunces a describir las distintas fases de su ciclo, limitándose a seguir su evolución en las cajas de cria. No puede aislarse a las especies de su medio ambiente; es preciso, muy al contrario, considerarlas en relación con ese medio, estudiándolas en sus condiciones naturales, en sus relaciones climatológicas y con los métodos de cultivo. Porque sus costumbres, sus emigraciones, y aun sus invernadas, difieren notablemente según aquellas condiciones, de variabilidad tan conocida en nuestra patria; la obra útil no puede venir de observaciones aisladas, sino de múltiples estudios que respondan a las distintas condiciones de la naturaleza, instalando Laboratorios en los campos y en los bosques, o al menos en sus proximidades. Con ello estaremos en condiciones de averiguar el punto vulnerable del enemigo, y prestaremos meritorio concurso en los casos de introducción de nuestras especies dañosas en otros países, que recíprocamente habremos de esperar en el caso de importación a nuestro suelo, porque esa mutua ayuda, consecuencia del carácter internacional que ha adquirido el problema de las plagas, es indudablemente esencial condición para el progreso de los pueblos.

El estudio metódico de los parásitos de nuestra riqueza agricola y forestal se impone urgentemente en nuestra España como labor de conjunto. No puede negarse que existe una valiosa contribución a este respecto; ella es el comienzo de la labor que nos correspon- 
de. Mas hay que abordarla, no con trabajos dispersos, sino con seria orientación, sin exclusivismos profesionales o colectivos, huyendo de las improvisaciones y buscando en la Ciencia, que es única en sus medios y en sus fines, las armas necesarias para interesar a los más aptos en ese ideal que une a los hombres en el santo servicio de la patria.

Los admirables descubrimientos que en la Medicina - en cuyo templo hoy, como años ha, nos cobijamos - permiten luchar victoriosamente contra las causas de destrucción de la Humanidad, resultados son de un método científico seguido por trabajadores infatigables que encadenaron sus investigaciones ante la indiferencia o la ignorancia de las gentes; y ha lugar a pensar que lo que la Ciencia consiguió en la Patología humana bien puede conseguirlo en la Patología vegetal, que en el vasto dominio que le incumbe, mucho ha de esperarse del concurso de las fuerzas naturales convenientemente dirigidas.

Triste es confesarlo; mas es cierto que, de la producción de nuestro suelo, lo que la muchedumbre de parásitos nos deja es 10 que realmente recogemos. Y sin embargo, estos asuntos sólo preocupan cuando, por condiciones meteorológicas favorables, un cambio de medio ambiente o una adaptación nueva, toman un carácter de invasión intensa que les permite demostrar sus desastrosos efectos, ocasionando pérdidas que se valúan en muchos millones de pesetas.

Bien es verdad que esa indiferencia que, en general, se tiene lacia los enemigos de nuestra riqueza vegetal obedece, sobre todo, a la insuficiencia de los medios de que se dispone cuando las invasiones adquieren la extraordinaria importancia de muchos casos, sobrado conocidos. Es indudable que además de los tratamientos basados en el empleo de productos químicos o de tóxicos vegetales, de circunstanciada utilización, hay otro medio de lucha que, no por ser poco conocido, es menos racional y susceptible de grandes mejoras: el empleo de auxiliares de orden natural, fundamentado por el insigne Pasteur, a quien no fué indispensable la investidura 
profesional para fundir su vocación con el sacerdocio de la Medicina.

A su ilustre sucesor Roux se debe en Francia la reorganización del Servicio de enfermedades de las plantas, al cual, por analogía con el de Epidemias y el de Epizootias, designó con el nombre de Servicio de Epifitias, logrando asi completar la triple institución que por medios análogos está destinada a combatir el azote parasitario bajo las tres formas en que constantemente acecha nuestro bienestar.

¿Por qué no hemos de aspirar a que nuestra patria posea una organización semejante? ¿Por qué no hemos de aprovechar la enseñanza de los más previsores, aunando los esfuerzos que se dirijan en el mismo sentido, sin caer en una innecesaria división del mismo trabajo? A esta labor puede colaborar provechosamente la Real Sociedad Española de Historia Natural, intimamente relacionada, con acertada orientación, con el Museo Nacional de Ciencias Naturales; $y$ al exponer el tema no he hecho otra cosa que interpretar el sentir de todos, ofreciendo la contribución de unos estudios desarrollados calladamente durante muchos años a la gran obra de reconstitución económica que demanda el país.

Si algún día llegara a realidad este deseo, ella constituiría preciada muestra del acierto de aquellos beneméritos españoles que en 1871, poniendo inteligencia y vocación de privilegio al servicio de las ideas que aquí nos congregan, cimentaron en España la magna empresa de fomentar los estudios de las Ciencias naturales. Desaparecidos la mayor parte por ley inexorable del tiempo, quedan por fortuna entre nosotros, alentándonos con su ejemplo, los maestros Bolívar, nuestro presidente honorario, y Gonzále\% Hidalgo, a quienes ofrecer, en ocasión de este cincuentenario, el testimonio de nuestra admiración.

El Excmo. Sr. D. Joaquín María Castellarnau, miembro honorario de la Sociedad, lee una Memoria sobre el tema «Algo acerca de la historia de las dos leyes biológicas fundamentales Omme viurm 
ex ovo y Omnis cellula ex cellula». (Véase la parte de Memorias de este volumen, pág. 3.)

En nombre de S. M. el Rey (q. D. g.), el Excmo. Sr. Presidente del Consejo de Ministros cerró la sesión con las siguientes palabras:

Con la venia de V. M.

SEÑORAS Y SEÑORES :

Me manda el Rey que resuma los discursos leidos, cosa difícil aun habiendo yo participado y colaborado en la medida de mis fuerzas, pero con el mayor entusiasmo, en la importante obra realizada por esta Sociedad durante los últimos cincuenta años; obra que con tanta elocuencia ha sido descrita por el Sr. Cabrera, el cual ha expuesto cuanto yo pudiera decir en el asunto.

El Secretario, en su discurso, ha acertado a presentar ante nuestra vista dos épocas de la vida de la Real Sociedad Española de Historia Natural, dos distintos periodos de su historia. Primeramente nos ha descrito los tiempos dificiles, cuando no se disponia de medios, cuando hasta las excursiones científicas se hacian con mil dificultades, cuando no existía el Club Alpino, y en nuestras excursiones a la Sierra de Gredos no teníamos más albergue que una tienda y, como podrá comprobar el Dr. Bolivar, aqui presente, hasta tuvimos que sufrir el ataque de los lobos. Después nos ha hablado del otro período, cuando, bajo la protección de S. M. el Rey, que Dios guarde - y agradezco el recuerdo que se ha dedicado a mi modesta intervención en aquel asunto-, la Sociedad pudo ampliar su esfera de acción, pudo publicar con más facilidad los valiosos trabajos que llenan tantos volúmenes y que la han hecho célebre en todas partes - digo mal: más conocida fuera de España que dentro de ella- , y cuando ha iniciado, en fin, esa patriótica labor en África, organizando expediciones y realizando estudios que nada tienen que envidiar a los que se hacen en el extranjero, incluso a los del marqués de Ségonzac. 
El trabajo doctrinal leído por el ilustre presidente de la Sociedad de Historia Natural ha sido tan concreto, tan técnico y tan acabado como era de esperar en quien, como él, ha sabido darse a conocer en todas partes como especialista en la parasitología de los vegetales, en la fitoparasitología, tanto forestal como agrícola. Nada podría yo añadir a sus afirmaciones, aunque recojo, en nombre del Rey y del Gobierno, las conclusiones que formula, por considerarlas dignas de la mayor atención, por lo que contribuirian, de llevarse a la práctica, a la prosperidad de nuestra producción agrícola y forestal.

Por último, el admirable estudio que a S. M. como a todo el auditorio ha complacido e interesado, leído por el Sr. Castellarnau, es de tan elevado valor científico, que en su género no recuerdo otro con el cual pueda yo compararle. En ese trabajo se muestra la sabiduría de su autor y sus dotes de expositor de las más abstrusas cuestiones técnicas, que ha sabido presentarnos uniendo lo ameno a lo instructivo.

En nombre del Rey, mi Señor, os felicito a todos y felicito a esta Sociedad por su obra meritoria. Como la ha venido realizando durante cincuenta años, debe seguir realizándola, y para ello cuenta con el apoyo y la protección de este Gobierno y de los Gobiernos que a éste sucedan, y por encima de todo, con el cariño del Rey, que así me encarga que os lo haga saber.

En nombre del Rey, pues, os estimulo a todos para que perseveréis en vuestra labor cientifica, con lo que, al hacer perdurables las glorias de esta Sociedad, contribuiréis a la prosperidad futura de la patria, a la cual todos amamos, pero a la que el Rey, nuestro Rey, por ser el primer español, ama más que nadie. ciones.

S. M. el Rey levantó la sesión en medio de entusiastas aclama- 



\section{MEMORIAS}





\section{ALGO ACERCA DE LA HISTORIA DE LAS DOS LEYES BIOLÓGICAS FUNDAMENTALES OMNE VIVUM EX OVO Y OMNIS CELLULA EX CELLULA}

POR

JOAQUIN MARIA CASTELLARNAU

Nos parece siempre lo más natural del mundo que todas aquellas conquistas de la Ciencia que de un modo muy directo influyen en nuestros conocimientos generales, hayan venido a nosotros de repente, sin esfuerzo alguno y sin lucha, ni haber pasado por una larga historia de vicisitudes: las creemos como si fueran algo nuestro, cuya posesión pertentece al género humano desde los tiempos más remotos. Y no.es asi. Hoy día, por ejemplo, está en nosotros tan arraigada la idea de que todo ser viro procede de otro ser vivo semejante a él, que a toda persona, por poco ilustrada que sea, le repugnaría la idea de que un ganso pudiera salir de la semilla de un árbol, o que las abejas nacieran de la carne corrompida de un toro. $\mathrm{Y}$, no obstante, esa repugnancia no la sintieron hombres de otras épocas que pasaban por tener, si no mucha ciencia, por lo menos mucha erudición, pues llevaba ya muchos siglos de vida la Europa civilizada y aun no había tomado pie firme la creencia de que todo ser vivo procedia de un progenitor semejante a él, siendo preciso esperar a que mediara el siglo xvir para que un naturalista pudiera proclamarlo en alta voz. Y eso lo hizo HARvey en su célebre tratado De Generatione animalium, impreso en Londres el año 1631, diciendo: Omne ens vivum ex ovo. Mas ese aforismo, que hoy dia constituye tal vez la ley biológica más fundamental que existe, no podia tener en aquella época otro valor que el de una intuición atrevida, expresada en son de protesta contra las groseras ideas entonces dominantes, pues, en realidad, el hechu positivo y ahoulutamenir. cierto que representa el Omne vivum e.t ovo es una conquista de la Ciencia de nuestros dias : el óvulo de los mamíferos lo descubrió 
Ernesto BAER el año 182T, y el de las plantas fanerógamas, HoFMEISTER, en 1874. ¿No sería materia de interés recordar a grandes rasgos las vicisitudes por que ha pasado la idea de la generación de los seres, hasta quedar asentado en firme el Omnia ex ovo, y ver al mismo tiempo cómo se ha puesto en relación con esa otra ley de la Teoria celular, que exige que toda célula proceda a su vez de otra célula? Por si lo fuere, voy a tratar de hacerlo en las siguientes lineas.

Durante toda la Antigiiedad fué cosa corriente el admitir la producción más absurdamente heterogénica de los animales, siempre que sus fases evolutivas no se presentaran de golpe a la vista y sin ningún esfuerzo de observación. Así, las ranas, por ejemplo, se hacian nacer de la humedad y del bochorno, cuando no se engendraban en las nubes y caían en lluvia; los gusanos, de la carne corrompida, etc.; y siguiendo por ese camino, sabios tan célebres como Platón y ARIstóteles no se limitaron a la heterogenia en los casos verdaderamente obscuros, sino que la extendieron sin reparo hasta la creencia grosera de que las ratas podian ser engendradas por la podredumbre de los vegetales, y las abejas nacer de la descomposición de las entrañas de un toro. Por cierto que el gran poeta Virgilio es culpable de haber difundido esta última creencia entre los amantes de la literatura, pues pocos serán los que no hayan leído, en el libro IV de las Geórgicas, las tristes lamentaciones del pastor Aristeo por haber perdido sus colmenas, tan ricas en miel, que cultivaba en los valles del Peneo, y el remedio que su madre, la diosa Cirene, le dió para formarlas de nuevo. «Sacrifica - le dijoen honor de los dioses cuatro toros de hermosa planta, y deja sus cuerpos abandonados en la espesura del bosque.» Sumiso obedece el mandato Aristeo; y cuando al noveno dia vuelve al monte, ve con asombro que de las carnes podridas de los animales sacrificados se levanta un hervidero de abejas que anubla la luz del sol, y que se reunen luego en largos racimos pendientes de las ramas de los árboles :

Immensasque trahi nubes, jamque arbore summa confluere et lentis uvam demittere ramis.

Y si esto ocurría en la época de oro de la Antigiiedad, ¿qué no hemos de esperar que sucediera durante la obscura y crédula Edad Media? Las versiones más absurdas pasaban entonces por artículos 
de fe, no ya respecto a la generación oculta de los animales inferiores, sino también a la de aquellos que ocupan los primeros lugares de la escala zoológica. Como muestra, citaré sólo un ejemplo: Vicente de BEAUvaIs, fraile dominico y luego obispo notable, que mereció por su gran erudición el sobrenombre de «Plinio de la Edad Media», escribió a mediados del siglo xur un libro titulado Speculum naturale, en el que, entre otras cosas prodigiosas, cuenta que en Escocia y en las islas Órcades crecen unos árboles junto al mar, de cuyos frutos, al caer al agua, nacen unas aves muy parecidas a los gansos. Y esa fábula, que según indicios data del siglo $\mathrm{x}$, perduró por lo menos hasta fines del xvi (iseiscientos años!), pues Sebastián Munster la reproduce como cosa cierta en su Cosmographie universelle, impresa en París en 1575, bautizando al ganso de tan extraña manera nacido con el nombre de Anser arboreus; y unos años después, AldROVANDo, por si acaso alguien dudara de la existencia de árbol tan peregrino, estampa su figura en un grabado en madera que ocupa toda una página de su tratado de las Aves (1). Alli se ve el árbol con todo género de detalles, cargado de frutos maduros y sin abrir unos y abiertos otros, dejando escapar de su interior pequeñas aves, de las cuales muchas han caido ya al agua y nadan ágiles para no desmentir los instintos de su raza. Y por si eso fuese poco, el monje franciscano Oderic de PoRTENAU, intrépido viajero del continente asiático que murió en olor de santidad, da la siguiente diagnosis del fruto del árbol que engendra gansos: Poma violacea et rotunda, ad instar cucurbita a quibus maturis exiit avis. ¡A más creo que no se puede llegar!

Las generaciones heterogéneas, aun las más disparatadas, continuaron a la orden del día durante el reinado de aquellos doctos varones que no admitian otras fuentes de saber que las que se hallaban escritas en los pergaminos empolvados de las bibliotecas, causándonos ahora gran extrañeza la mucha credulidad de personas a quienes no es posible negar que poseyeran una gran ilustración, atendido el tiempo en que vivieron. Entre ellas debe contarse, indudablemente, el segoviano Andrés LAGuna, muy conocido, entre otras cosas, por haber traducido $\mathrm{y}^{\mathrm{a}}$ anotado la Materia medicinal que escribió en griego Dioscórides, libro que, con sus muchas ediciones, fué casi la única farmacopea que estuvo en vigor en muestro pais durante un periodo de doscientos años. En un ejemplar que yo

(1) Ornithologiae, libri XII. Bolonia, 1599-1605. 
poseo, impreso en Amberes el año 1555, dedicado al entonces príncipe heredero y poco después rey de España Felipe II, no me choca nada, por ejemplo, que al hablar de los gusanos se lea "que se engendran de alguna corrupción en las entrañas de la tierra, asi como también en las del hombre: los cuales (los gusanos) sirven para infinitas cosas al cuerpo humano, al cual se comen después, en reconocimiento de lo servido»; pues atendiendo a la obscura generación de estos seres y a la época en que fué escrito, puede pasar. Mas lo que sí me extraña es que persona tan erudita como lo fué el Dr. LAGUNA, filólogo eminente, médico del papa Julio III y ccompañante del emperador Carlos $\mathrm{V}$ en las campanas de Flandes, pueda escribir de buena fe «que a veces las ranas se engendran de súbito sobre la haz de la tierra, quiero dezir de la lluvia y del polvo, con los bochornos: lo cual haze creer a algunos que llueven ranas». Y no menor credulidad supone el siguiente párrafo sobre la generación de las orugas y el medio de librarse de sus estragos: "Las orugas que nacen en la hortaliza - dice - verdadera pestilencia de los jardines, son unos gusanillos que de las hojas verdes se engendran: los cuales, cuando son viejos, apegados al tronco de algún árbol, suelen hazer un capullo amarillo, del cual, después de roto, salen las mariposas. Es muy probado remedio, para ahuyentar esta suerte de orugas, un cangrejo de rio, si se cuelga en el huerto.»

A mediados del siglo xirn se abrió una era de luz con la aparición de una pléyade de investigadores que, rompiendo con la tradición de repetir, aceptándolo como verdad inconcusa, cuanto dijeron Platón, Aristóteles y otros sabios de la Antigüedad, se dedicaron a observar directamente los fenómenos, descubriendo así, poco a poco, los secretos que la Naturaleza había tenido ocultos durante tantos anos. Para el asunto que a nosotros nos interesa, entre esos investigadores ocupan el primer lugar los italianos Fabricio AquAPENDENTE y Marcelo MALPIGHi, por haber sido los que primeramente estudiaron el desarrollo del embrión en el huevo de las gallinas; y sobre todo el último, que debe ser considerado como el verdadero fundador de la Embriología por sus trabajos De formatione pulli y De ovo incubato, que datan de fines del siglo xvil. Además, a MALpighi le somos deudores de muchos descubrimientos relativos a la anatomía de los insectos, tales como el de las tráqueas, del sistema nervioso, de las glándulas que llevan su nombre, etc., etc., y de un estudio muy acabado sobre el gusano de seda: Dissertatio de bombyci. 
Otro naturalista de la misma época, que contribuyó también muy poderosamente al esclarecimiento de la evolución de los seres vivientes por sus investigaciones sobre las metamorfosis de los insectos, fué el holandés Swammerdam; y de él se cuenta que, por medio de hábiles disecciones, demostró ante el Gran Duque de Toscana que en la crisálida estaban contenidos, en rudimento, todos los órganos de la futura mariposa. Estudió, además, la embriología de los anfibios, y de un modo particular la evolución de los renacuajos de las ranas, lo que hizo entrever la posibilidad de que podía ocurrir algo semejante en muchos casos en que la generación se presentaba de un modo obscuro, dándose así un gran paso hacia las ideas homogénicas. Sus muchas observaciones, publicadas en la Biblia naturae, constituyen un verdadero monumento del saber de aquellos tiempos; y fué lástima grande que, al final de su brillante carrera, un exagerado misticismo se apoderara del ánimo de SivAMMERDAM, y quemara microscopios, trabajos y dibujos a tanta costa adquiridos, dominado por la idea de que era un gran pecado profanar con la vista las cosas que Dios habia querido ocultar a la mirada de los hombres.

A los nombres de MALPighi y Sivammerdam hay que añadir el de otro investigador, que sin ser naturalista en el verdadero sentido de la palabra, contribuyó, no obstante, de un modo poderoso al verdadero conocimiento de la Naturaleza. Es éste el de LEEUWENHOEK (1), a quien se debe la revelación del mundo microscópico de las aguas y de los infusorios; de los glóbulos de la sangre, vistos por primera vez en la cola de los renacuajos; de las estrías de los músculos dependientes de la voluntad; de los vasos espirales y escaleriformes de las plantas, etc., etc. Un discípulo suyo, Hamado Hamman, tuvo la suerte de descubrir, en 1677, los zoospermos en el licor seminal, dando con ello el primer paso hacia el esclarecimiento del gían problema de la fecundación.

Preparado asi el terreno, apareció William HARVEY, profesor de Anatomía y médico de cámara del rey Carlos I de Inglaterra, revestido ya del prestigio que le daba el haber descubierto la doble circulación de la sangre en el cuerpo humano (De motu cordis et

(1) LeEuWEnHoEk iba dando ctrenta de sus descubrimientos a la Sociedad Real de Londres, a medida que los realizaba. Sus comunicaciones de los años 1680 a 1695 aparecieron en un tomo en 4.0 en 1708, con el titulo de Arcana naturae detecta, seu Epist. ad soc. reg. anglic. scripte. 
sanguinis, 1628). Dotado de gran sentido perspicaz, le pareció que la Naturaleza, en asunto tan fundamental como es el de la generación de los seres, no podía proceder tan caprichosamente como en tiempos anteriores se habia admitido; y puesto que en todos los casos perfectamente conocidos entonces se verificaba homogénicamente, esto es, por medio de óvulos procedentes de individuos semejantes al que dentro del óvulo se desarrollaba, creyó que ese modo de generación debía ser general y exclusivo para todos los seres vivientes. Y esa convicción la expresó por medio del aforismo Omne ens ex ovo, que figura por primera vez en el libro que antes he mencionado.

En realidad, HARvey se adelantó mucho a los conocimientos positivos de su tiempo, pues el Ovum de su aforismo sólo podía referirse de un modo cierto al que depositaban los animales oviparos, por ser el único que entonces se conocía. El de los animales viviparos era completamente desconocido, y solamente por deducciones podía suponerse que algo semejante constituia el principio del nuevo ser que se desarrollaba dentro del cuerpo de la madre. En la especie humana, por ejemplo, el verdadero óvulo permaneció oculto hasta que Carlos Ernesto BAER lo dió a conocer ciento setenta y seis años más tarde, estudiando a la vez su desarrollo y la formación de las hojas blastodérmicas. Y ni siquiera los folículos de Graaf (Folliculi Graafiani), que pasaron equivocadamente durante muchos años por ser los verdaderos óvulos de los mamíferos, eran conocidos cuando HARveY publicó su libro De Generatione animalium. Pero como el aforismo encerraba en sí una realidad, más presentida que comprobada, los tiempos modernos han venido afianzándolo cada dia hasta convertirlo en una de las leyes biológicas más fundamentales que hoy poseemos.

En cuanto a los organismos superiores se refiere, el aforismo de HARVEY no ha encontrado seria oposición para ser completamente admitido en el campo de la Ciencia desde sus principios; mas no ha sucedido otro tanto con respecto a los diminutos seres llamados microbios, que representan una organización incipiente. Para ellos se quiso resucitar la antigua saprobiosis, dándole el nombre nuevo de generación espontcinea. A mediados del siglo xvil, NeEDHAM, director entonces de la Academia de Ciencias de Bruselas, fué uno de sus más acérrimos defensores, y de sus ideas participó el gran naturalista Buffon. El abate SpAllanzani y SchusTER las combatieron, y después de varias alternativas de favor y 
de desgracia, murió por fin definitivamente la teoria de la generación espontánea ante las concluyentes experiencias del ilustre PASTEUR.

En el Reino vegetal, el verdadero Ovum, análogo al de los animales, no fué conocido hasta mediados del siglo pasado, que HoFMEISTER demostró su existencia en el saco embrionario de las Fanerógamas, y el conde LEsczyc-SuMinsky en el fondo de los arquegonios que se desarrollan en el protallu de lus Ilekeluns. Luego st ha visto que su existencia puede considerarse general en todo el Reino, pues si bien en algunos grupos de plantas criptógamas sólo se conoce la reproducción por esporos, substituyen éstos al Ovum para los efectos del aforismo de HARIEY.

Tres caminos distintos puede seguir el desarrollo ontológico del óvulo. El primero, al que corresponden la mayoría de los animales, es el desarrollo directo, que consiste en la evolución continuada y progresiva hasta alcanzar la forma adulta, sexuada y perfecta. El segundo es el desarrollo metamórfico, caracterizado porque la evolución, en vez de ser continua, se detiene temporalmente en formas intermedias que no se reproducen de ninguna manera hasta llegar a la forma final sexuada, como sucede, por ejemplo, en las mariposas; y el tercer modo es el llamado de las generaciones alternantes o metagenésicas, en el cual, del óvulo fecundado salen formas intermedias que se reproducen asexualmente, y dan origen a la forma final sexuada que vuelve a producir óvulos. A este modo de generación pertenecen algunos animales, como los Hidrozoarios, y la mayoría de las plantas. En este caso, el circulo generativo que comprende todas las formas, desde la primera que nace del óvulo. hasta la final sexuada que vuelve a producir óvulos, constituye un «individuo genealógico» según la denominación de HuxLEY.

Hasta aqui he hablado del «óvulo» dándole tan sólo la significación vaga de algo procedente de un ser orgánico que por sí solo, o después de sufrir los efectos de la fecundación, es el punto de partida de otro ser semejante al que a ese algo ha dado origen. Has hoy sabemos que el óvulo, antes y después de fecundado, está reducido a una simple célula, y como tal obedece a la gran ley contenida en el aforismo Omnis cellula ex cellula, que encierra de un modo implícito la idea de la continuidad de la vida en el Universo. A estas dos afirmaciones de trascendental importancia, por contener en sí los fundamentos de la ontogénesis, no se ha llegado sin una larga y paciente gestación, cuya historia va intimamente 
unida a la de la Teoria celular y a la de las vicisitudes por las que ha pasado la noción de la célula hasta adquirir el concepto que hoy nos formamos de ella. Esa historia es la siguiente:

Descubierto el microscopio hacia la mitad del siglo xyII, varios fueron los «curiosos de la Naturaleza» que, sin ser verdaderamente naturalistas, trataron de conocer la estructura de los objetos de un modo más intimo de lo que era posible a simple vista; y entre ellos merece especial mención Roberto HoOKE, porque en su obra, publicada en 1667 con el título de Micrography, or some physiological descriptions of minute bodies made by magnifying glasses, se encuentra por primera vez empleada la palabra "célula» (cell), que ha perdurado hasta nuestros días a pesar de su completa impropiedad, pues lo que hoy se llama "célula» en Histología, sólo de un modo muy remoto se relaciona con lo que Hooke creia ver en el tejido del corcho y de la medula de los vegetales, cuya estructura descubrió antes que nadie, aunque interpretándola de un modo erróneo. Pocos años después, MALPIGHI y GrEw, que deben considerarse como los iniciadores de la Histologia, hicieron importantes descubrimientos en la constitución intima de las plantas. MALPIGHI, en su Anatomes plantarum Idea (Bolonia, 1671), descubrió las fibras, los vasos espirales (spirales fistulae), los «tubos formados por series de vesículas abiertas, unidas en sentido longitudinal», y el tejido medular, compuesto de un conjunto de utrículos globulorum multiplice ordine. Añadiendo a esas descripciones las que se encuentran en la obra de Nehemias Grew, The Anatomy of Plants begun with a general Account of Vegetation founded Thereupon (Londres, 1671), se tendrá una idea exacta de los primeros pasos precursores de la actual Teoria celular.

MALPIGH y GREIV no encontraron al pronto quienes continuaran su obra, pues ni en lo restante del siglo xvI ni en todo el xvin se allegaron nuevos materiales que sirvieran realmente para su progreso. Merecen, no obstante, citarse dos nombres: el del médico y fisiólogo Gaspar Federico IVoLFF, y el del botánico Juan HedwiG. La personalidad de WOLFF adquirió mucho relieve por el gran tesón con que defendió las ideas evolucionistas, en contra de las de la preformación de los germenes. En su Theoria generationis (1759) se ocupa de la formación de las células vegetales, y atribuye su origen a una substancia gelatinosa saturada de jugos nutricios que se encuentra, según él, en el vértice vegetativo del tallo y de las ramas y en las verruguillas iniciales de las hojas y de las flores. 
En esa substancia aparecen al principio pequeñisimas vejigas que aumentan poco a poco de volumen, y acaban por formar los espacios grandes de las células; y la materia que entre ellos queda corresponde a las paredes celulares. Segín este modo de ver, las células nacerian por una especie de generación espontánea; y a pesar de que en su apoyo no existian pruebas positivas, fué admitido por muchos naturalistas de la época, y aun posteriores, pues el aforismo Omnis cellula ex cellula tardó aún cien años en ser proclamado como una de las bases de la actual Teoria celular, según vamos a ver en seguida.

La Teoria celular es una hija del siglo xix. Al principio los botánicos tomaron la delantera a los zoólogos, y se concibe que así fuera porque las investigaciones se dirigian principalmente a las paredes esqueléticas de los elementos que constituyen los tejidos, y éstas aparecen más patentes y fáciles de observar en las plantas que en los animales, en donde faltan muchas veces por completo. Al contenido dentro de esas paredes, o sea a lo que hoy dia consideramos como verdadera célula, no se le dió importancia hasta después del descubrimiento de la existencia constante de un nucleo, hecho por Roberto BRow, y de los estudios de MOHL sobre el utriculo primordial y el protoplasma de las células vegetales.

En muchos casos concretos, como, por ejemplo, en la formación de los vasos del sistema leñoso de las palmeras, estudiados por MoHL, se sabia que éstos derivaban directamente de la unión de series longitudinales de utrículos, y así flié ganando terreno la idea de que en muchos casos los elementos que constituian los tejidos de los animales y de las plantas, sobre todo de éstas últimas, no eran otra cosa que células o agrupaciones de células más o menos transformadas; mas faltaba ampliar esa idea y erigirla en principio general. Una tentativa para ello hicieron los botánicos Mirbel y SPRENGEL, pero sin aportar a su causa las pruebas necesarias. Tampoco Dutrochet estuvo afortunado al querer demostrar, en 1824, que todos los tejidos de que se componen los órganos de los animales y de las plantas podian reducirse a un tejido celular diversamente modificado, pues la mayor parte de los hechos en que se apoyaba eran falsos o estaban mal observados (1). La idea, no obstante, se habia abierto camino, y la gloria de haberla elevado a ley abso-

(1) DutRocheT, Recherches sur la structure intime des animaux el des vegetaux. Paris, 1824. 
luta para las plantas corresponde al botánico alemán Matías Jacobo Schleiden, pues su estudio sobre la Fitogenesis, publicado en el año 1838 en los Archivos de MüLler (1), se considera unánimemente como la consagración de la Teoria celular. Al año siguiente, el zoólogo Teodoro ScHWANN la hizo extensiva a los animales, en su clásico libro que lleva por título Conformidad de estructura y de crecimiento entre los animales y las plantas (2), y de esta manera quedó consolidada la Teoria celular, cuyo principio fundamental es lo único que ha llegado incólume hasta nosotros, pues en todo lo demás, sobre todo en lo referente al concepto de la célula y de su generación, las ideas actuales son completamente distintas de las que profesaban Schleiden y SchivanN, fundadores de la Teoria.

Sentada ya la constitución celular de los seres orgánicos, faltaba resolver el problema primordial del origen y de la multiplicación de las células que componen su cuerpo; mas para ello era preciso un conocimiento más profundo de la célula del que entonces se tenía, y así no es de extrañar que las soluciones propuestas fueran a cual más equivocadas. Antes ya he dicho cómo WoLfF trató de explicar la formación de las células en los vértices vegetativos de las plantas. Schleidex no estuvo en ese punto mucho más afortunado, pues influido por lo que equivocadamente se figuró ver en el saco embrionario de las Fanerógamas, durante la lucha que sostuvo con HoFMEISTER sobre la fecundación, creyó que las células nuevas nacian en el interior de células madres por una especie de formación libre, cuyo proceso se reducía a lo siguiente: Dentro de las células, según SCHLEIDEN, además del nícleo cuya existencia constante habia demostrado Roberto BRow en 1831, se hallaba una substancia amorfa, gelatinosa, granugienta y semiliquida, denominada por él citoblastema, y que más tarde recibió de Hugo de $\mathrm{MoHL}$ el nombre de protoplasma, con que aún hoy dia se la conoce (3). En esta substancia tenian lugar ciertas condensaciones granulosas, muy pequeñas al principio, las cuales, creciendo con rapidez, se convertian en nuevos nícleos, especie de centros vitales formativos de las nuevas célu-

(1) Schletiden, Beitrüge zur Phytogenesis, 1838.

(2) SchWann, Ubercinstimmung in der Struktur und dem Wachstum der Tiere und Pflanzen, 1839.

(3) En un articulo publicado en 1851 en el Diccionario fisiológico de WAGNER con el titulo de Dic vegetabilische Zelle. 
las. Alrededor de cada uno de esos núcleos (llamados citoblastos por SCHLEIDEN) se agrupaba una masa de citoblastema, que era la encargada de segregar la pared celular. De esta manera nacían células nuevas dentro de las células madres, por un acto generativo del citoblastema. ScHwann, además de este modo de generación, admitía para los animales otro, que consistía en el nacimiento libre de células en la substancia intercelular, a la que designaba también con el nombre de citoblastema. Según esto, para los fundadores de la Teoría celular, la producción de nuevas células se verificaba por una especie de generación espontánea en el seno de una substancia generativa amorfa, y por lo tanto en esa substancia, puesto que tenia la virtud de engendrar las células, era en donde debieran estar reunidas todas las propiedades trascendente's y etiológicas que hoy suponemos concentradas en la célula. Si ese modo de creneración fuese e! cierto, la Teoría celular jamás hubiera alcanzado la importancia que hoy tiene, pues entre las células de una misma especie animal o vegetal no existiría la íntima y continuada dependencia morfogenésica, que es precisamente la que nos abre el camino para resolver los más arduos problemas que nos ofrece la Biología. Esa dependencia morfogenésica queda asegurada con el único proceso de multiplicación que hoy se admite, el cual consiste en la biparticipación de las células, de modo que cada célula se convierte en dos células hermanas; y de esta manera una sola célula puede ser el origen de la multitud de millares de células de que se compone el cuerpo de un animal o de una planta.

El descubrimiento de la división celular se debe, en primer término, a los estudios de Hugo de MoHL sobre el crecimiento de las Algas (1); y luego los no menos interesantes de Unger, MEYEN, NAEgeli, Strasburger y de otros botánicos y zoólogos vinieron a demostrar que la división era el modo normal de propagarse las células durante el crecimiento de los animales y de las plantas; y sólo por excepción se admitía que la aparición espontánea de nuevas células en un líquido blastemático podía verificarse en algumos procesos morbosos, tales como tumores purulentos u otros semejantes. Mas no tardó mucho Virchow en demostrar que, aum en esos casos morbosos, la formación de las células seguia la ley general, y así pudo escribir en su célebre Patologia celular, publicada en 1851,

(1) Hugo von MohL, Ueber die Uermehrung der Pflanzenzellen durch Teilung. Flora, 1837. 
Omnis cellula ex cellula; esto es, no se encuentra nunca una célula donde no exista otra anterior que le dé origen. Y no es solamente en la célula considerada como unidad morfológica en donde la Naturaleza muestra repugnancia a la formación libre, sino también en cada una de sus partes esenciales, como en el núcleo, por ejemplo. Hoy sabemos a ciencia cierta que el núcleo nunca procede de la condensación del glomérulo plasmódico de la célula, como en algunos casos Ernesto HAECKEL admitía aún al publicar la primera edición (1868) de su Historia de la Creación natural, pues ha sido una gran conquista de los citólogos modernos el descubrimiento de que al dividirse la célula se divide también el núcleo, siguiendo un complicado proceso, en virtud del cual los cromosomas que le componen sufren al mismo tiempo una bipartición, con objeto de poder repartir por igual su substancia y constitución morfológica entre los dos núcleos hermanos. Por eso el aforismo de Wirchow, Omnis cellula ex cellula, encuentra hoy su complemento en este otro, formulado por, Oscar Hertwig: Omnis nucleo ex nucleo.

Hasta aqui sólo he tratado de esbozar a grandes rasgos la historia de las dos leyes biológicas que sirven de epígrafe a este pobre trabajo mí, y ahora, para terminarle, sólo me resta hacer ver qué relación guardan entre sí, esto es, qué es lo que significa el aforismo de HARvey en la Teoria celular. La gloria de haber resuelto este problema, por lo que a los vertebrados se refiere, corresponde de lleno a Roberto REMAK, pues si bien tuvo un precursor en la persona del anatomista Carlos Boguslaus Reichert, la fortuna no fué a éste favorable, por haber seguido una senda equivocada. REMAK demostró (1) en el año 1851 que lo mismo el diminuto huevo de los mamíferos descubierto veintitantos años antes por el ilustre Ernesto BAER, que el de los animales oviparos de considerable magnitud, está reducido en su esencia a una simple célula, que es la célula-huevo, la cual, por bipartición repetida, primero en dos, luego en cuatro, en ocho, diez y seis, etc., etc., proporciona los materiales para que se formen inmediatamente las dos hojas generativas o blastodérmicas, externa e interna, y más tarde la intermedia, de las cuales sale el embrión y sus anexos. Y desde esa fecha, una multitud de naturalistas han estudiado el problema ontogénico en las más diversas clases del Reino animal, viniendo todos a parar

(1) R. REMAK, Untersuchungen ïber die Entwikelung der Wirbelticre, 1851. 
a la misma conclusión, esto es, a que el desarrollo inicial de todo individuo empieza por una sola célıla, que es la célula-huevo, la cual, a partir de los Mesozoarios, forma, por divisiones repetidas, las dos hojas blastodérmicas que se convierten en el nuevo ser, siguiendo un proceso evolutivo más o menos complicado según la posición que el animal ocupe en la serie zoológica. El óvulo, antes y después de fecundado, es una simple célula que se desprende de los tejidos del cuerpo de la madre, y que contiene en si todos los rudimentos y predisposiciones necesarias para su futuro desarrollo, el cual se pone en actividad evolutiva, dentro o fuera del seno materno, bajo las influencias favorables del medio ambiente. En los Protozoarios que, como es sabido, su cuerpo está formado por una sola célula, ésta debe considerarse como célula-huevo cuando llega la época de la reproducción.

En los vegetales sucede lo mismo que en los animales: todos empiezan su existencia por el desarrollo de una simple célula, que constituye su verdadero óvulo. Hofmeister (1) fué el primero que demostró su existencia en el saco embrionario de las Fanerógamas en 1849, durante la porfiada lucha sostenida contra SchleIdEN (el fundador de la Teoría celular) y otros botánicos partidarios de las ideas polinistas, según las cuales el embrión se formaba en la extremidad del tubo polinico, y no existía, por lo tanto, en las plantas, según ellos, un óvulo comparable al de los animales. Y luego el mismo Hofmeister, Leszyc-Sumisky, NaEgeli, De Bary y otra porción de botánicos eminentes investigaron la reproducción de las Criptógamas, encontrandu también en ellas, como ley general, que el origen de la evolución ontogénica estaba circunscrito a una célula-huevo. Una simple célula es, pues, el punto de partida de los seres orgánicos, y esa célula contiene en su interior, de un modo hasta ahora desconocido, juntamente con el poder evolutivo, avivado por influencias externas, los rudimentos de todo to que los padres son capaces de transmitir a sus hijos, ya sea en virtud de la ley de la herencia específica, o de las propiedades que ellos mismos individualmente han adquirido.

Por medio de la bipartición celular, la vida específica, conservando sus caracteres, se perpetúa de célula a célula de un modo no interrumpido durante millares de años, a través de millones de mi-

(1) Hofmeister, Die Enlslchung des Embryos des Fancrogamen. Leipzig, 184!. 
Ilones de células, sin que nunca la veamos aparecer de nuevo donde una célula no exista de antemano.

La continuidad de la vida y la transmisión de la herencia, estos dos grandes problemas de la Naturaleza, están contenidos de un modo implícito en los dos aforismos cuya historia he pretendido trazar. ¡No en vano he dicho al principio que constituian dos leyes biológicas fundamentales!

Segovia, octubre de 1920.

\section{LAS PLAGAS DE LYDA HIEROGLYPHICA CHRIST. EN ESPAÑA}

POR

MANUEL AULLO

(Límina 1.)

\section{Lyda hieroglyphica Christ.}

L. hieroglyphica (Tenthredo h.), Naturg. Ins., pág. 459.

L. campestris Fabricius, Syst. Piez., pág. 45.

L. bimaculata Taschenberg, Berlin. Ent. Zeits., vol. V, pág. 194.

Nombre vulgar. - Arañuelo [Torrelodones, Galapagar (Madrid), poco usado].

Descripeión. - Imago: Negro, con la parte media del abdomen (desde el segundo hasta el quinto segmento) amarillo-rojiza. Boca, antenas, borde inferior de los ojos, escudete, rodillas, tibias y tarsos, amarillos. En los $\sigma \sigma$, las antenas con una mancha negra en la parte superior del escapo. Antenas largas, de 34-36 artejos. Alas hialinas, amarillas de oro. Longitud: ơ, 11-12 mm.; ?., 12-16 mm. Envergadura: 22-28 mm.

Huevo: Amarillo, en forma de barquilla, por cuya parte curva queda adherido a la hoja. Longitud: $3,5 \mathrm{~mm}$.

Larva: Verde sucio, amarillenta o rojiza, con la cabeza castañoclara, provista de ojos y antenas. Sin patas abdominales y con dos 
apéndices en el último anillo del abdomen. Longitud: a su nacimiento, 3-3,5 mm.; adulta, 30-32 mm.

Ninfa: Verde, según Ratzeburg. Este estado biológico me es desconocido.

Área. - Toda Europa.

Costumbres. - La evolución tiene lugar conforme al gráfico adjunto. Aparece el insecto perfecto a fines de mayo y primera quincena de junio, viviendo unos doce días en dicho estado. Pone los huevecillos aisladamente en las agujas de la parte alta de la copa de los pinos, generalmente cerca de su extremidad. La larva aparece pronto (a los diez días aproximadamente), teje un bolsón, donde van quedando retenidos los excrementos, y desciende, abri-

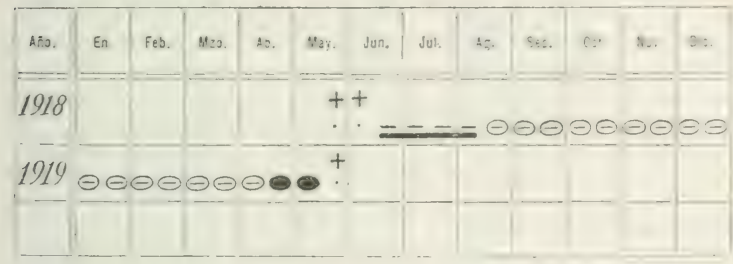

gándose en aquél, que queda adherido a lo largo del brote atacado, y que al mismo tiempo aumenta de tamaño hacia su parte inferior. Los pinos preferidos son los más jóvenes (en el monte público «Pinares Llanos», Ávila, los $P$. sylvestris de dos aĩos), aun cuando vive también en los de seis y ocho años $(P$. pinea y $P$. pinaster, de la finca "Las Regaderas", de Galapagar, Madrid, propiedad del Excmo. Sr. Conde de Gamazo), ambos casos de plantación artificial. Si bien en los pinos más jóvenes vive solamente una larva en cada uno, en los de seis y ocho años (caso de invasión intensisima) he contado hasta siete y ocho en cada brote, siendo atacados, además del terminal, los laterales. El daño comienza siempre por debajo de la yema y avanza, como he dicho, hacia la parte inferior. La larva, a mediados de julio ( Las Regaderas», altitud aproximada 800 metros) o principios de agosto ("Pinares Llanos:, altitud aproximada 1.500 metros), en relación con la salida del insecto perfecto, desciende al stielo para invernar. He tenido ocasión de descubrir alguna (mediados de abril), en hoyos de la expresada plan- 
tación de dos años, a $15 \mathrm{~cm}$. de profundidad y a $10 \mathrm{~cm}$. del pino atacado. La transformación en ninfa tiene, pues, lugar poco tiempo. antes de la aparición del insecto perfecto, en la primavera del año siguiente al descenso de la larva, sin negar pueda haber algún caso de mayor duración en el ciclo evolutivo, según supone como caso extraordinario RATZEBURG. En cautividad, en pinos de dos años, en maceta, la larva se enterró a $\mathrm{s}$ cm., y siempre separada de la. planta $(5 \mathrm{~cm}$.), no buscando, por tanto, abrigo en la raiz. Las plantas atacadas pueden, en general, restablecerse.

Los datos anteriores marcan para esta especie, en España, dos. excepciones a lo que la bibliografía extranjera señala como regla general. Son aquéllas las relativas al número de larvas por brote (en la Europa Central se considera extraordinario el número de dos) y a la edad de los pinos atacados (dos a cuatro años: EcKstein considera excepcional la de ocho a diez años; Schindowsky lo. admite para plantas enfermas).

Medios de extinción. - En los viveros y en superficie reducida, la recolección de larvas por arranque de los bolsones, muy visibles (junio y julio). En mayor extensión, pulverizaciones con una disolución de arseniato sódico anhidro a razón, si es de buena calidad, de 300 gramos por 100 litros de agua y 600 gramos de cal. Los efectos deben de notarse a las dos horas del tratamiento. Los insecticidas por contacto no pueden recomendarse para esta especie, que vive demasiado protegida en sus bolsones; asi resulta de los ensayos que he realizado. La destrucción de adultos, puestas, larvas invernantes y ninfas es difícil para fundamentar en ellas medios de defensa.

\section{Explicación de la lámina I.}

Daños, bolsón y diversos estados de la Ly’da hieroglyplica Christ.- - Las Regaderas= Galapagar (Madrid). Tam. nat. (Orig.) 


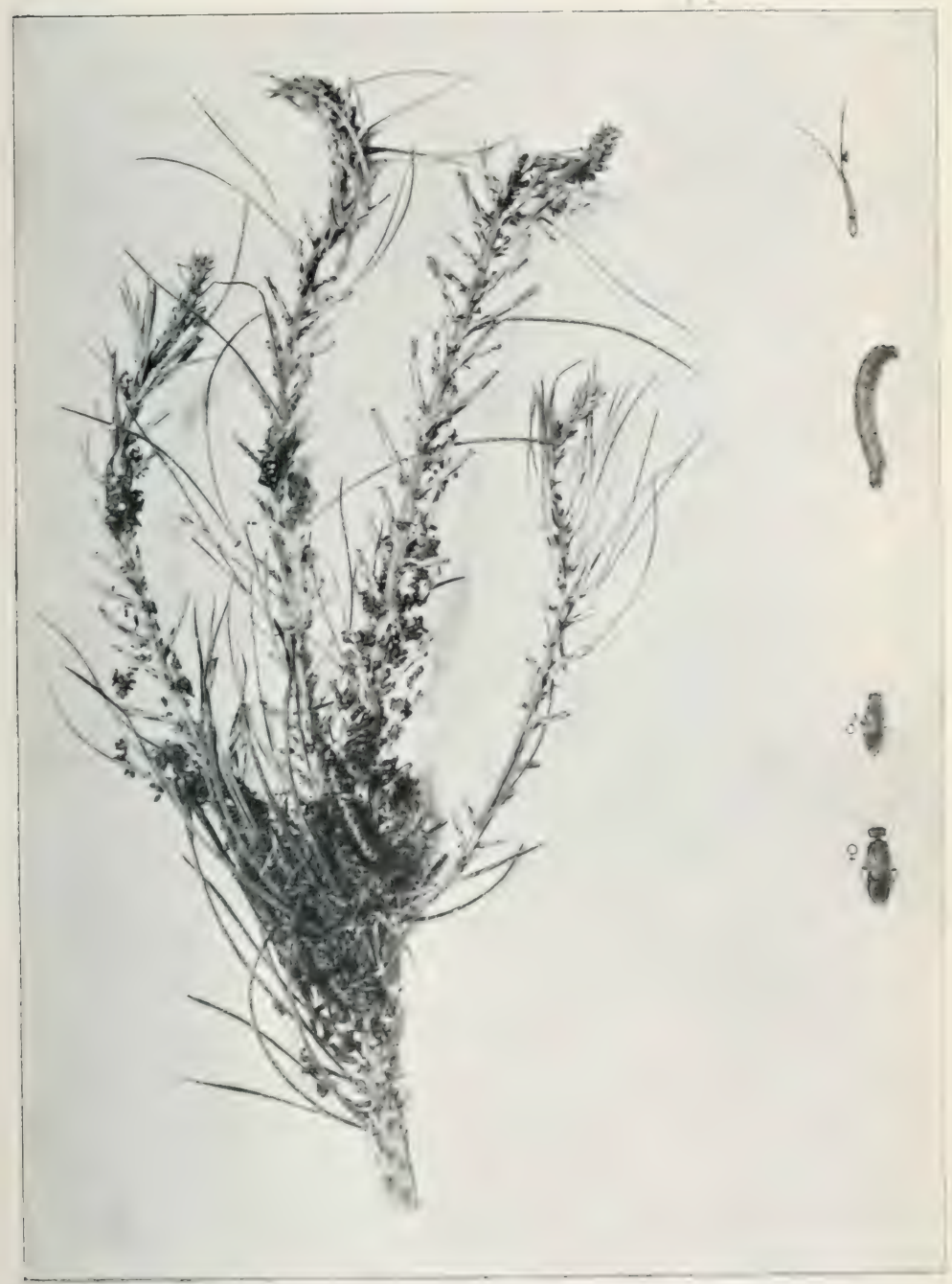





\section{LOS PECES FÓSILES DE LOS ALJEZARES DE TERUEL}

POR

\section{J. ROYO GOMMEZ}

(Láminas II y III.)

En 1916, las colecciones paleontológicas del Museo Nacional de Ciencias Naturales se vieron enriquecidas por varios ejemplares de moluscos (Helix y Glandina), peces y mamíferos (Hipparion gracile Kaup. y Gazella ?), procedentes de los aljezares de Teruel y donados por el Sr. Rodriguez López-Neira (E.), que motivaron una comunicación a esta Sociedad por parte del Sr. Hernández-Pacheco (1). Posteriormente, el Sr. Gómez Llueca recogió gran número de ejemplares, tanto de dicha localidad como de otros puntos de los alrededores de Teruel y Concud, que luego vinieron también a aumentar considerablemente aquellas colecciones al ser regalados por su colector.

Los ejemplares, muy numerosos, de peces que dichos señores han recogido y regalado al Museo son los que motivan la presente nota.

Datos geológricos del yacimiento. - El Mioceno de los alrededores de Teruel, lo mismo que el de toda su cuenca, está formado (2) por arcillas y margas rojas no fosiliferas, con intercalaciones de bancos de arena y pudingas de elementos pequeños, sobre las cuales descansan margas blancas fosiliferas y alguna vez yesíferas. En los sitios respetados por la erosión se encuentran aún, coronando a

(1) E. Hernández-Pacheco, Bol. R. Soc. Esp. de Hist. Nat., t. XVI, 1916, pág. 220.

(2) J. Vilanova, Ensayo de descripción geognóstica de la provincia de Teruel. Madrid, 1863. - D. CORTAzar, Bosquejo físico-geológico y' minero de la provincia de Teruel. (Bol. Com. Map. Geol. de España, t. XII, 1885, págs. 263-607.) - DEREIMS, Recherches géologiques dans le Sud de 'Aragon. Lille, 1898. 
la formación, unas calizas fosilíferas más o menos margosas y compactas, y algunos conglomerados de variable espesor.

En el nivel de las margas blancas es donde se encuentran los ricos yacimientos fosilíferos de Concud y de los aljezares, con moluscos y mamíferos de edad indudablemente pontiense (Hyaena eximia Roth. et Vagn., Ceratorhinus Schleiermacheri Kaup., Hipparion gracile Kaup., Gazella brevicornis Wag., etc.).

Los aljezares están situados en la carretera de Valencia y a un kilómetro próximamente de Teruel, estando constituídos sus estratos por las margas blancas superiores, apareciendo en su base un banco de yeso sacaroideo, que se explota como material de construcción, y el cual en su parte inferior (piedra buena) no es fosilifero, pero sí en la superior (losilla), de donde poseemos muy buenos ejemplares de Glandina aquensis Math., Helix sp. nov., Hipparion gracile Kaup., Gazella? y los peces objeto de nuestro estudio. El Sr. Cortázar. (1) cita, de esta localidad, una mandíbula de $\mathrm{Pa}$ laeomery $x$ y restos sin especificar de Batracios, de los cuales el Sr. Calderón (2) reconoció el género Rana. Tanto por su correspondencia estratigráfica con el yacimiento de Concud como por su fauna, se ve claramente que dichas capas de los aljezares pertenecen al Pontiense, y por lo tanto, también la especie nueva de Leuciscus que más adelante se describe.

Estudio le los peces fósiles. - Su hallazgo tiene una gran importancia para la Geología ibérica, por ser éstos los únicos peces que se conocen del Pontiense y hasta del Mioceno continental de toda la Peninsula. Se encuentran en el yacimiento con relativa abundancia, poseyendo nosotros gran cantidad de ejemplares que, en general, están en muy buen estado de conservación, excepto las escamas, pudiéndose examinar perfectamente todas las partes duras a causa de desprenderse con facilidad la ganga o aljez.

En todos los ejemplares que poseen aún la cabeza hemos podido observar los dientes faringeos, los cuales rara vez se han encontrado en las especies fósiles del género Leuciscus y en general de los Ciprínidos, labiéndose atendido siempre para su clasificación a la forma general, posición de las aletas, al esqueleto y a las escamas, que pocas veces se conservan, por lo que frecuentemente se han

(1) Loc. cit., paig. 188.

(2) S. Cildoerón, Adición al catálogo de los vertebrados fósiles de España. (Act. Soc. Esp. de Hist. Nat., t, VI, 1877, paig. 30.) 
incluído en este género especies de otros distintos, principalmente de Clupeidos, y quizás se deba a esto mismo el haberse citado como Leuciscus varias especies de Lorca (Murcia) que se encuentran mezcladas con otras esencialmente marinas (1).

El Sr. CORTÁzAr (2) ha sido el primero en citar los peces de los aljezares, clasificándolos como Clupea. El Sr. CAlderó:i (3), por unos datos encontrados en la colección de la Comisión del Mapa geológico, los cita como pertenecientes a la Clupea Gervaisi Bot., opinión admitida también por el Sr. MaLlada (4). Fácilmente se comprende que esta determinación es errónea, no solamente por tratarse de fósiles de una formación claramente continental, sino, además, por los caracteres de los mismos peces, y sobre todo por la existencia en ellos de dientes faríngeos, propios de los Ciprínidos.

\section{Leuciscus Pachecoi sp. nov.}

$$
\text { D. 3/7-8. A. 3/7-8. V. I0-11. P. 15-16. }
$$

Cuerpo de forma elegante, sobre todo cuando joven, con el perfil del dorso suavemente arqueado; $12 \mathrm{~cm}$. de longitud en los mayores ejemplares, y su altura está comprendida 4,3 veces en la longitud total sin la caudal. Cabeza contenida tres veces y media en dicha longitud, siendo casi dos veces más larga que alta.

Dientes faríngeos dispuestos en una sola fila y en número de 5-5. Casi todos tienen el extremo ganchudo o por lo menos con tendencia a encorvarse. Los anteriores son cortos, cónicos o ganchudos, y con uno o dos dientecitos en el borde (fig. 1, a). Los dos siguientes de cada lado son los más grandes y robustos (fig. 1, b y c), siendo cónicos o comprimidos, muy gruesos en la base, y con el extremo más o menos ganchudo y algo dentado en uno de los bordes (fig. 1, c); pueden estar más o menos desgastados, llegando a

(1) L. MalladA, Explicación del Mapa geológico de España, t. VI, 1998, pág. 545. Lista de peces fósiles de Lorca (Murcia) facilitada por D. Francisco Cánovas. Son los únicos Ciprinidos citados de nuestro Minceno.

(2) Loc. cit., pág. 188.

(3) Loc. cit., pág. 31.

(4) L. MAL.L.ADA, Catcilogo general de las especies fósiles encontradas en España. (Bol. Com. Map. Gcol. de España, t. XVIII, 1892, piig. 228.) 
desaparecer toda la parte terminal del diente. Los posteriores son los más delgados y frágiles, pero son los más ganchudos y con el borde más finamente denticulado (fig. $1, d$ ).

Columna vertebral robusta, generalmente bien conservada, cons-

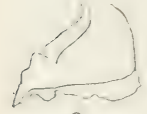

a
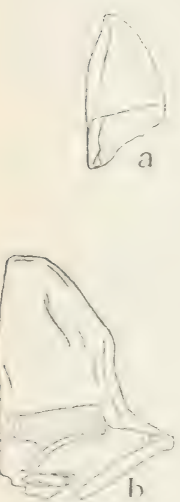
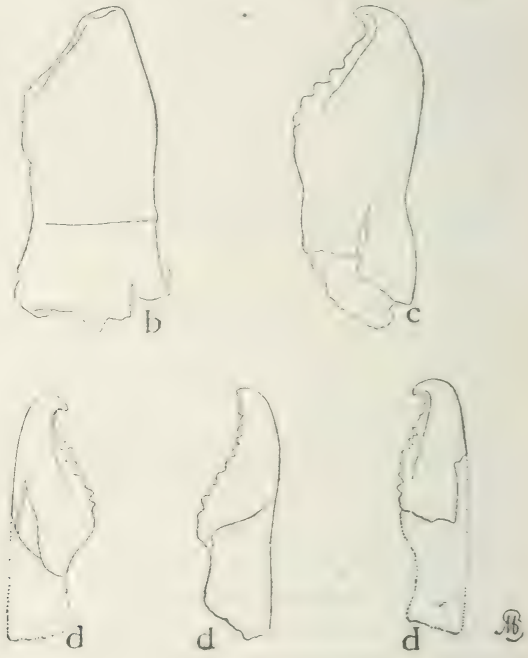

Fig. I. - Dientes faringeos del Lenciscus Pachecoi sp. nov. Muy aumentados.

tituída por vértebras casi tan largas como anchas, muy excavadas y con apófisis largas y algo gruesas, contando 16 caudales y 20-21 abdominales. Costillas fuertes y largas, en número de 17-18.

Aleta dorsal inserta entre la anal y las ventrales, viéndose en los mejor conservados que está formada por tres primeros radios sencillos y 7-8 bifurcados. Anal algo más corta que aquélla, pero con el mismo número de radios o con uno menos. Caudal más ancha que larga, comprendida cinco veces y media en la longitud total del individuo; lóbulos cortos y algo redondeados, radios en número de 5-10-10-7. Las aletas ventrales o abdominales, como suelen estar plegadas, es muy difícil contarles el número de radios, habiendo 
R. Soc. Esp. de Hist. Nat. - T. del 50. aniv.

LÁM. II.
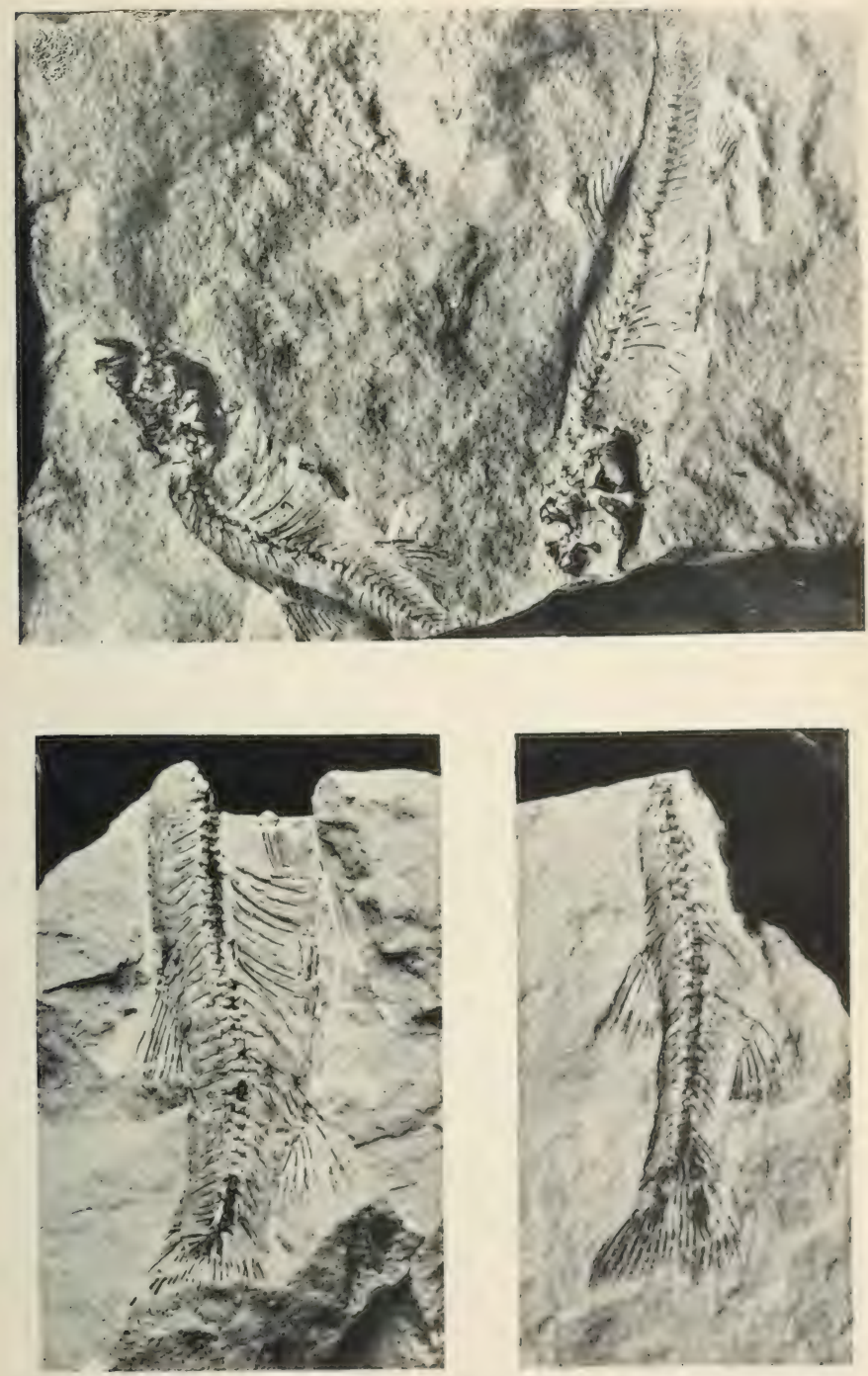

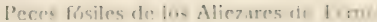





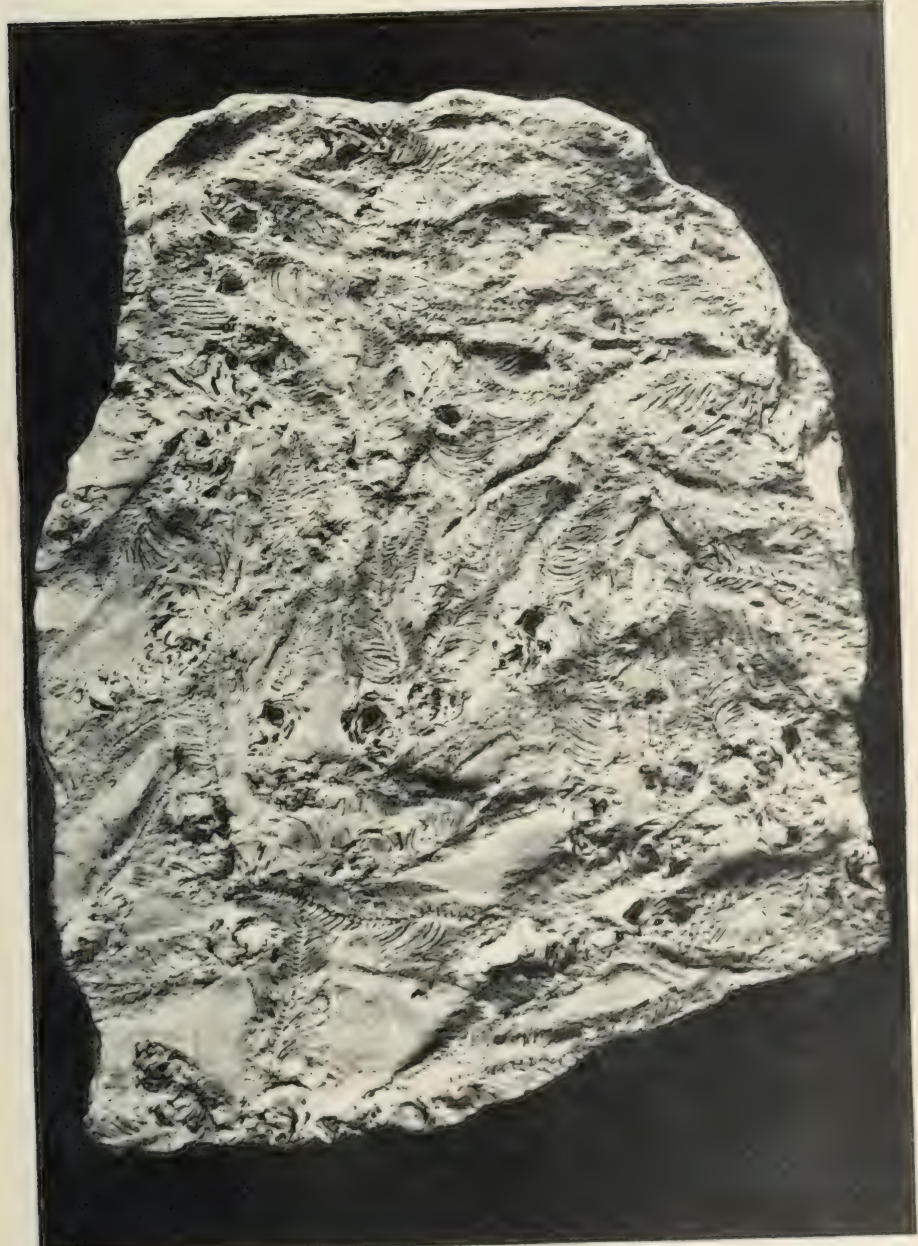



hallado como máximo 10-11. Las pectorales son relativamente cortas y con $15-16$ radios.

Por su forma, número de vértebras y de radios de las aletas, así como por el de dientes, se parece mucho al L. (Leucos) Arcasii Steind. (1), especie actual y propia de los ríos de España, sobre todo de los de vertiente al Atlántico; pero además de las proporciones, que son distintas, en los dientes es en donde reside la mayor diferencia, pues los de nuestra especie son denticulados, muy robustos y algo heterogéneos, como hemos visto ya por la descripción, mientras que los del L. Arcasii son más delgados, sin denticulaciones y bastante homogéneos. Gracias a la amabilidad de D. Luis Lozano Rey he podido confirmar estos datos con textos y ejemplares a la vista. En cuanto a las especies fósiles y a las restantes vivientes que conocemos, se distingue de todas ellas por los dientes faríngeos, y el número de vértebras, el de radios de las aletas, etc., que son diferentes.

Dedico esta especie a mi querido maestro el profesor D. Eduardo Hernández-Pacheco.

\section{Explicación de las láminas II y III.}

Lám. II. - Leuciscus Pachecoi spp. nov. Varios ejemplares. Tam. nat.

Lám. III. - Placa con gran cantidad de individuos de esta especie. Reducida próximamente a la mitad.

(1) F. STEINDACHNER, Ichthyologischer Bericht über eine nach Spanien und Portugal unternommene Reise. Sitzungsb. K. Akad. Wissenschaften, t. LIV, 1886. 
SOBRE LA ESTRUCTURA Y FUXCIONAMIENTO DE LOS ESTIGMAS

EN EL ORTÓPTERO BLATTA ORIENTALIS L.

POR EL

DR. D. MANUEL BORDÁS, Sch. P.

Presentamos este pequeño trabajo en obsequio a nuestro querido profesor Dr. D. Ignacio Bolívar, a quien creemos no disgustará el tema escogido, por ser, de tantos años a esta parte, dignísimo catedrático de Artrópodos, que con sus sabias enseñanzas ha producido en nuestra patria tantos aficionados a esta rama de las Ciencias Naturales.

A él mismo le habíamos oído decir en diferentes ocasiones que el estudio de los estigmas de los insectos era un campo todavía muy poco cultivado por los investigadores. Y, efectivamente, en lo que hemos hojeado sobre este tema nos hemos podido convencer de que el campo permanece yermo en gran parte e inexplorado, a pesar de tratarse de un aparato que tanta influencia tiene en una función tan importante como es la respiración de los insectos. Sea este trabajo como una pequeña piedra que ponemos en el edificio; piedra que bien pudiera ser la primera de una serie y el punto de partida de ulteriores investigaciones.

$$
4 \%
$$

Técnica empleada. - Para el estudio del conjunto del estigma nos ha dado excelentes resultados la disociación mecánica del dérmatoesqueleto, ayudada a veces por una previa maceración en la potasa disuelta en alcohol y en caliente. Todos los tejidos y elementos diferentes de la quitina se desprenden fácilmente con sólo agitar el líquido con alguna violencia, quedando la quitina perfectamente aislada y limpia. Con las agujas, y vigilando la operación con el microscopio de disección, se separan de los segmentos del dérmatoesqueleto las porciones blandas de las pleuras, en las que 
se encuentran implantados los estigmas. Se lavan con alcohol, y pueden desde luego observarse, montados en glicerina. Entre las diferentes posiciones en que quedan colocados sobre el porta los estigmas, se encuentran abundantemente las favorables a una buenat observación.

No hace falta arrancar las pleuras de los segmentos; pueden dejarse adheridas a ellos. Si se prefiere asi, hasta extender bieni sobre el porta, en una gota de glicerina, los segmentos para desenchufarlos. Asi está hecha la preparación de donde se ha copiado la figura 1. Tiene este procedimiento el inconveniente de que a veces los segmentos recubren el estigma y no permiten verlo con claridad y detalle.

También hemos empleado la maceración prolongada en alcohol de $60^{\circ}$ y disociación mecánica como antes, a fin de no destruir enteramente los tejidos no quitinosos. Las porciones disociadas se han coloreado con el picro-carmín de Weigert. La parte quitinosa y endurecida del estigma se tiñe de amarillo, mientras que los músculos abductor y adductor se colorean en rojo. El montaje se hace también en glicerina (1).

Para la obtención de cortes es preciso reblandecer previamente la quitina, pues, de lo contrario, se desmenuza bajo la acción de la navaja del microtomo. El reblandecimiento se consigue macerando durante unos días en la siguiente mezcla :

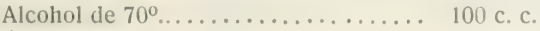

$$
\begin{aligned}
& \text { Ácido nítrico................... } 6 \text { - }
\end{aligned}
$$

Abundante lavado en agua.

También da buenos resultados la siguiente mezcla pícrica:

Solución acuosa de ácido pícrico saturada en frio. 100 c. c.

Ácido nitrico comercial . .................. 5 --

Maceración durante ocho dias. Abundante lavado en agua.

El ácido nitrico comercial suele contener el 25 por 100 de ácido puro.

Inclusión en parafina por medio del cloroformo.

(1) Para el cierre de las preparaciones montadas en glicerina, da muy buenos resultados el empleo de la pintura al esmalte del comercio. 
Los cortes se han hecho seriados con el microtomo Jung a espesor de $15 \mu, 30 \mu$ y $45 \mu$, según los casos.

Las coloraciones empleadas han sido: la safranina sola, el verde metilo combinado con la fucsina ácida, el picro-carmín de Weigert y el picro-indigo-carmín de Cajal. Con este último se colorean en azul-indigo las capas de quitina no endurecida, y las paredes del estigma permanecen amarillas.

Montaje en bálsamo del Canadá.

Todos los dibujos están hechos con la cámara clara directamente de preparaciones.

Número y situación de los estigmas.- Los estigmas en la Blatta orientulis son en mumero de ocho pares, de los cuales el primero es torácico y los siete restantes abdominales.

Se encuentran situados en la porción blanda de las pleuras que unen los terguitos y esternitos de los segmentos. Algunos autores, como L. BoutAn, presentan figuras del insecto; en las que representan los estigmas colocados en el segmento dorsal, fuera de la

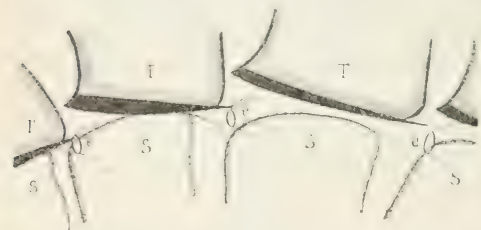

Fig. r. - Posición de los estigmas en la pleura: $T$, terguito; $S$, esternito; $\varepsilon$, mamelón de la pleura, en el que se abre el estigma. pleura. Lo mismo puede observarse en otros muchos attores que han copiado más o menos estas figuras. La figura 1 representa la situación de los estigmas abdominales, tomada directamente de una preparación. Las placas designadas con la letra $T$ representan los terguitos; las designadas con la letra $S$, los esternitos. Claramente se ve que los orificios estigmáticos $e$ no están colocados en una ni en otra placa, sino en la porción de tegumento blando que junta los dos segmentos, y precisamente en el punto en que se reunen cuatro de ellos. Pues aun cuando las piezas están algo separadas por la tracción verificada para distenderlas, se comprende fácilmente que volviendo a enchufarlas en su posición normal, el estigma viene a quedar próximamente en el punto de reunión de cuatro piezas. El primer par de estigmas está entre el mesotórax y metatórax; los 
pares abdominales se encuentran entre cada dos segmentos consecutivos, empezando por el espacio entre el metatórax y el primer segmento.

Además de estos estigmas, hemos notado que en el protórax y mesotórax existen unas formaciones especiales, ocultas también por los escudetes que forman los segmentos dorsales del tegumento, que, a nuestro modo de ver, pueden considerarse como estigmas atrofiados o no abiertos, correspondientes a estos dos primeros segmentos del tórax. Su estructura se diferencia de la del estigma torácico casi únicamente en la carencia de abertura externa. De manera que parecen estigmas torácicos cerrados.

El orificio estigmático queda mirando hacia la parte posterior del animal y un poco hacia el exterior. Está completamente recubierto o aprisionado entre los terguitos y esternitos, que pueden aproximarse más o menos por la acción de los músculos dorso-ventrales. La dirección del plano del orificio estigmático marca unos $45^{\circ}$ con el plano transverso del animal, de tal manera que para obtener secciones transversales del estigma nos ha sido preciso hacer los cortes con esa inclinación, con respecto al eje del insecto. Esta especial orientación del estigma se explica porque la membrana pleural no se extiende lisa y uniforme, sino que, como luego veremos, forma repliegues, sobre todo en el punto de convergencia de varios segmentos, que es precisamente en donde se encuentran los estigmas. Además, el mismo estigma forma un ligero mamelón, que aparece muy claro en las preparaciones por disociación (fig. 1). El resultado de todo esto es, como hemos dicho, la orientación especial del estigma.

El orificio estigmático es eliptico, y su eje mayor es horizontal. Aunque en la figura 1 parece lo contrario, eso es efecto de proyección, pues los estigmas en esta figura están vistos de lado y horizontalmente, $y$, por consiguiente, su eje horizontal se ofrece más corto en proyección que el vertical.

El par de estigmas torácicos está situado entre el meso y metatórax, también en la membrana pleural, y completamente oculto y defendido por el mesonoto, que se extiende por encima a modo de escudo.

Ilembruna pleural. - La membrana pleural, que lleva los orificios estigmáticos, se presenta en una particular disposición, que nos obliga a considerarla no sólo como medio de reunión de las porciones dorsal y ventral de cada segmento, sino como formando 
parte, si no del estigma, al menos del que podemos llamar aparato estigmático, o bien, considerarla como órgano accesorio, pero muy importante, del estigma. Para su examen en cortes seriados, procederemos de atrás hacia adelante del animal, es decir, desde un ani1 lo del insecto al precedente hacia la cabeza. Un corte practicado inmediatamente a continuación del estigma (fig. 2) nos muestra la

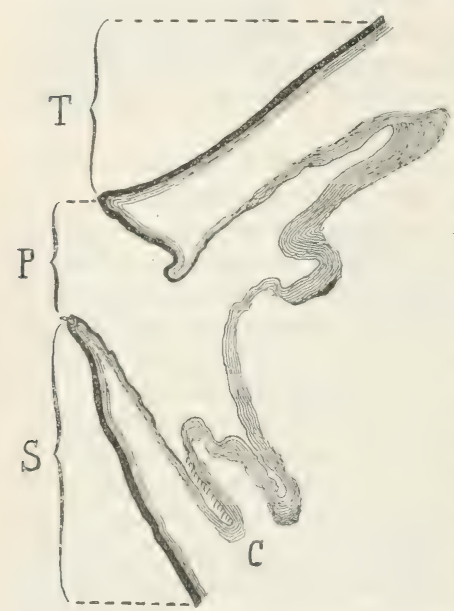

Fig. 2. - Forma de la membrana pleural inmediatamente a continuación de un mamelón ('stiurmático: $T$, terguito; $S$, esternito; $P$. pleu$\mathrm{ra} ; C^{\prime}$, principio del canal estigmático. $\times 50$. constitución especial de la membrana pleural en este sitio. La porción $T$ representa el segmento dorsal o terguito; la porción $S$, el segmento ventral o esternito. Los dos se encuentran unidos por la porción $P$, que es la pleura. Ésta se une en ángulo agudo con el terguito y esternito correspondiente, y se repliega debajo de cada segmento, disminuyendo gradualmente el espesor de su porción endurecida, hasta yue se continúa simplemente con la membrana o capa yuitinosa $n o$ endurecida. Esta última aparece formando capas estratificadas, y constituye un forro al extenderse por debajo de la capa endurecida de los segmentos del exosqueleto. En esta porción de la pleura, que es la más extensa, el número de capas estratificadas es considerable; lo cual proporciona mucha solidez a la membrana, sin perjudicarla en la necesaria flexibilidad, para permitir el movimiento de aproximación y distanciación de las porciones dorsal y ventral del insecto en los movimientos respiratorios. Debajo de toda esta capa estratificada, que se tiñe de índigo por el picro-índigo-carmin de Cajal, se encuentra la membrana de células quitinógenas, de cuya representación hemos prescindido en las figuras.

Pero lo que nos importa para el caso es que la porción de capa estratificada inmediata a la región o segmento ventral se encuentra 
sembrada de numerosas espinas (C), encorvadas, que dan a esta porción de la membrana, examinada de frente, el aspecto que presenta al microscopio la superficie de las alas de una mosca, es decir, el aspecto de una finísima carda. La región amplia y flexible de la pleura se reduce rápidamente a medida que avanza en dirección al estigma siguiente; de manera que al llegar a la distancia media que hay entre estigma y estigma, dicha amplia región queda reducida a

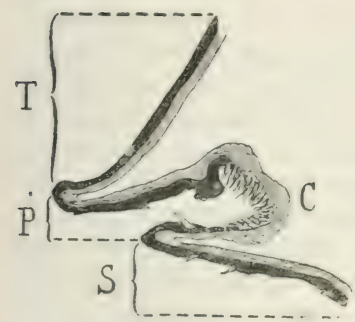

Fig. 3. - Las letras, el mismo significado que en la figura $2 . \times 50$.

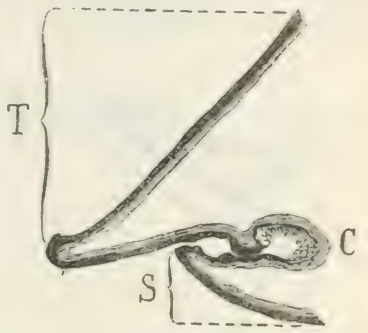

Fig. 4.-Estrechamiento del canal estigmático. Las•letras, el mismo significado que en la figura $2 . \times 50$.

un semicanal (fig. $3, C$ ), completamente erizado de púas y espinas de tamaño diverso, que se entrelazan en direcciones variadas las de un lado con las de enfrente. Este canal estigmático se estrecha a medida que se aproxima a la región del estigma, y llega a ser sumamente pequeño su diámetro, de modo que las espinas que erizan sus paredes constituyen un espeso fieltro (fig. 4). Es evidente que la anchura de la luz de ese canal estigmático pue-

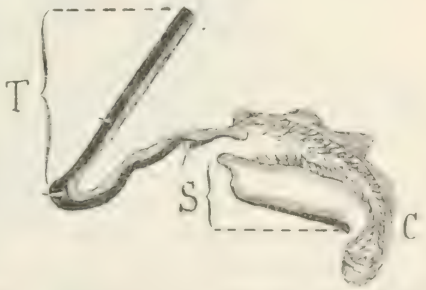

Fig. 5. - Alargamiento del canal, convirtiéndose en campo estigmálico. Lals letras, el mismo significado que en la figura $2 . \times 50$. de graduarla voluntariamente el animal por la contracción o relajamiento de los musculos dorso-ventrales, que aproximan o apartan uno de otro los segmentos del cuerpo y las porciones endurecidas de la pleura. Al llegar a las proximidades del estigma, este canal se encorva rápidamente 
hacia el dorso (fig. $5, C$ ), casi en ángulo recto, y se abre en un ancho campo estignático, también erizado de espinas, que bordea la inserción del estigma. De este modo, el estigma se encuentra rodeado, por este lado, de una región erizada de pelos y puias hasta cerca del mismo borde de la abertura. Recuérdese que hemos dicho que esta abertura exterior del estigma se encuentra orientada hacia atrás, y se comprenderá que mira precisamente hacia este campo estigmático. Consideramos este canal y campo como formando parte integrante del aparato estigmático, pues, aparte de estar inti-

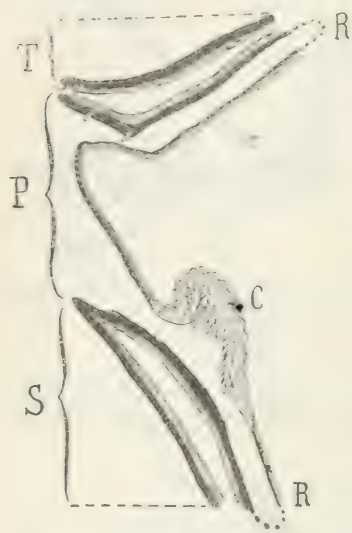

Fig. 6.-Mamelón estigmático: $R R$, repliegues dorsal y ventral de la pleura. Las demás letras, el mismo significado que en la figura $2 . \times 50$. mamente ligado, por sus relaciones estructurales, con el estigma mismo, según veremos más adelante, hemos de hacer notar aquí que tanto el canal como el campo estigmático dejan ver ordinariamente numerosas partículas de polvo y hasta gérmenes aprisionados en el fieltro de sus púas y aguijones; lo cual prueba que el aire atmosférico sufre aqui una primera filtración antes de penetrar en el estigma.

En la región estigmática, las pleuras vuelven a formar un profundo entrante o repliegue (figura $6, R R$ ) por debajo de los segmentos dorsal y ventral, al mismo tiempo que dejan un mamelón saliente situado entre los mismos segmentos. La membrana pleural se presenta ligeramente endurecida, excepto en una porción inmediata al segmento ventral, que permanece blanda, estratificada y recubierta de púas y espinas.

En este mamelón está situado el estigma propiamente dicho (fig. 7). Su posición, como la del mamelón mismo, es ablicua con respecto al eje vertical y antero-posterior del animal. Con respecto a este uiltimo, ya hemos dicho que forma con él un ángulo de unos $45^{\circ}$ en dirección al exterior. Con respecto al eje vertical, la desviación es menor. De esta manera queda la abertura exterior del estigma dirigida hacia afuera, atrás y algo hacia arriba.

Los estigmas torácicos están también situados en un campo 
estigmático erizado de púas, plano, sin formar mamelón, y resguardados por el escudo que forma el mesotórax.

Estructura del estigma abdominal.Como la estructura del único par de estigmas torácicos puede fácilmente deducirse de la de los abdominales, haremos la descripción de éstos, con lo que quedarán descritos

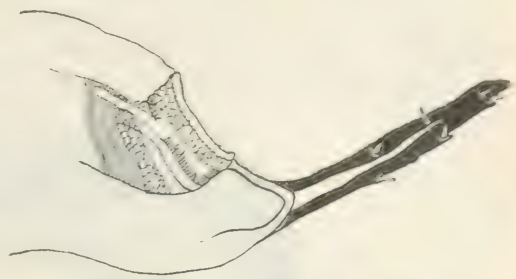

Fig. 7--Posición del estigma en el mamelón pieural.

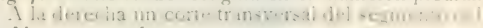
dérmatoesqueleto. $\times 7$. también aquéllos.

El estigma abdominal en la Blatta orientalis está constituido por un tubo estructurado, en el que distinguimos tres regiones: el vestibulo, el cierre estigmático y la cámara estigmática. El cierre estigmático separa el vestíbulo de la cámara.

Vestíbulo estigmático. - Lo constituye un tubo de sección elíptica (fig. 8, Ve.), que comunica con el exterior por la abertura

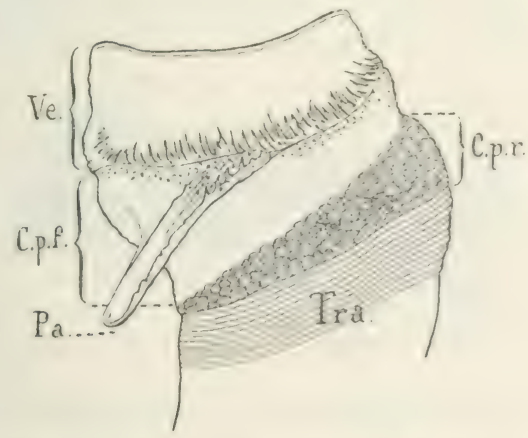

Fïr. 8. - Vista hateral y exterine del conjunto de un wisma: lés, vestibule: C.p.f., porción flexible de la cimara; C. p. r., porción rigida le la misma; Y'a., palanca; Tra., tráquea. (Por comodidad, el estigma ha sido orientado verticalmente, debiendo estar en realidad en posición casi horizontal.) $\because 150$.

externa del estigma, y posteriormente queda aislado de la cimara por el cierre estigmático. Sus paredes son quitinosas, y se pre- 
sentan esculturadas. El diámetro mayor mide, por término medio, $0,2 \mathrm{~mm}$; el menor, $6,16 \mathrm{~mm}$. Ese diámetro es aproximadamente el mismo en todos los estigmas abdominales; el par colocado entre los segmentos cuarto y quinto abdominales es algo mayor que los restantes; en cambio el último par es algo más pequeño.

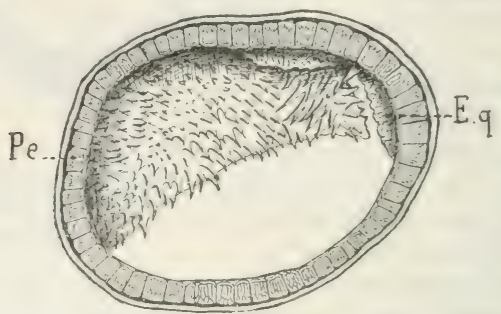

Fig. 9. - Estigma visto de frente: Pe., peritrema; $E$. q., eminencia quitinosa de la pared restibular. $\times 200$.

El borde del vestibulo forma un reborde al exterior e interior, diversamente esculturado, que constituye el peritrema del estigma. Mirado de frente (fig. 9, Pe.), aparece el peritrema dividido en una multitud de células, aproximadamente rectangulares y surcadas por

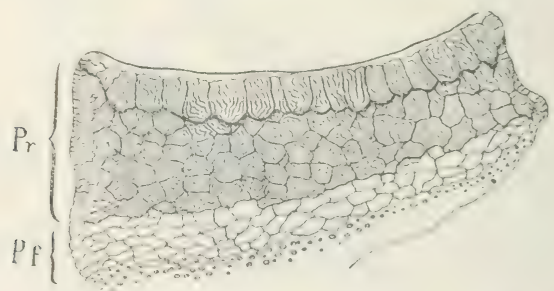

Fig. I0. - Vista lateral y exterior del vestibulo: $I$ r. $r$, porción rigida; $P$. f., porción flexible. $\times 200$.

lineas que forman salientes y entrantes, correspondientes a mayores o menores espesores de quitina. Cada célula corresponde, sin duda, a una célula primitiva quitinógena. Una vista lateral nos presenta el peritrema formado también por una serie de células (fig. 10), algo mayores que las precedentes, $y$ también esculturadas de di- 
versas maneras. Examinando con más detalle y con distinto plano de enfocamiento el borde inferior del peritrema, se ve que está formado (fig. 11) por una orla de finísimos dientes, que corre entre dos rayas paralelas y onduladas. Esta formación es importante, porque ella sirve de inserción a la membrana pleural, en que se abre el estigma. Por la parte interior presenta también el peritrema una finísima orla de dientes.

Por lo dicho se deduce que este peritrema corresponde al tipo primero de KRANCHER y HeNneguy.

La pared del vestibulo se divide en dos

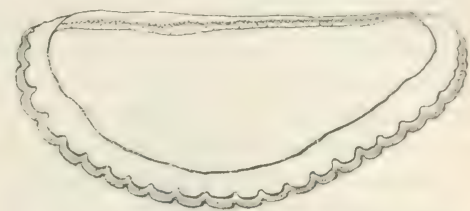

Fig. II. - Orla exterior del peritrema. $\times 200$. porciones: la primera, quitinosa y rigida; la segunda, flexible. La primera (fig. 10, P.r.) está formada por un conjunto de células quitinizadas, poliédricas $\mathrm{y}$ con diferentes rayas de endurecimiento y espesor. Interiormente presenta numerosas irregularidades (fig. 9, E.q.), formadas por amontonamientos de quitina, a modo de anchas verrugas, visibles sobre todo en cortes transversales, destinadas sin duda a reforzar la pared del vestibulo. La segunda porción (fig. 10, P.f.) está también formada por células quitinizadas, pero que conservan cierta flexibilidad, para permitir el juego del aparato oclusor, que le sigue inmediatamente. Al exterior no presenta ninguna arruga de endurecimiento; y por el interior, como puede verse en los cortes transversales, tampoco ofrece espesamientos notables. Esta región es algo más ancha en su porción dorsal que en la ventral; lo cual, como más adelante veremos, tiene influencia en el juego total del movimiento del estigma.

Al vestíbulo sigue el aparato oclusor del estigma, que dejaremos para lo último.

Cámara estigmática. - La cámara estigmática consta igualmente de dos porciones: una primera blanda y flexible, y otra segunda semirrigida, que sirve de punto de inserción y apoyo a la tráqquea estigmática. La relativa posición de estas dos porciones es, por consiguiente, inversa de la que presentan las del vestibulo (en el que la primera es rígida), y está siempre en relación con el funcionamiento del aparato oclusor. La primera porción (fig. $8, C . p . l$.) 
es blanda, anhista y formada por capas estratificadas de quitina no endurecida. Es más ancha por la región dorsal que por la ventral (como hemos advertido también al describir la región blanda del vestibulo), para permitir al estigma mayor amplitud de movimiento en este sentido. Presenta dos evaginaciones: una en forma de dedo de guante, que forra la palanca del aparato oclusor y se adhiere a ella; y otra ancha, que recubre el divertículo del mismo aparato. A esta primera porción de la cámara estigmática sigue la segunda, formada por una pared de células completamente quitinizadas, de contornos poligonales o redondeados (C. $p . r$.$) , y con diversas líneas$ de espesamiento quitinoso. No presenta engrosamientos interiores, por lo cual es semirrigida. Esta zona, al contrario de la precedente, es más extensa por la región ventral que por la dorsal, y presenta ventralmente una ligera curvatura, que orienta a la tráquea en dirección dorsal.

Aparato oclusor del estigma. - El aparato de cierre, regulador principal de la entrada de aire en la tráquea, se halla colocado entre

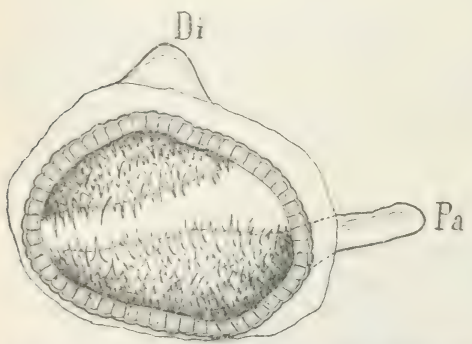

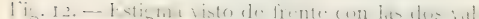

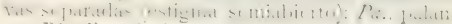
ca; Di., diverticulo. $\times 150$.

el vestibulo y la cámara estigmática. Está formado esencialmente por dos valvas quitinosas, erizadas de puas y espinas de longitud diversa, y que pueden moverse a modo de las dos valvas de una puerta. El cierre se verifica según el eje mayor; y como éste es próximamente horizontal, de aqui que el movimiento de las dos valvas sea también aproximadamente hori -

zontal. Una vista frontal (fig. 12) de un estigma medio abierto nos ofrece el conjunto de las dos valvas, que dejan entre sí una abertura longitudinal. La valva inferior presenta una palanca, que sobresale al exterior del cuerpo del estigma (figs. 7,8 y $12, P$ a.). Esta palanca corresponde a la leva de PETRI. La valva superior presenta una evaginación o divertículo cónico-aplastado (Di.). Corresponde al archetto del mismo autor y de VERSON. La valva inferior puede compararse en su forma a una raqueta: consta de mango y lámina. 
El mango lo constituye la palanca, que a su vez está formada por una varilla de quitina, fuertemente doblada como una horquilla, de manera que sus dos ramas quedan aproximadamente paralelas (figuras 13,14 y $15, P a$.). Esta porción es la que sobresale del cuerpo del estigma. Al penetrar en el tubo estigmático estas dos varillas, se separan y se ensanchan a la vez, dando origen a dos láminas, que representarían la pala de la raqueta. Las dos láminas se extienden por el fondo de la cavidad estigmática, y forman, las dos juntas, una

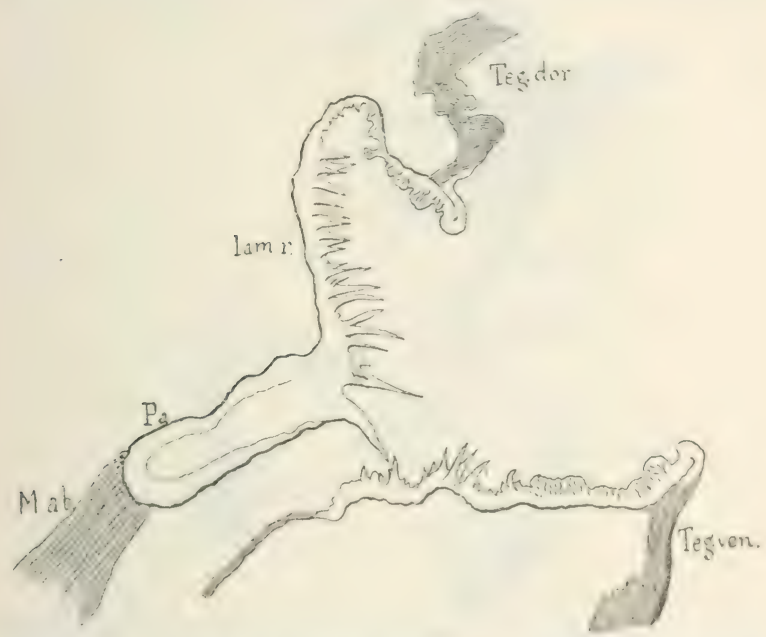

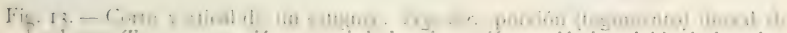
la pleura; Tig. ven. porción ventral de la misma; lum. r., lánina rigida de la valva; Pa., palancil; . I\%, ab., múscislo aluductor. (La abertura aparece muy grande a causa del aplastamiento que presenta la pared dorsal del vestibulo.) X 200.

valva del aparato oclusor. De estas dos láminas, la más próxima a la pared del vestibulo se continúa (fig. 13, laim.r.) con la porción blanda de dicha pared. Está sembrada de numerosas espinas; y en virtud del movimiento del aparato puede ponerse en la misma dirección de la pared del vestibulo. La otra lámina (fig. 14, lim. f.) se extiende por el fondo de la cavidad vestibular, y se dirige hacia la otra valva del aparato oclusor. Cuando llega cerca de dicha valva, se dobla ha- 
cia adentro, y se cortinúa con la porción flexible de la cámara estigmática. Esta lámina es semirrigida; su porción quitinosa es más delgada que en la otra lámina (que con ella forma la valva), y se halla revestida exteriormente de una membrana de quitina a capas estratificadas y no endurecidas, que es continuación de la que constituye la parte blanda de la cámara estigmática subyacente. El mango de la raqueta, o sea las dos varillas de quitina que forman la palanca $(\mathrm{Pa}$.$) , se halla revestido de una membrana que le envuelve como$

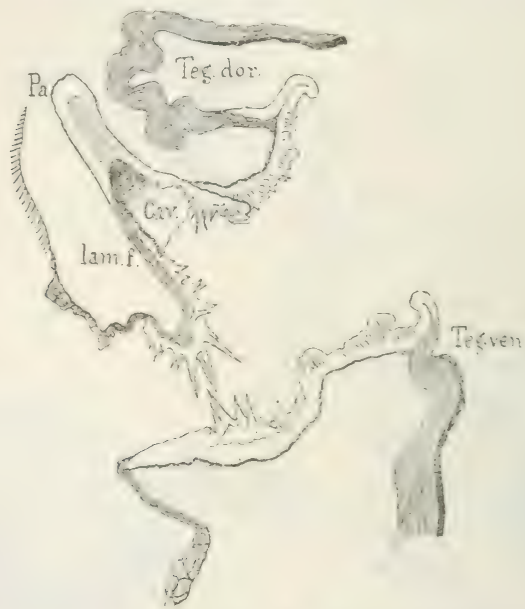

Fig. If. - Corte vertical de un estigma: Cav., cavidad formada por las varillas de la palanca y la membrana que las forra; lám.f., lámina flexible de la valva. Las demás letras, el mismo significado que en la figura $13 . \times 200$.

un dedo de guante, de modo que entre esa membrana y las varillas queda formada una cavidad alargada (fig. 14, Cav.), que comunica con el vestíbulo.

La otra valva del aparato oclusor tiene una forma parecida a la descrita, y sus relaciones con los órganos vecinos son iguales a las que acabamos de exponer. Está constituida por una sola lámina, adherida por un lado a la pared vestibular (fig. 15, lcim. r. d.), se extiende por el fondo de la cavidad, y por su borde libre se aproxima a la lámina de la otra valva. Toda ella está sembrada de abundantes 
espinas. Hacia la mitad de la linea de unión con la pared del vestíbulo presenta un divertículo (figs. 12 y 16, $\mathrm{Di}$.), formado por un recodo de quitina, doblado en ángulo casi recto (archetto de PETRI y VERSON), que está envuelto por su correspondiente membrana, dando origen a una cavidad cónico-aplastada en comunicación con el vestibulo. Por eso damos a esta formación el nombre de diverticulo.

El funcionamiento de estas dos valvas tiene lugar aproximándose o separándose. Al aproximarse entrecruzan intimamente sus

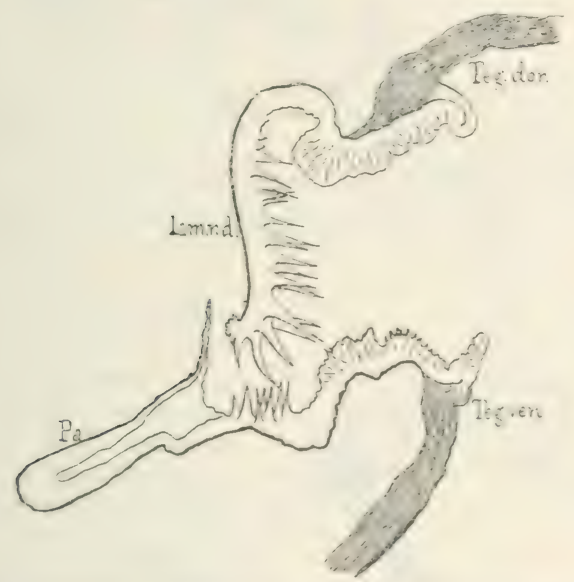

Fig. 15. - Corte vertical de un estigma : lim. $r$. d. lámina rigida de la valva del diverticulo. Las demás letras, como anteriormente. $\times, 200$.

espinas y púas, con lo que constituyen un espeso fieltro, que acaba de filtrar el aire que penetra en la tráquea. Ese movimiento de aproximación y separación de las dos valvas se verifica por medio de dos músculos estriados antagonistas. El misculo obturador se inserta por un lado en la palanca (fig. $17, M$. ad.), y por el otro extremo en el divertículo. Su función consiste, por consiguiente, en aproximar la palanca al diverticulo, y por lo tanto cierra la abertura, aproximando las láminas oclusoras. Esto puede comprenderse perfectamente con la figura 12 , si restituimos el misculo despren- 
dido por la macerac: ‘n. Antagonista con éste está el músculo abductor $(M . a b$.$) , que va desde la palanca al tegumento externo. Su$ contracción separa la palanca del divertículo, y por consiguiente abre la comunicación del vestíbulo con la cámara estigmática.

Además de este modo de cerrar o graduar la comunicación con el exterior, que depende del funcionamiento propio del aparato oclusor, posee la Blatta orientalis otro modo de ocultar la abertura estigmática externa. Recuérdese que el estigma está implantado en un mamelón situado entre el terguito y esternito corres-

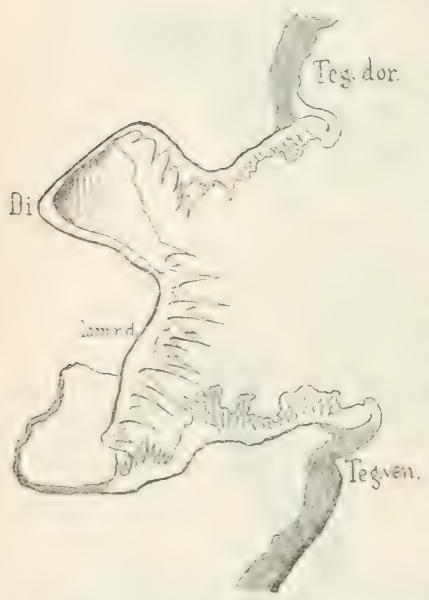

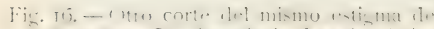

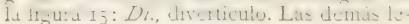
tras, como anteriormente. $\times 200$. pondientes (figs. 7 y 18). Pues bien: examinando los cortes transversales del estigma (figuras $13,14,15$ y 16$)$ se ve que el tegumento del mamelón no se endurece en la porción dorsal que está próxima al peritrema (Teg. dor.), sino que permanece blando y flexible. El endurecimiento empieza a cierta distancia del estigma. En cambio en la región ventral el endurecimiento llega hasta cerca del mismo peritrema (Teg. ven.), quedando sólo sin endurecerse una estrecha tira. Esto quiere decir que todo el estigma puede girar alrededor de la línea ventral de apoyo como alrededor de una charnela. Con un giro aproximado de $90^{\circ}$ la abertura exterior del estigma queda mirando al tegumento de la pleura dorsal. Si, además, el insecto contrae fuertemente el músculo dorso-ventral, la boca del estigma quedará completamente obturada por la pleura, a la cual se adhiere. Esto se comprende claramente inspeccionando la figura 18 , que representa un corte transversal que abarca los segmentos dorsal $(T)$ y ventral $(S)$ con su pleura correspondiente, y entre ellos el mamelón con el estigma.

Este hundimiento del estigma y obturación completa de la aber- 
tura exterior quedan altamente favorecidos por la estiuctura misma del tubo estigmático. En efecto, hemos visto que tanto el vestíbulo (fig. 10) como la cámara estigmática (fig. 8) tienen una porción

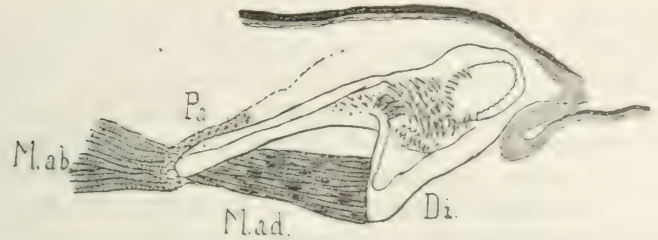

Fig. 17. - Estigma visto por la parte de dentro: Pu., palanca; $D i$, divertículo; I. $a b$., músculo abductor; H. $a d$., músculo adductor. $X$ I5O.

membranosa y flexible, más extensa en la región dorsal que en la ventral. Al hundirse, pues, el estigma, todo el tubo sufre un aplastamiento, a modo de acordeón, el cual es más pronunciado en la re-

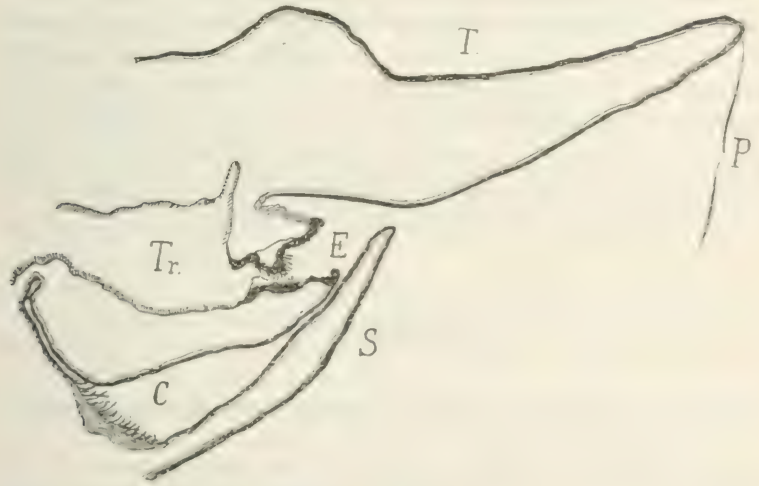

Fig. 18.-Corte transversal y vertical al nivel de un estigma: $T$, terguito; $S$, esternito; I. pleura; $C$, canal estignático; $E$, estigma; Tr., triquea estignatica. X $C$.

gión dorsal que en la ventral, y por consiguiente, la abertura estigmática toma también una dirección más dorsal, con lo que se favorece grandemente su ocultación en el repliegue de la membrana. 
La estructura y funcionamiento de los estigmas abdominales de la Blatta orientalis cumplen maravillosamente el fin que tienen asignado.

Los estigmas torácicos tienen una estructura más sencilla. Constan también de vestíbulo, aparato oclusor y cámara estigmática. El vestíbulo y la cámara tienen dibujos parecidos a los descritos anteriormente, pero sus paredes no están tan quitinizadas ni endurecidas: conservan su flexibilidad en toda su extensión. El peritrema es igual al descrito, pero también mucho más debil y delicado. El tamaño de la abertura es mayor que en los estigmas abdominales, pues el diámetro mayor mide unos $0,36 \mathrm{~mm}$. El aparato oclusor carece de palanca y de divertículo: queda reducido a dos repliegues de la pared misma del estigma, erizados también de púas y espinas, aunque mucho más cortas que las que se encuentran en los estigmas abdominales. Existen también, como parte complementaria, el canal y el campo estigmático. El estigma queda enteramente oculto debajo del borde del metanoto, que le sirve de defensa.

Los dos pares de estigmas torácicos atrofiados, correspondientes al protórax y mesotórax, están representados por un saco o cavidad, cerrada al exterior, semiovalada, de la que parten los troncos traqueales. Esa cavidad corresponde a la porción posterior y semirrígida de la cámara estigmática (fig. $8, C . p . r$.), que, como hemos visto, sirve de punto de partida y apoyo a las tráqueas. Sus paredes presentan las mismas células de contornos poligonales o redondeados, y están esculturadas por lineas de quitina.

\section{BIBLIOGRAFÍA}

1909. ALT, W. - Ueber den Bau der Stigmen von Dytiscus marginalis, L (Zool. Anz., 34 Bd.)

1909. Berlesse, A. - Gli Insetti. (Soc. Edi. Libr., Milano).

1893. BoAS, J. E. V.-Ueber die Stigmen der Melolontha Larve. (Zoul. Anz., 16 Jahrg.)

1894. BORDAS, L. - Anatomie du système trachéen des larves des Hyménoptères. (C. R. Ac. Sc. Paris, t. 118.)

1900. Boutan, L. - Zoologie descriptive, t. II, chap. XXVI.

1883. CARLET, G. - Sur un nouveau mode de fermeture des trachées (fermeture operculaire) chez les insectes. (C. R. Ac. Sc. Paris, t. 107.) 
1889. CARLet, G. - Sur les stigmates des Hyménoptères. (C. R. Ac. Sc. Paris, t. 103.)

1900. De MeIJere, J. C. H. - Ueber die Prothoracalstigmen der Dipteren puppen. (Zool. Anz., 23 Bd.)

1903. - Ueber die Prothoracalstigmen der Dipteren puppen. (Zool. Jahrb. Abth. Morph., 15 Bd.)

1890. DEwitz, H.-Einige Beobachtungen betreffend das geschlossene Tracheensystem bei Insekten larven. (Zool. Anz., 13 Bd.)

1905. EnderLeIN, G. - Laüsestudien. Schuppen als secundäre Athmuns organe. (Zool. Anz., 29 Bd.)

1874. GeRSTAECKER, A. - Ueber das Vorkommen von Tracheenkiemen b2i ausgebildeten Insekten. (Zeits. f. wiss. Zool., 24 Bd.)

1880. Hagen, H. - Beitrag zur Kenntniss des Tracheensystems der Libellen larven. (Zool. Anz., 3 Bd.)

1880. - Kiemenüberreste bei einiger Libelle: glatte muskelfasern bei Insekten. (Zool. Anz., 3 Bd.)

1881. - Einwürfe gegen Dr. Palmen's Ansicht von der Entstehung des geschlossenen Tracheensystems. (Zool. Anz., 4 Bd.)

1881. KRANCher, O. - Der Bau der Stigmen bei der Insekten. (Zeits. f. wiss. Zool., 35 Bd.)

1912. KUKENTHAL, W. - Leitfaden für das Zoologische Praktikum.

1866. LANDoIs, L. - Der Stigmenverschluss bei den Lepidopteren. (Arch. f. Anat., págs. 41-49.)

1866. - Der Tracheenverschluss bei Tenebrio molitor. (Ibid., pág. 391.)

1867. LANDois, H., et THELEN. - Der Tracheenverschluss bei den Insckten. (Zeits. f. wiss. Zool., $17 \mathrm{Bd}$.)

1895. Martin, J. - Origine et formation des faux stigmates chez les Nepidae. (Bull. Mus. Hist. Nat. Paris.)

1913. Moreno Rodriguez, A.--Contribución al estudio de los estigmas en los Insectos. Segovia.

1901. PANTEL, J. - Sur quelques details de l'appareil respiratoire et de ses annexes dans les larves des Muscides. (Bull. Soc. Ent. France.)

1901. Petri, L.-Osservazioni sopra gli stigmi della Sericaria mori. (Bull. Soc. Ent. Ital., anno 33.)

1872. PoucheT, G.-Développement du système trachéen de l'Anophèle (Corethra plumicornis). (Archiv. de Zuol. Exp., vol. 1.)

1903. Solowiow, P. - Zum Bau des Verschlussapparates der Stigmen bei den Insekten. (Zool. Anz., $34 \mathrm{~B}$ (i.)

1904. Thienemann, A.-Analkiemen bei den Larven von Glossosoma Bolteni, Curt., und einigen Hydropsychiden. (Lool. Anz., 27 Bil.)

1887. Verson, E. - Der Bau der Stigmen bei Bomby'x mori. (Zool. Anz., 10 Bd.)

1890. WISTINGHAUSEN, C. - Ueber Trachecnendigungen in den Sericterich der Raupen. (Zeits, f. wiss. Zool., 49 [3d.) 


\section{LOS MURINAE DE MARRUECOS}

\section{ÁNGEL CABRERA}

Todos los colectores de mamíferos saben que los ratones y ratas figuran en todas partes entre las especies más fáciles de obtener. En Marruecos, sin embargo, exceptuadas las formas parásitas de las poblaciones, esta facilidad es muy relativa, pues el estado de inseguridad en que todavía se halla la mayor parte del país, rara vez consiente alejarse de los poblados o los campamentos militares, en cuyas inmediaciones sólo se encuentran las referidas especies parásitas, especialmente el Rattus norvegicus, que alli como en todas partes contribuye a hacer cada vez más raros los pequeños roedores indigenas. Es, por tanto, muy verosimil que en Marruecos exista alguna forma del grupo que no figure en el presente trabajo, el cual no debe considerarse en modo alguno como definitivo, sino sólo como una base o punto de partida para futuras investigaciones. A publicarlo desde luego me ha movido, de una parte, el deseo de indicar a los naturalistas que visiten aquel país qué especies son las más notables o interesantes, y de otro lado, el temor de que algunas de estas especies lleguen a hacerse todavia más raras ante el avance lento, pero indudable, de la civilización. De que este temor no es infundado, no sólo respecto a los Murince, sino a los pequeños roedores en general, es prueba el hecho de que el ratón listado, el jerbo y otras especies, que hace pocos años se hallaban a las puertas mismas de Melilla, hoy sólo se encuentran a unos cuantos kilómetros de distancia, y aun así con poca frecuencia, lo que sin duda se debe a la roturación de terrenos, a la construcción de carreteras y ferrocarriles, a la lenta devastación de montes y matorrales $y$, finalmente, como ya he dicho, a la propagación de la rata común.

El numero de formas de la subfamilia Murince obtenidas hasta ahora en Marruecos es de doce, representando cuatro géneros. Seis 
de ellas sólo han sido encontradas en este pais, y de las restantes, culatro existen también en España, siendo una de ellas cosmopolita y seguramente de reciente importación europea.

\section{Clave de los Murince de Marruecos.}

a. Partes superiores de color uniforme, sin rayas; dedos primero y quinto posteriores más cortos que los tres intermedios, pero pasando de la base de éstos.

$b$. Molares primero y segundo superiores formados por tres láminas transversales con tres cúspides cada una; longitud del pie posterior, 22 a 26 mm........ Apodemus sylvaticus dichrurus (Rafin.).

$b^{\prime}$. Molares primero y segundo superiores formados por tres laminas transversales, las dos primeras con tres cúspides y la tercera con dos solamente.

c. Tamaño pequeño; longitud del pie posterior, 17 a 20 mm.; primer molar superior tan largo, por lo menos, como los otros dos juntos.

d. Cola próximamente de la longitud del cuerpo y la cabeza, cun frecuencia algo más larga.

e. Pelaje pardo claro; pies obscuros por encima.............. .................. Mus musculus brevirostris (Waterh.). $e^{\prime}$. Peiaje de color arcillostr: pies blances por encima.

...................... Mus musculus far subsp. $d^{\prime}$. Cola de 15 a 20 mm. más corta que el cuerpo y la cabeza juntos, $f$. Pelaje pardo rojizo.......... Mus spicilegus spretus (Lat.). $f^{\prime}$. Pelaje leonado ocráceo.. Mus spicilegus mogrebinus Cabr.

$c^{\prime}$. Tamaño mediano o grande; longitud del pie posterior, 22 a $45 \mathrm{~mm}$; primer molar superior siempre menos largo que los otros dos juntos.

g. Cola más corta que la cabeza y el cuerpo juntos........... ..................... Rattus norvegicus (Berkenli.), $g^{\prime}$. Cola más larga que la cabeza y el cuerpo juntos.

h. Longitud total, más de $250 \mathrm{~mm}$.; del pie posterior, $25 \mathrm{~mm}$. o más.

i. Tubérculo interno de la planta del pie alargado, mucloo más grande que el externo.

$j$. Partes superiores negruzcas.................

$j^{\prime}$. Partes suneriores pardas.

$k$. Longitud de la cabeza y el cuerpo, más de $150 \mathrm{~mm}$.; del cráneo, más de 35 mm................... ............. Rattus rattus frugivorus (Rafin.).

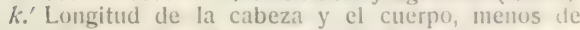
150 mm.; del crineo, menos de 35 mm.......... ............. Rattus rattus nericola subsp. 11.

$i^{\prime}$. Tubérculo interno de la planta del pie ovalado, sulo doble grande que el externo. Rattus calopus (Cahr.).

$h^{\prime}$. Longitud total, menos de $250 \mathrm{~mm}$; del pie posterior, menos de $25 \mathrm{~mm} . . . . . .$. Rattus peregrinus (De Wint.).

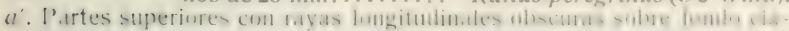
ro; dedos primero y quinto posteriores muy cortos, sin alcanzar at lit base de los tres intermedios........ Lemniscomys barbarus (Linn.). 


\section{Género Apodemus Kaup, 1829.}

Comprende este género los ratones de pelaje uniforme en las partes superiores, que tienen el $m^{1}$ y el $m^{2}$ formados por tres láminas transversales con tres cúspides cada una, de modo que la corona ofrece tres series longitudinales de a tres cúspides, una serie interna, otra central y otra externa. Hasta ahora no se conoce en Marruecos más que una forma de este género, que existe tambiẻn en el Mediodía de Europa, desde el Centro y Sur de la Península Ibérica hasta la Balkánica.

\section{Apodemus sylvaticus dichrurus (Rafinesque).}

Musculus dichrurus Rafin., Préc. Découv. Somiol. (1814), pág. 13. Mus hayi Waterl., Proc. Zool. Soc. Lond., 1837, pág. 76.

Mus sylvaticus hayi Barr.-Hamilt., Proc. Zool. Soc. Lond., 1900, página 410.

Apodemus sylvaticus dichrurus Miller, Cat. Manm. West. Eur. (1912), pág. 810.

Pelaje ante sucio o pardo madera, obscurecido en medio del dorso por numerosas puntitas negras. La superficie ventral de un blanco más o menos puro, pero siempre bien separado del color de las partes superiores. Con frecuencia, una mancha amarillenta en el pecho. Pies blancos, los posteriores con una mancha negruzca en el talón. Cola generalmente más larga que la cabeza y el cuerpo, obscura por encima y blanquecina por debajo.

Las dimensiones externas de un $\sigma^{\top}$ de Rincón de Medik (El Haus) son las siguientes: cabeza y cuerpo, $100 \mathrm{~mm}$.; cola, 107; pie posterior, 24; oreja, 19. El largo total del cráneo, en seis ejemplares medidos, oscila entre 24 y $26,8 \mathrm{~mm}$.

A mi juicio, Barrett-Hamilton estuvo en lo cierto al considerar el A. sylvaticus de Marruecos idéntico al de los países mediterráneos de Europa. Teniendo a la vista numerosos ejemplares de Marruecos (entre ellos tres de Tánger, topotipos de hayi) y de España, no puedo encontrar ninguna diferencia apreciable. Algutnos individuos muy adultos de Rincón de Medik son un poco más obscuros que cualquiera de los de nuestro pais; pero los de Tán- 
ger y una $q$ de Monte Negrón son como otros de la Sierra de Guadarrama.

Todos los ejemplares marroquies que conozco de esta subespecie proceden del Yebala. En el Museo Nacional de Ciencias Naturales existen ejemplares obtenidos por mí en distintos puntos entre Ceuta y Tetuán, y otros por Martínez de la Escalera en Tánger. En esta última localidad han encontrado el mismo ratón Drummond Hay y Barrett-Hamilton, y Dodson cerca de ella, en Xarf-el-Akab.

Lo mismo que en España, A. s. dichrurus habita en Marruecos preferentemente los parajes quebrados o montuosos. Sus agujeros los he hallado siempre al pie de las matas de jara o de palmito.

Género Mus Linné, 1758.

Actualmente sólo se comprenden en este género los ratones con el pelaje de las partes superiores uniforme, que presentan los siguientes caracteres dentarios: $m^{1}$ y $m^{2}$ con dos cúspides solamente en la lámina posterior, faltando la del lado interno; el $m^{1}$ tan largo, por lo menos, como los otros dos molares juntos, y el $m^{3}$ mucho más chico que el $\mathrm{m}^{2}$. Tamaño pequeño; planta del pie posterior con dos tubérculos subtarsianos pequeños y redondeados.

En Marruecos parece hallarse representado este género por dos especies, de cada una de las cuales se conocen hasta ahora dos formas locales.

\section{Mus musculus brevirostris (Waterhouse).}

Mus musculus Asso (no Linné), Intr. Oryct. Zool. Arag. (1784), pigilla 58.

Mus brevirostris Waterh., Proc. Zool. Soc. Lond., 1837, paig. 19.

Mus azoricus Schinz, Syst. Verz. Säug. (1845), pág. 161.

Mus flavescens Lataste (no Fitz.), Act. Soc. Linn. Bord., XXXVH (1883), pág. 21.

Mus musculus brevirostris Trouess., Cat. Mamm. Suppl. (190-4), paigina 380.

Mus musculus azoricus Mill., Cat. Mamm. West. Eur. (1912), piigina 380.

Color general pardo ante, tirando a veces a sepia o a pardo olivaceo, y pasando a ante sucio o leonado vinoso pálido en las partes 
inferiores. Los pies, por encima, obscuros, de color paño o pardo pelo. La cola, generalmente más larga que la cabeza y el cuerpo juntos, es casi tan obscura por debajo como por encima.

Dimensiones externas de un ox del Garet (Rif) : cabeza y cuerpo, $90 \mathrm{~mm}$.; cola, 92; pie posterior, 17,5; oreja, 14. La longitud total del cráneo, en los ejemplares marroquies, oscila entre 20,5 y $23 \mathrm{~mm}$.

El ratón casero del Mediodía de Europa parece hallarse extendido por todo el Norte de Marruecos; por lo menos, todos los ejemplares que yo he podido examinar en el Rif y en Yebala son absolutamente idénticos, en dimensiones y en pelaje, a los de color más claro que se ven en España. Lo que ya no me atrevo a decidir es si esta forma es alli indigena o ha sido introducida por nosotros. Yo sólo he obtenido ejemplares en localidades donde, aparte de una guarnición relativamente numerosa, hay un importante núcleo de población española.

Mus musculus far subsp. n. (1).

Tipo: $\sigma$ adulto, de Mogador, obtenido en 10 de agosto de 1911 por D. Fernando M. de la Escalera. Museo Nacional de Ciencias Naturales, núm. 11-XII-5-69.

Una raza del ratón vulgar, del tamaño de $M$. $m$. brevirostris, pero con el pelaje más pálido y más rojizo, y con los pies blancos por encima.

El pelo de las partes superiores es de color pizarra obscuro en la base y ante-canela claro hacia la punta, teniendo muchos de los del dorso las puntitas negras, resultando un color general entre arcilloso y ante-canela, lavado de negruzco por encima. El vientre es de un matiz ante ocráceo muy pálido, con la base de los pelos gris clara. Los pies, por encima, blancos.

Dimensiones del tipo : cabeza y cuerpo, $100 \mathrm{~mm}$; cola, 101; pie posterior, 20; oreja, 15.

Cráneo: longitud total, 23,5 mm.; longitud cóndilobasal, 22,8; nasales, 9,4; ancho cigomático, 11,8; ancho interorbitario, 4; ancho de la caja cerebral, 10,5; serie molar superior, 3,8 ; serie molar inferior, 3 .

(1) Far es el nombre árabe que se aplica a todos los ratones y ratas en Marruecos. 
Esta forma parece representar al ratón casero en el extremo Oeste de Marruecos. Todos los ejemplares que he examinado proceden de Mogador, habiendo sido obtenidos, no en la ciudad misma, sino en sus alrededores, y todos ellos ofrecen la misma coloración. Comparados con $M$. musculus brevirostris, se distinguen en seguida por sus pies blancos y su color más acanelado. En brevirostris, la parte pálida de los pelos ofrece un matiz avellana, no ante-canela. Un individuo de esta última raza obtenido por mi en Monte Arrui (Garet) se parece algo a los de Mogador, pero el color general es menos vivo, y los pies son obscuros.

Antes de decidirme a dar un nombre en esta forma, pensé si podría ser idéntico a los que en el opuesto extremo del África septentrional, en Egipto, se han descrito bajo los nombres $M$. gentilis y $M$. orientalis; pero el primero de éstos, según BonHote (1), es un ratoncillo con el pelo de la región ventral blanco hasta la base, y en orientalis el pelaje es más gris y hay una línea de color cervuno claro a lo largo de cada costado, separando el color del dorso del de las partes inferiores. Tampoco puede tratarse del $M$. algirus Pomel (2), porque éste tiene las partes inferiores blancuzcas, y la cola más corta que la cabeza y el cuerpo juntos. LATASTE consideraba $M$. algirus como un sinónimo de Apodemus sylvaticus, en cuya espécie lo incluyó también BARRETT-HAMILTON, como forma propia de Argelia, mientras Thomas designa con dicho nombre un verdadero Mus, pero más próximo a $M$. spicilegus que a M. musculus, según he podido comprobar por un ejemplar que este eminente zoólogo ha tenido la atención de remitirme. En cualquier caso, el nombre algirus tampoco puede aplicarse a estos ratones de Mogador, que, por consiguiente, me veo precisado a considerar como una forma no descrita.

\section{Mus spicilegus spretus (Lataste).}

Mus spretus Lataste, Act. Soc. Lim. Bord., XXXVII (1883), paig. 27, iigs. 5 y 6 .

Considero yo como spretus un ratoncito que he obtenido en las afueras de Tetuán, junto al rio Martín, al cual conviene muy bien la

(1) Proc. Zool. Soc. of London, 1909, pig. 79.4.

(2) Compt. Rend. Acad. Scienc, 185t, pig. 654. 
descripción de LATASTE, ofreciendo además completo parecido con algunos ejemplares que he visto de Argelia, y que creo deben pertenecer a esta forma. Sus caracteres, en general, son los del M. spicilegus de la Europa mediterránea, diferenciándose de la forma común en España (M. s. hispanicus) por su pelaje más obscuro, lo mismo en el dorso que en la región ventral. En las partes superiores el pelaje ofrece un matiz intermedio entre pardo rapé y pardo Saccardo, más pálido y algo acanelado en los lados de la cara. La base de los pelos es de un gris pizarra muy obscuro, casi negro. El pelo de las partes inferiores tiene la punta blanca, pero en muy pequeña extensión, dejando ver perfectamente la base color de pizarra, de modo que, en conjunto, el vientre aparece de un gris neutro pálido, menos blancuzco que en hispanicus. Los pies, por encima, blanco-amarillentos. La cola, negruzca por encima, algo más clara por debajo.

Las dimensiones externas de dicho ejemplar de Tetuán (una $q$ adulta) son las siguientes : cabeza y cuerpo, 83 mm.; cola, 66; pie posterior; 17; oreja, 12,5. El cráneo fué deteriorado por el cepo; en un ejemplar de Argelia, que evidentemente pertenece a la misma forma, mide $22 \mathrm{~mm}$. de longitud total.

No cabe la menor duda de que este ratón representa en la costa septentrional de África el $M$. spicilegus, tan abundante, en sus distintas razas locales, en todo el Mediodía de Europa. La cola, bastante más corta que el cuerpo con la cabeza, los pies pequeños, y el cráneo delicado, con el rostro relativamente corto y estrecho, impiden desde luego confundirlo con cualquier forma del M. musculus. Si mi determinación del referido ejemplar como spretus. es exacta, esta raza se extiende, por lo menos, desde las altas mesetas de la provincia argelina de Constantina hasta el Yebala.

\section{Mus spicilegus mogrebinus Cabrera.}

Mus musculus gentilis De Winton (no Brants), Proc. Zool. Soc. Lond., 1897, paig. 958.

Mus spicilegus mogrebinus Cabr., Bol. R. Soc. Esp. de Hist. Nat., XI (1911), pág. 556.

Pelaje algo más pálido que en M. s. spretus. Las partes superiores de un color leonado ocráceo, siendo lós pelos de un ante ocráceo que puede tirar un poco a asalmonado, con la base de un 
color negruzco de pizarra. Región ventral blancuzca, a veces ligeramente lavada de ante, y sin que se vea apenas el gris de la base de los pelos. Los pies, por encima, de un blanco marfileño. Cola parda sucia en su cara dorsal; blancuzca por debajo.

Dimensiones externas del tipo ( $q$ adulta de Tagüidert, provincia de Hajá) : cabeza y cuerpo, $85 \mathrm{~mm}$; cola, 66; pie posterior, 18; oreja, 14. En los varios ejemplares que he medido, la longitud total del cráneo varía entre 19 y $20,5 \mathrm{~mm}$.

Este ratón es el representante de $\boldsymbol{M}$. spicilegus en el Oeste de Marruecos, o acaso solamente en la región del argán. Todos loz ejemplares que yo he visto proceden de Mogador o de Tagüidert. y juzgando por las dimensiones, a la misma raza pertenecen los que cita DE WINTON de diversos puntos de las provincias de Ajmar y Hajá, bajo el nombre de M. musculus gentilis, que yo también empleé en otro tiempo, a imitación suya (1). El verdadero M. gentilis, que vive en Egipto, pudiera ser también una subespecie de spicilegus; pero se distingue desde luego de las formas berberiscas y de las del Sudoeste de Europa por tener el pelo de las partes inferiores blanco hasta la raiz, sin base gris. Muy afin a este grupo es también el $M$. algirus, que acaso algún día se encuentre hacia Tafilete o en alguna otra región de desiertos del interior de Marruecos, y que en cierto modo puede considerarse como el representante berberisco del M. bactrianus del Asia sudoccidental. En su aspecto general, en su coloración y en su cráneo, M. algirus difiere poco de algunas razas de $\boldsymbol{H}$. spicilegus, pero es más blanco por debajo (aunque con la base de los pelos gris), y tiene la cola próximamente tan larga como el cuerpo con la cabeza, y de un matiz muy obscuro, casi negro, hacia la punta.

Volviendo a M. s. mogrebinus, es interesante hacer constar la gran semejanza que en coloración $y$ aspecto general hay entre esta forma y el $\boldsymbol{M}$. musculus de la misma región; el primero tiene, sin embargo, la cola mucho más corta y el cráneo más pequeño y delicado, sobre todo la porción rostral.

(1) Bol. R. Soc. Esp. de Hist. Nat., VI (190ti), paig. 36 ti. 


\section{Género Rattus Fischer, 1803.}

Este género, que corresponde al Epimys de TrouessarT, comprende las ratas, que se distinguen de los ratones propiamente dichos (Mus) por su mayor tamaño, por tener el tubérculo subtarsiano interno mayor que el externo, y de forma oval o alargada, por su cráneo con dos aristas supraorbitarias bien salientes, que se prolongan sobre los parietales, limitando lateralmente la parte superior de la caja cerebral, y por ciertas particularidades dentarias. El $\mathrm{m}^{1}$, que sólo tiene, como en $\mathrm{Mus}$, dos cúspides internas, es siempre más largo que el $m^{2}$, pero nunca tan largo como éste y el $m^{3}$ juntos. El $m_{1}$ presenta una cúspide accesoria interna, muy pequeñita, en la tercera lámina transversal; el $m_{2}$ tiene una puntita análoga en la primera lámina, y otra en la segunda, y el $m_{3}$ una en la primera lámina.

En Marruecos se han obtenido hasta ahora seis formas de este género, cuatro de las cuales parecen ser propias del país.

\section{Rattus norvegicus (Berkenhout).}

Mus norvegicus Berkenlı., Outl. Nat. Hist. Great Brit., I (1769), pág. 5.

Mus decumanus Pall., Nov. Spec. Quadr. Glir. Ord. (1778), pág. 91.

Mus surmulottus Sever., Tent. Zool. Hungar. (1779), pág. 73.

Epimys norvegicus Satun., Mitt. Kaukas. Mus., IV (1908), pág. 111.

Tamaño grande; cola de 20 a $60 \mathrm{~mm}$. más corta que el cuerpo y la cabeza juntos; orejas relativamente cortas, llegando apenas a los ojos cuando se las echa hacia delante; tubérculo subtarsiano interno estrecho y alargado. Pelaje mezclado con cerdas acanaladas; en las partes superiores pardo claro, variando del tierra de sombra al ante ocráceo lavado de negruzco; en las inferiores blanco grisáceo o amarillento. Son frecuentes los casos de melanismo y de albinismo parcial o total.

Cráneo muy estrecho y alargado, con las aristas superiores casi paralelas en los parietaies.

Dimensiones externas, por término medio: cabeza y cuerpo, $220 \mathrm{~mm}$; cola, 190; pie posterior, 42; oreja, 21. La longitud total del cráneo es de unos $50 \mathrm{~mm}$. 
La rata común de nuestras cuadras y alcantarillas es en Marruecos de muy reciente importación, pero se está extendiendo allí con la misma rapidez que en el resto del mundo. Cuando yo visité el Yebala, en 1913, en los poblados indígenas del interior era casi desconocida; pero en las calles de Alcazarquivir y de Larache vi con frecuencia ejemplares muertos; y en el vado de la Neyma, sobre el Lucus, donde se había establecido un depósito de víveres, se había instalado una numerosa colonia de estos voraces roedores, que minaban las escarpadas orillas del río y salian de sus agujeros en pleno día. En el Rif, la misma especie parece ir empujando hacia el interior a los jerbos y otros pequeños mamíferos indigenas.

\section{Rattus rattus chionogaster subsp. n.}

¿Mus rattus De Winton (no Linné), Proc. Zool. Soc. Lond., 1897, página 958 (parte).

Mus rattus Cabr., Bol. R. Soc. Esp. de Hist. Nat., VI (1906), página 365.

Tipo: $\sigma$ muy adulto, de Mogador, obtenido en 2 de septiembre de 1905 por D. Manuel M. de la Escalera. Museo Nacional de Ciencias Naturales, núm. 2.160.

Caracteres generales como en $R$. $r$. rattus, es decir, tamaño grande, cola de 15 a $40 \mathrm{~mm}$. más larga que el cuerpo y la cabeza juntos, y orejas grandes, que llegan hasta los ojos si se echan hacia delante; pero el color de las partes inferiores no es gris, sino blanco puro hasta la base misma de los pelos, y perfectamente separado del negruzco de las partes superiores por una línea bien definida.

En realidad, esta forma podria describirse como un $R$. rattus frugivorus negro, en vez de pardo claro. En las partes superiores el pelaje es fusco o gris ratón obscuro, casi negro en medio del dorso por la abundancia de largos pelos gruesos enteramente negros, de unos $30 \mathrm{~mm}$. de longitud. Toda la superficie ventral, a partir del labio inferior y parte baja de las mejillas, de un blanco de nieve, limitado en los flancos por una línea bien marcada. En el tipo y en algún otro ejemplar, el color del dorso, algo más pálido, se extiende por la parte interna de los miembros posteriores, pero lo corriente es que los miembros sean interiormente blancos. Los cuatro pies blancuzcos, ligeramente lavados de gris en medio de su cara superior. 
El cráneo, d ntro de los caracteres propios de la especie, es un poco más ancho en la región interorbitaria que en la forma típica, y tiene las aristas superiores algo más divergentes, lo que da relativamente mayor anchura a la figura piriforme que la caja cerebral ofrece mirada por encima.

Dimensiones del tipo: cabeza y cuerpo, $160 \mathrm{~mm}$.; cola, 179; pie posterior, 30; oreja, 22.

Cráneo: longitud total, 40 mm.; longitud cóndilobasal, 38,2; nasales, 15; ancho cigomático, 19,5; ancho interorbitario, 11; ancho de la caja cerebral, 17,3; serie molar superior, 11,5 ; serie molar inferior, 11.

Todas las ratas que he visto de esta raza proceden de la parte más occidental de Marruecos. En un principio, atendiendo a su pelaje negro, las consideré como verdaderas rattus, pero después me ha llamado la atención el hecho de que mientras en los ejemplares de $R$. r. rattus de Europa las partes inferiores son siempre grises, fundiéndose este color gradualmente con el del dorso, y otro tanto ocurre en los procedentes de América, Fernando Poo y la Guinea continental española, todos ellos de evidente origen europeo, estas ratas marroquies tienen siempre la región ventral blanca y bien limitada; es decir, que difieren de $R$. r. rattus exactamente como $R$. $r$. frugivorus difiere de $R$. $r$. alexandrinus, y al mismo tiempo se diferencian de frugivorus como rattus de alexandrinus. Si consideramos, por consiguiente, estas tres formas como distintas, es necesario distinguir de ellas la que nos ocupa, tanto más cuanto que estas ratas negras de vientre blanco parecen ser peculiares de una región determinada, y además no son ratas de ciudad, sino que todos los ejemplares que yo he examinado estaban capturados en el campo. Probablemente, DE WINTON se refiere en parte a esta forma al mencionar varios ejemplares de "Mus» rattus de diferentes localidades del Oeste de Marruecos, añadiendo que en ellos «están representadas ambas variedades, negra y parda». Por desgracia, los ejemplares negros no se conservan en el Museo Británico, adonde he acudido en consulta, y no sé si serían iguales a los de Mlogador. Desde luego, las ratas negras de Mogador y las localidades vecinas no parecen ser casos de melanismo individual de frugivorus, pues su color negruzco es general a todos los ejemplares que yo he visto; y por otra parte, entre los muchos individuos de la forma frugivorus que he visto de la Península Ibérica y de Baleares, no hay ni uno sólo con las partes superiores negruzcas. Las ratas negras de 
España tienen siempre el pelo del abdomen gris, pudiendo ser más o menos claro, pero siempre gris; es decir, son siempre $R$. r. rattus.

Rattus rattus frugivorus (Rafinesque).

Musculus frugivorus Rafin., Préc. Découv. Somiol. (1814), pág. 13.

Mus tectorum Savi, Mov. Giorn. Letter., X (1825), paig. 71 .

Myoxus siculae Lesson, Man. de Manim. (1827), pág. 274.

Mus rattus De Winton (no Linné), Proc. Zool. Soc. Lond., 1897, página 953 .

Incluyo con duda esta forma entre los Murince marroquies, pues yo nunca he visto un ejemplar de esta procedencia igual al R. r. frugivorus del Mediodía de Europa; pero el distinguido zoólogo Martín A. C. Hinton, al comunicarme amablemente algunos detalles sobre las ratas obtenidas por Dodson en el Oeste de Marruecos, y mencionadas bajo el nombre rattus por DE WINTON, considera como frugivorus dos ejemplares, una of de Xarfel-Akab, al Sur de Tánger, y un o joven de Ecru, al Sur de Mogador. Creo sería conveniente comparar estos ejemplares con otros europeos. En estos últimos, las partes superiores ofrecen siempre matices pardos claros, que varian del oliváceo leonado al ante ocráceo, con bastantes pelos largos y negros en el dorso, y las partes inferiores de un blanco puro hasta la base de los pelos. Acerca de la coloración de los citados ejemplares marroquies, Hinton me escribe solamente: "Brown back, pure white underparts.» Las dimensiones de la ㅇ son : cabeza y cuerpo, $171 \mathrm{~mm}$.; cola, 203; pie posterior, 30; oreja, 24. Los ejemplares españoles que yo he medido tienen siempre el pie algo más largo.

Según me comunica el mismo naturalista, otro ejemplar de Xarfel-Akab, un $\delta$, es de un color "dusky gray», con los pelos ventrales de un blanco muy sucio o ceniciento en toda su extensión. "Y should not like - añade HINTON - , to be compelled to label this specimen with an exact name! » Tal vez fuese preciso considerar este individuo como un verdadero rattus; pero por ahora es más conveniente no aventurarse a designarlo como tal.

Yo creo que en Europa la forma típica de esta especie y la forma alexandrinus son, como generalmente se admite, resultado de tma inmigración medieval; pero me parece que las ratas con el pelo del vientre completamente blanco son, en los paises que rodean el Me- 
diterráneo, perfectamente indígenas, y que el día que sean bien estudiadas, acaso haya que reconocer en ellas varias formas locales, tan distintas por lo menos como las que en la India ha reconocido Hinton (1). Como hemos visto, en el extremo Oeste de Berbería encontramos una forma que me parece bien caracterizada por el color negruzco de sus partes superiores, y en el Rif, o por lo menos en la cuenca del bajo Muluya, he hallado otra raza que creo igualmente distinta, y que es la que describo a continuación.

\section{Rattus rattus nericola subsp. $n$.}

Tipo: $q$ adulta, aunque no vieja, del vado de Saf-Saf (bajo Muluya), obtenida por mí en 25 de mayo de 1919. Museo Nacional de Ciencias Naturales, núm. 20-VI-47.

Esta raza se parece a $R$. r. frugivorus, pero es bastante más pequeña, con el pelaje más gris y con los pelos largos del dorso mucho más cortos y finos.

Las partes superiores ofrecen un color pardo ante que tira un poco a ante oliváceo en la parte baja de los flancos, y a pardo oliváceo en medio del dorso, donde abundan. los pelos negros, largos y gruesos, los cuales no tienen nunca la longitud que en frugivorus, rattus o alexandrinus, midiendo sólo de 14 a $17 \mathrm{~mm}$. en vez de 28 ó 30. Los demás pelos son de un gris claro, parecido al gris gaviota obscuro de Ridgway, con la porción terminal visible amarilla ante y a veces una puntita negra. Hacia los flancos la parte amarilla es muy pálida, casi blanca, y los pelos negros escasean. Ei conjunto resulta muy distinto del.oliváceo leonado o el ante ocráceo de frugivorus. Las partes inferiores y la cara interna de los miembros son blancas, con un ligero matiz amarillo, casi ante oliváceo pálido. La cara dorsal de los pies posteriores y la de los anteriores en su parte central está teñida de un color negruzco sucio.

El cráneo ofrece los caracteres peculiares de la especie; pero comparado con el de $R$. $r$. rattus es, con relación a su tamaño, un poco más ancho posteriormente, con las aristas supraorbitarias más divergentes.

Dimensiones del tipo: cabeza y cuerpo, $125 \mathrm{~mm}$; cola, 159; pie posterior, 28,5; oreja, 19.

(1) Journal of the Bombay Nat. Hist. Soc., XXVI (1918), pág. 59. 
Cráneo: longitud total, 33,7 mm.; longitud cóndilobasal, 32; nasitles, 11,8; ancho cigomático, 17; ancho interorbitario, 5,5; ancho de la caja cerebral, 16; serie molar superior, 7 ; serie molar inferior 6,4 .

Evidentemente, esta subespecie es muy afín al $R$. $r$. frugivorus de las costas meridionales de España; pero comparada con numerosos ejemplares de frugivorus del Este y Mediodia de España, que difieren muy poco de la figura publicada por BONAPARTE bajo el nombre de Mus tectorum, se distingue desde luego por su coloración y por su tamaño. Hay más diferencia entre nericola y frugivorus, que entre este último y el R. r. arboreus de la India, que sin duda pertenece al mismo grupo de razas.

Yo solamente he encontrado esta rata en los bosquecillos de adelfas de las orillas del bajo Muluya, pero seguramente existirá en otros puntos del Rif, y es muy verosímil que se extienda hasta la parte occidental de Argelia. En este último caso, nada tendría de particular que los naturalistas franceses no hubiesen fijado su atención en ella, por la creencia en que hasta hace poco se estaba de que el $R$. rattus no tenía más que dos formas occidentales: una negra (rattus) y otra leonada o parda (alexandrinus).

\section{Rattus calopus (Cabrera).}

Mus calopus Cabr., Bol. R. Soc. Esp. de Hist. Nat., VI (1906), pigina 365.

Esta especie tiene, como $R$. rattus, la cola más larga que el cuerpo y la cabeza juntos, y las orejas bastante grandes, llegando a cubrir el tercio posterior del ojo si se estiran hacia delante; pero es fácil de distinguir en seguida por sus pies posteriores, de estructura más delicada, y con el tubérculo subtarsiano interno sólo doble grande que el externo y en figura de óvalo casi perfecto.

El color general del pelaje es parecido al ante sonrosado o el canela sonrosado de Ridgway, más obscuro y ligeramente variado de negro en el dorso. Los pelos son en casi toda su longitud, a partir de la base, de color pizarra, y ante solamente en la punta. En el lomo hay muchos pelos más gruesos enteramente negros, de cerca de $20 \mathrm{~mm}$. de longitud. Todas las partes inferiores, la cara interna de los miembros y los cuatro pies, de un blanco puro; los pelos, sin embargo, sólo son enteramente blancos en el centro del abdomen, teniendo en lo demás la base gris. Los cortos pelillos de la cola, 
que no llegan a cubrir las escamas, son negruzcos por encima y blancos en los lados y por debajo.

El cráneo es muy estrecho y alargado, recordando la forma caracteristica del de $R$. norvegicus, aunque tiene la caja cerebral más plana por encima y con las aristas laterales mucho menos salientes. Los globos auditivos son relativamente pequeños.

Los dientes se diferencian de los de las especies precedentes en varios detalles. E1 $m^{1}$ y el $m^{2}$ tienen las cúspides internas muy desviadas hacia atrás, casi como en Mus musculus; el $m^{3}$ presenta tres cúspides internas y una externa, esta tiltima (que parece representar el protocónulo) unida por crestas a la segunda y tercera externas, formando una $c$ algo irregular. Los molares inferiores se asemejan a los de $R$. norvegicus, salvo que el $m_{1}$ presenta las dos primeras láminas transversas unidas en el centro, formando aspa.

Dimensiones externas del tipo ( $\sigma^{-1}$ adulto de Mogador): cabeza y cuerpo, $120 \mathrm{~mm}$; cola, 137; pie posterior, 25; oreja, 24,8.

Dimensiones del cráneo (1): longitud total, $31 \mathrm{~mm}$; longitud cóndilobasal, 30,5; nasales, 13; ancho cigomático, 15; ancho interorbitario, 5; ancho de la caja cerebral, 12,5; serie molar superior, 5; serie molar inferior, 4,5 .

Esta especie sólo ha sido encontrada hasta ahora en Mogador, siendo probablemente peculiar de la región del argán.

Rattus peregrinus (De Winton).

Mus peregrinus De Winton, Proc. Zool. Soc. Lond., 1897, pág. 958.

Esta especie, que probablemente pertenece al subgénero Mastomys, es el único murino descrito de Marruecos que yo no he visto, por lo cual me limitaré a traducir la descripción original, que dice así:

«Color por encima gris, lavado de amarillo pardusco, con menos mezclilla en las mejillas y flancos; partes inferiores blancas, no muy bruscamente limitadas; cola muy ligeramente más obscura por encima que por debajo, prácticamente desnuda.

(1) En la descripción original de esta especie, las medidas del cráneo están equivocadas, por haberlas tomado con un calibre defectuoso y sin extraer el crálleo por completo. 
\El color general de este ratón es bastante parecido al del amari$110 \mathrm{M}$. gentilis, sólo que lả mezclilla de los pelos es más basta, asemejándose más a la de $M$. (= Apodemus) sylvaticus. Comparado con este último es bastante mayor en tamaño, la cola mucho menos peluda y las escamas más finas, en anillos menos regulares.

\Tipo: + , Ras-el-Ain, Hajá, 24 de junio de 1897.

„Dimensiones tomadas por el colector: cabeza y cuerpo, $97 \mathrm{~mm}$.; cola, 103; pie posterior, 22; oreja, 18.

„Cráneo: nasales, $10,6 \times 3,3$; estrechamiento postorbitario, 4,4; ancho de los cigomáticos en su unión con el malar, 12,3; longitud del paladar, 12,1; agujeros palatinos, 6,5; serie molar superior, 4,5; diastema, 7,3; ancho por fuera de los $m^{1}, 5,5$; ancho por dentro de los $m^{1}, 3$.

„El único ejemplar, una hembra joven, no presenta indicios de mamas, pero casi no me cabe duda de que resultará ser un representante septentrional de los conocidos ratones etiópicos que poseen más de doce mamas. En cuanto al color, la especie más próxima se encuentra en Matabelelandia, pero difiere en łamaño, asi como en la cantidad de pelo en la cola; este ratón de Marruecos, en efecto, tiene en la cola menos pelo que cualquiera de los ratones más pequeños conocidos que se puedan comparar con él.

„El cráneo, desgraciadamente muy incompleto, muestra sin duda estrecha afinidad con el grupo de mamas simples; el dibujo de los molares es el mismo; los incisivos superiores e inferiores son extraordinariamente fuertes; la mandibula es también bastante más fuerte que en la mayoria de las especies próximas, con una apófisis angular muy corta que no se extiende tan atrás como el cóndilo.»

\section{Género Lemniscomys Trowessart, 1881.}

Este género sólo comprende especies africanas, fáciles de conocer por su pelaje listado o manchado, y por tener el primero y el quinto dedos, lo mismo en los pies anteriores que en los posteriores, sumamente cortos. En las extremidades torácicas, el primer dedo es un mero tubérculo sin uña, y el quinto es rudimentario, con una uña roma, no ganchuda como en los otros géneros. En las posteriores, los tres dedos medios son muy largos, pero en cambio el primero y el quinto ni siquiera llegran a la base de aquéllos. En vez de dos 
tubérculos subtarsianos, hay uno sólo, el interno, pero sumamente pequeñito, hasta el punto de ser a veces casi invisible.

Lo mismo que en las ratas y los ratones propiamente dichos, el $m^{1}$ y el $m^{2}$ sólo presentan dos cúspides internas, faltando la de la tercera lámina transversal.

\section{Lemniscomys barbarus (Linné).}

Mus barbarus Linné, Syst. Nat., ed. 12. a, I (1766), add.

Tamaño un poco mayor que el de Apodemus sylvaticus dichrurıss; cola más larga que el cuerpo con la cabeza. Pelaje de las partes superiores ante-canela claro, ligeramente sombreado de negruzco en la cabeza, por ser negras las puntitas de muchos pelos, y palideciendo en las partes inferiores hasta convertirse en blanco en medio del abdomen y en los pies. A lo largo del dorso, desde la parte posterior de la cabeza, corre una raya negra, y a cada lado de ésta, ocupando el.flanco por completo, hay otras cinco rayas más anchas, negras también, cada una de las cuales encierra una línea media estrecha de color algo más pálido que el resto del pelaje.

Dimensiones externas de una $q$ de Tánger : cabeza y cuerpo, $120 \mathrm{~mm}$.; cola, 128; pie posterior, 25; oreja, 15. La longitud total del cráneo es de unos $30 \mathrm{~mm}$.

Esta especie parece encontrarse en todo Mlarruecos. Yo he visto ejemplares en Tánger, Casablanca y Tagüidert, y he oido hablar de ella en Alcazarquivir y en Kebdana; y DE Winton la menciona en Enzel, al Este de Marrakesh. El único ejemplar de Tánger que he estudiado tiene la raya dorsal muchı más ancha que los de las localidades más meridionales; pero esto pudiera ser una diferencia puramente individual, y el material examinado no induce a creer en la existencia de formas geográficas distintas.

Desde luego, este ratón es puramente campestre, y sólo se le encuentra en sitios abundantes en maleza, lejos de poblado, lo que explica que no se le capture con frecuencia. 


\title{
UNA ESPECIE NUEVA DE PUCCINIA EN ASPHODELUS
}

\author{
POR
}

\author{
ROMUALDO GONZÁLEZ FRAGOSO
}

(Lámina IV.)

El Rvdo. P. Luis M. de Unamuro, que con gran acierto y constancia viene hace tiempo estudiando los hongos parásitos de Asturias, como lo demuestra su interesante Contribución al conocimiento de los Uredales y Ustilagales de los alrededores de Llanes (Oviedo), presentada en el Congreso celebrado en Bilbao, en septiembre de 1919, por la Asociación Española para el Progreso de las Ciencias, ha encontrado recientemente una Puccinia sobre Asphodelus albus, que considero como nueva.

Aseméjase la para mi nueva éspecie, por su facies ecídica, a la P. Asphodeli Moug. (1), de la que difieren muchisimo sus teleutosporas, y por éstas se aproxima a la $P$. Barberyi (Roum.) P. Magnus (2). En ninguna de estas especies se citan picnidios por los autores, ni yo los vi nunca, siendo fácil encontrarlos en la nueva especie, como en el Ecidium Asphodeli-microcarpi Gz. Frag., que por su facies ecidica se aproxima a la segunda de las especies antes citadas. Las dimensiones de las ecidiosporas se aproximan algo a las de la $P$. Asphodeli; pero su episporio es tan densamente verrugoso, que las verrugas, muy próximas unas a otras $y$ muy regularmente dispuestas, semejan estrias. Las teleutosporas se asemejan en forma, y en la tenuidad de su episporio, a las de la P. Barberyi (Roum.) P. Magnus, pero son de mayores dimensiones, alcanzando muy comúnmente a $64 \times 36 \mu$ y en la especie dicha no

(1) Véase Movgeot in Duby. Bot. Gall., II, 1830, pigr. 891. - Sydow, Mon. Ured., I, 1904, paig. 617.

(2) Véase P. Magnus in Bot. Zcit., 1893, pág. 115. - Sydow, Mon. Ured., I, 1904, pág. 618. 
pasando de $46 \times 32 \mu$. Por último, el pedicelo, que en la $P$. Barberyi es siempre largo, alcanzando con frecuencia $95 \mu$, en nuestra
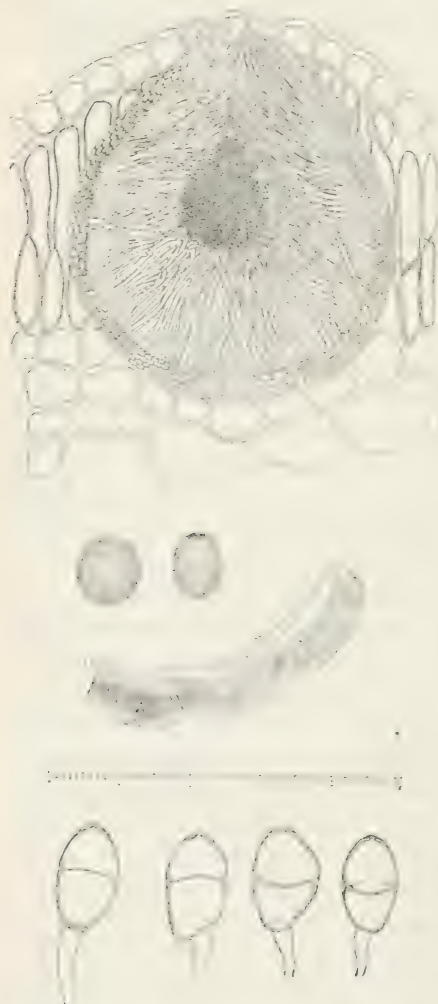

Fig. x. - Picnidio, ecidiosporas, células peridia. les, escala $(3,5 \mu$ cada división) y teleutosporas de Puccinia Linamunoi Gz. Frac. en hojas de Asphodelus alluss. especie es siempre corto, y raras veces alcanza a unas $40 \mu$ de longitud. La $P$. Barberyi, por último, sólo es conocida en $A s$ phodelus fistulosus y Asphodelus tenuifolius, la nueva especie parasita el Asphodelus albus, sobre el cual sólo se citó la $P$. Asphodeli, tan diversa en su facies teleutospórica, que toda confusión es imposible. He aquí la descripción de la nueva especie:

\section{Puccinia Unamunoi}

Gz. Frag. sp. nov.

Pycnidiis subepidermicis, numerosis, inter æcidiis sparsis, inmersis, globosis, usque $175 \mu$ in diam., apice conoideo-truncatis, subostiolatis, periphysibus paucis, hyalinis, brevibus, deciduis, contextu pseudoparenchymatico, minute cellulosis. Ecidiis amphigenis vel tantum hypophyllis, rariis caulicolis, in maculis rubro-aurantiaceis, vel flavidulis, insidentibus vel non, in sicco borde obscure circumdatim, sparsis vel plerumque in greges irregularibus vel orbicularibus dispositis, mediocribus 1-3,5 mm., irregularibus, vel circularibus, 
R. Soc. Esp. de Hist. Nat. - T. del 50. aniv.

LÁM. IV.

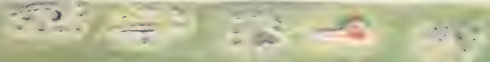
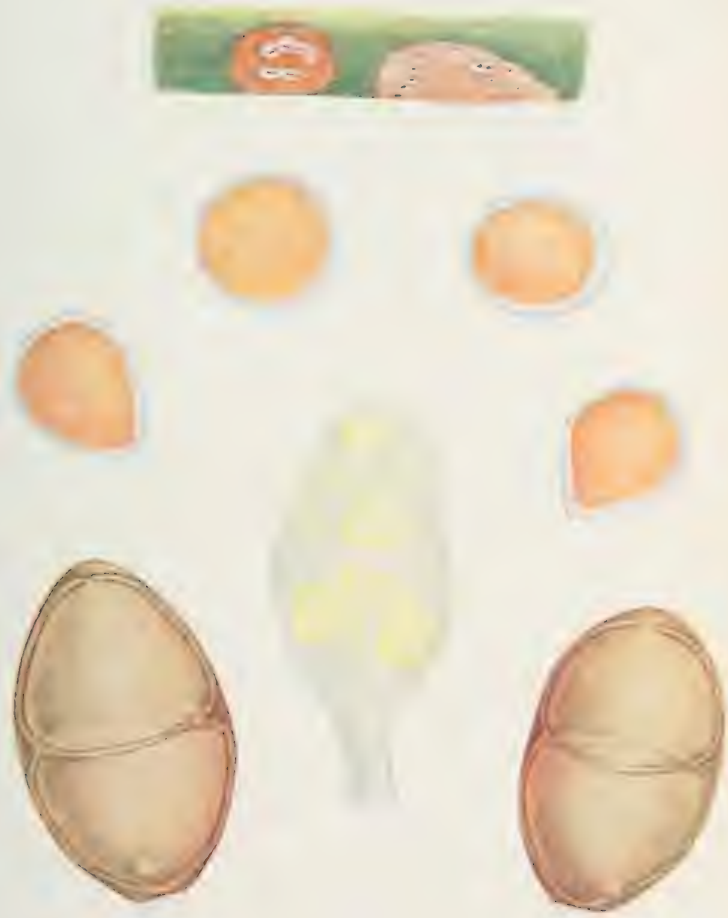

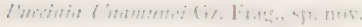



pseudocopulatis, primum clausis, demum rima longitudinali vel irregularibus deshicentibus, amœne rubro-aurantiaceis, margine albescentibus, irregulariter laciniato, suberecto vel revoluto; cellulis pseudoperidii imbricatis, usque $42 \times 18 \mu$, tunica extus valde incrassata, usque $24 \mu$, substriati, intus tenui, levi; æcidiosporis breviter catenulatæ, globosis, subglobosis, vel late ellipsoideis, 25-38 $\times$ $24-32 \mu$, episporio hyalinis, usque $3,5 \mu$ crass., minute, regulariter, densisque verrucosis, substriati, intus rubro-aurantiaceis. Teleutosoris sparsis, minutis, in maculis flavidis, vel inter æcidiis, vel circumdantibus, vel in greges irregularibus, vel orbicularibus, dispositis, rarissimis confluentibus, in maculis flavido-rufescentibus, in sicco rufo-brunneis, rotundatis, oblongis vel linearibus, primum epidermidis tectis, plumbeis, demum rupta, fissa, cinctis, atris; teleutosporis oblongis, oblongo-ovoideis, vel ellipsoideis, $32-64 \times$ $26-36 \mu$, amœene castaneis, junioribus hyalinulis intus flavidis crasse granulosis, utrinque rotundatis, apice leniter incrassatis, usque $7 \mu$ subpapiliforme, episporio tenui, levi, poro infero prope pedicello, superior in apicem; pedicello hyalino, usque $10 \mu$ crass., brevibus vel spores subæquantibus, usque $40 \mu$ long., nunquam longioribus. In foliis scapisque viviis Asphodeli albi, prope Llanes (Oviedo) Hispaniæ leg. claro mycologo P. Dr. L. M. Unamuno cui dicata species.

Damos en dibujos, según escala, picnidio, células peridiales y teleutosporas de esta especie. De las figuras en color de la lámina, las teleutosporas están representadas a escala triple que los dibujos en negro, y las hojas, tan sólo un tercio más que el natural.

\section{Explicación de la lámina IV.}

Trozos de hojas de Asphodelus albus atacadas de Pucciniu Unamurnoi sp, nov: Ecidiosporas, y teleutosporas (una joven y maduras las demás). Acuarelas de doña Luisa de la Vega. 


\title{
ESCENA PICTÓRICA CON REPRESENTACIONES DE INSECTOS DE ÉPOCA PALEOLITICA
}

\author{
POR \\ FRANCISCO HERNÁNDEZ-PACHECO
}

En el Boletin de nuestra Sociedad correspondiente al mes de febrero (1) se dió cuenta del descubrimiento de pinturas prehistóricas en Bicorp (Valencia) por el profesor de la Normal de Maestros de dicha ciudad D. Jaime Poch.

Con objeto de estudiar estas nuevas manifestaciones del arte paleolítico, la Comisión de Investigaciones Paleontológicas y Prehistóricas de la Junta para ampliación de estudios e investigaciones científicas organizó una expedición, compuesta por el profesor don Eduardo Hernández-Pacheco, como jefe; el Sr. Benítez Mellado, como auxiliar artístico, y el autor de esta nota, como auxiliar técnico; salió la expedición de Madrid para el lugar del descubrimiento en los primeros dias de julio, agregándosenos en Játiba el descubridor de las pinturas, Sr. Poch y Garí, el cual, por sus conocimientos del país, prestó valiosa ayuda para cumplir el fin de la expedición.

La copia y trabajos de campo relativos al conocimiento de las nuevas localidades pictóricas duró unas dos semanas, pues las pinturas son más numerosas de lo que en principio se creyó.

Los resultados obtenidos y la reproducción de las pinturas será objeto de una publicación especial por el jefe de la Comisión, don Eduardo Hernández-Pacheco, el cual me ha encargado para que, como avance a dicho estudio, dé a conocer un singular y original aspecto del arte pictórico paleolítico que se manifiesta en la nueva localidad, de las cuevas de la Araña.

La región en que están estas pinturas es en extremo accidentada, pues las calizas miocenas, algo inclinadas hacia el Norte, descansan sobre los conglomerados de base de dicho terreno o directamente

(1) Bol. R. Soc. Esp. de Hist. Nat., febrero de 1920. "Comunicaciones verbales», por E. HERNANDEZ-PACHECO, pígs. 58-61. 
sobre la caliza cretácica, la cual está más inclinada y en la misma dirección que las capas superiores. Toda la formación está dislocada por fallas sucesivas, formándose numerosos paredones, tajos y escarpes, pasando a veces bastante de los 60 metros de altura. Destácanse en las cumbres los cerros testigos, que forman lo que en esta región denominan muelas, o sea porciones de terreno destacadas del conjunto por escarpes circulares y con frecuencia difíciles de escalar. La base de toda esta formación es el Triásico, que a veces queda al descúbierto en el fondo de los barrancos y vaguadas. Encima de un tajo de éstos, denominado Salto de la Rebolla, y en un barranco que por él vierte sus aguas, es donde están las cuevas de la Araña.

Los sitios pintados son tres cavidades de la roca de escasa profundidad, sumando el total de figuras más de un centenar, componiendo diversas escenas, principalmente de caza. Son las pinturas de tipo levantino y análogas a las de Alpera (1), Charco del Agua Amarga (2) y sobre todo a las de Morella la Vella (3), con las que coinciden por su gran número, por su técnica, estilo y pequeño tamaño. Son abundantes las representaciones humanas y numerosos los animales figurados, dominando los ciervos, cabras, toros, caballos y algunos carnívoros, faltando los animales distintos a la fauna actual. Superpuestas a todas las figuras existen otras en extremo toscas y sin duda de una edad mucho más moderna. Entre las distintas escenas que figuran en el abrigo principal, hay una en extremo interesante, que da luz sobre la vida y costumbres de los hombres de aquellos tiempos. El color de las figuras es rojo ladrillo, que se destaca bastante bien sobre el fondo amarillo-rojizo de la roca, y sobre todo si ésta está humedecida.

De dos trazos gruesos juntos y horizontales en lo alto salen tres líneas finas y paralelas que descienden y cruzan por todo el lienzo de pared, estando de vez en cuando unidas unas a otras por cortos trazos horizontales; en la parte superior, y próximo a lcs dos trazos

(1) L'Anthropologie, t. XXIII, 1912, píg. 529. «es peintures rupestres d'Espagne. Les Abris del Bosque ì Alpera (Albacete), par II. Breull., P. Serrano Gómez et J. Cabré Aguiló.

(2) Com. Inv. Pal. y Preh. Mem. I. El Arte rupestre en España, piigina 529, lám. XI, por J. CABRÉ, 1915.

(3) Com. Inv. Pal. y Preh. Nota 1ti. Estudios de Arte prehistórico. Prospección de las pinturas de Morella la Vella, por E. HernínoEz-P'ACHECO, 1918. 
2

\&
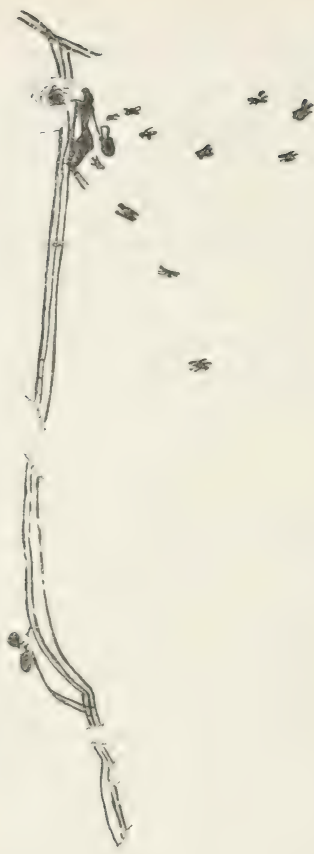

Fig. I. - Escena pictúrica en la cueva de la Araña. Escala I:4.

I

11 
gruesos, existe un pequeño agujero natural de la roca, por encima del cual pasan las líneas. A la altura de este agujero hay representado un hombre, alrededor del cual existen varias pequeñas figuras repartidas por la pared, que luego interpretaremos. Bastante más abajo hay otro hombre en contacto con las líneas (fig. 1).

Para la interpretación de dicha composición conviene advertir que en los altos tajos próximos a este sitio las abejas suelen anidar en las concavidades y quebradas de las peñas, y sucede a veces que si algunos de estos nidos no están muy difíciles de alcanzar, en la actualidad, aprovechando los frios días del invierno, los cogen para utilizar su miel.

Con esta advertencia es fácil interpretar lo que el artista quiso representar : dos hombres trepando por unas cuerdas, las cuales se sujetan a unos palos que en lo alto de un tajo están, a su vez, sujetos, se apoderan de un nido de abejas para aprovechar su miel. Para facilitar la ascensión han formado con las tres cuerdas, al unirlas unas a otras, una escala primitiva y rudimentaria.

El primer hombre, detenido a la altura del agujero, se sujeta a la escala con las piernas y se agarra con un brazo a una de las cuerdas; en el otro, que está extendido, tiene un recipiente, quizá un morral de piel, con un asa o agarradero patente y claro (fig. 2). Las pequeñas figuras, repartidas por la pared en número de diez y seis, las interpretamos como abejas volando, pues en algunas se distinguen claramente la cabeza, el abdomen, las patas y las alas en la actitud de vuelo.

El hombre que está más abajo, y que sube o baja, tiene un objeto a la espalda semejante al que tiene el otro, para de esta manera estar más libre en sus movimientos y poderse valer mejor de manos y pies. Las cuerdas, por la presión que hacen sobre ellas, se han desviado de la vertical, lo cual refuerza la opinión de que el hombre figurado en la parte inferior trepa por cuerdas.

Los dos hombres están desnudos y sin defensa aparente contra las picaduras de las abejas; pero sabido es que estos insectos en el invierno, adormecidos por el frío, son mucho menos molestos que durante los calurosos días del verano.

Repasando el conjunto de las pinturas rupestres, no encontramos escena alguna semejante a la que se acaba de describir; sin embargo, en localidad no lejana a ésta, en Alpera (cueva de la Vieja). existe una figura humana en contacto con un largo trazo vertical de color rojo, pintura que guarda cierta relación con las que he 
descrito (fig. 3) y que reproducimos aqui para su comparación. Es tan análogo el carácter de esta figura, que no dudo en conside-

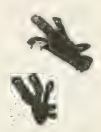

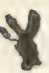

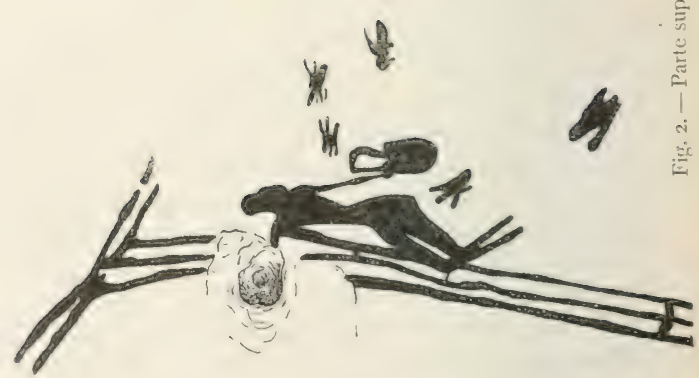

rarla contemporánea a las de la cuevas de la Araña, y a la cual Mr. H. BREulL da la siguiente interpretación al describir las figu- 
ras humanas de dicha localidad: «... un montant à tune cord (?) ou à un mât (?) dans l'attitud des Australiens qui gripent avec les mains et les pieds sans s'aider des genoux» (1).

EI Sr. CABRÉ (2) se ocupa por incidencia de esta misma figura, diciendo: «Estos animales representan cánidas de especificación no muy fácil, probablemente lobos, chacales o zorros, siendo significativo, por una parte, que cerca de uno de ellos se vea pintado un hombre subiendo a un árbol.»

No es de extrañar que se dude si es un árbol, una cuerda o un mástil, pues esta figura no se presenta tan clara como la de que tratamos, pues quizá pertenezca a una composición borrada o en parte desaparecida, y por tanto difícil de interpretar.

De todos modos, se ve que un hombre, en actitud muy parecida a los de Bicorp; sube por una cuerda o palo; en su cabeza se advierte un trazo horizontal, que pudiera ser un cubrecabezas, un adorno o también un objeto sujeto en la cabeza, para de esta manera quedar, como el otro, libre de manos.

En toda esta región abunda el esparto, planta que fácilmente se teje sin preparación previa; así es que no es extraño que estos hombres aprovechasen tan útil vegetal para tejer estas cuerdas, y no sólo esto, sino también gran número de utensilios por el estilo de los encontrados por GÓNGORA en la cueva de los Murciélagos (3), aunque éstos sean de una edad mucho más reciente.

Es la primera vez que de un modo indudable se figuran insectos en el arte paleolítico, probándonos además este hecho que existian abejas con el mismo desarrollo y costumbres que actualmente, lo cual contribuye a demostrar que las condiciones climatológicas y faunísticas eran muy semejantes a las actuales en la región.

(1) Loc. cit., 1912, paig. 551, fig. 3.

(2) Com. Inv. Pal. y Preh. Mem. I, 1915, píg. 193, figr. 90.

(3) Manuel de Góngora y MARtinez, Antigïedades prehistóricas de Andalucta, pág. 25, lám. I, 1868. 


\title{
NOTAS SOBRE ALGUNAS ESPECIES DE BRIOZ00S DE ESPAÑA
}

\author{
(ESPECIES DEL GOLFO DE VALENCIA)
}

POR

MANUEL GERÓNIMO BARROSO

Las especies de que doy cuenta en estas notas han sido determinadas separándolas de los materiales que me ha remitido nuestro consocio D. Enrique Rioja, bien conocido por sus esfuerzos en pro del conocimiento de la fauna marina y su distribución geográfica en nuestras costas.

La recolección de los citados materiales se efectuó durante el mes de agosto de 1919 en las regiones de Valencia, Denia y Castellón. La observación de todos ellos aun no está terminada, así como la de otros nuevos procedentes de Mahón, que serán objeto de notas sucesivas.

Electra verticillata Lamouroux, 1816.

1912. Electra pilosa, forma verticillata G. Barroso, Brioz. Est. Biol. mar. Santander, Trab. Mus. de Cienc. Nat., núm. 5, pág. 21.

Colonias procedentes de Castellón.

La $E$. pilosa (Linné) es uno de los briozoos más antiguamente señalados y que se presenta con numerosas variaciones, figurando en diversos trabajos como una forma de ésta la $E$. verticillata, que actualmente se separa como especie distinta.

\section{Eilectra monostacliys (Busk.).}

1919. Electra monostachys G. Barroso, Bol. R. Soc. Esp. de Hist. Nat., abril, pág. 200.

Colonias sobre zosteras procedentes de Valencia y Denia. 


\section{Callopora lineata (Limé).}

1912. Membranipora lineata G. Barroso, Loc. cit., pág. 20.

Tres colonias sobre algas procedentes de Valencia.

Flustra laciniosa nov. sp.? aut.

1902. Flustra papyracea, var. laciniosa Calvet, Bryoz. mar. de la reg. de Cette, pág. 2§, lám. I, fig. 4.

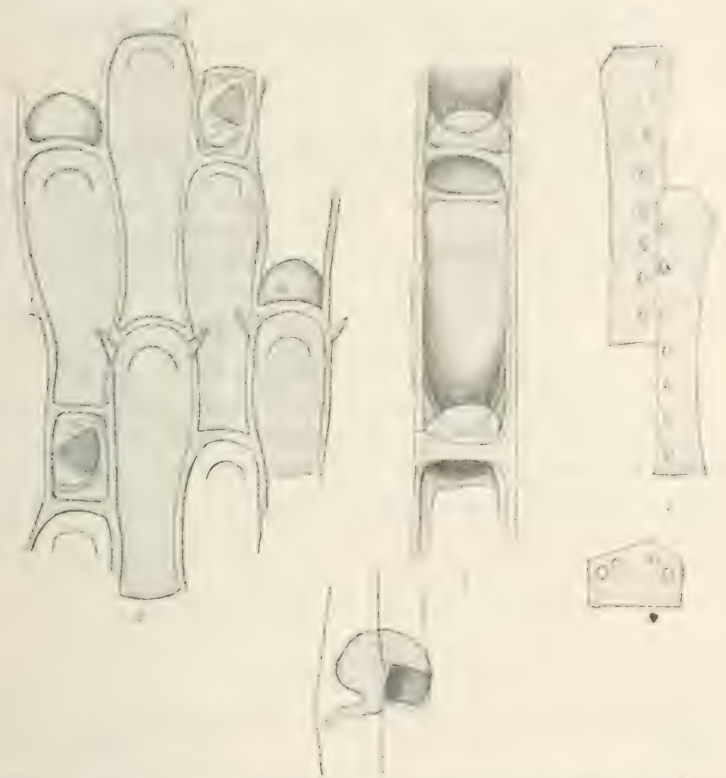

Fig. 1. - Rilustra laciniosa nov. sp. ? X $40 ; b$, zoccias desprovistas de la frontal membranosa mostrando las ovicelas; $c$, pared lateral de las zoccias.

Colonias procedentes de Valencia.

Se ha señalado en distintos puntos del Mediterráneo una especie de Flustra con el mismo porte de la $F$. securifrons Pallas, y con frecuencia clasificada como tal su sinónima $F$. truncata Linné por Heller (1867) e HiNCKS (1886) del Adriático, Waters (1879) 
de Nápoles, Calvet (1900) de Cette, Barroso (1912) de Valencia. Se habia hecho notar, sin embargo, la existencia de avicularias situadas oblicuamente y la presencia de espinas, carácter este último no conocido en la $F$. securifrons, y además en ésta las avicularias son elípticas y verticales. Esto indujo a CALvet (1902) a considerar estas formas como una variedad laciniosa de la $F$. papyracea Solander. Pero la forma típica de $F$. papyracea (abundante en Santander) no alcanza nunca las dimensiones de estos ejemplares mediterráneos, y la forma de las ramas es muy distinta en el extremo. No presenta tampoco avicularia, y las espinas son constantes.

Las principales diferencias podrían resumirse así :

\section{F. papyracea.}

Dimensiones hasta 4 ó $5 \mathrm{~cm}$. de altura, ramas ensanchadas en el extremo, de un modo apreciable.

Sin avicularias.

Dos espinas en los ángulos superiores de la zoecia, una a cada lado.

\section{F. laciniosa.}

Dimensiones hasta $8 \mathrm{~cm}$. de altura; ramas estrechas, apenas o nada ensanchadas en el extremo.

Con avicularias esparcidas en ambas caras de la colonia y dispuestas oblicuamente.

Accidẻntalmente dos pequeñas espinas en la parte superior.

El conocimiento exacto de la ovicela en su constitución y músculos operculares con sus relaciones podria resolver las dudas acerca de la separación de estas especies. Como esto exige preparaciones especiales y materiales en condiciones, a ser posible en fresco, más adelante intentaré insistir sobre esta cuestión.

\section{Scrupocellaria reptans (Limé).}

1912. Scrupocellaria reptans G. Barroso, Loc. cit., págs. 12 y 61.

Abundantes colonias de Benicásim (Castellón), Valencia y Denia (Alicante).

Los ejemplares presentan una notabilísima reducción de la espina interna opercular, reducida a una sola bifurcación.

\section{Scrupocellaria scrupea Busk.}

1912. Scrupocellaria scrupea G. Barroso, Loc. cit., págs. 13 y 61.

Varias colonias de Valencia. 


\section{Scrupocellaria scruposa (Linné).}

1912. Scrupocellaria scruposa G. Barroso, Loc. cil., pág. 12.

Colonias de Castellón y Valencia, las de la última procedencia recogidas en la pesca del bou.

\section{Cabcrea Boryi (Audouin).}

1912. Caberea Boryi G. Barroso, Loc. cit., pág. 13.

Fragmentos de colonias con otros briozoos de Valencia.

Bugula neritina (Linné).

1912. Bugula neritina G. Barroso, Loc. cit., págs. 14 y 61.

1915. - - G. Barroso, Bol. R. Soc. Esp. de Hist. Nat., octubre, pág. 413.

Numerosas colonias de Valencia y Denia.

Bugula avicularia (Linné).

1912. Bugula avicularia G. Barroso, Loc. cit., págs. 15 y 62 .

1915. - - - G. Barroso, Loc. cit., pág. 414.

Colonias de Valencia.

Bugula calathus Norman.

1912. Bugula calathus G. Barroso, Loc. cit., pág. 15.

Varias colonias sobre Watersipora cucullata de Valencia.

Cellaria Johnsoni Busk.

1917. Cellaria Johnsoni G. Barroso, Bol. R. Soc. Esp. de Hist. Nat., octubre, pág. 495.

Fragmentos de colonias procedentes de Castellón.

\section{Cellaria fistulosa (Limné).}

1912. Cellaria fistulosa G. Barroso, Loc. cit., paigs. 23 y 62 .

Abundantes colonias de Castellón y Valencia. 


\section{Puellina radiata (Moll.).}

1912. Cribrilina radiata G. Barroso, Loc. cit., pág. 22.

1917. Puellina radiata G. Barroso, Loc. cit., pág. 495.

Colonias sobre algas de Valencia.

Puellina Gattya (Busk.) var. balcarica G. Barroso.

1919. Puellina Gattyc, var. balearica G. Barroso, Bol. R. Soc. Esp. de Hist. Nat., julio, pág. 340.

Colonias sobre algas de Valencia y Benicásim (Castellón).

\section{Chorizopora Brongniarti (Audouin).}

1912. Chorizopora Brongniarti G. Barroso, Loc. cit., pág. 31.

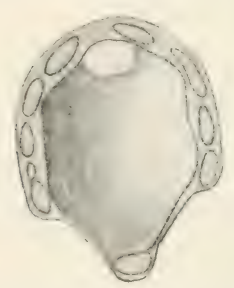

ut

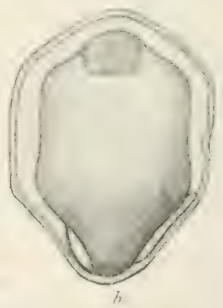

Fìr. 2-Chorizopona Brongniarti (Audouin), ancéstrula; a, lado dorsal; $b$, lado frontal, $\times$ roo.

Colonias sobre algas de Valencia.

Schizoporella longirrostris Hincks.

1915. Schizoporella unicornis, forma longirrostris G. Barroso, Loc. cit., pág. 416 .

1917. Schizoporella longirrostris G. Barroso, Loc. cit., paig. $490^{\circ}$

Abundantes colonias de Castellón. 
Schizoporella unicornis (Johnston).

1912. Schizoporella unicornis G. Barroso, Loc. cit., pág. 37.

1918. - - G. Barroso, Bol. R. Soc. Esp. de Hist. Nat., noviembre, pág. 409 .

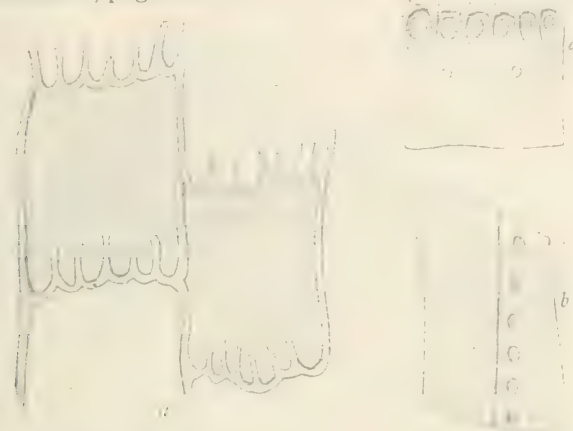

Fig. 3.-Schizoporella tunicomis (Jolnston); a, zoecias vistas por el lado dorsal; $b$, pared lateral de una zoecia; $c$, pared distal.

Abundantes colonias de Valencia.

Schizoporella sanguinea (Norman).

1912. Schizoporella sanguinea G. Barroso, Loc. cit., págs. 38 y 63.

1915.

G. Barroso, Loc. cit., pág. 417.
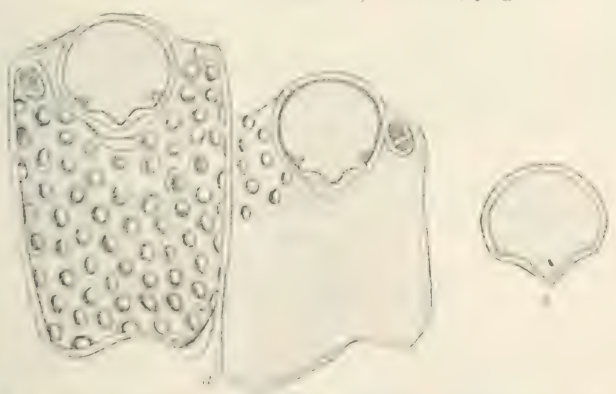

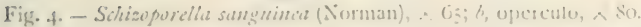

Colonias de Valencia. Muchas zoecias carecen de avicularias, y en algunas existe una pequeña, casi eliptica, a un lado del orificio. 


\section{Hipodiplosella Pallasiana (Moll.).}

1912. Lepralia Pallasiana G. Barroso, Loc. cit., pág. 32.

1917. Hipodiplosella Pallasiana G. Barroso, Loc. cit., pág. 497.

Fragmentos de colonias de Valencia y Denia.

\section{Microporella ciliata (Pallas).}

1912. Microporella ciliata G. Barroso, Loc. cit., pág. 26.

1915. - - - G. Barroso, Loc. cit., paig. 415.

1917. - _ G. Barroso, Loc. cit., pág. 497.

Colonias sobre algas de Denia.

Microporella Malusi (Audouin).

1912. Microporella Malusi G. Barroso, Loc. cit., pág. 27.

Colonias sobre algas de Valencia.

\section{Watersipora cucullata (Busk.).}

1917. Watersipora cucullata G. Barroso, Loc. cit., pág. 498.

Colonias con Bugula calathus sobre Schizoporella unicornis de Valencia. Otras con Bugula neritina de Denia.

Son frecuentes pronunciadas inflexiones en las colonias, correspondiendo a ellas zoecias muy deformadas (véase fig. 5).

Tubucellaria cereoides (Ell. y Sol:).

1917. Tubucellaria cercoides G. Barroso, Loc. cit., píg. $49 \mathrm{~S}$.

Colonias de Castellón.

En ocasiones se ha puesto esta especie como sinónima de Tubucellaria opuntioides (Pallas), figurando asi en el Catálogo de Mss. Jelly; pero Levinsen (1909) indicó que debian separarse, hecho señalado también por OsBurn (1914). En 1917, CANU ha pretendido facilitar la distinción entre las principales especies del 
género Tubucellaria, y establece una nueva, T. mediterranea, fundándose sobre todo en la longitud de los segmentos $(2,5 \mathrm{~cm}$.) y de las zoecias $(1,5 \mathrm{~mm}$.$) . Nuestros ejemplares son muy parecidos a$ las figuras de CANU, pero no alcanzan las dimensiones citadas.

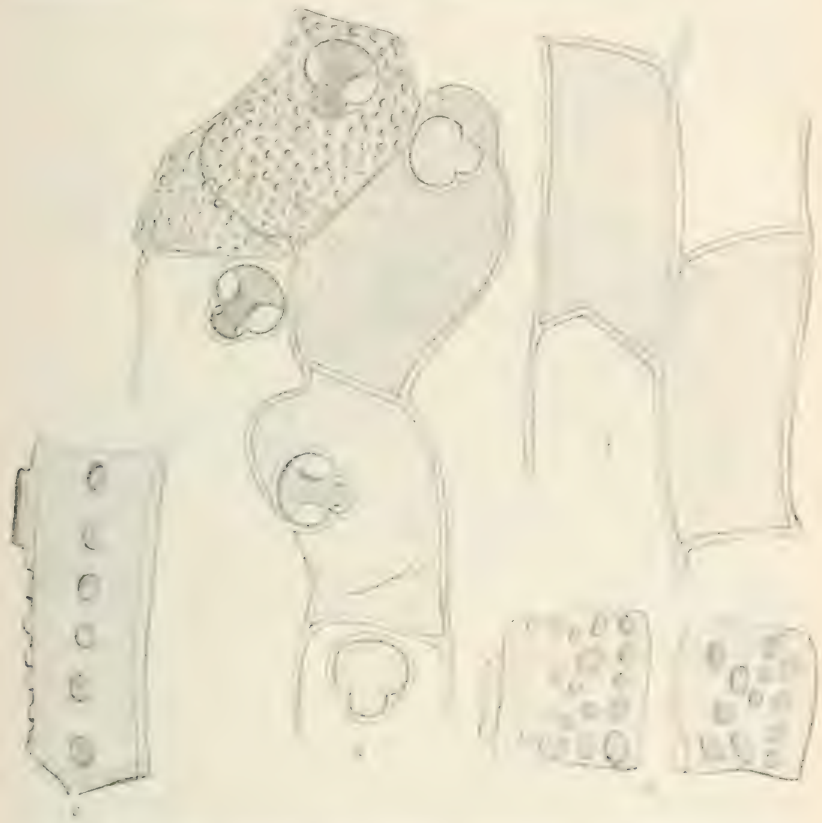

Fig. 5.- Whatersipora cucullath (Dusk.), zoccias deformadis correspondientes a inflexiones de la colonia, $x \neq 0 ; b$, zoecias vistas nor el lado dorsal; ci pared lateral de una zoecia; $d$, paredes distal y proximal.

Cellepora armata Hinchs.

1917. Cellepora armata G. Barroso, Loc. cit., pig. 499.

Varias colonias de Valencia. Como particularidades presentan las de poseer en los contornos de muchas zoecias algunos poros areolados y ser escasas las grandes avicularias espatuladas interzoeciales. 
Lelsythopora robusta nov. sp.

Una pequeña colonia sobre algas de Valencia.

Colonia incrustante, con las zoecias urceoladas o irregulares, sólidamente calcificadas y marcadamente verrucosas, desprovista de perforaciones. Orificio primario con un anter semicircular y un poster prolongado en un pronunciadísimo seno, llevando en su origen dos dentículos a cada lado y entre ellos una escotadura.

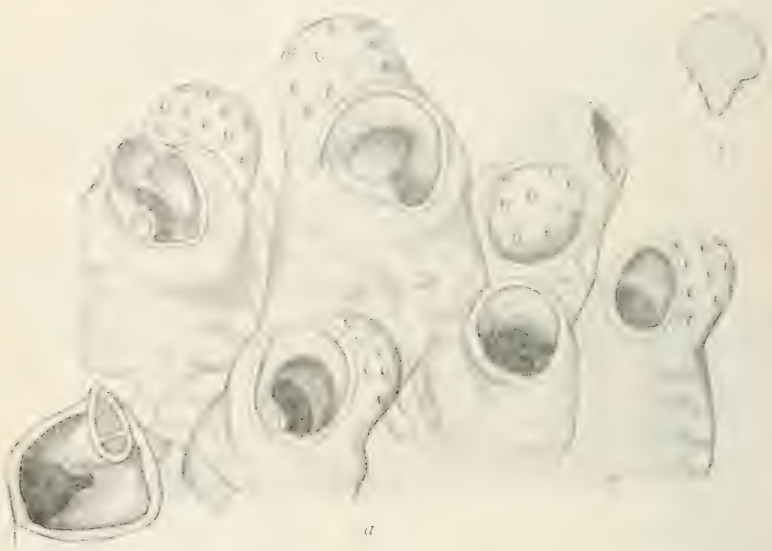

Fig. 6. - Lykethopora robusta nov. sp.; $a$, zoecias, $\times$ So; $b$, orificio primario, $\times$ so.

Alrededor de este orificio primario se desarrolla un fuerte peristoma tubuloso, con una avicularia proximal, que raramente falta, resultando a veces alojada del todo en el interior del tubo peristomático.

Ovicelas peristomiales suborbiculares, con poros dispuestos con alguna regularidad. En el caso de conservarse completo el peristoma, forman las ovicelas un saliente en la parte frontal de él.

Crisia geniculata (Milne-Edwards).

1912. Crisia geniculata G. Barroso, Loc. cit., pág. 50.

Colonias sobre algas de Valencia. 
Crisia eburnea (Linné).

1912. Crisia eburnea G. Barroso, Loc. cit., pág. 49.

Abundantes colonias de Valencia.

Stomatopora major (Johnston).

1912. Stomatopora major G. Barroso, Loc. cit., pág. 51 .

Colonias frecuentes sobre algas de Valencia.

Tubulipora liliacea (Pallas), 1766.

1766. Millepora liliacea Pallas, Elenchus zoophytorum, pág. 248.

1875. Tubulipora serpens Busk.

1880. Idmonea serpens Hincks.

1886. Tubulipora serpens Smitt.

1898. Tubulipora liliacea Harmer.

1902 y 1906. Idmonea serpens Calvet.

1912. Idmonea serpens G. Barroso.

1912. Tubulipora liliacea Osburn.

1917. Reptotubigera serpens Canu.

1918. Tubulipora liliacea Nordgaard.

Los briozoologistas del siglo XIx han llamado a esta especie Tubulipora serpens, cuyo nombre resulta clásico, por lo cual CANU propone respetarlo, a pesar de las reglas de prioridad.

La interpretación de las figuras antiguas ofrece muchas veces extraordinarias dificultades para determinar los briozoos. Fué HaRMER (1898) quien reconoció esta especie como la Tubulipora liliacea (Pallas), y no la Tubulipora serpens Linné, 1758.

Una colonia de Castellón.

\section{Diastopora patina (Lamarck).}

1912. Diastopora patina G. Barroso, Loc. cit., pág. 54.

1915. - - G. Barroso, Loc. cit., pig. 419.

Colonias de Valencia y Castellón. 


\section{Lichenopora hispida (Fléming).}

1912. Lichenopora hispida G. Barroso, Loc. cit., pág. 59.

Colonias de Castellón sobre Cellaria fistulosa. Otras sobre algas.

\section{Amathia lendigera (Linné).}

1766-1768. Sertularia lendigera Linné. Syst. Nat., pág. 1311.

1880. Amathia lendigera Hincks. Brit. mar. Polyz., pág. 516, lám. 74, figs. 7-10.

1889. Amathia lendigera Jelly, Syn. Cat. mar. Bryoz., pág. 11.

Colonias de Benicásim (Castellón).

Citada por primera vez de las costas españolas. Especie muy extendida en el Mediterráneo, señalada por varios autores de diversas localidades. También de las costas inglesas, SO. de Francia, islas Azores y África del Sur.

\section{Amathia semiconvoluta Lamouroux.}

1821. Amathia semiconvoluta Lamouroux, Encycl. met. Zooph., pág. 44. 1889. - - - Jelly, Syn. Cat. mar. Bryoz., pảg. 13.

Colonias de Valencia. Citada por primera vez de las costas españolas.

Especie señalada en el Mediterráneo (LAMouroux), mar Toscano (Richiardi), Nápoles (Waters), región de Cette (CAlvet) y Adriático (Stossich, Vidovich).

Bowerbankia pustulosa (Ellis et Solander).

1912. Bowerbankia pustulosa G. Barroso, Loc. cil., pág. 8.

Colonias de Valencia. 


\title{
NOTA SOBRE UN HIMENÓPTERO GINANDROMORFO
}

\author{
POR
}

\section{GONZALO CEBALLOS}

Aunque de relativa frecuencia, sobre todo en los lepidópteros, son siempre los ginandromorfos unos curiosos insectos, aun considerando simplemente su extraño aspecto, ya que si estudiamos detenidamente el caso biológico que representan, aumenta el interés que nos ofrecen, por llevarnos directamente al esclarecimiento de los intimos problemas de la fecundación.

Considerados desde el punto de vista de sus formas, el aspecto exterior del insecto ginandromorfo resulta de la combinación de casos diversos de dos cuestiones diferentes: la primera, que pudieramos llamar modalidad del ginandromorfismo, se refiere a la repartición de las zonas $\delta$ y $q$ en cada ejemplar; la segunda consiste en la diferencia más o menos notable que respecto a caracteres sexuales secundarios tengan los dos sexos de la especie estudiada. Desde el primer punto de vista, el ginandromorfismo puede ser lateral (lidu derecho $q$ e izquierdo $\sigma^{\star}$, o viceversa), dorsoventral (plano dorsal $\&$ y ventral $\sigma$, o viceversa), frontal (cabeza y abdomen $f$ y tórax $\sigma$, etc.), y puede haber, finalmente, ejemplares llamados ginandromorios en mosaico, en los que salpicadamente. sin limitacion definida, existen zonas de $\quad y$;. Se comprende fácilniente que lon casos de ginandromorfismo lateral, en especies de gran dimorfismo sexual externo, son los más bonitos y chocantes, pues los otros tres casos pueden pasar muchas veces inadvertidos sin un detenidisimo estudio.

No se reducen las manifestaciones de esta anomalía de fecundación al aspecto exterior del insecto; existen, sin duda, en los órganos internos de la generación diferenciaciones laterales que le convierten en una especie de hermafrodita estéril, ya que, probablemente, ni podrá copular con uno u otro sexo, ni será posible en él la autofecundación. Aunque de estos ejemplares, dado su es- 
caso número, no suele hacerse una disección encaminada a dilucidar estas cuestiones de anatomía interna, basta observar la asimetría terminal del abdomen para comprender que las armaduras genitales están constituidas respondiendo a una diferenciación profunda de los órganos reproductores.

Diversas hipótesis se han emitido respecto a la causa intima del ginandromorfismo; en resumen pueden referirse a dos puntos de vista diferentes: según MORGAN, el fenómeno se debe a que el insecto proviene de un huevo dispérmico, esto es, que un segundo espermatozoide logra entrar en el huevo cuando ya el primero se

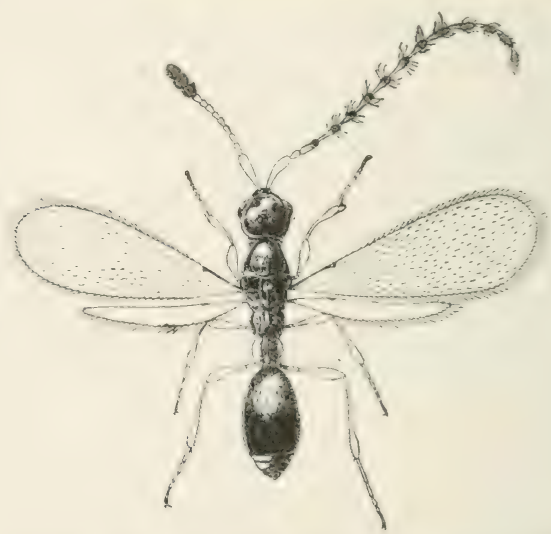

Fig. I. - Loxotropa sulata Kieff., ginandromorfo lateral; lado derecho, macho; lado izquierdo, hembra.

ha fusionado con el núcleo $q$ y han empezado a dividirse; el embrión contendrá, pues, productos de la división de dos núcleos, uno de los cuales poseía cromatinas ơ y $q$, y el otro solamente cromatina ơ ; según Boverı, la causa del fenómeno es la tardía segmentación del núcleo del espermatozoide único; supone el autor que la paranucleina, localizada en el llamado cuello del espermatozoide, basta para provocar, uniéndose al nuicleo 9 , la segmentación; el nucleo ơ , fundiéndose posteriormente con el de uno de los blastómeros formados, imprimiría en esta zona caracteres sexuales diferentes de la que 
no posee sino nucleina $f$. Ambas opiniones parecen haber tenido la misma aceptación por parte de los biólogos.

El ejemplar que ha motivado esta nota es un precioso caso de ginandromorfismo lateral observado en el proctotrípido Lo.rotropu sulcata Kieff.; dado el gran dimorfismo sexual que existe en los géneros de la subfamilia Diapriinae, la asimetría es muy patente y notable; aparte de la diferente constitución de las antenas, puede observarse en el dibujo la mayor longitud de las patas y alas del lado derecho $(\circlearrowleft)$ con relación a las del izquierdo ( $(x)$, asi como la marcada diferencia de los órganos terminales de las tibias anteriores, y de los metatarsos correspondientes; la segmentación del abdomen también es anormal en la extremidad, dejando casi apreciar una diferenciación lateral de las armaduras copulatrices.

Este precioso insecto fué cazado por D. Ignacio Bolívar en Villa Rutis (La Coruña).

\section{NOTAS CARPOLÓGICAS}

POR

\section{BLAS LÁZARO E IBIZA}

Aunque desde tiempo muy antiguo se ha prestado atención a los frutos de las plantas como órganos de los más típicos que pueden utilizarse para la distinción y característica de las especies vegetales, y aunque en los últimos tiempos los progresos de la Fitografía han hecho avanzar el estudio científico de estos órganos de un modo tan considerable que la clasificación que de ellos se admite en las obras modernas la creemos tan perfecta y sólidamente establecida que en sus leyes fundamentales no vacilamos en considerarla definitiva, no creemos que esta materia esté agotada, ni mucho menos. Pensamos que la crítica puede mejorarla en ciertos puntos secundarios, purgándola de algunos defectos y llevando a su tecnicismo mayor rigor y precisión, para que no sigan confundidos y designados bajo un mismo nombre casos que por su naturaleza y constitución son realmente diversos, y a ello van encaminadas nuestras observaciones.

En la Carpología antigua se dieron nombres propios a algunos 
frutos que han resultado luego meras variantes de otros tipos admitidos en las clasificaciones modernas, y que por referirse a plantas notables no sólo han conservado sus nombres, sino que siguen admitidos como tipos diversos, aunque en realidad no lo sean. Por otra parte, frutos de constitución muy diferente continúan designándose con la misma denominación, sin otra razón para ello que la de que los primitivos observadores, guiados sólo por apariencias externas, no supieron darse cuenta de las diferencias que ofrecia la constitución de unos y de otros.

Así, por ejemplo, mientras se reconocieron como tipos los llamados eterios, que no son otra cosa que los poliaquenios de las rosáceas, y el cinarrodon de los rosales, que también es un poliaquenio del género tipo de las mismas rosáceas, se vienen designando con el nombre de baya frutos tan diversos, que unos son monocárpicos, como el del agracejo; otros sincárpicos y de carpelos cerrados, como el de las solanáceas y el de las uvas, y otros son sincárpicos también, pero originados por carpelos abiertos, como los de las pasionarias.

De igual manera el fruto llamado glande no es específicamente diverso de los aquenios, aunque por su tamaño, por su forma típica y sobre todo por la cúpula que le acompaña y le envuelve en más o menos parte, creyeran los antiguos que debiera considerársele como un tipo carpológico, y por ser también el fruto típico de las encinas, de los robles, de las coscojas, de los alcornoques y demás especies del género Quercus, tan importantes en nuestros bosques. No es lógico distinguir un tipo carpológico por un órgano que, como la cúpula, no corresponde al fruto; como no se han admitido como tipos carpológicos los de las hayas y castaños, aunque sus cúpulas no sean menos notables. En realidad todos estos frutos de las cupuliferas son realmente aquenios, aunque de mayor tamaño que los de otros géneros de la misma familia, como los de los carpes u hojaranzos, a los que nadie regatea aquel nombre, pues en realidad el tamaño no sirve nunca de diferencial en los tipos carpológicos, y así como hay bayas grandes y chicas y pepónides pequeños, grandes y grandísimos, puede haber aquenios pequeños, medianos y grandes.

No menor anarquia se advierte en el empleo del nombre drupa, que unas veces se aplica a los frutos monocárpicos, que teniendo su capa media carnosa, sarcocarpio, y su capa interna de consistencia más o menos leñosa, fueron originados por un solo carpelo cerrado, 
como los de las amigdaláceas; otras a frutos sincárpicos constituidos por dos carpelos cerrados (oleáceas), por tres y aun cinco carpelos cerrados (ramnáceas), y aun por carpelos abiertos no pocas veces.

No pretendemos que los nombres innecesarios antes mencionados, habiéndose usido durante tan largos años, sean recosidu- pero sí que se consideren como meras variantes dentro del tipo carpológico a que realmente correspondan. Tampoco intentamos que todos los casos en que haya una diferencia en la constitución de los frutos se erijan en tipos, sino cuando esta diferencia afecte fundamentalmente a la constitución del fruto. Lo contrario sería complicar el tecnicismo, sembrando pródigamente y sin discreción neolorismos innecesarios.

Tampoco examinaremos en estas notas todas las variaciones de que los frutos son susceptibles, pues esto exigiría un espacio enorme, y nuestra pretensión se limita a rectificar un cierto número de casos en los que la impropiedad del empleo de determinadas voces técnicas es harto evidente, y sólo propondremos el de algunas nuevas en aquellos casos en que sean absolutamente necesarias.

La división de los frutos en monocárpicos o simples, policárpicos o múltiples y sincárpicos o compuestos está tan claramente definida y se acomoda tan perfectamente a los tipos de constitución que la Naturaleza nos ofrece, que entendemos que esta división primaria no podria ser mejorada en ningún concepto ni necesita de aclaraciones. A lo sumo, la separación de los policárpicos y sincárpicos podría ofrecer duda en algún caso, porque la soldadura de los diversos carpelos en los últimos puede presentarse en grados muy diversos, descle el caso en que nada acusa al exterior la composición del fruto, hasta aquellos otros en que sin seccionar el fruto se puede contar el número de carpelos que le constituyen.

Así, por ejemplo, en un hesperidio, en una baya esférica, en un pepónides de sección circular (melón, sandia, etc.), nada hace acusar al exterior el número de carpelos que lo forman, ni si éstos son abiertos o cerrados; pero en una caja de liliácea, por ejemplo, se acusan manifiestamente los tres carpelos consiguientes, o en un fruto constituido por tres carpelos monospermos e indehiscentes de aquellos para los cuales propondremos el nombre de rinaquenios, como el de las capuchinas o el de la olivilla, se acusan claramente los tres carpelos constituyentes.

Tales casos puede decirse que constituyen una transición de los 
frutos sincárpicos a los policárpicos, sobre todo si la soldadura de los carpelos no tiene lugar más que en el ángulo interno de éstos, apareciendo libres en el resto de su superficie; mas aun así entendemos que esta división tiene siempre un significado preciso y absoluto, pues siempre que entre los carpelos procedentes de un mismo género exista soldadura en grado mayor o menor, el fruto será sincárpico, y para ser policárpico, los carpelos deberán estar absolutamente libres, y aunque se hallen apretados no han de presentar coherencia alguna entre sí.

Hecha esta aclaración, expondremos ordenadamente los diversos casos a que estas observaciones se refieren.

\section{Aquonios.}

Aun tratándose de frutos tan definidos, éstos pueden ser de dos clases, según su origen y constitución. Unas veces provienen de un solo carpelo cerrado y uniovulado, que es el caso general y al que realmente se refiere la calificación de los aquenios como frutos monocárpicos, y otras proceden de dos o tres carpelos abiertos y soldados entre sí en la región ovárica, formando un ovario unilocular y uniovulado, en el que el número de carpelos se reconoce por hallarse éstos libres en la porción estilar (compuestas, paroniquiáceas, poligonáceas, quenopodiáceas) y aun de cinco carpelos en las mismas condiciones (Statice, Armeria).

Para el clasificador que observe el estado definitivo de uno de estos frutos, el resultado podrá parecer idéntico, pues sólo observa un fruto en apariencia sencillo, seco, indehistente, monospermo, en el que el pericarpio se aplica sobre la semilla sin soldarse con ésta; pero si nos remontamos al origen del órgano, veremos que en el primer caso el fruto es realmente monocárpico, y en el segundo es en realidad sincárpico, por lo que proponemos que el primero de estos frutos se denomine sencillamente aquenio, y el segundo se designe con el nombre de aquenio sincárpico.

Casos hay también dudosos entre el aquenio y la drupa, por ser la carnosidad del mesocarpio tan poco acentuada, que puede desecarse sin experimentar descomposición. Así sucede que en familias en que es normal el fruto aquenio, por ejemplo, en las quenopodiáceas, algún género, como el Blitum, lo presenta débilmente carnoso, y en tal caso debe calificarse siempre de drupa. 


\section{Drupas.}

De igual manera que en los aquenios, en las drupas pueden distinguirse dos casos diversos por su constitución y origen, pues mientras las v́erdaderas drupas proceden siempre de un solo carpelo cerrado y con frutos verdaderamente monocárpicos, otras lo hacen de dos carpelos cerrados y soldados entre sí, y constituyen, por tanto, frutos realmente sincárpicos, como ocurre con los de las oleáceas; y por si esto fuera poco, se lee con frecuencia en las obras fitográficas el nombre de fruto drupáceo sin definir su naturaleza, lo que engendra no pocas confusiones. Como el lenguaje fitográfico no puede ser preciso y exacto cuando se forma con desprecio o desconocimiento de la Organografia, ni ésta puede tener realidad sino cuando distingue todos los casos que la Naturaleza nos presenta, y únicamente éstos, no todos los que la razón pudiera sugerirnos como teóricamente distintos, creemos que tales discrepancias entre el lenguaje técnico de la Fitografía, las nociones organográficas tienen que desaparecer, unificándose así el significado y valor de las voces técnicas empleadas por los botánicos.

Puede calificarse de drupáceo todo fruto que tenga las condiciones esenciales de la drupa, esto es, un mesocarpio más o menos carnoso, y un endocarpio leñoso, o por lo menos endurecido o fibroso. Pero dentro de estas condiciones distinguiremos el fruto monocárpico o verdadera drupa, del cual es tipo el de las amigdaláceas de los frutos de origen sincárpico, y aun dentro de estos últimos podremos considerar dos casos, según sus carpelos constituyentes sean de los llamados abiertos o cerrados.

Cuando esté constituído por carpelos abiertos, caso del cual es tipo la nuez, y los frutos todos de las yuglandáceas, debe designarse con el nombre de nuculanio, nombre que ya ha corrido algo, aunque no todo lo que debiera, ni siempre con exacto empleo. Cuando el fruto drupáceo esté constituido por carpelos cerrados, proponemos que por analogia se designe con el nombre de drupilanio. Asi podremos considerar nuculanios no sólo los frutos de las yugrandáceas, sino también los de las miricáceas y los de algunas fumariáceas (Fumaria, Platicapnos, Sarcocapnos). Los drupilanios son mucho más numerosos, y de ello tenemos buenos ejemplos en las ramuáceas, empetráceas, cornáceas, ilicáceas, etc. 


\section{Foliculos.}

Entre los frutos monocárpicos secos y dehiscentes aparecen el folículo y la legumbre, frutos bien conocidos que sólo difieren por su dehiscencia, que en el primero se reduce a que los bordes de la hoja carpelar, que se habian unido para cerrar el carpelo, vuelven a separarse en la madurez para la diseminación, mientras que en el segundo, simultáneamente con esta dehiscencia, llamada ventral, se efectúa la dorsal, o sea la separación de las dos mitades de la hoja carpelar, por hendirse ésta hasta su base por su nervio medio.

Ambos frutos pueden ser alguna vez carnosos, siendo en este caso indehiscentes las legumbres; mientras que cuando el folículo tiene sus paredes carnosas es perfectamente dehiscente en dos valvas, no sólo en su endocarpio, como suele ocurrir en alguna variante de las drupas, sino en su epicarpio, sarcocarpio bastante grueso y endocarpio. El mejor ejemplo que en toda la serie vegetal hallamos de esta clase de frutos, para los que proponemos el nombre de sarcofoliculo por su carnosidad, es el que nos ofrecen la nuez moscada y demás especie del género Myristica. Este fruto no puede referirse a una drupa que fuese dehiscente en todas las capas de su pericarpio, porque para ser considerado como tal, habria de tener un endocarpio grueso, duro y leñoso, o por lo menos muy fibroso, condición que le falta en absoluto, pues su endocarpio está reducido a una capa membranosa muy tenue.

\section{Sámara y samaridio.}

También el nombre de sámara se ve a veces empleado con evidente impropiedad, pues si el fruto así llamado ha de ser necesariamente un fruto mesocárpico, no resultará propio el empleo de este nombre en los casos en que sea originado por dos o más carpelos.

Así, las sámaras del olmo son verdaderas sámaras, pues aunque en un principio en las ulmáceas como en todas las familias del orden de las urtícidas, se inician dos carpelos cerrados en el gineceo, sólo uno de ellos llega a desarrollar su región ovárica. De igual manera, las sámaras del género Ptelea, de la familia de las rutáceas, son verdaderas sámaras, por deberse su formación a un solo carpelo; no asi las de los fresnos, que están constituidas por dos carpelos cerrados, y no son, por lo tanto, frutos monocárpicos, sino sincár- 
picos. Para todos los frutos de aspecto de sámara, pero originados por dos o más carpelos, debe emplearse como nombre propio el de samaridio, que no es nuevo, pero que debe quedar reservado exclusivamente para este caso, en vez de usarse indistintament. para estos frutos sincárpicos y para los policárpicos constituídos por sámaras, o sean los llamados propiamente polisámaras.

\section{Poliaquenios.}

Definidos estos frutos múltiples por estar constituidos por aquenios resultantes de una sola flor, debemos tener presentes las indicaciones antes hechas respecto de estos frutos, y sólo considerar como poliaquenios aquellos en que los aquenios están sobre un receptáculo, sea éste seco, como en las clematídeas, anemóneas, ranuncúleas, y en los casos particulares llamados eterios de las rosiceas, sea carnoso, como el de las fresas y fresones, o sea grande y hueco, como en el caso particular del cinarrodon de los rosales, y en el muy semejante a este último en su origen y morfología del género Calycampnus.

Por los ejemplos citados se ve que no carece de variantes este tipo de los frutos múltiples, y aun podrian distinguirse otras variaciones del mismo, como las que presentan los aquenios verticilados (málveas, Alisma, etc.); pero no creemos conveniente complicar la nomenclatura designando con un nombre propio cada uno de estos casos, aunque no pretendamos la supresión de los ya antiguos y vulgarizados (eterio y cinarrodon), que tampoco tiene razón de ser.

\section{Polidrupas.}

En trabajos anteriores hemos empleado ya esta voz para designar los frutos múltiples de las zarzas, frambuesas y demis especies del género Rubus.

Esta voz técnica, que creemos haber sido los primeros en proponer y emplear, ni puede ser más adecuada ni más en armonía con la nomenclatura de Ins demás frutos múltiples, puesto yue sus componentes son en realidad drupitas numerosas. 


\section{Sinaquenios.}

Cuando el fruto en apariencia múltiple, por ostentar claramente el número de carpelos que le forman, presenta éstos soldados entre sí, en una extensión apreciable, aunque estos componentes tengan todas las condiciones y caracteres de los aquenios, el fruto total no puede ya calificarse de .poliaquenio, puesto que para serlo es condición indispensable que los aquenios estén libres, es decir, que no exista adherencia o soldadura parcial entre ellos. Así, por ejemplo, los frutos de las capuchinas (Tropceolum) y de la olivilla (Cneorum) constan de tres carpelos secos, indehiscentes y monospermos; pero nadie puede calificar tales frutos de triaquenios porque los carpelos presentan extensas soldaduras entre sí. Pero si :.o son poliaquenios ni ninguna clase de frutos múltiples, sino verdaderos frutos sincárpicos, es evidente la necesidad de admitir un nuevo tipo de frutos sincárpicos al cual puedan referirse los ejemplos citados y todos los demás casos en que el fruto se componga de aquenios soldados entre sí. Para este caso proponemos el nombre. de sinaquenio, que expresa claramente su constitución.

\section{Sinfoliculo.}

De igual manera que hemos distinguido de los poliaquenios los sinaquenios, habremos de distinguir de los polifolículos, que son frutos necesariamente múltiples, es decir, que tienen los folículos no entresoldados, aquellos otros casos en que teniendo los carpelos la dehiscencia y demás condiciones de los folículos, por encontrarse ampliamente soldados entre sí, su conjunto constituye un verdadero fruto sincárpico. Así, en las ranunculáceas de las tribus de las helebóreas y delfineas existen frutos que son incuestionablemente polifolículos: Helleborus, Aconitum, Paonia, Aquilegia, Delphinium, etc.; pero en el género Nigella los foliculos están soldados en tanta extensión, que constituyen verdaderos frutos sincárpicos. Esta soldadura llega a ser tan extensa en algunas especies del mencionado género (Nigella Damascana), que para no calificar de caja el fruto asi formado, tenemos necesidad de observar que los carpelos conservan la dehiscencia folicular.

Para frutos de esta condición proponemos el nombre de sinfolículo. 


\section{Sinsámara.}

Del mismo modo que hemos separado el fruto sámara, monocárpico, del samaridio, fruto sincárpico por estar formado por más de un carpelo, pero que conserva la morfología externa de una verdera sámara, debemos distinguir de la polisámara, fruto múltiple, el caso de los frutos sincárpicos, en que el dorso de sus carpelos presenta una aleta bien desarrollada, como ocurre con los frutos de los Melianthus, en las zigofiláceas. Estos frutos se han calificado de cajas por algunos autores; pero entendemos que siendo los frutos de este último nombre excesivamente complejos y variados, hasta el punto de que, como luego veremos, se necesita hacer una verdadera clasificación del tipo de los frutos cajas, no conviene complicar más las variantes de dicho fruto incluyendo en él el que es realmente el caso que entre los sincárpicos corresponde al policarpo, llamado polisámara. Para esta clase de frutos, que, además del ejemplo citado, se presenta en algún género de terebintáceas exóticas y de dipterocarpáceas, proponemos el nombre de sinscimara.

\section{Cajas y cápsulas.}

En todos los frutos sincárpicos interesa distinguir si los carpelos componentes son de los llamados abiertos o de los cerrados, detalle en que la antigua Carpología no había puesto atención, pero que actualmente se puede apreciar la condición de la situación de las placentas, parietales en general en los primeros y axilares en los segundos, y en los casos excepcionales puede haber placentación bacilar en los carpelos abiertos y alguna vez central en los cerrados. Prácticamente puede apreciarse no sólo si los carpelos son de una u otra condición, sino hasta el número de ellos que entran en la composición del fruto, por el número de placentas en los de los carpelos abiertos, y por el número de celdas en los de los carpelos cerrados.

Aunque esta distinción sea hoy tan fácil de hacer, es lo cierto que la nomenclatura carpológica ha designado hasta hoy a todos estos frutos sincárpicos, secos y dehiscentes, indistintamente con los nombres de cajas o cápsulas, estimados como sinónimos, no obstante el sinnumero de variantes que ofrecen, por la constitución de 
sus carpelos, por sus tipos de placentación y sobre todo por sus diversas dehiscencias. Resulta de esto que decir de un fruto que es una caja, es un concepto tan poco definido, que sólo equivale a decir que es sincárpico, seco y dehiscente. Para que esta anarquía termine, hemos de comenzar por aplicar una denominación diferente, según que los distintos carpelos estén cerrados o abiertos, cosa tanto más factible cuanto que ya existen dos nombres corrientes, y bastará con fijar bien el sentido de cada uno. Para esto proponemos que el nombre de caja se aplique a los frutos pluriloculares o constituidos por carpelos cerrados, y el de cápsula se reserve para los uniloculares, o sea los constituídos por carpelos abiertos, y en raro caso, por carpelos cerrados, cuyos tabiques se reabsorben prematuramente, cariofiláceas y portulacáceas.

Cajas y cápsulas pueden dividirse a su vez por el número de carpelos que las forman, llamándose dicarpelares o tricarpelares. Cada uno de estos tipos puede, a su vez, subdividirse por el procedimiento de dehiscencia que en cada caso se manifieste. Así, por ejemplo, diremos que la caja de las solanáceas es, en general, dicarpelar y loculicida; la de las liliáceas es tricarpelar y loculicida; la de las colchicáceas, tricarpelar y septicida, y la de un Antirrhinum es dicarpelar y poricida. De igual manera, las cápsulas de un Papaver serán pluricarpelares y poricidas; las de una Viola, tricarpelares y con dehiscencia dorsal, y las de un Helianthemum, tricarpelares y con dehiscencia placentaria o sutural, etc.

\section{Carcérulo y ergástulo.}

Como en el caso anterior, los frutos sincárpicos, secos e indehiscentes pueden dividirse, según-consten de carpelos cerrados o abiertos, y muy acertadamente se ha empleado el nombre de carcérulo para designar estos frutos, llamados también cajas indehiscentes. Esta última denominación es realmente viciosa, pues la idea de caja envuelve el concepto de algo que tiene un modo natural de abrirse, y al calificarla de indehiscente le da un sentido contradictorio. El nombre de carcérulo le reservaremos para los frutos sincárpicos, secos e indehiscentes que constan de carpelos cerrados, como el de los tilos, que son los que por antonomasia se han designado con esta denominación.

Para los sincárpicos secos e indehiscentes formados por carpelos uniloculares, o sea por carpelos abiertos, se necesita una denomi- 
nación diferente, y creemos que puede ser utilizado el nombre de ergástulo, que proponemos para frutos como los llamados cápsulas indehiscentes de algunas paroniquiáceas y gencianáceas, y de estos frutos pueden considerarse como tipo los del género Menyanthes.

\section{Pixidios.}

Tambiẻn los pixidios pueden estar constituidos por carpelos abiertos o cerrados, pudiendo distinguirse tres tipos de estos frutos: el pixidio simple, que es fruto monocárpico y del cual nada nuevo tenemos que hacer observar; el pixidio de carpelos cerrados, fruto sincárpico del cual es tipo el de los beleños, y el igualmente sincárpico constituído por carpelos abiertos, como el de las amarantáceas, y el de algún género de primuláceas (Anagallis).

Como estos dos últimos, por su típica dehiscencia, merecen igualmente el nombre de pixidios, será suficiente que para su distinción llamemos pixidios cleistocárpicos a los formados por carpelos cerrados, y pixidios esjadocirpicos a los uniloculares, o sean los constituídos por carpelos abiertos.

\section{Bayas.}

Como en otros frutos sincárpicos, las bayas pueden estar originadas unas veces por carpelos cerrados y otras por carpelos abiertos. Dejando a un lado las bayas monocárpicas, que necesariamente tienen su único carpelo cerrado, como, por ejemplo, las bayas de las berberidáceas, para no confundir las bayas sincárpicas de una y otra condición, proponemos que, como en los casos análogos, se califiquen de cleistocárpicas las originadas por carpelos cerrados, y de esjadocirpicas las constituidas por carpelos abiertos.

Así serán cleistocárpicas las bayas de las solanáceas, las de la Bryonia, las dioscoreáceas, Tamus, las de esmiláceas y tantas otras, porque los frutos de esta condición no son nada raros, mientras que entre las bayas esjadocárpicas aparecerán las de los muérdagos y demás lorantáceas, las de las raflexiáceas, papayáceas, pasifloráceas, etc., frutos que tampoco son raros. De esjadocárpicas calificaremos también las bayas del género Cucubalus, que como las demás cariofiláceas tienen carpelos originariamente cerrados, pero cuyos tabiques se reabsorben antes de la antesis. 
Para apreciar si los carpelos están cerrados o abiertos habrá de examinarse la sección transversal del ovario o del fruto joven, nunca del que esté próximo a su maduración, por ser caracteristico de las bayas que tanto los tabiques como toda la parte interna del fruto se conviertan en pulpa, borrando este carácter.

\section{Elaterio.}

Los frutos sincárpicos, así llamados por la condición común a todos ellos de abrirse bruscamente, lanzando las semillas a cierta distancia, son por las demás condiciones muy diversos entre sí; por lo menos habremos de distinguir dos clases, según la condición del pericarpio en la madurez. Así, por ejemplo, el elaterio de las euforbiáceas puede calificarse de seco, mientras que en otros ejemplos el elaterio es carnoso y aun muy carnoso al llegar a su madurez y efectuar su deshicencia. De esto último hallamos ejemplos en las balsamináceas, Impatiens Balsamina, y en las cucurbitáceas Ecballium, Momordica.

\section{ALGUNAS PARTICULARIDADES MORFOLÓGICAS Y BIOLÓGICAS DE LA PISTORINIA HISPANICA D. C.}

POR

\section{EDUARDO REYES PRÓSPER}

(Límina V.)

La Pistorinia Hispanica D. C. (Cotyledon Hispanica L.) es una preciosa crasulácea que vive en nuestro pais, en Portugal y en Marruecos.

TOURNEFORT, en sus Institutiones Rei Herbaria (Paris, 1719, pág. 90), definiala de este modo:

"Cotyledon maritima, sedi folio, flore carneo, fibrosa radice.»

El distinguido botánico barcelonés Juan MinUART, a quien 
Loefliva dedicó el género . Minuartia, publicó en . Hadrid (17.34)\} un breve estudio sobre la crasulácea en cuestión, describiéndola asi : "Cotyledon Hispanica sedi tereti folio, flore umbellato rubro, fibrosa radice.»

Loefling en su Iter Hispanicum (Estocolmo, 1758, pág. 7\%), la describe copiando a TOURNEFORT :

"Cotyledon Hispanica, maritima, sedi folio, flora carneo, fibrosa radice.» $\mathrm{Y}$ da una figura en la que el porte general de la planta se halla representado con exactitud.

Linveo, en su Species Plantarum (Estocolmo, 1762 a 1763, tomo I, pág. 615), escribe :

"Cotyledon Hispanica foliis oblonguis, subteretibus, floribus fasciculatis.»

En la Flora Española de D. José Quer, continuada desde el tomo V por el Dr. Casimiro Gómez OrtegA (Madrid, 1762 a 1784), QUER, después de copiar las descripciones que de la Cotyledon Hispanica (su Cotyledon II) dieron Minuart, Tournefort y LiNNEO, añade :

"Esta pequeña y curiosa planta se cria en el circuito de Madrid, en el soto Luzón, más abaxo del molino, a la ladera del Prado y en muchas partes de las cercanías del Real Sitio de Aranjuez. También la he visto en muchos sitios de la Mancha, en terrenos y suelos áridos, incultos y arenosos. Es annua y florece por junio y julio.»

"Descripción.-Crece a tres o cuatro pulgadas de alto. La raíz es delgada, blanquecina, y las más veces dividida en tres fibras; el tallo es sencillo, redondo y apenas esquinado, a quien se asen las hojas carnosas, de media pulgada, semejantes a las de la siempreviva, de hoja rolliza y pobladas de algunas ampollitas que rojean.

„Las flores tienen tres líneas de longitud y casi una de grueso, y están divididas por la extremidad en cinco partes, como si estuviesen formadas de cinco pétalos, llanos y agudos; por la parte superior súbitamente roxas, con orillas o ribetes violáceos y señalados de cinco manchas purpúreas cerca del escudo; por la inferior de un amarillo azafranado, adornadas de ampollitas, casi roxas y asidas a sus piececitos, ramosos y formando como una umbela en el extremo del tallo. El cáliz es de cinco esquinas de media línea, de donde nace el pistilo, que horadando la parte infima de la flor pasa a fruto envuelto en la misma flor, y consta de cinco vainillas, estrechamente unidas. Las semillas son pequeñas y relucientes, de color de paja. » 
Esta detallada descripción, asegura Gómez Ortega que la dejó extendida antes de su muerte D. José QuER.

En 1770 encontró Gómez OrTEga una planta, antes ya recolectada por D. Juan Minuart, que Gómez Ortega estimó diferente, aunque afín a la Cotyledon Hispanica L., y creó una nueva especie, que llamó Cotyledon Pistorinia G. Ort., dedicándosela al Dr. D. Jaime Pistorini, segundo médico del rey, de sólida instrucción, tanto en Medicina como en Botánica.

Publicó Gómez Ortega la descripción y lámina de esta especie en 1772, que fueron transcritas por él en su Apéndice a la Flora Española de QUER (tomo VI de dicha Flora, 1784).

La descripción es detallada, aunque carece del profundo espiritu de observación que revela QueR en la suya.

El inmortal ginebrino A. P. DE CANDOLLE dió a la imprenta (de 1799 a 1829), en colaboración con REDOUTÉ, la más espléndida Monografía de las plantas crasas que se conoce (Plantarum succulentarum historia). En la lámina 122 se dibuja la Pistorinia Hispanica D. C.

Entendió De Candolle que dentro del género Cotyledon no podia colocarse la $C$. Hispanica L., y al crear para dicha especie el género Pistorinia dióle a éste los caracteres siguientes:

"Calix 5-partitus, tubo multo brevior. Corola gamopetala hypocrateriformis, tubo longo tereti, limbo patente, 5-partito. Stam. 10 tubo per totam longitudinem adnata, at faucem libera exerta. Squamæ 5 oblongæ obtusæ. Carpella 5 in stylos longos filiformis desinentia. Herba annua aut biennis, erecta. Folia subteretia, oblonga, sparsa sessilia. Flores cymosis rubelli. Habitus planta fere umbilici (Mucizoniz). Flores Cotyledonis.» (Prodromus Systematis Naturalis Regni vegetalis, tomo III, pág. 399. Paris, 1828.)

Agrega De Candolle que la Pistorinia Hispanica D. C. es propia de España y Berberia, y que es la misma planta que LoEFling llamó Cotyledon Hispanica y Gómez OrTEga Cotyledon Pistorinia.

Otro eminente botánico suizo, Edmundo Borssier, en su soberbia obra Voyage botanique dans le Midi de l'Espagne (Paris, 1830 a 1845, tomo III), describe y dibuja la Pistorinia Salzmanni Boiss., especie española y marroquí, que demandó también colocarse en un género que no fuese el Cotyledon.

SchuUland, en su Monografia de las Crasulciceas (Leipzig, 1891), cree que la Pistorinia Hispanica D. C. y la Pistori- 
nia Salzmanni Boiss. deben ser especies del género Cotyledon; pero se ve obligado a crear en este género una Sección Pistorinia, dentro de la cual incluye las dos especies del desechado género de DE CANDOLle.

Según el Index Kewensis Plantarum Phanerogamarum (Oxford, 1895), no sólo debe desaparecer el género Pistorinia, sino que sus dos especies son iguales al Cotyledon Hispanica L.

He recogido la Pistorinia Hispanica D. C. (Cotyledon Hispanica L.) en más de setenta localidades españolas, en su mayoria esteparias, la he cultivado en mi propia casa durante tres años, y obtenido preciosos céspedes de ella, que han crecido, florecido y fructificado a mi vista. Estudié la organografía y la estructura microscópica en muchos ejemplares, y puedo dar a conocer de su morfología y su biología algunos datos curiosos no publicados hasta ahora.

Ante todu debo manifestar que para mi la Pistorinia Hispanica D. C. ofrece tres formas:

a genuina. La describe y figura LoEfLING en su Iter Hispanicum, y es la misma que describe QueR como Cotyledon II (Cotyledon Hispanica L.). Su tallo, por estatura que tenga (de 7 a $12 \mathrm{~cm}$.), no se ramifica claramente; las hojas y flores son más rubiginosas que en la forma $\%$.

: minor. De 3 a $5 \mathrm{~cm}$. de estatura. Más rubiginosas aún que en la forma genuina las hojas y flores. En el haz de la parte libre de los pétalos el matiz es cárneo-purpúreo muy subido y las manchas son poco perceptibles.

i major. Forma de la que dió descripción y lámina Gómez OrTEGA en 1772, con el nombre de Cotyledon Pistorinia G. Ort., y en el Apéndice a la Flora Española de Quer (tomo VI de dicha Flora). El tallo se ramifica siempre, y en la terminación de cada rama hay una inflorescencia. La estatura es de 10 a $14 \mathrm{~cm}$. El tallo y hojas son más verdes y de mayor robustez que en la forma genuina. Las hojas se adelgazan mucho en el ápice y aparecen engrosadas y como gibosas en la base. Las flores, en el haz de la parte libre de los pétalos tienen color carmesí-violáceo claro, y las manchas carminoso-purpúreas muy obscuras.

En una misma localidad pueden presentarse las tres formas, pero domina una de ellas.

Citaré como ejemplo de localidades de la forma senuina las cer- 
canías de Tarancón, Huete y Palomares del Campo (Cuenca). Los cerros de Aranjuez (Madrid), los de Granada, etc.

La forma minor vive en el Valle de Tejadilla (Segovia), monte de El Pardo y Chamartín (Madrid), Nijar y Sorbas (Almeria), etc.

La forma major habita en el monte de La Marañosa (Vaciamadrid), Boadilla del Monte, Cristo de Ribas y Moncloa (Madrid), Salinas y cerros de Belinchón (Cuenca), Mancha Real (Jaén), Guadix y Benalúa (Granada), etc.

Las formas genuina y minor son propias de terrenos arenosoarcilloso-yesosos.

La forma major se encuentra en los arenoso-yesoso-salinos.

Gran parte de los tejidos de las raíces de esta planta se esclerifican extraordinariamente, y no le sirve la raiz más que de órgano de sostén. En cambio, durante la antesis de las inflorescencias y en el transcurso de la fructificación se agotan los depósitos amiláceos del tallo y hojas, siendo estas últimas, sobre todo, las que, arrugándose y secándose, dan sus elementos nutritivos al vegetal.

Es curioso que en la planta adulta las hojas vengan a desempeñar el papel fisiológico de los cotiledones.

La viscosidad del tallo, hojas, y sobre todo de las flores, de la Pistorinia Hispanica D. C. obedece a pelos glanduliferos en el ápice, que recubren la parte aérea del cuerpo de la planta. Muchas veces, insectos de pequeño tamaño se encuentran adheridos al vegetal, y abundan los pelos glanduliferos, que se encorvan, como sujetando los insectos, sobre la superficie de la planta. Deberá considerarse a la Pistorinia Hispanica D. C. como insectivora en mayor o menor grado.

Los estambres de tan preciosa crasulácea ofrecen particularidades no citadas hasta ahora.

La antera se divide en cuatro cuerpos; los filamentos, en la parte no unida a la corola, que emerge fuera de ella, son rollizos, ensanchados en la base y recubiertos de pelos. Cinco estambres son más cortos y cinco más largos.

Los granos de polen son de color blanco, y tienen tres estrías de dehiscencia.

Los carpelos, aguzados en larga punta, son acrescentes después de la fecundación y salen por la garganta de la corola, estando recubiertos en la base por ella.

Los cinco folículos encierran semillas diminutas, cuya superficie esta recubierta de surcos longitudinales. 



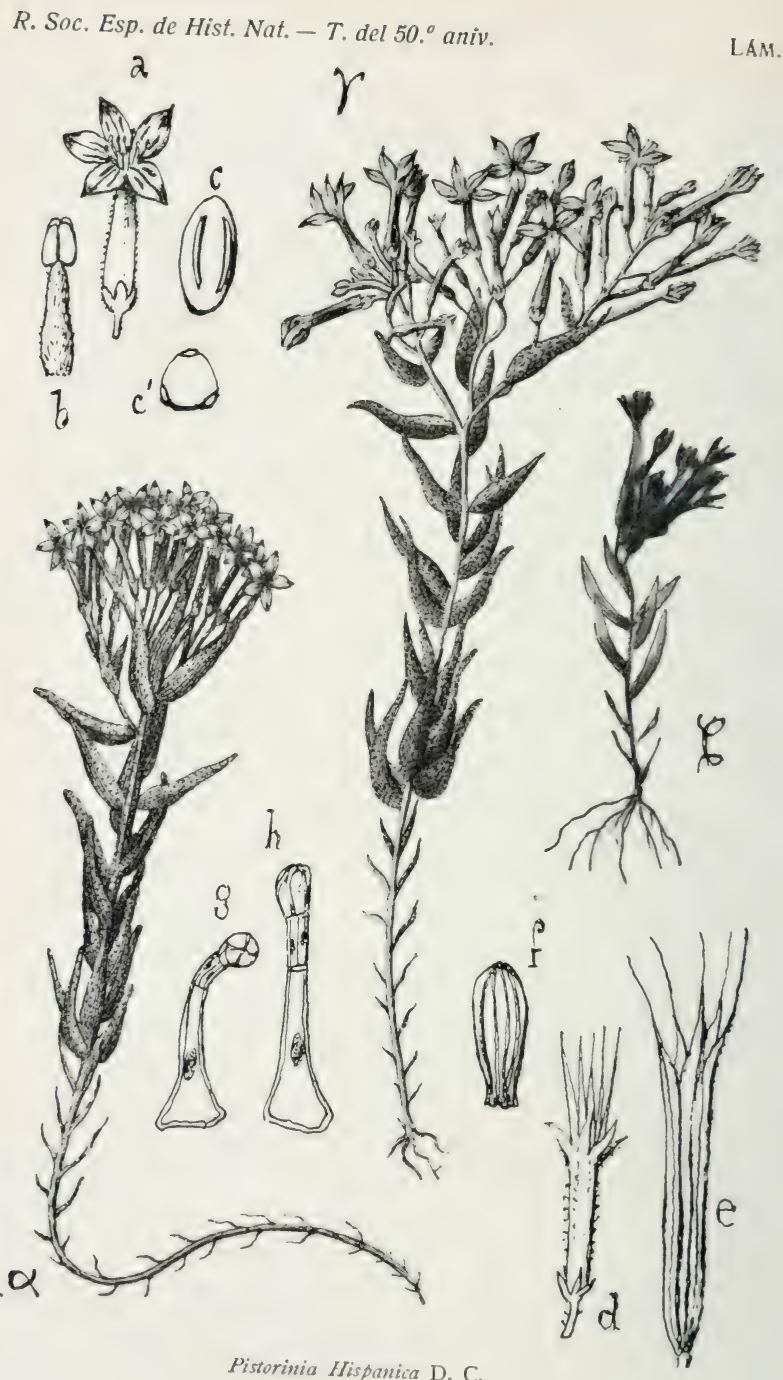


Es sumamente curioso que cada una de las flores se cierre al anochecer durante cinco o seis dias consecutivos y se abra a la mañana de esos mismos dias, después de haber recibido una hora u hora y media de luz solar. Esta repetición de la antesis floral hace que los céspedes de la Pistorinia Hispanica D. C. sean cada día más bellos, pues el número de flores abiertas aumenta sucesivamente, y flores que eran capullos verifican su antesis al mismo tiempo que otras más adultas.

Esta plantita merece ser cultivada en los jardines, donde substituiría con ventaja a especies de Sedum.

\section{Explicación de la lámina $\mathrm{V}$.}

a. - Forma genuina, segrún Loefling.

6. - Forma minor, fotografía del natural.

Ү. - Forma major, según Gómez URTEGA.

a. - Flor aumentada, cuatro veces mayor que el tamaño natural.

b. - Parte libre de un estambre, aumentada en siete veces el tamaño natural. cy $c^{\prime}$.-Dos posiciones del grano de polen, visto al microscopio Leitz $\frac{o c 5}{o b j 6}$.

d.-Flor qque deja ver las extremidades de los folículos, aumentada cuatro veces.

e. - Fruto aumentado cinco veces.

f. - Semilla vista al microscopio Leitz $\frac{v_{i} 1}{0 b_{j} \sigma^{\circ}}$.

$g$ y h. - Pelos glandulíferos Leitz $\frac{o c 3}{a b j 6}$. 


\title{
EL YACIMIENTO DE MAMÍFEROS ClATERNARIOS DE VALVERDE DE CALATRAVA Y EDAD DE LOS VOLCANES DE CIUDAD REAL
}

\author{
POR \\ EDUARDO HERNÁNDEZ-PACHECO
}

(Láminas VI a IX.)

Anteredentes resperto al volcanismo del interior de España.Las primeras noticias acerca de la existencia de formaciones volcánicas en Ciudad Real y campos de Calatrava se deben a los geólogos de mediados del siglo pasado, informaciones que son en extremo sucintas, lo cual no es de extrañar en una época de gran turbulencia como era aquélla, en la que se iniciaban en España los estudios geológicos.

Tales noticias, sin embargo, son lo suficientemente claras y concretas para juzgar de la naturaleza geológica de los yacimientos. Así, D. Joaquín EzQuerra del BAyo, en el Semanario Pintoresco Español, editado en Madrid y correspondiente al año 1844 , hace referencia en su artículo «Basaltos» a los de la provincia de Ciudad Real. En el mismo año, D. Amalio MaEstre, en el Boletin Oficial de Minas, publicó el trabajo titulado "Observaciones acerca de los terrenos volcánicos de la Península». De unos años antes es una nota respecto a los depósitos basálticos de la Mancha, según datos de EZQUERRA, publicados en los Neue Jahrbuch en 1836.

El trabajo más concreto e importante respecto al asunto es el de Quiroga, ya en el último tercio del siglo pasado, en 1880, titulado "Estudio micrográfico de algunos basaltos de Ciudad Real», publicado en los Anales de la Sociedad Española de Historia Natural. Se refiere este estudio a los basaltos de las localidades próximas a Ciudad Real, el Arzollar y cerro de la Ciruela y a otros del Castillejo del Río, cerca de Puertollano. El estudio de QUIRO$\mathrm{GA}$, como su título indica, es de índole petrográfica, deduciendo la 
consecuencia de que se trata de basaltos nefelínicos. En el uiltimo capítulo hace algunas consideraciones respecto a la edad de las manifestaciones volcánicas, e influenciado por la opinión dominante en su tiempo de la situación costera de los volcanes, expone la opinión que durante la época terciaria, de máxima energía de los volcanes del centro de la Península, éstos «ocupaban una de las riberas más meridionales del extenso lago terciario, en cuyo seno se estaban depositando los materiales que constituyen hoy dia tocla la Mancha y una parte de las provincias de Guadalajara, Madrid y Toledo». $\mathrm{Y}$ añade: "Como pruebas de la contemporaneidad del fenómeno eruptivo con el sedimento lacustre, existen en los diversos puntos de aquella recrioin tobas formadas con granos de lapilli, cementado; mediante la caliza terciaria.»

Más adelante en este trabajo me ocuparé de la edad que asigno a ciertos materiales considerados como terciarios; en cuanto a la existencia de extensos lagos, ocupando el ámbito de las Castillas durante el terciario, creo haber demostrado cumplidamente, por mis trabajos anteriores, que tal opinión no es ya sostenible en vista de los descubrimientos paleontolósicos y geológicos efectuados an estos últimos años (1).

El ingeniero CORTÁzAR publicó en el tomo VII del Boletin de la Comisión del Mapa Geológico (Madrid, 1880) una «Reseña física y geológica de la provincia de Ciudad Real», en la que destina algunos párrafos a las rocas basálticas de esta provincia, describiéndolas atendiendo únicamente a su aspecto externo y citando diversidad de localidades con afloramientos de esta clase de rocas. Por lo que respecta a su edad, las considera anteriores al mioceno, diciendo: "La aparición de los basaltos de Ciudad Real parece debió tener lugar antes de la sedimentación de las calizas miocenas, pues éstas se hallan en su contacto perfectamente horizontales y sin haber sufrido las alteraciones que existen en rocas más antiguas por entre las que cruza la masa hipogénica.»

A partir de la fecha, ya antigua, de estos últimos trabajos, no se han publicado, que yo sepa, otros relativos a las erupciones y rocas volcánicas de los campos de Calatrava, a no ser alguna pequeña referencia en obras generales o incidentalmente al tratar de otros estudios de Geologia de España.

(1) E. Hernandez-PAcheco, Geología y paleonlologia del mioceno de Palencia. (Com. de Inv. Pal. y Preh. Mem. núm 5. Madrid, 1915.) 
Exploración de la región volcinica en 1914 y 1915. - Esta falta de conocimiento de una región tan interesante me hizo pensar en la conveniencia de emprender su estudio y visitar algunas de las localidades volcánicas más importantes del territorio de Ciudad Real y de los campos de Calatrava.

Coincidió esto con la noticia que me dió el entonces catedrático del Instituto de Ciudad Real, D. Antonio Martínez y FernándezCastillo, del descubrimiento de un molar de elefante en Valverde de Calatrava, localidad distante unos 10 kilómetros al Oeste de la capital, siendo lo más interesante de la noticia el haberse encontrado el resto fósil bajo una capa de materiales volcánicos.

Procediendo la comunicación de una persona tan competente como el profesor Martínez, no podía dudarse de la autenticidad de los datos, por lo cual, en vista de la importancia del hecho, me trasladé en 1914 a la expresada localidad, reconociendo el yacimiento y efectuando el estudio del mismo, que se detalla más adelante (1). Quiero hacer constar aquí mi gratitud al joven licenciado en Medicina D. Francisco Colás, de Ciudad Real, a cuyas gestiones se' debe en gran parte el haber podido efectuar el estudio y la obtención de los moldes de los ejemplares, hechos hábilmente por el preparador del Museo Nacional de Ciencias Naturales Sr. Molina, quien me acompañó a Ciudad Real. Los ejemplares no pudieron obtenerse del propietario del terreno donde aparecieron, quien los consideró de un valor material extraordinario, si bien amablemente me dió todo género de facilidades para el estudio de ellos y lia obtención de vaciados.

Efectué una segunda expedición en la primavera de 1915, en compañia de los geólogos, entonces mis discípulos, Sres. Gómez de Llarena y Royo Gómez, estudiando los voicanes de la región cercana a Ciudad Real y extendiendo las exploraciones hasta Piedrabuena. El presente trabajo es resultado de aquellas expediciones, y en él me ocuparé tan sólo de los volcanes más directamente relacionados con el yacimiento.

(1) Una sucinta noticia del yacimiento y de los ejemplares de mamiferos fósiles en él encontrados se publicó en mi discurso inaugural de la Sección de Ciencias Naturales del Congreso que la Asociación Española para el Progreso de las Ciencias celebró en Valladolid en 1915, discurso titulado Estado actual de las investigaciones en España respecto a $\mathrm{Pa}$ leontologia y Prehistoria. 
Topografía del territorio volcainico de Cimlad lieal. - En el $+x-$ tremo Sudoeste de la dilatada planicie mancheca, constituida por depósitos del mioceno continental, está edificada Ciudad Real, en una llanura tan poco accidentada, que las carreteras que parten de la población se prolongan en línea recta grandes distancias sin la menor desviación ni pendiente, resultando que faltan las trincheras en donde pueda apreciarse la constitución litológica del país.

Hacia el Oeste de la ciudad, a una decena de kilómetros, acaba la llanura, y pasado el Guadiana comienza un terreno accidentado, que constituye la extensa formación paleozoica de los campos de Calatrava, con régimen orográfico de penillanura, con montañas de terrenos silúricos poco elevadas, si bien con frecuencia ásperas y escarpadas a causa de la naturaleza de las rocas, que son dominantemente cuarcitas, y también por lo plegadas y fracturadas que se presentan las capas rocosas: tal acontece en las sierras de la Zarzuela y de las Medias Lunas.

De la extensa zona paleozoica de los campos de Calatrava se destaca, avanzando hacia la llanura, la serrata de Alarcos, con sus bellos pliegues anticlinales del cerro del·Despeñadero, y más hacia el Este todavía asoma, aislada totalmente en la llanura, alguna otra serrata silúrica de muy poca elevación, accidentes topográficos que cesan pronto, para dejar que hacia el Norte, Este y Sudeste la planicie miocena se extienda dilatada a lo lejos hasta el horizonte.

Tanto por el territorio montañoso como por el llano asoman los volcanes, constituidos por bajos y redondeados conos de lavas que por su forma apenas destacan en el paisaje, y a los que llaman cabezos en el país. En otros sitios los materiales volcánicos consisten simplemente en extensas masas de basalto, que apenas forman relieve en la llanura arcillosa o que se han abierto paso a través de los estratos silúricos, ocupando las cumbres o laderas de las montanas de cuarcita de los campos de Calatrava. En relación directa con capas claramente de edad miocena no he visto ningún cono volcánico ni corriente lávica, pues todos están en los bordes de la llanura, sobre la que está edificada Ciudad Real, o ya en pleno territorio de la penillanura o zona de pequeñas montañas del paleozoico.

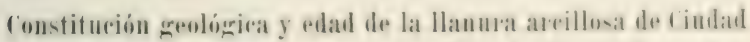
Real. - La planicie sobre la cual está edificada Ciudad Real, y la que se extiende hacia el Sudeste por Miguelturra, está constituida por tierras.arcillosas o arcilloso-calcáreas, que llegan a una gran pro- 
fundidad, habiéndose abierto en estos materiales numerosos pozos de noria, en gran parte actualmente abandonados y en general profundos una docena de metros, hasta alcanzar la capa acuífera, que se comprende está bajo el espeso manto de materiales arcillosos en el contacto con el terreno sobre el que se depositaron.

Considero que estos depósitos arcillosos están formados en gran parte por la desćomposición de espesos mantos de lapilli y de cenizas, descompuestos y más o menos mezclados con materiales finos procedentes de aluvionainiento o transporte subaéreo de materiales sedimentarios del terciario. Domina esta formación hacia el Sudeste por Miguelturra.

Hacia el Oeste y Noroeste de Ciudad Real constituye la formación de superficie una marga terrosa, muy arcillosa, grisácea, sin fósil alguno que permita fijar la edad y que en gran parte parece también producto de descomposición de finos materiales volcánicos.

En esta formación margosa se aprecian delgadas capas y lentejones más o menos extensos de calizas: unas blancas y terrosas, otras grisáceas y compactas, pero todas arcillosas y con aspecto tobáceo. Considero a estos lentejones y capas calcáreas como de formación posterciaria, pues son análogos y con los mismos caracteres que los que se extienden por diversidad de lugares sobre la formación miocena de las regiones meridionales y orientales de Castilla la Nueva, especialmente hacia Albacete.

Son semejantes a las costras y lentejones calcáreos que ocupan las formaciones superficiales de los terrenos de las zonas levantinas y meridionales de la Península y Norte de Marruecos, y también a las que encontré y describí de la costa occidental de Lanzarote, correspondiendo a una formación actual con subfósiles (1).

Estas calizas, propias de los climas secos, son de origen subaéreo y formadas sobre el terreno o bajo la tierra vegetal por la acción de las aguas pluviales, las cuales, cargadas de anhídrido carbónico, al infiltrarse en el terreno disuelven el carbonato cálcico, el cual abandonan en la estación seca al ascender por capilaridad y

(1) E. Hernández-PACheco, Estudio geológico de Lanzarote y de las isletas canarias. (Mem. de la R. Soc. Esp. de Hist. Nat., t. VI, páginas 186 y sigs. Madrid, 1909.) - E. HeRnANDEZ-PACHECO, Las tierras negras del extremo Sur de España y sus yacimientos paleoliticos. (Trab. del Mus. Nac. de Cienc. Nat. Serie Geol., núm. 13, paigs. 11 y sigs. Madrid, 1915.) 
evaporarse en la superficie o inmediatamente bajo la superiicie. Teniendo en cuenta este proceso de formación, no es de extrañar que contengan englobado en su masa algún fragmento lávico procedente de los cercanos volcanes de edad anterior a la formación calcárea, y que también se encuentren en ellas algunos es(queletode caracoles terrestres contemporáneos a su formación, como aprecié en Ciudad Real, y que confirman el origen cuaternario o reciente de tales depósitos tobáceos.

Es probable que de este tipo sean las calizas en las que QuirogA encontró inclusiones de lapilli, por lo que las refiere al terciario, y sean las mismas que CORTÁZAR observó en contacto con los basaltos, perfectamente horizontales y sin haber sufrido alteración alcuma.

Los voleanes de ('iudad Real próximos al yacimiento de mamiferos fósiles. - Basta examinar el mapa que acompaña a este trabajo (págs. 104 y 105) para apreciar lo numeroso de los volcanes en las cercanías de Ciudad Real.

El Guadiana, unos kilómetros antes de llegar al congosto de Alarcos, corre lentamente por una llanura aluvial, en la que se expansiona, se divide en brazos y forma meandros divagantes en esta parte del valle, plano y fácilmente inundable en las crecidas.

Por la margen derecha el valle se eleva algunos metros sobre el cauce actual y permite el establecimiento de vinedos y olivares, que crecen en la llanura marginal, cerca del pueblecito de Valverde de Calatrava; en esta llanura, entre el pueblo y el río, está el yacimiento de mamíferos cuaternarios, del que me ocuparé más adelante.

A uno y otro lado del río son numerosos los volcanes que rodean a la pequeña llanura donde está el yacimiento.

Por la margen izquierda, del lado de Ciudad Real, se distinguen, como volcanes más próximos al yacimiento, los siguientes:

El cabezo de Palos, que consiste en una ancha intumescencia de lavas, elevada unos 60 metros sobre la llanura de Ciudad Real y 90 sobre el río; en este volcán no se reconoce cráter alguno y parece constituye un volcán homogéneo, cuyas lavas fluirian por abertura que fué tapada por la masa eruptiva; lavas que se expansionaron todo en derredor, formando una mancha lávica de contorno redondeado, de unos 4 kilómetros de diámetro. EI campo de lavas está sumamente alterado, y tan sólo hacia la cumbre de la suave loma que forma el acumulo volcánico se reconocen en superficie buenos ejemplares de lavas cordadas. 


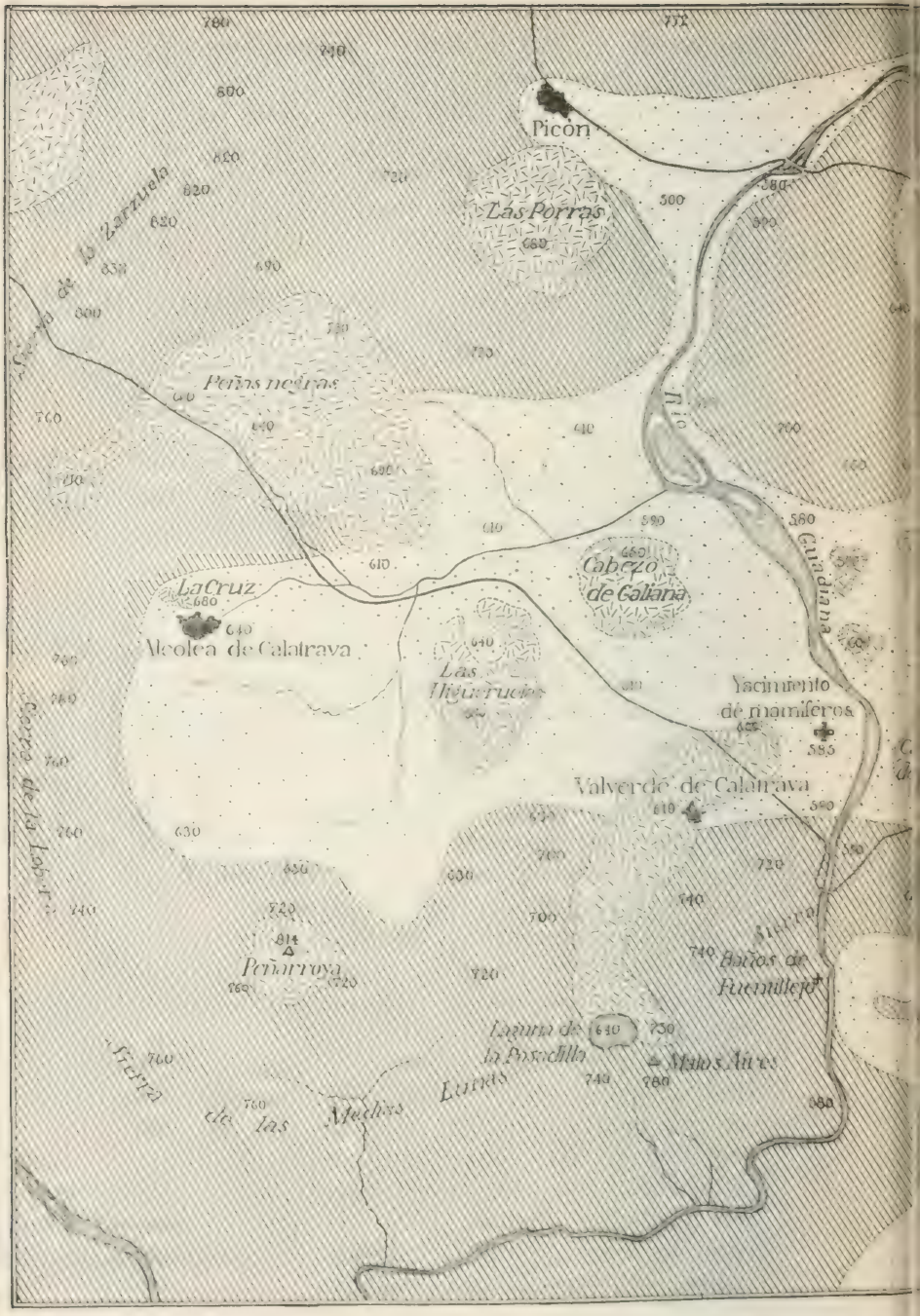

Mapa del territorio volcánic 
Dos afloramientos basálticos, de tan sólo unos 500 metros de diámetro cada uno, están situados entre esta gran masa del cabezo de Palos y el río. Tampoco presentan el menor indicio de cráter y tienen más bien el aspecto de dos masas lávicas destacadas de la masa principal por las acciones erosivas, que de afloramientos independientes de basalto.

Al Sur de éstos se eleva una masa de escorias y de lavas escoriáceas y cordadas, de un kilómetro de diámetro, con suave y apenas pronunciada depresión crateriana en lo alto. Es el llamado cabezo del Hierro, elevado unos 75 metros sobre el río; frente a él, en la otra margen del rio, está situado el yacimiento fosilífero. La erosión ha abierto un barranco en la ladera meridional, que deja percibir la constitución del cono formado por la acumulación de masas escoriáceas y de gruesos lapillis (lám. VI).

En la serrata silúrica de Alarcos, cerca de la fuente del Arzollar, existen restos de otro volcán, muy erosionado y reducido a las masas basálticas del Arzollar, que se explotan para la construcción de adoquines (lám. VII).

A la derecha del Guadiana los volcanes son también numerosos; los más próximos al río son el del cerro de Malos Aires, el del cerro de las Higueruelas y el cabezo de Galiana.

El volcán de Malos Aires está situado en el extremo oriental de la sierra de las Medias Lunas, cerca de la cumbre y de la margen derecha del Guadiana, aguas abajo del congosto de Alarcos. Presenta una extensa depresión crateriana ocupada temporalmente por aguas invernizas, constituyendo la laguna de la Posadilla, de unos 400 metros de diámetro máximo. El borde Sur de la depresión lo forman los altos crestones de cuarcita silúrica del pico de Malos Aires; el borde oriental es un gran mogote de lavas basálticas, del cual parte la corriente que, formando el borde Norte del cráter, baja avanzando en un trayecto de unos 5 kilómetros, con una anchura de más de medio, por la ladera de la montaña silúrica hasta el valle del Guadiana, pasando el borde de la corriente lávica junto al pueblecito de Valverde de Calatrava. Los lapillis y las masas de cenizas descompuestas se acumulan en gran cantidad en el reborde crateriano septentrional.

También es de tobas escoriáceas y de cenizas y con cráter patente, abierto hacia el Norte, el volcain de las Higueruelas, situado entre el camino de Alcolea a Valverde y la carretera que de Ciudad Real, pasando por el puente de Alarcos, conduce a Piedrabuena. 
Constituye baja prominencia que destaca poco en la llanura el cabezo de Galiana, situado entre el caserío de Benavente y el Guadiana.

Más alejado del yacimiento y del rio existen otros varios volcanes, que no detallo, siendo los de aspecto más reciente y claramente escoriáceos el de Peñarroya, en la cumbre del cerro de este nombre, y el situado junto a las casas del pueblo de Alcolea de Calatrava, constituyendo el cerro de la Cruz, cuyas escorias negras y con aspecto reciente engloban multitud de pequeños cantos de cuarcita vitrificados en superficie.

Composición petrografióa de los materiales rolcanions. - La composición mineralógica de las rocas de algunos de estos volcanes fué estudiada por Quiroga en su Memoria antes citada. Últimamente, el Sr. González Regueral (1) hizo por mis indicaciones, y como trabajo de laboratorio, un estudio petrográfico de algunos de los materiales litológicos que trajimos de la excursión que realicé con mis discípulos los Sres. Gómez de Llarena y Royo Gómez.

Las rocas estudiadas por el profesor QUIROGA proceden del volcán del Arzollar; las examinadas por GonzÁlez REgueral son lavas procedentes del volcán de Palos y del de Malos Aires. Del estudio efectuado se deduce que existen dos tipos litológicos de lavas: las del Arzollar, en la serrata de Alarcos, y las de Peñas Negras, junto al cráter del volcán de Malos Aires, que son consideradas como basaltos nefelínicos. La corriente del volcán de Palos ha sido clasificada como basalto labradórico.

Tipos de las ermpeiones. - Aunque muy destruidos los conos volcánicos y muy alteradas las corrientes lávicas, y más aún los mantos de lapillis y de cenizas, pueden obtenerse algunas deducciones respecto a la naturaleza de las erupciones y tipos de éstas.

La multitud de aparatos volcánicos distribuidos en gran número por toda la extensa comarca de los campos de Calatrava y territorios inmediatos, hacen ver que las manifestaciones volcánicas se realizaron, no en los mismos sitios consecutivamente como diversas erupciones de un mismo volcán, sino que por lo general cada erup-

(1)' J. R. Gonzalez Regueral, Estudio microscópico de algunas rocas basálticas de Ciudad Real. (Bol. de la R. Soc. Esp. de Hist. Nat., t. XX. Madrid, 1920.) 
ción rompía por sitio distinto, edificando un pequeño cono de escorias, elevando una masa homogénea de lavas, u originando una corriente más o menos extensa.

Ciertos volcanes, especialmente los llamados cabezos (aunque no todos los de esta denominación), parecen corresponder al tipo de los volcanes homogéneos: las lavas surgieron viscosas, acumulándose sobre la abertura de salida sin edificar grandes conos de escorias, extendiéndose el manto lávico alrededor de la boca por donde surgió, tapando a ésta.

En otros casos, como en el del volcán del cabezo del Hierro, la erupción edificó un cono con la acumulación de lavas y escorias; existiria depresión crateriana y los fenómenos de proyección fueron relativamente intensos; en el volcán citado hay en las laderas bombas y masas de proyección de hasta más de medio metro cúbico. Fueron erupciones de tipo estromboliano las que edificaron estos volcanes, pues aunque existen en grandes cantidades lavas escoriáceas, escorias y lapillis, faltan en absoluto las cineritas y tobas de cenizas. La más clara erupción de este tipo es la que edificó el amontonamiento de escorias del cerro de la Cruz junto a Alcolea de Calatrava, y también tiene este tipo el volcán de Peñarroya.

Sin embargo, creo que también se han realizado en la comarca erupciones de tipo más violento y explosivo que las estrombolianas, pues ya he dicho antes que atribuyo los depósitos arcillosos que existen en la llanura de Ciudad Real en una cierta parte al resultado de la descomposición de masas de lapillis, y especialmente de cenizas lanzadas por los volcanes de la región. En la base de la sierra de Alarcos, en las trincheras de la carretera antes de llegar al puente de Alarcos, se aprecian claramente estas masas arcillosas, resultantes, según creo, de la alteración de las cenizas. En algún rellano de la ladera septentrional de la misma serrata, al Este de la masa basáltica del Arzollar, existen costras superficiales sobre las cuarcitas, formadas por tobas de cenizas que engloban gran cantidad de diminutas piedrecillas y arenas cuarzosas procedentes de las cuarcitas de la serrata; materiales que han sido mezclados mecánicamente con las cenizas por los arrastres de las aguas de lluvia.

La presencia de tobas formadas por finos lapillis y por cenizas se observa más claramente en el volcán de Malos Aires, pues el reborde que da lugar a la laguna crateriana de la Posadilla está formado por estos materiales, como se advierte en una excavación que existe en esta zona. Los materiales eruptivos de este volcán 
contienen, además de la masa de basalto de Peñas Negras. escoriats abundantes, lapillis y las mencionadas cenizas descompuestas. y una gran corriente de lava, que descendió por la ladera de la montaña y llega hasta la llanura del valle del Guadiana.

Considero que se trata en este caso de un volcán explosivo con erupción probablemente de tipo vulcaniano, juzugando por los matcriales eruptivos que lo integran; volcán cuya vida se redujo a una única erupción con proyecciones violentas de cenizas y lapillis, materiales que han desaparecido, los que caerian sobre los altos crestones de cuarcita silúrica que rodean la depresión crateriana por el Sur, barridos y arrastrados por las lluvias en el largo transcurso de tiempo desde la erupción hasta la fecha, mientras que en la parte del Norte aun subsisten contenidos por la masa de lavas que formaron el mogote basáltico de Peñas Negras y la corriente que desciende hasta Valverde de Calatrava.

El yacimiento paleontológico de Valverde de Calatraya.-E1 hallazgo de restosfósiles de mamíferos deépoca claramente determinable en relación con los materiales volcánicos, permite señalar la época de las erupciones de los volcanes de Ciudad Real con una seguridad hasta ahora desconocida.

Está el yacimiento en cuestión en una planicie plantada de vinedos y de otros cultivos, próximamente a kiló-

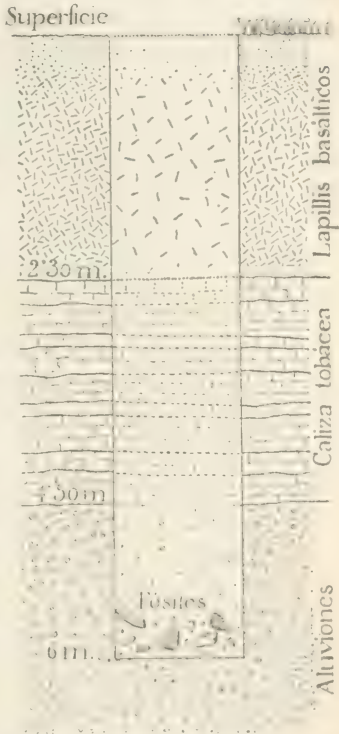

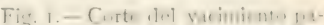

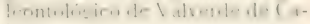
latrava. metro y medio al Este de Alcolea de Calatrava, y distante menos de un kilómetro de la actual margen del Guadiana, que por este lugar divaga con mansa corriente antes de penetrar en el congosto de Alarcos (lám. VII).

En la planicie, al excavar un pozo para instalar una noria, se atravesaron, contando desde la superficie, las siguientes capas, de las que da idea el gráfico adjunto (fig. 1): 1.", tierra vegetal, que 
a los $30 \mathrm{~cm}$. pasa insensiblemente a lapillis de naturaleza basáltica, cada vez menos alterados, según aumenta la profundidad; tiene el conjunto de la capa de tierra y el manto de lapillis un espesor total de 2,30 metros; $2 .^{a}$, capa de caliza blanca tobácea, subdividida en varios lechos, que en conjunto alcanzan un espesor de 2,30 metros; 3 . $^{\text {a }}$, masa de aluviones constituídos por arenas y gravas de elementos cuarzosos. En estos aluviones se alcanzó la capa acuífera, ligeramente carbónica, con desprendimientos de anhídrido carbónico, que dificultaban las operaciones de excavación. Los aluviones se excavaron hasta una profundidad de metro y medio, y entre los materiales del fondo del pozo, o sea a los 6 metros de profundidad, se encontraron los restos fósiles, que consistían en fragmentos óseos de varios animales, indeterminables específicamente, algunos de cuyos fragmentos se retiraron en mi presencia del aluvión. Juntamente con tales fragmentos se encontraron dos molares de elefante, otras piezas dentarias de hipopótamo, un fragmento de mandibula y un diente de ciervo y dos molares de caballo.

Como dato interesante conviene apuntar que la capa de caliza situada sobre los aluviones fosiliferos y bajo la capa de lapillis volcánica es, por su aspecto y caracteres, análoga a los lentejones y capas calizas existentes en la llanura de Ciudad Real, y que considero como de edad cuaternaria o reciente y de formación subaérea.

Conviene también apuntar que los aluviones fosiliferos no contenian fragmento alguno de basalto.

Examen de la fauna fósil de Valrerde de Calatrava. - Cuatro especies de mamíferos están representadas en el yacimiento, que son las siguientes:

Elephas meridionalis Nesti.

Hippopotamus amphibius Linné, subesp. major Owen.

Equus caballus fossilis Cuv.

Cervus sp.

Del Elephas meridionalis se tiene: un molar superior casi completo y un gran fragmento de otro, en el que se conserva la mayor parte de la corona. Ambos parecen corresponder a un mismo individuo y son los simétricos.

Se trata de ejemplares de una forma específica clara y típica, como se aprecia en la fotografía (lám. VIII), contándose en estos mo- 
lares seis pliegues transversos de esmalte en uno y seis y parte de un séptimo en el más completo. Teniendo en cuenta la forma general del diente, se puede suponer que faltan en cada molar dos o tres colinas, lo cual hace suponer que son los segundos o terceros molares definitivos, es decir, que corresponden a un animal adulto.

Se aprecia al primer golpe de vista, en los ejemplares, que son muy anchos; por otra parte, las colinas o pliegues de esmalte son a su vez anchos, muy irregulares, distanciados entre si y de forma arqueada o sinuosa; conjunto de caracteres que hacen considerar que estos molares corresponden al $E$. meridionalis Nesti, diferenciándose de los del $E$. antiquus. Falc., también de clima cálido, por tener esta especie mayor número de colinas o pliegues de esmalte, generalmente rectos y menos anchos y más estrecho el diente en su conjunto.

La especie encontrada en Valverde es el elefante más antiguo del cuaternario del Occidente de Europa y regiones circunmediterráneas, correspondiendo cronológicamente a la primera y segunda época interglaciar.

Los restos de Hippopotamus amphibius Linné, subesp. major Owen, procedentes del yacimiento castellano, son: un gran frag-, mento de canino inferior izquierdo, de unos $25 \mathrm{~cm}$. de largo; otro fragmento más pequeño, de unos $8 \mathrm{~cm}$., de un canino inferior derecho; un fragmento del último molar izquierdo, correspondiente al talón. Todas estas piezas (lám. VIII) parecen corresponder a la mandibula inferior de un mismo individuo; hueso que sería destrozado por los obreros que excavaron el pozo, pues las fracturas de los ejemplares son frescas; no así un fragmento de cráneo correspondiente a la porción orbitaria, también de un hipopótamo, hueso que apareció más tarde y cuyas fracturas indican estaba ya fragmentado cuando fué incluído en los aluviones del río.

El fragmento mayor de los caninos tiene $91 \mathrm{~mm}$. de diámetro antero-posterior y $61 \mathrm{~mm}$. de diámetro transverso. Conserva su esmalte en perfecto estado, con las estrías características de la especie.

Comparados estos restos con las porciones análogas de un cráneo de hipopótamo adulto) (que existe en las colecciones del Museos Nacional de Ciencias Naturales, procedente del África central, se advierte que el ejemplar del (iuadiana tendria doble tamano yue el africano del Museo, calculando la longitud de su cráneo en un metro, y por lo tanto mereciendo la denominación de major que se da a la raza o subespecie cuaternaria. 
El Hippopotamus major, superviviente de los tiempos pliocenos, era un animal de clima cálido, característico también, como su compañero el Elephas meridionalis, de la primera y segunda época interglaciar, si bien el hipopótamo pasa a la tercera en Europa, habiéndosele encontra to juntamente con industria humana, y BouLE to ha señalado de las cuevas de Grimaldi. Actualmente habita el África central, extendiéndose en época histórica por casi todo el Nilo.

Del Equus caballus fossilis Cuv, aparecieron en el pozo de Valverde dos molares: uno inferior, con la corona en excelente estado de conservación y de desgaste (lám. IX); otro superior, al que le falta gran parte de la muralla externa y de la corona; además se trata de un molar apenas desgastado por el uso, y por lo tanto sin buenos caracteres específicos.

El molar inferior, que es un penúltimo molar izquierdo, corresponde claramente al E. caballus y no al E. Stenonis, lo cual me lleva a incluir el yacimiento de donde proceden estos fósiles en la segunda época interglaciar, mejor que en el plioceno superior o primer periodo interglaciar.

Examinando los numerosos ejemplares de molares de caballo que - procedentes del cuaternario medio existen en las colecciones del Museo Nacional de Ciencias Naturales, no pueden señalarse particularidades de importancia para considerar al de Valverde de Calatrava como específicamente diferente. Las dimensiones del diente, medidas en la corona, son: diámetro antero-posterior, 29 mm.; diámetro transverso, $18 \mathrm{~mm}$.

Correspondientes a un Cervus de talla bastante grande son un fragmento de mandíbula izquierda, con el último molar y un molar suelto de la mandíbula superior izquierda (lảm. IX). Sus caracteres coinciden en términos generales con los dientes análogos del Cervus elaphus Linné, tan abundantes en el cuarternario medio de España; pero teniendo en cuenta las grandes semejanzas que presentan los molares de las diversas especies de ciervos cuaternarios, no puedo, con sólo estos dos dientes, determinar con seguridad la especie. Las dimensiones son: molar inferior, diámetro antero-posterior de la corona, $32 \mathrm{~mm}$.; diámetro transverso, $14 \mathrm{~mm}$. Molar superior, diámetro antero-posterior de la corona, 17 mm.; diámetro transverso, $15 \mathrm{~mm}$.

Edad de los voleanes de Cindad Real. - Hasta el presente los volcanes del centro de la Península Ibérica se han considerado como 
terciarios: para el ingeniero CORTÁzAR son anteriores al depósito de las calizas miocenas, porque no las han alterado; para el profesor QUirogA, contemporáneos de los depósitos miocenos, por cuanto las calizas que supone de esta edad engloban y cementan a lapillis y materiales eruptivos. Ya he expuesto mi opinión, según la cual las calizas tobáceas de la llanura de Ciudad Real, inmediatas o en relación con los materiales eruptivos, deben considerarse, no como miocenas, sino como cuaternarias y aun modernas. La observación de estos materiales litológicos en diversidad de localidades del Suroeste y Sur de España y de Fuerteventura y Lanzarote, englobando a moluscos terrestres cuaternarios o subfósiles, me había llevado a este. convencimiento, y la presencia de una potente capa de caliza blanca terrosa de más de 2 metros de espesor sobre aluviones con fósiles de mamíferos de edad cuaternaria en el yacimiento de Valverde de Calatrava, lo comprueba plenamente.

No es de extrañar la creencia, que juzgo errónea, de los dos ilustres greólogos citados, pues las analogías y semejanzas de algunas calizas del terciario medio y superior con las formadas posteriormente son muy grandes; por otra parte, la falta de documentos paleontológicos les privaba de la prueba decisiva en estratigrafía.

En el territorio por mí explorado en Ciudad Real y parte de los campos de Calatrava no he visto en contacto los materiales volcánicos con los estratos de edad terciaria indudable. Una investigación cuidadosa en este respecto debe aún intentarse para fijar la fecha inferior de algunas erupciones, pues teniendo en cuenta el diverso estado de alteración de los materiales volcánicos, es probable que las erupciones del centro de la Península se hayan desarro. llado en un periodo de tiempo amplio, probablemente desde el final de los últimos movimientos orogénicos del terciario superior hasta bien entrado el cuaternario, y quizá hasta el período holoceno o actual. Los estudios que viene haciendo Roro Gómez (1) respecto al terciario de Castilla la Nueva, según los cuales, movimientos de indole orogénica o por lo menos de diastrofismo se han realizado en el interior de España, plegando y dislocando los estratos miocenos, señalan un fenómeno que pudo ser concomitante con el comienzo de las erupciones volcánicas de que ine ocupo.

Circunscribiéndome a las erupciones próximas a Ciudad Real, el

(1) J. Royo Gómez, Datos para la geologia de la submeseta del Tajo. - (Bol. de la R. Soc. Esp. de Hist. Nat., t. XVII. Madrid, 1917.) 
feliz hallazgo de fósiles de mamíferos en relación con materiales volcánicos, en clara estratigrafia, permite establecer que por lo menos algunas de las erupciones de los volcanes de Ciudad Real se realizaron con posterioridad al cuaternario inferior, por cuanto el conjunto de las especies Elephas meridionalis, Hippopotamus amphibius subesp. major, Equus caballus fossilis y Cervus sp. intercaladas en aluviones fluviales sin cantos volcánicos, corresponde al segundo período interglaciar, formación a la que superpone una gruesa capa de caliza y otra de lapillis basálticos. Este hecho lleva a suponer que es muy probable que los hombres del paleolítico inferior vieran a los volcanes del centro de España en pleno desarrollo de su grandiosa actividad.

\section{Explicación de las láminas VI a IX.}

Lám. VI. - Fìg. I. Cono del volcán del cabezo del Hierro visto desde la planicie del Guadiana.-Fig. 2. Barranco de crosión mostrando las escorias que constituyen el cono volcánico del cabezo del Hierro.

Lám. VII. - Fig. I. Prismas de basalto del volcán del Arzollar. - Fig. 2. Planicie del Guadiana, situada al pie del volcán del cabezo del Hierro, donde está el yacimiento de mamiferos cuaternarios de Valverde de Calatrava.

Lám. VIII.-1 y 2, molares de Elephas meridionalis Nesti, a mitad de su tamaño; 3 y 4 , fragmentos de caninos inferiores de Hippopotanus amphibius Linné, subespecie major Owen, a mitad de su tamaño; 5 , fragmento de molar de $H$. amplibibius, a tamaño natural.

Lám. IX. - I, fragmento de mandíbula de Cervus, sp. con el último molar; 2, el mismo molar visto por la corona; 3 y 4 , molar superior de la misma especie visto de frente y por la corona; 5 y 6 , molar inferior de Equus caballus fossilis Cuv. visto por la corona y de frente. (Todo en tamaño natural.) 


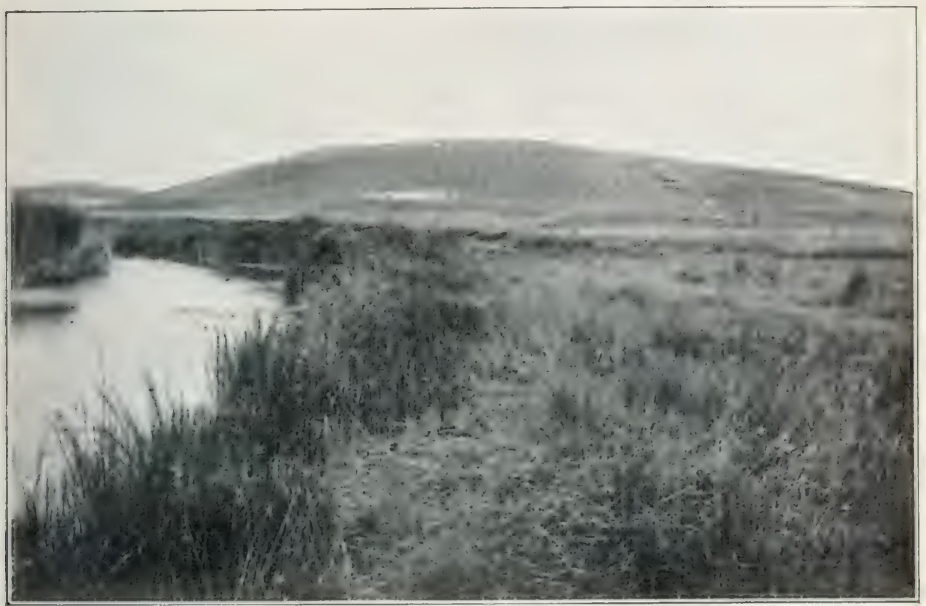

Fig. I. - El cabezo del Hierro desde el Guadiana.

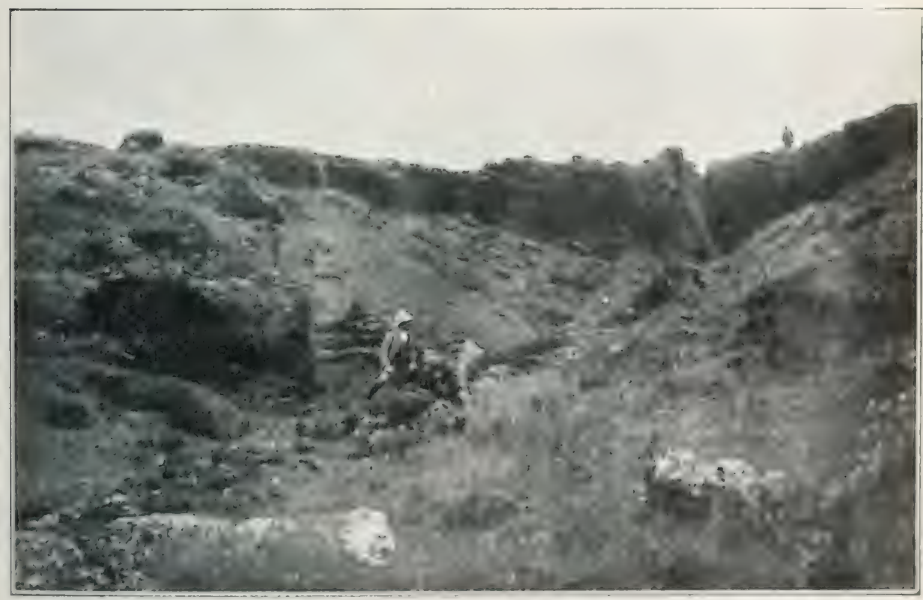





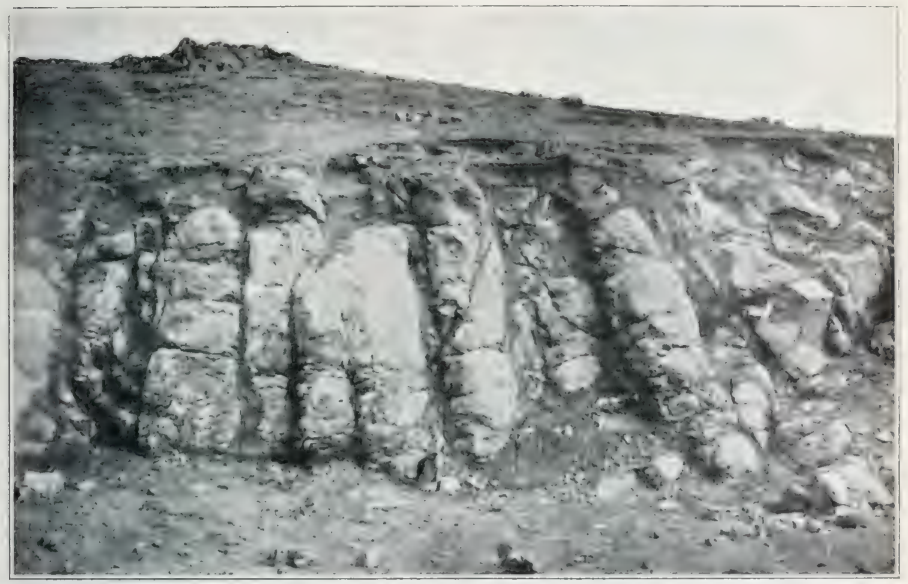

Fig. 1. Basaltus del draillin

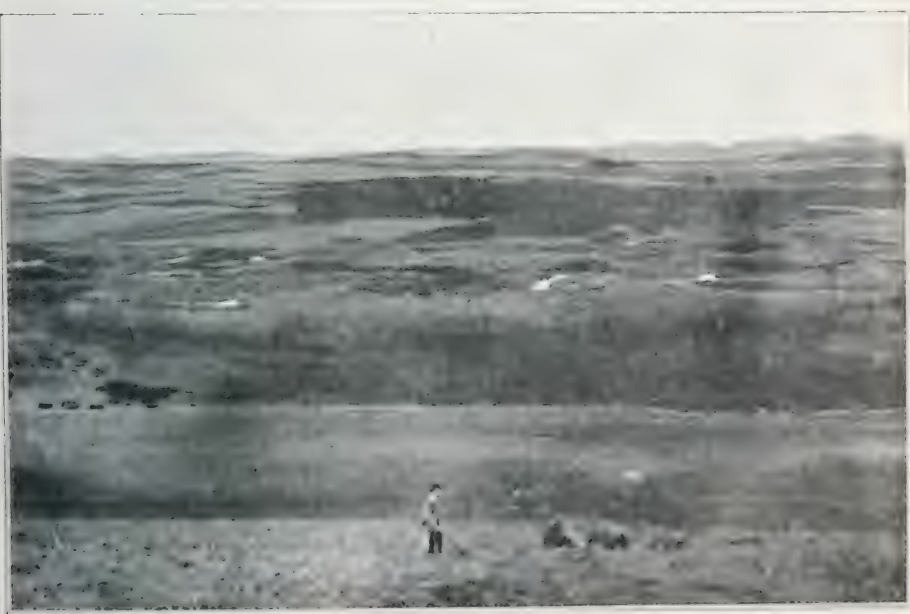

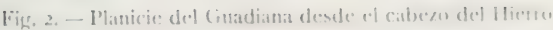



R. Soc. Esp. de Hist. Nat. - T. del $500^{\circ}$ aniv.

LANI. VIII.

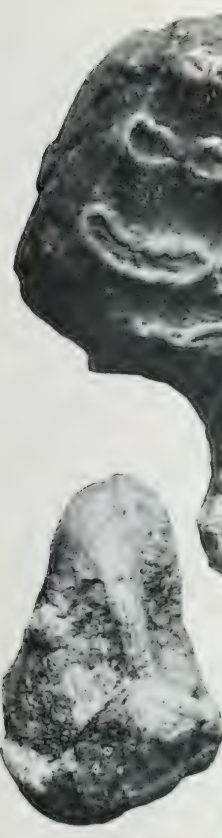

5
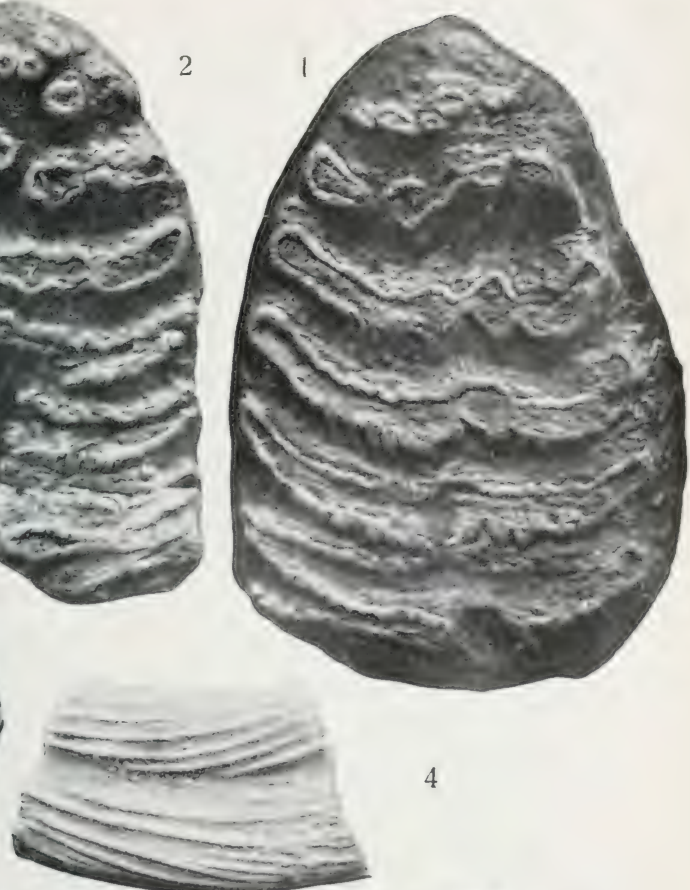

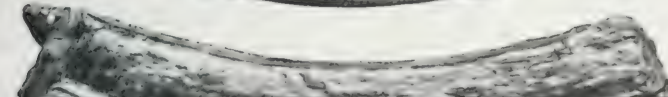

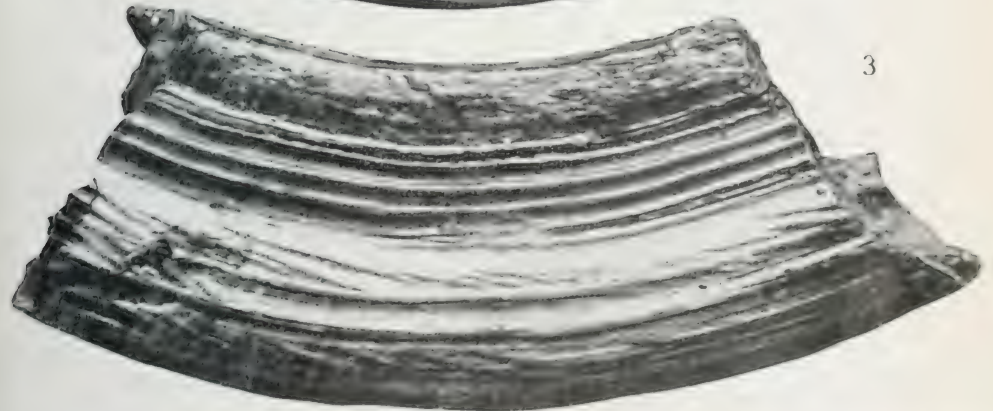

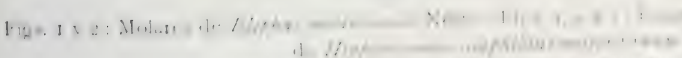

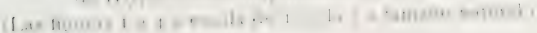



R. Soc. Esp. de Hist. Nat. - T. del $500^{\circ}$ aniv.

LÁM. IX.
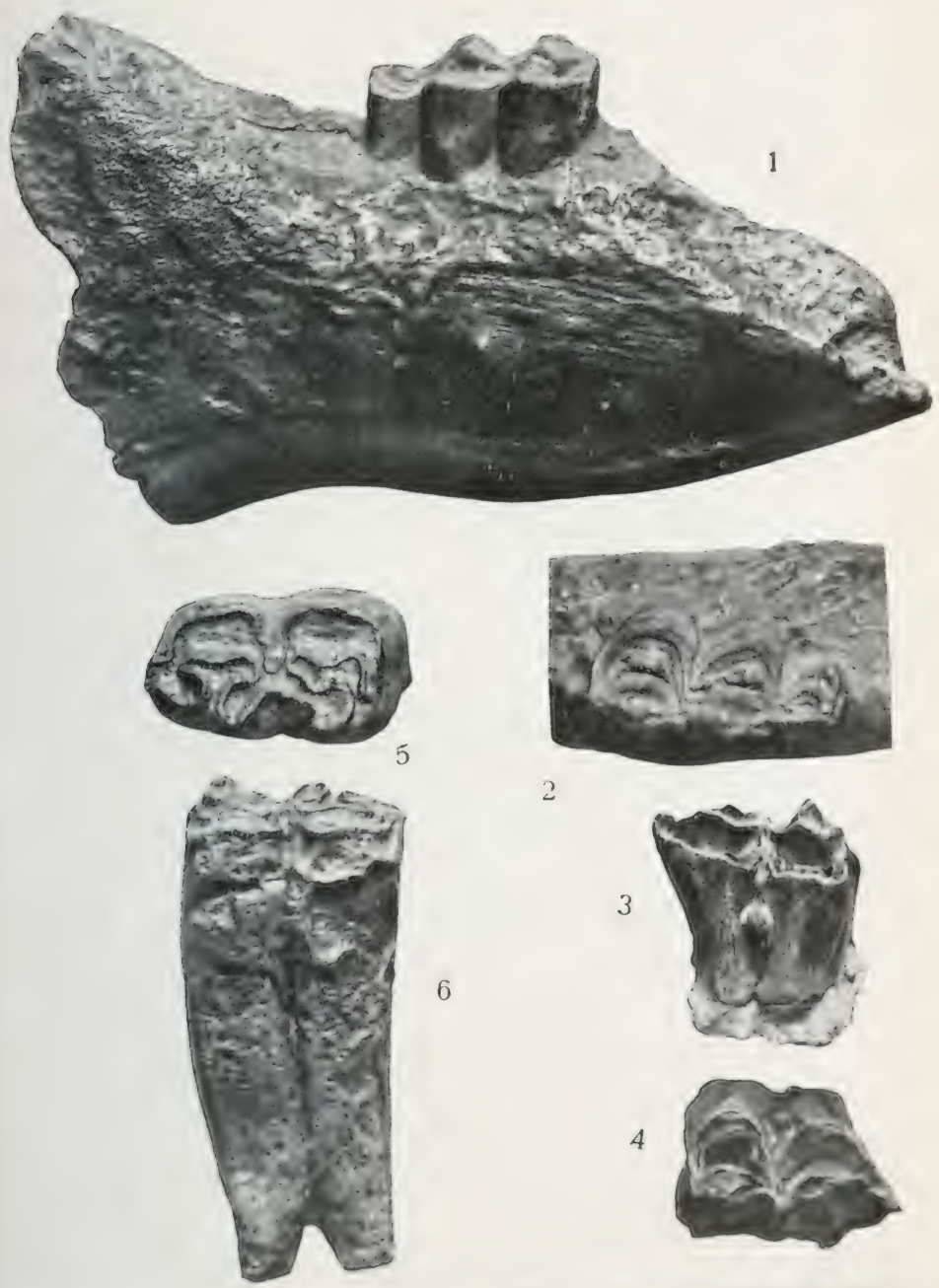

2
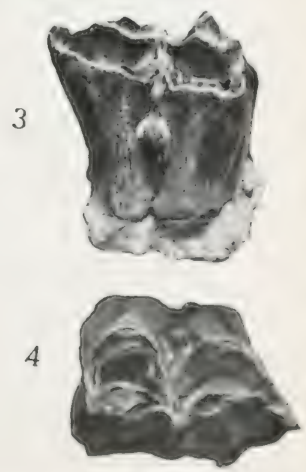

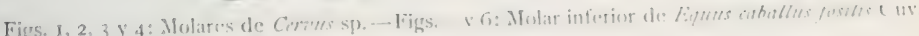





\title{
ALGUNAS CONSIDERACIONES ACERCA DE LA MORFOLOGÍA DE LOS EQUINODERMOS
}

\author{
POR
}

\section{ENRIQUE RIOJA}

El interesante grupo de los Pelmatozoa está constituido en su inmensa mayoría por formas fósiles que aparecen ya en el cámbri. $\mathrm{co}$, siendo escasas las vivientes y conservando éstas caracteres arcai- cos manifiestos. IJabitan casi todas ellas en las grande's profundidades oceánicas, juntamente con especies de otros grupos, que conservan también de un modo patente caracteres primitivos, buscando sin ducia refugio y defensa en la tranquilidad y uniformidad de aquellat aguas contra la concurrencia de especies más evolucionadas. Una contraprueba de esta opinión nos la proporcionan los géneros litorales actuales de crinoideos (Antedon, Halopus, Actinometra), muy especializados, como demuestra la carencia de pedúnculo en la edad adulta.

El corto número de especies vivientes y la persistencia en ellas de los caracteres ancestrales llamaron nuestra atención y nos indujeron a estudiar los grupos exclusivamente fósiles de los Pelmalozoa (Cystoidea y Blastoidea), emprendiendo un trabajo meramente informativo sobre aquellas formas extinguidas, buscando datos para comprender de un modo más exacto la morfología de los equinodermos actuales en general, y más particularmente las relaciones que ligan entre sí a los Pelmatozoc con los Eleutherozoa. Este estudio nos ha sugerido algunas ideas acerca de la morfología comparada de los equinodermos que damos a conocer en esta nota.

Las formas más sencillas de los equinodermos las encontramos en los Amphoridea, siendo tal vez el equinodermo más primitivo conocido el Aristocystis bohemicus Barrande, encontrado por su 
autor en el ordovícico de Bohemia, y cuya descripción sucinta hacemos a continuación, para mejor comprender las consideraciones que siguen más adelante.

El fósil de que nos ocupamos está constituído por una masa ovoidea o piriforme, que representa el cáliz del Antedon (fig. 1, a, $b$ y $c$ ), estrechada inferiormente, por donde se supone que se fijaba
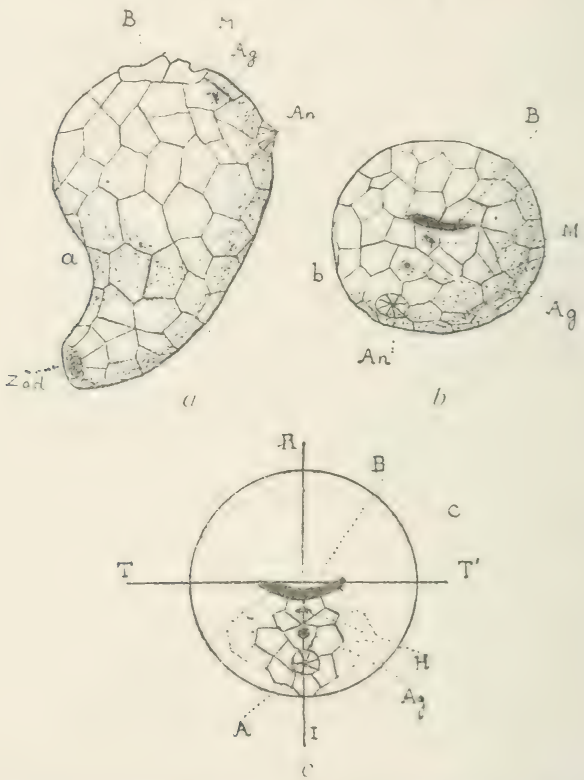

Fig. I. - Aristocystis bohemicus Barrande: $a$, visto lateralmente; $b$, visto por la cara oral; $c$, esquema mostrando la disposición de las aberturas del cáliz y de los planos por ellas determinados ( $a$ y $b$, según BARRANDE): $A n$, ano; $d g$, abertura genital; $\mathcal{B}$, boca; $M$, hidróporo; $Z a d$, zona de adhesión; $R T$, plano anal equivalente al (III-5) de otros equinodermos; 'TT', plano transversal o adradial.

de un modo imperfecto, mediante pequeña zona de adhesión. Carece en absoluto de braquiolas, y todo él está cubierto de placas esqueléticas poligonales, dispuestas de un modo desordenado, de contorno irregular, pero con cierta tendencia a la adquisición de la forma 
exagonal. Lo más interesante en esta forma es la disposición de las cuatro aberturas del cáliz, sobre cuya significación insistiremos.

La boca se presenta como una hendidura transversal, encorvada hacia arriba en sus extremos, por debajo de la cual existe una pirámide (fig. 1, $a, b$ y $c, A n$.) integrada por seis a ocho placas triangulares, en cuyo vértice se halla el ano. Entre estas dos aiberturas se encuentran otras dos más pequeñas, que representan al hidróporo y al orificio genital, siendo el primero el más próximo a la boca, y el segundo el situado al lado del ano.

Si nos fijamos en la colocación de estas cuatro aberturas, observaremos que la boca y el ano determinan un plano (fig. 1, c, RI), en el que están colocados la abertura genital y el hidróporo, y que divide al cáliz en dos porciones, derecha e izquierda, próximamente iguales. La boca, por su forma alargada transversalmente, da lugar a que consideremos la existencia de un plano, perpendicular al ya mencionado, que divide al cuerpo en una porción anterior, sin abertura de ningún género, y otra posterior, en la cual estån colocados el ano y las otras aberturas del cáliz.

Si tenemos en cuenta que todos los órganos situados en la mitad posterior y en el plano anal son netamente interradiales en todos los equinodermos, podemos considerar la porción colocada por encima del plano transversal (fig. 1, $c, T T^{\prime}$ ) como equivalente a un radio, y la inferior o posterior, anal, como un interradio. Sabemos que en los equinodermos existe un plano de simetria bilateral, determinado por la excentricidad del ano, que en la numeración empleada por DELAGE y Herocard es el (III-5); es decir, el determinado por el radio (III) y el interradio 5 o posterior (1), que holinologamos en absoluto al plano anal del Aristocystis. Teniendo en cuenta las anteriores consideraciones, podemos suponer que el Aristocystis

(1) La numeración empleada por estos autores en su Traité de Zoologie concrète nos parece la más clara y sencilla. Otros autores, siguiendo a CARPENTER y CUÉNOT, denominan $\mathrm{A}$ al radio opuesto al interradio que lleva la madreporita, y B, C, D y E a los restantes. Los interradios se designan por las letras de los radios que los limitan. Según esta nomenclatura, el plano (III-5), en el que está el ano, estaria determinado por el radio D, y el interradio (A-B) y el interradio en el que está colocada la madreporita, o sea el 2 de Delage y HérouArD, se denominaría (C-D). LuDWig emplea en algunos de sus trabajos una nomenclatura propia, que es poco seguida. 
está constituido por un solo antímero, formado a su vez por un radio y un interradio, separados entre sí por un plano adradial, o sea el que antes hemos considerado como transversal (fig. 1, $c, T T^{\prime}$ ).

Esta constitución peculiar determina un predominio grande de la simetria bilateral, por presentarse la simetría radial en esta forma primitiva, formada por un solo elemento o antímero, por lo que podemos suponer la superposición de la simetría bilateral con otra monorradial, del mismo modo que existe aquélla con la pentarradial en los equinodermos formados por cinco antímeros.

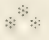

En los equinodermos de simetría pentarradial se dan algunos casos en que persisten en el mismo interradio la abertura del aparato acuifero, el órgano genital único y su orificio exterior, y la última porción del intestino con el ano de un modo semejante a lo que sucede en el Aristocystis, indicando esta disposición un carácter primitivo. Examinaremos esta cuestión en los siguientes casos: $1 .^{\circ}$, en la larva del Antedon; $2 .^{\circ}$ en los holotúridos, y $3 .^{\circ}$, en los espatánguidos, en donde reviste gran interés por ser formas muy evolucionadas en que se observa una tendencia a recuperar aquella disposición.

Según ha demostrado Russo (1), en la larva fitocrinoide del Antedon aparecen los elementos sexuales como un acúmulo celular situado en una formación mesenteroide ya descrita por LUDIviG (1880) y por SEeliger (1892), situada en el interradio 5 (C-D para Russo, que emplea la nomenclatura de CUÉNOT y que asimila este interradio al en que está colocado el hidróporo, en tanto que nosotros le homologamos al anal), mostrándose con posterioridad, después de su desaparición, los órganos genitales definitivos. Si observamos durante este estado larvario la disposición del ano y del canal

(1) A. Russo, Sulla omologia dell' organo assile dei Crinoidei e su altre quistioni riguardanti la morfologia degli Echinodermi. (Zool. Anz., pág. 288, 1899.) - Nuovo contributo all embriologia degli Echinodermi. (Boll. Soc. Nat. di Napoli, 1894.) - Sul cosidetto canale problematico delle Oloturie, etc. (Ibid., 1897.) - Sull aggruppamento dei primi elementi sessuali nelle larve di Antedon, etc., etc. (Rendiconti R. Accademia dei Lincei, pág. 361, 1900.) - Sullo sviluppo dell' apparato madreporico di Antedon. (Zool. Anz., pág. 529, 1901.) 
petroso (fig. 2), veremos que coincide con la que presentan en el Aristocystis, estando colocado este último en la formación mesenteroide antes mencionada, perdiendo sus primitivas relaciones al bifurcarse los brazos de la larva. Estos hechos indican una estrecha relación entre los crinoideos y los holotúridos, en los que se

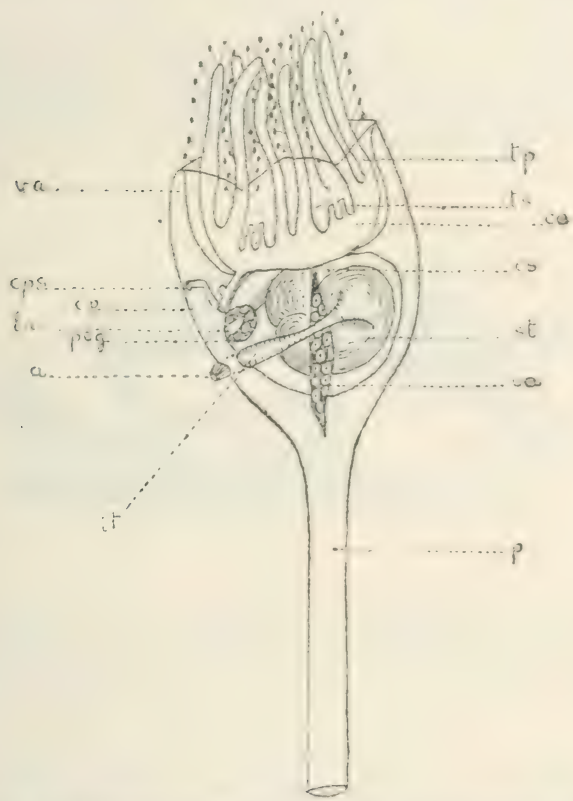

Fig. 2.- Larva de Antedon rosacea a los ocho dias de su fijación (segrún Russo). $a$, abertura anal; $c a$, canal acuífero oral; $c p$, canal petroso; $c p s$, canal petroso secundario; es, esúfago; $i l$, intestino terminal; $l a$, laguna aboral; ol, brgano axial; peg, elementos sexuales prinitivos; st, estómago; $t p$, tentáculos primarios; $t s$, tentáculos secundarios; $r$, valva oral; $p$. pedúnculo de fijación.

encuentran en la edad adulta aquellos órganos en el mismo orden que en la larva del Antedon.

En el mesenterio dorsal de los holotúridos (fig. 3), que se puede considerar homólogo a la formación mesentcroide de la larva del 
Antedon, se encuentra colocado en su espesor el canal petroso, cuya madreporita se abre al exterior en varios Elasipodidae; en algunos otros géneros de esta familia y en ciertos Molpadidae el canal continúa soldado con la pared del cuerpo, sin abrirse al exterior, desarrollándose una madreporita interna, y por último, en la mayoría (fig. 3) de los dendroquirótidos y aspidoquirótidos abandona la pared del cuerpo, quedando libre su extremidad en el celoma. Por detrás de éste se encuentra el canal genital, que recorre parte de la porción superior del mesenterio, terminando exteriormente por el poro genital. El ano ha emigrado, haciéndose terminal,

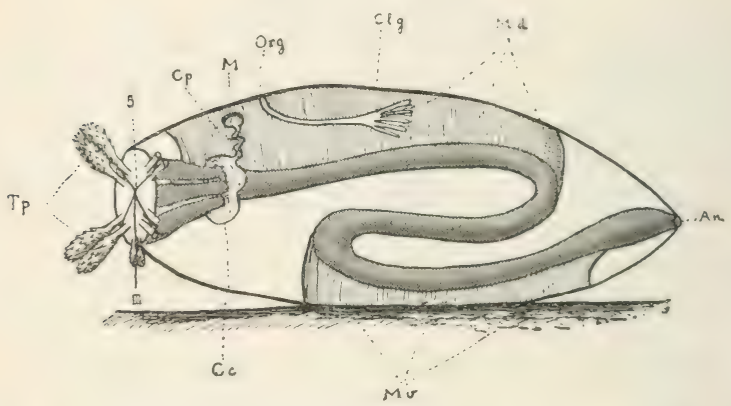

Fig. 3. - Esquema de la disposición de los brganos de un holotúrido: An, ano; $C o$, canal oral; $C p$, canal petroso; $G l g$, glándula genital; $M I$ madreporita; $\boldsymbol{M} d$, mesenterio dorsal; $\Lambda / v$, mesenterio ventral; $O r g$, orificio genital; $T p$, tentáculos peribucales.

caso frecuente en los equinodermos, observándose en ciertos casos en los mismos cistoideos una separación grande entre la boca y el ano, como sucede en el género Dendrocystis.

Es interesante encontrar en grupos, al parecer tan distintos como los Crinoidea, Cystoidea y Holothurioidea, la misma disposición relativa de aquellos órganos, lo que nos indica una comunidad de origen o por lo menos una relación de descendencia. El hecho señalado por Russo, de la existencia de un órgano genital único en la larva del Antedon, nos conduce a considerar a los Crinoidea como un eslabón que une las dos series que HAECKEL establece en los equinodermos, atendiendo al número de glándulas genitales, y 
que denomina Monorchonia y Pentorchonia, seguin que existan una sola glándula o, por el contrario, cinco.

Resumiendo lo dicho se pueden considerar como formando parte del primer grupo de HAECKEL a los Cystoidea y Holothurioidea, y. del segundo a los Blastoidea, Asteroidea, Ophiuroidea y Echinoidea, y a los Crinoidea como un grupo intermedio de transición, por ser monorchonia en las primeras fases larvarias (fitocrinoide), y pentorchonia en el resto de su vida.

Homologando el plano anal del Aristocystis con el (III-5) de los otros equinodermos, y existiendo las relaciones señaladas con los holotúridos, no es posible admitir la numeración que Delage y

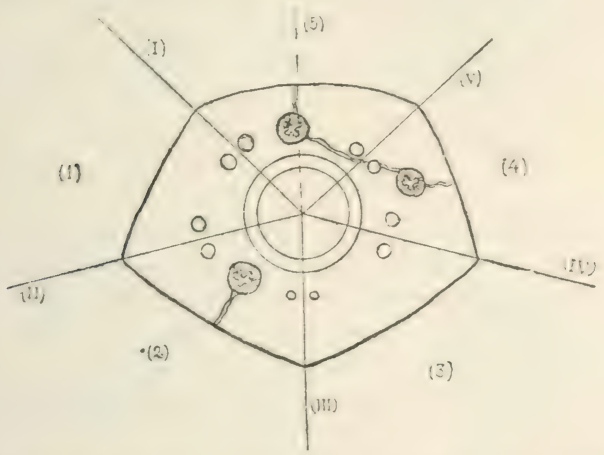

Fig. 4. - Esquema mostrando la numeración de los radios e interradios del triviun y bivium de los holotúridos en su relación con los tentáculos peribucales, el intestino y los distintos mesenterios que le sujetan a las paredes del cuerpo: (I), (II), (III), (IV) y (V), radios; (I), (2), (3), (4) y (5), interradios.

HÉROUARD establecen en este grupo para los radios e interradios del bivium y trivium, teniendo en cuenta tan sólo la existencia del canal petroso en el mesenterio dorsal. Según el criturio moriológico seguido por nosotros, el interradio superior del bivium, en el que está colocado el mesenterio dorsal con el canal petroso y el genital, sería el número 5, y el radio opuesto, o sea el mediano del trivium, sc:ria el III (fig. 4), perfectamente señalado por el menor desarrollo que tiene el par de tentáculos peribucales que a él corresponde (figs. 3 y 4). El interradio 5 estaría limitado por los dos radios del bivium, que siguiendo nuestro punto de vista serian el I y el V; 
los radios del trivium serían el II, el III y el IV, que alternarian con los interradios 2 y 3 (fig. 4).

El último caso que vamos a estudiar reviste gran interés, por realizarse en formas indudablemente muy especializadas, como los

$n$ (IIII)

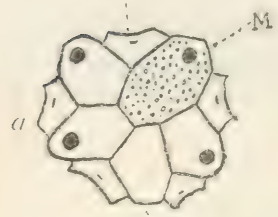

$\sin (5)$

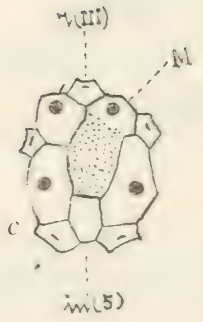

$\eta(\mathrm{III})$
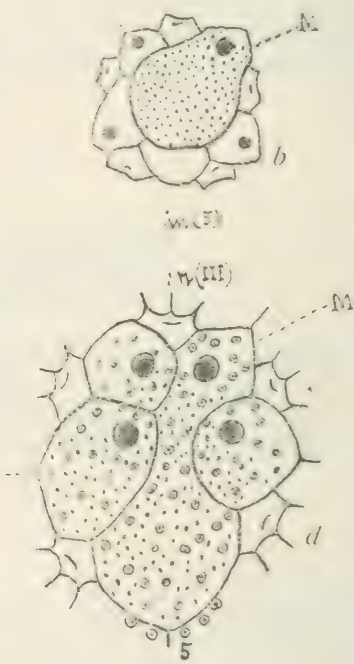

Fig. 5. - Sistema apical de varios equínidos irregulares, para demostrar la desaparición de la basal correspondiente al interradio 5 y su substitución por la madreporita, $M: a$, Discoidea contica Des., del cretácico albiense (según Lovín); $b$, Holectypus depressus Des., del oolítico bajociense (según Lovis); c, Pyrina Durandi P. y G., del cretácico turoniense (según Lovén); d, Spatangus purpureus O. F. Müller, actual (según Lovén); in, interradiales o basales; $r$, radiales; . II, madreporita.

espatánguidos, y que presentan, como veremos, cierta tendencia a reconquistar la disposición señalada más arriba en otros grupos.

El ano emigra en los espatánguidos en el interradio posterior, o sea el 5, abandonando la región apical y arrastrando en este movimiento a la placa basal o genital 5 , que desaparece, quedando reducidas a cuatro las placas basales (fig. 5 , d). El espacio que queda 
libre por desaparición de aquella placa, es ocupado por la madreporita (fig. $5, d, M$ ), que colocada en el interradio 2 y sin abandonar éste, se prolonga y se intercala entre las radiales I y $\mathrm{V}$, estando, por tanto, emplazada casi toda ella en el plano (III-5); es decir, que vuelve a ocupar en parte su lugar primitivo, en donde la hemos hallado en el Aristocystis, en la larva del Antedon y en el mesenterio dorsal de los holotúridos. Esta emigración no se verifica de un modo brusco, observándose, por el contrario, una evolución que se inicia ya en los Holectypida, desapareciendo paulatinamente la basal número 5 , al mismo tiempo que la madreporita invade el espacio que ella deja libre (fig. 5, $a$-d).

Este ejemplo es sumamente curioso, por mostrarnos cómo formas muy evolucionadas pueden recobrar una disposición, evidentemente primitiva, que se encuentra en especies arcaicas, recordando tal vez una relación de descendencia.

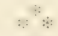

Sabido es que la simetría pentámera es la más frecuente en los equinodermos vivientes, produciéndose, por desdoblamiento de los cinco radios típicos, una simetría de orden superior, como sucede en el género Promachocrinus, que tiene diez radios y un número aún mayor en varios géneros de las familias Helliasteridae y Brisinguidae. Esta tendencia al desdoblamiento de los radios se observa de un modo patente en varios grupos en los cuales los brazos se ramifican, como sucede en todos los Crinoidea y en la mayoría de los Cladophiurida.

Es frecuente en los Cystoidea una simetria trimera, muy manifiesta en mucha especies, y cuya influencia se nota aún en formas que tienen ya simetría pentarradial, determinando una cierta disposición de las placas esqueléticas (placas basales de los Blastoidea). Estos hechos han inducido a BATHER (1) a suponer la simetría trirradial como primitiva, originándose de ésta la pentarradial por desdoblamiento de los dos radios posteriores, entre los cuales están colocados el ano y los orificios de los aparatos acuíferos y genital (fig. 6, c). Si atendemos a lo dicho más arriba respecto a la constitución del Aristocystis, podremes completar esta idea -upuniomats

(1) BATHER, A Treatise on Zoologv, Part III, " The Echinoderma , 190 !. 
que el radio originariamente único (fig. $6, a$ y b) se bifurca en su

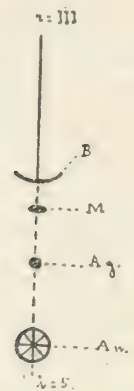

$a$

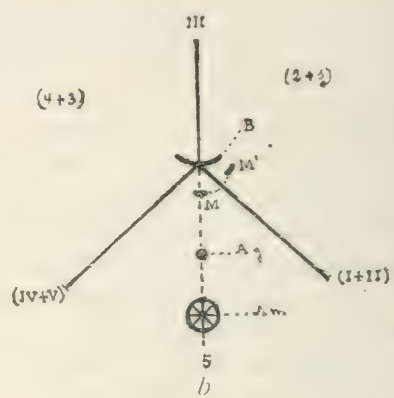

III.
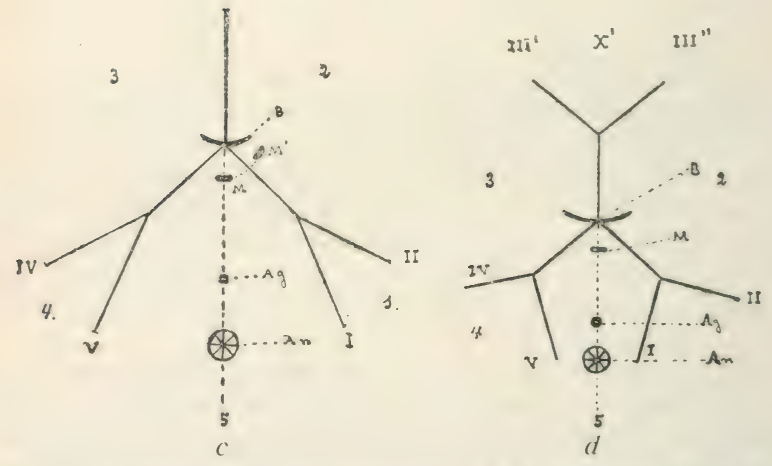

Fig. 6.- Esquemas para explicar la adquisición de la simetria pentarradial y exarradial, partiendo del Aristocystis: a, disposición de las aberturas del cáliz en los Amphoridea primitivos (Aristocjstis); $r$, equivalente al radio III; $i$, homólogo del interradio $5 ; b$, simetria trimera: el radio posterior derecho dará origen a los radios $(\mathrm{I}+\mathrm{II})$ que están aún fusionados; el radio posterior izquierdo, a los $(\mathrm{IV}+\mathrm{V})$; interradio $(2+1)$, que se desdoblará en el 2 y el 1 ; interradio $(4+3)$, que se desdoblará en los 3 y $4 ; c$, constitución de la simetria pentámera por desdoblamiento de los dos radios posteriores (I, II, III, IV y V), radios; (I, 2, 3, 4 y 5), interradios: d, constitución de la simetría exámera por desdoblamiento del radio anterior (III),

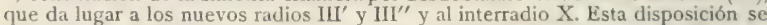
encuentra en el género Ilemicosmites: $A n$, ano; $A g$, abertura genital; $b$, boca; $M$, posición primitiva de la madreporita; $M^{\prime}$, posición definitiva de la madreporita.

extremo anal, dando lugar a los tres radios que supone BATHER 
como primitivos, los cuales, a su vez, dan origen, del modo indicado anteriormente, a la simetría pentarradial (fig. 6, c). Puede darse el caso de dividirse, además de los dos radios posteriores, también el anterior, y entonces dar lugar a formas de seis radios, como se observa en algunos géneros de los mismos Cystoidéa, como el Hemicosmites (fig. 6, d). No es frecuente la existencia de esta simetria exarradial, tal vez porque con ella desaparece el plano (IIl-5), tan típico e importante para la morfologia del crupo de los equinodermos.

Como confirmación de lo expuesto, podemos citar las variaciones que se observan en el número y distribución de las braquiolas
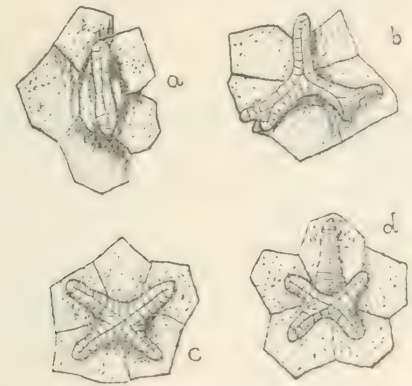

Fig. 7.- Origen de las braquiolas en la Echinosphaera aurantium: a, cxistencia de una sola braquiola; $b$, caso de existir tres braquiolas, de las que las dos posteriores presentan una pequeña ramificación; $c$ y $d$, existencia de cuatro braquiolas por atrofia de la anterior. (L_as figuras $a, b$ y $c$, según Volbortir.)

de la Echinosphaera aurantium. Vemos por las figuras (fig. 7, a) que puede existir una sola braquiola, la cual se ramifica a veces, dando lugar a tres (fig. 7, b), de las que las dos posteriores, por el mismo proceso, dan origen a cinco, que nos indican una simetria pentámera, como en la mayoría de los equinodermos. Se dan algunos casos de existir en esta especie cuatro braquiolas, cuya presencia es posible explicar por atrofia de la anterior después de la consiguiente división de las dos posteriores (fig. 7, a).

La situación típica de la madreporita en el interradio se explicilría por simple desviación del hidróporo, que quedaria entonces a la derecha del radio posterior derecho, y al bifurcarse éste, quedaria en su posición definitiva (fig. $(5, b$ y c). La multiplicación de los 
órganos genitales nos conduciría a la serie Pentorchonia, con las cinco glándulas genitales características y la abertura del aparato acuífero en el interradio 2.

En resumen, las consideraciones anteriores nos prueban cómo, por simple y sucesivo desdoblamiento del radio único del Aristocystis, se da lugar a los equinodermos con varios radios, y cómo a medida que éstos aparecen, los distintos órganos interradiales, situados primitivamente juntos en el plano anal de aquel fósil, y en ciertos casos señalados (en los holotúridos y larva del Antedon, por ser formas primitivas), se distribuyen en los nuevos interradios que sucesivamente se forman.

\section{DOS NUEVAS ESPECIES DE STERNOCOELIS DE MARRUECOS}

(COL. HISTERIDAE)

POR

MANUEL M. DE LA ESCALERA

Sternococlis cancriformis sp. nov. (fig. 1).

Longitud, $1,8 \mathrm{~mm}$.

Localidad : Larache.

Cuerpo de color rojo-ladrillo, lustroso, acaramelado; con doble pubesćencia sobre el protórax, élitros y abdomen: una sentada, de cerditas cortas, finas y doradas, moderadamente densa, naciendo de un fondo liso, y otra de cerdas más fuertes, aisladas, largas y erectas, que nacen de unas fositas circulares superficiales, y más profundas en la primera mitad del élitro.

Protórax transverso, de lados paralelos en sus dos tercios anteriores y ensanchado en su tercio posterior para formar los ángulos bastante agudos, mientras que los anteriores son obtusamente redondeados; de borde anterior poco escotado, y el posterior apenas sinuado, en línea casi recta oblicuada hacia el escudete y con una 
fuerte impresión oblonga cerca de los ángulas posteriores, que lis hace aparecer algo levantados; disco casi plano, apenas convexo y de bordes laterales cortantes.

Élitros bastante convexos, obtusamente truncados en el ápice, con la sutura lisa poco hundida y algo obscurecida, como el extremo apical y la base; con dos estrias finas y enteras desde la base al ápice de igual longitud, y una primera dorsal corta, extinguida en el primer tercio de la longitud del élitro.

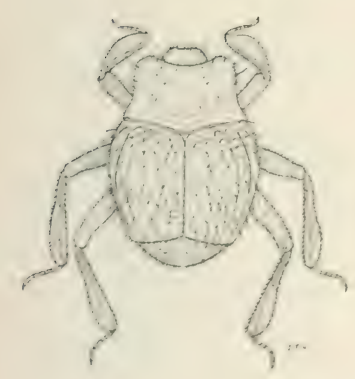

Fig. 1. - Sternocoelis cuncriformis Sp), nov., $\times 15$.

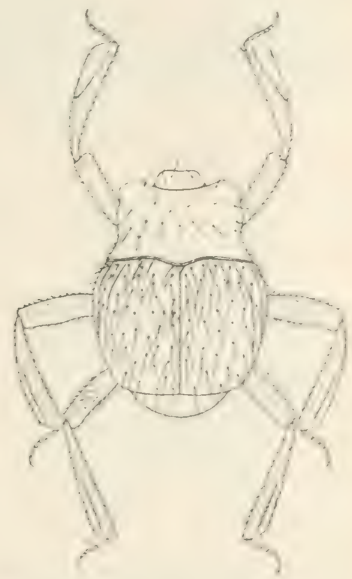

Fig. 2. - Sternocuelis araclunoides Fairm., X 15 .

Propigidio menuda y superficialmente punteado.

Patas largas, de tibias largamente mazudas, redondeadas en su extremidad, acanaladas en su borde dorsal para recibir los tarsos, que son también largos, con los bordes de los surcos tibiales largamente ciliados.

Especie próxima a $S$. arachnoides Fairm. (fig. 2), de la que se separa por la doble pubescencia de nuestra especie y por tener más transverso el protórax, más obtusos los ángulos posteriores, mayor paralelismo y menor flexuosidad en sus lados, diferente estriación elitral y menor longitud de las patas. 


\section{Sternocoelis aureopilosus sp. nov. (fig. 3).}

Longitud, 1,9 mm.

Localidad: Larache.

Color rojo-ladrillo tostado, achocolatado, lustroso; con pubescencia sencilla muy corta, dorada y sentada, bastante densa, naciendo las cerditas cada una de una fosita muy pequeña, pero apreciable; a cierta luz y con poco aumento parecen el protórax élitros y abdomen como nevados, sin fosillas mayores ni cerdas largas.

Protórax transverso, subtrapezoidal, de ángulos anteriores obtusamente matados, y con los posteriores bastante agudos; borde anterior poco escotado, y el posterior en línea algo flexuosa avanzada

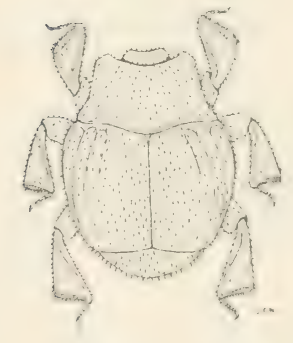

Fin. 3.- Sternocoelis aureopilosus sp. nov., $\times 15$.

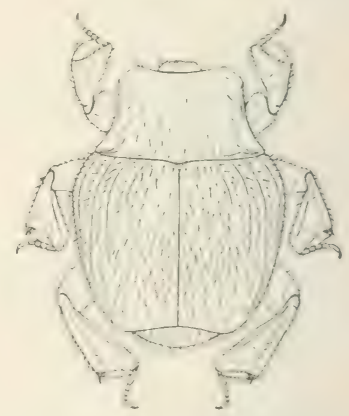

Fig. 4. - Stemocoelis acutangulus Lewis, $X 15$.

hacia el escudete, donde se redondea el lóbulo, con una fosa fuerte triangular cerca de los ángulos posteriores, que aparecen de resultas algo levantados; disco moderadamente convexo.

Élitros bastante convexos, truncados casi en linea recta en el ápice, con la sutura lisa nada hundida ni obscurecida; con cuatro estrias anchas, libres de pubescencia y muy apreciables, aunque no muy hundidas, de las que la primera dorsal se extingue antes de la mitad del élitro, la segunda pasada ésta en el último tercio, la tercera muere cerca del extremo y la cuarta o lateral se oculta por debajo de los húmeros y corre a lo largo de la parte rebatida del élitro hasta el ápice. 
Patas moderadas, gruesas y fuertes, con las tibias triangulares, truncadas en su extremo y excavadas alli para recibir los cortos tarsos, con una estría en su cara interna, que determinan quillas cortantes en la cara inferior de las tibias, muy adelgazadas aquí.

Especie próxima a S. acutangulus Lewis (fig. 4), a cuya sección pertenece, $\mathrm{y}$ distinta por su tamaño menor, protórax más curtamente transverso, ángulos posteriores protorácicos menos agudo-, diferente estriación elitral y falta de las cerdillas largas de dicha especic.

\section{SOBRE LA EYOLUCIÓN DE LAS NEURONAS RETINIANAS EN LOS LEPIDÓPTEROS}

POR

DOMINGO SÁNCHEZ Y SÁNCHEZ

Quienquiera que consulte la copiosa bibliografía neurológica aparecida durante el último decenio del siglo pasado y el primero del presente, echará pronto de ver la escasez de trabajos relativos al sistema nervioso de los artrópodos en general y particularmente de los insectos. Y este fenómeno llama tanto más la atención cuanto que forma notable contraste con la gran importancia que en las obras de Biologia zoológica general se concede, durante aquel período, a ese interesante grupo zoológico.

Débese principalmente semejante hecho, a nuestro modo de ver, a las grandes dificultades con que se tropezaba al tratar de aplicar en esos animales, como en la generalidad de los invertebrados, los métodos considerados como específicos para el estudio del sistema nervioso, cuyo empleo había proporcionado tan abundantes y sazonados frutos, especialmente en los vertebrados.

Mas de algunos años a esta parte se han ido logrando, mediante el empleo del método de Golgi, el del nitrato de plata reducido de Cajal, el del azul de metileno de Ehrlich y el de Bielschowski con sus varias modificaciones, resultados bastante lisonjeros, sobre todo cuando se tiene la fortuna de acertar con la fórmula apropiada a cada caso, y esta circunstancia ha atraído la atención de los investigadores hacia el campo de la neurología de los insectos, ansiosos de penetrar los arcanos de su complicadísima estructura y ambicio- 
nando quizá descubrir el artificio en que radique el substractum de sus sorprendentes instintos.

Consecuencia lógica de estos hechos es la natural reacción, que ha dado y seguirá dando como resultado la aparición de importantes y numerosos trabajos sobre este interesante asunto, ejecutados a base de aquellos métodos.

Esto, sin embargo, no quiere decir que no se hayan llevado a cabo en lo que va transcurrido del presente siglo, mediante el empleo de los llamados métodos comunes de coloración histológica, buen número de interesantes trabajos, con puntos de vista muy diversos, sobre la neurología de esos animales.

Sólo en lo relativo a los órganos visuales, para limitarnos a lo que más directamente se relaciona con el asunto concreto de que ahora vamos a ocuparnos, podrían citarse alrededor de una treintena de trabajos a cual más interesantes, unos relativos a la morfología y distribución topográfica de los ganglios o al estudio de sus funciones, otros destinados al conocimiento de la estructura intima y relaciones reciprocas de los elementos componentes. Sin contar a Pankrath, Exner, Johansen, Crevatin, Kenyon y algunos otros cuyas obras sobre este asunto aparecieron en las postrimerias del siglo xix, podríamos invocar los nombres de DiETRICH, Hesse, Phillips, Heller, Vigier, Radl, Franz, Zavrel, Cajal, Zaivarzin, Eltringham, etc., cuyos trabajos atesoran rico caudal de conocimientos.

Si hubiésemos de hacer un cómputo comparativo del concurso prestado por cada una de las naciones que principalmente han contribuído a esta labor, sería fácil demostrar que a nuestra patria corresponde lugar muy preferente, acaso el primero y tal vez con notorio predominio sobre los demás. Bastaría para ello consultar una lista completa de los trabajos publicados sobre esta cuestión en los tres últimos lustros (1).

(1) Desde el año 1909, en que apareció el primer trabajo de nuestro sabio maestro, el ilustre histólogo español D. Santiago Ramón Cajal, se han publicado los siguientes :

S. Ramón Cajal, Nota sobre la retina de la mosca. Musca vomitoria L. (Trab. del Lab. de Inv. Biol., t. VII, 1909.)

S. Ramon Cajal, Nota sobre la retina de los muiscidos. (Bol. de la R. Soc. Esp. de Hist. Nat., enero de 1910.)

S. RAMÓN CAJAL, Observaciones sobre la estructura de los ocelos y vias 
Empero de los trabajos que acabamos de mencionar, la mayor parte se refieren al conocimiento estructural del aparato visual de los insectos. En cambio los relativos a su fisiologismo y desarrollo evolutivo son escasos. Y no es de extrañar que así suceda, pues que si la extraordinaria complicación de tales aparatos y las dificultades técnicas que el asunto ofrece, son factores que por sí solos acaso basten para explicar la escasez relativa de publicaciones referentes al primer grupo de los arriba indicados, acrecienta sobremanera su valor cuando se trata de los segundos, especialmente de los relativos a la investigación del proceso evolutivo, a lo que contribuye también no poco la tarea, generalmente difícil, de proporcionarse material adecuado.

Por lo que hace relación a este último punto de vista, cuya importancia no es necesario encarecer, merecen especial mención, entre los trabajos realizados con los métodos comunes de coloración, los de Patten (1), Viallanes (2), Pankrath (3), Johansen (4),

nerviosas ocelares de algunos insectos. (Trab. del Lab. de Inv. Biol., t. XVI, 1918.)

S. Ramón Cajal y D. SÁnchez, Contribución al conocimiento de los centros nerviosos de los insectos. Parte I: "Retina y centros ópticos." (Ibid., t. XIII, 1915.)

D. SÁNCHEZ y SANCHEZ, Datos para el conocimiento histogénico de los centros ópticos de los insectos. Evolución de algunos elementos retinianos del "Pieris brassica». Nota preliminar. (Ibid., t. XIV, 1916.)

D. SANCHEZ Y SANCHEZ, Sobre ciertos elementos aisladores de la retina periférica del «Pieris brassica» L. (Ibid., t. XVI, 1918.)

D. SÁNCHEZ Y SÁNCHEZ, Sobre el desarrollo de los elementos nerviosos en la retina del «Pieris brassica» L. (Ibid., tomos XVI, 1918, y XVII, 1919.)

D. SANCHEZ Y SÁNCHEZ, Sobre la existencia de un aparato tactil en los ojos de algunos insectos. (Ibid., t. XVIII, 1920.)

(1) W. PAtTEn, Development of the eye of Vespa, with observations on the ocelli of some insects. (Journ. of Morphology, Boston, 1863.)

(2) H. VIALLANES, Le ganglion optique de quelques larves de Diptères, (Ann. Sc. Nat., 6 ${ }^{\circ}$ série, t. XIV, 1885.)

(3) O. Pankrath, Das Auge der Raupen und Phryganidenlarven. (Zeitschr. f. wiss. Zool., Bd. XLIX, 1890.)

(4) H. JoHANSEN, Ueber die Entwicklung des Imagoauges von Vanessa. (Zool. Anz., 15 Jalır., 1892.) - Sur le développement de l'ail composé de Vanessa. (Congr. Intern. de Zool. de Moscou, II p., 1893.) - Die Entwicklung des Imagoauges von "Vanessa urticaes L. (Zool. Jahrb., Morph. Abth., Bd. VI, 1893.) 
Phillips (1) y Zavrel (2). Mas con los métodos de acción selectiva sobre los elementos nerviosos, puede decirse que no existen más trabajos que los recientemente publicados por nosotros sobre el desarrollo de los ojos compuestos en el Pieris brassicae, citados en la nota de la página anterior; porque aun cuando ZAwARZIN (3) ha hecho un excelente estudio sobre el sistema nervioso de las larvas de Aeschna, se refiere casi exclusivamente a la estructura de dichos órganos, prescindiendo por completo o casi por completo de lo relativo a su evolución.

Nosotros poseemos copiosísimos datos sobre el desarrollo de los ojos compuestos en numerosas especies de insectos de muy diversos órdenes; mas aquí nos limitaremos, ya que el espacio de que podemos disponer no permite otra cosa, a consignar los más importantes de los relativos a los elementos nerviosos de los lepidópteros, principalmente a los eslabones de la cadena visual.

Aun cuando nuestras preparaciones relativas a este asunto han sido ejecutadas por diversos métodos, no nos referiremos en este trabajo más que a las obtenidas con la reacción cromo-argéntica de Golgi, ya con fijación previa por la mezcla osmio-bicrómica (método rápido de Cajal), ya con la mezcla de bicromato potásico y formol, análogamente a como las usaron DUBOSCQ y KENYON y las empleamos nosotros en nuestros anteriores trabajos sobre neurología de insectos.

Las especies de lepidópteros sobre las que poseemos datos de alguna importancia son las siguientes: el gusano de seda (Sericaria mori), la mariposa de la col (Pieris brassicce), la procesionaria del pino (Thaumetopoea pityocampa), la del olmo y alguna otra.

Para la más fácil comprensión e interpretación de algunos términos que hemos de emplear en lo sucesivo, indicaremos sucinta-

(1) E. J. Phillips, The Structure and Development of the compound eye of the Bee. (Amer. Nat., vol. XXXVIII, 1904.)-Structure and Development of the compound eye of the Honey Bee. (Proc. of the Acad. Nat. Sc. Philadelphia, vol. LVII, 1905.)

(2) F. Zavrel, Die Augen einiger Dipteren Larven und Puppen. (Zool. Anz., Bd. XXXI, 1907.)

(3) A. ZAWARZIN, Histologische Studien über Insekten. VI: Die optische Ganglien der Aeschna Larven. (Zeitschr. f. wiss. Zool., Bd. CVIII, 1914.) 
mente las principales formaciones de que se considera integrado en los individuos adultos el complejo constitutivo de la porción cominmente designada con el nombre de retina en los ojos compuestos de los artrópodos.

Compónese ésta de tres grandes porciones, denominadas, respectivamente, retinas externa, intermediaria e interna o profunda, en relación con su situación respectiva.

La retina externa o periférica comprende tres zonas diferentes: una superficial formada por la capa de las corneolas y la de los cuerpos cristalinos; otra media, que es la de los bastoncitos retinianos o cuerpos fotosensibles (primera neurona visual), y la otra interna, que es la membrana limitante o basal de la formación epidérmica.

La retina intermediaria, llamada también perióptico, comprende igualmente otras tres zonas bien distintas: una externa, que es la fenestrada, llamada por CAJAL y nosotros de los kiasmas múltiples, y por algunos autores de las fibras subretinianas; otra media, la de los granos externos o células monopolares (segunda neurona visual), y la otra profunda, llamada plexiforme externa o de los cartuchos ópticos.

Por último, la retina profunda o interna, que con frecuencia se denomina epióptico, comprende, a su vez, otras tres capas o estratos: uno externo, formado por fibras entrecruzadas, que es el kiasma intermediario (externo de muchos autores); otro medio, el de los granos internos, donde residen los cuerpos de las células ganglióntcas (tercera neurona visual) y las amacrinas, y otro profundo, que es la capa plexiforme interna.

A continuación de ésta, que es la última capa de la verdadera retina, hállase una formación constituida por gran número de fibras, centrifugas y centripetas, algunas entrecruzadas, reunidas en un grueso manojo, que es el kiasma interno o nervio óptico, y casi at mismo nivel otra formación gangrionar importantisima, designada generalmente con el nombre de lóbulo óptico.

A estas formaciones siguen ya los ganglios cerebrales, a los cuales se unen aquéllas intimamente.

A) Bastoncitos retinianos. - Todavía durante la vida larval, antes de que aparezca la forma de ninfa o imago, existen ya algunos de los elementos nerviosos visuales de los ojos compuestos de la ninfa y del insecto perfecto. 
Hacia el final del período comúnmente llamado de crisalidación, casi siempre desde el final del segundo día o principios del tercero de la suspensión de las orugas, principian a denunciarse en el área oftálmica epitelial del incipiente ojo compuesto, mediante la acción del cromato argéntico, las células generadoras de los bastoncitos retinianos, con los mismos caracteres que muestran al principio de la vida ninfal.

Ofrecen éstas, tanto en la mariposa de la col como en el gusano de seda y la procesionaria del pino, análogamente a lo que sucede en otros muchos insectos, fases de desarrollo semejantes a las

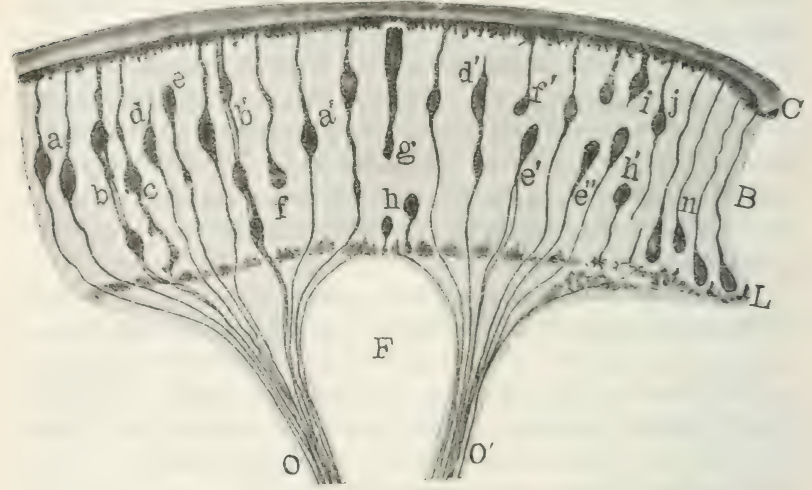

Fig. I. - Porción superficial del ojo compuesto de una crisálida de Pieris de menos de veinticuatro horas: $C$, cutícula quitinosa; $B$, zona de los bastoncitos; $L$, capa limitante; $O, O^{\prime}$, manojos de fibras visuales; $F$, fenestra limitada por las columnillas o manojos de fibras. Las letras minúsculas indican corpúsculos retinianos impregnados por el cromato argéntico.

que presentan los conos y bastoncitos de los vertebrados, si bien experimentan aún mayores modificaciones y cambios que éstos desde su aparición hasta alcanzar su forma final definitiva.

En las últimas horas del periodo de crisalidación de las orugas y desde el primer día de la vida de las crisálidas, nótanse en la zona epidérmica del área visual, además de ciertos granos globosos o piriformes desprovistos de prolongaciones, tres clases de células bien diferentes entre sí. Dos de ellas son monopolares : una con la. expansión dirigida hacia fuera (fig. $1, f, f^{\prime}$, etc.), y la otra con ella 
dirigida hacia adentro, en sentido centrípeto (fig. $1, e, e^{\prime}$, etc.). Sun, respectivamente, la primera y segunda forma monopolar 'descritas por nosotros. Las del tercer tipo son bipolares, es decir, provistas de una expansión centrífuga o periférica y la otraßprofunda:o centrípeta (fig. $1, a, a^{\prime}$, etc.).

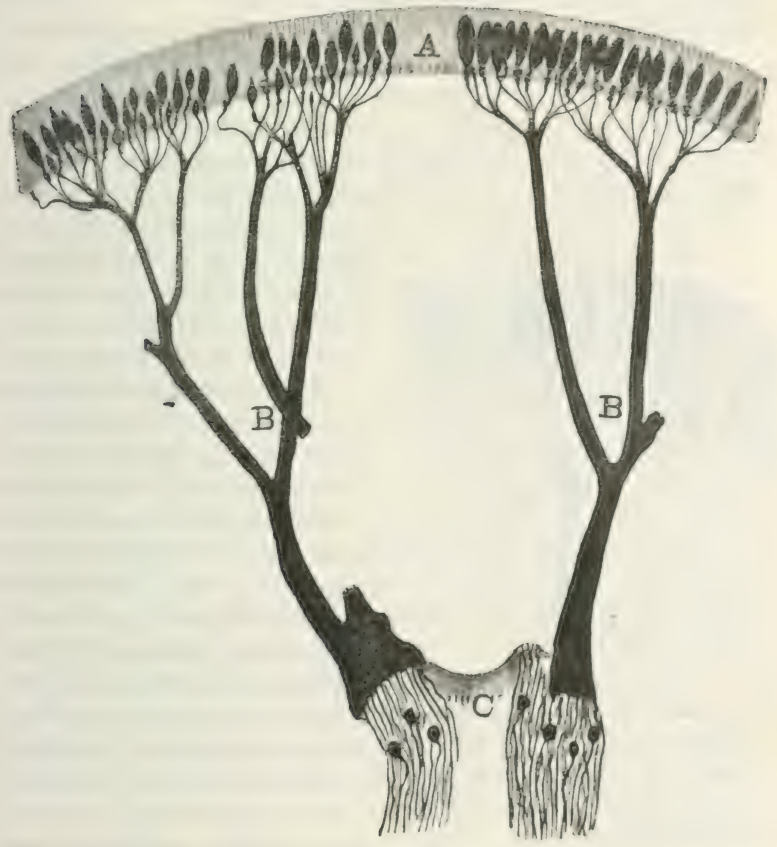

Fig. 2. - Porciones periférica e intermediaria del ojo compuesto de Pieris cogida a fines de abril: $A$, retina periférica; $B, B$, columnillas o manojos de fibras visuales recorriendo la zona fenestrada; $C$, rudimentos de la lámina ganglionar del perióptico.

Esta es la primera forma bipolar de los neuroblastos de los bastones, y es la más abundante durante los primeros períodos de la vida de las crisálidas. Probablemente pasan por ella todos los nenroblastos durante las primeras fases del desarrollo. 
En un segundo periodo o fase evolutiva, los neuroblastos sufren una importante transformación: la expansión periférica se acorta y absorbe, desviándose de la cutícula externa, adoptando así los corpúsculos nuevamente forma monopolar de expansión centrípeta. Al mismo tiempo se estrecha la capa epitelial y principia a bosquejarse la zona de los conos o cuerpos cristalinos.

La figura 2 representa una disposición típica de esta nueva forma monopolar y revela los caracteres que acabamos de indicar.

En esa fase, la zona fenestrada, ocupada por las columnillas o manojos de fibras visuales o cilindros-ejes de los bastones (figura, $1, O, O^{\prime}$; fig. $2, B, B$ ), alcanza un espesor considerable.

Más adelante los neuroblastos generan una nueva prolongación

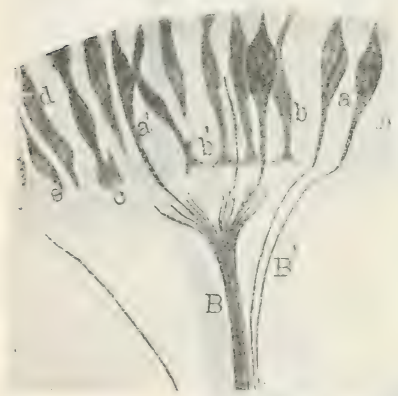

Fig. 3.- Porción de la retina periférica y il. - ia mua fenustratla diel njo compuesto de una crisálida de Sericaria mori de un capullo de cuatro dias: $A$, retina periférica; $B, B^{\prime}$, manojos de fibras visuales que recorren la zona fenestrada: $a, a^{\prime}$, neuroblastos de bastones; $b, b^{\prime}$ c. células epiteliales. periférica, adquiriendo otra vez forma bipolar, la cual, andando el tiempo y después de experimentar cambios importantes, se convertirá en definitiva.

Las expansiones centrifugas o periféricas de la forma bipolar definitiva o final se convierten, mediante los aludidos cambios y modificaciones, en órganos receptores de la acción luminosa y van a ponerse en contacto con los cuerpos cristalinos correspondientes, los cuales no parecen diferenciarse por completo hasta épocia relativamente avanzada del desarrollo.

Aun cuando con formas y aspectos diferentes, esos tipos se reproducen en todos los lepidópteros. Los del gusano de

seda (fig. 3) son más gruesos y cortos que los de las otras especies estudiadas por nosotros.

Las expansiones profundas o cilindraxiles de los neuroblastos de los bastoncitos se reunen, después de atravesar la membrana basal o limitante de la retina periférica, en grupos más o menos numerosos que caminan por las columnillas, formando los manojos de fibras subretinianas o de la zona fenestrada (fig. $1, O, O^{\prime}$; fig. $2, B, B$ ). 
Estas últimas expansiones, que son comúnmente denominadas fibras visuales, están provistas con frecuencia, en las primeras fases del desarrollo, de conos de crecimiento análogos a los que ostentan las homólogas en los vertebrados.

Durante el desarrollo de las crisálidas, especialmente en las de larga vida, tales como las de Pieris, es relativamente fácil seguir en su marcha centrípeta a las fibras visuales y reconocer sus dos tipos o clases diferentes.

Unas, las primeras que aparecen, atraviesan todos los estratos superficiales y medios del ojo y se encaminan a la retina profunda o epióptico, en cuyas zonas superficiales terminan por arborizaciones, primero muy sencillas, reducidas casi a un abultamiento poco distinto de un cono de crecimiento, que van complicándose tanto más cuanto más avanza el desarrollo de las crisálidas. Estas son las fibras visuales largas o bastones largos, descubiertos por CAJAL en la mosca azul y confirmados después por él y nosotros en esa misma y otras muchas especies de insectos, por lo que estimamos muy verosimil su existencia en todos.

Al pasar estos conductores del territurio uil yute habrá de denenvolverse la lámina ganglionar formadora del perióptico, de la que en las primeras fases del desarrollo ninfal no hay más que ligeros rudimentos, se les ve cruzarse unos con otros para dar origen al kiasma intermediario, esa enigmática formación cuyo destino se mantiene oculto a las miradas de los fisiólogos.

Las otras fibras visuales, más tardias en desarrollarse que las anteriores, no aparecen hasta una época en que ya están bastante desarrolladas las zonas ganglionares, granulosa y plexiforme del perióptico o retina intermediaria, y no pasan de esta última zona. Son los bastones cortos, únicos descritos por otros autores ( $\mathrm{Z}_{\mathrm{A}}$ WARZIN entre ellos) que se ocuparon de estos asuntos.

Como estos bastones o fibras visuales no pasan de la lámina ganglionar de la retina intermediaria, no toman parte en la formación del kiasma intermediario.

B) Neuronas monopolares. - Los corpúsculos visuales intermediarios o células monopolares (homólogas, según es bien sabido, de las bipolares de la retina de los vertebrados) no se desarrollan hasta época bastante avanzada de la vida de las crisálidas.

Este hecho es muy fácil de observar en las crisálidas de evolución lenta, como sucede en la mariposa de la col y otras especies 
análogas, que invierten muchos meses en su desarrollo. Pero puede demostrarse también en las de evolución rápida, como las vanesas, los gusanos de seda, las procesionarias, etc. En todas las estudiadas por nosotros puede comprobarse, sirviéndose de los métodos comunes de coloración (hematoxilinas, nitrato de plata reducido de $\mathrm{Ca}$ jal, etc.), que en los primeros períodos del desarrollo los rudimentos del ganglio que por su evolución han de engendrar las zonas media (granulosa) e interna (plexiforme) del perióptico, están reducidos a un mamelón relativamente pequeño situado en la cara externa de las masas nerviosas centrales.

En ese pequeño mamelón, que es atravesado desde muy temprano por las fibras visuales largas, hállanse, diseminados entre éstas, durante las primeras fases del desarrollo, ciertos corpúsculos indiferentes, globosos o esféricos, enteramente desprovistos de expansiones. Mas llegado un momento, que en el Pieris coincide con la época en que, al acercarse la primavera, parece despertar la actividad formadora en las demás partes del cuerpo, avívanse también esos corpúsculos y no tardan en mostrar los primeros indicios de sus expansiones. Son las neuronas monopolares.

Como las generadoras de los bastones, las neuronas monopolares presentan en su evolución progresiva fases análogas a las de sus homólogas, las bipolares de los vertebrados.

Pasada la primera fase, que puede llamarse, como en aquéllos, apolar, en la que o no hay aún prolongación alguna o se observan solamente una o dos acuminaciones opuestas, a veces provistas de una pequeña espina o espolón, muéstranse francamente monopolares, con una expansión muy corta, ofreciendo una forma que corresponde perfectamente a la fase de neuroblastos de His (fig. 2, C).

Prolóngase sucesivamente esa expansión, que camina en sentido centripeto, para dirigirse a la retina profunda o epióptico, donde, como es sabido, tiene su territorio de destino definitivo.

Las expansiones de las células monopolares se unen a las fibras visuales largas, atraviesan con ellas la que será después zona plexiforme del epióptico, en la que poco a poco generan una arborización local destinada a establecer alli conexión con los bastones y con ciertos elementos centrifugos que más tarde llegarán a esa región, toman parte después, en unión de las fibras visuales largas, en la formación del kiasma intermediario, y se dirigen, por fin, a la retina profunda, donde terminan.

Sus cabos terminales, al principio ligeramente abultados, no 
tardan en dar origen a las arborizaciones terminales, las cuales van poco a poco diversificándose $\mathrm{y}$ adquiriendo forma y distribución diversa, aunque siempre, naturalmente, dentro de la formación plexiforme del epióptico.

Los caracteres de los cuerpos celulares, así como los de sus arborizaciones terminales, ofrecen ciertas diferencias y variaciones

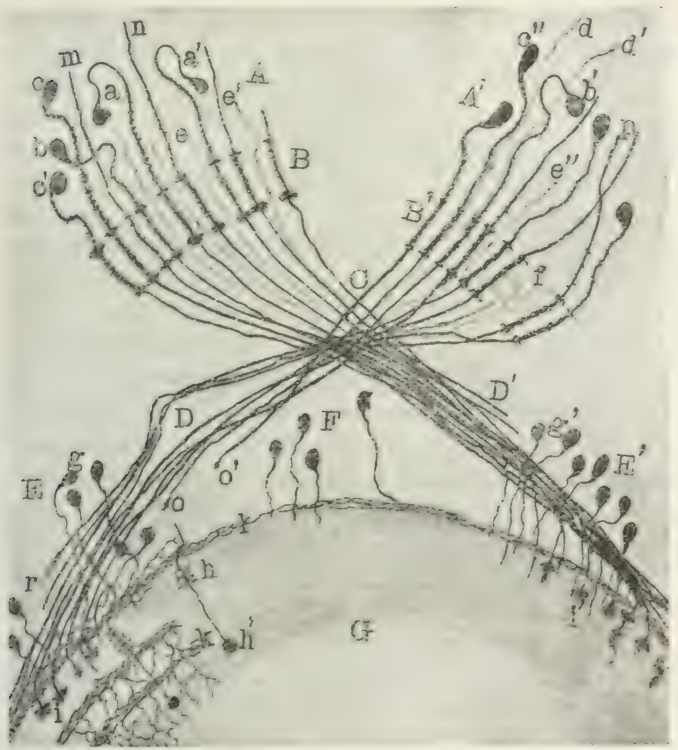

Fig. 4. - Porcion de las retinas intermediaria y profunda de un ojo compuesto de crisúlida de Pieris cogida a principios de abril, destinada principalmente a mostrar rasgos de las neuronas monopolares durante su desarrollo.

en las distintas especies, sobre todo cuando se acercan al estado perfecto o cuando lo alcanzan; pero de esas variaciones no podemos ocuparnos aqui, por falta material de espacio.

La figura 4 , que corresponde a una crisálida de Pieris cogida a principios de abril, muestra dos grupos de esas neuronas (I3, (J'). 
cuyas expansiones cilindraxiles ofrecen aủn una brevisima arborización en la zona plexiforme externa, todavía poco desarrollada. Dichas expansiones se cruzan, luego de atravesar esa última capa del perióptico, en el kiasma intermediario (fig. $4, C$ ), y corren después a la retina profunda, en cuyo estrato superficial penetran, ostentando algunas un abultamiento o pequeñisima arborización terminal, la cual se desarrolla ampliamente en las fases sucesivas siguientes.

C) Formación del kiasma intermediario. - Un hecho interesantísimo del proceso evolutivo de los órganos visuales de los insectos es la formación del kiasma intermediario, cuyo mecanismo, sorprendido ahora por primera vez, vamos a resumir brevemente, ateniéndonos principalmente al Pieris brassica, del que poseemos el mayor número de datos. Mas a juzgar por nuestras preparaciones de gusanos de seda, procesionaria, etc., el mecanismo parece ser análogo, si no idéntico, en todas estas especies, y quizá en todos los lepidópteros, a pesar de la diversa rapidez con que en unas y otras se realiza.

Sabido es de antiguo, y el hecho es muy fácil de observar en los individuos adultos de todos los grupos de insectos, que las fibras procedentes de las neuronas situadas en las regiones externas de las formaciones superficiales de la retina (retinas externa e intermediaria) van a situarse y distribuirse en las regiones internas del epióptico o retina profunda, y que, por el contrario, las procedentes de las regiones internas, más próximas al plano medio, se distribuyen por las zonas externas de aquella formación. Colócanse, por último, las procedentes de los territorios medios o centrales en las regiones centrales o medias, aunque en lados opuestos, con respecto a su origen. De donde resulta que las fibras se cruzan entre sí con relación a un eje o línea vertical.

Ese entrecruzamiento es formado primero por las fibras visuales largas (fig. $5, D$ ), a las que luego se asocian otros elementos diversos, tales como las expansiones de las monopolares, fibras centrífugas, etc. Importa, pues, ante todo, conocer el mecanismo de la decusación de aquéllas, el cual se realiza, en términos generales, de la manera siguiente:

Los axones de los neuroblastos generadores de los bastoncitos retinianos primero aparecidos, que ocuparán la región más externa o posterior del ojo compuesto del adulto, son los primeros en llegar, después de atravesar el pequeño mamelón cordiforme, primer rudi- 
mento de la lámina ganglionar externa, al epióptico, todavía rudimentario, cuyos primeros esbozos están situados en la cara externa de las masas nerviosas centrales o cerebroides, immediatamente por dentro del referido mamelón.

Los axones que siguen a ésos, que proceden de los neuroblastos del grupo o generación de bastones nacida inmediatamente después de aquéllos, y que están situados por dentro o por delante de los indicados, se encaminan, como sus congéneres precursores, hacia las regiones profundas del ojo. Mas cuando sus cabos terminales, después de atravesar la masa generadora de la lámina ganglionar del perióptico, van a llegar al epióptico, los de los bastoncitos que les precedieron se han desviado hacia dentro o adelante por virtud del crecimierito de esas masas ganglionares, teniendo aquéllos que cruzar necesariamente las fibras de éstos para llegar a la masa plexiforme interna.

Inmediatamente después de aquéllos se desarrolla un nuevo brote o generación de neuroblastos de bastones situados por dentro o delante de los precedentes, y sus expansiones camiran también por las columnillas de la zona fenestrada, hacia las formaciones internas del ojo, atraviesan las capas ganglionares de la rudimentaria retina intermediaria y se dirigen al epióptico. Mas para llegar a él tienen que cruzarse con las de todos los anteriores, porque los cabos terminales de éstos han continuado desviándose hacia adentro; o quizá fuera más propio decir que como la masa ganglionar constitutiva del epióptico va creciendo hacia fuera y las fibras últimamente llegadas tienen que situarse en el borde externo de dicha masa, han de cruzarse necesariamente con todas las que les precedieron para llegar al territorio en que deben terminar.

Ese mismo mecanismo va repitiéndose continuamente a medida que se desarrollan nuevos grupos o brotes de neuroblastos de bastones en la retina periférica, brotes que van apareciendo sucesivamente de fuera a dentro o de atrás a delante, y cuyos axones van colocándose, sucesivamente tambiélı, unos por dentro de los otros, cruzándose, por consiguiente, en su camino.

Así van desarrollándose de fuera a dentro nuevos neuroblastos genr-radores de hastoncitos, y enviando sus exprusiones centripetas o cilindraxiles, por las columnillas de la zona subretiniana (que va estrechándose cada vez más a medida que avanza el desarrollo) y a través de la retina intermediaria, al epióptico, hasta formarse todos los bastones largos, únicos elementos fibrilares que, como ya 
queda indicado, toman parte en los primeros tiempos de la vida nirfal en esta decusación (fig. 5).

Para explicar el entrecruzamiento de las fibras visuales y su causa, hemos hablado de brotes o generaciones de neuroblastos como si éstos se desarrollasen por grupos más o menos numerosos separados entre sí por intervalos de reposo o quietud de cierta duración.

Mas este modo de evolución, aunque no deje de observarse alguna vez, especialmente en crisálidas de desarrollo lento, no es cons-

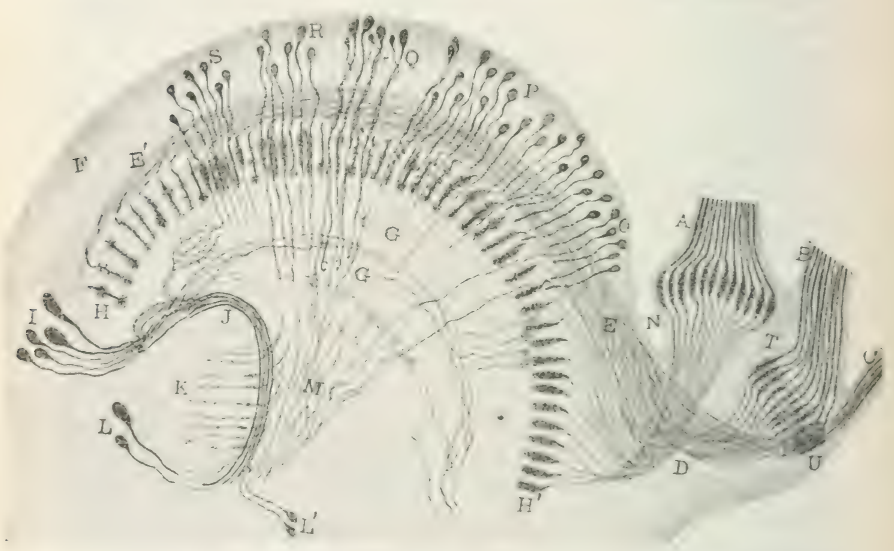

Fig. 5. - Conjunto ligeramente esquematizado para mostrar la formación del kiasma intermediario por las fibras visuales largas y las terminaciones de éstas en el epióptico.

tante ni siquiera el más general. La evolución de los bastoncitos es continua, sucesiva, a veces muy rápida, como acontece en las especies en que el periodo ninfal es breve, de manera que todos los axones se cruzan entre sí, tanto los correspondientes a cada haz, que caminan por cada columnilla, como los de todas ellas, sin que por los caracteres de sus arborizaciones terminales sea posible distinguir separación en semejantes grupos. Pero considerando en su conjunto la gran bóveda formada por dichas arborizaciones terminales en la zona superficial de la masa plexiforme interna, es suma- 
mente fácil apreciar la mayor complicación estructural de las más internas, que son las más antiguas, en comparación con las externas, que son las más jóvenes, y cómo esas diferencias van atenuảndose y aun borrándose por las numerosas formas intermedias.

La complicación estructural de las arborizaciones terminales refleja claramente la edad relativa de los bastoncitos a que pertenecen. Mas la diferencia entre las contiguas es tan pequeña, inapreciable en la generalidad de los casos, como consecuencia legítima de la casi simultaneidad del desarrollo, que de no apreciarse en conjunto, acaso no pudiera señalarse distinción entre ellas.

Hay que tener en cuenta, sin embargo, otro factor para poder interpretar, por los caracteres de las arborizaciones terminales, la edad relativa de los bastoncitos. Consiste éste en que no todos los correspondientes a cada región del ojo se desarrollan al mismo tiempo. Es frecuentisimo hallar, en efecto, durante casi todo el desarrollo de las crisálidas, en las distintas zonas de la retina externa, neuroblastos en muy diversas fases del desarrollo, observándose unos en la fase bipolar última junto a otros que afectan todavía las monopolares o bipolares primitivas.

Sin duda la mayor parte de esos neuroblastos de desarrollo tardio engendran bastoncitos cortos cuya expansión profunda terminará en la retina intermediaria; pero otros son seguramente bastones largos y, por tanto, sus expansiones cilindraxiles tienen que pasar entre las de los más antiguos e ir a situar sus arborizaciones terminales entre las de éstos, en la zona plexiforme del epióptico. A esto se debe la presencia de alguna arborización rudimentaria de las fibras visuales largas entre otras mucho más avanzadas en su desarrollo.

La figura 5, que pertenece a una crisálida de Pieris cogida a principios de marzo, antes de que aparecieran las monopolares en la retina intermediaria, muestra bien claramente la formación del kiasma intermediario. En él no tomaban parte todavía más que las fibras visuales largas.

Aqui, sin embargo, con estar relativamente adelantado el desarrollo, aparece ya bastante complicada la decusación. En épocas más tempranas, cuando llegan al epiriptico lus primeros manojos di. fibras visuales, se ve aún más claramente la génesis del kiasma.

Cuando más adelante las neuronas monopolares se desarrollan. emitiendo sus expansiones, éstas se encaminan, como guiadas por las fibras visuales largas, a las que parecen acompañar, hacia la 
retina profunda, pasando por el kiasma, en cuya formación toman parte, resultando de hecho entrecruzadas, como las correspondientes a los bastones.

Mas cuando aquéllas atraviesan el kiasma, pasan ya también por él ciertas fibras centrífugas procedentes de diversos origenes; con lo cual la decusación, como las demás formaciones del aparato visual, van complicándose desde esa época con relativa rapidez, de manera que se hace cada vez más difícil la persecución de los elementos integrantes de cada una en su proceso evolutivo.

En el gusano de seda, la procesionaria del pino y en general en las especies de evolución rápida, no resulta tan fácil y cómoda la observación de la génesis del referido kiasma; pero procediendo con atención, es casi seguro que pueden comprobarse las mismas fases que acabamos de bosquejar.

D) Células gangliónicas y amacrinas. - Más precoz que la de las neuronas monopolares es la aparición de algunas de las gangliónicas y amacrinas. Y decimos que sólo algunas de éstas son más tempranas que aquéllas, porque en realidad los granos de la corteza del epióptico van apareciendo, análogamente a lo que sucede con los bastoncitos retinianos, de modo sucesivo desde los primeros rudimentos del ojo compuesto hasta cerca del término del desarrollo ninfal; mientras que las monopolares no principian a reconocerse hasta época bastante avanzada de la vida de las crisálidas, y probablemente se han desarrollado todas mucho antes de la época de la metamorfosis.

Esas dos grandes categorias neuronales, gangliónicas y amacrinas, tan distintas en los insectos adultos por su morfología y funciones, son tan semejantes durante los primeros tiempos del desarrollo, que no es fácil distinguir las unas de las otras.

Importa hacer constar que aunque relativamente precoces en su desarrollo, según acabamos de indicar, no existen, o cuando menos no están diferenciadas, durante el periodo larval, y aun se hallan en su inmensa mayoría como corpúsculos indiferentes o indiferenciados al principio del período ninfal. Son, pues, elementos de nueva formación, que nada tienen que ver con las neuronas de los ganglios cefálicos o cerebroides de las orugas. El epióptico, o cuando menos la mayor parte de él, es de nueva formación, como lo son la retina periférica y el perióptico.

Las neuronas de la corteza ganglionar del epióptico muestran 
primero una fase apolar, que se impregna por el cromato de plata. Esta reacción las denuncia primero en la región superficial de la capa de los granos; pero no tardan en hallarse diseminadas por todo el espesor y aun entre las fibras visuales procedentes del kiasma, si bien entonces ya existen otras fases del desarrollo.

La fase apolar parece ser de muy escasa duración : pronto ostentan los somas una acuminación que les da el aspecto de una pequeña pera, una lágrima o una coma con la cabeza algo gruesa. Esa pequeña acuminación se prolonga en seguida, y entonces adoptan la forma típica de los neuroblastos de His, semejantes a los de los vertebrados.

La inmensa mayoria de esos corpisculos ofrecen en esta fase la forma típica monopolar, pero no es raro hallar algunos, variables en número y forma según las especies, con dos prolongaciones; una, periférica o externa, generalmente corta y delgada, terminada a menudo por un pequeño abultamiento, y la otra, profunda, mucho más importante, que se dirige, por regla general, directamente hacia la masa plexiforme.

Esta última es la expansión principal, y muestra muy a menudo, en su extremo libre, un abultamiento, ordinariamente fusiforme, a veces algo irregular y con frecuencia teñido con menos intensidad que el resto de la fibra. Semejante abultamiento debe interpretarse, cuando existe, como un verdadero cono de crecimiento, con significación análoga a la de los neuroblastos de los vertebrados.

Durante las primeras fases del desarrollo de estos corpúsculos es empresa relativamente fácil seguir los cilindros-ejes en su crecimiento, no sólo en el espesor de la capa de los granos (granos internos), sino también a través de los estratos de la capa plexiforme interna. Pero en esas fases no es posible distinguir todavía las neuronas gangliónicas de las amacrinas. Sólo más adelante, en los periodos avanzados del desarrollo, cuando las expansiones de las gangliónicas pasan del epióptico y penetran en el territorio del kiasma interno para trasladarse a las formaciones centrales, y las correspondientes a las amacrinas extienden sus arborizaciones terminales en los diferentes estratos de la masa plexiforme, es cuandn puede establecerse, de manera clara y terminante, la distinción entre unos y otros elementos.

Algunos grupos celulares de la zona cortical del epióptico ofrecen particularidades dignas de atención. Tal sucede con el llamado foco o ganglio angular anterior (fig. $6, K$ ), en cuya formación 
toman parte corpúsculos muy diversos por su forma, tamaño y distribución. Mas como, dada la relativamente escasa extensión de este trabajo, no es posible reseñar ni siquiera los tipos más importantes de las distintas especies, y mucho menos aún las variaciones que ofrecen en unas respecto de las otras, nos limitaremos a indicar que, cuando menos una gran parte de ellos, deben ser elementos de asociación entre centros relativamente distantes.

Hay entre ellos, en efecto, en todas las especies por nosotros

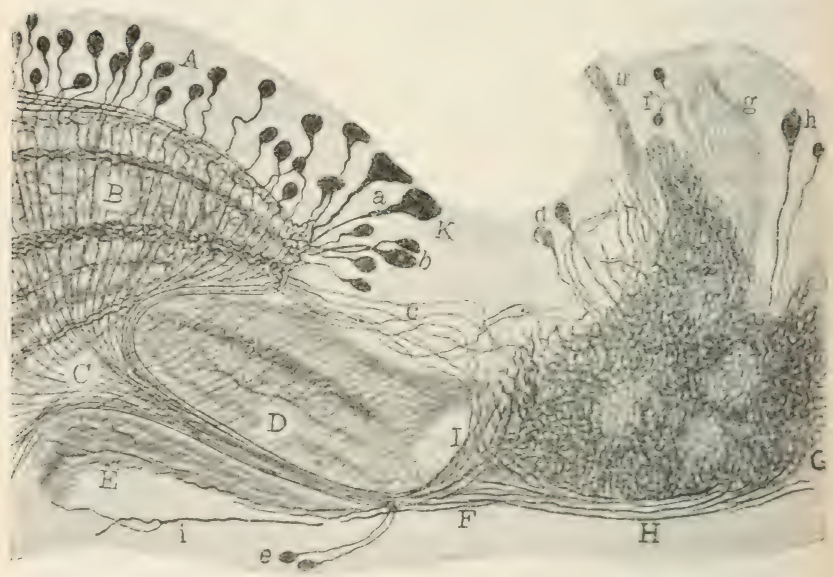

Fig. 6. - Porción de un corte procedente de la cabeza de una crisálida cogrida en abril : $A$, capa de los granos del epióptico; $B$, formación plexiforme del mismo; $C$, kiasma interno; $D, E$, porciones anterior y posterior del lóbulo óptico; $F, I$, manojos que unen el lóbulo óptico con el cerebro; $G$, masa plexiforme del cerebro; $H$, cordón comisural posterior; $K$, ganglio angular anterior.

estudiadas, numerosos corpúsculos gigantes cuya expansión se divide, a poco de abandonar el soma celular, en dos gruesas ramas. Una de éstas recorre extensión considerable en los estratos concéntricos (láminas de fibras serpenteantes) de la zona plexiforme interna, donde parece entrar en conexión con varias arborizaciones de otras fibras. La otra rama se encamina hacia el lóbulo óptico o hacia los ganglios cerebrales, marchando, ya por la gran vía constituída por el kiasma interno, ya por la indicada por $\mathrm{ZA}_{\mathrm{A}}$ 
WARZIN y comprobada después por CAJAL y nosotros, que bordea por delante el foco oval del lóbulo óptico (fig. 6, c).

Esta figura 6 representa varias de las disposiciones mencionadas y las relaciones principales de la retina interna con el lóbulo óptico y con las masas nerviosas cerebroides.

E) Elementos centrífugos de la retina. - Los elementos fibrilares de que hasta ahora nos hemos ocupado son de curso centripeto, y, a excepción de las células amacrinas, que parecen destinadas a establecer relaciones derivadas, si cabe expresarse así, todos ellos corresponden a los tres eslabones fundamentales de la cadena visual. Pero hay también en las formaciones retinianas intermediarias y profundas de los lepidópteros, como en las de los demás insectos, numerosas fibras centrífugas.

Éstas son de dos clases: unas de origen intrínseco, es decir, procedentes de células cuyos somas residen en los territorios ganglionares a que están destinadas sus terminaciones, y las otras extrinsecas, cuyas neuronas generatrices residen más allá de las formaciones ganglionares retinianas.

En los elementos llamados intrínsecos es relativamente fácil seguir su marcha evolutiva.

En el perióptico de los lepidópteros estudiados por nosotros no parecen existir elementos centrifugos locales, o a lo menos nosotros no hemos podido ponerlos de manifiesto. Las fibras centrifugas que a él llegan provienen de las zonas corticales que circundan el epióptico o dimanan de territorios ganglionares más profundos, a veces de localización todavia desconocida.

Tanto unas como otras llegan a esa formación en periodo bastante avanzado del desarrollo ninfal, y son por lo general tan delicadas, que con frecuencia es preciso recurrir a grandes aumentos para poderlas seguir y darse cuenta de la formación de los plexos que sus arborizaciones originan.

Una parte de esas fibras son homolaterales, es decir, no cruzadas, sino destinadas al mismo lado del eje del ojo en que residen sus células de origen. Otras, por el contrario, son cruzadas y forman parte del kiasma intermediario.

Los elementos centrífugos del epióptico son muy numerosos, provienen de origenes diferentes y llegan a él por vías y trayectos diversos.

Gran numero de esos conductores proceden de las masas gan- 
glionares 'centrales y se encaminan al epióptico por dos vías diferentes. Una de ellas, la más importante, es el nervio óptico o kiasma

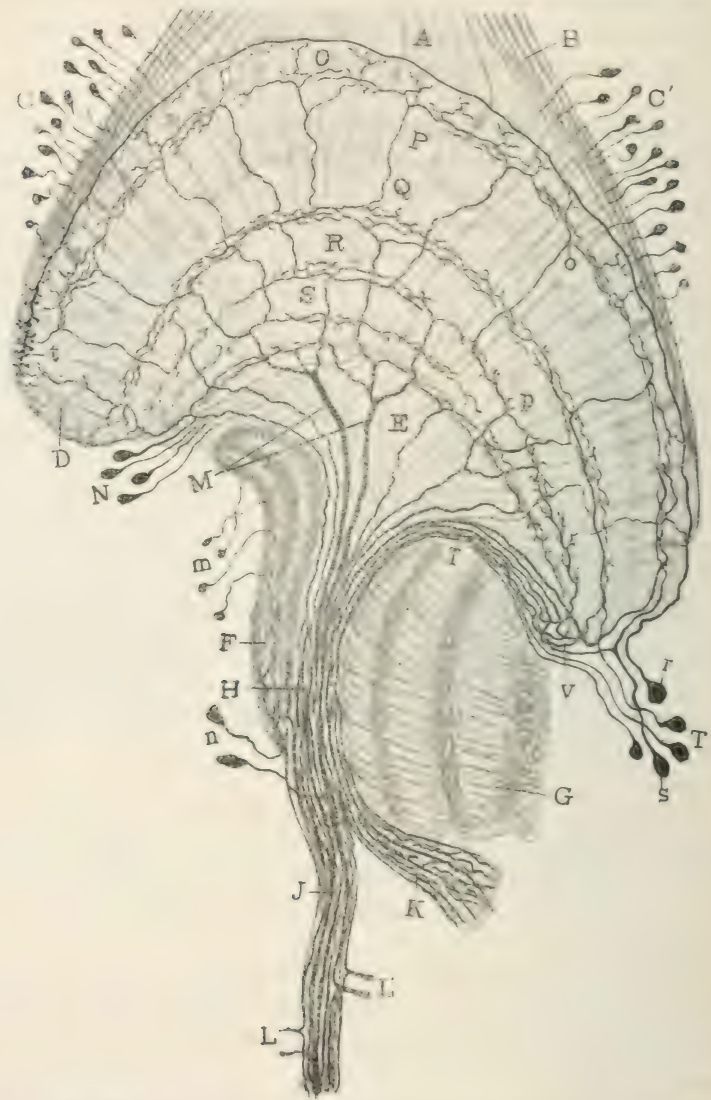

Fig. 7. - Reconstitución un poco espuemática de la distribución de ciertas fibras centrífugas en la masa plexiforme interna de una crisálida cogida a fines de marzo.

interno, por el cual llegan numerosísimas fibras centrifugas de muy 
diverso calibre, que se distribuyen a los distintos estratos de la masa plexiforme interna. Algunas la atraviesan, y pasando por el kiasma intermediario llegan a la plexiforme externa, donde terminan.

Las que se distribuyen por el epióptico emiten largas, y a veces robustas, ramas horizontales o concéntricas, que se extienden por las láminas de fibras serpenteantes y plexos difusos.

La figura 7 muestra la arribada y distribución de un gran grupo de fibras centrífugas llegadas a la retina profunda por el kiasma interno.

La otra vía, menos importante, o cuando menos no tan copiosa, pasa por delante del lóbulo óptico y corresponde al haz mencionado por Zawarzin en las larvas de Aeschna. Algunos de los elementos integrantes de esta vía están representados en la figura $6, c$.

Otro origen de fibras centrífugas destinadas al epióptico son ciertos granos situados en los ganglios vecinos, principalmente en la corteza posterior de la zona correspondiente al foco laminar del lóbulo óptico. En estas regiones no es difícil observar el desarrollo de esos elementos, cuyas fibrās pueden seguirse a veces en largos trayectos antes de llegar a ramificarse en sus arborizaciones terminales.

- Hay, por último, centrífugas destinadas a los plexos difusos y láminas serpenteantes de la copa plexiforme interna, y proceden principalmente de dos origenes diferentes: de granos residentes en los territorios vecinos, y de los ganglios centrales.

Entre las primeras merecen especial mención las originadas por ciertos corpúsculos del ganglio angular anterior, cuya evolución es fácil seguir, al menos en los primeros periodos. Algunas de ellas están destinadas por entero a las láminas y plexos de referencia; pero otras engendran a poca distancia del soma, antes de penetrar en la masa plexiforme, dos ramas más o menos robustas, una de las cuales se encamina, como antes se ha indicado, al epióptico (centrifuga), y la otra (centripeta) hacia los ganglios centrales.

Las procedentes de los centros cerebrales llegan a la zona plexiforme interna en periodo bastante avanzado del desarrollo ninfal, por cuya causa, dada la gran complicación estructural que entonces alcanzan ya esas formaciones retinianas, no es fácil seguir todas las vicisitudes de su evolución. Sin embargo, creemos haber logrado sorprender las más importantes.

Algunas robustısimas fibras centrifugas de las destinadas a las laminas serpenteantes no han sido ubservadas, al parecer, hasta ahora 
más que en ciertas crisálidas de lepidópteros; mas no es probable que sean patrimonio exclusivo de estos insectos.

Resulta, pues, como en otros trabajos hemos indicado, que en los lepidópteros, como en los insectos hasta ahora sometidos a nuestra observación, que corresponden a diferentes órdenes, la evolución de los elementos nerviosos retinianos (y aun pudiéramos hacer extensiva esta conclusión a los de los demás territorios orgánicos) está sometida, en cuanto a sus rasgos fundamentales, a las mismas leyes que los de los vertebrados, y que, como en éstos, la independencia neuronal se mantiene y conserva constantemente tanto durante los estados embrionarios como en la edad adulta.

\section{ALgUNOS DATOS NUEVOS PARA EL ESTUDIO DE LA FLORA MICOLÓGICA DE LA PROVINCIA DE OVIEDO}

POR EL

P. LUIS M. DE UNAMUNO, O. S. A.

Durante los dos años que llevo de residencia en nuestro Colegio de Llanes, además de las publicadas en el Congreso de Ciencias de Bilbao, he logrado reunir un número suficiente de especies de hongos microscópicos para hacer una nota de algún interés para el conocimiento de la casi completamente desconocida micoflora de la provincia de Oviedo.

Las especies de uredales que hoy damos a conocer constituyen un complemento de las publicadas en mi trabajo titulado "Contribución al estudio de la flora micológica de la provincia de Oviedo» (1). Fueron recolectadas desde mayo a noviembre de este año, y gran parte de ellas proceden de las excursiones realizadas por mi y por mi asiduo colaborador y compañero el Rvdo. P. Ricardo Fernández a la sierra plana de La Borbolla, a la del Llabre y al cercano pueblo de Nueva, en los meses de agosto y septiembre últimos.

Las especies de los demás grupos fueron recogidas en las cerca-

(1) Asoc. Progr. Cienc., Congreso de Bilbao, t. VI, primera parte. 
nias de Llanes desde octubre de 1918 hasta noviembre de 1920. Todas ellas figuran en el Herbario micológico del Museo Nacional de Ciencias Naturales, y su determinación ha sido comprobada y sancionada por mi amigo y maestro el sabio micólogo Dr. D. Romualdo González Fragoso, profesor del mismo Museo.

\section{Uredales (Brong.) Dietel.}

\section{Pucciniaceae Schröt.}

1. - Puccinia graminis Pers. - Syd., Mon. Ured., I, p. 692.

En sus fases urédica y teleutospórica de la f. sp. Avenae de Eriksson. En las hojas y cañas de Avena sativa y Cynosurus cristatus. En las tierras cultivadas próximas al cementerio de Camplengo y praderas de Cué, VI-VIII-1920. En Cynosurus cristatus es matriz nueva para la flora mundial.

2. - Puccinia Anthoxanthi Fuck. - Syd., Mon. Ured., I, p. 729.

En las hojas y cañas de Anthoxanthum odoratum en sus fases urédica y teleutospórica. Praderas próximas a Cué y a Parres, VI-1920. Es matriz nueva para la flora ibérica.

3.-Puccinia Agropyrina Erikss. - Syd., Mon. Ured., I, p. 712.

En las hojas de Agropyrum repens en sus fases urédica y teleutospórica. Playa de Póo, IX-1920. Es especie nueva para la flora ibérica.

4.-Puccinia Poac trivialis Bubák. - W. Migula, Pilze, Bd. III, 1. Teil, p. 436.

En las hojas y cañas de Poa trivialis en sus fases urédica y teleutospórica. Titeras cultivadas próximas al cementerio de Camplengo, VIII-1920. Es especie nueva para la flora ibérica.

5. Puccinia Festucae Plowr. in Gard. Cliron., 1890, II, pp. 42, 139, et 1891, I, p. 640. - Syd., Mon. Ured., I, p. 752.

En las hojas y cañas de Festuca rubra. Atalá, VIII-1920. Es matriz nueva para la flora ibérica. 
6. - Puccinia Caricis (Schum.).-Rebent., Fl. Neomarch., 1804, p. 356. Syd., Mon. Ured., I, p. 648.

En las hojas y tallos de Carex distans y Carex sp. En las praderas de la finca denominada "La Velilla», de los Sres. Garcia Álvarez, y en la sierra plana de La Borbolla, VI-1920. En Carex distans es matriz nueva para la flora mundial.

7. - Puccinia paludosa Plowr. in Monog. Ured., 1889, p. 174. - Syd., Mon. Ured., I, p. 671.

En las hojas de Carex sp. Sierra plana de La Borbolla, VIII-1920.

8. - Puccinia silvatica Schroet. in Cohn., Beitr. III, 1879, p. 68. Syd., Mon. Ured., I, p. 656.

En las hojas y tallos de Carex asturica y otras varias especies de Carex en su fase urédica. En las praderas de la finca denominada "La Velilla», Llanes y a los lados de la carretera de Corao a Cuevas de Mar, Nueva, VI-VIII-1920. En Carex asturica es matriz nueva para la flora mundial.

9. - Puccinia Allii (D. C.) Rudolphi, Linnaea, 1829, IV, p. 392. - Syd., Mon. Ured., I, p. 614.

En las hojas y tallos de Allium Ampeloprasum en sus fases urédica y teleutospórica. Tierras cultivadas de Póo, VII-1920.

10. - Puccinia punctata Linck, Obs. Myc., II, p. 30, in Magaz. naturf. Freunde Berlin, 1816. - Syd., Mon. Ured., I, p. 213.

En las hojas de Galium palustre en sus fases urédica y teleutospórica. A los lados de la carretera de Corao a Cuevas de Mar, Nueva, IX-1920. Es matriz nueva para la flora ibérica.

11. - Puccinia Valantiae Pers., Obs. Myc., 1796, II, p. 25.-Syd., Mon. Ured., I, p. 217.

En las hojas y tallos de Galium sp. Sierra plana de La BorboIla, VIII-1920.

12. - Puccinia Pruni-spinosae Pers. in Syn., 1801, p. 226. - Syd., Mon. Ured., I, p. 484.

En las hojas de Persica sp. y Prunus spinosa en sus fases urédica y teleutospórica. Huerta de los Sres. García Álvarez, Pan- 
car y Póo, cerca de la carretera, VIII-XI-1920. En Prunus spinosa es matriz nueva para la flora ibérica.

13. - Puccinia Galactitis Syd., Mon. Ured., I, p. 86.

En las hojas de Galactites tomentosa. Cerca de la playa de Póo, VI-1920.

14. - Puccinia major Diet. in Mittleil. Thur. Bot. Ver. Neue Folge, 1894. - Syd., Mon. Ured., I, p. 66.

En las hojas y tallos de Crepis paludosa en sus fases urédica y teleutospórica. Al lado de la vía férrea, Pancar, VI-1920. Es especie nueva para la flora ibérica.

15. - Puccinia Millefolii Fuck., Symb. Myc., 186', p. 55. - Syd., Mon. Urei., 1, p. 2.

En las hojas de Achillea Millefolium. Cerca de Póo, VI-1920.

16. - Puccinia Centaureae Mart., Fl. Mosqu., p. 226. - Syd., Mon. Ured., I, p. 39.

En las hojas de Centaurea nigra en sus fases urédica y teleutospórica. Paseo de San Pedro, Llanes, IX-1920. Es matriz nueva para la flora ibérica.

17. - Puccinia Cirsii Lasch in Rabh., Fg. eur., n. 89. - Syd., Mon. Ured., I, p. 55.

En las hojas de Cirsium anglicum en sus fases urédica y teleutospórica. Cerca de la carretera de Corao a Cuevas de Mar, Nueva, y en el cerro del Cristo, Llanes, IX-XI-1920. Es matriz nueva para la flora mundial.

18. - Uromyces Junci (Desm.) Tul. in Ann. Sc. Nat., ser. IV, 1854, II, p. 146. - Syd., Mon. Ured., II, p. 287.

En los tallos de Juncus effusus en sus fases urédica y teleutosprírica, acompanado de Darluca vagans. Sierra plana de La BorboIla, VIII-1920. Es matriz nueva para la flora ibérica.

19. - Uromyces Fabae (Pers.) De Bary, Ann. Sc. Nat., ser. IV, t. XX, 1863, p. 72. - Syd., Mon. Ured., 1I, p. 103.

En las hojas y tallos de Vicia varia en sus fases urédica y teleutospórica. Atalá, VIII-1920). Es matriz nueva para la flora mundial. 
20. - Uromyces flectens Lagh. in Svnsk. Bot. Tidskrift, 1909, III, p. 36. Syd., Mon. Ured., II, p. 360.

En las hojas y tallos de Trifolium repens. Paseo de San Pedro, Llanes, VII-1920. Es especie nueva para la flora ibérica.

21. - Uromyces Anthyllidis (Grev.) Schroet. in Hedwigia, XIV, 1875, p. 162. - Syd., Mon. Ured., II, p. 64.

En las hojas de Hipocrepis. comosa en sus fases urédica y teleutospórica. Atalá, VIII-1920. Es matriz nueva para la flora mundial (1).

22. - Uromyces Loti Blytt in Christiania Vidensk-Selskabs Forhandl., 1896, n. 6, p. 37 (extr.).--Syd., Mon. Ured., II, p. 110.

En las hojas y tallos de Lotus hispidus en sus fases urédica y teleutospórica. Al lado de la vía férrea, Pancar, VII-1920. Es matriz nueva para la flora mundial.

23. - Uromyces striatus Schroet., Abhandl. Schles. Ges. f. vaterl. Cultur, 1869/72, Breslau, 1872, p. 2.-Syd., Mon. Ured., II, p. 115.

En las hojas y tallos de Medicago polycarpa y M. Iupulina. Al lado de la vía férrea, Pancar, VII-1920. Las dos son matrices nuevas para la flora ibérica.

24. - Phragmidium Tormentillae Fuck., Symb. Myc., 1869, p. 46. Syd., Mon. Ured., III, p. 105.

En las hojas de Potentila Tormentilla en sus fases urédica y teleutospórica. La Cabanzona, al lado de la carretera vieja, Llanes, X-1920.

25. - Phragmidium violaceum (Schultz.) Wint. in Pilze, Deutscl!, 1884, p. 231. - Syd., Mon. Ured., III, p. 139.

En las hojas de Rubus sp. Cerca de la carretera de Corao a Cuevas de Mar, Nueva, VIII-1920.

(1) Sobre esta matriz lo distingue el Dr. MAYOR como U. Hippocrep:dis E. May. ('ex Gz. Frag, in litt.). 


\section{Melampsoraceae Schröt.}

26. - Pucciniastrum Galii (Linck) Ed. Fisch. in Die Ured. der Schweiz, p. 471. - Syd., Mon. Ured., III, p. 476 (sub Thekopsora guttata).

En las hojas de Galium divaricatum en sus fases urédica y teleutospórica. Fuente de Valde de Espadañas, sierra del Llabre, IX-1920. Es matriz nueva para la flora mundial.

27. - Thekopsora Vacciniorum Karst. in Myc. Fenn., IV, 1879, p. 58.Syd., Mon. Ured., III, p. 462.

En las hojas de Vaccinium Myrtillus en su fase urédica. Cerca de la carretera de Corao a Cuevas de Mar, Nueva, VIII-1920.

28. - Thekopsora (?) Fischeri Cruchet in Bull. de la Soc. Vanud. des Sc. Nat., vol. 51, n. 189, pp. 77-79, f. 3-4, Laussanne, 1916.

En las hojas de Erica ciliaris en su fase urédica. Sierra plana de La Borbolla, al lado de la carretera de Corao a Cuevas de Mar, Nueva, y en el cerro del Cristo, Llanes, VIII-IX-1920. Es especie nueva para la flora ibérica, y matriz nueva también para la flora mundial.

Es una especie poco común y sólo conocida hasta la fecha en una localidad de Suiza, Payerne, donde la encontró el Dr. CRUCHET en 1916, parasitando a la Calluna vulgaris. Es género dudoso aún, pues no se conoce más que su fase uredo; pero el Dr. CRUChEt, que hizo su descripción, la ha colocado, ad interim, en el género Thekopsora por sus analogías con los uredos de Th. Vacciniorum Karst y Th. Sparsa Wint.

El hongo encontrado por mí en la planta y localidades citadas conviene en sus caracteres con la descripción que hace de él el Dr. Cruchet. He consultado el caso con el maestro Sr. GonzÁLEZ FrAGOSo, y está conforme también en incluirle en este género y en esta especie.

29. - Milesina Blechni Syd. in Ann. Myc., V1II, 1910, p. 491, et in Mon. Ured., III, p. 478.

En las frondes de Blechnum Spicant en su fase urédica. Al 
lado de la carretera de Corao a Cuevas de Mar, Nueva, y La Cabanzona, Llanes, VIII-IX-1920.

30. - Melampsora pinitorqua Rostrup in Overs. ev. d. Kgl. Danske Vidensk. Selsk. Forlı., 1884, p. 14.-Syd., Mon. Ured., III, p. 340.

En las hojas de Populus pyramidulis en sus fases urédica y teleutospórica. Al lado de la carretera, Nueva, VIII-1920.

31. - Melampsora Euphorbiae-exiguae W. Müller in Centalbl. f. Bakter., etc., II. Abt., 1907, p. 210, XIX, etc. - Syd., Mon. Ured., III, p. 379.

En las hojas de Euphorbia exigna en sus fases urédica y teleutospórica. Lomas próximas al cementerio de Camplengo, VIII-1920.

32. - Melampsora Lini (Pers) Castagne in Tulasne, Ann. Sc. Nat. Bot., IV, ser. II, 1854, p. 93. - Syd., Mon. Ured., III, p. 381.

En las hojas y tallos de Linum angustifolium y L. gallicum en sus fases urédica y teleutospórica. Camplengo y playa de Toró, VIII-1920.

Oomicales (Corda) Sacc. et Trav.

33. - Cystopus candidus Leveillé. - W. Migula, Pilze, Bd. III, 1. Teil, p. 153.

En las hojas de Brassica oleracea, Br. Napus, Barbarea intermedia, Capsella bursa-pastoris, Cardamine sp., Lobularia maritima. Común en todos los alrededores de Llanes.

34. - Cystopus Tragopogonis (Pers.) Schroet. - W. Migula, Pilze, Bd. III, 1. Teil, p. 154.

En las hojas y tallos de Tragopogon Porrifolium. Atalá, V-1919.

35. - Plasmopara viticola (Berk. et Curt.) Berlese et De Toni. W. Migula, Pilze, Bd. II, 1. Teil, p. 161.

En las hojas de Vitis sp. (vid silvestre). Atalá, VII-1920. 
36. - Plasmopara nivea (Unger) Schroet. - W. Migula, Pilze, Bd. III, 1. Teil, p. 159.

En las hojas de Pimpinella Saxifraga. Camplengo, VI-1919.

37. - Peronospora Viciae (Berk.) De Bary. - W. Migula, Pilze, Bd. III, 1. Teil, p. 169.

En las hojas de Vicia sativa. Pancar, III-1919.

38. - Peronospora eĩusa (Grev.) Rabenhorst. - W. Migula, Pilze, Bd. III, 1. Teil, p. 174.

En las hojas de Atriplex hastata. Atalá, VII-1919. Es matriz nueva para la flora española.

39. - Peronospora affinis Rossmann. - W. Migula, Pilze, Bd. III, 1. Teil, p. 173.

En las hojas de Fumaria muralis. Al lado de la carretera, cerca de San Roque del Acebal, XI-1920. Es especie nueva para la flora española.

40. - Phytophtora infestans (Mont.) De Bary. - W. Migula, Pilze, Bd. III, 1. Teil, p. 156.

En las hojas de Solanum tuberosum. Común en todos los patatales de la región, VII-1919.

Chytridineae De Bary et Wor.

Synchytriaceae De Bary.

41. - Synchytrium aureum Schroet. - W. Migula, Pilze, Bd. III, 1. Teil, p. 151.

En las hojas de Plantago lanceolata. Al lado de la vía férrea, Pancar, V-1920. Es especie nueva para la flora española.

42. - Synchytrium Taraxaci De Bary et Woronin. - IW Migula, Pilze, Bd. III, 1. Teil, p. 110.

En las hojas, escapos y cabezuelas de Taraxacum officinale. En la finca llamada "La Velilla», V-1920. Es especie nueva para la flora española. 
43. - Pycnochytrium Succisae (De Bary et Woronin) Schroet.W. Migula, Pilze, Bd. III, 1. Teil, p. 436.

En las hojas de Succisa pratensis. Praderas de Póo, VI-1920. Es especie nueva para la flora española.

\section{Ascomycetae (Fr.) Sacc. et Trav. Pyreniales (Fr.) Sacc. et Trav.}

Sphaeriaceae (Fr.) Sacc.

44. - Guignardia Buxi.(Fuck.) Feltgen. - W. Migula, Pilze, Bd. III, 3. Teil, 1. Abt., p. 261.

En las hojas de Buxus sempervirens. Jardin del Hospital Sobrino, IV-1920. En su fase ascospórica es nueva para la flora española.

45. - Laeptosphaeria Rusci (Wallr.) Sacc., II, p. 74.

En los tallos y cladodios de Ruscus aculeatus. Lomas próximas al cementerio de Camplengo, IV-1920.

46. - Pleospora Evonymi Fuckel.-W. Migula, Pilze, Bd. III, 3. Teil, 1. Abt., p. 423.

En las hojas putrescentes de Evonymus europaeus. Junto al cementerio de Camplengo, V-1919.

47. - Pleospora herbarum (Pers.) Rabh. - Sacc., II, p. 74.

En los tallos secos de Seseli cantabricum. Atalá, III-1919. Es matriz nueva para la flora española.

48. - Stigmatea Robertiani (Fr.) Fr. - W. Migula, Pilze, Bd. III, 3. Teil, 1. Abt., p. 12.

En las hojas de Geranium Robertianum. Camplengo y Pancar, II-1919.

49. - Coleroa Geranii (Fr.) Trav. - Sacc., Syll., I, p. 541.

En las hojas de Geranium rotundifolium. Camplengo, I-1919. 
50. - Capnodium Citrinum Penzig. - Ed. Prillieux, Mal. des Plant. Cult., t. II, p. 55.

En las hojas de Citrus Limonium. VII-1919. Es especie nueva para la flora española.

51. - Capnodium salicinum Mont. - Sacc., I, p. 73.

En las hojas de Salix cinerea. Vidiago, VIII-1920.

52. - Capnodium Tilliae (Fuck.) Sacc. - W. Migula, Pilze, Bd. III, 3. Teil, 1. Abt., p. 9.

En las hojas de Tilia platyphylla. Al lado de la carretera, Nueva, VIII-1920. Es especie nueva para la flora española.

53. - Erysiphe Galeopsidis (D. C.) Sacc., I, p. 16. W. Migula, Pilze, Bd. IIl, 3. Teil, 1. Abt., p. 72.

En las hojas de Stachys sp. en sus fases conídica y ascospórica. Tierras cultivadas de Camplengo y La Carúa, III-1920.

54. - Erysiphe Umbelliferarum (Lev.) De Bary.-W. Migula, Pilze, Bd. III, 3. Teil, 1. Abt., p. 72.

En los tallos de Angelica Razulii. Boca de la Riega, sierra del Llabre, VII-1920.

55. - Phyllactinia Corylea (Pers.) Karst. - Sacc., I, p. 5. - W. Migula, Pilze, Bd. III, 3. Teil, 1. Abt., p. 80.

En las hojas de Corylus avellana, Alnus glutinosa y Quercus robur. El Bolado, XI-1919. En Alnus glutinosa es matriz nueva para la flora española.

56. - Phyllachora graminis (Pers.) Fuck. - Sacc., II, p. 602. - W. Migula, Pilze, Bd. HI, 3. Teil, 1. Abt., p. 687.

En las hojas de Poa trivialis. Atalá, VIII-1920.

57. - Phyllachora Dactylidis Delacr., Bull. Soc. Myc., 1892, p. 191, t. XVIII, f. 1, et in Le Bret. Niel. Champ. Norm., V, Liste, p. 153.

En las hojas de Dactylis glomerata. Al lado de la carretera, cerca de Póo, II-1919. Es especie nueva para la flora española. 
58. - Phyllachora Trifolii (Pers.) Fuck. - Sacc., II, p. 613. - W. Migula, Pilze, Bd. III, 3. Teil, 1. Abt., p. 687.

En las hojas de Trifolium incarnatum en sus fases conidica (Polythrincium Trifoll Kunze) y ascospórica. Tierras cultivadas de Pancar, III-1920.

\section{Histeriales (Cda.) Sacc. et Trav.}

Hypocreaceae De Not.

59.-Epichloe ty phina (Pers.) Tul.-W. Migula, Pilze, Bd. III, 3. Teil, 2. Abt., p. 762.

En las cañas de Agropyrum repens, Dactylis glomerata, Holcus lanatus y Agrostis alba en sus fases ascospórica y conidica, Sphacelia typhina (Pers.) Sacc. Es especie nueva para la flora española.

\section{Histeriaceae Cda.}

60. - Histerium vulgare De Not.-Sacc. De Not., II, p. 745.-W. Migula, Pilze Bd. III, 3. Teil, 1. Abt., p. 788.

En la corteza de cerezo. Camplengo, III-1919.

\section{Discales (Fr.) Sacc. et Trav.}

\section{Phacidiaceae Fr.}

61. - Pseudopeziza Trifolii (Biv. Bern.) Fuck. - Sacc., VIII, p. 727. W. Migula, Pilze, Bd. III, 3. Teil, 2. Abt., p. 1269.

En las hojas de Trifolium incarnatum. Tierras cultivadas de Pancar, V-1919.

62. - Pseudopeziza repanda (Fr.) Karst., Rev., p. 161. - W. Migula, Pilze, Bd. III, 3. Teil, 2. Abt., p. 856.

En las hojas de Sherardia arvensis. Tierras cultivadas próximas a Camplengo, III-1920.

63. - Fabraea litigiosa (Rob. et Desm.) Sacc.

En las hojas de Ranunculus repens. Celorio, II-1919. Es especie nueva para la flora española. 
Deuteromycetae Sacc. Sphaeropsidales (Lev.) Lindau.

\section{Sphaerioidaceae Sacc.}

\section{4. - Phyllosticta Angelicae Sacc., Syll, III, p. 46.}

En las hojas de Angelica Razulii, acompañada de Fusicladium depressum. Boca de la Riega, VIII-1920. Es especie nueva para la flora española.

65. - Phyllostictina Ericae v. Hohnel, Hedwigia, mayo 1920, p. 2.

En Erica ciliaris. Sierra plana de La Borbolla. VIII-1920. Es especie nueva para la flora española.

66. - Ascochyta graminicola Sacc., Syll., III, p. 407.

En las hojas de Arrhenaterum elatius. Tierras cultivadas de Camplengo, II-1920.

67.-Ascochyta Silenes ElI. et Ev. f. Cerastii.-Sacc., Syll., III, p. 148.

En las hojas de Cerastium pumilum. Al lado del camino nuevo al cementerio de Camplengo. Es especie nueva para la flora española.

68. - Darluca vagans Cast. - Sacc., Syll., III, p. 410.

En los soros de Uromyces Junci y de AEcidium bellidis. Canıplengo y sierra plana de La Borbolla, II-VII-1920.

69. - Hendersonia culmicola Sacc. in Mich., I, p. 210. - Syll., III, p. 437.

En las hojas de Brachypodium sylvaticum. Atalá, X-1920.

70. - Stagonospora Iridis C. Mass., Bot. Centr., 1890, 11. 26, p. 148.

En las hojas de Iris Xiphoides. Atalá, III-919. Es especie nueva para la flora española.

71. - Stagonospora Caricis (Oud.) Sacc, Syll., III, p. 452.

Var. Caricis asturicae, Unam. nov.

Sporulis hyalinis, rectis vel parum curvatis, absque pedicelli ventigio, et plerumque 5 septati, nucle is deficientibus, $25-40,4-5 \%$. 
In foliis, caulibusque siccis Caricis asturicae et cujusdam $\mathrm{Ca}$ ricis sp. indeterminatae. In loco (vulgo) :La Velilla et in oppido, Nueva, prope Llanes, VI-VIII-1920.

72. - Septoria Brachypodii Pass. - Sacc., Syll,, III, p. 563.

En las hojas de Brachypodium sylvaticum. Atalá, IX-1920. Es especie nueva para la flora española.

73. - Septoria Cerastii Rob. et Desm. - Sacc., Syll., III, p. 518.

En las hojas de Cerastium pumilum. Es matriz nueva para la flora ibérica. La Sep. Cerastii de espórulas pluriseptadas es análoga a la Sep. Stellariae, de la que aquélla sólo es distinguible por la matriz. Es sabido que la Sep. Stellariae es la fase picnídica de la Spherella isariphora, y es probable que la Sep. Cerastii lo sea también.

74. - Septoria cornicola Desm. - Sacc., Syll., III, p. 492.

En las hojas marcescentes de Cornus sanguinea. Atalá y Pancar, IX-1920.

\section{5. - Septoria Fernandezii Unam., n. sp.}

Maculis ferrugineis, epiphyllis, circularibus vel irregularibus, insidentibus, saepe confluentibus, nimbo aliquantulum clariori circumdatis, magnam folii partem adurentibus; pycnidiis numerosis, sparsis, amphygenis, plerumque epiphyllis, fuligineis, inmersis, globosis vel ovatis, $112 \mathrm{~d}$. $\times 94 \mu$ alt., ostiolo circulari pertuso, $21 \mu \mathrm{d}$,, zona obscura circumdate; sporulis filiformibus, hyalinis, rectis curvulisve, utrinque rotundatis, 1 septatis, $26-30,5 \times 1,6-2 \mu$.

In foliis vivis Lactucae virosae, Pancar, prope Llanes (Asturias), II-1920. Differt ab omnibus Septoriis in Lactucis vigentibus praecipue ob sporidiorum septum.

Claro Professore Hist. Nat. Collegii (vulgo PP. Agustinos de Llanes), assiduo coadjutore et fratre meo carissimo R. P. Richardo Fernández (O. S. A.), libenter dicata species.

76. - Septoria Ficariae Desm. - Sacc., Syll., III, p. 522.

En las hojas de Ficaria Ranunculoides. Pancar, I-1919. Es especie nueva para la flora española. 
77. - Septoria Hederae Desm., Ann. Sc. Nat., 1843, XIX, p. 430.Sacc., Mich., I, pág. 172.

En las hojas de Hedera Helix. Atalá, IV-1919. Es especie nueva para la flora española.

78.--Septoria Levistici West., Bull. Ac. Roy. Belg., Il ser., Bd. XXI, n. 7.

En las hojas de Levisticum officinale. Tapia, VII-1918, y Llanes, VI-1919. Es especie nueva para la flora española.

79. - Septoria Petroselini Desm. - Sacc., Syll., III, p. 530.

En las hojas de Petroselinum sativum. Huerta del Colegio de PP. Agustinos de Llanes, VI-1920.

80. - Septoria polygonina Thüm. - Sacc., Syll., III, p. 554.

En las hojas de Polygonum Lapathifolium. Atalá, IX-1920.

81. - Septoria Pseudoplatani Rob. et Desm., 14 Not. 6, p. 21.

En las hojas de Acer Pseudoplatanus. Al lado de la carretera, Póo, X-1919. Es especie nueva para la flora española.

82. - Septoria Stellariae Rob. et Desm. - Sacc., Syll., III, p. 502.

En las hojas de Stellaria media. Póo, I1-1919.

83. - Rhabdospora Thümeniana (Pass.) Sacc., Syll., III, p. 587.

En los tallos de Euphorbia exigua. Es especie nueva para la flora española.

Melanconiales (Corda) Sacc. et Trav.

84. - Glocosporium arvense Sacc. et Penz. - Sacc., Syll., III, p. 710.

En las hojas de Veronica arvensis. Póo, III-1919. Es matriz nueva para la flora española. Los conidios varian algo de la forma tipo.

85. - Gloeosporium Ribis (Lib.) Mont. et Desm. - Sacc, Syll., III, p. 706 .

En las hojas de Ribes grossularia. Huerta del Colegio de PP. Agustinos de Llanes, VII-1919. 
86. - Marsonia Potentillae (Desm.) Fisch. in Rabh., Fl. eur., 1857.Sacc., Syll., III, p. 770.

En las hojas de Potentilla reptans. El Bolado, Atalá y Camplengo, VI-1920.

Hifales (Mart.) Sacc, et Trav.

Tuberculariaceae Ehrenb.

87. - Tubercularia persicina (Ditm.) Sacc., Syll., IV, p. 653.

En Uredos de Rosa sp. y Ecidios de Bellis perennis. Playa de Toró y camino de Cué, V-VII-1920.

88. - Fusarium roseum Linck. - Sacc., Syll., IV, p. 669.

En las hojas de Nerium Oleander. Jardines públicos de Llanes, VI-1919.

\section{Stilbaceae Fries.}

89. - Isariopsis albo-rosella (Desm.) Sacc., Syll., IV, p. 630.

En las hojas de Cerastium pumilum. Camino nuevo al cementerio de Camplengo, V-1919. Es especie nueva para la flora española, y es sabido que constituye la forma conidiana de la Spherella isariphora (Desm.) Ces. et De Not.

\section{Dematiaceae Fries.}

90.-Coniosporium Bambusac (Thüm. et Bolle) Sacc., Syll., IV, p. 244.

En las cañas y hojas de Bambitsa arundinacea. Jardines públicos de Llanes, VI-1920.

91.-Camptoum curvatum (Kunze et Schm.) Linck.-Sacc., Syll., IV, p. 276.

En las hojas muertas de Carex riparia. El Bolado, III-1919. Es matriz nueva para la flora española.

92. - Fusicladium pirinum (Lib.) Fuck. - Sacc., Syll., IV, p. 346.

En las hojas y frutos de Pirus communis. Huerta del Colegio de PP. Agustinos de Llanes, V-1919. Es la forma conidiana de Venturia pirina. 
93. - Cercospora smilacina Sacc., Syll., IV, p. 476.

En las hojas de Smilax aspera. Atalá, II-1919.

94.-Cladosporium herbarum (Pers.) Linck.-Sacc., Syll., IV, p. 350.

En los pétalos de Rosa sp. Huerta del Colegio de PP. Agustinos de Llanes, V-1919.

95.-Cladosporium punctulatum Sacc. et Ellis, Mich., II, p). 578, 1892.

En las hojas de Arum italicum. El Bolado, al lado de la vía férrea, III-1919. Es matriz nueva para la flora mundial, y especie nueva para la flora española.

96. - Macrosporium commune Rabenl. - Sacc., Syll., IV, p. 524.

En los pétalos de Rosa sp. Huerta del Colegio de PP. Agustinos de Llanes, V-1919.

97. - Alternaria Brassicae (Berk.) Sacc., Syll., IV, p. 546.

Var. $\beta$ macrospora Sacc. En los tallos de Brassica oleracea. Huertas de Cué, I-1920.

Mucedinaceae Linck.

98. -- Oidium monilioides (Nees) Linck. - Sacc, Syll., IV, p. 593.

En las hojas de Hordeum vulgare. Campos cultivados de Camplengo, V-1920.

99. - Oidium erysiphoides Fries. - Sacc, Syll, IV, p. 41.

En las hojas de Brassica Napus, Cucurbita pepo, Oenotera biennis, Erodium cicutarium, Epilobium tetragonum, Plantago major, Ranunculus bulbosus, R. nemorosus. Común en todos los alrededores de Llanes.

100. - Oidium quercinum Thïm - Sacc., Syll., IV, p. 44.

En las hojas de Quercus robur. Común en todos los robledales de Llanes y Tapia, VI-VII-1916-1919. 
101. - Ovularia primulina Karst. - Sacc., Syll., IV, p. 143.

En las hojas de Primula officinalis. Praderas próximas a la playa de Póo y el monte Soberón, IV-1919. Es especie nueva para la flora española.

102. - Botrytis cinerea Pers. - Sacc., Syll., IV, p. 129.

En las hojas de Ranunculus tuberosus. Praderas próximas al cementerio de Camplengo, X-1918.

103. - Ramularia Ari Fautr. - Sacc., Syll., XI, p. 605.

En las hojas de Arum italicum. Al lado de la vía férrea, cerca del paso de Pax, III-1919.

104. - Ramularia Geranii (IVest.) Fuck. - Sacc., Syll, IV, p. 306.

En las hojas de Geranium dissectum y $G$. rotundifolium. Camplengo, VI-1919. Al parecer es la forma conidiana de la Coleroa Geranii. Por sus manchas bien definidas y de color coriáceo parece la forma macrophylogena. En el Geranium dissectum va acompañada de Stigmatea Robertiani, y en el $G$. rotundifolium, de Coleroa Geranii.

105. - Ramularia Lampsanae (Desm.) Sacc., Syll., IV, p. 207.

En las hojas de Lampsana communis. Vidiago, VI-1919, y Cué, VII-1919. Es especie nueva para la flora española.

106. - Ramularia nigricans (Mass.) Ferr. - Sacc., Syll., XIV, p. 1059.

En las hojas de Helleborus foetidus. Pancar, I-1919.

107. - Ramularia Parietariae Pass. - Sacc., Syll., IV, p. 216.

En las hojas de Parietaria officinalis. Al lado de la carretera, Llanes, X-1920. Es especie nueva para la flora española.

108.-Ramularia pseudo-coccinea Lindr.-Sacc, Syll, XVIII, p. 553.

En las hojas de Veronica Chamaedrys. Pancar, X-1920. Se distingue principalmente de la $R$. Veronicae por los esporidios biseptados y por los conidióforos más largos y ramosos. Es especie nueva para la flora española. 
109. - Ramularia recognita Mass. - Sacc., Syll., XI, p. 601.

En las hojas de Helleborus viridis. Pancar, I-1919. Es especie nueva para la flora española.

110. - Ramularia sambucina Sacc., Syll., IV, p. 197.

En las hojas de Sambucus nigra. Vidiago, al lado de la vía férrea, X-1920. Es especie nueva para la flora española.

111. - Ramularia Urticae Ces. - Sacc., Syll., IV, p. 216.

En las hojas de Urtica dioica. Pancar, VII-1919.

112. - Ramularia Vincae Sacc., Syll., IV, p. 215.

En las hojas de Vinca minor. Pancar, VI-1919.

113. - Microstroma Juglandis (Bereng.) Sacc., Syll., IV, pág. 9.

En las hojas de Juglans regia. Camplengo, VI-1919.

\section{RESUMEN}

El número total de especies comprendidas en esta nota es de 113, que se distribuyen en la siguiente forma:

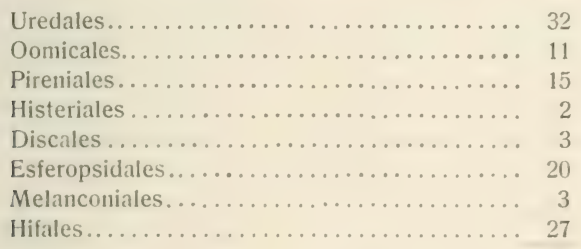

TitTal............ 113

De ellas es nueva para la flora mundial una especie; a saber: la Septoria Fernandezii, sobre Lactuca virosa; y una variedad, la Caricis asturicae, de la Stagonospora Caricis, y las matrices siguientes: Cynosurus cristatus con la Puccinia graminis, Carex distans con la $P$. Caricis, Carex asturica con la $P$. silvatica, Cirsium anglicum con la P. Cirsii, Vicia varia con el Uromyces Fabae, Hipocrepis comosa con el U. Hippocrepidis, 
Lotus hispidus con el U. Loti, Galium divaricatum con el Pucciniastrum Galii, Erica ciliaris con la Thekopsora Fischeri y el Arum italicum con el Cladosporium punctulatum. Total, 10.

Son especies nuevas para la flora española las siguientes: Puccinia Anthoxanthi, P. agropyrina, P. major, P. Poae-trivialis, Uromyces flectens, U. Hippocrepidis, Thekopsora Fischeri, Peronospora affinis, Synchytrium Taraxaci, Pycnochytrium Succisae, Capnodium citrinum, C. Tiliae, Epichloe typhina, Fabraea litigiosa, Phyllosticta Angelicae, Phyllostictina Ericae, Ascochyta Silenes, Stagonospora Iridis, Phyllacora Dactylidis, Septoria Brachypodii, S. Ficariae, S. Hederae, S. Levistici, S. Pseudo-Platani, Rhabdospora Thümeniana, Isariopsis albo-rosella, Cladosporium punctulatum, Ovularia primulina, Ramularia Lampsanae, R. Parietariae, R. Pseudococcinea, $R$. recognita, $R$. sambucina y $R$. Urticae. Total, 36.

Finalmente, son también nuevas para la flora española la fase ascospórica de la Guignardia Buxi, y las matrices siguientes: Festuca rubra con la Puccinia Festucae, Galium palustre con la P. punctata, Prunus spinosa con la P. Pruni-spinosae, Centaurea nigra con la $P$. Centaureae, Juncus effusus con el Uromyces Junci, Medicago lupulina y $M$. polycarpa con el $U$. striatus, Atriplex hastata con la Peronospora effusa, Seseli cantabricum con la Pleospora herbarum, Alnus glutinosa con la Phyllactinia Corylea, Veronica arvensis con el Gloeosporium arvense y el Carex riparia con el Camptoum curvatum. Total, 13.

Colegio de PP. Agustinos de Llanes, 27 noviembre 1920. 
NOTAS HIDROBIOLÓGICAS

\section{LARVAS PLANKTÓNICAS DE ARQUIPTEROS DE LA LAGLYA DE PEÑALARA}

POR

\section{CELSO ARÉVALO}

Entre las formas curiosas que he observado examinando el plankiton de superficie de la pequeña laguna de Peñalara. voy a referirme en esta nota a tres larvas submicroscópicas que, por pertenecer a grupos de insectos cuyos estados larvarios son poco conocidos, aun tratándose de especies de la fauna europea y norteamericana, es oportuno señalar. Como tratándose de larvas tan poco estudiadas es inútil pretender su clasificación específica, las designaremos provisionalmente por letras, ya que, aun teniendo la convicción de que todavía no han sido descritas, el crear para ellas nuevos nombres sin saber si el adulto ha sido ya denominado, es exponerse a aumentar la lista de sinónimos sin objeto alguno. Por otra parte, añadiendo a esta nota los adjuntos dibujos, que han sido ejecutados directamente de preparaciones microscópicas de los ejemplares pur muestru dibujante Sr. Simón, siempre se estará en condiciones, por cualquier persona, de clasificarlas. Como puede juzgarse por dichos dihujos, dos de estas larvas parecen corresponder a los plecópteros, de los que se conocen una veintena de larvas, para muchas de las cuales su identificación es dudosa, puesto que en algunas obras son sólo mencionadas o descritas muy insuficientemente.

La primera de dichas larvas, y que designaremos como larva A (fig. 1), es de un porte interesantisimo, por lo manifiesto de su adaptación planktónica, que delata: su pequenez, la extremada longitud de sus apéndices, especialmente de las antenas y cercos, y el tener el cuerpo, y especialmente dichos apendices, erizadus de pelos rigrdos, asi como también la facies longitudinal del cuerpo, caracteres todos que revelan recursos para facilitar la flotación mediante un 
aumento de superficie, por ser mayor el rozamiento contra el agua, haciendo más difícil la sumersión y la consiguiente sedimentación, que es el mayor peligro para la vida planktónica. Estos recursos son aún más necesarios en aguas como las de dicha laguna, que por proceder de la fusión de nieves próximas, y que por correr en poco trayecto y sobre rocas cristalinas, disuelven pocas substancias, siendo, por tanto, casi destiladas y muy poco densas.

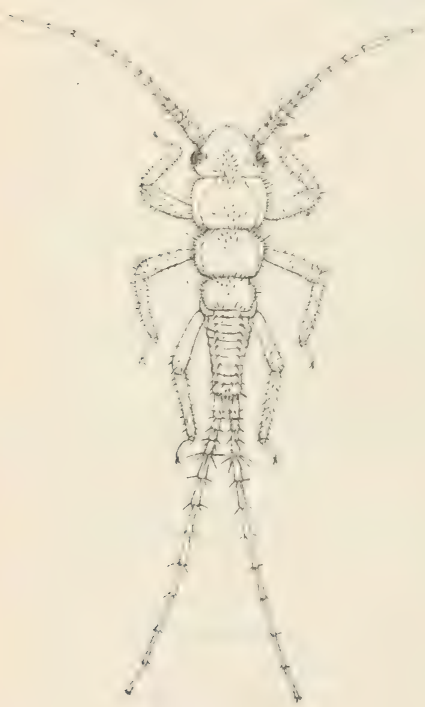

Fig. I. - Larva A.

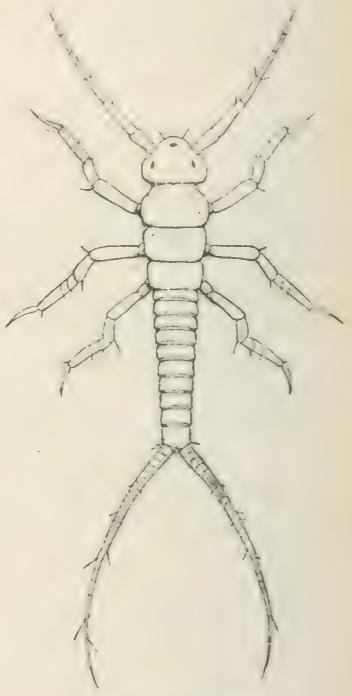

Fig. 2, - Larva B.

Es muy notable, por otra parte, la aparente analogía que muestran estas larvas, y especialmente la que ahora nos ocupa, con los copépodos, que son las formas mejor adaptadas a la vida planktónica; su conformación general, y especialmente el gran desarrollo de las antenas pelosas y la semejanza de los dos cercos con la furca de dichos entomostráceos, y en las larvas de los efeméridos la situación latero-abdominal de las vesículas seudobranquiales, como si correspondiesen a los sacos ovigeros de aquéllos, muestra cómo 
pueden existir semejanzas morfológicas entre seres sin próximo parentesco taxonómico, resultado de la acción del medio que origina estas convergencias de forma entre seres afiliados a grupos distantes en la clasificación, y cómo el carácter morfológico puede ser utilizado en las clasificaciones de orden biológico.

Respecto a la identificación sistemática de esta larva, puede desde luego referirse a la familia nemúridos, y en ella quizá al género Nemura, por sus cercos nudosos, provistos en cada artejo de un verticilo de pelos, y por la conformación de sus tarsos, bien que no en todos sus caracteres coincida con los que se dan como propios de las larvas de dicho género, deducidos del estudio de algunas de sus especies.

Por lo demás, los autores que se han ocupado en el estudio de estas larvas, aunque reconocen que su biología es desconocida, indican la existencia de unas reófilas, habitantes de las aguas vivas, y otras limnofilas, propias de las detenidas, y a las cuales pertenecería la nuestra; pero no como habitante entre la vegetación sumergida, como afirman los autores que de ellas se ocupan, pues su vida planktónica no sólo la deduzco de su morfología y del

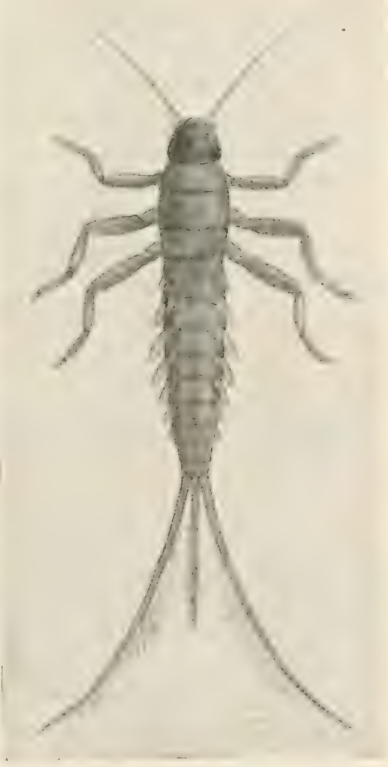

Fig. 3. - Larva C. hecho de haberla capturado con otros organismos del plankton superficial, sino que en la laguna de Peñalara la vida entre la vegretación sumergida es imposible, por no existir dicha vegetación.

Más difícil es aún localizar taxonomicamente la que designamos como larva B (fig. 2), pues si su porte es de plecóptero, la falta de uñas dobles la aproxima a los efemerópteros. También su adapta- 
ción planktónica es bien manifiesta, aunque menos que en la anterior, puesto que sus apéndices son más cortos y menos pelosos.

La larva C (fig. 3) es indudablemente de un efemeróptero, y nos muestra los caracteres de la familia bétidos, y dentro de ella los de su género tipo Baetis, pues sus branquias son semejantes y monolamelares; de sus tres cercos, los laterales están ciliados solamente en su borde interno, y sus antenas son relativamente cortas. De las numerosas especies de este género sólo se conocen dos larvas, a ninguna de las cuales puede referirse la nuestra, que pertenece al tipo nadador, de los cuatro tipos biológicos que en estas larvas se consideran, y que delata, a más de su conformación y de haber sido recogida en el plankton superficial, su régimen probablemente planktófago.

El hallazgo de estas larvas no debe maravillarnos, sino, antes al contrario, puesto que ellas son elementos peculiares de la fauna de los lagos alpinos, como se deduce de los trabajos recopilativos de ZsCHOKKE.

\section{BIBLIOGRAFÍA}

1843. Pictet, F. J. - Histoire naturelle gén. et part. des insectes neuroptères.

1885-88. EAton, A. E.-A Revisional Monograph of Recent Ephemeridae or Mayflies. (Trans. Linn. Soc. London, Zool., vol. III.)

1900. ZsсноккE, F. - Die Tierwelt der Hochgebirgseen.

1903. MIALL, L. C. - Natural history of acuatic insects.

1909. KLAPALEK, F.-Ephemeridae. (Siisswasserfauna Deutschland H., 8.)

1913. BROCHER, F. - L'Aquarium de chambre.

1917. Lestage, J. A. - Contribution à l'étude des larves des Éphémères paléartiques. (Ann. Biol. Lac., VIII, pág. 213.)

1918. Baldwin, H., and Chandler, G. - Fresh-Water Biology.

1917-20. Rousseau, E. - Les larves aquatiques des insectes d'Europe. 


\title{
LEVANTAMIENTO RECIENTE DE LA MESETA CENTRAL DE LA PENÍNSULA
}

\author{
POR \\ J. DANTIN CERECEDA
}

El fenómeno capital morfológico que decide de la tectónica y del relieve peninsular es, sin duda, la presencia y papel de horst resistente que en todo momento ha desempeñado la Meseta central de la Península Ibérica.

Algunos hechos parecen abogar en favor de un reciente levantamiento de dicha Meseta con producción de una flexión en la vecindad de nuestra frontera con Portugal, en este caso más natural de cuanto viene pareciendo.

Los hechos con que puede defenderse el reciente levantamiento en cuestión son de diversa naturaleza: unos, de índole puramente morfológica, y otros, exclusivamente biogreográficos. Helos aquí :

\section{I}

Singularmente, en los bordes orientales de la Meseta (región de mesetas y altiplanicies de mesozoica fecha del Sistema Ibérico) el paisaje erosivo del país, acusador de extraordinarias energías, ofrece formas muy jóvenes. Los ríos de la vertiente ibérica y de la grande atlantica corren profundamente encajados (hoces del (iallo en el macizo triásico alcarreño, hoces del . Ilesa, del Jalón, del Tajo, y en general de todos los ríos que de una y otra vertiente arrancan).

En la vieja penillanura meseteña, ya libre de sedimentos horizontales y posteriores (Extremadura), ya por ellos cubierta (submeseta septentrional, porción oriental de la submeseta meridional), es proverbial el hondo encajamiento de los ríos en tuertos escobios (meandros encajados), el cual, en cuanto la penillanura conserva las formas seniles y las márgenes están todavía por modelar, inconsecuentes con el presente teatro, acusa la fecha reciente del levan- 
tamiento. Hay, pues, un nuevo ciclo de erosión, que, de otra parte, está en sus comienzos.

El eje del levantamiento puede situarse en el borde Nordeste de la Meseta; la red fluvial es en gran parte congruente con las pendientes (atlántica y mediterránea) que este levantamiento ha determinado. Probablemente, el levantamiento se añade, para acrecerlos, a otros verticales que de eje paralelo al presente le habrán antecedido.

Pero acaso en la región en que con más clara evidencia e intensidad este fenómeno de la juventud de la erosión y reciente encajamiento de los ríos se manifiesta, es en el Levante de España, allí en donde los bordes orientales del macizo meseteño peninsular interfieren con los plegamientos subbéticos al Sur y caen en rápido declive al Mediterráneo, del que quedan próximos.

Los ríos Mijares, Palancia, Guadalaviar, Cabriel y Júcar, Serpis, etc., presentan en la mayor parte de su curso cauce y régimen enteramente torrenciales, y ofrecen, alli en donde cortan, hienden y tajan los plegamientos penibéticos que se yerguen perpendiculares a su dirección, numerosos meandros encajados, sin otra posible explicación sino la de un levantamiento en masa del macizo, y no la de un cambio del nivel de base, harto más difícil de imaginar y de admitir. Ciertamente que si interesante en el proceso genético, tanto montaria para el resultado. De todos estos ríos, el Júcar, como dotado de mayor caudal y por otros motivos que no son del caso, encaja su cauce con máxima hondura a través del eje de levantamiento (hoces de Cofrentes) e invade, en parte grande de su curso superior, la Meseta misma (1).

El curso de estos rios, tajadores de la ancha faja levantina, no pierde su carácter torrencial sino a muy pocos kilómetros del mar, alli en donde, frente a los escobios angostos, se abre y dilata la planicie litoral, en gran parte engendrada por los depósitos de estratificación deltaica de sus potentes aluviones (formaciones deltaicas del Turia, Júcar, etc.).

En la vertiente occidental atlántica, las consecuencias de este patente movimiento epeirogénico han sido diferentes. La producción de un pliegue en flexión - acaso coincidente con este levantamiento - explica la condición de los tramos varios en que los ríos

(1) Nos reservamos para otra ocasión el estudio de la significación tectónica del Júcar, esencial en la historia de la Meseta. 
que desaguan la Meseta pueden ser divididos. Desde luego, del Sistema Ibérico - en que se acusa el máximo del levantamiento hasta el encuentro con el pliegue en flexión, se señala un hecho general: el encajamiento de los rios-principalmente Tajo y Guadiana en la submeseta meridional - en convivencia con formas seniles de un ciclo anterior, en gran parte todavía sin rejuvenecer por la eficacia erosiva del nuevo ciclo. Tan sólo en la más occidental Extremadura la vieja estructura herciniana - de tan recia supervivencia - impone direcciones a la red fluvial (tramo medio del Guadiana), En el resto, recubierta la Meseta por sedimentos posteriores, el encajamiento fluvial no ha alcanzado en muchos sitios la sepulta plataforma estructural arrasada. Aqui y allá se ofrece algún valle epigénico (torno del Tajo, en Toledo), bien que, en gran parte, las vaguadas se alojen todavía en el espesor de los sedimentos.

La presencia del pliegue en flexión queda bien acusada en las cercanías de la frontera portuguesa por el cambio brusco de la naturaleza del cauce y curso de los ríos (1), al aparecer súbitamente rápidos y cascadas (arribes del Duero, por ejemplo), hoy ampliamente utilizados por la industria hidroeléctrica (saltos del Duero).

\section{II}

Los hechos de índole biogeográfica son de no menor evidencia. De todos los países situados en torno al mar Mediterráneo, es la Península aquel a quien más ampliamente invade la vegetación mediterránea. Llega hasta las mismas fronteras con Portugal (bosque de encina y de alcornoque de Extremadura, formaciones de cistáceas y de labiadas leñosas del borde meridional de la Meseta o Sierra Morena, y con ésta, de toda la submeseta meridional, principalmente en su porción más occidental, como Extremadura, por ejemplo).

Esta tan extensa invasión por la vegetación mediterrảnea es tanto más sorprendente cuanto que la Meseta, en su mayor parte, está inclinada, bien que no grandemente, hacia el Atlántico, y no

(1) En el tramo internacional, frente a Paradella, corre el Duero a 596 metros de altitud, precipitándose por un desnivel de 420 metros - en el corto trayecto de 140 kilómetros - hasta salir de las angostas hoces fronterizas frente a Barca d'Alva, a la altitud de 176 metros. La pendiente media es, pues, de 3 por 1.000 . 
da frente al mar Mediterráneo; antes bien, parece precisamente volverle la espalda.

La explicación del fenómeno puede ser la siguiente: en otros tiempos - todavía por determinar con precisión, pero no muy remotos-, la Meseta, bien horizontal, bien inclinada al Mediterráneo, y no de espaldas a él como se encuentra al presente, quedaria invadida hasta sus extremas partes occidentales por la peculiar vegetación mediterránea. La carta de FIScher (1) localiza el olivo, con máxima concentración, en La Vera y valle del Alagón (porción extrema occidental de la Meseta), sin olvido de la extensión y preponderancia que alcanza en el valle del Guadalquivir y Portugal, ambos francamente orientados al Atlántico. Precisamente todo el cuadrante Sudoeste meseteño - del alto valle del Tajo al cabo de San Vicente (Castilla la Nueva, Extremadura, Andalucía, Portugal) - es, por excelencia, en España la región del olivo, y con él lugares donde impera - singularmente en el ámbito de la Mesetauna vegetación típicamente mediterránea, en cuanto toca a sus peculiares formaciones de bosque y matorral (2). En ninguno de los países mediterráneos el matorral de cistáceas alcanza la extensión y la densidad que junto al borde de Sierra Morena (3), extraño a toda orientación mediterrảnea.

Tras esta invasión tan total de la vegetación mediterránea, que llegó en el Occidente a límites tan extremos, sufrió la Meseta el reciente levantamiento que por todas partes se acusa, con inclinación evidente hacia el Atlántico, quedando su vegetación mediterránea, corroboradora de los hechos morfológicos, en firme testimonio de una posición anterior, hoy incongruente con su actual orientación atlántica. La aridez del clima sostiene la supervivencia de una flora que viene persistiendo - al parecer sin alteraciones sensibles - en lugares hoy apartados y no influidos directamente por el Mediterráneo, como son la porción central de la Meseta, la penillanura occidental en que han parado los viejos plegamientos hercinia-

(1) Th. FISCHER, Der Ölbaum. Seine geographische Verbreitung, seine Wirtschaftliche und Kulturhistorische Bedeutung. (Dr. A. Petermanns Mitteilungen, Ergänzungsheft, núm. 147, 87 págs., con una carta. Gotha, 1904.)

(2) O. Drude, Die Florenreiche der Erde. (Dr. A. Petermanns Mitteilungen, Ergänzungsheft, núm. 74, 74 págs., con tres cartas. Gotha, 1884.)

(3) GRISEBACH, Vegetation der Erde. 
nos, la propia Sierra Morena y aun el mismo valle del Guadalquivir, hundido y sometido al influjo del Atlántico, al que ampliamente se abre y se inclina.

La configuración de la Meseta, altiplanicie en todos rumbos limitada por rebordes montañosos, ya procedentes de plegamientos, ya originados por bordes cubiertos de fallas, en estadios diferentes de evolución, privando a la cuenca central del influjo de clima más húmedo, y su altitud misma y posición centro-continental, al extremar las temperaturas, confina la vieja flora mediterránea e impide también sea substituida por otra más conforme con la atlánticat oric:ntación, prolongando su persistencia.

\section{LOS ÁPIDOS DE ESPAÑA}

POR

JOSÉ M.^ DUSMET Y ALONSO

V

Géneros Stelis Panz., Dioxys Lep., Ammobates Latr., Phiarus Gerst., Pasites Jur. y Biastes Panz.

El presente trabajo, como los cuatro anteriores de la serie (1), tiene por objeto dar alguna ayuda a quienes estudian los himenópteros de España para el conocimiento de sus especies. Siempre quiero repetir, sin embargo, que faltando por explorar muchas provincias, es muy fácil que se hallen aquí más especies, sean nuevas para la Ciencia, o bien conocidas en otras comarcas paleárticas, especialmente en las mediterráneas. En cada género cito las que pudieran hallarse más fácilmente.

Los ejemplares que he estudiado proceden del Museo Nacional de Ciencias Niturales de Madrid o de la coleccion en él depositada

(1) Los Apidos de España. I: Géneros Melecta, Crocisa y Epeolus. (Bol. de la R. Soc. Esp. de Hist. Nat., 1905.) -II: Género Colioxys. (Ibid., 1906.) - III: Género Anthidium. (Mem. de la R. Soc. Esp. de Hist. Nat., t. V, 1908.) - IV: Género Nomada. (Ibid., t. IX, 1913.) 
del Sr. Garcia Mercet. Otros muchos me han sido enviados generosamente para su estudio por D. José María Bofill y D. Ascensio Codina, de Barcelona. Los restantes son de mi colección, en su mayoría cazados por mí, y otros regalados por el R. P. Navás, de Zaragoza, y por los Sres. Andréu, La Fuente, Vidal López, Lauffer, P. Saz, Arias, Fernández Navarro, Boscá y Flórez. A todos manifiesto mi sincero agradecimiento.

He utilizado descripciones, citas o datos de las obras siguientes, cuyo número servirá de referencia en el texto:

1. Alfken, J. D.-Beitrag zur Kenntniss der Apidenfauna von Ostpreussen. (Schriften der Physik-ökonom. Gesellsch. zu Königsberg, 1909.)

2. - Die Bienenfauna von Ostpreussen. (Schriften der Physik-ökonom. Gesellsch. zu Königsberg, 1912.)

3. - Die Bienenfauna von Westpreusen. (Westpr. Bot. Zool. Ver., Dantzig, 1912.)

4. - Die Bienenfauna von Bremen. (Abh. Nat. Ver., XXII, Bremen, 1913.)

5. - Beitrag zur Kenntniss der Bienenfauna von Algerien. (Mém. Soc. Ent. Belg., XXII, Bruxelles, 1914.)

6. Bofill, J. M. ${ }^{\mathrm{a}}$ - Catàlech de insectes de Catalunya. Hymenòpters, XIX Familia Apidex. (Inst. Cat. d'Hist. Nat., Barcelona, 1904-1905.)

7. Cockerell, T. D. A.-Descriptions and Records of Bees, XXVIII. (Ann. Mag. Nat. Hist., London, 1910.)

8. Dalla Torre, C. G. - Catalogus Hymenopterorum. Vol. X: «Apida, (Lipsiæ, 1896.)

9. Dominique, Abbé J. - Mellifères de la Loire Inférieure. (Soc. Sc. Nat. O. France, Nantes, 1894.)

10. Dusmet, J. M. ${ }^{a}$ - Himenópteros de la sierra de Albarracin, Calamocha y Calatayud. (Bol. Soc. Arag. C. Nat., Zaragoza, 1906.)

11. - Himenópteros de Aragón. (Bol. Soc. Arag. C. Nat., Zaragoza, 1915.)

12. Frey-Gessner, E. - Fauna insectorum Helvetice, Hymenoptera Apida. (Bull. Soc. Ent. Suisse, Berne, 1909-1912.)

13. Friese, H.-Die Bienen Europa's, t. I. (Berlin, 1895.)

14. - Neue paläarktische Sammelbienen. (Entom. Nachr. J. XXV, n. 18 y 21, Berlin, 1899.)

15. Gaulle, J. de.-Catalogue systématique et biologique des hyménoptères de France. (Feuille J. Nat., Paris, 1906-1908.)

16. GRÆFFE, Ed.-Die Apiden-Fauna des österreichischen Küstenlandes. (Verhandl. k. k. zool. bot. Gesellsch., Viena, 1902.)

17. HöPPNER, H. - Nordwestdeutsche Schmarotzerbienen. (Ver. für Naturkunde, 1898-1899.) 
1.. HöPPNER, H. - Die Bienenfauna der Dünen und Weserabhänge zwischen Uesen und Baden. (Abh. Nat. Ver., Bremen, 1901.)

19. LePeletier De ST. Fargeau, Comte A.-Histoire naturelle des insectes. Hyménoptères, t. II. (Paris, 1841.)

2.). LuCAS, H.-Exploration scientifique de l'Algérie. Histoire naturelle des animaux articulés. (Paris, 1847.)

21. Magretti, P. - Sugli Imenotteri della Lombardia. Memoria prima. (Soc. Entom. Ital. Firenze, 1881.)

22. - Imenotteri di Siria raccolti dall'avvto Augusto Medana (Ann. Mus. Civ. Stor. Nat., Génova, 1890.)

23. MARQUET. - Aperçu des insectes hyménoptères qui habitent une partie du Languedoc. (Toulouse, 1875.)

24. MoCsary, Alex. - E fauna apidarum Hungarice. (Termesz. Füzetek, Budapest, 1894.)

25. MORAwitZ, F.-Die Bienen des Gouvernements von St. Petersburg, 1870.

26. - Beitrag zur Bienenfauna Russlands, 1870.

27. - Neue Sudeuropäische Bienen. (Hor. S. E. R., 1872.)

28. - Die Bienen Daghestans. (Hor. S. E. R., 1873.)

21. - Viaje de Fedtchenko al Turkestán, Mellifera. (San Petersburgo, 1875.) (En ruso y latin.)

3!. - Zur Bienenfauna des Caucasusländer, 1875.

31. - Nachtrag zur Bienenfauna Caucasiens. (Hor. S. E. R., San Petersburgo, 1876.)

32. - Ein Beitrag zur Bienenfauna Mittel-Asiens. (Mél. Biologiques, 1880.)

33. - Supplement zur Bienenfauna Turkestans. (Hor. S. E. R., 1893.)

34. - Beitrag zur Bienenfauna Turkmeniens. (Hor. S. E. R., 1894.)

35. NYLANDER, IV. - Revisio synoptica Apum Borealium, 1851.

3i. PÉREZ, P. - Contribution à la faune des Apiaires de France. (Act. Soc. Linn., Bordeaux, 1879.)

37. - Catalogue des mellifères du Sud-Ouest. (Act. Soc. Linn., Bordeaux, 1895.)

38. - Espèces nouvelles de mellifères de Barbarie. (Bordeaux, 1895.)

39. - Espèces nouvelles de mellifères. (Proc. verbaux Soc. Linn., Bordeaux, 1902.)

41. Radoszkowsky, O. - Matériaux pour servir à l'étude des insectes de la Russie. IV: «Notes sur quelques hyménoptères de la tribu des Apides,s (Hor. S. E. R. V.)

i1. - Faune hyménoptérologique transcaspienne. (H. S. E. R. XX, 1885.)

42. SAunders, Edw. - Synopsis of British Hymenoptera. Part II: - Apidae.s (Trans. Ent. Soc., London, 1884.)

43. - Balearic Insects. Hymenoptera aculeata collected in Majorca and Minorca by Poulton, Thomas and Pocock. (The Ent. Month. Mag., London, 1901.) 
44. SAUNDERS, Edw. - Hymenoptera aculeata from Majorca and Spain.

(Trans. Ent. Soc., London, 1904.)

45. - Hymenoptera aculeata collected in Algeria by Eaton and Morice.

Part III: "Anthophila.» (Trans. Ent. Soc., London, 1908.)

46. SCHENCK, A. - Die nassauischen Bienen. (Nass. nat. Jahrb. XIV, 1861.)

47. - Beschreibung der nassauischen Bienen. Zweiter nachtrag. (Nass.

Ver. für Naturkunde, Wiesbaden, 1868.)

48. Sмiтh, F. - Catalogue of British Hymenoptera in the collection of the

British Museum. Part I: «Apidie. (London, 1855.)

49. Spinola, Max. - Insectorum Ligurice species nove aut rariores. (Genuæ, 1808.)

50. Willoughby Gardner. - A list of the Hymenoptera aculeata of Lancashire and Cheshire. (Trans. Liv. Biol. Soc., Liverpool, 1901.)

51. GRIBODo, G. - Nuovi genere e nuove specie de Imenotteri antofili. (Bull. Soc. Ent. Ital., XXVI, Firenze, 1894.)

\section{Género Stelis Panzer.}

Sinonimia: Gymnus Spinola = Andrena Fabr. = Anthidium Latr. = Anthophora $\mathrm{III} .=$ Gyrodroma $\mathrm{KL} .=$ Heriades Spin. = Megachile Latr. = Megilla Fabr. = Trachusa Jur.

Labro alargado, obtuso. Mandibulas dentadas. Celdilla radial grande, estrechada al extremo. Dos cubitales casi igruales. Segundo nervio transverso-discoidal más hacia el ápice del ala que el segundo transverso-cubital. Escudete y postescudete sin dientes. Uñas con pulvillum. Abdomen corto, grueso, sin escobilla ventral en las $q$, inerme en los $\sigma^{\top} \sigma^{\top}$ (sólo en St. signata con una espina.)

Este género se halla representado en distintas regiones: en la paleártica hay más de veinte especies, de las cuales diez se han hallado en España.

De aspecto muy semejante al Anthidium, se distinguen bien las $q f$ por la falta de escobilla, pero son muy fáciles de confundir algunos $\sigma^{\star} \sigma^{*}$, como ya indicaremos. Hay también especies que se parecen a algumas Trachusa o Eridudes: pero en esos géneros el segundo nervio transverso-discoidal esta más cerca de la base del ala.que el segundo transverso-cubital. 


\section{Cuadro para distinguir las especies.}

1. Abdomen negro, sin manchas claras................... 2

- Abdomen con manchas claras....................... 5

2. Bordes de los segmentos abdominales pálidos.. 5, aterrima Panz.

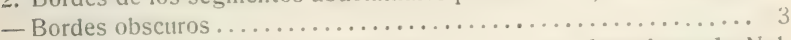

3. Abdomen con fajas de pelos blancos....... 6, breviuscula Nyl.

- Abdomen sin tales fajas........................ 4

4. Borde del epistoma saliente............... 7, phaoptera K.

- Borde del epistoma escotado.............. 8, murina Pér.

5. Patas amarillas o rojas. Fajas o grandes manchas abdominales... 6

- Patas negras. Pequeñas manchas abdominales............. 9

6. Manchas blancas. Patas rojas. Epistoma escotado. Abdomen alargado. (Subg. Stelidomorpha Mor.).............. 1, nasuta Latr. - Manchas amarillas. Abdomen corto. (Subg. Protostelis Fr.)..... 7

7. 6-7 mm. Segmento anal $\delta^{7}$ formando una espina; en $q$ pequeño y redondeado........................... 2, signata Latr.

- 10-12 mm. Segmento anal $q$ triangular, ancho ............. 8

8. Epistoma, escamillas y manchas del tórax amarillos. Segmento anal $\delta$ 3-dentado..................... 3, Frey-Gessneri Fr.

- Epistoma negro, con puntos amarillos. Escamillas ferruginosas. Tórax negro....................... 4, hispanica 11. sp.

9. Alargado. Metatarso posterior $q$ y tercer segmento ventral $\delta$, normales.......................... 9, minuta Lep.

- Más grueso. Metatarso posterior $q$ ensanchado, tercer segmento ventral $\sigma^{\star}$ con elevación o quilla............... 10, ornatula Kl.

\section{Stelis nasuta Latr., Descr. (13) (*).}

Sinonimia: Anthidium nasutum Latr. = Stelidomorpha nasuta Mor.

Cuarenta y dos ejemplares estudiados. - Prov. de Madrid : Escorial y Los Molinos (Garcia Mercet!). - Prov. de Ávila : Navalperal (Garcia Mercet !). - Cataluña (Bofill! y Codina !).

Citas. - Argelia (Alfken). - Austria, Alemania y Hungria (Friese). - Europa Central y Meridional (Dalla Torre). - Francia (Dominique, Pérez). - Turquestán (Morawitz).

$\left(^{*}\right.$ En cada especie señalo, por la lista bibliográfica, lis obras en que se hallan las descripciones más extensas, para ampliación de las mias que he tratado de abreviar 
DESCRIPCIÓN. - + : longitud, 7-9 mm. Cabeza y tórax con puntos profundos, abundantes. Epístoma convexo, el borde deprimido, con una gran escotadura limitada por dos lóbulos anchos. Mandibulas con tres dientes, el terminal agudo. Escudete semicircular, sin dientes laterales, con ligera escotadura central. Abdomen brillante, con puntos separados. Alas ligeramente ahumadas. Pilosidad gris, no muy abundante. En la boca pelos largos, dorados.

Negro. De color rojo ferruginoso son dos manchas alargadas en el vértex, que pueden faltar, así como las escamillas y las patas, excepto su base. De un blanco amarillento dos o cuatro puntos en el borde interno de los ojos, dos en la parte anterior del mesonoto, dos rayas onduladas en el primer segmento abdominal, cuatro manchas en los segundo a cuarto, y dos en el quinto. Pueden variar en su extensión y en su color desde blanco marfil al amarillo limón. Los puntos de la cabeza y tórax, a veces faltan. Borde de los segmentos decolorado o blanquecino.

ơ: longitud, 5-8 mm. Epístoma poco escotado, amarillo. Manchas de la cara mayores y constantes. Escamillas a veces manchadas de amarillo. Pueden faltar los puntos del quinto segmento. Vientre excavado, con pestañas gris-amarillentas en los bordes.

Biología. - Sobre Marrubium vulgare (según Mercet); sobre Teucrium, Stachys y Ajuga (según Friese). Parásito de Chalicodoma muraria (según Friese.)

\section{Stelis signata Latr., Descr. (13).}

Sinonimia : Anthidium signatum Latr. = Anthidium parvulum Lep.

Trece ejemplares estudiados. - Prov. de Madrid: Madrid!, Escorial! - Prov. de Zaragoza: Calatayud. - Prov. de Ávila: Santa Cruz del Valle! -- Valencia (Moroder). - Cataluña: Pedralbes.

CiтAs. - Cataluña: Bergues, Vallvidrera, Tarrasa, La Garriga (Bofill). - Europa (Dalla Torre). - Alemania, Finlandia, Sicilia, Dalmacia, Cáucaso y Suiza (Friese). - Francia (Pérez).

Descripción. - o: longitud, 5,5-7 mm. Cabeza bastante más estrecha que el tórax, con puntuación profunda y espesa. Mandibulas con sólo el diente final marcado. Epístoma truncado, casi recto, con puntos profundos. Labro liso y brillante. Antenas cortas; segundo artejo grande, tercero y cuarto poco distintamente separados, cortos. Escudete semicircular, algo separado de sus lóbulos 
literales; su puntuación tan gruesa como la del mesonoto. Abdomen con puntos profundos, en el sexto segmento muy abundantes, uniéndose casi todos. También el vientre punteado. Pilosidad escasa, corta, amarillenta; en el borde de los segmentos ventrales pestanas cortas, doradas. Alas algo ahumadas; estigma negro.

Negro, manchado de amarillo huevo. En la cabeza son amarillos los espacios entre el epístoma y los ojos, manchas sobre éstos, otra pequeña en la frente y parte del epístoma. En el tórax, dos rayas en los angulos anteriores del mesonoto, dos manchas en el escudete. sus lóbulos laterales, manchas en las mesopleuras, que pueden faltar, callos humerales y parte anterior de las escamillas. Los cuatro o cinco primerus sermentos abdominales con manchas grandes, Hegando casi a los lados, siendo mayores las del tercero, y menores las del primero y quinto. Patas amarillas; caderas y fémures en su base negros.

$\sigma$, muy semejante a la . . Epistoma todo amarillo. Antenas, a veces de un ferruginoso obscuro.

Este insecto es absolutamente del mismo aspecto que Anthidium strigatum Latr. y lituratum Panz. Se distinguen porque las $q$ $q$ de aquéllos tienen escobilla ventral. El ơ del strigatum lleva una larga espina en el vientre, y el del lituratum los fémures anteriores dentados.

Biologí. - Parásito de Anthidium strigatum Latr. (según Schenck y otros). Sobre Sedum y Reseda (según Friese), Thymus y Jasione (Alfken).

3. Stelis Frey-Gessneri Friese, Descr. (13).

Una f, prov, de Barcelona : Castelldefels (Bofill !), en julio.

CitAs. - Siders, Suiza (Friese).

Descripción. - q de Cataluña: longitud, 10 mm. (10-12 según Friese). Cabeza y tórax rugoso-punteados, así como el sexto segmento; los anteriores tienen puntos abundantes, pero separádos. Cabeza más estrecha que el tirax. Mandibulas con dos fuertes dirnites. Epístoma punteado, redondeado, poco más ancho que largo. Antenas cortas: artejos intermedios mais anchos que largos. Escudete con gruesos puntos, por lo cual el borde es denticulado; algo escotado en el centro y marcindose los bobulos laterales, sin llenar a ser espinosos. Alas algo ahumadas; estigma y nervios castaños. Pilosidad escasa, amarillenta; sólo es más abundante en la cara y 
en los segmentos ventrales, en los que se forman pestañas de pelos largos, pero escasos. Los bordes de los segmentos dorsales y ventrales son lisos y brillantes, y los últimos decolorados.

Negro, manchado de amarillo huevo. Antenas negras por encima, castañas por debajo. En la cabeza son amarillos el epistoma, borde interno de los ojos y grandes manchas occipitales, que casi se reunen. En el tórax, los ángulos anteriores del mesonoto, callos humerales, escamillas, lóbulos laterales del escudete, dos manchas a los lados de éste y otras dos largas en las mesopleuras. En el abdomen grandes fajas, situadas más bien en la base de los segmentos; las dos primeras interrumpidas, las siguientes casi llenando el segmento. El sexto con mancha grande amarilla (según Friese es negro). Vientre negro. Patas de un amarillo-ferruginoso; caderas y base de los fémures castaños.

E! $\sigma^{\nearrow}$ (según Friese) tiene la cabeza con pelos blancos, escudete sin manchas, segmentos sexto y séptimo negros, y el último !igeramente tridentado. Antenas negras.

Este hallazgo es muy interesante, pues sólo le habia visto su autor en el Valois, y no creo se haya vuelto a citar.

Se parece muchísimo a los Anthidium, especialmente al A. Latreille $i$, que tiene su misma forma y coloración. Solamente la falta de escobilla ventral en la $q$ y el abdomen encorvado del pueden distinguirlo.

BIología. - Sobre Centaurea y Scabiosa (según Friese). Parásito de Anthidium interruptum F. Vuela en julio (Friese).

\section{Stelis hispanica n. sp.}

Una f, Valladolid (Martínez Escalera !), 14 de junio de 18(2). (Mus. de Madrid.)

Long., $12 \mathrm{~mm}$. Caput et thorax rugoso-punctati, opaci. Caput thorace latius. Mandibulce fortes, rugis longitudinalibus et tribus fortibus dentibus. Epistoma latius yuam longius, punctis impressis profundis. Antenna breves, articulis $40^{\circ}$ et $5 .^{\circ}$ minutis. Pili flavo-rufi, in capite et thorace densi. Abdomen subnitens, punctis impressis profundis, haud copiosis. Segmentum sextum abdominale triangulare, apice rotundato. Sternita abdominis marginibus lavibus, latis, decoloratis. Pili grisei rarique, in abdominis dorso; ultima sternita |ciliis longis, aureis, parum densis. 
Nigra, vitellino maculata. Caput duabus maculis lateralibus in vertice, aliis duabus in epistomate et marginibus oculorum internis, flavis. Singula segmenta abdominalia duabus maculis elongatis, nec basim nec marginem tangentibus, sensim majoribus usque ad quintum, in quo confluunt; sextum una centrali notatum. Squamulce, apex femorum, tibio, tarsi et maculce coxarum ferruginece.

Esta especie se parece al St. Frey-Gessneri Friese, pero no creo pueda ser la misma. Su cabeza es más ancha y la coloración demasiado diferente, siendo en aquél amarillo todo el epistoma. numerosas manchas en el tórax, las escamillas y callos; las patas casi amarillas, y la pilosidad escasa.

El St. hispanica tiene aspecto muy parecido al Anthidium laticeps Mor., siendo probable que los $\sigma^{7}$ sean sumamente semejantes.

El ejemplar único, existente en el Museo Nacional de Madrid hace veintiocho años, tiene un Stylops, que aparece bajo el cuart" segmento ventral.

5. Stelis aterrima Panz., Descr. (13).

Sinonimia : Apis aterrima $\mathrm{Panz} .=$ A. punctulatissima $\mathrm{Kl} .=$ Megilla ate rrima $\mathrm{F} .=$ Gyrodroma aterrima $\mathrm{Kl} .=$ Megachile aterrima $\mathrm{F} .=$ Anthophora aterrima III. = Gymnus aterrima Spin. = Heriades punctatissima Spin. = Stelis cognata Kohl.

Cincuenta ejemplares estudiados. - Prov. de Madrid: Madrid!, Villalba!, Los Molinos !, El Pardo! y Alcalá! - Pros. de Cilladalajara: Cutamilla! - Prov. de Oviedo: Cangas de Tineo (Flórez !). Prov, de Zaragoza: Ambel! - Valencia (Boscá !). - Prov. de Alicante: San Juan (P. Saz !), - Cataluña (Bofill! y Codina !). - Italia (Silvestri). - Hungría (Strobl). - Bélgica (Bequaert).

Citas. - Toda Europa (Friese), - Europa (Dalla Torre), -Francia (Lepeletier). - Alemania (Alfken, Schenck, Höppner). - Cincaso (Morawitz). - Inglaterra (Smith), - Siria (Magretti).

DESCRIPCIÓN.- $q$ : longitud, $7-11 \mathrm{~mm}$. Cabeza y tórax con puntos muy espesos, que se reunen. Epístoma truncado y denticulado en el borde. Mandibulas con arrugas longitudinales; su borde brillante, con tres dientes fuertes. Artejos intermedios de las antenas más largos que anchos. Escudete redondeado en el borde, con dien- 
tes laterales. Abdomen grueso, convexo por arriba, brillante, con puntos separados. Pilosidad gris, corta, en cabeza y tórax; más abundante en la cara y pecho. Alas algo ahumadas, con ligero reflejo violáceo.

Negro, con sólo el extremo de los tarsos algo pardo, y las antenas a veces ferruginoso-obscuras. Característico de esta especie es el color blancuzco del borde de los cuatro primeros segmentos abdominales, decoloración que se suele marcar menos en el primero.

7., muy semejante. Abdomen más curvo, excavado por debajo, con los bordes de los segmentos ventrales algo escotados, y en los uiltimos pestañas de pelos dorados.

Biologí.-Se halla en las zarzas (según León Dufour y Smith); sobre Centaurea y Sedum (según Friese). Parásito de Osmia adunca, O. aurulenta y O. fulviventris (según Smith y Saunders); de Anthidium manicatum (según Höppner); sobre Senecio, Carduus, Jasione, Thymus (Alfken); sobre Scabiosa (Schenck); sobre Cichorium, Knautia, Crepis y otras (Höppner).

6. Stelis breviuscula Nyl., Descr. (13).

Sinonimia: Heriades breviuscula Nyl. $=$ Stelis pygmaa Schenck. = Stelis pusilla Mor.

Una f, prov. de Madrid: Cercedilla !, 2 de septiembre de 1917; una o, Cataluña (Col. Antiga).

CitAs.-Alemania (Schenck, Alfken, Höppner, Friese). - Hungria, Tirol y Dalmacia (Friese). - Europa Boreal y Central (Dalla Torre), - Crimea (Morawitz). - Argelia (Alfken). - Francia (Dominique, Pérez).

DESCRIPCión. - $\subsetneq$ : longitud, $6 \mathrm{~mm}$. Cabeza y tórax con puntos profundos, más espesos en aquélla. Labro muy alargado, truncado en su extremo. Mandibulas con tres dientes fuertes. Antenas cortas; artejos intermedios tan anchos como largos. Abdomen brillante, con puntos más separados. Pilosidad gris, corta, abundante tan sólo en la cara y mesopleuras. Bordes de los segmentos abdominales decolorados; sobre ellos hay pestañas de pelos blancos, siendo más largas por el lado ventral.

Insecto negro por completo; tan sólo las mandibulas, antenas y tarsos pueden ser castaño muy obscuro. 
б, no le he visto. Según Friese, es muy semejante a la $f$.

Ha de advertirse que las pestañas de los segmentos abdominales deben ser de pelos bastante caedizos. En el ejemplar de Cataluña existen; en el de Cercedilla se notan muy poco y se ve que es igual al otro, siendo sumamente característico el labro largo y truncado.

Brología.-Parásito de Heriades truncorum y H. nigricornis (según Friese); de Osmia Spinolce (según Giraud). En los postes o troncos viejos (según Friese); sobre Tanacetum, Senecio, Achillea (Alfken); sobre Jasione y Potentilla (Höppner).

\section{Stelis pliacoptera Kirb., Descr. (13)(42) (49).}

Sinonimia: Apis phceoptera $\mathrm{Kl}$. = Megachile phceoptera Latr. $=$ Anthophora phceoptera $\mathrm{III}=$ Gyrodroma phcooptera Kl.

Una $f$, Sevilla, mayo de 1917; dos $q$ $q$, prov. de Barcelona: Ribas (Bofill !), 27 de julio de 1904; un ơ, prov. de Segovia: Marazoleja (Callejo !) (Mus. de Madrid); una $q$ y un $\delta$, sin localidad (Mus. de Madrid).

CitAs. - Argelia (Alfken). - Asia Central (Morawitz), - Inglaterra (Saunders). - Europa, Asia Central (Dalla Torre). - Francia (Dominique, Pérez). - Turquestán (Morawitz).

Descripción. - $q$ : longitud, $9-11 \mathrm{~mm}$. Puntuación fuerte, más espesa en la cabeza que en el tórax y aún más en el epistoma, cuyo borde es poco saliente y levemente denticulado. Escudete semicircular con pocos y fuertes puntos; lóbulos laterales ligeramente denticulados. Abdomen brillante, con puntos profundos, pero muy escasos en los primeros segmentos y cada vez más abundantes hasta el último, que es triangular en conjunto y algo anguloso a los lidos. I. us sermentos ventrales basilares son brillantes y con puntws fuertes; los terminales mates y con numerosos puntos pequeños. Alas ahumadas, especialmente en la celdilla radial.

Negro por completo, con pilosidad gris bastante abundante, pero esparcida. En los bordes de los segmentos abdominales son los pelos más espesos, pero no llegan a formar las fajas bien definidas del St. breviuscula.

o: : longitud, 8-9 mm. Semejante a la $f$. Tercer segmento ventral algo escotado; cuarto y quinto excavados, con pestanas doradas.

Biologia. - Se halla sobre las malvas (Smith); sobre Centaurea 
y en las tapias, en cuyos agujeros busca las Osmia; sobre Senecio (Alfken); sobre Lotus (Höppner). Parásito de Osmia fulviventris (según Smith); O. emarginata y O. inermis (según Friese); O. ventralis y O. Leaiana (Alfken); O. Solskyi (Höppner).

\section{Stelis murina J. Pérez, Descr. (36).}

Citas. - España, Provenza, Sicilia y Argelia (Pérez).

Muy semejante al St. phocoptera, del cual acaso sea una variedad. Copio la descripción del autor:

«La femelle diffère de la précédente (phceoptera) par sa forme moins allongée, la pubescence blanchatre mime chez lindividu frais éclos, celle du dessous des tarses postérieurs brunâtre; le chaperon échancré en arc de cercle au milieu, ses côtés très obliques et faiblement sinués; les appendices latéraux de l'écusson dénués d'épine, le dernier segment surbaissé, son extrémité obtuse, presque tronquée; le bord des segments ventraux 2-4 absolument dépourvu de ponctuation, tout à fait lisse et brillant.»

En mi colección hay un o de Beni-Hadim (Trípoli) (Alluaud !, 1899), que seria de esta especie, si subsiste. El o no se habia citado.

PÉREZ le obtuvo en abril de conchas de Helix Cirta, de Argelia, en las que había numerosas Osmia vidua Gerst., de la que sería parásito.

9. Stelis minuta Lep., Descr. (13) (19).

Sinonimia: St, nana Schenck.

En mi colección tengo una $q$ y un $\delta$ de Alemania.

Citas.-Prov. de Barcelona: La Garriga, 11 de junio de 1903. (Cat. Ins. Catalun!ja.) - Europa y Argelia (Alfken). - Norte y Centro de Europa (Friese). - Francia (Pérez).

DESCRIPCIÓN. - P (de Alemania): longitud, $7 \mathrm{~mm}$. Forma alargada. Antenas cortas. Escudete casi plano. Puntuación poco espesa, cuerpo brillante. Segmento anal redondeado. Metatarso posterior de forma normal.

Negro. Los tres primeros segmentos con una mancha pequer̃a, transversa, ebúrnea, a cada lado. 
б: longitud, 5,5 mm. Séptimo segmento truncado, con un pequeño diente en el centro. Tercer segmento ventral liso. Sólo hay manchas en los dos primeros segmentos.

Biología. - Parásito de Osmia leucomelcena, O. gallorum y O. tridentata (según Dufour, Schenck y Giraud); O. ruborum (según Pérez): Heriades campanularum (según. Morawitz): O. paruula (Alfken).

Se halla en los postes y vallados, rara vez sobre Campanula (Friese); sobre Trifolium (Alfken).

NotA. - La o citada en el Catálogo de Cataluña (6) es la que he tenido a la vista y cito en el St. ornatula, porque creo es de esa especie. Por lo tanto, no consta hasta ahora que el minuta se haya encontrado en España.

\section{Stelis ornatula Klug, Descr. (13) (42).}

Sinonimia: Gyrodroma ornatula Klug $=$ St. 8-maculata Schenck.

Una f, prov. de Barcelona: La Garriga, 11 de junio de 1893. (Col. Antiga.) (Clasif. por M. Pérez como minuta Lep.)

CiTA.-Según carta del Sr. Codina, en la colección Bofill existió un ejemplar de St. 8-maculata, de Cataluña, que falta actualmente. Acaso sea el mismo citado en Cat. Ins. Catalunya de San Julián de Vilatorta, 22 de julio de 1900.

Tengo en mi colección una pareja de Alemania (Trautmann), y se ha citado de Austria, Alemania, Finlandia y Suecia (Friese).

Es muy semejante al St. minuta, de su misma longitud, pero más ancho. La ㅇ tiene el metatarso posterior ensanchado. En el hay una elevación en el tercer segmento ventral, formando una pequeña quilla algo hendida. M. Pirk\% (.36) cree que s-maculata es sólo una variedad de minuta.

Biología.-Parásito de Osmia leucomelcena (segun Dours y Saunders); O. claviventris (según Morawitz); Ceratina cucurbitina (según Handlirsch).

Otras especles de Stclis que acaso se hallen en España.

Stelis leucostoma Costa (13). De Cerdeña. ठ, 6 mm. Debe ser próxima al minuta, pero con toda la cara blanca. Puntos abdominales amarillos.

St. ruficornis Mor. (27) (13). De Rodas y Amasia (Asia Menor). 
9-10 mm. Dice el autor que se parece al signata, pero no tiene la espina abdominal de éste en el $\delta^{\nearrow}$. Las antenas y patas son rojas, y el tamaño minayor.

St. simillima Mor. (30) (33). Del Cáucaso. 9-10 mm. Negro como aterrima, pero con el epistoma mate, sin puntuación visible.

St. minima Schenck (13). De Alemania. Según FrIESE debe ser una variedad de minuta Lep. Abdomen con puntos separados.

St. 6-signata Costa (13). De Nápoles. $8 \mathrm{~mm}$. Del grupo del minuta y por su breve descripción, difícil de separar de otras especies.

St. denticulata Friese (14). De Siria. 5,5-6,5 mm. Próximo a signata, según el autor, distinguiéndose por el epistoma dentado, y por el vientre ferruginoso de la $q$, y el segmento anal del $\sigma^{x}$ escotado y con un diente central.

St. Vachali Pér. (38). De Argelia. §ð, 8 mm. Dice su autor que es próximo al nasuta, pero con puntuación doble más fina y epistoma más escotado. Dibujos como Anthidium lituratum.

St. cassiopcea Saund. (45). De Argelia. 7-8 mm. Semejante a phocopte$r a$, con la cara más ancha y la cabeza y el tórax mates, con puntuación fina y espesa.

\section{Género Dioxys Lepeletier.}

Sinonimia : Cœlioxys Nyl. = Trachusa Jur. = Heriades Spin.

Labro alargado, truncado. Abdomen corto y grueso, de seis segmentos, en el $\delta$ encorvado hacia abajo. Escudete con dientes laterales curvos. Postescudete espinoso. Dos celdillas cubitales casi iguales. Nervio segundo transverso-discoidal más hacia la base del ala que el segundo transverso-cubital.

Próximo al Coelioxys, del que se distingue por el postescudete dentado y por no ser su abdomen agudo ni terminado en espinas en $\operatorname{los} \sigma^{x} \sigma^{x}$.

Se han citado unas veinte especies paleárticas, de las que seis han sido hasta ahora cazadas en España. Son parásitos de Osmia, Megachile y Chalicodoma.

Cuadro para distinguir las especies.

1. Abdomen negro.............................. 2

- Abdomen en parte rojizo. Escudete sin diente central. ........ 3

2. 4 mm....................... D. mœsta Costa (Cerdeña).

- 7-11 mm. Escudete con diente central..... 1, D. tridentata Nyl. 
3. Abdomen con el extremo negro................... 4

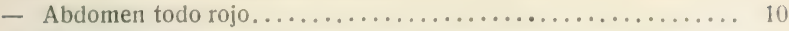

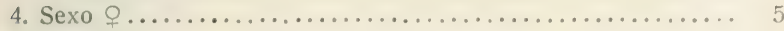

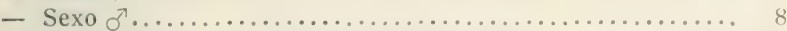

5. Patas negras; a lo más los tarsos ferruginosos............. 6

- Patas en gran parte rojizas............ 5, D. pumila Gerst.

6. Segmento anal truncado, algo escotado................ 7

- Segmento anal redondeado............ 4, D. rotundata Pér.

7. 9-12 mm. Extremo del abdomen menor que la mitad de su anchura máxima....................... 2, D. cincta Jur.

- $7 \mathrm{~mm}$. Extremo del abdomen igual a su anchura máxima. Forma general más estrecha. Color rojizo más claro... 3, D. spinigera Pér.

8. Cuarto segmento ventral ligeramente arqueado, sin dientes ni espinas....................... 5, D. pumila Gerst.

- Cuarto segmento con escotadura limitada por dientes triangulares, sin espinas....................... 2, D. cincta Jur.

- Cuarto segmento con escotadura limitada por espinas agudas . 9

9. Sexto ventral con dientes laterales anchos y romos..............

3, D. spinigera Pér.

- Sexto ventral con ángulos laterales poco salientes.

4, D. rotundata Pér.

10. Antenas negras............. D. dimidiata Lep. (Versalles).

- Antenas en gran parte rojas ............6. 6, D. ardens Gerst

\section{Dioxys tridentata Nyl., Descr. (13).}

Sinonimia : Calioxys tridentata Nyl. = Dioxys fasciata Schenck.

Prov. de Gerona: cuatro 9 . de Ribas; un $\varnothing^{\nearrow}$ de Viladráu (Codina !). - Prov. de Barcelona : Empalme y San Julián de Vilatorta (Antiga y Bofill!).

CitAs.-- Alemania, Austria, Hungria (Friese). - Suecia (Thomson). - Francia (Pérez). - Europa Boreal y Central (Dalla Torre).Centro y Sur de Europa (Alfken). - Cáucaso y Kazán (Morawitz).

DEscripción. - Q : longitud, 10-11 mm. Cabeza y tórax con puntuacion espesa, mates. Epistoma lampiño, cara con abundanten pelons grises. Escudete con un pequeno diente central, muchn menon que el largo y oblicuo del postescudete. Abdomen con puntos fuertes, espacios intermedios brillantes; sexto segmento dorsal poco convexo, con el borde algo escotado. Los cuatro primeros segmentos con fajas de pelos blancos, más anchas a los lados; la del primero se une a otras dos grandes manchas laterales de la parte ver- 
tical (al modo del género Crocisa). Completamente negro; solamente los tarsos y mandibulas pueden ser algo ferruginosos.

$\checkmark$, semejante. Sexto y séptimo segmentos dorsales escotados, el quinto con franja de pelos. Las de los últimos ventrales son amarillas. Cuarto ventral sin escotadura; sexto con dientes romos laterales.

Biologia. - Hasta ahora en España sólo se le conoce de Cataluña, a pesar de estar extendido en Europa. Siempre en julio. Parásito de Chalicodoma muraria y Megachile argentata (según Friese); de Osmia adunca (según Morawitz).

\section{Dioxys cincta Jur., Descr. (13) (36).}

Sinonimia : Trachusa cincta Jur. = Dioxys maura Lè. $=$ Dioxys pyrenaica Lep. $=$ Heriades cincta Spin.

Treinta y un ejemplares estudiados. - Prov. de Madrid: Madrid, Villaverde!, Montarco !, Las Navas!, Cercedilla (Mercet !), Aranjuez (Bolívar !). - Prov, de Guadalajara: Alcarria (Sanz !). Prov, de Cáceres: Baños de Montemayor!-Prov. de Cádiz: Algeciras (Bolivar). - Prov. de Barcelona: Olesa, Vacarisas y San Julián de Vilatorta (Antiga y Bofill !). — Baleares: Mahón (Vidal y López !).

Citas.- España y Argel (Friese). - Austria, Hungria, Grecia, Baleares (Friese). - Francia (Lepeletier, Pérez, etc.). - Argel (Alfken). - Italia (Spinola).

DESCRIPCIÓN. - q : longitud, 9-12 mm. Puntuación rugosa, espesa, por lo cual es bastante mate. Epístoma con el borde algo ondulado y elevado. Antenas con los artejos tercero y quinto tan largos como anchos; el cuarto es más corto. Pilosidad gris, abundante; que es larga en cabeza y tórax, corta en el abdomen, el cual tiene además franjas de pelos cortos en el borde de los cuatro primeros segmentos dorsales y ventrales. Sexto dorsal doble de ancho que largo, ligeramente escotado, como el ventral, que sobresale un poco. La anchura en el extremo del sexto dorsal es menor que la mitad de la anchura máxima del abdomen (segundo segmento).

Negro; el primer segmento dorsal rojizo.

$\sigma$, cuarto segmento ventral con una escotadura cuyos extremos se prolongan en un diente triangular, agudo, pero no espinoso; sexto ventral con dientes laterales agudos. 
Var. pyrenaica Lep. Segmentos dorsales, uno, dos y rara vez el tres (en algún rojos; manchas laterales en el ventral segundo.

Var. maura Lep. Completamente negro, con sólo un matiz ferruginoso en los primeros segmentos.

De estas dos variedades la última no la he visto de España, aunque es fácil se halle. En cambio, la pyrenaica es la que realmente representa aqui la especie, puesto que, salvo dos ejemplares que son del tipo y algunos que se pueden considerar como paso o transición, los restantes que cito corresponden a dicha variedad.

Bıología.-Es parásito de Chalicodoma muraria (según Giraud); Ch. sicula y $C h$. pyrenaica (según Friese); Osmia cyanoxantha (según Gaulle): Osmia Spinolce (según Giraud). Abril a junio.

OBSERVACión.-Con el nombre de Dioxys minor se hallan cuatro $f$ f en la colección Bofill, la cual, como la del difunto Antiga (en ella refundida), fueron estudiadas en parte por J. Pérez, de Burdeos, por lo que pudiera dudarse si a él se debía dicho nombre de una especie inédita. Tanto $M$. Ch. Pérez, profesor en la Sorbona e hijo del ilustr himenopterólogo fallecido, como mi amigo señor Bofill, han contestado amablemente a mis preguntas, pero no han podido ilustrarme sobre el origen del nombre $D$. minor. Desde luego, los cuatro ejemplares son bien diferentes : dos de ellos son, sin duda, $D$. rotundata Pér., cuya etiqueta también llevan. Los otros dos, entudiados por mi detenidamente, no parece que tengan caracteres para formar una especie nueva, constituyendo una de las variedades que sirven de paso insensible entre el $D$. cinct $a$ var. pyrenaica Lep. y D. spinigera Pér., al cual más bien creo que pertenezcan. Ambas especies, cuyos of $\sigma^{7}$ se distinguen bien, son muy fáciles de confundir en las $\bigcirc$. FrIESE considera el spinigera como variedad solamente del cincta. Pudiera realmente ser asi, porque el verdadero carácter diferencial, las espinas del cuarto segmento del $\sigma^{*}$, en algunos ejemplares tienen un desarrollo intermedio.

\section{Dioxys spinigera Pérez, Descr. (36) (13).}

Sinonimia : Dioxys cincta Jur., var. spinigera Pérez (según Friese).

Seis $q$, prov. de Gerona: Ribas y Pedralbes (Antiga y Bofill!): una ., Setcases !; un $\precsim$, Viladráu (Bofill !).

Citas. - España y Francia (Pérez), - Argelia (Alfkenı). 
DESCRIPCIÓN.—o: longitud, $7 \mathrm{~mm}$. Muy semejante al Dioxys cincta var. pyrenaica. Forma general más estrecha. Color rojizo más claro. Puntuación más escasa y menos profunda, siendo el abdomen más brillante. Extremo del segmento anal de una anchura igual a la mitad de la anchura máxima del abdomen (segundo segmento).

$\sigma^{1}$ : longitud, $7 \mathrm{~mm}$. Se diferencia mejor del cincta por tener el borde del cuarto segmento ventral elevado en el centro, con una escotadura muy profunda, limitada por verdaderas espinas largas. El sexto ventral tiene sus dientes laterales anchos y romos.

Siendo las $q$ q bien diferentes, los of de rotundata y spinigera son muy semejantes, como después diremos.

Véase en $D$. cincta la opinión de FrIESE sobre la unión de ambos.

Bıología. - Mayo a julio.

\section{Dioxys rotundata Pérez, Descr. (13) (36).}

Once ejemplares estudiados. - Prov. de Madrid: Las Navas ! Prov. de Ciudad Real: Pozuelo de Calatrava (La Fuente !).-Provincia de Alicante: Orihuela (P. Saz !). - Almería (Fernández Navarro !). - Prov. de Barcelona: La Garriga. - Prov, de Gerona : Camprodón y Ribas (Antiga y Bofill!).

CiTAs. - Marsella ? y España (Pérez). — Argelia (Saunders). Francia (Gaulle).

DESCRIPCIÓN. -9 : longitud, 7-8 mm. Puntuación fuerte en el tórax y cabeza, incluso el epístoma, cuyo borde es redondeado y algo elevado en cordón liso. Antenas con los artejos 4-6 poco más anchos que largos. Espinas laterales del escudete cortas. Abdomen bastante convexo; sexto segmento casi plano en su parte posterior, su extremo redondeado, así como el correspondiente ventral, que es un poco más largo. Franjas de pelos blancos, cortos, caedizos, en los cuatro primeros segmentos y a veces en el quinto.

Negro. Los tres primeros segmentos de color rojizo por encima, pero solamente a los lados por debajo.

б, muy semejante. Más velloso en cabeza y tórax. Cuarto segmento ventral con escotadura central, limitada por dientes espinosos, como en $D$. spinigera. Sexto ventral con ángulos laterales poco salientes, que no llegan a formar diente. Por esto se distin- 
gue del citado, al que se parece muchísimo, hasta el punto que no tengo gran certeza al atribuir los ejemplares o $\sigma^{*}$ a uno u otro.

Este $\sigma$ de rotundata creo que era inédito, aunque se halla con tal nombre en la colección Bofill, lo que hace sospechar que sería visto por el autor.

En la colección Mercet está clasificado como rotundata (acaso por Mr. Vachal ?) otro ơ de Río Alberche. Su cuarto segmento ventral, sin espinas, le coloca en el $D$. pumila Gerst. Desde luego que él y el de la colección Bofill son diferentes. Ambos están clas:ficados como rotundata, y sólo puede serlo uno de ellos, que creo será el de Cataluña.

Biología. - De abril a julio. - Es parásito de Osmia viridana (según Gaulle).

5. Dioxys pumila Gerst., Descr. (13).

Sinonimia probable: D. variipes Stef. (Natur. Siciliano, VI, 1887.)

Veintitrés ejemplares estudiados. - Prov. de Madrid: Madrid!, Río Alberche!; Madrid y Río Alberche (Mercet!, Arias!), - Sevilla!

Citas. - Isla de Rodas (Loew !) (Tipo de Gerstäcker en el Museo de Berlin). - Sicilia (según Friese, D. variipes).

DESCRIPCIÓN.- - : longitud, 6-7 mm. Cabeza y tórax con puntuación fuerte, poco visible por la abundante, aunque corta, pilosidad gris algo amarillenta. Antenas con los artejos 4-6 más anchos que largos. Labro muy largo. Dientes del escudete más bien cortos. Abdomen con puntuación más fina y abundante, por lo cual es mate. Segmento anal redondeado, semejante al de $/$ ). momiam. Burd. de los cinco primeros segmentos con cortos pelos grises.

Cabeza y tórax negros, pudiendo ser más o menos ferruginosos; el labro, base de las mandíbulas y funículo, con mucha variedad. Patas ferruginosas, siendo negros las caderas, los fémures anteriores, a veces los intermedios y rara vez los posteriores. Segmentos abdominales 1-3, parte del cuarto y con menos frecuencia del quinto, rojizo-ferruginosos.

б : longitud, 5-6 mm. Muy semejante. Menos peloso; epístoma casi lampiño. El color ferruginoso apenas se observa en antenas y patas. Cuarto segmento ventral ligeramente arqueado en el cen- 
tro, sin dientes ni espinas. El quinto tiene pequeños dientes romos laterales.

Aunque no conozco los tipos de $D$. variipes Stef. $q$ o y de D. pumila Gerst. $\sigma$, es casi seguro que ambas especies sean una sola, y a ella correspondan nuestros ejemplares. El segundo nombre es el que tiene prioridad. Las descripciones, algo diferentes, se refieren una al $\delta$ y la otra más bien a la $q$, y, como hemos dicho, varia bastante la extensión del ferruginoso en tórax y patas. La identidad de sexos es segura, y el $\sigma$ de Río Alberche lo cogí con las $q$. $q$. El carácter de los artejos 4-6 de las antenas cortas es muy marcado y lo señala GERST ÄCKER.

Biología.--Se ha cazado en España en pocas localidades, pero siempre en cierta abundancia. Mayo y junio.

\section{Dioxys ardens Gerst., Descr. (13).}

No conozco esta especie, citada por su autor del Sur de España, y que no ha vuelto a ser hallada.

De la descripción detallada que copia FRIESE (no he visto la original) se deduce que debe ser fácil de reconocer por su tamaño (11 mm.) y las patas, abdomen y funículo licht mennigroth (rojo minio claro).

Otras especies de Dioxys que acaso se hallen en España.

Dioxys masta Costa (1). No he visto la original. De Cerdeña. Negro, $4 \mathrm{~mm}$.

D. dimidiata Lep. (19) (13). De Versalles (Francia). 11,25 mm. Abdomen y patas ferruginosos. Debe ser muy próximo al ardens, pero sus antenas son negras.

D. (Paradioxys) pannonica Mocs. (24) (13). 7,5-11 mm. De Hungria. La + tiene el quinto segmento dorsal triangular, alargado, y mucho más el sexto, lo que le hace constituir un paso al género Calioxys. El ơ tiene dientes a los lados del quinto y sexto segmentos ventrales. Se formó con él el género Paradioxys.

D. (Paradioxys) Moricei Friese (14). De Biskra (Argelia). Poseo un $\sigma^{\lambda}$ y he visto $q$ y $\delta^{\pi}$ en la culección Mercet. Tórax negro; antenas, patas y abdomen rojizos. Pilosidad abundante y corta, que cubre casi todo el cuerpo, siendo en el abdomen como un tomento. Longitud, 6-8 mm. No parece que sus caracteres le lleven al subgénero Paradioxys. 
D. rufiventris Lep. (19) (13). De Orán. $14,5 \mathrm{~mm}$. Su descripción se parece mucho a la del dimidiata Lep.

D. chalicoda Luc. (20) (13). Por la descripción se parece al D. cincta Jur., salvo que tiene abundante pilosidad rojo-ferruginosa. De Argelia.

D. limbifera Pér. (38). De Berbería. 9, $7 \mathrm{~mm}$. Espinas laterales del escudete muy cortas. Cuatro segmentos dorsales y dos ventrales rojos. Sexto segmento casi ojival. Parece próximo al pumila Gerst.

D. rufispina Pér. (38). De Berberia. ㅇ, $9 \mathrm{~mm}$. Abdomen, antenas y patas rojos.

D. longiventris Pér. (38). De Berbería. $9,16 \mathrm{~mm}$. Abdomen muy largo.

D. Boghariensis Pér. (39). De Boghar (Argelia). $11 \mathrm{~mm}$. Cercano al chalicoda Luc.

D. carnea Grib. (51). De Boghar (Argelia). $11 \mathrm{~mm}$. Caheza y tórax negros, abdomen rojizo con fajas negras en varios segmentos, antenas negras y patas rojas.

\section{Género Ammobates Latreille.}

Sinonimia: Phileremus Latr.=Ammobatoides Schenck (nec Rad.)= Rhineta Klug = Anthophora $\mathrm{III} .=$ Epeolus auct.

Labro largo, estrechado y redondeado en el extremo. Tercer artejo de las antenas hastante corto. Celdilla radial apendiculada. Dos celdillas cubitales. Cuerpo grueso. Abdomen muy convexo. Escudete inerme.

○: Antenas con doce artejos. Abdomen de seis segmentos, el último grande, truncado en el extremo. Quinto ventral comprimido: sexto en forma de apéndice ahorquillado.

$\sigma:$ Antenas con trece artejos. Abdomen de siete segmentos, el último ancho.

Este género tiene especies en varias regiones, pero la mayor parte son de América del Norte, o bien paleárticas. De estas uiltimas hay unas doce, de las que seis se hallan en España.

Son insectos estivales, parásitos de las Eucera o Anthophora. Se distinguen bien de otros géneros a primera vista, pues súlo se podrian confundir con Pasite's o Biastes, de que hablaremos, o con Dioxys, que tiene el escudete tridentado. 


\section{Cuadro para distinguir las especies.}

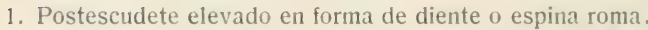

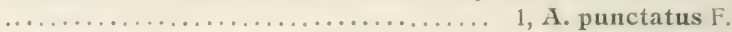

- Pustescudete sin furmar diente ....................

2. Postescudete liso, muy poco elevado. Sexto segmento $q$ aquillado. 3

- Postescudete algo elevado....................... 4

3. Antenas cortas; cuarto y quinto artejos más anchos que largos, menores que los siguientes. Segmento anal $\delta$ redondeado........... ...............................

- Antenas más largas; cuarto y quinto artejos tan largos como anchos, iguales a los siguientes. Segmento anal $\delta$ truncado.............. ............................. major n.

4. ․ Segmento anal iruncado. Quinto ventral con fuerte quilla que forma diente al extremo.............. 4, A. Handlirschi Fr.

- Segmento anal triangular........................ 5

5. Abdomen y patas rojos.............. 5, A. rufiventris Latr. - Patas y extremo del abdomen negros...... 6, A. vinctus Gerst.

\section{Ammobates punctatus' Fabr., Descr. (47) (40) (13).}

Sinonimia: Epeolus punctatus Fabr. = Rhineta punctata $\mathrm{Kl} .=$ Phileremus Kirbyanus Latr.=Ammobates bicolor Lep.=Ammobatoides bicolor Schenck.

Ochenta y tres ejemplares estudiados. - Prov. de Madrid: Madrid !, El Pardo !, Rio Alberche !, El Escorial !, Villaviciosa !, Cercedilla !, Vaciamadrid!, Aranjuez, Los Molinos, Montarco (García Mercet !). - Prov. de Ávila: Navalperal. - Prov. de Segovia: San Rafael (García Mercet !). — Prov. de Guadalajara: Cutamilla ! Prov. de Barcelona: Olesa. - Prov. de Gerona: Viladráu (Bofill ! y Codina !). - Valencia (Moroder !). - Portici (Italia). - Fürth (Baviera).

Citas.-España, Tirol, Turingia, Berlín, Viena, Holanda, Hungria, Suiza, Turquestán (Friese). - Europa Central (Dalla Torre).Argelia (Alfken). - Irkustk (Radoszkowsky). - Suiza (Frey-Gessner).

DESCRIPCIÓN. - $\sigma$ : longitud, $7-8,5 \mathrm{~mm}$. Cabeza y tórax con puntuación abundante y gruesa. Epistoma algo convexo; su borde liso y recto en el centro, avanzando más a los lados en las partes declives. Antenas cortas; tercer artejo bastante más largo que el 
cuarto. Pilosidad abundanté, formando un tomento plateado en la cara, pronoto, mesopleuras y lados del metatórax. Escudete casi plano, no tuberculado. Postescudete elevado, formando como un grueso diente romo. (FrIESE dice: pustscutello spiniformi prolongato. Sin embargo, no llega a parecer prolongación espinosa.) Abdomen algo brillante; puntuación fina, poco profunda, igual en la base que en el extremo de los cinco primeros segmentos; más gruesa en el sexto, cuya forma, visto desde arriba, es la de trapecio, con líneas laterales algo cóncavas. Segmentos ventrales con puntuación fina; el quinto tiene una quilla central cada vez más elevada hacia el ápice y formando al extremo una espina saliente del borde; sexto segmento u horquilla con sus ramas hastante divergentes. Los segmentos dorsales con manchas laterales de pelos blancos situadas en el borde; aumentando en tamaño del primero al tercero; formando fajas en el cuarto y quinto. Alas algo ahumadas. Cabeza y tórax negros. Abdomen generalmente de color rojo obscuro, que lo es más en los segmentos últimos y también en el borde. A veces se obscurece mucho, siendo casi negro todo el abdomen, o al menos tres o cuatro segmentos. Patas rojizas, más o menos obscurecidas.

$\sigma^{\star}$, muy semejante. Séptimo segmento ancho, redondeado.

Los ejemplares de Cataluña que he visto son muy obscuros, casi negros. Todos los demás son de abdomen rojo; a lo más son negros los tres últimos segmentos. Una $q$ de Baviera y un $\sigma$ de Italia son iguales a los de Madrid.

Un ơ de Madrid (Mercet !), 16 de junio de 1912, tiene el postescudete menos elevado. sin marcarse hien el diente. Por lo demilis, parece idéntico.

BiologiA. - Es parásito de Anthophora bimaculata Panz. (según Alfken), el cual dice se halla sobre Centaurea rhenana. En España se ha cazado de mayo a julio.

2. Ammobates carinatus Mor., Descr. (27) (13).

Sinonimia: A. algeriensis Rad.

Prov. de Madrid: una $q$, Montarco !; cinco $\sigma \sigma$, Villaverde !; una + , Collado Mediano !; una $f$, Seseña !; cuatro $q$ y tres $\sigma \sigma$, Sevilla!

Citas.-España, Marsella, Siracusa y Argel (Friese).-Cala- 
bria (Morawitz). - Argel (Alfken y Saunders).-Cataluña (Catcilo(ro Bofill). (De esta última cita véase lo que decimos en A. major.)

DESCRIPCIÓN.- $q$ : longitud, 8-10 mm. (según Friese, 10-12). Puntuación gruesa y profunda en cabeza y tórax, más escasa en la región occipital, más espesa en el escudete. Los espacios intermedios brillantes. Epístoma bastante convexo, escotado. Antenas cortas algo nudosas; cuarto y quinto artejos más anchos que largos, más cortos que los siguientes. Escudete casi plano por arriba, con surco en la parte posterior. Postescudete nada elevado. Alas ligeramente ahumadas. Abdomen brillante, con puntuación fina, que en la base de los segmentos es algo más gruesa y abundante. Por el lado ventral se marca más la diferencia, siendo muy brillante y con puntos finísimos toda la porción apical de cada segmento. Sexto dorsal comprimido, formando una quilla muy fuerte, truncado en su extremo. Último ventral $u$ horquilla con ramas gruesas, divergentes. Pilosidad gris, esparcida, en la cabeza y tórax. En el abdomen solamente los segmentos quinto y sexto tienen tomento abundante; en los anteriores no se marcan manchas laterales, o muy poco.

Cabeza y tórax negros, asi como las patas, siendo los tarsos algo ferruginosos. Abdomen rojizo; sexto segmento dorsal negro.

o', semejante. Longitud, 8-11,5 mm. Último artejo de las antenas truncado oblicuamente. Segmento anal redondeado. El tomento blanco se marca más en los dos últimos segmentos y forma manchas poco extensas en los tercero a quinto.

BiologíA. - Se ha cazado en España siempre en mayo.

\section{Ammobates major $11 . \mathrm{sp}$.}

Una $q$, Madrid (Garcia Mercet!); prov. de Barcelona: tres $q q$ y tres $\sigma^{\nearrow}$, Vallvidrera, y un $\sigma$, Sabadell (Antiga !).

Affinis carinato Mor.

Typus: una ㅇ (Vallvidrera); long., $10 \mathrm{~mm}$. Antennœ parum nodosa, $4 .^{\circ}$ et $50^{\circ}$ articulis aque latis ac longis, aqualibus sequentibus. Scutellum bilobatum, a parte anteriore sulcatum. Postscutellum haud prominens. Alce leviter infumatce. Abdomen lave et nitens, minutissime punctatum, paulo distinctius ad segmentorum basim; sexto tergito compresso, carinato, apice truncato. Furcula ramis crassis, divergentibus. Pili grisacei, in capite et thorace abundantes. In abdomine formant 
tomentosam fasciam in $5 .^{\circ}$ segmento et maculas lateroposteriores in tribus precedentibus.

Caput, thorax, pedesque nigri. Tarsi ferruginei. Abdomen rufo ferrugineum, sexto segmento nigro.

Paratypi. ㅇ: long., 11-12,5 mm. Haud sensibiliter differunt.o : long.; 11-12,5 mm. Ultimus articulus autennarum forma ordinaria, truncatura propria carinati leviter indicata. Secundum segmentum anale apice truncatum. Hacule tomentosa valde sensibiles in segmentis 2-5, itidemque fasciis in 6-7.

Todos los ejemplares catalanes proceden de la colección Antiga, y me han sido amablemente prestados por su actual poseedor. Sr. Bofill. Fueron cazados en marzo y abril de 1902, y figuran (con algún otro de Sabadell, que no he visto) en el Catilech de insectes de Catalunya, con la denominación de $A$. carenatus Mor. = major Pérez.

Aparte de la palabra carenatus, errata de imprenta por carinatus, no sé en qué se fundará la identificación de ambas especies. Los siete ejemplares que he visto tienen sólo puesto el nombre de A. major Pérez. Es casi seguro que serian vistos, al menos algunos de ellos, por el sabio profesor de Burdeos, que les dió nombre. pero no llegó a describirlos. ¿Por qué, después, aparece esta tspecie en el Catàlech como sinónima de carinatus? ¿Rectificaría el autor su opinión? A mi juicio, deben ser admitidos como tipos de una nueva especie, a la cual tengo el gusto de conservar el nombre con que la pensó describir M. PEREz, y con el que stguramente la vieron ya señalada diversos entomólogos en la colección Antiga.

La $q$ de Madrid figura en la colección Mercet clasificada como muticus. Spin. por algún especialista cuyon nombre no con-ta. La descripción de SPINOLA se refiere sólo al ð̋, es muy poco precisa y no me parece que conviene a este ejemplar.

4. Ammobates Handlirschi? Friese, Descr. (13).

Una , Madrid (García Mercet !).

DESCRIPCIón. - Longitud, 8 mm. Cabeza y tórax con puntos grruesos; los espacios intermedios brillantes. Epistoma truncado. Labro muy largo, redondeado en el extremo, punteado en la base, finamente surcado en toda la porción apical. Antenas largas. Escudete casi plano por encima, algo surcado por detrás. Postescudete 
muy poco elevado. Sexto segmento dorsal truncado; su extremo poco más ancho que la base; en el borde una pestaña gris-amarillenta. Quinto ventral con quilla aguda, que termina en una espina saliente, separada por escotaduras de los ángulos laterales redondeados. Alas ahumadas.

Negro. Labro casi negro, algo ferruginoso en el extremo. Tarsos de un ferruginoso obscuro. Abdomen rojo en los tres primeros segmentos, negro en los tres últimos; lo mismo por el lado ventral. Los segmentos dorsales cuarto y quinto tienen fajas poco espesas de pelos grises.

Este insecto se acomoda bien a la descripción de FrIESE; con la diferencia, aparte de otras muy ligeras, de que el Handlirschi tiene todo el abdomen rojo, así como el labro y mandibulas, y la longitud es de $9 \mathrm{~mm}$.

Sólo ccnozco como citas la ł tipo, cazada por Handlirsch en Orán el 12 de junio de 1891, y existente en el Museo de Viena, y otra $q$ de Biskra (también Argelia) hallada sobre Amberloa lippii por Eaton en 8 de abril de 1897 y citada por SAUNDERS.

¿Será este ejemplar una especie nueva o una modificación del Handlirschi? Si se hallasen más, se podría decidir.

\section{Ammobates rufiventris Latr., Descr. (13).}

Sinonimia: Anthophora abdominalis Ill.=Ammobates muticus Spin.

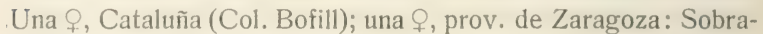
diel (P. Navás !) (Col. Dusmet).

CitAs. - Puigreig (Mercader) (Cat. Bofill). - Portugal (Lepeletier). - España y Argelia (Dalla Torre). - Argel (Friese).

DesCripción. - Longitud, 10-11 mm. Cabeza y tórax negros; puntuación fuerte, pilosidad gris abundante, formando manchas alrededor de las antenas, en el pronoto y en los lados del meso y metanoto. Epístoma bastante convexo. Labro ferruginoso obscuro. Antenas más bien largas; tercer artejo poco más largo que el cuarto; los siguientes tan largos como anchos. Escapo ferruginoso obscuro que aún lo es más en el funículo. Escudete grande, ligeramente bilobulado. Postescudete poco elevado. Abdomen todo rojo, muy convexo, poco brillante, con puntuación fina en la base de los segmentos y aún más fina en las fajas apicales. Sexto segmento con la base lampiña, en la que hay unas excrecencias o verrugas; el extre- 
mo brillante, liso en su base y con verrugas al borde; está atravesado por una faja transversa de tomento amarillo. Los segmentos cuarto y quinto tienen fajas menos marcadas. Quinto ventral no aquillado. Patas ferruginosas, las caderas negras y a veces los fémures muy obscuros.

$\widehat{\gamma}$ (según Friese) semejante a la q. Color negro más extendido. Fajas de pelos más marcadas en los segmentos cuarto y quinto. El séptimo es redondeado y obscuro, como el extremo del sexto.

Las dos 9 c citadas parece que son rufiventris. Sin embargo, FRIESE dice que las patas son rojas, aun las caderas. Así que en este respecto se acercan al $A$. vinctus Gerst., pero éste tiene el uiltimo segmento negro. Ha de advertirse que FrIFsE los considera muy próximos, pensando si rufiventris será sólo una forma meridional de vinctus. De reunirse ambas especies en una, quedaria, por más antiguo, el nombre rufiventris.

\section{Ammobates vinctus? Gerst., Descr. (13).}

Sinonimia: Anthophora epeolina III. (sin descr.) = Amm. setosus Mor.

Un ơ, Madrid (Garcia Mercet!), 15 de julio de 1904.

Citas. - Balenyá (Cat. Bofill). - Portugal (Gerstäcker), - Tirol, Belgrado, Hungria, Túnez (Friese), - Rusia (Morawitz y Radoszkowsky).

DESCRIPCIÓN. - o : longitud, 7 mm. Epístoma rugoso-punteado, convexo, saliente; las porciones declives, que avanzan más, lisas y brillantes. Antenas cortas; artejos del funículo, el primero relativamente grande, los tercero y siguientes más anchos que largos, especialmente los tercero y cuarto. Tórax con puntos fuertes, pero separados, brillante; mesonoto algo surcado y más el escudete, que está bien dividido en dos lóbulos; postescudete poco elevado. Segmentos del abdomen con sus porciones apicales anchas, brillantes, dccoloradas. Segmento anal triangular, con el extremo redondeado y los bordes laterales ligeramente ondulados, rugoso-punteado. Pilosidad gris, más abundante en la frente, pronoto, meso y metaplenras, tibias y tarsos, y formando tres fajas anchas en los segmentos dorsales cuarto a sexto. Alas ligeramente ahumadas.

Cabeza y tórax negros. Antenas y patas de un ferruginoso muy obscuro, casi negro. Abdomen rojizo, claro en los tres primeros 
scgmentos, obscureciéndose sucesivamente en los siguientes; el séptimo negro.

q (según Friese), muy semejante. Sólo encuentro como diferencia lo referente al escudete, del cual dice que es durch seichten Längseindruck getheilt, o sea con surco ligero, mientras que en el nuestro es bien profundo. En cuanto al $\sigma$, dice FriESE que el segmento anal es margine flexuoso, y su dibujo marca una ondulación más fuerte que en nuestro ejemplar. Es, sin embargo, muy probable que sea el vinctus, ya citado, de España y Portugal.

Biología. - Julio y agosto. Sobre Centaurea Biebersteini (según Friese). Parásito de Macrocera graja y M. ruficornis (según Mocsary).

Otras especies de Immobates que acaso se hallen en España.

Ammobates rufipes Saund. (45). De Argelia. He visto dos $\nmid$ (col. Mercet). Muy próximo al rufiventris, si no es una variedad.

A. erythropus Alfk. (5). De Argelia. 7,5-8 mm. Parece muy próximo, por la descripción, a rufiventris y rufipes.

A. hipponensis Pér. (39). De Bona (Argelia). Negro, con tendencia a brun rougêatre en el abdomen. Fajas completas abdominales de pelos blancos, ensanchadas en el medio. $10 \mathrm{~mm}$.

A. Abeillei Pér. (39). De Nazareth (Palestina). $6 \mathrm{~mm}$. Negro, por debajo brun rougêatre. Fajas estrechas, centrales, sin llegar al borde.

A. oraniensis Lep. (19) (13). De Sicilia, Dalmacia, Argelia, Túnez. (Tengo en mi colección una $q$ de Hungria.) Negro. Manchas de pelos blancos en los segmentos dorsales. $12 \mathrm{~mm}$.

A. latitarsis Friese (14). De Siria. 8,5-9,5 mm. Negro, con manchas de pelos blancos, como oraniensis. Tarsos del $\delta$ ensanchados, más que las tibias.

A. syriacus Friese (14). De Jericó. $8 \mathrm{~mm}$. Semejante a rufiventris, pero segmento anal cóncavo y finamente rugoso.

A. rostratus Friese (14). De Jericó. 6,5-7,5 mm. Semejante a biastoides, pero epistoma convexo y prolongado. Parece que debe asemejarse a rufiventris.

A. biastoides Friese (13). De Argelia. 7 mm. Negro, con abdomen y patas rojos. Epistona plano, no convexo. Antenas muy próximas. Dice el autor que es una transición al gènero Biastes.

A. armeniacus Mor. (30). De Érivan. $7 \mathrm{~mm}$. Negro, con abdomen rojo. Fajas de pelos blancos interrumpidas en el centro. Postescudete no elevado. Próximo a punctatus.

A. Dufouri Lep. (19) (13) : Il n'a que deux cellules cubitales, dont la 
première est seule fermée. De Francia. Según su autor, género nuevo. Segun FrIESE, sinónimo de otra especie. ¿No seria un ejemplar anómilı en su nerviación?

\section{Género Phiarus Gerstïcker.}

Sinonimia : Ammobatoides Rad. $=$ Euglages Gerst. $=$ Paidia Rad. $=$ Ammobates Först. $=$ Phileremus Ev .

Labro largo, truncado. Tercer artejo de las antenas largo. Palpos maxilares de seis artejos. Escudete bilobulado. Dos celdillas cubitales. Abdomen cordiforme.

ㅇ: Antenas con 12 artejos. Abdomen con seis segmentos; el último pequeño. redondeado; quinto ventral plano, transverso, escotado en el margen, con pestaña. Sexto ventral bipartido, terminado en apéndices digitados.

$\checkmark$ : Antenas con trece artejos. Abdomen con siete segmentos; el último estrecho, alargado.

Esta diagnosis, que tomo de FrIESE, distingue bien el género, que, como otros que estudiaremos, ha sido muchas veces mal conocido y cambiado de lugar por los autores. Sólo tiene dos especies, poco semejantes entre sí.

\section{Phiarus melectoides Sm., Descr. (40) (13).}

Sinonimia: Phileremus melectoides Sm. = Ammobatoides melectoides Rad. $=$ Euglages scripta Gerst. $=$ Paidia melectoides Rad $=$ Euglages melectoides Pér. = Phiarus melectoides D. T. et Fr. = Phiarus scriptus Saund.

Dos $Q \nmid$, prov. de Madrid: Villaviciosa (Martinez Escalera!) (Mus. de Madrid); una ९, Málaga (P. Navás), 1902 (Col. Dusmet); cuatro Q 9 y cuatro $\sigma^{*} \sigma^{*}$, prov. de Barcelona: Balenyá, La Garriga y Clesa (Col. Bofill y Codina); $u$; ; Espana (Mie.ur). - Extranjerus vistos: trece $q$ y un $\sigma^{\circ}$, Mogador (Marruecos) (Mus. de Madrid).

CitAs. - Granada (Friese), - Francia (Gaulle). - Albania (Friese). - Argelia (Saunders), - Siberia (Radoszkowsky). -- Varias localidades de Cataluña (Cat. Bofill).

DESCRIPCIÓN DE LOS ESPAÑOLES, - q : longitud, 10,5-12 mm. Antenas largas; tercer artejo tan largo como los dos siguientes. 
Epístoma elevado, truncado. Labro largo. Cabeza y tórax con puntos profundos, pero brillantes los intermedios. Escudete bituberculado. Pilosidad larga y abundante, blanca en la cara, epístoma, parte superior de las mesopleuras y lados del metatórax; negra en las demás regiones. Alas algo ahumadas. Patas con pelos blancos. Abdomen ancho, poco convexo, con puntuación fina y espesa, por lo cual es menos brillante que el tórax. Pilosidad escasa: el primer segmento con dos grandes manchas laterales de pelos blancos; en los segundo a cuarto, en el borde y a los lados, manchas alargadas de pelos blancos, sucesivamente más largas, que en el cuarto casi se reunen. El quinto tiene estas mismas bandas, pero muy cortas y de pelos más cortos. (En ningún autor veo citadas estas manchas en el quinto). Dicho segmento tiene una quilla longitudinal. Sexto segmento estrecho, redondeado en el extremo, con pilosidad rojiza. Vientre más convexo que el dorso. Quinto seg. mento escotado, con pelos rojizos en el borde. Sexto ventral amarillento, membranoso, muy escotado, terminando en sus dos extremos en unas prolongaciones digitadas.

Insecto negro. Tercer artejo de las antenas ferruginoso por debajo. (Este carácter, que se halla en todas las $q q$ de España y no he visto en los autores, se marca mucho más en las de Marruecos.)

\%, muy semejante. Antenas ferruginosas por debajo en más o menos extensión, salvo los dos primeros artejos y el último. Éste es aplastado. Quinto segmento con banda de pelos blancos en el borde; séptimo, alargado, redondeado en el extremo. En la cabeza y y tórax domina la pilosidad gris, que también se halla en el abdomen, además de las manchas blancas.

Bıología. - Los de Cataluña se han cazado en junio. Es parásito de Melitturga caudata (según Gaulle).

Este raro insecto, muy escaso en todas sus localidades, tiene el aspecto de Melecta, lo que debe advertirse por si los principiantes no lo cazasen creyéndolo de aquel género. Las dos celdillas cubitales (en Melecta, 3 ) es lo que más pronto le distingue.

Otra especie que puede hallarse en España.

Phiarus abdominalis Ev. (Ammobates extraneus Först.) De Hungria, Rusia, Dalmacia, Siria y Turquestán. Insecto dimorfo; la $q$, de abdomen rojo; el $\delta$, de abdomen negro, con pelos amarillos abundantes, no se parece al melectoides. Siendo parásito de Melitturga clavicornis, bien pudiéramos encontrarle en España. 


\section{Género Pasites Jurine.}

Sinonimia : Ammobates Smith, Radoszkowsky. = Anthophora Ill. = Phiarus Rad. (nec Gerst.) = Phileremus Förster, Schenck.

Antenas largas, de doce artejos en ambos sexos; el tercero corto. Labro largo. Epistoma poco alargado, no elevado. Celdilla radial apendiculada. Dos cubitales, la primera bastante mayor que la segunda. Postescudete no elevado. Abdomen muy convexo.

f: Seis segmentos abdominales. Sexto dorsal pequeño. Quinto ventral algo comprimido. Sexto ventral como apéndice espiniforme. truncado y no hendido en el extremo.

$\sigma^{x}$ : Siete segmentos abdominales, el último redondeado. Epístoma con pinceles laterales.

Tiene tres especies, dos de ellas europeas y poco semejantes.

Pasites maculatus Jur., Descr. (40) (47) (13) (29).

Sinonimia $\left({ }^{*}\right)$ : Anthophora histrio Ill.= Pasites histrio Ill.=Nomada albomaculata Luc. $=$ Pasites Schottii Ev. $=$ Ammobates variegatus Sm. $=$ Phileremus rufiventris $\mathrm{Sm} .=$ Ammobates Kirbyanus Rad. $=$ Phiarus maculatus Rad.

Una f, Mac'rid (García Mercet!); una \&, Valencia (Moroder !) (Mus. de Madrid); una f, Alicante (Mercet!) (Mus. de Madrid); un $\sigma$, prov. de Almería: Huércal-Overa (Vidal y López) (Colección Dusmet); tres 9 q y tres $\delta$, prov. de Barcelona: Balenyá, Olesa y San Erichan? Palautordera (Col. Pofill y Codina). Fixtranjeros vistos: dos $₹ ?$ y dos $\sigma \sigma^{\circ}$, Budapest (Mocsary !) (Col. Mercet).

Ciras. - Otras varias localidades de Cataluña (Cat. Bofill). Francia (Dominique, Gaulle, Pérez). - Alemania, Hungria, Dalmacia, Suiza, Grecia (Friese).- Chipre (Cockerell).-Siberia (Ra-

(*) Las especies de Pasites y Biastes han sido colocadas en diversos géneros, confundiéndolas entre si y con Ammobates, Epeolus y otros. En Su confusa sinonimia, me limito a copiar las de FrIESE y DALLA TORRE, pues no tengo medios de comprobar directamente la exactitud o el error de las denominaciones aplicadas por los autores. 
doszkowsky). - Transcaucasia y Turquestán (Morawitz). - Argelia (Saunders). - Suiza (Frey-Gessner).

DESCRIPCIÓN. - q : longitud, 6-8 mm. Cabeza y tórax brillantes. Puntuación gruesa e irregular. Epístona convexo, truncado. Antenas bastante largas, muy próximas; tercer artejo poco más largo que el cuarto. Mesonoto con una quilla longitudinal. Escudete con fuertes tubérculos. Alas ahumadas, las anteriores con espacios hialinos exteriores a las celdillas cubitales y discoidales; segunda cubital mucho menor que la primera. Abdomen de seis segmentos, convexo, brillante, sobre todo en los bordes de los segmentos: el primero grande, con una depresión transversal que con un aumento ligero puede hacer creer que son dos segmentos. Quinto muy convexo, ocultando casi siempre el sexto. Quinto ventral también muy convexo, llevando una prolongación espiniforme, no bifurcada. Cabeza y tórax con pelos cortos y escasos; solamente son abundantes en la cara y mesopleuras. Sègmentos abdominales segundo a quinto con manchas de pelos blancos en los bordes. (Según FrIESE, estas manchas son cuatro en el segundo y tercero, y dos en el cuarto y quinto. Según Radoszkowsky, son cuatro en todos. En los ejemplares que he visto varian algo, siendo de suponer que son muy caedizas. En el primero nunca hay, pero he visto cuatro en el cuarto y otras veces dos; 10 mismo en el segundo.)

Cabeza y tórax negros, siendo de un rojo ferruginoso el labro, callos humerales, escamillas y las antenas en su base y por debajo, en más o menos extensión. Abdomen y patas rojizos; los últimos segmentos, los trocánteres y fémures obscurecidos, a veces casi negros.

\%, semejante. Antenas, también con doce artejos. Abdomen con siete segmentos, el último poco visible. Pilosidad más extendida en general. Las manchas abdominales mayores.

Var. brunneus Friese. La formó sobre ejemplares de Tánger, de color hell chocoladen-brann (chocolate claro), siendo sólo negro el centro del metatórax y a veces la quilla central del mesonoto.

La 9 de Madrid debe referirse a esta variedad, no citada de España. Su color, más bien que chocolate claro, es el rojizo ferruginoso de ciertas Nomada.

Biologí. - En España se ha cazado en junio y julio. Es parásito de Nomia diversipes Latr., y acaso también de $N$. femoralis Pall. y N. ruficornis Spin. (seguin Friese); de Melitturga cla- 
vicornis L. (según Gräffe). Se halla sobre Thymus serpyllum (Friese) y sobre Helianthus (Gräffe).

Insecto de área de dispersión extensa, pero muy escaso. Su aspecto es más bien de. Vomada, distinguiendose de ellas por tener dos celdillas cubitales. El mayor tamano de la primera y la longitud e inserción de las antenas le separan con facilidad del género Biastes.

Otra especie que puede hallarse en España.

Pasites minutus Mocs. Aunque sólo se ha citado de Budapest, como es parisito de Camptopceum frontale (Según Mocsary), pudiera estar th la Península. Es muy diferente del maculatus (tengo una o de Pest). Sólo 5,5 mm. Escudete plano, alas hialinas, y como carácter esencial, aunque difícil de observar, palpos maxilares de cuatro artejos, que en maculatus sólo tienen uno.

\section{Género Biastes Panzer.}

Sinonimia : Pasites Sm. = Phileremus Sm. $=$ Biastoides Schenck $=$ Melittoxena Mor. = Rhineta III. = Ammobates Rad. $=$ Nomada auct. $=$ Stelis Ev. = Tiphia Panz.

Labro corto, transverso. Epistoma largo, convexo, elevado. Antenas cortas, de doce artejos, excepto en brevicornis $\sigma$; tercer artejo corto. Dos celdillas cubitales, la primera algo menor que la segunda. Abdomen oval, casi plano por encima, convexo por debajo.

f: Abdomen con seis segmentos. Quinto dorsal truncado; sexto, muy corto, hendido. Quinto ventral transverso; sexto, membranoso, bipartido.

$\because$ : Siete segmentos, el último redondeado, los ventrales en el centro, con placas tomentosas muy especiales.

Se comprende al ver la sinonimia la dificultad de asignar lugar a las especies de este género. De el se conocen cuitro, todas ellas paleárticas. 
1. Biastes emarginatus Schenck, Descr. (19) (47) (13).

Sinonimia: Phileremus punctatus Lep.=Phileremus kirbjanus Schenck = Phileremus emarginatus Schenck $=$ Pasites punctatus Schenck $=$ Phileremus nasutus Gerst. $=$ Biastoides punctata Schenck $=$ Biastes punctatus Rad.

Una +, prov. de Vizcaya: Zaldívar !, 5 de agosto de 1916; una 오, prov. de Gerona: Camprodón (Col. Bofill), 25 de julio de 1903, clasificada como Pasites punctatus y citada como tal en el $\mathrm{Ca}$ tàlech.

CitAs. - Francia (Gaulle, Friese). - Alemania (Gerstäcker, Sickmann, Schenck, Friese). - Grado (Gräffe). - Hungria (Friese). - Rusia (Morawitz y Friese).

DESCRIPCIÓN.- O : longitud, $8 \mathrm{~mm}$. Cabeza prolongada; epístoma convexo; frente no formando entre las antenas una quilla aguda, sino una elevación ancha que en su centro lleva una linea brillante y hace que las antenas estén muy separadas. Éstas son cortas, de doce artejos más anchos que largos, siendo especialmente cortos el cuarto y quinto, y también el escapo de mucha menos longitud que en los géneros próximos. Mesonoto dividido en dos lóbulos por un surco longitudinal, lo mismo que el escudete; postescudete algo elevado. La cabeza y tórax son punteados, habiendo en el mesonoto varias zonas lisas. Pilosidad escasa, salvo unas manchas de abundantes y cortos pelos blancos en la parte superior de las mesopleuras y otras menores en el centro y lados del escudete. Alas ahumadas, con varios espacios claros. Celdilla radial apendiculada (FrIEsE dice que no). Primera celdilla cubital menor que la segunda. Abdomen oval, más convexo por debajo; quinto segmento dorsal escotado; el sexto más profundamente, teniendo a cada lado un fuerte diente encorvado hacia dentro; quinto segmento ventral con una impresión central; sexto, membranoso, en forma de gallardete, sus bordes como cordones y el resto muy transparente; en los extremos hay unas prolongaciones digitadas, semejantes, aunque mucho menos marcadas, a las del Phiarus. En cada segmento cuatro manchas, a veces dos, de cortos pelos blancos, que deben ser caedizas, y por tanto variables. Cabeza y tórax negros. Mandibulas y primeros artejos del funículo ferruginosos. Patas de un rojo ferruginoso, casi negro. Abdomen ferruginoso en el centro de los segmentos, a cuyos 
lados hay grandes manchas negras, tanto en el dorso como en el vientre.

$\sigma$ (según Friese, que lo toma de Gerstäcker) debe ser semejante, pues las diferencias, pequeñas, se refieren a coloración o pilosidad. Segmentos ventrales tercero a quinto con abundantes pelos amarillos. Las antenas serán de doce artejos, pues en la característica del género dice FRIESE que sólo las del y de brevicornis tienen trece. Éste es carảcter muy extraño.

Biología.-Parásito de Rhophites 5-spinosus Spin. (según Morawitz). Se halla sobre Ballota nigra (Schencli) y sobre Thymus (Sickmann).

\section{Biastes brevicornis Panz., Descr. (49) (19) (46) (47) (40) (13).}

Sinonimia: Tiphia brevicornis Panz. $=$ Nomada atrata $\mathrm{F} .=$ Nomada Schottii F. = Anthophora Schottii III. = Pasites atra Spin. = Rhineta brevicornis III. = Rhineta Schottii $111 .=$ Stelis aberrans Ev. = Biastes brevicornis Gerst. = Pasites Schottii Schenck = Biastes Schottii Rad.

Una 9 y un $\sigma^{7}$, prov. de Barcelona: Balenyá; una + , Monserrat; un $\sigma^{\circ}$, Tarrasa (Col. Bofill y Codina). - Extranjeros vistos: dos $q$ ㅇ y dos $\sigma^{\star}$, Budapest (Mocsary !) (Col. Mercet).

Citas. - Otras varias capturas en Cataluña (Cat. Bofill). Francia (Lichtenstein y Pérez). - Suiza (Friese). - Alemania (Irirse). - Austria (Kolaczy). - Hungría (Friese). — Grecia (Erber). Rumania (Mann).-Cáucaso (.Morawit\%).-Siberia (Radoszkow:l.y).

DESCRIPCIÓN. - $q$ : longitud, 7-7,5 mm. Cabeza algo prolongada; frente elevada, pero menos que en emarginatus. Antenas distantes, cortas, siéndolo también el escapo. .llesonoto no dividido: el escudete apenas lo está. Pustescudete grande, elevado. Cabcra y tórax con puntuación espesa, sin líneas lisas en el mesonoto. Pilosidad muy escasa, sin manchas de pelo, que solo se observan con las metapleuras. Alas ahumadas, con aldrunos espacios clarns: celdilla radial no apendiculada; primera cubital mucho menor qu: la secrunda. Abdomen corto y ancho, convexo, con puntuación abundante e igual. Sin manchas de pelos blancos. Quinto segmento dorsal con una placa central en el borde, algo elevada y cubierta de tomento blanco a sus lados; pestanias de pelos dorados. Segmentos ventrales con puntuación más fina. 
б, diferente. Longitud, $8 \mathrm{~mm}$. Abdomen más estrecho y alargado. Sexto segmento dorsal con borde algo aserrado: en el centro forma una placa algo elevada; séptimo, redondeado. Por el lado ventral, el tercero, cuarto y algo el quinto tienen el centro con un tomento gris dorado muy marcado. Insecto completamente negro; tarsos algo ferruginosos. Lampiño. Según FrIESE hay ejemplares que por la coloración del abdomen y patas podían creerse $q$ ㅇ․

Biología. - Los de España se han cazado en mayo y junio. Es parásito de Systropha curvicornis Scop. y S. planidens Gir. (según Friese); de Eucera ruficornis F. (según Dalla Torre). Se halla sobre Convolvulus arvensis (según Alfken); sobre Echium y Convolvulus (según Friese).

Otra especie que puede estar en España.

Biastes truncatus Nyl. (Phileremus punctatus Gerst. = Melittoxena truncata Mor.). De Alemania, Estiria y Rusia. Se debe distinguir del brevicornis por las manchas abdominales de pelos, como en emarginatus, y de éste por las antenas negras y la falta de las manchas de pelo en las mesopleuras.

ALGUNAS CONSIDERACIONES SOBRE LA REPRESENTACIÓN GRÁFICA DE LOS SERES NATURALES, Y DESCRIPCIÓN DE UN APARATO ESPECIAL DESTINADO A HACER FOTOGRAFIAS DE LOS MISMOS, ESPECIALMENTE DE LOS PECES

POR

\section{LUIS LOZANO Y REY}

Reconociendo la conveniencia de que en las obras de Zoología sistemática se hagan descripciones detalladas de las especies, es evidente que la representación gráfica de estas últimas es un complemento valiosísimo para la determinación de las mismas.

A pesar de esto, hay muchas obras en las que se prescinde en absoluto de las láminas o se ponen escasas: unas veces por opinar el autor que su uso hace descender el nivel del libro; otras, porque 
su inclusión en el trabajo supone un gasto que puede ser muy con:siderable.

La verdad es que ordinariamente no se puede pretender lograr el reconocimiento de una especie utilizandusólo su descripción u- representación gráfica, a no ser que se trate de alguna que ofrezca caracteres tan salientes que su simple referencia sirva para determinarla.

Las descripciones resumidas son insuficientes. Son la sintesis de una representación mental del autor, y no pueden tener siempre la virtud de sugerir igual representación en el lector. Las detalladas son más eficaces, porque se acercan a un análisis minucioso, que el autor se limita a trasladar al lector, el cual se encuentra próximo a la observación directa del objeto descrito; pero estas descripciones suelen ser muy extensas, a veces de insopurtable lectura. sobre todo si hay que compararlas con otras análogas de especies próximas; y tienen además el defecto de que ofrecen los verdaderos caracteres distintivos, que siempre suelen ser poco numerosos, confundidos con un fárrago de caracteres secundarios y hasta superfluos.

La forma y el color constituyen la base de la descripción de las especies. Ni la una ni el otro pueden ser frecuentemente expresados con precisión por escrito. Para expresar la forma se compara la del cuerpo o partes del cuerpo del ser descrito con la de objetos o seres conocidos o con las figuras y formas que extraemos del arsenal de la Gi:ometria; pero este procedimiento comparativo es harto deficiente. Las descripciones de la inmensa mayoría de los peces comienzan con la afirmación de que su cuerpo es fusiforme: unas veces corto, otras largo, comprimido o deprimido. La verdad es que no hay una sola especie que sea perfectamente fusiforme, pues nunca su cuerpo adopta la forma de un sólido de revolución, y ni siquiera el huso, del cual se hace tan reiterada referencia, es una forma de caracteristicas geométricas invariables.

La comparación con las figuras geométricas da resultados igualmente imperfectos, porque la irregularidad es la ley que rice en la forma de las lineas y superficies del cuerpo de los seres vivos, los cuales, a lo más, se someten a una simetría radiada o bilateral u ofrecen una tendencia a estar limitados por superficies cilindrácals o esferoidales.

Pero hay que tener en cuenta que con frecuencia los autores se permiten licencias excesivas al apelar al recurso de la comparacion 
con las figuras geométricas. Así, un anatómico puede quedar satisfecho afirmando que el hueso etmoides es cúbico en conjunto, lo que no puede admitir un geómetra.

Convencidos los autores de la insuficiencia de las descripciones clásicas, comienzan a dar importancia a otros caracteres que ciertamente dependen de la forma, como son los de las dimensiones relativas de las distintas partes del cuerpo. De esto nos hemos ocupado (1) y pensamos ocuparnos con mayor extensión, por estimar que pueden obtenerse características eficaces para la distinción de las especies, y hasta para descubrir el proceso del desenvolyimiento morfológico de las mismas, mediante la determinación aproximada de ciertos puntos característicos de su cuerpo, refiriéndolos a ejes coordenados.

Tampoco puede darse en las descripciones una idea exacta del color. El caso más favorable se da cuando el color del ser descrito puede ser referido a los fundamentales del arco iris. Sin embargo, es evidente que no puede haber precisión, porque al mencionar el color verde, por ejemplo, no se da más que una idea, que fluctúa entre los infinitos matices que puede ofrecer ese color. Mayor dificultad se ofrece cuando se hace mención de colores compuestos, como el gris o el pardo, de los cuales cada persona tiene una noción diferente, y aún mayor error puede obtenerse cuando se compara el color de la especie descrita con el de otras substancias, objetos o seres. Las nociones de color de tierra, color de paño, color leonado, son absolutamente arbitrarias.

Por esta causa son muy loables las tentativas de algunos autores (2) que han hecho obras en las que se ofrece extensísima gama de colores, distinguidos por números o por nombres cuidadosamente elegidos, cuyos colores pueden servir de tipos comparativos para referir al más parecido de ellos el color que se trate de determinar en el ser sometido a estudio.

Desgraciadamente estas obras son poco conocidas, y quizás ofrezcan la dificultad de que sufran alteración con el tiempo las muestras de colores, y aun pudiera ocurrir que haya sido imposible imprimirlas con la perfección precisa para que en todos los ejem-

(1) Estudio de los caracterés métricos y morfológicos del cuerpo de los peces. (Rev. de la R. Acad. de Cienc. Exact., Fis. y Nat. Madrid, 1918, t. XVII, núms. 1 a 3, págs. 9 a 39, y núms. 4 a 6 , págs. 142 a 200.)

(2) Entre ellos, RidgewAY, Color Standards and Color Nomenclatures. 
plares resultasen idénticas las tonalidades de las muestras análogas de cada color.

Como los seres suelen tener el cuerpo cubierto de distintos colores y matices que cubren áreas diversas, a veces de contornos complicados, la referencia de estos nuevos caracteres aumenta y complica grandemente la descripción.

Todas las dificultades señaladas desaparecen, o al menos se reducen de modo considerable, representando gráficamente y con la mayor exactitud posible la especie descrita o las partes de su cuerpo que se estime conveniente. La forma, las dimensiones relativas y hasta el color pueden ofrecerse así con una perfección que no puede ser igualada por el procedimiento descriptivo, por muy perfecto que éste sea.

El propio valor de la descripción puede ser realzado por la adición de la lámina. Aquélla se hace más inteligible y de lectura menos pesada. Puede además hacerse más concreta y reducirse a llamar la atención sobre los caracteres más importantes expresados en el dibujo, que por sí solo da una idea muy completa de todos los restantes caracteres de la especie.

La ejecución de las láminas ofrece no pocas dificultades, bien sean debidas a la mano del artista dibujante o se hagan por procedimiento fotográfico.

Cuando las láminas se hacen a mano debe concurrir en su factura el perfecto conocimiento científico de los caracteres de la especie representada, y un gran dominio de la técnica para reproducir con exactitud la forma y el aspecto del ejemplar representado.

Difícilmente se reunen en una sola persona las aptitudes necesarias para conseguir ese resultado, y ordinariamente se asocia el hombre de ciencia con el dibujante, dando el primero al segundo instrucciones preliminares, vigilando la marcha de su trabajo y dándole al final el visto bueno.

Sabido es que para hacer láminas de especies naturales destinidas a estudio no basta con ser dibujante o pintor, sino que es preciso una labor de especialización que requiere no poco tiempo y a la que no se adaptan todos los artistas, muchos de los cuales se entregan en la actualidad a cultivar estilos puramente impresionistas, logrados a favor de la adopción de sencillas y primitivas fórmulas técnicas de dibujo y de color, siendo incapaces de hacer copias fieles y correctas de los objetos naturales.

La imperfección de los dibujos, frecuente en los de las obras 
antiguas, da lugar a no pocas confusiones. No sólo especies, sino hasta géneros imaginarios, se deben a malos dibujos que han servido para su creación.

El procedimiento fotográfico realizado en condiciones convenientes tiene la gran ventaja de constituir un testimonio casi irrefutable de veracidad científica. Ofrece además la gran ventaja de que mediante él se obtienen láminas con economia y rapidez. Tiene, no obstante, la dificultad de que muy frecuentemente los ejemplares que sirven de original no pueden disponerse de modo conveniente para ofrecer visibles sus caracteres distintivos, los cuales pueden ser realzados en un dibujo a mano, y que además, al ser reproducidos por el fotograbado $u$ otros procedimientos análogos en papeles no apropiados, aparecen como empastados, faltos de relieve y con aspecto poco artístico.

En la inmensa mayoría de los casos los ejemplares que han servido de modelo para la ejecución de las láminas de las obras zoológicas pertenecían a las colecciones de estudio; es decir, estaban muertos y conservados por los procedimientos usuales, que por muy perfectos que sean no llegan a impedir las alteraciones que el ser experimenta en cuanto deja de existir.

Algunos animales, como muchos insectos, pueden conservarse bastante bien en las colecciones sin que experimenten alteraciones notables en la forma y color; otros seres, por el contrario, se alteran profundamente y hasta son imposibles de conservar con su forma normal y menos con su color.

Por eso deben copiarse vivos los ejemplares, y si es posible se debn procurar sorprenderlos en su propio medio vital, porque asi se nos ofrecen adoptando actitudes reales o realizando actos de su vida cuyo conocimiento puede ser de interés.

El ideal es, pues, copiar a los seres vivos en su propio medio; pero esto constituye un problema cuya solución es distinta en cada caso, según la especie de que se trate, pues cada una tiene su ambiente peculiar, no siempre accesible.

No son pocos los naturalistas que se han preocupado de esto ideando procedimientos y aparatos para la obtención de fotografías de animales en plena naturaleza. Dignas son de mención las fotografías de grandes mamíferos obtenidas del natural y que se coleccionaron en la obra de A. RADClyfFe Ducimore (1), como también

(1) Camera adventures in the African Wilds. 
es notable el procedimiento utilizado en América del Norte por los hermanos WiLLAMS, que han aplicado el cinematógrafo al medio submarino.

Múltiples, aunque generalmente inéditos, son los procedimientos más o menos perfectos que los investigadores realizan en sus laboratorios para realzar y perfeccionar el estudio morfológico de las especies y su representación gráfica. Sería muy útil divulgar esos procedimientos técnicos y añadir otros nuevos, reuniendo luego todos en una obra sistematizada. en la que comenzando por ...tudiar los procedimientos más convenientes para sorprender a los seres en su propio medio vital, se terminara por investigar los perfeccionamientos técnicos que pueden operarse en el campo de la Tipograilia para la obtención de las mejores láminas y figuras de seres naturales.

De todo esto tenemos esbozado un extenso programa que aun no estamos en condiciones de desarrollar de una manera metódica, pero que ya hemos iniciado (1), al que hoy volvemos y en el que hemos de insistir siempre que se ofrezca oportunidad.

\section{Descripción del esquema de un aparato fotográfico destinado a la obtención de fotografias de peces.}

El esquema de la figura 1 es parecido al de otros aparatos similares empleados en algunos laboratorios y talleres, perc sus el 'mentos constitutivos forman un conjunto más completo y están distribuidos y modificados del modo que mejor conviene para el fin que ha de cumplir el aparato.

Los elementos constitutivos de éste son los siguientes:

CAmara fotográfica, A. - La cámara es de fuelle de largo tiro, y tiene el eje óptico orientado en sentido horizontal. La tablilla del objetivo es fija, verificándose el enfoque mediante la movilidad del marco del cristal esmerilado. Las placas se colocan en este aparato en sentido apaisado.

PRISMA, B. - El prisma está destinado a recoger los rayos luminosos que parten del plano de la platina, que es horizontal, y dirigirlos a través del objetivo sobre el plano vertical de la placa.

Platina, D.-La platina es una luna transparente, rectangular, y orien-

(1) Estudio de los caracteres métricos y morfológicos del cuerpo de los peces. (Rev. de la R. Acad. de Cienc. Exact., Fis. y Nat. Madrid, 1918.) 
tada en sentido horizontal y apaisado, que está destinada a sostener los ejemplares que se van a fotografiar.

La transparencia de la platina permite obtener clisés con imágenes de perfiles correctos, que no proyectan sombra sobre el plano de sustentación, lo cual constituye una ventaja considerable, porque cuando las fotografías de seres naturales destinadas a fines cientificos ofrecen sombras, éstas restan claridad a las pruebas y disminuyen su aspecto artistico, no siendo siempre fácil suprimirias por el retoque.

Fondo, E. - El fondo es una lámina o lienzo, situado siempre fuera del foco de la cámara (debajo de la platina), que está teñido de un tono

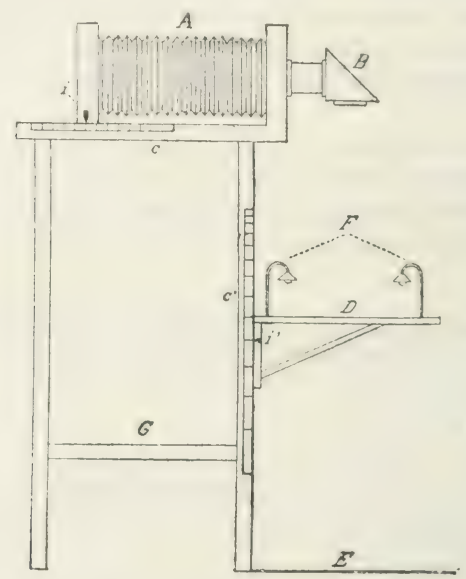

Fig. I. - Esquema del aparato.

uniforme o anubarrado, y que permite se destaque con la mayor claridad posible el objeto fotografiado.

Foco Luminoso, F. - El foco luminoso está formado por varias lámparas convenientemente distribuidas, que pueden producir, a voluntad del operador, un armonioso reparto de luces y de sombras en el ejemplar fotografiado, y cuya intensidad conocida permite dar a los clisés el tiempo de exposición que necesiten, lo que no se puede lograr siempre utilizando la luz del dia, que es muy variable y dificil de graduar.

SOPORTE, G. - Esta parte del aparato, además de servir de sostén a las restantes porciones del mismo, está provista de dos pares de correderas: una, $c$, para el marco del cristal esmerilado, y otra, $c^{\prime}$, para la platina. 
Cada corredera tiene su escala graduada, y tanto el marco del cristal esmerilado como la platina están provistos de sendos índices, $i$ e $i^{\prime}$, para marcar la posición de ambos sobre las respectivas escalas.

Las señales de la escala graduada del marco del cristal esmerilado deben estar separadas una de otra por una distancia que sea por lo menos igual al valor minimo de la profundidad del foco del objetivo, trabajando éste a plena abertura, y deben distinguirse por números.

A cada una de estas señales corresponderá otra, igualmente numerada, en la escala de la platina, que determinará el punto en que habrá de colocarse el indice de la platina, a fin de dejar ésta a la altura debida para que la cámara quede enfocada.

La posición de las señales de ambas escalas se podrá determinar por medio del cálculo, utilizando la ecuación de los focos conjugados, o también empíricamente, por enfoques sucesivos.

Gracias a esas escalas, la operación de enfocar es sencillísima, reduciéndose a colocar los indices de la platina y del cristal esmerilado sobre sus escalas en señal de igual número. Así, cuando la platina esté en el número $\mathrm{X}$ de su escala se enfocará la máquina, poniendo el marco del cristal esmerilado también en el número $\mathrm{X}$ de la suya, y si la primera está en el $\mathrm{X}+1$, el segundo deberá ponerse en el $\mathrm{X}+1$. Además, si la platina está entre dos señales de su escala, como entre X y X +1 (espacio que es igual a la profundidad del campo del objetivo), la máquina se enfocará poniendo el cristal esmerilado en la señal $\mathrm{X}$ o en la $\mathrm{X}+1$, y aún mejor, en un punto intermedio de la distancia que separa a ambas (la que es igual a la profundidad del foco del objetivo).

INDICADOR DE LA AMPLITUD DEL CAMPO FOTOGRAFIABLE. - Tiene por objeto facilitar el conocimiento, para cada posición de enfoque, de la porción de superficie de la platina que puede ser fotografiada.

Claro es que esa operación puede hacerse directamente sobre el cristal esmerilado; pero nosotros tratamos de suprimirla, porque si bien supone una pérdida insignificante de tiempo y de trabajo cuando se trata de hacer fotografias aisladas, llega a ser considerable y enojosa cuando es preciso hacer muchas.

El accesorio consiste en dos pares de reglillas, que se pueden desplazar paralelamente a los lados de la platina y que constantemente limitan entre ellas un espacio rectangular semejante al rectángulo de la platina, que a su vez lo es al del cristal esmerilado.

Es evidente que para que esas reglillas se proyecten en cualquier posición de enfoque sobre los bordes del cristal esmerilado, será preciso que cuando la platina se acerque al objetivo se aproximen las unas a las otras, circunscribiendo un espacio menor, y que cuando la platina baje, lo limiten mayor, apartándose unas de otras. Todo se reduce, pues, a introducir entre las reglillas de cada par una pieza o cuña que regule ese apartamiento. 
El dispositivo mecánico mediante el cual se obtiene la separación precisa de las reglillas es sencillo, como puede verse en el esquema de la figura 2, donde, para mayor simplificación, se representan sólo las reglillas pequeñas paralelas a los lados menores del rectángulo de la platina. Los movimientos del otro par de reglillas, de las cuales se puede prescindir en la práctica, se logran por medio de un dispositivo igual al representado en el esquema, colocando el nuevo mecanismo de modo que funcione actuando en ángulo recto respecto del anterior, como corresponde a la posición recíprocamente perpendicular de ambos pares de reglillas.

El accesorio representado en la figura 2 funciona del modo siguiente: a medida que la platina, $D$, desciende resbalando sobre sus correde-

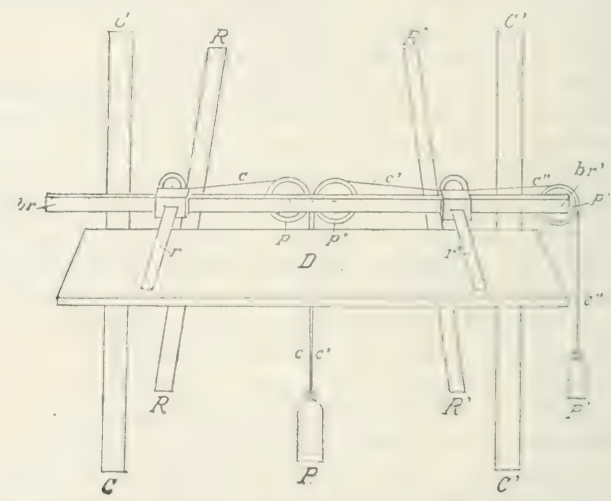

Fig. 2. - Esquema del indicador de la amplitud del campo fotografiable.

ras $C C$ y $C^{\prime} C^{\prime}$, las reglillas $r$ y $r^{\prime}$ se separan, guiadas por las rampas $R R$ y $R^{\prime} R^{\prime}$, que se intercalan entre ellas. Cuando la platina sube, las reglillas, que mediante la acción de los cordones $c c$ y $c^{\prime} c^{\prime}$ y el peso $P$ tienden a juntarse, siguen apoyándose en las rampas y se aproximan la una a la otra, porque las rampas citadas convergen hacia arriba.

La barra $b r b r^{\prime}$ sirve de corredera a la base de las reglillas $r$ y $r^{\prime}$, obligando a éstas a moverse únicamente en sentido paralelo a su posición inicial. Las poleas $p$ y $p^{\prime}$ tienen por objeto cambiar la dirección de los cordones $c c$ y $c^{\prime} c^{\prime}$, para que actúe en el sentido debido el peso $P$.

Como el excesivo espacio ocupado por ambas rampas obliga a mantener demasiado separadas entre sí a las correderas de la platina, se puede suprimir una de ellas, como la $R^{\prime} R^{\prime}$, añadiendo en cambio el cor- 
dón $c^{\prime \prime} c^{\prime \prime}$, la poleita $p^{\prime \prime}$ y el peso $P^{\prime}$, el cual debe tener sólo la potencia precisa para arrastrar a la reglilla $r^{\prime}$. Fácilmente se comprende que cuando la platina baje, la reglilla $r$, guiada por la rampa $R R$, se separará del centro de la platina, haciendo ascender al peso $P$, dejando actuar al $P^{\prime}$ de la reglilla $r^{\prime}$, la cual, por esa causa, se apartará también del centro de la platina. Cuando ésta suba, la pendiente de la rampa $R R$ permitirá a la reglilla $r$ acercarse de nuevo al centro de la platina, con lo cual descenderá el peso $P$, que a su vez arrastrará hacia el centro de la platina a la reglilla $r^{\prime}$, venciendo la acción del menor peso $P^{\prime}$.

Las reglillas deben tener en el centro de su cara superior una rayita transversa, que servirá para marcar en todo momento la posición del eje longitudinal de la platina, con lo que basta para centrar los ejemplares que se van a fotografiar, pudiéndose prescindir por esta causa, generalmente, del otro par de reglillas, obteniéndose asi una simplificacion en el aparato.

Es conveniente que las reglillas sean de un material muy ligero, como una hoja delgada de madera, pudiendo, para ser menos pesadas, reducirse a su mitad basal, pues aunque sólo circunscriban la mitad del campo, el resto del mismo se aprecia fácilmente a simple vista con la aproximación que se requiere en la mayoria de los casos. Los extremos de las reglillas, reducidas a la mitad, determinan la posición del eje longitudina! de la platina, puesto que están cortados al nivel de las rayitas que hemos mencionado antes. En el caso de que exista el otro par de reglillas, sus extremos determinarán la posición del eje transverso de la platina. No conviene dibujar o trazar dichos ejes sobre la platina, porque no deben salir reproducidos en las pruebas fotográficas, pues las afean.

\section{Proyecto de construcción del aparato descrito anteriormente.}

Uno de los modelos de aparato cuyo esquema acabamos de describir es el que está representado en la figura 3, a la cual referimos la descripción que hacemos seguidamente, enunciando una tras otra sus piezas componentes, las que consideramos suficientemente dercritas al tratar de su esquema, agregando respecto de ellas lo que se estime conveniente. Las letras que enciabezan los párrafos son las de la figura 3.

a. - Cámara fotográfica de tiro largo.

o. - Objetivo y prisma.

m.-Marco del cristal esmerilado.

i. - Indice del cristal esmerilado. 
e. - Escala del cristal esmerilado.

b. y $b^{\prime}$. - Barras superiores anterior y posterior destinadas a enlazar la parte superior de los costados del soporte del aparato y a sostener las correderas del marco del cristal esmerilado.

c. - Corredera del marco del cristal esmerilado.

$t$. y $t^{\prime}$. - Travesaños superior e inferior de uno de los costados del soporte del aparato.

p. a. y p. p. - Pie anterior y pie posterior de uno de los costados del soporte del aparato. Los pies anteriores deben ser divergentes en su parte inferior para que pueda colocarse entre ambos, ell el suelo, el fondo $f$.

$p$. $d$. - Pie derecho vertical que enlaza los travesaños superior e inferior de un costado del soporte del aparato y que sostiene a una de las correderas de la platina.

c. p. - Corredera de la platina. La del otro lado ha sido suprimida en el dibujo.

e. p. - Escala graduada de la platina.

i. p. - Indice de la platina.

p. - Platina de cristal.

pl. p.- Palomilla que sirve de sostén a la platina y a todos sus accesorios. La del otro lado no ha sido representada.

t. p. - Tornillo de presión para sujetar la palomilla de la platina sobre su corredera a la altura que se desee.

cl. - Columnitas que pasan a través de unas perforaciones ovaladas que tiene la platina cerca de sus ángulos. Estas perforaciones están prolongadas en el sentido de la mayor longitud de la platina, para permitir a ésta distintas posiciones de inclinación hacia sus lados menores.

$c x$. y $e x^{\prime}$. - Par de excéntricas, unidas en un mismo eje, en las que se apoya uno de los lados de la platina.

La platina no está sostenida directamente sobre sus palomillas, sino que descansa sobre cuatro excéntricas caladas en dos ejes provistos de manubrios. Según la inclinación que se dé a los manubrios, se puede elevar la platina por uno de sus lados menores o por ambos a la vez. Esto es preciso, porque como el cuerpo de los peces tiene un grosor a veces considerable, la superficie visible de los mismos quedaria desenfocada, muy por encima del plano determinado por las reglillas que marcan la extensión del campo fotografiable y la posición del plano de enfoque que se utiliza en cada caso.

Para colocar el plano principal de enfoque del cuerpo del pez a la altura determinada por esas reglillas, es preciso graduar la posición de la platina de cristal, subiéndola o bajándola lo que sea preciso. Como el cuerpo de los peces es más grueso en la región cefálica que en la caudal, hay que hacer-descender la platina de cristal más por la parte ocupada por la cabeza del pez que por la del otro extremo, a cuya circunstancia se debe la necesidad de que la platina sea inclinable. 
En suma, la existencia de esas excéntricas permite colocar el plano sagital o de simetria del pez en posición perfectamente horizontal, y po-

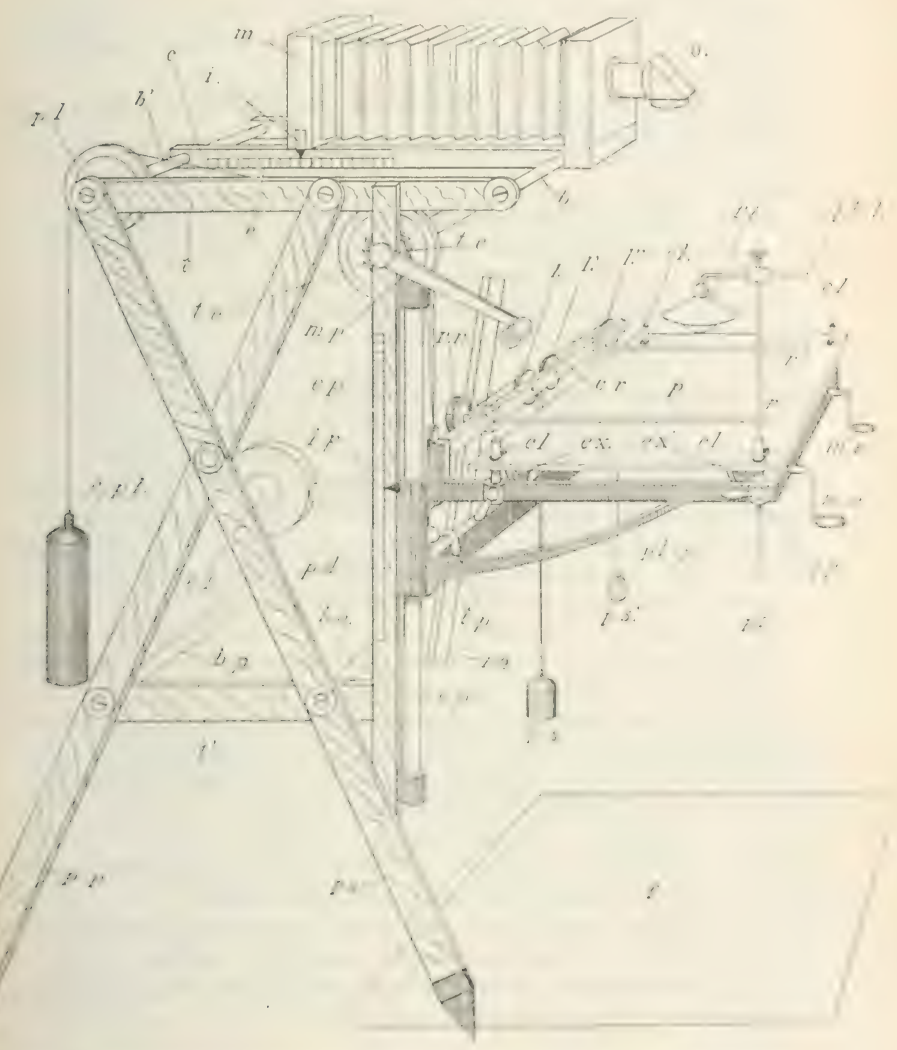

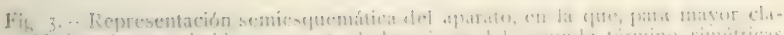

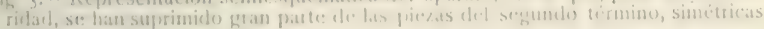
del primero.

ner el plano principal de enfogue elegido en el cuerpo del mismo coinci- 
diendo con el determinado por las reglillas que limitan la amplitud del campo.

$m$. $е$. y $m^{\prime}$. $e^{\prime}$. - Manubrios de los ejes de ambas excéntricas.

$r$. y $r^{\prime}$. - Reglillas que indican la amplitud del campo fotografiable.

$r$ r. - Ruleta de la reglilla $r$, destinada a rodar por el perfil de la rampa $r$. $a$.

c. r. - Corredera de sección cuadrada o rectangular, a lo largo de la que circulan las reglillas $r$ y $r^{\prime}$.

ps. - Peso que tiende a acercar al centro de la platina a las dos reglillas $r$ y $r^{\prime}$.

$p s^{\prime}$. - Peso que tiende a separar del centro de la platina a la reglilla $r^{\prime}$.

l. $l^{\prime}$. y $l^{\prime \prime}$. - Poleitas por las que pasan los cordones que unen a las reglillas $r$ y $r^{\prime}$ con sus pesos $p s$ y $p s^{\prime}$.

r. a. - Rampa que regula los movimientos de la reglilla $r$.

c. pl. - Contrapeso de la platina. Este peso tiende a equilibrar el peso total de la platina y de todos sus accesorios, para evitar que ésta baje a lo largo de sus correderas con demasiada violencia.

e. l. - Peso equilibrador de la platina. Es una masa de plomo unida a cada una de las palomillas de la platina, que se sitúa en el espacio comprendico entre las zancas del soporte del aparato y que sirve para equilibrar el peso de la platina, impidiendo que ésta, con todos sus accesorios, tienda a caer hacia adelante, produciendo un esfuerzo nocivo de flexión sobre sus correderas, a lo largo de las cuales debe resbalar, cayendo a plomo sin ejercer presión o esfuerzo lateral alguno.

p. l. - Segunda polea, por la que pasa el cordón que une a la platina con su contrapeso. La primera polea no se ve en la figura, porque está detrás de la polea del torno elevador de la platina.

t. e. - Torno elevador de la platina. Este torno, que sirve para elevar la platina con todos sus accesorios, funciona con dos cables o dos cintas fuertes que parten de las dos palomillas de la platina. En la figura no está representada más que la mitad del torno (1).

m. p. - Manivela del torno elevador de la platina.

t. e. - Trinquete del torno elevador de la platina. El trinquete impide que el torno gire hacia atrás y que la platina descienda.

b. a. y b. p. - Barras inferiores anterior y posterior que enlazan por su parte inferior a las piezas laterales del soporte del aparato.

f. $l$. - Foco luminoso. Es una luz con su pantalla. Debe haber lo menos cuatro, uno en cada esquina de la platina.

(1) En lugar del torno puede emplearse un manubrio en cuyo eje esté calado un piñón que engrane en una cremallera solidaria de la platina, de modo que ésta subirá y bajará según el sentido de las vueltas que dé el piñón. El empleo del torno es ventajoso por ser de construcción más fácil y económica. 
p. f. - Pie del foco luminoso. Es una varilla que se ajuste. en la cavidad cilindrica de cualquiera de las columnitas $c l$ que atraviesan la platina y que sirven de sostén a un foco luminoso. El extremo superior de esta varilla tiene una dilatación, provista de una perforación cilindrica horizontal, sobre la que actúa un tornillo de presión.

t. f. - Tornillo de presión del pie del foco luminoso. Cada una de las columnillas $c l$ tiene en su base uno de estos tornillos, mediante los cuales se pueden sujetar en posición fija los pies o varillas que sirven de sostén a los focos luminosos.

p. f. l.-Percha del foco luminoso. Es una varilla horizontal, que sostiene la luz con su pantalla, que se ajusta en la cavidad cilíndrica de la cabeza del pie vertical del foco y que puede inmovilizarse por medio del tornillo de presión que existe sobre dicha cabeza.

Dando al pie y a la percha del foco luminoso la longitud debida, mediante la gran movilidad de estas piezas, se puede iluminar del modo más variado la superficie de la platina.

Podrá ser conveniente en algún caso añadir, hacia la mitad de cada uno de los lados largos de la platina, un foco luminoso más.

f. - Fondo. Es el lienzo o cartón coloreado sobre el que debe destacarse el objeto fotografiado. No necesita soporte especial, pues basta colocarlo en el suelo. Como tiene un tamaño mayor que la platina y no cabría entre los pies anteriores del soporte del aparato, es preciso hacer a éstos divergentes por su parte inferior.

El modelo que acabamos de describir tiene todas sus piezas

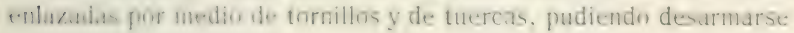
por completo, prestándose a ser transportado adonde sea preciso con relativa facilidad.

El aparato puede funcionar con objetivos distintos, de longitudes focales diferentes; pero cada objetivo nuevo requiere el empleo de excalas, especialimente gnuduadas, para el marco del oristal esmerilado y para la platina, asi como una adecuada inclinación de las rampas sobre las que corren las ruletas de la base de las reglillas que limitan la amplitud del campo fotografiable. 


\section{LAS SIDERITIS HÍBRIDAS ESPAÑOLAS}

POR EL

DR. P. FONT QUER

(Láminas X a XIII.)

De todos los botánicos que herborizan es conocida la extraordinaria facilidad con que se hibridan las especies de algunos géneros de labiadas. Difícil sería hallar juntas o próximas dos especies de Mentha, por ejemplo, sin que entre ellas hubiese formas mixtas nacidas de la unión de dos distintas. En estos últimos años se han descubierto en España buen número de estos híbridos, no sólo del referido género Mentha, sino también de los Teucrium, Lavandula (1), Marrubium, Brunella, Phlomis, Thymus, y sobre todo Sideritis, ya bastante numerosos estos últimos para que pueda ser de utilidad su enumeración en este trabajo.

Como verá el lector, apenas es posible hallar dos individuos híbridos iguales entre los naciulos de unos mismos padres. De la $X$ Sideritis difficilis describimos cuatro, correspondientes a los cuatro ejemplares descubiertos; de la $\times$ S. Costae, tres, con cuatro individuos; de la $\times S$. iberica, cuatro, con cinco ejemplares, y aun el quinto no es exactamente igual al que más se le parece. Los caracteres de los padres se mezclan en estos híbridos de mil maneras, como resultado de un sin fin de combinaciones posibles entre cada par de caracteres opuestos. Para un solo par de caracteres opuestos tenemos una serie de formas mixtas, desde aquellas en cuyos órganos aquel carácter es más semejante al de uno de los

(1) Nuestra $\times$ Lavandula Sennenii (L. pedunculata Cav. $>$ L. Staechas L.), publicada este año en Treballs del Musel de Ciències Naturals de Barcelona, "Contribució al coneixement de la flora catalana occidental», píg. 32, deberá llamarse $\times L$. Senneniana Font Quer, por existir ya otra $\times$ L. Sennenii Fouc. 
padres, pasando por los que lo tienen justamente medio, hasta los que lo presentan ya más parecido al del otro padre. Hay que pensar en el número grande de pares de caracteres opuestos que tienen los padres del hibrido, para hacerse cargo de las numerosas series de caracteres intermedios que será posible obtener. Y' como, en definitiva, el híbrido habrá de tomar de cada una de esas series sus propios caracteres, se comprende cuán gran número de combinaciones se podrán presentar, y por tanto cuántos hibridos, en realidad distintos, cabrán en una sola fórmula de hibridación.

Pero no sólo en lo anteriormente dicho cabe apoyar la posibilidad del pleomorfismo de un híbrido, sino que ése estará afectado además del polimorfismo propio de las especies que lo originan. Y el polimorfismo es muy notable en casi todas las especies de Eusideritis. De los cinco híbridos que se mencionan del grupo de la $\times$ Sideritis Viciosoi Pau, tres fueron producidos por cruzamiento de unos mismos padres, o sólo por formas de unos mismos padres; los otros dos proceden de combinaciones en que intervitnen Sideritis distintas, variedad o raza, de aquellos mismos tipos especificos que engendraron los tres ya dichos.

Indudablemente, sólo un estudio experimental, la producción de estos hibridos artificialmente, permitirá obtener datos ciertos acerca de su origen y de la influencia mayor o menor del padre o de la madre en la formación del tipo mixto, y además se podrá saber si los caracteres de sus descendientes, ya que algunos de ellos, al menos, nos consta que son fértiles, son fijos o variables, y si obedecen, en fin, a la ley de Mendel, cosa que no nos parece probable para la mayoría de ellos.

Sin otro objeto que el de agrupar aquí los datos diversos que sobre Sideritis hibridas españolas hemos podido recoger y adjuntarles los resultados de nuestras propias observaciones en el campo. publicamos esta nota, que comprende todas las conocidas hasta hoy, de Espana, producidas naturalmente entre plantas silvestres.

$X$ Sideritis difficilis, hybr. nov.

\section{S. Bubanii Font Quer $\times$ S. hirsuta L.}

La Sideritis Bubanii Font Quer (in Butlleti de la Institucio Catalana d'Historia Natural, octubre, 1920) vive en la parte alta del valle del Seure, en los yermos y matorrale's de Martinet y Bell- 
ver, cerca de la Seo de Urgel. En los ribazos y cultivos abandonados crece, bastante frecuente, la Sideritis hirsuta L., una forma de tallos e inflorescencia muy tomentosos, que algunos hemos llamado var. tomentosa (Pourret) (1). El dia 4 de julio del año pasado herborizamos por la mañana, en Bellver, siguiendo las faldas de los montes río arriba, por la margen derecha. Nos fué un poco difícil hallar mezcladas las dos Sideritis aquí nombradas; sólo en una pequeña garriga, poco antes de ensancharse el valle del Segre para formar la Cerdaña, dimos con algunos ejemplares aislados de la S. hirsuta, entre otros abundanies de la S. Bubanii. Al poco rato de buscar, hallamos un pie único híbrido, con cinco ramitas nada más, de poca talla, y sin ninguna flor en sus inflorescencias. El mismo dia, por la tarde, recorrimos a pie el trayecto que media entre Bellver y Martinet, siguiendo el Segre aguas abajo y por la misma orilla derecha. Ya cerca de ese último pueblo, en el desmonte de la carretera y en los matorrales, pudimos encontrar de nuevo las dos especies juntas, y a poco de buscar, descubriamos tres nuevos pies híbridos y en muy buen estado para su estudio.

Las cuatro plantas son distintas, caso común entre las Sideritis; y $\sin$ otros datos que los que resultan del estudio morfológico de los ejemplares herborizados, es muy difícil decidir cuál de sus progenitores domina en la forma compuesta. Los caracteres específicos de los padres se combinan de tal manera, que los del híbrido son a menudo exactamente medios entre los de aquéllos. Y todavía viene a complicar la cuestión, aumentando el polimorfismo de los híbridos, el propio polimorfismo de las especies del género Sideritis, bastante notable, en este caso concreto, en la S. Bubanii. Así es que la interpretación que vamos a dar de los cuatro siguientes hay que entenderla provisional, que sólo numerosas experiencias de hibridación podrían decidir de manera cierta. En dos de los cuatro híbridos creemos ver mayor afinidad con la S. Bubanii; en los otros dos, con la $S$. hirsuta; tomamos como tipo el más próximo a aquélla:

a typica $=$ S. Bubanii $>$ S. hirsuta Font Quer.-Humilis,

(1) S. hirsuta et S. tomentosa Pourret eamdem plantam revocant, ut me certiorem fecit earum inspectio in illius Herbario Matrit. asserv. Reperiuntur ibidem specimina, quae demonstrant quanta fuerit haesitatio penes Pourret, num sub uno, vel sub altero traheret nomine. (BUBANI, Fl. pyr., vol. I, pág. 454.) 
15 cent. alt., dense hirsuto-tomentosa, foliis lanceolatis, etiam superioribus dentatis; verticillastris paucis, approximatis. bracteis villosis, calycibus fere Sideritidis Bubanii. Hab. in Valle Sicoris, prope pagum Bellver (Ilerda), inter parentes, ubi d. 4 jul. 1920, legi.

Este hibrido tiene los verticilastros mayores que los de la $S$. hirsuta, y las brácteas y cálices más parecidos a los de la S. Bubanii, con hojas dentadas, semejantes a las de algunas formas de esa última especie; este que tomamos como tipo es el que más se parece, de los cuatro herborizados, a la $S$. Bubanii, aunque por su talla y vestidura recuerda mejor la $S$. hirsuta. El otro, en que dominan también los caracteres de la $S$. Bubanii, presenta los verticilastros semejantes a los de la $S$. hirsuta, y es dificil distinguirlo de ella al primer golpe de vista; tiene las hojas superiores enterísimas. Lo proponemos como:

i fallax $($ lám. X) $=S$. Bubanii $>$ S. hirsuta, forma altera.A Sideritide hirsuta foliis integris vel pauci dentatis, minus villosis, caule et inflorescentia minus tomentosis; verticillastris paucis, in apice ramorum plus minusve approximatis, multifloris; bracteis majoribus; corolla a labio superiore breviore, differt. A Sideritide Bubanii statura humiliore, tomento copiosiore, verticillastris minoribus, bracteis calycibusque hirsutotomentosis, corolla a labio superiore albicante, discrepat. Hab. in Valle Sicoris, prope pagum Martinet, inter parentes, ubi legi d. 4 jul. 1920.

; elongata $=$ S. Bubanii $<$ S. hirsuta Font Quer. - Folia ut in Sideritide hirsuta, sed majora et minus villosa; caulis elongatus; verticillastra remota, multiflora, dentibus bractearum calycumque spinis tenuis munitis; corolla ut in Sid. Bubanii sed labio superiore albicante. Hab. cum praecedente, prope Martinet.

i Gautieri $=$ S. Bubanii $<$ S. hirsuta, forma altera. - A Sideritide hirsuta, cui habitu simile, foliis superioribus paucidentatis vel subintegris; verticillastris multifloris; corolla ut in Sid. Bubanii sed labio superiore albicante, differt. Hab. cum praecedentibus, prope Martinet.

Estas dos últimas tienen más de $S$. hirsuta que de S. Bubanii; la y elongata presenta tallos más o menos flexuosos, hasta de $40 \mathrm{~cm}$., y sus verticilastros, de muchas flores, son grandes, pero distantes, como en la primera de aquellas dos; la is Gautieri, que 
llamamos así como recuerdo a Gastón Gautier, compañero de Coste en su exploración por este valle del Segre, tiene los tallos sólo de 15 a $20 \mathrm{~cm}$., y los verticilastros pequeños, y por su aspecto apenas difiere de la $S$. hirsuta. Tanto en una como en otra de estas últimas, y también en la $\beta$ fallax (la a typica no tenía ninguna flor abierta en la inflorescencia), las corolas denuncian en seguida la influencia de la $S$. Bubanii; la corola sirve a maravilla para distinguir las dos especies progenitoras, con el labio superior alargado y blanco en la $S$. hirsuta, más corto que el inferior y amarillo pálido en la $S$. Bubanii; los hibridos más parecidos a aquélla tienen el labio superior de sus corolas acortado y ancho, aunque pálido o casi blanco, y este carácter permite distinguirlos con seguridad.

\section{Sideritis Marcelii Elias et Sennen.}

S. hirsuta L. $\times$ S. scordioides L.

Las campañas botánicas que los hermanos SEnNen y Elías han realizado en el alto valle del Ebro, en Miranda y sus alrededores, han dado por resultado el descubrimiento de una porción de plantas interesantes. Entre ésas se encuentran algunos híbridos de las Sideritis scordioides L. var. Cavanillesii (Lag.) Willk., S. linearifolia Lamk. y S. hirsuta L., frecuentes en aquella región. El primero fué descubierto en Bujedo por el hermano Elias en 1907, y es el siguiente:

a typica $=S$. Marcelii Elias et Sennen, in Bulletin de Géographie Botanique, 1911, págs. 120-121, et Plantes d'Espagne, núm. 479 (1907); S. tomentosa Pourr. $\times$ S. Cavanillesii Lag., eor.; S. hirsuta L. > S. scordioides L. var. Cavanillesii (Lag.) Willk.Habitu Sid. hirsuta sed magis ramosa, ramis strictis, simplicibus vel parum ramosis, praecipue ad inflorescentiam dense patuleque villosis, verticillastris ut in Sid. hirsuta, corolla tota lutea. Hab. prope Bujedo (Vallis Iberi); leg. Elias!, 8 jul. 1907.

$\beta$ mirandana $=X S$. Mirandana Sennen et Elias in schaed.; S. Cavanillesii Lag. $\times$ S. tomentosa Pourr., eor.; S. hirsuta L. <S. scordioides L. var. Cavanillesii (Lag.) Willk. - Praecedente similis sed magis suffruticosa, ramis minus tomentosis, foliis parvis, verticillastris in spica angusta approximatis, 
bracteis brevioribus. Hab. prope Susana (Vallis Iberi), leg. Elias !, 12 jul. 1918.

La que herborizó el propio hermano Elías en Miranda de Ebru (18-VII-1918) no nos parece bastante distinta de la \% typica; SE. NEN cree, sin embargo, que es más próxima de la $S$. scordioides.

\section{$\times$ Sideritis aragonensis Sennen et Pau.}

\section{S. hirsuta L. $\times$ S. spinulosa Barnades.}

El hermano Sennen descubrió este híbrido en Teruel y en Monreal del Campo en agosto de 1910; entre los ejemplares que examinamos rimos dos tipos distintos, ya descritos en otro lugar. y un tercer ejemplar. producido por una variedad de la Sideritis spinulosa, lo está también en el mismo trabajo:

a typica $=\times$ S. aragonensis Sennen et Pau, in schaed., Plantes d'Espagne, num. 1.015, part., et apud Sennen, Bol. Soc. Aragonesa de C. N., 1912, pág. 235; S. spinulosa Barn. X S. hirsuta L., eor.; S. hirsuta L. > S. spinulosa Barn., ap. Font Quer, Acerca de las Sideritis aragonesas del grupo de la S. spinulosa Barn., con sus hibridos, Bol. Soc. Ibér. de C. N., 1920, pág. 140. - Hab. Teruel, Sennen, VIII-1910; Monreal del Campo, Sennen, 28-VIII-1910.

B Benedictoi $=\times$ S. Benedictoi Font Quer; S. hirsuta L. <S. spinulosa Barn., ap. Font Quer, loc. cit., Bol. Soc. Ibér. de C. N., 1920, pág. 140. - Hab. Teruel, Sennen, VIII-1910.

; Rubioi $=\times$ S. Rubioi Font Quer; S. hirsuta L.> S. spinulosa Barn. var. subspinosa (Cav.), ap. Font Quer, loc. cit., Bol. Soc. Ibér. de C. N., 1920, pág. 140. - Hab. en Aragón austral, en Torre del Comte, c. Fresneda, leg. Rubió, 6-VII-1919.

\section{Sideritis Costae Font Quer.}

\section{S. hirsuta L. $\times$ S. ilicifolia Willd.}

Estas dos Sillerilis se hibridan con facilidad donde crecen juntas. Descubrimos lus primeros ejemplares en el Montsant (Tarragona). y este verano pasado hemos hallado otro pie entre Vinaixa y Floresta (Leirida), y podrán encontrarse sin duda en todas partes donde viva la Sideritis ilicifolia, ya que la $S$. hirsuta es frecuente 
en su área de dispersión. Se reconocen en seguida esos hibridos por la pubescencia característica que les comunica la S. hirsuta, y los más parecidos a esta última, por los tallos rígidos y dientes de las hojas espinositos, propios de aquella otra especie. Mencionaremos los siguientes:

* typica $=$ S. hirsuta L. $<$ S. ilicifolia Willd. (1), Font Quer, Contribució al coneixement de la flora catalana occidental, pág. 29 (1920). - Hab. Montsant (Tarragona), 650 m. alt., inter parentes; entre Vinaixa y Floresta (Lérida), $400 \mathrm{~m}$. alt., inter parentes. La planta de Vinaixa apenas difiere de la del Montsant más que por los dientes de las hojas, un poco más espinosos y en mayor número.

$\beta$ gracilis (lám. $\mathrm{XI})=S$. hirsuta $\mathrm{L} .>$ S. ilicifolia Willd. Gracilis, caulibus 20 cent. alt., hirsutis; foliis angustis, acutissimis, dentibus minutis spinosis munitis, inflorescentia dense tomentosa, verticillastris $3-4$, multifloris, parvis; corollae labio superiore albo.-Hab. Montsant, $950 \mathrm{~m}$. alt., inter parentes.

; Cadevallii $=S$. hirsuta L. $>$ S. ilicifolia Willd., forma altera Font Quer, loc. cit., pág. 30 (1920). - Hab. Montsant con la anterior, de la cual se distingue fácilmente por su talla más elevada, vellosidad mayor, verticilastros más grandes y numerosos, hojas más anchas y menos espinosas, etc.

\section{$X$ Sideritis segobricensis Pau.}

\section{S. angustifolia Lag. $\times S$. hirsuta $\mathrm{L}$.}

En la parte meridional del reino de Valencia, y más hacia el Sur, la Sideritis hirsuta L. es rara o falta por completo en la tierra baja. Al menos lasi lo observamos en nuestras herborizaciones de Chiva, Játiba, Enguera, Almansa, Bocairent, Biar, Castalla, Tibi, Tobarra, etc., y el Sr. Gros, que recorrió Andalucía durante tres meses, no nos trajo ni un solo ejemplar de aquella especie, a pesar de herborizar con interés todas las Sideritis. La afirmación de Willkomi en el Prodromus, refiriéndose a la dispersión en Es-

(1) Aceptamos el parecer de PAU respecto a esta especie de WILLDENow. Cree el Sr. PAU que no es oriental, sino española, y, por lo tanto, no tiene razón de ser la var. hispanica de Willkomм. 
paña de la forma vulgar de la $S$. hirsuta L., "fere undique», resulta muy poco concreta.

En Segorbe, sin embargo, y al Norte de la provincia de Castellón, es posible hallar juntas, a poca altitud, la susodicha S. hirsuta L. y la S. angustifolia Lag., y ejemplares híbridos de ambas. Los híbridos de $S$. angustifolia y $S$. hirsuta fueron los primeros que se descubrieron en España; PAU halló un pie mixto el dia 1 de mayo de 1886 en los olivares de Segorbe. Gracias a la liberalidad del Sr. PAU, hemos podido estudiar un fragmento procedente del primer pie descubierto, que tomamos como tipo:

" typica $=\times S$. segobricensis $\mathrm{Pau}$, in schaed.; S. hirsuta L. $\times$ S. Tragoriganum Lag., ej., loc. cit.; S. angustifolia Lag. $<S$. hirsuta L. - Caulibus a basi breviter tomentosis, ad inflorescentiam dense lanatis; foliis lanceolatis, acutis, in spina debile terminatis, acute dentatis, supra glabrescentihus: verticillastris distantibus, bracteis latis, subherbaceis. Hab. prope Segobriga, in olivetis, ubi cl. Pau, d. 1 majii 1886, legit.

La $S$. angustifolia Lag. es muy polimorfa, y si bien en sus caracteres de conjunto el grupo queda bien definido, las formas se multiplican como resultado de $u$ análisis minucioso. Sumamente variables son la inflorescencia, brácteas, cálices, etc., y cada forma distinta daría lugar a hibridos en mayor o menor grado diferentes. Por este motivo no concretamos más la descripción.

Otro hibrido herborizado por PAU lo propondremos asi:

i Pauana $=X$ S. segobricensis Pau, var., ap. ej. in shaed.; S. hirsuta L. X S. Tragoriganum Lag., ej.; S. angustifolia Lag. S. hirsuta L., forma altera.-Habitu, inter S. angustifolia et $S$. hirsuta, media; ramis elongatis, virgatis, foliis lanceolatis, obtusis, crenatis, supra glabrescentibus; verticillastris numerosis distantibus. A Sid. angustifolia foliis latioribus, crenatis, inflorescentia elongata, dense longeque tomentosa, bractearum calycumque dentibus minus spinosis, distat. A Sid. hirsuta, ramis elongalis, rigidioribus, minus hirsutis, foliis angustioribus, secedit. Hab. in aridis, prope Segobriga, secus viam quae ad Marroyo ducit, ubi cl. Pau, junii 1908 et + julii 1917 , legit.

rvalentina $=\times S$. valentina Sennen et Pau (forma laxiflora), ap. Sennen, Plantes d'Espagne, num. 742; S. Tragoriganum Lag. $\times$ S. hirsuta L., eor., loc. cit., et ap. Sennen, Bulletin de Géographie Botanique, 1911, pág. 120; S. angustifolia Lag. > 
S. hirsuta L. - Differt a praecedentibus foliis angustioribus, integris vel paucidentatis; verticillastris minus distantibus; bracteis rigidioribus. Hab. in Regno Valentino, Peñíscola et Benicarló, ubi cl. Sennen, jul. 1909, legit.

La S. Tragoriganum Lag. parece que puede incluirse en el grupo de la S. angustifolia del mismo autor; es forma muy dudosa.

\section{Sideritis Loscosiana Font Quer.}

S. scordioides L. $X$ S. spinulosa Barn.

Descubrimos este híbrido entre el material herborizado por el Sr. Rubió, colaborador del Museo de Barcelona, en el Bajo Aragón. El tipo descrito se parece por su porte a una Sideritis spinulosa Barnades, pero se distingue de ella por las brácteas cortas, los verticilastros pequeños, formando una inflorescencia floja, por las hojas cortas, etc. Es la siguiente :

a. typica (lám. XII $)=S$. scordioides L. var. Cavanillesii (Lag.) Willk. <S. spinulosa Barn., ap. Font Quer, loc. cit., Bol. Soc. Ibér. de C. N., 1920, pág. 140. - Hab. cerca de Castelserás, lèg. Rubió, 3-VII-1919.

$\times$ Sideritis Baluei, hybr. nov.

S. ilicifolia Willd. $X S$. scordioides L.

Conociamos la existencia en Espluga de Francoli, Vinaixa y Floresta de la Sideritis ilicifolia Willd., y poseíamos en las colecciones del Museo de Barcelona la Sideritis scordioides L. var. Cavanillesii (Lag.) Willk., de Puigvert (Lérida), remitida por nuestro amigo el Sr. Xiberta Raig, farmacéutico militar. De Floresta a Puigvert hay unos 17 kilómetros en línea recta, y pensamos nosotros que quizá en una localidad intermedia nos seria dado encontrar conjuntamente aquellas dos Sideritis, en Borjas Blancas, por ejemplo, por su situación y por empezar allí la estepa catalana, donde es frecuente la S. scordioides var. Cavanillesii. Y con el fin de comprobar nuestras suposiciones y ver si era posible hallar el hibrido de aquellas dos Sideritis, el 19 de junio pasado salimos de Barcelona para Vinaixa, donde empezamos a trabajar. En seguida encontramos la $S$. ilicifolia, muy frecuente en los matorrales, 
herborizando una porción de formas curiosas, y por la tarde nos dirigimos a Floresta y Las Borjas por la vía del ferrocarril. Entre Vinaixa y Floresta continua frecuente la S. ilicifolia; pero al llezar a esta última, y sobre todo entre Floresta y Las Burjas. empieza a disminuir visiblemente. En los 16 kilómetros que hay de Vinaixa a Las Borjas no vimos otras Sideritis que la que lemos consignado, la $S$. hirsuta y la $\times S$. Costae. Pero en Floresta se encuentran ya diseminadas algunas matas de Retama sphaerocarpa y otras de Lygeum Spartum, que se hacen más frecuentes a medida que descendemos al llano, y nos anuncian la proximidad de la estepa donde vive la $S$. scordioides var. Cavanillesii. Todos nuestros temores eran de que llegara a desaparecer la $S$. ilicifolia antes de encontrar aquella otra, hasta que, por fin, a menos de un kilómetro de L:is Borjas, distinguimos los primeros pies de $S$. scordioides var. Cavanillesii. El sol se habia puesto hacia mucho rato y habia poca luz, y asi intentamos explorar unas garrigas a la derecha de lat línea del ferrocarril, y pronto descubrimos la $S$. ilicifolia junto a la otra. Buscamos de firme, y sólo después de mucho escudriñar, cuando ya apenas podiamos distinguir las plantas, hallamos un pie hibrib, viejo, con una sola ramita en flor. Fué para nosotros una verdadera alegria, pues aunque nos apenaba lo mísero del ejemplar, confiamos hallar otros mejores el día siguiente. El día 20 por la mañana exploramos de nuevo los matorrales de los alrededores de Las Borjas, encontrando en varios sitios las dos Sideritis juntas: pero sólo después de mucho buscar, a mediodia, pudimos descubrir utro ejemplar híbrido, si bien éste en muy buenas condiciones y con abundantes ramitas floridas. Tiene todo el porte de la S. scordioides var. Cavanillesii, pero sus tallos menos vellosos, sus hojas más largas y angostas, con dientes espinositos y menos rellosas también, denotan al purito la influencia de la S. ilicifolia. Este ejemplar, que tomamos como tipo, lo describiremos así :

a typica (lám. XIII, fig. 1) = S. ilicifolia Willd. $<$ S. scordioides L. var. Cavanillesii (Lag.) Willk. - A S. Cavanillesii, cui habitu simile, cuulibus minus villosis e pilis brevioribus restitis; foliis longioribus angustioribusque, dense glandulnsis (glandulis non stipitatis), dentibus minoribus acutisque suhspinosis; calycis faucihus pilis creberrimis obturatis, demiluis calycinis brevioribus erectioribusque, corolla grandiore, differt. Mab. prope Les Borges (Ilerda), ubi d. 20 junii I!121), lesi. Honoris gratia patri nostro M. F. Balué qui, scientia studium 
nobis communicavit et tantum ilerdenses terras cognovit et amavit Sid. Baluei dicamus.

El que hallamos el día anterior es tan parecido como el que acabamos de describir a la $S$. Cavanillesii, pues aunque las hojas tienen dientes más espinosos son más cortas y vellosas, así como los tallos. La damos como:

$\beta$ spinifera $=S$. ilicifolia Willd. $\langle$ S. scordioides L. var Cavanillesii (Lag.) Willk., forma altera. - A praecedente, foliis brevioribus spinosis; caulibus magis villosis, dentibus calycis subarcuatis, distat. Hab. cum praecedente prope Les Borges.

Ambas viven en el mismo sitio, a poca distancia una de otra, a 300 metros de altitud, en las garrigas de Las Borjas, donde crecen además: Genista Scorpius, Brachypodium ramósum, Avena bromoides, Thymus vulgaris, Linum suffruticosum, Euphorbia nicaensis, Lithospermum fruticosum, Helianthemum marifolium, H. pilosum, Ephedra distachya...

$\times$ Sideritis Llenasii Font Quer.

S. angustifolia Lag. $X S$. scordioides L.

En los confines de Cataluña y Valencia, en las garrigas de la orilla derecha del río Cenia, cerca de Ulldecona, descubrimos el 12 de junio de 1916 el primer híbrido de este grupo. El hermano SENNEN ha publicado en su exsiccata, con el número 2.923, una raza, $S$. Fontii, de la $S$. scordioides $L$., procedente de la mencionada localidad, que nosotros herborizamos junto con el hibrido y la S. angustifolia Lag. En Ulldecona, sin embargo, la S. scordioides no está representada únicamente por la forma que SENNEN ha llamado S. Fontii, sino que existen otras además más o menos espinosas en los dientes foliares o calicinales, más o menos hirsutas, etc. Todas ellas, en conjunto, parece que se pueden colocar entre la var. Cavanillesii (Lag.), mejor caracterizada, y otra forma notable que llamamos provisionalmente var. tarraconensis, quizá próxima por sus brácteas grandes a la $S$. scordioides de LiNNÉ. Una de esas formas, parecida a la var. Cavanillesii (Lag.), es la que ha producido, por cruzamiento con la S. angustifolia (Lag.), la $\times$ S. Llenasii Font Quer.

En el valle de Villena, en Alicante, en La Cañada, Benejama, Biar, Castalla, etc., vive otra variedad de la misma S. scordioi- 
des L., caracterizada por sus tallos elevados y por las hojas muy poco vellosas, verticilastros distantes y numerosos, brácteas que no llegan a la mitad de los cálices, etc. Es la que CAVANilles llamó S. chamaedryfolia, como hemos demostrado en otro lugar (1). Esa Sideritis se cruza también con la S. angustifolia y nos da un segundo hibrido de ese grupo, $\times S$. Cavanillesiana:

a typica $=\times$ Ș. Llenasii Font Quer, loc. cit., pág. 31 (1920); S. scordioides L. var. Cavanillesii (Lag.) Willk. $X S$. angustifolia Lag., Font Quer, loc. cit.; S. angustifolia Lag. $\langle$ S. scordioides L. var. Cavanillesii (Lag.). - Hab. cerca de Ulldecona (Tarragona), 12-VI-1916.

3 Cavanillesiana $=S$. angustifolia Lag. $\langle$ S. scordioides L. var. chamaedryfolia (Cav.) Font Quer. - Differt a Sid. chamaedryfolia, cui habitu simile, caulibus magis tomentosis; foliis elongatis, lanceolatis, minus dentatis; bracteis majoribus. Hab. prope Biar (Alicante), $600 \mathrm{~m}$. alt., inter parentes. Legi d. 23 jul. 1919.

La $\alpha$ typica y la $\beta$ Cavanillesiana son bastante diversas. Las diferencias no proceden solamente de las variedades de la S. scordioides, sino también de la $S$. angustifolia, que es muy cana en Ulldecona y menos tomentosa en Biar. La $\times$ S. Llenasii tipica tiene los tallos cubiertos de pelos más abundantes que la $\times S$. $C_{(l-}$ vanillesiana, $\mathrm{y}$, por otra parte, los dientes foliares son más agudos, las hojas más pequeñas, etc.

$\times$ Sideritis iberica Sennen.

\section{S. linearifolia Lamk. $\times S$. scordioides $\mathrm{L}$.}

Estas dos especies, alejadas por una porción de caracteres muy acusados, dan hibridos por este motivo fáciles de reconocer. La Sideritis linearifolia tiene hojas muy largas y estrechas, agudisimas, enteras, lampiñas; los tallos delgados, muy poco vellosos; la inflorescencia densa, con brácteas más largas que los cálices y lampiñas, estrechas y altas; cálices grandes, con dientes estrechos y largos.

(1) FONT QUER, En recerca de les Sideritis chamaedryfolia i S. leucantha de Cavanilles. (Butlleti de la Inst. Cat. d'Hist. Nat., 1920, pags. ti.t y sigs.) 
La S. scordioides L. tiene, representada por su variedad Cavanillesii (Lag.), hojas cortas y anchas, obtusas o subobtusas, dentadas, vellosas en ambas páginas; los tallos cubiertos de pelo, la inflorescencia formada por verticilastros distantes, con brácteas mitad más cortas que los cálices y vellosas, anchas y bajas; cálices pequeños, con dientes cortos y arqueados hacia fuera. Los hibridos de esas Sideritis tienen hojas estrechas, pero con algunos dientes, más cortas que las de la $S$. linearifolia y vellosas; la inflorescencia floja, con brácteas casi iguales a los cálices y vellosas, de forma más parecida a las de una u otra especie, según los casos; cálices medianos; tallos pubescentes. Estos híbridos han sido hallados en la cuenca superior del Ebro; el primer ejemplar fué descubierto por el hermano SENNEN, cerca de Miranda, el dia 1 de octubre de 1905. No tomamos éste como tipo, por su estado deficiente, a causa de la estación avanzada en que fué herborizado.

\% typica $=\times$ S. iberica Sennen, in schaed.; S. Cavanillesii Lag. $\times$ S. linearifolia Lamk., ap. Sennen, loc. cit.; S. linearifolia Lamk. $<S$. scordioides L. var. Cavanillesii (Lag.).Folia lanceolato-linearia, villosa, dentibus 1-2 minutis in utroque margine munita, vel edentata; verticillastra distantia, grandia, bracteis calycibus subaequantibus, villosis. Hab. prope Cellorigo, ubi leg. Fr. Elias!, 17 julii 1908.

$\beta$ brevibracteata $=S$. Eliasii Sennen, in schaed.; S. Cavanillesii Lag. X S. linearifolia Lamk., ej.; S. linearifolia Lamk. $<$ S. scordioides L. var. Cavanillesii (Lag.), forma altera. A praecedente verticillastris minoribus, bracteis parvis calycibus duplo brevioribus, minus profunde dentatis, differt. Hab. prope Cellorigo (Burgos), ubi cl. Fr. Elias, 15 julii 1915, legit.

Por los caracteres de los verticilastros, brảcteas y cálices es más semejante de la $S$. scordioides var. Cavanillesii que la ๘ typica. Los cálices son muy parecidos a los de ese pariente, por su tamaño, por su forma y por su vestidura.

$\because$ Eliasii $=\times$ S. Eliasii Sennen, in schaed.; S. linearifolia Lamk. X S. Cavanillesii Lag., ej.; S. linearifolia Lamk.> S. scordioides L. var. Cavanillesii (Lag.). - Folia lineari-lanceolata, elongata, villosa, dentibus 1 -3 in utroque margine munita; verticillastra distantia, grandia, bracteis profunde dentatis, villosis, calycibus subaequantibus; calycis dentes longi, erecti. A priore differt foliis longioribus, angustiori- 
busque, magis acutis; bracteis elongatis, profunde dentatis. Hab. prope Bujedo (Burgos), ubi Fr. Elias, 27 junii 1915, legit.

Una cuarta forma dada por el hermano SExwex como $\times$ S. iberica var. minor, apenas se puede separar de la « typica; sólo las brácteas han quedado un poco más cortas en est hibrido, y por este carácter se aproxima a la $\beta$ brevibracteata, que procede también de Cellorigo, leg. Elias, 15 julio de 1915. La primera que fué herborizada por el hermano SENNEN, antes citada, corresponde a un hibrido distinto de los dos ya descritos. Es, de tudis lis yue hemmvisto de este grupo, el que tiene las hojas menos vellosas y menos dentadas. Lo proponemos así :

o Sennenii $=\times$ S. iberica Sennen, in schaed. (1905); S. pungens Benth. $X$ S. scordioides L., ej., loc. cit.; S. linearifolia Lamk. > S. scordioides L. var. Cavanillesii (Lag.), forma altera.-Folia lanceolato-linearia, subintegra, nervi excepti, glabra, luteo-virens; verticillastra approximata vel laxe imbricata, parva, bracteis calycibus aequantibus, subglabris. Hab. prope Miranda de Ebro, ubi cl. Fr. Sennen, 1 oct. 1905, legit.

\section{Sideritis Pardoana Font Quer.}

\section{S. ilicifolia Willd. $\times$ S. spinulosa Barn.}

Descubrió este híbrido nuestro amigo D. Fernando A. Rubió en su excursión por tierras aragonesas el año pasado. Hibrido muy difícil de distinguir, porque está producido por la var. subspinosa (Cav.) de la Sideritis spinulosa Barn.; de gran semejanza con la S. ilicifolia Willd. La forma descrita la propusimos así:

\% typica $=$ XS. Pardoana Font Quer, Bol. Soc. Iberr. de C. N., 1920, pág. 141; S. ilicifolia Willd. <S. spinulosa Barn. var. subspinosa (Calv.), ap. ej., loc. cit. Hab. inter Fresneda et Calaceite (Aragonia austr.), ubi F. A. Rubió, d. 6 jul. 1919, legit.

\section{Sideritis Viciosoi Pau.}

\section{S. angustifolia Lag. $\because \mathrm{S}$. inconna $\mathrm{L}$.}

En la tierra baja del reino de Valencia es frecuente en los yermos y matorrales la Sideritis angustifolia Lag., que llega hacia 
el Norte hasta Cataluña, en San Carlos, Ulldecona y La Cenia, y por el Sur va hasta la parte meridional de Andalucía. Es una de las especies más polimorfas del género, y es posible que alguna de sus formas sea la verdadera $S$. Tragoriganum de LAgASCA, especie muy dudosa.

Es común también en Valencia la $S$. incana $L_{i}$, pero, a diferencia de la anterior, vive preferentemente en los montes y se la encuentra rara vez a menos de 500 metros de altitud. Es también polimorfa, pero asi como la $S$. angustifolia no tiene sus formas localizadas, las de la $S$. incana son bastante fijas con frecuencia, y cada comarca tiene las suyas propias. Muy buena variedad valenciana es la S. sericea Pers, de hojas y tallos cubiertos completamente de lana blanca; y una raza excelente es la $S$. edetana Pau, de flores purpurinas, propia del macizo de Chiva; en otros sitios de Valencia y Murcia crecen formas medias entre las que corresponden a la $S$. sericea y las alampiñadas de las sierras de la provincia de Málaga.

La S. incana no asciende tanto a lo largo de la costa como la anterior, pues no parece pasar de la provincia de Valencia, pero entra más hacia la parte central de la Península, llegando hasta más allá del Duero en tierras de Burgos, y por el Sur se extiende hasta la provincia de Cádiz.

En localidades montuosas del reino valenciano no es raro hallar las dos Sideritis. En la sierra de Chiva, por ejemplo, la S. angustifolia, tan común en los alrededores de aquella población, empieza a escasear cuando se llega a los 500 metros, justamente al aparecer las primeras matas de $S$. incana; pero en una faja bastante ancha conviven las dos especies, y es alli donde no son raros los híbridos.

El primero de este grupo fué descubierto por Carlos Vicioso el 23 de junio de 1915, y publicado en marzo de 1916 en el Boletin de la Real Sociedad Española de Historia Natural, con el nombre de $\times S$. Viciosoi Pau. El-año pasado nuestras exploraciones (t) las provincias de Valencia y Murcia nos han proporcionado algunos otros, producidos por variedades distintas de la $S$. incana y formas diversas de $S$. angustifolia; todos ellos son los que figuran a continuación :

\%. typica (lám. XIII, fig, 2) $=\times$ S. Viciosoi Pau, ap. Vicioso, Plantas de Bicorp, Bol. R. Soc. Esp. de H. N., 1916, pág. 143; $S$. incana var. sericea $\times$ S. Tragoriganum C. Vicioso; S. an- 
R. Soc. Esp. de Hist. Nat. $-T$. del $500^{\circ}$ aniv. 200 Láma X.

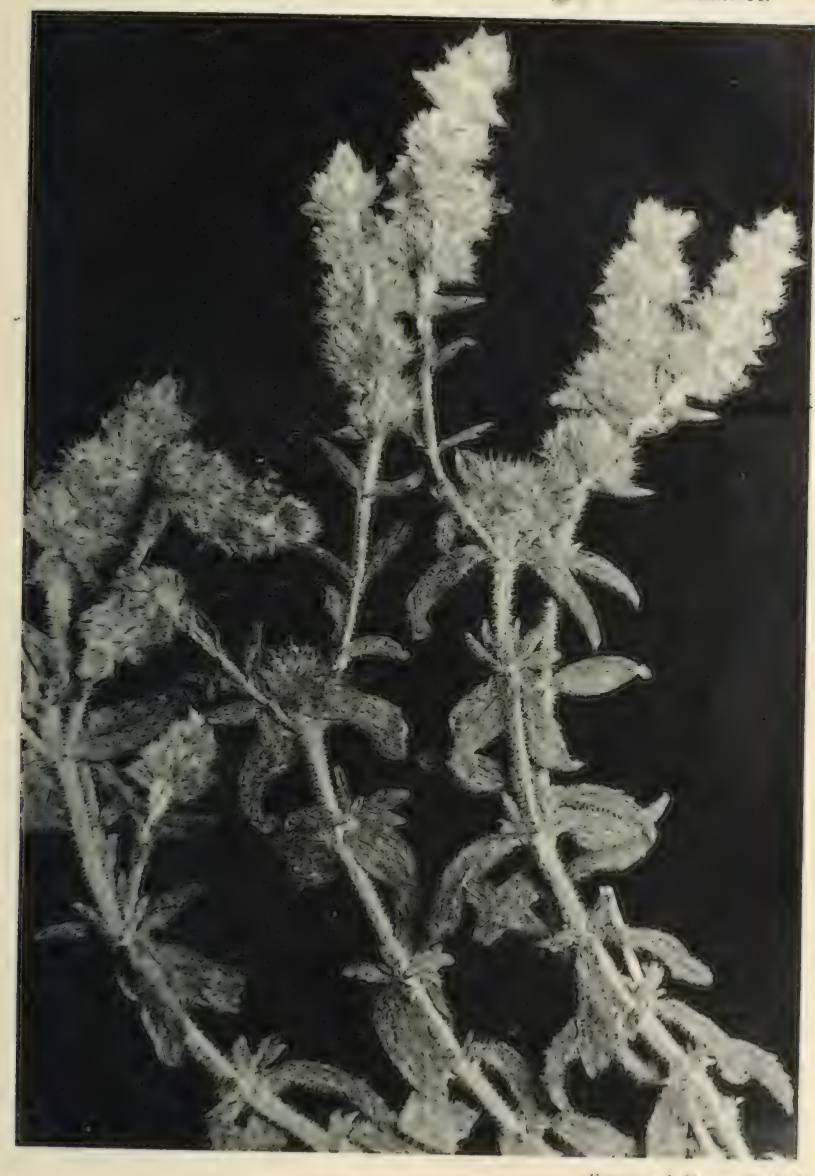

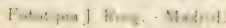

- Sideritis difficilis F. QUER, $\beta$ fallax ( $\%$ tamaño natural). 

R. Soc. Esp. de Hist. Nat. $-T$. del $500^{\circ}$ aniv. Zy I Lámina XI.

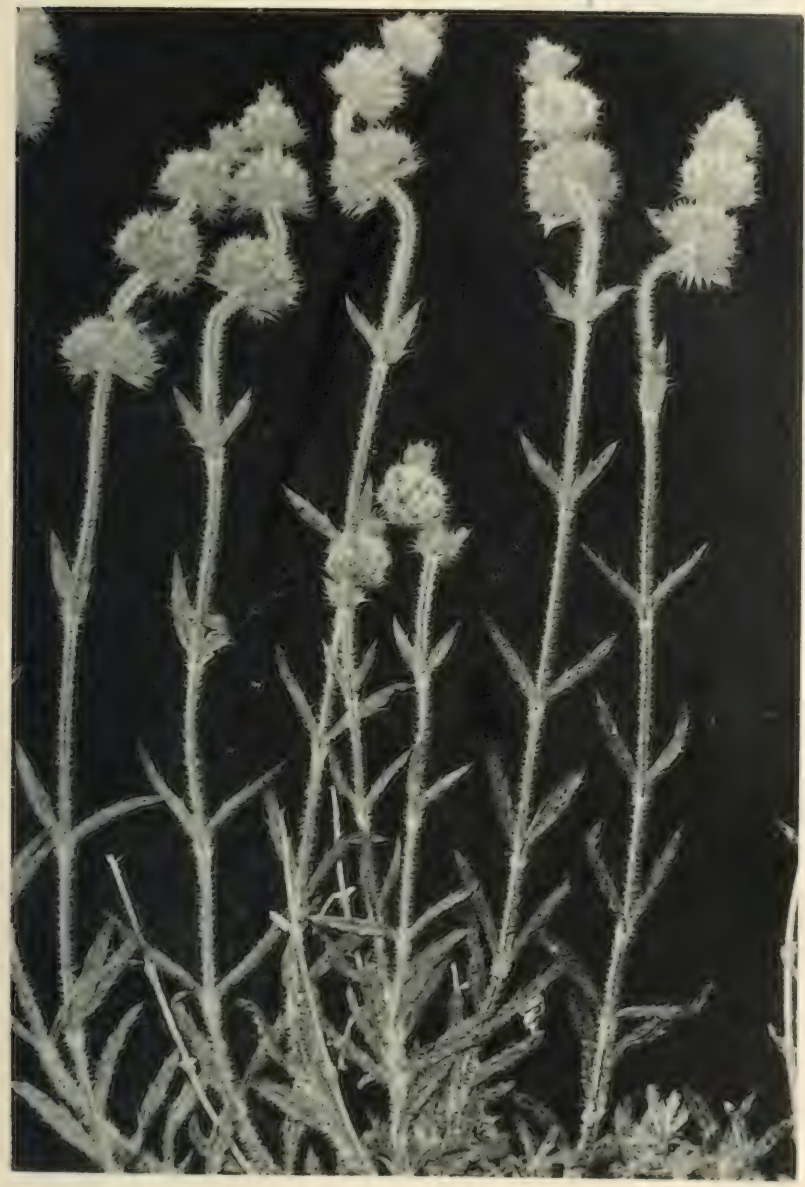

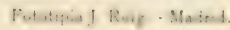

X. Sideritis Costae F. QUER, $\beta$ gracilis ( $/ / 3$ tamaño natural). 



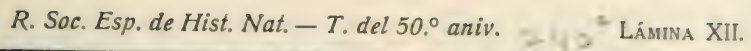

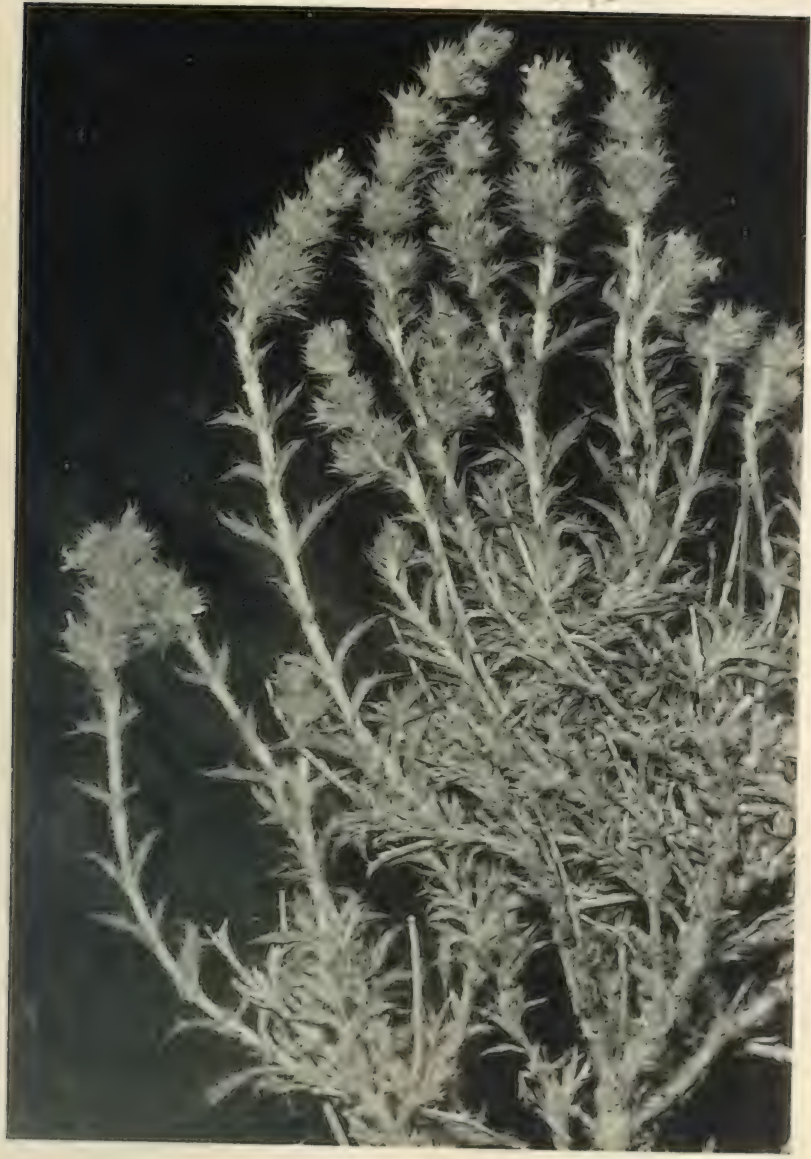

Fototipia J. Roig. - Madrid.

$\times$ Sideritis Loscosiana F. QUeR, a typica ( $\%$ tamaño natural). 

R. Soc. Esp. de Hist. Nat. - T. del $500^{\circ}$ aniv. - Limorna XIII.

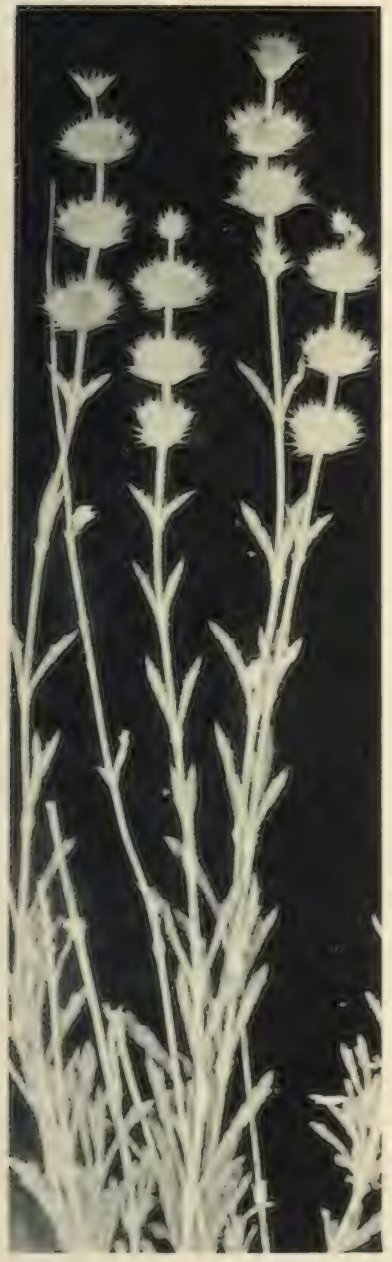

Figersa 1

* Sicierits Balce: F. Qus, w weice $(\%$ tamanos satural).

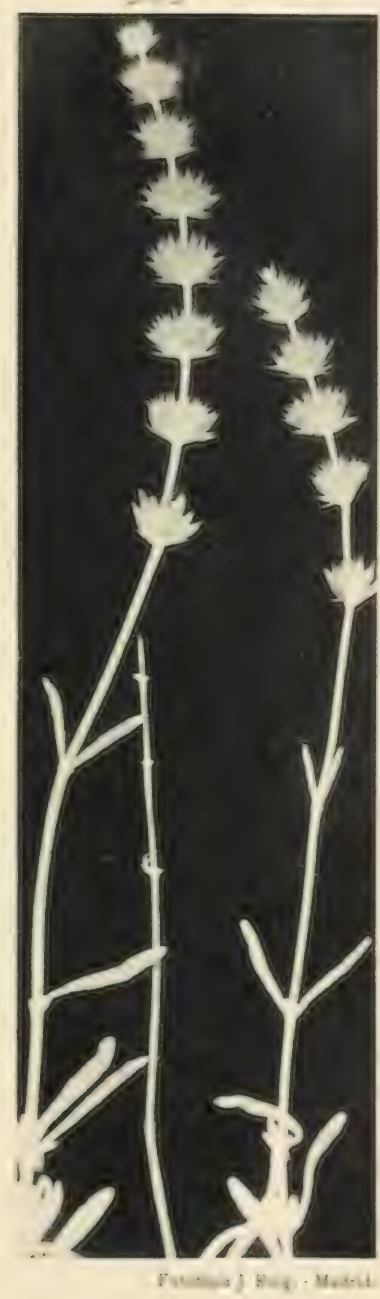

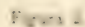

- Siferites Vicesua lose, a cypir:

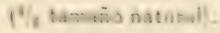



gustifolia Lag. <S. incana L. var. sericea (Pers.) Willk. Bicorp (Valencia), leg. C. Vicioso, 23-VI-1915.

i murcica $=S$. angustifolia Lag. <S. incana L. - Habitu Sid. incana, sed foliis acutis mucronato-spinulosis, bracteis latioribus, profunde dentato-spinosis, floribus luteis. Hab. prope Almansa (.Murcico Resno) ad pedem montis. Hurón dictos (non Mugrón), $850 \mathrm{~m}$. alt., ubi legi d. 3 junii 1920.

Bastante distinta de la $\times S$. Viciosoi « typica, pues la nuestra tiene sólo 1-2 verticilastros, carácter que la aproxima más a la $S$. incana; en cambio las brácteas son más parecidas a las de la S. angustifolia. La $S$. incana de Almansa corresponde a una forma que llamamos intermedia, porque lo es entre las formas alampiñadas andaluzas y la var. sericea (Pers.) Willk., que ha engendrado la $\times S$. Viciosoi a typica.

; affinis $=S$. angustifolia Lag. $<S$. incana L., raza edetana (Pau).-Sid. Viciosoi « typica affinis, sed magis elata, tenuissime incana, corolla sordide flava. Hab. in Regno Valentino, Sierra de Chiva, $l$. $d$. Fuente del Enebro, $500 \mathrm{~m}$. alt., ubi d. 7 julii 1919 , legi.

Sumamente parecida a la S. Viciosoi \% typica, la ; affinis producida por la raza edetana Pau pro var., de tallos largos y alampinados y flores purpurinas. tiente las flores más pequenas que dicha raza edetence, perro con el labio superior profundamente bilobulato como las de aquélla, 'y ambos labios amarillo sucio, con la garganta y tubo corolinos de un color vinoso, y estrias de este mismo color, que penetran en los labios; es mucho menos cana que la S. Viciosoi « typica.

is stricta $=S$. angustifolia Lag. $\times$ S. incana L., raza edetana (Pau), forma rigida. - A Sideritide angustifolia et Sideritide incana prole edetana exacte intermedia; foliis brevibus obtusisque, mucronato-spinulosis, verticillastris 3-9 approximatis, bracteis latis, regulariter dentatis, dentibus calycis triangularis in spinula $1 \mathrm{~mm}$. longa terminatis; corolla sordide lutea, purpurescente. Caulis 20-25 cent., strictus, tenuiter incanus; bracteae calycesque e pilis, inter eos parentes mediis, vestiti. Hab. prope Siete Aguas, Sierra de Chiva, ubi 8 julii 1919, legi.

: Aemiliae $=$ S. angustifolia Lag. $>$ S. incana L., raza edetana (Pau). - Foliis brevibus, angustis, acustisque, mucronato-spinulosis; verticillastris 2-5, bracteis minutis ut in S. inca- 
na; calycis ut in S. angustifolia; corolla sordide lutea. Caulis 20 cent.; habitu S. angustifolia. Hab. circa Siete Aguas, ubi, cum Aemilia uxore nostra, legimus, d. 8 julii 1919.

\section{Explicación de las láminas X a XIII.}

Lám. X: X Sideritis difficilis F. Quer, $\beta$ fallax, $3 / 6$ tam. nat.

Lám. XI: X Sideritis Coslae F. Quer, $\beta$ gracilis, $5 / 6$ tam. nat.

Lám. XII: X Sideritis Loscosiana F. Quer, a typica, $5 / 6$ tam. nat.

Lám. XIII.-Fig. I : $\times$ Sideritis Baluei F. Quer, a typica, $5 \%$ tam. nat.-Fig. $2: \times$ Sideritis Viciosoi Pau, a typica, $5 / 6$ tam. nat.

\section{UREDALES (ROYAS) DE LAS PROVINCIAS DE CASTELLÓN $Y$ VALENCIA}

POR

\section{F. BELTRÁN}

Durante mi estancia en el verano de 1913 en la Estación alpina de Biología que en el Guadarrama posee el Museo Nacional de Ciencias Naturales, tuve la suerte de pasar algunas semanas con mi querido amigo y sabio micólogo D. Romualdo (inNz.A.E\%. FRA(ios(), ocupado a la sazón en el estudio micológico de la referida sierra. La ocasión que se me ofrecía para estudiar micromicetos no podía ser más favorable, conviviendo con maestro tan conspicuo, y al efecto, en la continua observación de la Naturaleza, recogiendo ejemplares, y en aquellas horas de asiduo trabajo de laboratorio, que tan insensiblemente como agradables se deslizaban en aquella paz y soledad de la sierra, haciendo preparaciones microscópicas y manejando libros de clasificación de las expresadas criptógamas, logré ejercitarme en el estudio de tan curiosisimos vegetales y que se me despertase en favor de los mismos vivísimo interés, gracias a las incesantes lecciones de tan bondadoso profesor. Ocasión es ésta para que le exprese el profundo agradecimiento que siento, no sólo por las aludidas atenciones, sino también por las molestias continuas que le ocasioné desde mi alejamiento del Mluseo Nacional de Ciencias Naturales de Madrid, consultándole frecuentemente dudas 
que me surgian y que me resolvia con su reconocida y habitual competencia. De no haber contado con tan valiosa ayuda, no me atrevería a dar con seguridad algumas especic- de ate mosimatir trabajo, en cuya determinacion tropecé con dificultad a que silio am especialista de su experiencia y de su documentacion en bibliognfía y herbarios puede esclarecer.

Varios años llevo ya reuniendo materiales de la flora valenciana, entre los cuales figuran una cantidad no despreciable que hacen referencia a uredales, conocidos vulgarmente con el numbin. If royas, y sobre las cuales ha de versar esta nota.

Harto conocido es el enorme interés de estos hongos en Patología vegetal; las pérdidas que ocasionan son asombrusa-; cmpero permitaseme haga mención de los estragos enormes que produce en la región valenciana la roya que vive en Fabn imlsaris thaha). que es el uredal que más perjudica en tal region. IJe visto algum años perderse completamente la cosecha de varion pueblos; sirva de ejemplo el año 1914, durante el cual campos extencos (de la Plume (n) particular) fueron tan castigados, que murieron las plantas mucho antes que el fruto madurase.

Con frecuencia es atacada la misma planta intensamente desde muy joven, lo cual se acusa por el color blanquecino que toman las hojas, que anunciándole al labrador un mal augurio, no es raro verle on la mayor decisión arrancar la joven planta. para sendorar wh especie diferente. Asi lo observamos alguna vez en Museros y huerta de Valencia. Estudiando la planta enferma, sólo algún raro uredosoro anuncia su presencia al exterior; en cambio, la observación microscópica nos pone de manifiesto el micelio de la roya que consume a la planta. Ejemplares enfermos sonservadio en at halm-

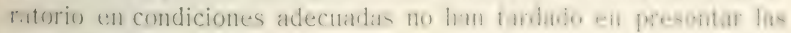
I'*queñas manchas uredosporiferas caracteristicas de la enfermedad.

Merece también ser citada la roya del guisante, que habitualmente merma extraordinariamente la producción. Este mismo parisito, que también vive en el Maestrazgo sobre Lathurus satiuns (almortas, jigas), llega alguna vez a anular la cosecha, segin hemos tenido ocasión de observar en los modestos cultivos que de tal especie se hacen en Benasal, Culla, etc.

$$
*^{*} *
$$

Los uredales citacios hasta la fecha del territorio al yue se refiere 
este trabajo llegan al número de 31 especies, según se consigna a continuación, con expresión de las matrices en que se encontraron y autores que las publicaron.

El eximio botánico y prestigioso catedrático de la Facultad de Farmacia D. Blas LÁzARO, en su Noticia de algunos ustilagináceos y uredináceos de España (1), menciona la

1. Puccinia Acanthi en Onopordon Acanthium, Nules, leg. Beltrán.

Don Romualdo González Fragoso, en su Contribución a la Flora micológica española (2), indica las especies que siguen, recogidas en Segorbe por el insigne botánico D. Carlos PAU :

2. Puccinia Chondrillina en Chondrilla juncea.

3. Puccinia Sonchi en Sonchus tenerrimus.

4. Puccinia Menthae en Mentha aquatica, M. rotundifolia y $M$. aquatica $\times$ rotundifolia.

5. Puccinia annularis en Teucrium Pseudo-Chamaepytis.

6. Puccinia triticina en Triticum vulgare.

7. Uromyces appendiculatus en Phaseolus vulgaris.

8. Coleosporium Inulae en Inula viscosa.

9. Coleosporium Senecionis en Senecio vulgaris.

10. Aecidium Euphorbiae en Euphorbia Peplus.

11. Roestellia cancellata en Pyrus communis.

El mismo Sr. Fragoso, en Micromicetos varios de España y de Cerdaña (3), publica las tres especies que siguen:

12. Puccinia Pruni-spinosae en Prunus domestica y Prunus sp., Segorbe, leg. Pau.

13. Uromyces Rumicis en Rumex pulcher, Montes de Bicorp, leg. Vicioso.

14. Phragmidium Fragariastri en Potentilla reptans, Segorbe, leg. Pau.

En una nota del Sr. Fragoso insertada en el Boletin de la Real Sociedad Española de Historia Natural (4), se menciona el

15. Peridermium Pini en Pinus Halepensis, Segorbe, leg. Pau.

(1) Trab. del Mus. Nac. de Cienc. Nat. Ser. Bot., núm. 2, 1913.

(2) Bol. de la R. Soc. Esp. de Hist. Nat., págs. 137-152, 1913.

(3) Trab. del Mus. Nac. de Cienc. Nat. Ser. Bot., núm. 9, 1916.

(4) Tomo XVI, págs. 277-278. 
El distinguido ingeniero de montes M. Aulló y Costilla, en Resumen de los trabajos verificados durante los años 1911 a 1916 por la Comisión de la Fauna Forestal Española, cita

15 bis. Peridermium Pini en Pinus maritimus, Portaceli.

Por fin, en un nuevo trabajo del Sr. Fragoso, titulado Enumeración y distribución geográfica de los uredales conocidos hasta hoy en la Peninsula Ibérica e islas Baleares (1), reune todos los datos que se acaban de exponer, con la pequeña variante de agregar al Peridermium Pini su especie afín

16. Peridermium Cornui en Pinus Halepensis, Segorbe, leg. Pau.

Indica además las especies que siguen:

17. Puccinia Maydis en Zea Mays.

18. Puccinia purpurea en Sorghum halepense.

19. Puccinia Porri en Allium sativum y Allium sp.

20. Puccinia Silenes en Silene inflata.

21. Puccinia Eryngii en Eryngium campestre.

5 bis. Puccinia annularis en Teucrium aureum, Pico Caroche, leg. Vicioso.

22. Puccinia annularis f. Chamaedrys en Teucrium Chamaedrys.

23. Puccinia Cardui-pycnocephali en Carduus pycnocephatus.

24. Puccinia Cirsii en Cirsium Monspessulanum.

25. Uromyces Junci en Juncus sp.

26. Uromyces Polygoni en Polygonum Bellardi, Bicorp, leg. Vicioso.

27. Uromyces Fabae en Faba.

28. Uromyces excavatus en Euphorbia pubescens.

29. Uromyces monspessulanus en Euphorbia serrata.

30. Uromyces sublevis en Euphorbia polygalaefolia.

31. Melampsora Gelmi en Euphorbia falcata, Bicorp, Vicioso.

32. Puccinia Cardui-pycnocephali en Carduus tenuiflorus, Chiva, leg. Font.

33. Uromyces Ononidis en Ononis repens, Bocairent, leg. Font Quer, y en Ononis spinosa, Villarreal, leg. Pau.

(1) Trab. del Mus, Nac, de Cienc, Nat. Ser, Bot., mím, 15, 1918. 
Estas especies que se acaban de indicar sin localidad proceden todas de Segorbe, leg. Pau, excepto la forma en Teucritum Chamaedrys, de Corachar, leg. Paı, y en Euphorbia serrata, Carlet, leg. Pau (1).

En estas especies que acaban de enumerarse figuran las cuatro siguientes, que no logré recolectar:

1. Puccinia Acanthi. Esta especie, que yo mismo recogí y regalé al profesor LÁzARO, no pude verla con posterioridad a la fecha de su publicación, debido sin duda a que en el sitio en que se recogió desaparecieron los Onopordon en donde vivía.

2. Raestellia cancellata.

3. Peridermium Pini.

4. Peridermium Cormui.

También entre las matrices citadas existen algunas que yo 10 cogi o recolecté, atacadas de enfermedad diferente. Helas a continuación:

1. Sunchus tenerrimus; la Puccinia Sonchi que en esta planta se cita, la encontré en otras especies de Sonchus.

2. Teucrium aureum; repito lo anterior.

3. Mentha aquatica $\times$ rotundifolia; idem id.

4. Prunus domestica y Prunus sp.; idem id.

5. Polygonum Bellardi; idem id.

6. Euphorbia pubescens, y

7. Euphorbia polygalaefolia. Aunque recolecté enfermas estas dos especies de Euphorbia, la roya era de especie diferente.

El número de especies por mi recogidas es mucho mayor, llegando a 120, y las matrices observadas son-157, figurando lo mismo en unas que en otras especies muy interesantes y hasta algunas nuevas para la Ciencia o para la flora peninsular. Aunque los expresados números representen una cantidad respetable de especies, seguro distan mucho del total de las que viven en la región. Para tener un conocimiento acabado de las mismas necesitanse repeti-

(1) Terminado este trabajo, llega a mis manos una publicación del Sr. Fragoso, titulada Algunos uredales del herbario del Museo de Ciencias Naturales de Barcelona, en la que se citan dos especies que deben figurar a continuación de las 31 que indicába citadas de las dos provincias a que se refiere esta nota. 
das excursiones y observaciones muy detenidas, no solamente en localidades que yo no visité, sino hasta en las que me son mejor conocidas. Dificil me seria señalar alguna excur vion (no siendn muy pequena), aun referente a localidades por mi harto exploradas, que no me haya proporcionado algún nuevo dato sobre los hongos en cuestión. Por otra parte, téngase en cuenta que sierras enteras y cuencas extensas de las provincias que estudio no recibieron mi mirada. Cúmpleme, sin embargo, manifestar que entre las localidades visitadas figuran los habitat más variados que pueden scialarse en la región; sirvan como ejemplo: Fredes y sus altas montañas, expresión de lo más frio y septentrional del reino valenciano, y Gandía, uno de los rincones más meridionales y abrigados de la provincia de Valencia; localidades exploré que reciben las brisas del Mediterráneo, como Burriana, Nules, huerta de Valencia, etc., y otras como Culla, Benasal y Andilla, que lindan o están muy próximas de Aragón; contrastan con las lomas más áridas del Maestrazcro algunos parajes de la Sierra Espada. de exuberante veretación, y no pocas localidades castellonenses bañadas por las aguas del río Cenia.

Nos demostrará que el número de royas existentes en la región excede a las que yo encontré, la consideración de no figurar entre estas últimas algunas que viven en plantas tan abundantes en estals tierras como el lentisco, Phillyrea angustifolia, pinos, caña común, especies de Carex, gladiolos, juncias, etc., y que se citan de profusión de localidades españolas.

Sigue a esta larga y pesada introducción la relación de uredales valencianos existentes en mi herbario, todos ellos recogidos por mi, salvo tres especies que poseo de diferente procedencia con respecto a las por mi recolectadas, y que debo a los buenos amigos E. Moroder, R. Trullenque y C. Garcia. El orden que sigo es el adoptado por el Sr. Fragoso en su citada obra (1).

(1) Enumeración y distribución geográfica de los uredales, etc. 


\section{Pucciniáceos.}

\section{Puccinia Link.}

\section{En Gramináceas.}

\section{1. - Puccinia Agropyri Ellis et Everhart.}

En hojas de Agropyrum campestre, facies urédica y teleutospórica, Nules. Esta matriz es nueva para la Península Ibérica.-En Agropyrum littorale, uredosoros, dehesa de la Albufera. Matriz nueva para la flora mundial.

2. - Puccinia agropyrina Eriksson, Ann. Sc. Nat, ser. VIII, IX, p. 273.Sacc., Syll., XVII, p. 384; Mon Ured., I, p. 712.-Fisch., Ured. der Schweiz, p. 365. - Grove, Brit. Rust Fungi, p. 263.

En facies urédica y teleutospórica, sobre hojas de Agropyrum repens. Es frecuente encontrarla en Nules, Burriana, Moncófar y Villarreal. Especie nueva para la flora de la Península Ibérica.

3. - Puccinia Baryi (Berk. et Br.) Winter.

En hojas de Brachypodium distachyum, facies urédica y teleutospórica, Játiba.

\section{4. - Paccinia Cesatii Schroeter, f. Heteropogonis nov.}

A typo differt, uredosoris epi vel hypophyllis aurantiacoflavidis; $21-30 \times 16-19 \mu$, poris germinativis usque 6 ; teleutosporis ellipsoideis, apice rotundatis vel conico-attenuatis, medio non vel vix constrictis, basi rotundatis vel conico-attenuatis, 33-42 $\times 15-18 \mu$, pedicelo gracili, brevissimo. In foliis Heteropogonis Allionii, in Artana (Castellon) in loco dicto "aigues vives».

\section{5. - Puccinia Cynodontis Desmazières.}

En hojas de Cynodon Dactylon, Nules. Aunque abundantisima esta crraminea, sólo una vez pude encontrar la roya que la parasitiza. 
6. - Puccinia Fragosoi Bubák, in Fungi nonnulli novi hispanici, Hedwigia, Bd. LVII, p. 2 (Sep.), 1915. - González Fragoso, in Adic. a la Micofl. esp., Bol. Soc. Esp. Hist. Nat, 1915, p. 340.

En hojas de Koeleria hirsuta, facies urédica y teleutospórica, Buñol, Villarreal y Nules. Cítase esta especie por vez primera en Koeleria hirsuta.

\section{7.- Puccinia Fragosoana sp. nov. (fig. 1).}

Soris minutis 1,2 mm. diam., elongatis, solitariis vel in lineas longitudinales confluentibus, brunneo-obscuris, epi vel hypophyllis, in maculis diffusis bruneo-pallidis; uredosporis multiformis, subglobosis, subtriangularibus, ovoideis, ellipsoideis piriformibus, brunneo-castaneis, verruculosis, $24-45 \times 16-27 \mu$, membrana apice incrassata usque $8 \mu$, poris germinativis $4-j$ instructis; pedicello breve, hyalino, fragile, paraphysibus numerosis, hyalinis, sed apice subflavidus vel melleis, vel brunneolis, usque ad 60 н. long., capitatis in apice subesferoideis vel piriformibus, usque $20 \mu$ diam.; teleutosoris hypophyllis, in maculis pallide brunneis, saepe numerosis, punctiformis, vel oblongis, usque $0,5 \mathrm{~mm}$. longis, sparsis vel confuentibus, quandoque subseria-

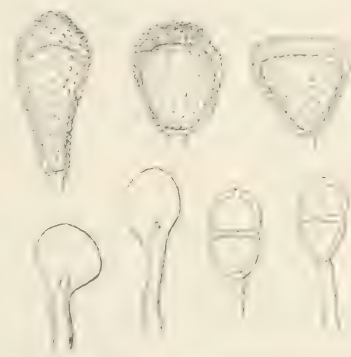

Fig. 1.-Puccimiu Praguseum Beltrán: uredosporas, parafisos y teleutosporas.

tis, primum tectis, dein epidermide rupta cinctis, atro-ferrugineis, teleutosporiis subglobosis ovoideis, oblongis vel ellipsoideis, 2.-37 $\times 1+-22 \mu$, non vel vix constrictis, brunneocastaneis, episporio egaliter incrassato usque 1,5 $\mu$; poro superiore prope apicem, inferiore c. septum; pedicello hyalino, crasso, saepe laterali usque $48 \mathrm{~m}$ longis. In foliis Imperatae cylindricae, in dehesa de la Albufera, huerta de Valencia, Museros, Moncofar, Nules, Burriana, Villarreal. A clarissimo micologo Dr. Fragoso dicata species. 
8. - Puccinia glumarum (Sclim.) Erikss, et Henn.

En hojas de Brachypodium pinnatum, facies urédica y teleutospórica, dehesa de la Albufera. Matriz nueva para la flora mundial.

9. - Puccinia glumarum (Schm.) Erikss, et Henı., f. Bromiicola (Sacc.).

En hojas de Bromus maximus, facies urédica y teleutospórica, Benasal.-En hojas de Bromus matritensis, facies urédica y teleutospórica, Nules, Burriana, Villarreal y huerta de Valencia. - En hojas de Serrafalcus machrostachys, facies urédica y teleutospórica, Burriana y Villarreal._En hojas de Serrafalcus mollis, facies urédica, Burriana; facies urédico-teleutospórica, Nules y huerta de Valencia.

10. - Puccinia glumarum (Schm.) Erikss, et Henn., f. Laguri Sacc. et Trott., in Fungi Tripol., Ann. Myc., XI, 1913.

En hojas de Lagurus ovatus, facies urédica y teleutospórica, Játiba. En España sólo se ha encontrado esta forma en Cataluña y Baleares.

11.-Puccinia glumarum (Sclım.) Erikss. et Henn., f. Loliicola (Sacc.).

En hojas de Lolium strictum, facies urédica y teleutospórica, Nules, Moncófar, Villarreal y Sagunto.-En hojas de Lolium rigidum, var. tenue, en las mismas facies, Nules.

\section{2. - Puccinia graminis Pers.}

En hojas de Triticum sativum, facies urédica y teleutospórica, Nules. Es curioso poner de manifiesto que en los trigos cultivados no pude ver este hongo; la cita que hago es de unos pies que crecian espontáneamente en la línea férrea.-En hojas de Panicum repens, facies urédica. Con frecuencia se ve este hongo en la huerta de Valencia, dehesa de la Albufera, Catarroja, Museros, Nules, Moncófar, Chilches, Villarreal, Burriana y demás huertas. Matriz nueva para la Península Ibérica.-En hojas de Setaria verticillata, facies urédica, Nules y alrededores de Valencia. Esta matriz es nueva para la Península. 
13. - Puccinia holcina Erikss.

En hojas de Holcus lanatus, Benasal y Fredes, en sus dos facies.

14. - Puccinia Imperatae (P. Magn.) sp. nov.; Sin. Uredo Imperatae P. Magnus, in Verhandl.Zool. Bot. Ges., Wien, 1909, p. 439, tab. III, f. 17-21.-Sacc., Syll. Fung., XVI, p. 361; Hariot, Les Uréd., p. 309.

Teleutosoris punctiformibus, ellipticis vel oblongis $1 \mathrm{~mm}$., plerumque confluentibus in linneas longitudinaliter formantes, castaneis, pulverulentis, epi vel hypophyllis in maculis pallidis, brunneis, vel sine maculis; teleutosporis ovoideis, ellipsoideis, subglobosis vel pyriformibus elongatis, brunneoluteis, non vel vix constrictis, 30-45 $\times 19-26 \mu$, apice incrassato usque 7 u, poro germinativo loculi subapicali vel apice approximato, loculi inf. contiguo septis; pedicello longissimo, usque $125 \mu$, hyalino, firmo, plerumque insertis. In foliis Imperatae cylindricae, dehesa de la Albufera, huerta de Valencia, Villarreal, Nules, Burriana.

Esta especie sólo era conocida en la facies urédica, que describió Magnus de $\mathrm{Pa}$ lestina. En esta facies la encontró el profesor CABAllero en Cabo de Salóu (Tarragona), y, que yo sepa, no volvió a señalarse de otra localidad europea. En esta misma facies es frecuente encontrarla en las localidades en que la he recogido; pero para conseguirla en facies teleutospórica, hay que esperar el final del otoño o los albores del invierno.

Tenemos, pues, dos especies de royas

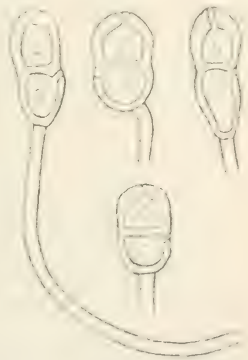

Fig. 2. - Puccinia Imperatne (P. Magnus) Beltrin : teleutosporas. sobre la Imperata cylindrica, muy fáciles de distinguir a simple vista, merced a la presencia de los uredosoros anaranjados, en la Puccinia Imperatae; en Pucc. Fragosoana son pardo-obscuros, más pequeños y no prominentes, como en aquella especie, sino, por el contrario, asoman ligeramente en la hendidura alargada que producen en, la epidermis.

Observadas ambas especies al microscopio, resaltan más patentemente los caracteres diferenciales: en Pucc. Imperatae, el pedicelo es larguísimo, y más corto en Pucc. Fragosoana, presentando 
ésta el episporio igualmente engrosado, y aquélla ofrece un manifiesto espesamiento en el ápice; la forma también es muy diferente. Para diferenciar las uredosporas basta atender al ápice, notablemente engrosado en Pucc. Fragosoana, el cual falta en la otra especie.

15. - Puccinia Andropogonis-hirti (Maire) Beltrán, sp. n. - Maire, in Bull. Soc. Myc. de France, vol. XXI, p. 162.-Sacc., Syll. Fung., XXI, p. 810. - Hariot, Les Uréd., p. 309. - Maire, in Mycoth. Boreali-Afr., n. 66, et in Schedae (Bull. Soc. d'Hist. Nat. de l'Afr. dı Nord, 1915, p. 129).

Telentosoris hypophyllis in maculis brunneis, primum tectis, demun epidermide rupta cinctis, minutis 0,5-1 $\mathrm{mm}$. long., solitariis vel gregariis, linneas longitudinales $2 \mathrm{~mm}$. formantes, ferrugineo-atris; teleutosporis parafisibus uredosporisque
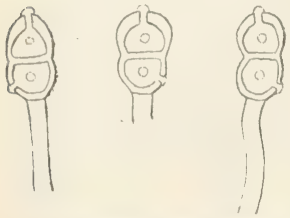

Fig. 3.-Puccinia Andropogonis-lirti (Maire) Beltrán: teleutosporas.

plerumque inmixtis, ochraceis, loculo superiore plerumque castaneis, ovoideis, ellipticis vel oblongis, utrinque rolundatis, raro apice aut versus basim attenuatis, apice leniter incrassato usque $4,5 \mu$, aut non, medio non vel modice constrictis, raro satis, $30-37 \times 19-25 \mu$, poris germ. papilla hyalina instructis, superiore apicale, inferiore in medio loculi aut basim versum aproximato, pedicello hyalino, crasso, usque $67 \mu$ long., quandoque oblique insertis. In foliis Andropogonis hirti, Villavieja et Nules.

\section{6. - Puccinia Lolii Niels.}

En hojas de Avena barbata, frecuente en Nules, Burriana, ViIlarreal, Moncófar, huerta de Valencia y Puzol, en facies urédica y teleutospórica.-En Avena sterilis en iguales facies, Játiba. En Avena sativa en las mencionadas facies, Puebla de Benifazá.

\section{7. - Puccinia Magnusiana Koern.}

En hojas y vainas de Phragmites communis, facies urédica y teleutospórica, Nazaret, proximidades de la Albufera y Nules. Los 
Ranunculus, en que se da la facies ecídica, viven en los mismos parajes que los Phragmites, pero no tuve la suerte de encontrarlos atacados.

\section{8. - Puccinia Maydis Berenger.}

En hojas de Zea Mays es frecuente en la huerta de Valencia, Nules, Villarreal y IIoncófar, pero sin que ataque a la planta con gran intensidad. Se encontró en facies urédica y telentospúrica. No pude encontrar su facies ecídica, que se da en Oxalis corniculata, planta común en esta región.

19. - Puccinia Phragmitis (Schum.) Koern.

En Phragmites communis es muy frecuente en los almarjales de la huerta de Valencia, Chilches, Nules, Moncófar, Almenara, Catarroja, contornos de la Albufera y Gandia.-En Rumex pulcher, facies ecidica no es tan frecuente encontrarla, pero poseo ejemplares de Nules, Moncófar, huerta de Valencia y dehesa de la Albufera.

\section{0. - Puccinia Poarum Niels.} Nules.

En hojas de Poa nemoralis, facies urédica y teleutospórica,

\section{1. - Puccinia purpurea Cooke.}

En Sorghum halepense, facies urédica y teleutospórica, $\mathrm{Nu}$ les.-En Sorghum vulgare, huerta de Valencia.

22. - Puccinia simplex (Koern.) Erikss.

En hojas y vainas de Hordeum vulgare, facies urédica y teleutospórica, Nules. - En hojas y vainas de Hordeum murinum, huerta de Valencia, Nules, Burriana, Villarreal y Moncófar.

23. - Puccinia Triseti Erikss.

Hojas y vainas de Trisetum neglectum, ambas facies, Nules, Burriana y Villarreal.

\section{4. - Puccinia triticina Erikss.}

Esta roya, en facies urédica y teleutospórica, es frecuente en el trigo cultivado; la poseo de la huerta de Valencia, Catarroja, Museros, Moncófar y Nules. 


\section{En Ciperáceas.}

25. - Puccinia Scirpi DC.

En Scirpus lacustris, Nules, Moncófar, Chilches y proximidades de la Albufera de Valencia.

\section{En Juncáceas.}

26. - Puccinia rimosa (Link) Winter.

En Juncus maritimus, facies urédica y teleutospórica, dehesa de la Albufera, Nules, Moncófar y Chilches, en los parajes paludosos contiguos a la playa. Esta especie fué encontrada por Haire en Mallorca sobre la misma planta, pero jamás se citó de la Península.

\section{En Liliáceas.}

27. - Puccinia Allii (DC.) Rudolphi.

En Allium Porri es frecuentísima en Nules, Moncófar, Villarreal, Burriana y huerta de Valencia.-En Allium sativum, Nules.

\section{8. - Puccinia Asphodeli Mougeot.}

En Asphodelus cerassiferus, Fredes, en todas sus facies. Es matriz nueva para la Península Ibérica.

29. - Puccinia Barbeyi (Roum.) Magn.

En hojas y escapos de Asphodelus fistulosus es muy frecuente en todas sus facies en Torrente, Gandia, Paterna, Godella, Sagrunto, Nules, Burriana y Villarreal. En España sólo se citó esta especie de Ampurias (Cataluña).

30. - Puccinia Porri (Sow.) Winter.

En hojas y escapos de Allium roseum, Gandía. - En hojas de Allium sp., Nules. 
En Aristoloquiáceas.

31. - Puccinia Aristolochiae (DC.) Winter.

En tallos y hojas de Aristolochia lonea. Nules y huerta de Valencia, facies ecídica. Rara. En la misma planta y en Carlet recogió esta roya D. Ramón Trullenque, el cual tuvo la atem ion de remitirme ejemplares.

\section{En Buxáceas.}

\section{2. - Puccinia Buxi DC.}

En hojas de Buxus sempervirens, Fredes y Ballestar. Representan estas localidades el habitat más meridional hasta hoy señalado en España para esta roya.

\section{En Poligonáceas.}

\section{3. - Puccinia Acetosae (Schum.) Körnicke.}

En hojas de Rumex intermedius, facies urédica y teleutospórica, Benasal y Fredes. Cítase por vez primera esta matriz en la Peninsula. Sobre Rumer diferentes la teníamos citada de una localidad pirenaica y de El Paular.

\section{En Cariofiláceas.}

\section{4. - Puccinia Silenes Schroeter.}

En silene inflatu, facios ecidica, en Ciandiat urolos. en Akith de. Chi-bert; facies urédica y teleutospurica. en Jatiba, Nules, Burriana y Villarreal.

\section{En Rusáceas.}

\section{5. - Puccinia Pruni-spinosac Pers.}

En hojas de Armeniaca vulgaris, uredo y teleutospórica, Museros, Albalat dels Sorélls, Jardin Botánico de la Universidad. huerta de Valencia, Nules, Moncófar y Sagunto. - En Persica vul-

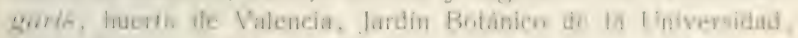
Puzol, Burriana y Nules. - En Am!grdalus communis, Nules. 
En Malváceas.

\section{6. - Puccinia Malvacearam Mont.}

En tallos, hojas, estípulas, cáliz y calículo de Malva sylvestris, Buñol. - En Malva vulgaris, huerta de Valencia, Alcira, Nules, Moncófar, Burriana, Villarreal, Museros y Sagunto.-En Lavatera Cretica, Moncófar y Nules, - En Althaea rosea, barraca de la huerta de Valencia y jardines. - En Malope malacoides (matrix nova), Jardín Botánico de la Universidad.

\section{7. - Puccinia Èryngii DC}

En Eryngium campestre, facies urédica y teleutospórica, Aldaya, Villavieja, Nules y Puebla de Benifazá.

38. - Puccinia Pimpinellae (Str.) Martins.

En hojas de Reutera puberilis Losc. et Pardo, uredos y teleutosporas, Benasal. Es matriz nueva.

39. - Puccinia Epilobii-tetragoni (DC.) Winter.

En Epilobium hirsutum, facies urédica y teleutospórica, Moncófar y Nules.

En Oleáceas.

40. - Puccinia Jasmini DC.

En Jasminum fruticans, facies teleutospórica, Benasal (proximidades de la fuente de Ensegures). Esta roya deforma los tallos de su huésped, hipertrofiándolos exageradamente.

En Labiadas.

41. - Puccinia annularis (Str.) Schl.

En Teucrium Pseudo-Chamaepytis, Nules.

42. - Puccinia anuularis (Str.) Schl., f. Cliamaedrys (Ces.) Crucliet. En tallos y hojas de Teucrium Chamaedrys, Fredes y Benasal. 
43. - Puccinia Betonicae (Alb. et Schw.) DC.

En hojas de Betonica officinalis, Benasal. Sólo tenemos dos citas españolas de esta expecie : una de Asturias y otra de Catuluña.

44. - Puccinia istriaca Sydow, Mon. Ured., I, p. 301, n. 472, et p. 878.Sacc., Syll. Fung., XVIII, p. 331; Sydow, Ann. Myc., 1903, p. 244.Trott., Ured. de la Fl. ital., pp. 166-167. - Hariot, Les Uréd., p. 162 .

En tallos y hojas de Teucrium aureum, Buñol y barranco de la Landiga, en la sierra de Chiva. Especie nueva para la Peninsula Ibérica, y matriz nueva para la flora mundial.

\section{5. - Puccinia Menthae Pers.}

En Mentha viridis, ambas facies en una huerta de Culla.-En Mentha rotundifolia, Morella._En Mentha aquatica, Navajas.En Micromeria marifolia Cav., facies urédica, Villavieja, Andilla y Sagunto. Esta matriz es nueva para la flora mundial.

46. - Púccinia punctata Link.

En Gallium verum, facies urédica y teleutospórica, en tallos y hojas, Andilla. Esta matriz es nueva para la flora ibérica.

47. - Puccinia Valantiae Pers.

En Gallium rigidum, Benasal. Matriz tambiẻn nueva para la Península.

En Compuestas.

48. - Puccinia Acarnae Sydow.

En brácteas, tallos y hojas de Picnomon Acarna, uredo y teleutosoros, Villavieja y Nules. Estas localidades extienden notablemente en España el área geográfica de esta especie, que sólo teníamos citada de Madrid y Guadalajara.

4i. Puccinta Andryalac ingubwi Babs. tiil.

En hojas de Andryala mollis (Asso) Pau (matrix nova), Já- 
50. - Puccinia Calcitrapae DC.

En hojas, tallos y brảcteas de Centaurea Calcitrapa, Fredes, Nules, Burriana, Villarreal, Moncófar, alrededores de Valencia, Gandia, Torrente, Jérica y Godella. En España sólo se citó de Sevilla y Madrid.

\section{1. - Puccinia Cardui-pycnocephali Sydow.}

En tallos, hojas y alguna vez en brácteas de Carduus tenuiflorus, facies urédica y teleutospórica, Benasal y Buñol.--En Carduus pycnocephalus en las mismas facies, Aldaya y Játiba.

52. - Puccinia Carduorum Jacky.

En Carduus Assoi, Morella y Benasal.-En Carduus tenuiflorus, Burriana, Nules y Villarreal, frecuentisima.

\section{3. - Puccinia Centaureae DC.}

En hojas de Centaurea aspera var. subinermis, Nules. En Centaurea homeoscevos Pau (1) (matrix nova), Castillo de Játiba.-En hojas de Centaurea Beltranii Pau (matrix nova), Nules.-En hojas de Centaurea Seridis var. maritima, facies urédica y teleutospórica, dehesa de la Albufera y playa de Nazaret. Matriz nueva. Los caracteres de esta última roya difieren ligeramente del tipo; las uredosporas son de $24-27 \times 18-27 \mu$; teleutosporas pardo-pálidas, $30-42 \times 21-28 \mu$; pedícelo alargado.

54. - Puccinia Centaureae DC., var. australis Trotter, in Ann. Myc., 1913, p. 411.

En tallos y hojas de Centaurea Melitensis, Játiba y Aldaya. Esta variedad citase por vez primera en la Península.

55. - Puccinia Chondrillina Bubák et Sydow.

En tallos, hojas y brácteas involucrales de Chondrilla juncen, Villavieja, Nules, Moncófar, Villarreal, Burriana, Alcalá de Chisbert, Sagunto, huerta de Valencia, Alcira y Paterna.

56. - Puccinia Chrysanthemi Roze.

En hojas de Pyrethrum indicum, Jardín Botánico de la Universidad y jardines de los alrededores de Valencia.

(1) Bol. de la Soc. Aräg. de Cienc. Nat., febrero de 1913. 
57. - Puccinia Cichorii (DC.) Bellynck.

En hojas, tallos y pedicelos florales de Cichorium Intybus, facies urédica y telentospórica, Nules. Burriana, Villarreal. Rosell. Fredes. huerta de Valencia y Museros. Especie hastante frecuente. y hasta la fecha citada sólo de tres localidades españolas.

58. - Puccinia Cirsii Lasch.

En hojas de Cirsium monspessulanum, Gandia.

59. - Puccinia Cirsii-lanceolati Schroeter.

En hojas de Cirsium lanceolatum en todas sus facies, Morella y Benasal.

60. - Puccinia crepidicola Sydow.

En tallos y hojas de Barkhausia taraxacifolia, facies urédica y teleutospórica, Fredes, Benasal, Nules, huerta de Valencia y Agullent.

\section{1. - Puccinia Crepidis-blattarioidis Hasler.}

En hojas de Crepis virens en todas sus facies, Benasal. - En hojas de Crepis albida en todas sus facies, Fredes. Recientemente publicó el P. Unamuxo esta matriz como nueva para la flora mundial.

\section{2. - Puccinia Echinopis DC.}

En tallos y hojas de Echinops Ritro en ambas facies, Aldaya. 1:-pecie nueva para la Peninsula Ibérica. El Sr. Fragoso (1) la cita como species inquirendae, y dice: "La creo muy probable en los Pirineos catalanes.:

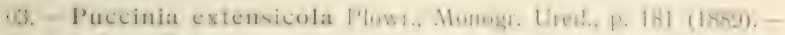
Sacc., Syll. Fung, p. 311; Sydow, Mont. Ured., I, p. 667, 11. 981. -

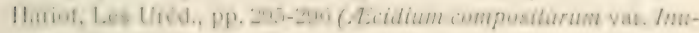
lac-crithmoidis Pat.). - Trott., Ured. de la Fl. ital., pp. 274-275. Grove, Brit. Rust Fungi, p. 248.

En hojas de Inula crithmoides, facies ecidica, dehesa de la Albufera. Las facies urédica y teleutospórica se dan en Carex exten-

(1) Loc, cit, prig. 116. 
$s a$, especie que es frecuente en la dehesa referida y que vive mezclada con la Inula, portadora de los ecidios. Miré detenidamente en varias ocasiones el citado Carex y no pude ver las fases que del mismo se citan. Trátase de una especie nueva para la Peninsula Ibérica.

64. - Puccinia Hieracii (Sclum.) Martius.

En hojas de Hieracium pilosella, Benasal.

65. - Puccinia hispanica Bubák, in Fungi nonnulli novi hispanici, Hedwigia, Bd. LVII, pp. 1-2 (Sep.), 1915. - González Fragoso, Bosquejo de una flor. hispal. de microm., p. 26. - Ib., Intr. al est. de la flor. de microm. de Cat., p. 42.

En hojas de Thrincia hispida, huerta de Valencia, Moncófar, Nules, Burriana y Villarreal.-En hojas de Thrincia hirta, Buñol y Benasal. Especie muy interesante, hasta hoy sólo conocida de Sevilla, Barcelona y Asturias.

66. - Puccinia Hypochaeridis Oudemans.

En hojas de Hypochaeris radicata, Rosell, Fredes, Benasal, Burriana, Villarreal, Nules y huerta de Valencia.

67. - Puccinia Jaceae Otth.

En hojas de Centaurea Jacea, Benasal. En España sólo fué citada esta especie de Reinosa (Santander) y Póo (Asturias).

68. Puccinia Podospermi DC.

En hojas de Podospermum calcitrapaefolium DC. en todas sus fases, Benasal. Sólo teníamos citada esta especie de Madrid y Cataluña.

69. - Puccinia Sonchi Rob.

En hojas de Sonchus aquatilis Pourr., Nules. Matriz nueva para la flora mundial.-En hojas de Sonchus arvensis, Nules, Burriana y Moncófar. Matriz nueva para la Península Ibérica. - En hojas de Sonchus_oleracens, Villarreal y Burriana.

70. - Puccinia suaveolens (Pers.) Rostrup.

En hojas de Cirsinm arvense, uredo y teleutosoros, Fredes, Benasal, Artana, Nules, Moncófar y Torrente. 
71. - Puccinia Taraxaci (Reb.) Plowr.

En hojas de Taraxacum tomentosum Lg. (matrix nova), Fredes, Benasal y Andilla.-En hojas de Taraxacum dens-leonis, huerta de Valencia, Nules, Moncófar, Chilches, Villarreal y Burriana.

72. - Puccinia Tyrimni González Fragoso, in Enum. y distr. geogr. de los Ured. Pen. lbér., pp. 130-131.

En tallos y hojas de Tyrimnus leucographus, facies urédica y teleutospórica, Traiguera.

73. - Puccinia Urospermi Thümen.

En hojas de U'rospermum Dalechampii, Gandía. Las únicas citas peninsulares que tiene esta especie refiérense a la provincia de Barcelona.

\section{Uromyces Link.}

En Gramináceas.

\section{4. - Uromyces Dactylidis Otth.}

En hojas de Dactylis glomerata var. vulgaris, Traiguera, Rosell y Benasal.

\section{En Juncáceas.}

75. - Uromyces Junci (Desm.) Tulasne.

En Juncus sp., Torrente.

\section{En Poligonáceas.}

76. - Uromyces Rumicis (Schum.) Winter.

En tallos y hojas de Rumex pulcher, facies urédica y teleutospórica, Gandia, huerta de Valencia, Cheste, Benasal, Mloncófar, Nules, Villarreal y Burriana.-En tallos y hojas de Rumex conslomeratus, huerta de Valencia, Nules, Chilches, Moncófar, Burriana y Villarreal, en las mismas fases que el anterior. Esta matriz es nueva para la Península Ibérica. 
77. - Uromyces Polygoni (Pers.) Fuckel.

En hojas de Polygonum aviculare, Fredes, Nules, huerta de Valencia y dehesa de la Albufera.

En Cariofiláceas.

78. - Uromyces Behenis (DC.) Unger.

En hojas de Silene inflata, facies ecídica y teleutospórica, Benasal, Nules, Burriana, Villarreal y huerta de Valencia.

79. - Uromyces caryophyllinus (Schranck) Schroeter.

En Dianthus Caryophyllus (cult.), Valencia.

80. - Uromyces Silenes (Schl.) Fuckel.

En tallos y hojas de Silene inflata, facies ecídica, urédica y teleutospórica, Benasal. Solamente el P. Unaniuno citó esta especie de localidades españolas (La Carna y Tiebes, en Asturias) (1), pero con referencia a matriz diferente.

En Papilionáceas.

81. - Uromyces Anthyllidis (Grev.) Schroeter.

En cálices, hojas y tallos de Physanthyllis tetraphylla, ambas facies, desierto de la Murta (Alcira). - En tallos y hojas de Anthyllis Vulneraria en iguales facies, Fredes y Benasal.

82. - Uromyces appendiculatus (Pers.) Link.

En hojas y legumbres de Phaseolus vulgaris, facies urédica y teleutospórica, huerta de Valencia, Museros, Puzol, Moncófar, Chilches y Nules. - En hojas de Dolichos melanophthalmos, huerta de Valencia, Nules y Moncófar, en las mismas facies. Esta matriz es nueva para la Península Ibérica.

(1) Contr. al est. de la Flora micol. de la prov. de Oviedo. (Asoc. Esp. para el Progr. de las Cienc., Ciencias Naturales, t. VI.) 
83. - Uromyces Ciceris-arietinis (Grogn.) Jaczewski.

En hojas de Cicer arietinum, ambas facies, Nules, Museros y huerta de Valencia. Sólo tenemos citada esta especie en España, de Orense y Sevilla.

84. - Uromyces Fabae (Pers.) De Bary.

En tallos y hojas de Faba vulgaris, facies urédica y teleutospórica, huerta de Valencia, Museros, Benifayó, Puzol, Sagunto. Nules, Chilches, Moncófar, Burriana, Bechí y Villarreal.--En tallos y hojas de Vicia angustifolia, en iguales facies, Benasal.

85. - Uromyces Fabae (Pers.) De Bary, f. Viciae-sativae Sacc.

En tallos y hojas de Vicia sativa, huerta de Valencia y Nules. Esta forma sólo la tenemos citada de la provincia de Sevilla.

86. - Uromyces Laburni (DC.) Fuckel.

En hojas de Cytisus patens (matrix nova), Benasal. Especie nueva para la flora española.

\section{7. - Uromyces Ononidis Passerini.}

En hojas de Ononis procurrens, Nules, Burriana y Villarreal. Sólo veo una cita española de esta especie (San Juan de las Abadesas, en Cataluña) (1).

88. - Uromyces Pisi (Pers.) De Bary.

En hojas, peciolos y legumbres de Pisum sativum, Benasal, Artana, Nules, Burriana, Torrente, Picasent y huerta de Valencia. Es la segunda cita que sobre esta matriz se hace de la Peninsula.In tallos, hojas, peciolos y lecrumbres de Lathyrus satious en facies urédica y teleutospúrica, Benasal. Matriz nueva para la Peninsula Ibérica.

89. - Uromyces striatus Schroeter.

En hojas y tallos de Medicago minima en facies urédica y teleutosporica, Benasal. Indicase por vez primera esta matriz en la flora peninsular. - También en hojas y tallos de Hedicaso satiua y en las mismas facies, huerta de Valencia, Moncófar y Nules.

(1) Véase la nota de la página 246. 
90. - Uromyces Trifolii (Hedw. f.) Léveillé.

En hojas de Trifolium fragiferum, facies urédica y teleutospórica, Benasal, Nules y Burriana. Matriz nueva para la flora peninsular.

91. - Uromyces Trifolii-repentis (Cast.) Liro.

En hojas y pecíolos de Trifolium repens en todas sus facies, Villarreal, Burriana, Nules, Moncófar y huerta de Valencia.

\section{En Umbeliferas.}

92. - Uromyces Bupleuri P. Magnus, in Verandh. Zool. Botan. Gesellsch., Wien, 1899, p. 90, t. II, f. 16-17. - Sacc., Syll. Fung., XVI, p. 259. - González Fragoso, in Enum. y distr. geogr. de los Ured. Pen. Ibér., p. 159.

En tallos y hojas de Bupleurum fruticescens, Benasal. Especie muy interesante y sólo conocida de Persia sobre Bupleurum graminifolium, y de la provincia de Teruel, citada recientemente por el Sr. Fragoso en la misma especie por mí recogida (1).

En Euforbiáceas.

93. - Uromyces monspessulanus Tranzschel.

En hojas de Euphorbia serrata, Benasal, Nules, Sagunto, Godella, Picasent y Alcira.

94. - Uromyces sublevis Tranzschel.

En hojas de Euphorbia nicaensis, Puebla de Benifazá, Benasal y Fredes.

En Plumbagináceas.

95. - Uromyces Limonii (DC.) Léveillé.

En hojas de Statice Limonium en todas sus facies, dehesa de la Albufera. Es la segunda cita peninsular que se hace de esta especie.

(1) A estas localidades hay que añadir Sierra Tejeda (Málaga) elı Bupleurum spinosum, según cita muy reciente del Sr. Fragoso. 
Gymnosporangium Hedw.

96. - Gymnosporangium clavariaeforme (Jacq.) DC.

En hojas de Crategus monogyna, facies ecidica, Fredes.

97. - Gymnosporangium Amelanchieris Ed. Fisch.

En Amelanchier vulgaris, facies picnídica, Fredes. No citada como tal especie anteriormente.

\section{Phragmidium Link.}

\section{En Rosa.}

98. - Phragmidium disciflorum (Tode) James,

En Rosa indica (cult.), Jardín Botánico de la Universidad, jardines de Valencia, Torrente y Nules.-En Rosa centifolia (cult.) en las mismas localidades.

99. - Phragmidium tuberculatum J. Müller.

En Rosa canina, Fredes.-En Rosa micrantha, Benasal.

En Potentilla.

100. - Phragmidium Fragariastri (DC.) Schroeter.

En hojas de Potentilla reptans, huerta de Valencia.

101. - Phragmidium Potentillae (Pers.) Karsten.

En hojas de Potentilla verna var, hirsuta, Benasal.

En Poterium.

102. - Phragmidium Sanguisorbae (DC.) Schroeter.

En Poterium dictyocarpum, Benasal. 
En Rubus.

103. - Phragmidium violaceum (Schultz) Winter.

En Rubus discolor, huerta de Valencia, Navajas, Jérica, Nules, Burriana, Villarreal y Fredes.

Kühneola Magnus.

104. - Kühneola Fici (Cast.) Butler.

En hojas de Ficus Carica, siempre en facies urédica, Jardín Botánico de la Universidad, huerta de Valencia, Catarroja, Torrente, Puzol, Chilches, Moncófar, Vall de Uxó, Villavieja, Artana y Nules. Especie muy frecuente, pero sólo citada en España de Constantina (Sevilla).

\section{Coleosporiáceos.}

Coleosporium Léveillé.

105. - Coleosporium Campanulae (Pers.) Léveillé.

En hojas de Campanula Beltrani Pau (matrix nova), Fredes. 106. - Coleosporium Inulae (Kze.) Ed. Fischer.

En hojas de Inula viscosa, dehesa de la Albufera, Godella, Sagunto, Villavieja y Nules, siempre en facies urédica.

\section{7. - Coleosporium Senecionis (Pers.) Fr.}

En hojas de Senecio gallicus, facies urédica, Benasal. - En hojas de Senecio vulgaris, facies urédica y teleutospórica, Nules, Benasal y huerta de Valencia.

108. - Coleosporium Senecionis (Pers.) Fr., f. Senecionis Doronici Ed. Fischer in Zur Biol. von Col. Senecinnis, in Myc. Beitr., 6. (Sep. aus den Mitt. d. Naturforsh. Ges. Bern, 1917.)

En hojas de Senecio Doronicum, facies urédica, cerro de Santa Escolástica, en Puebla de Benifazá. Esta forma es nueva para la Peninsula. 


\section{Melampsoráceos.}

Pucciniastrum Otth.

109. - Pucciniatrum Agrimoniae-Eupatoriae (DC.) Tranzschel.

En hojas de Agrimonia Eupatoria, Artana, Nules, Burriana, Moncófar y huerta de Valencia.

Melampsora (Pers.) Cast.

En Salix.

110. - Melampsora Evonymi-Caprearum Klebahn.

A esta especie parece corresponder la roya que muy frecuentemente ataca a Salix cinerea en la huerta de Valencia. La falta de teleutosporas no permite dar la especie con seguridad absoluta.

En Populus.

111. - Melampsora Allii-populina Klebahn.

En Populus nigra, facies urédica, proximidades de la Albufera y huerta de Valencia.

112. - Melampsora pulcherrima (Bubák) Maire.

En Populus alba, facies urédica, Puebla de Benifazá, en las proximidades del convento.

\section{En Euphorbia.}

113. - Melampsora Gelmi Bresadola.

En hojas de Euphorbia segetalis, facies urédica, Nules. Es matriz nueva para la Peninsula._-En Euphorbia nicaensis, monte de San Cristóbal, 1.000 metros sobre el nivel del mar, en Benasal. También esta matriz es nueva para la Península Ibérica.

114. - Melampsora Euphorbiac-Gerardianae W. Miiller.

En Euphorbia characias, facies uredica, Fredes, Benasal.-En Euphorbia falcata, facies urédica, Benasal. 
115. - Melampsora Helioscopiae (Pers.) W. Müller.

En hojas y brácteas de Euphorbia Helioscopia, facies urédica y teleutospórica; es frecuentísima en la huerta de Valencia, Torrente, Museros, Gandía, Benifayó, Puzol, Sagunto, Chilches, Moncófar, Nules, Vall de Uxó, Burriana y Villarreal.-En hojas de Euphorbia polygalaefolia, facies urédica, Benasal. Matriz nueva para la flora mundial.

116. - Melampsora Euphorbiae-Pepli W. Müller.

En hojas y brácteas de Euphorbia Peplus, facies urédica y teleutospórica, Gandía, Játiba, Alcira, Picasent, Benifayó, Torrente, huerta de Valencia, Godella, Buñol, Chiva, Museros, Sagunto, Jérica, Artana, Nules, Bechí, Alcalá de Chisbert y Morella. Es especie muy frecuente.

117. - Melampsora Euphorbiae-Cyparissiae W. Müller.

En hojas de Euphorbia serrata, Burriana y Nules. Matriz nueva para la Península.-En hojas de Euphorbia pubescens, Ballestar y Nules. Todas en facies urédica.

En Linum.

118. - Melampsora Lini (Pers.) Castagne.

En hojas y tallos de Linum catharticum, facies urédica y teleutospórica, Benasal y Fredes.-En tallos y hojas de Linum strictum, Benasal, en iguales facies. - En hojas de Linum gallicum, Villamarchante (leg. E. Moroder), Torrente.

\section{Uredales imperfectos.}

\section{Uredo Pers.}

Uredo Andropogonis-hirti Mare. [Vease Puccinia Andoponis-hirti (Maire) Beltrán.]

Uredo Andryalae Sydow. [Véase Placinia Andryalae (Syd.) Maire.]

Uredo Fici Castagne. [Véase Kühneola Fici (Cast.) Buttler.]

Uredo Imperatae P. . Magnus. [Véase Pucinia Imperatae (Magni.) Beltrán.] 
119. - Uredo Ravennae Maire, in Bull. de la Soc. d'Hist. Nat. du Nord d'Afrique; Uredo Fragosoano Caballero, in Nuevos datos micológicos. Publicaciones de la Facultad de Ciencias (Sec. Nat.) de la Univ. de Barcelona, XII, 1919.

En hojas de Erianthus Ravennae, dehesa de la Albufera. Es la segunda localidad espanola de esta especie, rucientemente publicada. Fué recogida en una excursión efectuada con el profesor Caballero.

120. - Uredo Ricini Bivona-Bernardi.

En Ricinus communis, Jardín Botánico de la Universidad.

\section{Aecidiolum Ung.}

Aecidiolum colliculosum (Berk.) Sacc. [Véase Gymnosporangium juniperinum (L.) Fr., del cual representa su facies picnídica.]

\section{Aecidium L.}

121. - Aecidium Euphorbiae Gmelin.

En hojas de Euphorbia nicaensis, Fredes. Matriz nueva para la Peninsula.- En Euphorbia Chumaesyce, Gandia (legr. C. Garcia). También esta matriz es nueva para la Península.

Aecidium Compositarum Martius, var. Inulae-crithmoidis Pat. [Véase Puccinia extensicola Plowr., de cuya especie representa su facies ecidica.]

\section{RESUMEN}

Las especies oformas enumeradas distribuyense de la sirruiente manera :

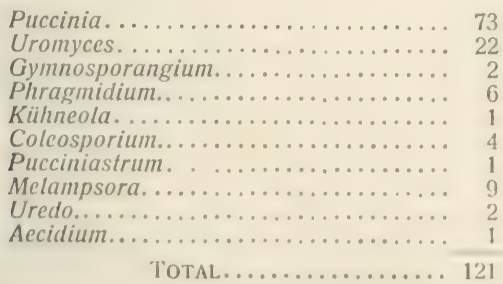


Se añaden las siguientes

ESPECIES O FORMAS NUEVAS PARA LA FLORA MUNDIAL

1. Puccinia Fragosoana Beltrán en Imperata cylindrica.

2. Puccinia Imperatae (Magn.) Beltrán en igual planta.

3. Puccinia Cesatii Schr. f. Heteropogonis Beltrán en Heteropogon Allioni.

4. Puccinia Andropogonis-hirti (Maire) Beltrán en Andropogon hirtum.

ESPECIES O FORMAS NUEVAS PARA LA PENINSULA IBÉRICA

1. Puccinia agropyrina Erikss.

2. Puccinia rimosa (Link) Winter.

3. Puccinia istriaca Sydow.

4. Puccinia Centaureae DC. var. australis Trotter.

5. Puccinia Echinopis DC.

6. Puccinia extensicola Plowr.

7. Coleosporium Senecionis (Pers.) Fr. f. Senecionis-Doronici Fischer.

8. Gymnosporangium Amelanchieris Ed. Fischer.

\section{MATRICES NUEVAS PARA LA FLORA MUNDIAL}

1. Agropyrum littorale, matriz de Puccinia Agropyri.

2. Koeleria hirsuta, matriz de Puccinia Fragosoi.

3. Lolium rigidum var, tenue, matriz de Puccinia glumarum, loliicola.

4. Malope malacoides, matriz de Puccinia Malvacearum.

5. Reutera puberula, matriz de Puccinia Pimpinillae.

6. Teucrium aureum, matriz de Puccinia istriaca.

7. Micromeria marifolia, matriz de Puccinia Menthae.

8. Andryala mollis, matriz de Puccinia Andryalae.

9. Centaurea homeosceros, matriz de Puccinia Centaureae.

10. Centaurea Seridis var. maritima y C. Beltrani, matrices de Puccinia Centaureae.

11. Sonchus aquatilis, matriz de Puccinia Sonchi.

12. Taraxacum tomentosum, matriz de Puccinia Taraxaci.

13. Cytissus patens, matriz de Uromyces Laburni.

14. Silene inflata, matriz de Uromyces Silenes.

15. Campanula Beltrani, matriz de Coleosporium Campanulae.

11. Euphorbia polygalaefolia, matriz de Melampsora Helioscopiae.

\section{MATRICES NUEVAS PARA LA PENINSULA IBÉRICA}

1. Agropyrum campestre, matriz de Puccinia Agropyri.

2. Brachypodium pinnatum, matriz de Puccinia glumarum.

3. Panicum repens, matriz de Puccinia graminis. 
4. Setaria verticillata, matriz de Puccinia graminis.

5. Asphodelus cerassiferus, matriz de Puccinia Asphodeli.

6. Rumex intermedius, matriz de Puccinia Acetosae.

7. Gallium verum, matriz de Puccinia punctata.

8. Gallium rigidum, matriz de Puccinia Valantiae.

9. Rumex conglomeratus, matriz de Uromyces Rumicis.

10. Dolichos melanophthalmos, matriz de Uromyces appendiculatus.

11. Lathyrus sativus, matriz de Uromyces Pisi.

12. Medicago minima, matriz de Uromyces striatus.

13. Trifolium fragiferum, matriz de Uromyces Trifolii.

14. Euphorbia segetalis, matriz de Melampsora Gelmi.

15. Euphorbia nicaensis, matriz de Melampsora Gelmi.

16. Euphorbia serrata, matriz de Melampsora Euphorbiae-Cyparissiae.

17. Euphorbia nicaensis, matriz de Aecidium Euphorbiae.

18. Euphorbia Chamaesycae, matriz de Aecidium Euphorbiae.

19. Sonchus arvensis, matriz de Puccinia Sonchi.

Universidad de Valencia. Laboratorio de Historia Natural, 22 diciembre 1920.

\title{
GENERALIDADES SOBRE LOS TÓMBOLOS Y DESCRIPCIÓN DE DOS DE ELLOS SITUADOS EN LA PROVINCIA DE SANTANDER
}

POR

\author{
ORESTES CENDRERO
}

(Láminas XIV a XVI.)

dieneralidades solure los tombolos y origen de los mismos.Sabido es que con el nombre de tombolo, que equivale a decir vuelta, rodeo o recodo, se designan en Italia algunas formaciones recientes (geológicamente hablando) que unen una isla al continente.

También es sabido que Gulliver, en su Topografic litoral Shoreline Topographly. Proceedings of the American Aculemy. 1895), fué quien generalizi el uso de esta palabra, que actualmente puede considerarse como naturalizada en todos los idiomas y como un término técnico de la Geografía física, en la cual se da el nombre de tómbolos a los cordones litorales de la época cuatermaria o de la moderna que, uniendo la isla a la costa más próxima, determi- 
nan la formación de una península. Las penínsulas que tienen este origen no pueden confundirse nunca con las penínsulas propiamente dichas, porque en éstas el istmo está constituido por roca firme, mientras que en los tómbolos es de cantos rodados, de arenas o de ambos materiales; es decir, de elementos incoherentes. Generalizando, se aplica también esta denominación a aquellos cordones recientes que unen dos islas o islotes entre sí.

Habida cuenta de los materiales que forman los tómbolos, es indudable que éstos habrán de originarse en aguas relativamente tranquilas donde existan abundantes materiales para su construcción. Esto ocurrirá preferentemente tanto en la proximidad de las rías como en aquellas costas donde la ablación marina sea muy intensa y haya una corriente litoral vigorosa que lleve dichos materiales a los sitios donde las aguas estén tranquilas, tal como en la proximidad de las islas y en las ensenadas y bahias, donde los depositarán. Como el sitio de aguas más tranquilas en la proximidad de las islas es en la parte de éstas opuesta al mar libre y que mira al continente, alli es donde se depositarán los materiales, originando los tómbolos.

De lo dicho se desprende que los materiales que forman los tómbolos pueden téner dos orígenes predominantes: el fluvial y el marino. De los dos tómbolos de que luego hablaré, uno, el de Berria, tiene sus materiales de origen principalmente fluvial, y otro, el de Ris-Castrejón, de origen marino.

Clasificación de los tómbolos. - Aun cuando todos los tómbolos tienen el origen que acaba de indicarse, las condiciones locales influyen grandemente en su formación e imprimen un sello especial a cada uno. Dos casos principales pueden distinguirse. En unos el avance se hace de frente desde el fondo de una bahía, es decir, se hace en línea recta desde el continente hacia el mar libre y hacia la isla que ha de detener su avance cuando se conexione con ella; dicho avance se realiza, por tanto, siguiendo próximamente el radio del arco que forma la bahía. Un ejemplo demostrativo de esta clase de tómbolo es el de San Sebastián (según puede apreciarse en la lámina XIV), en el cual está edificada la mayor parte de la actual población.

En otros el avance no es lacia el mar libre, sino que se hace desde un cabo o un promontorio hacia un lado del mismo y protegido por él, siguiendo una línea que es próximamente una cuerda 
del arco de la bahía o ensenada donde se forma. Tal es el caso de los tómbolos de Berria y de Ris-Castrejón, en la provincia de Santander (lám. XV, fig. 1, y lám. XVI, figs. 1 y 2).

Para expresar abreviadamente estas dos génesis y morfolugias tan distintas, propongo designar con el nombre de trimbolo frontal al primero, y con el de tómbolo lateral al segundo.

Aun puede agregarse otra denominación sintética: quien vea la figura 2 de la lámina XVI asegurará, desde iuego, que se trata de un tómbolo frontal; pero si pasa pur la región en una pleamar equinuccial, y aun en las pleamares de elevado coeficiente sin ser equinocciales, podirá apreciar que el cordón que tan claramente aparece en la fotografia está completamente cubierto por las aguas. Para estos aparentes tómbolos propongo el nombre de penitrombolos (lat. puene, casi), porque de ellos pliede asegurarse que, de per-istir durante algún tiempo las condiciones que actualmente reinan en la regiún, terminarán por convertirse eni timbolos propiamente dichos. Desde luego se comprende que estos penitómbolos podrán ser también frontales y laterales.

Con frecuencia se observan en los litorales dunosos extensiones variables de rocas que se ve evidentemente que en tiempo no lejano han estado formando un tómbolo, pero que actualmente Se encuentrant of totalmente enghobadis por las dunas o incluidas en éstas sólo por la parte continental. Es el estado final del tómbolo, por lo cual se le podria calificar de tómbolo viejo o muerto, para distinguirle de los penitómbolos o tómbolos en formación o nacimiento y de los tómbolos adultos o propiamente dichos.

Lo antedicho podría resumirse diciendo que el ciclo de vida de los tómbolos está constituído por tres fases: la inicial, durante la cual constituyen los penitómbolos; la adulta, en que forman los verdaderos tómbolos, y la final, en la que constituyen los tómbolos viejos o muertos.

Tómbolo de Berria (lám. XV, fig. 1, y lám. XVI, fig. 1).

Situación e itinerario. - Está situado entre el monte Brusco y el de Santoña, al NE. del primero y al NW. del segundo, en la base de los cuales se apoya; su parte N. forma la playa de Berria, y la S. está limitada por las marismas de Santona.

El viaje más cómodo y rápido se hace partiendo de Santander 
por el ferrocarril de Santander a Bilbao y apeándose en la estación de Gama, de dunde parte un automóvil de línea que va a Santona y pasa por la carretera trazada en el mismo tómbolo. También puede irse hasta Treto y de aquí pasar embarcado la bahía de Santona hasta esta villa, de la cual dista el tómbolo unos 3 kilómetros por carretera.

Desrripeión. - Es un ejemplo de tómbolo lateral, según se dijo antes. Stı longitud total es de 1.700 metros, y su anchura media, de 150 .

La mayor parte de sus materiales primitivos provienen de las aportaciones que el rio Asón, cuya desembocadura se denomina ría de Marrón, ha hecho en la bahía de Santoña; estos materiales son los que han constituido los cimientos del tómbolo, sobre los cuales, y por ser la de Berria una playa extensa, se han originado dunas formadas por los vientos NE. y NW.

En el centro del tómbolo existe un islote de rocas (lám. XVI, fig. 1), a cuyo abrigo han debido de comenzar a formarse dos pequeños tómbolos laterales hacia el NIV. y NE.; según esto, el actual puede considerarse como un tómbolo rejuvenecido constituido por la fusión de otros dos viejos. La unión del tómbolo del NE. a la base del monte de Santona ha sido relativamente reciente, pues las personas ancianas con quienes he hablado recuerdan haber oido decir a sus padres que en las grandes mareas equinocciales podian salir al mar libre desde la bahía de Santoña por un estrecho estero que existía próximamente al pie y algo al Norte del actual edificio del Dueso, que se ve en la fotografía.

Tómbolo de Ris-Castrejón (lám. XVI, fig. 2).

Situación e itinerario. - Está situado en la bahía de Juyel, al NW. de Noja y parte de las dunas de La Cueva, donde tiene su base, dirigiéndose hacia el pueblo llamado Isla, frente al cual termina el pumal, que es el nombre que en Santander se da a las flechas litorales.

Saliendo de Santander por el ferrocarril de Santander a Bilbao y apeándose en Beranga, se toma aqui un automóvil de linea que va a Noja, muy cerca de la cual se encuentra el tómbolo.

Inescripción. - Es otro ejemplo de tómbolo lateral. Su longitud total es de unos 1.200 metros, y su anchura mayor, unos 100 . 


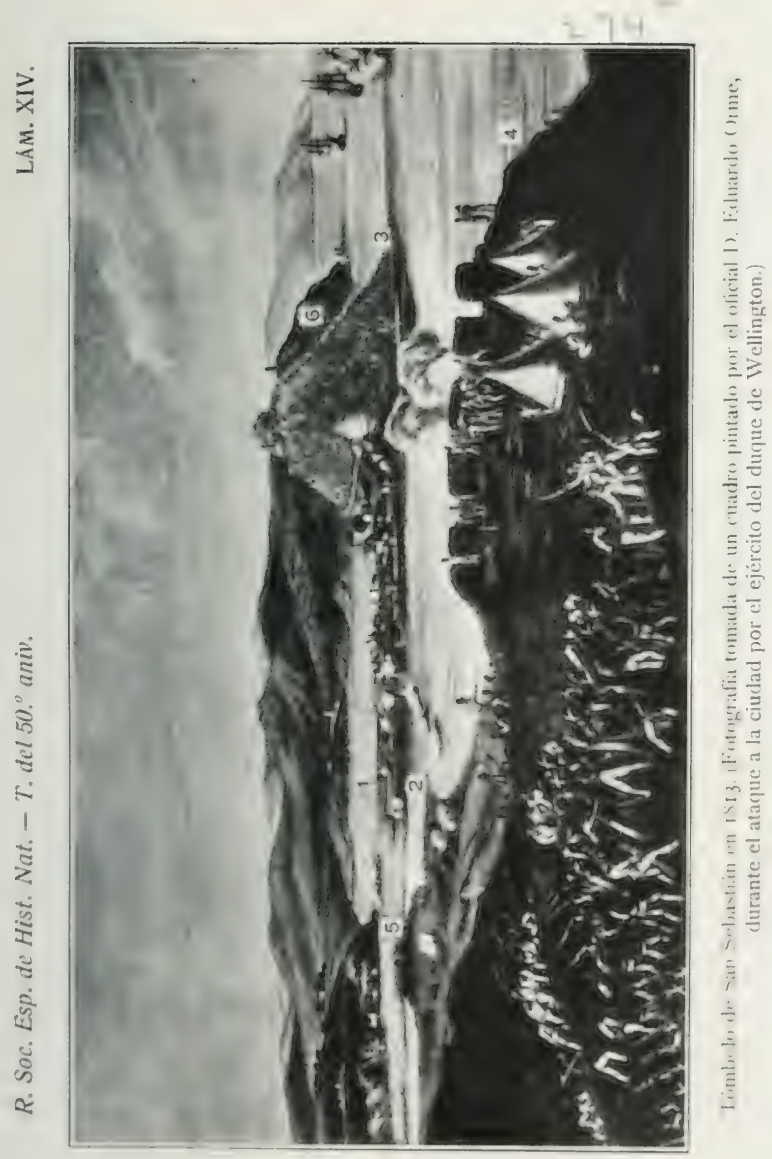





Los materiales que le forman son marinos en su mayor parte, y prowicnen principalnente de lus numernas islotes situalus frente él, y de los cabos Quejo y Punta Garfanta.

En sus origenes fué un cordón litoral que sólo por accidente ha pasado a tómbolo, debido a que en su avance hacia Isla ha englobado a los islotes llamados matos de Cuarezo o de Castrejón, grande al NW. y pequeño al NE. (1). De la parte media, próximamente, del tómbolo nace el penitómbolo de Suaces, que une el islote o mato de Suaces con el tómbolo (lám. XV, fig. 2, y lám. XVI, fig. 2).

Le doy el nombre de tómbolo Ris-Castrejón, teniendo en cuenta que lus naturales del pais dermminan Ri- a la zoad ommpresdido nure las dunas de La Cueva y el penitómbolo de Suaces y el de Castrejón, a la que se extiende desde éste a los matos de Cuarezo, cerca de los cuales comienza el puntal o flecha litoral, cuya punta se dirige y ayanza rúpidamente hacia Isla, donde terminará por tocar en plazo breve (desde el punto de vista geológico), pues actualmente la distancia que media entre ambos en las bajamares normales es sólo de una decena de metros y durante ellas se puede pasar perfectamente a Isla sin que el agua moje más arriba de los tobillos. Como en la bahía de Juyel no desembocan más que arroyuelos que se secan durante el estio y la ablación marina circundante es muy intensa, el puntal terminará, según se ha dicho, por tocar en Isla, y la bahía de Juyel se convertirá entonces en una laguna parecida a los haff del Báltico.

\section{Explicación de las láninas XIV a XVI.}

Lám. MIV. - Tómbolo de San Selastiain en isi 3. (Fotonrafia tomada del cuadro clibujado y pintaulo en el terreno mismo por el olicial de Estaulo Mavor J). Fduardo Urme, durante el ataume a la ciulued por el ejército del duyue del Wellington. Da mejor ietes del tombolo que: las fotogralias obtenidus hoy, en las que: este: aparece cubierte de edificaciones.) - I, hahia de la Concha; 2 , ric Crumea; s, monte:

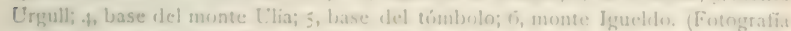
momunicada por la Sirta. Jimenez Crozat, directora de la Normal de. Maentras de. San Sebastitin.)

Lam. XV. - Fig. 8. Vista tomala deste el pico mis elevado del monte de. Santoina (r.l Bucieso, 403 metros, con nbjeto de que puedan apreciarse los dos

(1) La palabra malo, eon el significado que le dan en esta parte de Santander, es un regionalismo que equivale a decir cerro poco elevado, de poca superficie y formado en su mayor parte por roca viva. 
tómbolos laterales de Berria (2) y Ris-Castrejón (5): $x$, parte del Buciero en el monte de Santoña; 3, promontorio del monte Brusco; 4, Punta Garfanta; 6, cabo Quejo. (Fot. O. Cendrero.)

Fig. 2. Vista a contraluz del penitómbolo de Suaces (Noja), tomada a media bajamar desde la región de Punta Garfanta. En segundo término y formando ángulo con él, el puntal que continúa el tómbolo Ris-Castrejón, y que en la fotografia parece formar un tómbolo con Isla. (Fot. O. Cendrero.)

Lám. XVI. - Fig. I. El tómbolo de Berria (Santoña), tomado en pleamar ordinaria desde el monte Brusco: I, El Buciero desde el punto en que está tomada la fotografía de la figura 2; 2, El Dueso; 3, roca del centro del tómbolo a que se hace referencia en la descripción. (Fot. O. Cendrero.)

Fig. 2. La bahía de Juyel y el tómbolo de Ris-Castrejón (Noja), tomados en pleamar equinoccial desde el cerro (down) llamado Coronillas, en el pueblo de Soano: I, base del tómbolo; 2, mato de Suaces; no se aprecia el penitómbolo; 3, tómbolo; 4, mato grande de Cuarezo; más hacia el tómbolo está el mato pequeño; 5 , Isla; 6 , cabo Quejo. Paralelo al tómbolo y más próximo a tierra que éste existen fragmentos de un dique artificial. (Fot. O. Cendrero.)

NUEVOS HALLAZGOS DE ARTE RUPESTRE EN EL BAJO ARAGÓN(1) POR JUAN CABRÉ AGUILÓ-y LORENZO PÉREZ TEMPRADO

(Láminas XVII y XVIII.)

Las pinturas rupestres objeto de estas lineas fueron descubiertas por uno de nosotros (PÉREz TEMPRADO) en 1917 en el término municipal de Mazaleón, provincia de Teruel, y en la partida llamada dels Secans.

Su estudio llevóse a cabo el 5 y 7 de octubre de 1919, al regresar de nuestras excavaciones oficiales de Azaila (Teruel), y después de la visita al célebre yacimiento eneolitico del Cañaret (Calaceite), en el que se descubrió una sepultura colectiva de in-

(1) Acerca de este descubrimiento presentamos una comunicación en el Segundo Congreso de Historia de la Corona de Aragón, celebrado en Huesca en abril de 1920, titulada: "Las pinturas rupestres paleoliticas dels Secans (Mazaleón-Teruel) y sus relaciones etnograficas con la indumentaria actual aragonesa.» 
humación, perteneciente a un rito muy poco conocido en la Península Ibérica (1).

El hallazgo de las pinturas rupestres dels Secans no se debe al azar. PÉREz TEMPRADO, desde que dimos a conocer al mundo científico los ciervos de Calapatá, Cretas, (2), de los que tuvimos conocimiento en 1903, no cejó en su empresa de recorrer toda la comarca en busca de documentos arqueológicos similares, particularmente el término de Mazaleón, por residir en esta localidad, siendo negativas las primeras pesquisas con este fin, investigaciones que se intensificaron a partir del momento en que nuestro comin y buen amigo el Sr. EsteBAN descubre las pictografías del Charco del Agua Amarga (Alcañiz).

La labor de PÉREz TEMPRADO era muy ardua, pues, debido a que toda la comarca que se propuso recorrer es de constitución geológica miocénica, hay en ella innumerables vales, como llaman en el pais (valles), de muchas leguas de recorrido, con miles y miles de abrigos en rocas de arenisca, muy a propósito para albergar manifestaciones artísticas del hombre primitivo. Por último las halla en donde menos podía presumir que estuviesen: al final de la $\mathrm{Val}$ dels Secans, en su desembocadura en el río Matarraña, de aguas perennes y muy caudalosas en invierno, en unas peñas que buzan hacia el rio y que éste en su día casi bañó, pues se alzan sobre su nivel unos 25 metros. (Véase lám. XVII, fig. 1.)

Dicho descubrimiento rebate la teoría emitida por los especialistas en estos estudios consistente en que las pinturas homogéneas a las dels Secans se encuentran, casi sin excepción, en regiones pobrísimas de agua y muy cerca de manantiales: Cueva de la Vieja, Alpera (Albacete); Tortosilla, Ayora (Valencia); Navazo, Albarracin (Teruel); Charco del Agua Amarga, etc., etc., o frente a pozos naturales, denominados tolls en el pais, de los arroyos intermitentes: Cogrul, Calapatá, Cuevas de la Saltadora, Caballs, Sevil y otros de la Valltorta, de Castellón de la Plana; los covachos con arte mural del desfiladero de Tello o de Liria, de Vélez-Blanco (Almería), etc., etc.

Con relativa facilidad y sin guia alguno de la región se pueden visitar las pinturas dels Secans, ya que se hallan en el covacho

(1) Véase Juan Cabré Aguntó, Un osario humano del enceliticu de Caluceite (Teruel). (Bol. de la R. Soc. Esp. de Hist. Nat., febrero 1920.)

(2) Bul.de Mist. y Geogr. del Bujo Aragón, pigss. 68-75. Zaraguza, 19017. 
mayor, orientado hacia el Este, de la serie de peñones situados a unos 20 pasos y a pie llano de la carretera que parte del puente de Matarraña (de la de Alcolea del Pinar a Tarragona) y muere en Maella; tales peñas dan frente al hectómetro 1 del kilómetro 8 (1, partiendo del pueblo de Mazaleón). (Véase la lámina XVII, en cuyo fondo está el pueblo de referencia indicado por una flecha.)

El covacho de referencia es de pequeñas dimensiones: de unos 8,20 metros de longitud, 2,50 de altura y un par de fondo. Delante de él hay una plataforma rocosa de 8,50 de extensión.

Al pie de esta plataforma se ve mucho pedernal tallado a flor de tierra y un yacimiento en uno de los abrigos más inmediatos; con afloramientos de hogares, que nos reservamos el derecho de excavar sin ingerencias que consideramos perjudiciales para la ciencia en general.

PÉREz TEMPRAdo ha descubierto por toda la cuenca del Matarraña otros muchos yacimientos con industria lítica, siempre en abrigos parecidos a los dels Secans; y al construirse la carretera aludida del puente de Matarraña a Maella, sus desmontes han dejado al descubierto cortes de otros varios, al parecer de época paleolítica. La mayoría de ellos radican en las cercanías de las pinturas que describiremos.

Las inmediaciones de Mazaleón, por fin, son muy pródigas en testimonios culiurales arqueológicos de épocas inmediatas más modernas, siempre en sitios a la vista del Matarraña. Pueden citarse: las viviendas de carácter bastante primitivo que se alzan en la cumbre del ingente cerrillo que hay a un kilómetro, o poco menos, del abrigo dels Secans, en dirección a Maella, y en la misma vertiente del río; la serie de agrupaciones de sepulturas bajo túmulo, en forma de cista, del lado opuesto del río; el poblado ibérico de las cercanias de la ermita de San Cristóbal, y los dos poblados de la primera edad del hierro o del fin del bronce de Les Codines, excavados por el Institut d'Estudis Catalans.

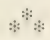

En la actualidad tan sólo se conservan de las pictografías primitivas dels Secans las figuras que reproducimos (lám. XVIII), las cuales se aprecian muy bien; así que el que las visite, estando un poco entrenado en estos estudios, las leerá sin esfuerzo alguno.

Hemos dicho que tan sólo se conservan las reproducidas por 
nosotros, porque suponemos, con fundamento de causa: que la composición a que pertenecen sería mucho más complicada. A primera vista se observa que las figuras hoy día existentes, dada su actitud: sólo son parte de asuntos venatorios o bélicos. El lienzo de pared en donde se admiran presenta muchos desconchados y erosiones producidas por las inclemencias de los agentes atmosféricos y por las lumbres y hogueras que han encendido continuamente los que se han albergado en el covacho que las contiene. Éste es sin duda alguna el más a propósito, en la zona de terreno en que radica, para guarecerse los pastores y en particular los peones de las huertas inmediatas cuando llueve, comen o descansan, y a la vez sirvio de asilo a varios obreros al construirse la carretera antes aludida. De aquellas figuras desaparecidas, aún confusamente se conservan, aparte de las copiadas por los firmantes, una extremidad inferior de ciervo, de buen estilo, que se ve a unos 15 centímetros sobre el incompleto contorno del animal que aparece a la derecha de nuestra lámina XVIII.

Todas estas figuras que reproducimos hállanse en la misma disposiciún en que las contempla el lector en dicha lámina, en el fondo del covacho, casi en el centro de él, en un saliente del mismo y a 80 centímetros sobre el nivel actual del suelo.

La lámina XVIII, por otra parte, nos ahorra la descripción prolija de las pictografias dels Secans, por haber sido reproducidas a su real colorido y a la mitad justa de su tamaño natural.

Solamente hemos de añadir :

1. ${ }^{\circ}$ Que la escuela pictórica rupestre española a que pertenecen es la del Levante de la Peninsula Ibérica, pero al conjunto artístion del Bajo Aragon, el más realista quizi de los de su género de nuestra patria, siendo las localidades mís clásicas del mismo las pinturas de las rocas dels Cuartos o dels Moros y dels Gascons, del Calapatá, Cretas (1), y las del Charco del Agua Amarga, de Alcañiz (2). Els Secans tiene de comín o coincide con la primera localidad del Calapatá en el estilo de las figuras de animales siluetadas, de trazo continuo y de rojo claro, que en ambos sitios pertenecen a la primera fase de sus composiciones, y por lo tanto deben

(1) J. CABRE, El Arte rupestre en España. Madrid, 1915, paigs. 129-144, láms. VI a IX.

(2) J. Cabré y C. Esteban, La Val del Charco del Agua Amarga y sus estaciones de arte prehistórico. Madrid, 1915. 
ser contemporáneas entre si. Con las pictografias dels Gascons, en las figuras humanas, de rojo morado, las cuales presentan las mismas características y son de la misma época que las dos de rojogris-obscuro de Mazaleón. Con las del Charco del Agua Amarga, en el tocado de las cabezas de varón, y en particular en la forma de los calzones anchos y cortos o zaragüelles que llevan, al modo de los que usan los actuales labradores de la comarca de Tortosa, en ciertas regiones del Levante de España y en el valle de Ansó, Tauste, etc., etc., y en otras localidades de Aragón. La figura varonil del centro de la escena dels Secans está pintada con la misma tonalidad de color que los incomparables ciervos de Calapatá y que los individuos más realistas y de tíltimo término de la lucha humana central de la composición del Charco del Agua Amarga, alguno de los cuales también lleva esa especie de aditamentos a modo de colgantes que penden de las piernas, a los que se ha dado en llamar impropiamente jarreteras.

2. ${ }^{\circ}$ Juzgamos las pinturas dels Secans, a pesar de sus varias coloraciones, como pertenecientes a dos fases distintas e inmediatas, y sin ninguna duda, al paleolítico, a la misma edad que el núcleo más realista de las pictografías homogéneas del Levante de España, edad puesta en litigio por algunos (1) por la ausencia de animales extinguidos en ellas. (Los bisontes de Cogul y el alce de la Cueva del Queso, de Alpera, insistimos en su carácter dudoso, y los rinocerontes de Minateda, falta que los sancione in situ la crítica.)

$$
* * *
$$

A los prehistoriadores en general, y en particular a los especialistas en las investigaciones de arte rupestre, nos permitimos, con la debida modestia, pero a la vez con insistencia, llamarles la atención sobre un hecho que hemos observado, que se repite ya con significativa frecuencia, y por lo tanto podria dar la solución al problema de la cronología de las pinturas, en roca, del Levante de Es-

(1) Uno de ellos, E. H.-PACHECO, que, a pesar de sus protestas de fe paleolitica en este arte rupestre, acaba confesando su creencia de que pertenece a la "Edad Mesolitica». Véase su articulo «Problemas y métodos de estudio del Arte rupestre", publicado en el Boletin de la Real Sociedad Española de Historia Natural, t. XIX, pág. 414, cuyo texto no responde a su título. 
paña, o por lo menos puede servir de base para los estudios conducentes a este fin. Nos referimos al hallazgo de pedernales o cuarcitas talladas en el interior de los covachos con pictografias, o en sus inmediaciones, con labra al parecer auriña-solutrense, y raras veces magdaleniense y jamás neolitica, y en ciertos sitios pertenecen al capsiense superior.

Uno de nosotros (1), al describir antaño las pinturas rupestres de la roca dels Moros, de Calapatá, expuso que al pie del acantilado en donde ellas existen habia encontrado útiles de silex y cuarcita, entre los que habia un ejemplar de tipo premagdaleniense, el cual reproducimos en las figuras 1-4. Como puede apreciarse por dicho dibujo, se trata de una punta de hoja con la cara inferior plana y con retoque de superficie marginal por ámbas caras, característica del principio del solutrense.

Los restantes instrumentos pétreos que acompañan en nuestra publicación al descrito proceden de las cercanías dels Secans, del Matarrana, donde fucron descubiertos por PÉREz TEMPrado. Lno de ellos (núm. 1) parece que es un buril con punta arqueada, retoques muy diminutos y con escotadura en ambas partes de la base. Este útil, aunque no muy perfeccionado, puede considerarse del auriñaciense. El numero 2 presenta la forma de la típica hoja de laurel solutrense sin muesca, y el otro se considera como un raspador oval muy retocado.

Cuando Breuil hizo con Motos y CaBré la copia de las pinturas (de la misma familia artística de las del Bajo Aragón) de la (ueva Chiquita de los treinta, de cerca de Chirivel (Almeria), aquel reconoció, dentro del covacho que contiene las refuridas manifestaciones de arte, que «le sol, malheureusement violé, et en grande partie calciné, contenait des foyers de divers âges, parmi lesyuels, un niveau à os très fossilisés, certainement paléolithique, auquel nous atribuons avec doute une jolie fleche de taille probablement solutréenne; elle pourrait être néolithique, mais le fait que cette forme n'est pas représentée dans les séries néolithiques ou postérieures si considerables de la collection Siret, nous incline a la croire pl::s ancienne» (2).

Este fenómeno de morfología litica descrito por Briatil fui

(1) J. CABRÉ, El Arte rupestre en España, pág. 138.

(2) H. BREUIL, L'Anthropologie (Institut de Paléontologie Humaine. -Rapports sur les travaux de l'année 1913»), t. XXV, pág. 242. 
observado idénticamente por CABRÉ en los llanos o explanada que hay sobre las Cuevas del Puntal, del Barranco de la Valltorta,
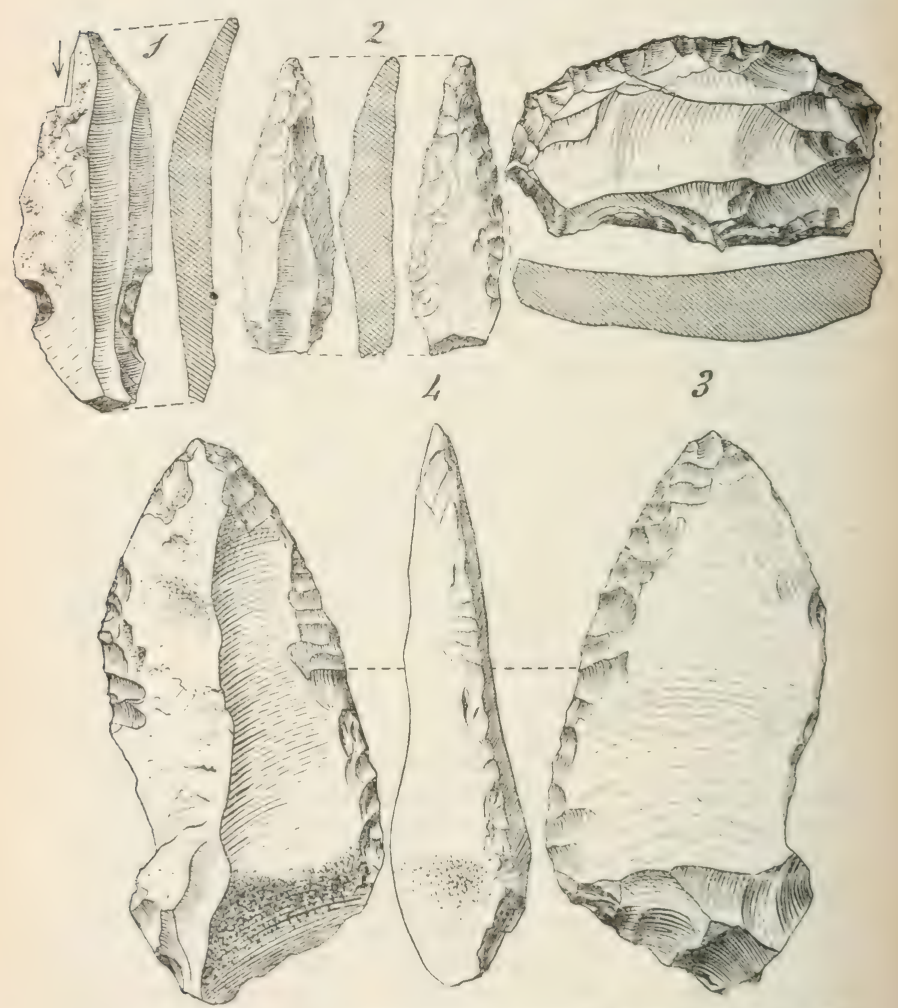

Figs. I-4. - I, 2 y 3. Silex tallados de un yacimiento del Matarraña, Mazaleón (Teruel). - 4. Cuarcita descubierta en la base de las pictografías de la roca dels Moros, de Calapatá, Cretas, Teruel. (Tamaño natural.)

de Albocácer (Castellón de la Plana), en 1917, después que con el Sr. Pallarés, comisionado éste por el Institut d'Estudis Catalans, 
descubrieron muchas flechas de sílex y bastantes pedernales tallados a flor de tierra. Dicha meseta da frente al foco principal de cuevas con pinturas rupestres de la Valltorta, en particular a la llamada "La Saltadora».

También, según Breull (1), en los Cantos de la Visera, del Arabi, Yecla (Murcia), en una pequeña excavación que hizo fueron descubiertos silex, de carácter paleolitico algunos de eilos, especialmente uno, del mismo aspecto industriai que la mayoria de los descritos con anterioridad, cuyo hallazgo relata en los iquientes términos: "Les silex recueillis présentent les formes suivantes: petits nucleus à lamelles, un lot de ces dernières, ne dépassant guère trois centimetres de longueur; un fragment de lamelle un peu plus forte (la base) retouchée à la manière d'une fenille de scule solutréenne sur la face superienre; trois éclats lamellaires peu réruliers à retouche unilatérale les transformant en sortes de racloirs; plusieurs éclats larges, tenant du racloir et du grattoir et plusieurs grattoirs épais plus au moins nucléiformes très usagés. Les seuls tessons de poterie recueillis, de caractère très primitif, l'ont été dans la couche superficielle.»

El Sr. HLGLET, descubridor de las pinturas de Cogul, presentí al II Congreso de la Corona de Aragón, celebrado en Huesca en 1920, un lote de sílex, procedentes algunos de las inmediaciones de la localidad rupestre famosa, de indudable aspecto del capsiense superior, habiendo donado varios a CABRÉ, de tamaño y tipo microlitico, de dorso muy retocado y forma semilunar, etc., etc. Por otro lado, las flechas que llevan los arqueros de Alpera, con punta lateral, a modo de banderilla, se supone que están constituidas con punzones hechos con asta de ciervo, con un bisel en el extremo más ancho para su adaptación al palo de la flecha, los cuales, en los yacimientos de Castillo, Cueto de la . Hina y utros, se hallan ya en los niveles solutrenses.

Al describir EsteBAN y CABRÉ las pinturas de guerreros y cazadores del Charco del Agua Amarga, insistieron en el paralelismo muy patente que existe entre las flechas con punta bilateral que aquéllos usan y lanzan, con las que se ven sobre los cuerpos de un bisonte y de un caballo en la caverna del Pindal, sobre ntro

(1) H. BREUIL et M. BURKITT, Les peintures rupestres d'Espagne. VI : Les abris peints du Monte Arabi pris Yecla, Murcie (L'Anthropulagie, t. XXVI, pág. 317.) 
bisonte de la de Niaux y en dientes perforados del yacimiento de Sordes. Dichas flechas bilaterales, dada la finura del dibujo de ellas, podrian haberse hecho también con dos punzones de asta, tal vez desde el origen del solutrense, ateniéndonos a los yacimientos antes indicados.

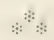

BREuIL, en su estudio de las pictografías de Minateda (1), que son de la misma familia artística de las dels Secans y de las del Bajo Aragón, supone o, más bien đicho, pretende afirmar que existe una influencia septentrional en el arte de aquella localidad, y por consiguiente en el de todo el Levante de nuestra Península y en el de los animales de las cavernas cantábricas y de los Pirineos. Esa influencia, dicho autor la supone en la segunda y tercera serie de las superposiciones cronológicas que ha establecido en su estudio de aquellas pinturas (2), y para él es más que evidente, en la cuarta y quinta de la misma. Hemos de hacer constar al lector que los esquemas de trazo continuo de tinte rojo claro de las figuras de animales dels Secans, de la Roca dels Moros de Calapatá y del gran toro del Charco del Agua Amarga, dado su estilo, obligan a admitir cierta concordancia y edad afín entre éstas y las agrupadas por BREUIL en la cuarta y quinta superposición.

Como quiera que este autor clasifica del Antiguo magdaleniense de los Pirineos cantábricos las figuras de animales análogas a las de Minateda que existen en la caverna de la Pasiega y en otras de la provincia de Santander, hemos de exponer nuestras reservas a la conclusión final, que pretende deducir tácitamente de dichas premisas, la que no es otra, que nuestro arte español

(1) Les roches peintes de Minateda. (L'Anthropologie, t. XXX, enero a abril de 1920.)

(2) Nada menos que trece fases, y ello como mínimum, establece BREUIL en la serie de superposiciones de las pinturas murales de Minateda. Lejos de nuestro ánimo está el negar tal cronologia, porque no hemos visitado aún esa localidad, pero nos reservamos el derecho de no hacernos solidarios de ella mientras no la veamos, pues muchas veces no se pueden considerar como fases las superposiciones, obras de varios artistas (si cabe esta denominación a todo el que pinta) de diversa mentalidad que a la vez o después de un corto intervalo de tiempo pintaron en el mismo covacho. 
oriental emana de los influjos del francés-cantábrico, y con esta afirmación se pretende que es una hijuela del último.

Este problema está todavía sin resolver, y modestamente nos atrevemos a plantearlo en los siguientes términos:

a) El arte rupestre del Este y Levante de España, más o menos costero y exclusivo por ahora de nuestra patria en Europa, ¿es genuinamente español, por crearse en ella, durante la civilización del capsiense inferior (1), paralelamente con el cantabrian-irancis y sin iniluencias avasalladoras de éste? Por de pronto, el ideal o finilidad artística del pueblo que pinta en nuestro Oriente espuñ. t. diametralmente opuesto a la del cantábrico. Éste lo realiza en las reconditeces, repliegues y lugares más inaccusibles casi si-unpre de los antros subterráneos y sin intervención realista de la figura humana, y aquél, considerando al hombre como elemento primordial, al aire libre y en abrigos dispuestos a modo de escenarios. No olvidemos que el capsiense nace en África con el auriñaciense, y una de sus ramificaciones europeas, a la que OBERMAIER denomina el «tercer centro mediterráneos (2), de mucha intensidad, se ha manifestadu en Itaía, espocialmente en el territorio de Grimaldi. lugar del hallazgo de los esqueletos auriñacienses con restos de adornos corporales, que se supone serian análogos a los que se ven en las piernas y brazos de los cazadores y mujeres de nuestras pictografias. Quizá ese pueblo capsiense, que llegó a Europa en parte por Italia, sea el mismo que esculpió los bajorrelieves de la Dordoña, de Lausel, las célebres esculturas con carácter antropológico africano, por su marcada esteatopigia y el esbelto tronco del supuesto arquero, considerados como auriñacienses. El yacimiento de Lausel, excavado por LALANNE, finaliza con el solutrense.

b) Dicho arte levantino español, ¿se puede admitir como hijuela

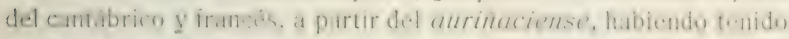
larga vida en el solutrense sobre todo, y se origina por completo en el Norte? Si bien los yacimientos con arte mobilier los hay hasta en Rusia, no se encuentran pictografias murales más allá de Italia, hoy por hoy, y ellas son del mismo estilo que las de la región cantabrica; pero han dado en considerar la ama de la industria litica solutrense, la Europa oriental.

(1) En el superior, según Obermaier en su Hombre fósil.

(2) Loc. cit., paig. 27. 
Por lo que se infiere de las anteriores manifestaciones, nosotros somos partidarios de la suposición o hipótesis de que el arte rupestre del Bajo Aragón, y por ende todo el similar levantino, nace y se desarrolla durante la convivencia de los indigenas del país con el pueblo capsiense, que vino a España de África, como supone muy acertadamente OBERMAIER, en el capsiense inferior, o sea durante el auriñaciense europeo, a cuya época y no al superior, como dijimos antes que manifestó el autor de El Hombre fósil, pertenecen gran parte de las pictografías del Levante de nuestra Península, y muy probablemente, a la vez, ya que se prodigan los hallazgos de industria lítica en Cataluña y en otras regiones del Este y Mediodía de España, y en general cerca de las pinturas rupestres del estilo de las dels Secans, con carácter o aspecto solutrense, esta fase de la industria primitiva fuera conocida en la zona de nuestras pinturas como evolución lógica del auriñaciense, como sucede y ha comprobado en Asturias el Conde de la Vega del Sella en sus excavaciones del Cueto de la Mina y en otros lugares cantábricos; y por fin, que parte del arte naturalista que se describe y estudia en este artículo con figuras humanạs, pertenece a una fase paralela a la del antigno magdaleniense cantubrico, y las más estilizadas al final del capsiense, sin que se pretenda con ello creer que admitimos influencias acentuadas del del Norte al Este, sino que vislumbramos puntos de contacto entre ellos, los cuales se hallan siempre en todo arte que nace y se desarrolla con virilidad por estar saturado de fines idealógicos y por tener como fuente de inspiración el estudio de la naturaleza, los seres vivos y en pleno movimiento.

\section{Explicación de las láminas XVII y XVIII.}

Lám. XVII. - I. El río Matarraña desde la partida dels Secans; $X$, covacho con pinturas rupestres; $\downarrow$, pucblo de Mazaleón. - 2. El covacho dels Secans con arte rupestre. Lugar en donde existen las pinturas.

Lám. XVIII. - Fragmento de la composición de arte rupestre que aún se con-

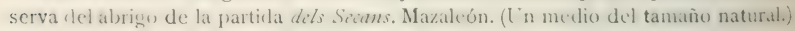

(Clisés y dibujos de J. Cabré.) 


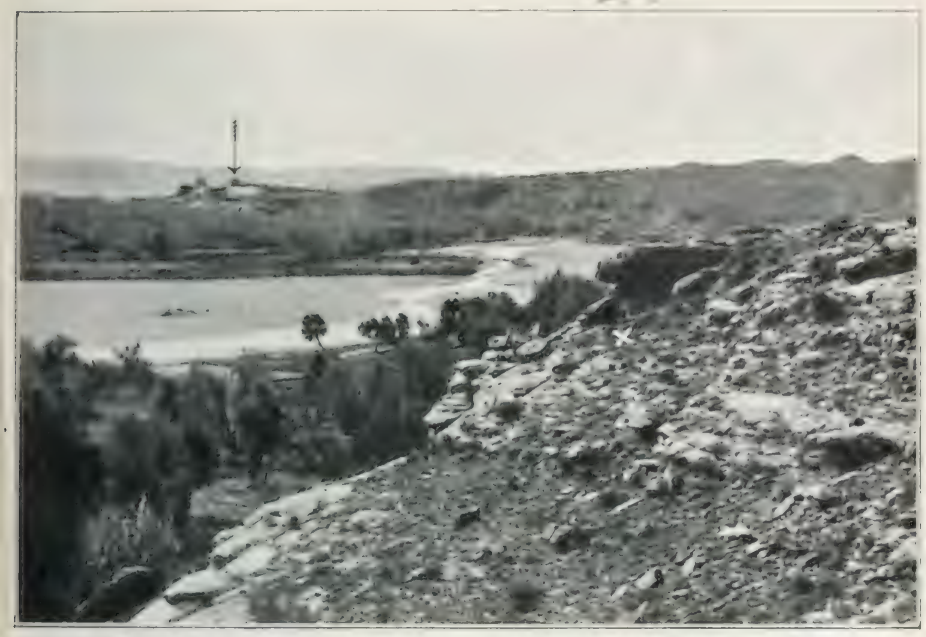

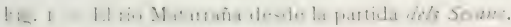

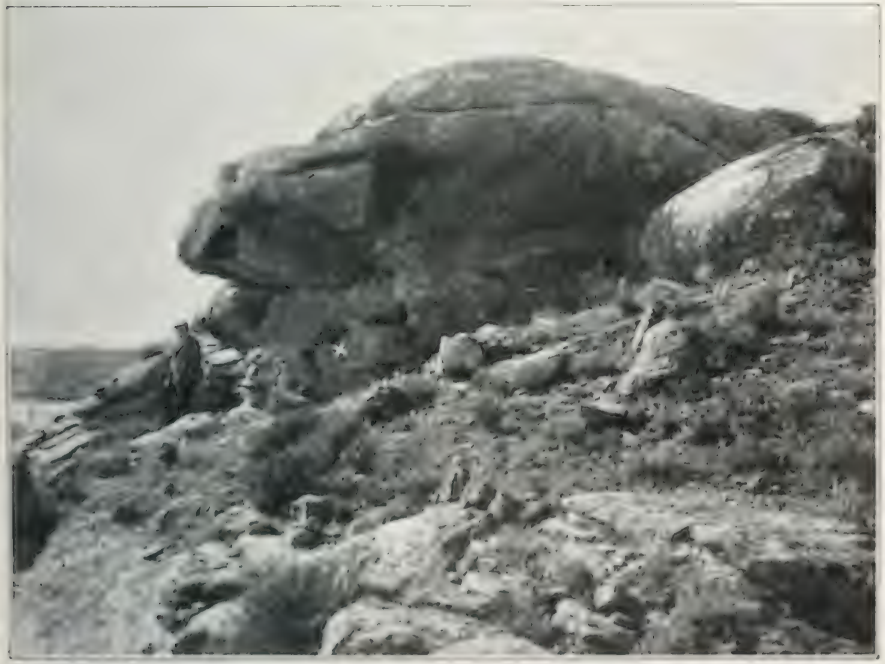

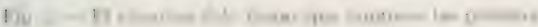





$$
<
$$





\title{
DIEZ DÍAS EN SIERRA MORENA
}

\author{
(DEL 12 AL 22 DE MAYO DE 1920)
}

POR

C. PAU

A la buena amistad de D. Romualdo Aguilar Blanch, dueño de unos cotos mineros en la cuenca granítica del río Guadanuño, y de su encargado, el valenciano Ramón Doménech, que habitaba en la dihesa de Trespuentes (Villaviciosa) y fué mi comnañero ral las currerias, debo et haber efectuado el viaje más delicioso de mi vida cientifica.

Cuando conoci en este ni país a Doménech y me habló de una digital que abundaba en Sierra Morena, sospeché en seguida que se trataba de la Digitalis Mariana, y como la desconocía, le ofrecí una visita únicamente con el fin de procurármela. Llegó el mes de mayo y me exigieron el cumplimiento de mi palabra; y a pesar de mis temores. por las reliquias 3 . un caturro gastrogripal pudecidu. no pude negarme, y me aventuré a emprender el viaje.

El día 12 de mayo cai en Córdoba, y aquella misma tarde, después de mi obligada visita a la Mezquita, en el tren de la Sierra subimos a la estación de Ovejo. En una borriquilla mandamos por delante nuestra impedimenta, y Doménech y yo hicimos a pie la corta distancia que mes separaha de. Trespuentes, herborizmulo por el camino.

En el primer arroyo que cruzamos me sorprendió una planta quıe me iur imposible reconocer: las hojas parecidas a las de la sulurvia montana; pero su estación y el olor fuerte y penetrante de menta me confundieron. Dando vueltas y más vueltas en mi memeria a la dichosa planta, terminé por quedarme a obscuras; y como otras curiosidades me llamaron la atención, olvidé por completo este vegetal, hasta que una vez en casa me di cuenta de que se trataba de la Preslia cervina. A buena hora podía yo dar con el nombre 
de esta especie, careciendo de flores y siendo del Norte de la Península.

Este descubrimiento, como algún otro que pudiéramos añadir, pueden explicarse sin necesidad de considerarlos «reliquias aquilónicas» ni como residuos de una flora boreal. Yo creo que hemos abusado de la época glacial en la explicación de parecidos fenómenos geográfico-botánicos. Aquí, a mi entender, no existe más que una reliquia floral de una época geológica húmeda. Durante el período dominante de lluvias, ciertas especies hidrófilas debieron ser abundantes; pero llegado el clima actual, aquellos representantes no pudieron subsistir sin procurarse un medio más o menos semejante al disfrutado por sus antecesores, si nos referimos a especies inadaptables.

La diferencia de altitud no pasa de 200 metros; por este motivo la vegetación es uniforme en la cuenca del Guadanuño; sin embargo, ciertas especies no se encuentran más que en las despejadas cumbres del Toril y Plaza de Armas. Abundan las praderas, y me parecieron campos abandonados de cultivo, como lo demuestran los ejemplares aislados del piruétano, y la abundancia, junto a los ranchos desaparecidos, de la Rosa gallica (plena). Las encinas (chaparros) también me parecieron relativamente jóvenes: no vi encinares de árboles colosales. Los incendios provocados y las roturaciones han destruido los enormes jarales arbóreos. Nos pudimos formar ligera idea de ellos en las pocas manchas que se salvaron de los incendios. El hombre desaparece en el jaral como un conejo en cualquier monte bajo; la marcha se hace dificultosa y casi imposible en aquel laberinto de maleza; los compañeros no se distinguen a cuatro pasos, y ni se ve el cielo ni el suelo. Y cuando se atraviesa un jaral después de la lluvia, como nos sucedió a nosotros..... En verano es tal la abundancia de ládano que destila la jara manchada, que Doménech me dijo que ha llegado a coger una picaraza aprisionada por el Cistus ladaniferus. Los pajaritos se ven con frecuencia retenidos por la viscosidad de la jara.

No quise salir de aqui sin visitar las cuevas de los caballistas, y estuve en las de la Chimorra: son dos naves regulares que envidiarían numerosas iglesias de aldeas españolas. La del Tempranillo, por estar su dueño en la capital, no pude verla; pero me dijeron que no está tan bien construída como las de la Chimorra. Es preciso vivir unos dias por aqui para darse cuenta de la vida miserable de aquellos «desgraciados» : únicamente se concibe en seres desequili- 
brados, amorales, psicipatas, más merecedores de casa de salud que de presidio. iY que de la historia de estos individuos anormales se haya confeccionado el alimento espiritual del pueblo por otros escritores no menos inadaptables al progreso psiquico!.....

Hoy existe seguridad absoluta, según me cuenta Doménech; pero él, por si acaso, nunca sale de casa sin llevar la escopeta al hombro. Aproveché esta circunstancia para hacer algunos tiros por alto y aumentar la ración del cocido: fuera de la torcaz, tórtola y perdiz, me fueron desconocidos los demás pájaros. En Aragón y Valencia no los he visto.

El término de Ovejo concluye a cuatro pasos de la estación; la parte izquierda del Guadanuño pertenece a Córdoba, y las tierras de su derecha, a Villaviciosa. No subí al cerro del Álamo, pero sí al Toril y Plaza de Armas. Alturas de unos 700 metros.

En la Plaza de Armas existió un castramento; se ven restos de numerosas torres cuadradas; no vi fragmentos de cerámica. Cerca se encuentra el castillo de Navafria, y desde donde lo miraba no se distinguian en el cerro restos de murallas.

El día 20 bajamos por la vía hasta la Valanzona, y el día 22 nos despedimos de este valle y de los buenos colonos de Trespuentes, saliendo para Córdoba.

\section{Ranunculus Aleae Willk.}

Esta planta, que no se habia indicado en ambas Andalucias con certeza, nos parece una forma que por sus pedúnculos delgados se acerca al $R$. Broteri.

\section{Ranunculus dubius Freyn.}

Bajo sus dos formas biológicas, que se encuentran mezcladas y propuestas como variedades por FREYX (heterophyllus y submersus). Aunque indicada fuera de Sierra Morena, nos parece propia, hasta el dia, de esta cordillera. (Véase Wilıkom., Suppl., pág. 315.)

Ranunculus flabellatus Desf., $\Leftarrow$ mollis Freyn, f. subpinatus (Freyn).

Para nosotros no se trata más que de una forma hidrófila de la variedad mollis Freyn, vulgar en España. Lacinias foliares algo más dilatadas; color de la planta verdoso, glabrescente; habita en las praderas humedas y orillas de riachuelos. 
Fumaria muralis Sond.

Tres son las formas diferentes que de esta especie he recogido: la más divergente fué la de las cumbres próximas a la Plaza de Arınas, var. glaucescens (glauca, caespitosa, foliorum laciniis brevibus, bracteae longitudine pedunculorum subsuperanti, nuculis parvulis). Las otras dos son de los vallados. La una pertenece a la variedad vagans (Jord.), la otra es una variedad tenuisecta (foliorum laciniis ut in $\mathrm{F}$. Vaillantii, sed brevioribus).

Euzomodendron longirrostre (Boiss.) Pau = Brassica longirrostra Boiss. = Sinapis longirrostris Boiss. $\mathrm{hb}_{0}=$ Erucastrum longirrostre Nyman.

Abundantísima en los regueros peñascosos de las cumbres del Toril y Plaza de Armas. Son sus semillas muy apetecidas por las tórtolas y las perdices, según Doménech me dijo.

No tengo noticias de que esta notable especie haya sido recogida, después de BoIssier, por ningún naturalista; el año pasado me comunicó Gros un solo pie, y como se verá en mi Segunda contribución a la flora de Granada, la trasladé al género Euzomodendron.

Iberis linifolia Loefling, Iter Hisp., pág. 78 (1758)=I. contracta Pers., var. angustifolia Lge.

Esta especie abundaba entre el cerro Muriano y la Valanzona, en las trincheras de la vía férrea. Esta forma no crece en Francia ni quizás tampoco en Portugal.

La I. contracta Pers., como dije en el trabajo citado, es I. linifolia Loefling, $\beta$ contracta (Pers.) Pau; y la localidad clásica de la I. linifolia! son los cerros de Butarrón (Madrid).

$\times$ Cistus Aguilari Pau, hybr. nov. $=$ C. ladaniferus $\times$ populifolius.

Al pie del cerro del Murciélago, cerca del rancho del Manco. En sus inmediaciones existian también los hibridos $C$. populifolius $\times$ salvifolius y $C$. monspeliensis $\times$ populifolius, que no fueron indicados en Andalucía.

Folia 7-8 cm. longa ovato-lanceolata simillima C. nigricanti Pourr. = C. longifolio Lam. (non Miller, 178S), sepala ovata subvillosa lepidota, petala maculata et capsula 7-valvata. 
Cuando en una hibridación entran los C. monspeliensis y C. ladaniferus, los productos de estas combinaciones son tan parecidos por las hojas, que únicamente se pueden separar con claridad por los cálices; sirvan de ejemplo los C. monspeliensis $\times$ populifolius y $C$. ladaniferus $\times$ populifolius. Por este motivo, el único pie sin flores que recogimos subiendo al Toril por su espolón oriental, y que tomamos por $C$. ladaniferus $\times$ monspeliensis, pudiera resultar dudoso y no nuevo para la flora española. En este valle no se encuentra más que la forma de pétalos manchados del C. ladaniferus.

La planta del Toril difiere por su humildad, abertura de sus tallos, por carecer en absoluto de la vaina en figura de copa de las hojas en su base, por ser más cortas, más angostas, más agudas y menos ensanchadas superiormente. Estos caracteres acusan uıa influencia extraña y propia del $C$. monspeliensis.

\section{Helianthemum guttatum Mill.}

La variedad macrosepalum es rara y solamente la vi junto a Trespuentes; la otra forma es frecuente y participa de la eriocaulon por llevar en el tallo y eje floral pelos largos como ésta, pero mezclados con pelos glandulíferos como en la forma serratus.

Viola Kitaibeliana R. et Sch.

Un solo pie en la cumbre del Toril.

Probablemente a esta misma especie debemos referir la planta de La Carolina ( $V$. tricolor var. segetalis Lange, in Prodr. fl. hisp., III, pág. 702), por ser idéntica a la de Guadarrama. A esta misma forma Kitaibeliana habrá también que referir la variedad parvula indicada en el cerro Muriano y recogida por F. Amor, según Lange, en el lugar citado. La verdadera $V$. parvula Tin. no la conozco más que de Sierra Nevada, y ésta en su variedad tenella (Webb.) Patt.

Silene Mariana Pau, n. sp.

Ribazos de Trespuentes; rara.

Annua viridis, caule erecto parce piloso, basi ramoso, ramis longioribus, foliis anguste lanceolatis acutis, ciliatis, floribus lave racemosis erectis sat pedunculatis, calyce membranaceo clavato-cylindrico subincurvo et subaperto 10-striato 
ad nervos setoso striis viridibus venullis nullis dentibus late ovatis brevibus rotundato apice, podocarpo $2 / 3$ calycem aequante, petalorum unguibus exertis limbo roseo, capsula oblonga longitudine stipite, seminibus parvis reniformibus dorso canaliculato faciebus profunde depressis.

Las especies más cercanas que conozco son la S. hirsuta Lag. y $S$. vespertina Retz. Difiere de la primera por su virescencia, glabrescencia, hojas, cálices, cápsula, podocarpo y semilllas.

Es muy parecida a la $S$. vespertina, de la que difiere notablemente por su inflorescencia pauciflora y laxiflora, dientes calicinales anchamente aovados y obtusos, glaberrimo el tubo calicino entre sus nervios, cápsula oblonga y de la misma longitud que el podocarpo y semillas finamente estriadas. La S. vespertina se presenta con dientes calicinales lanceolados, angosta su membrana marginal, cápsula ventruda, doble mayor que el podocarpo y semillas tuberculosas.

Spergularia purpurea (Pers.) $=S$. rubra var. longipes Lange! = $S$. longipes Nyman $=S$. Langei Foucaud!.

Es idéntica a mis ejemplares de Aranjuez, localidad que creo sea clásica.

Genista Obelii DC., var. Mariana $\mathrm{Pau}=G$. polyanthos Laguna sec. Willk. (Prodr., III, pág. 432) = G. aspalathoides Laguna, Flora forestal, II, pág. 326.

Cerros del Toril y Plaza de Armas; escasa y en ejemplares aislados.

Humilis 20-40 cm. ramis erectis foliolis prontus fugacibus, linearibus, villosis, exstipulatis, parvulis, pedicellis bracteolatis calycem subaequantibus, calycis laciniis velutinis dentibus inaequalibus tubum aequantibus, carinae et alae erectae.

Extraordinariamente parecida a la G. Obelii DC., var. hystrix (Lange) $=G$. hystrix Lge., de la cual se aparta por los cálices mayores y no sedosos, dientes ni tan angostos ni tan agudos y estandarte doble más ancho.

De la G. Obelii DC., var. baetica $($ Spach $)=G$. baetica Spach. $=G$. aspalathoides Boiss., por carecer casi de hojas, cálices menores y dientes más cortos.

$\mathrm{Y}$ de la $G$. Obelii DC., var. polyantha (Roemer) $=G$. polyan- 
thos Roemer, por su humildad, flores en corto número y peduculillos mayores.

Lupinus hispanicus B. et Rt., var. pelicanus Pau.

Ribazos de los campos, subiendo a las cuevas de la Chimorra. Legumina argenteo-villosissima.

No se había citado esta especie de Andalucia. Nuestra planta se: aparta de la madrilena por la vestidura plateada de las lezuatire.

Ononis subspicata Lagasca, Descripción de dos plantas nuevas.... Soc. Med. Quir. de Cádiz, t. IV, págs. 1-5 (1824), nov. var. cordubensis Pau $=$ O. Picardi B. et Rt., 3 grandiflora Wilk., Prodr. fl.'thisp., III, pág. 390 .

Cerro del Toril y Plaza de Armas.

Muy parecida a la O. subspicata Lagasca $=0$. Picardii B. et Rt.! a que differt indumentov iscoso-villoso, floribus majoribus, calycis laciniis latioribus, corollae majori, vexilo in cacumine rotundato.

De la O. subspicata Lag., var. Broteriana(DC.) Pau=Ononis Broteriana DC. $(1825)=0$. racemosa Brot. = O. Bourgeaii B. et Rt. = O. Picardii, ; grandiflora Cosson, difiere por su vestidura $\mathrm{y}$ «espigas» florales.

Pirus communis L. (forma cimarrona).

He visto con frecuencia el piruétano en la cuenca del Guadanuño, pero siempre en ejemplares aislados y en los campos abandonudus por los antigurs habituntes de los ranchos destruidos. Fista afirmación se ve confirmada por la Rosa gallica (plena), que abunda cerca de los edificios abandonados. No es la variedad mariani$c a$, representada por LAGUNA en su. Atlas. Poseo un ejemplar de Ciudad Real yue no se distingue de la del Gundanuno nuh yute i o r las hojas menores. Tampoco es el $P$. acerba, que poseo de Burgos (entre Villavelayo y Neila) y Sierra de Guadarrama.

Cotyledon umbilicus L., var. marianica Pau.

No es rara, pero las plantas de la parte baja estaban agostadas.

Corolla minor pedunculis brevioribus.

De la C. umbilicus L., var. horizontalis DC., difiere por sus flores pendulinas. Forma de corola doble menor que en el tipo y cortamente pediceladas sus fiores. 
Centaurea paniculata L., var. marianica Pau.

Frecuente, pero muy atrasada.

Simillima C. paniculatae L., var. micranthae (Hffg. et Link ut sp.) nihil ominus diversa foliorum laciniis latioribus, capitulis solitariis, anthodii squamis longe aristatis.

Digitalis purpurea L., var. Mariana (Boiss.) Pau =D. Mariana Boiss.

Frecuente y abundante en los peñascos.

$\mathrm{El}$ indumento es inconstante, y no descubro diferencias morfológicas suficientes para separarla especificamente del tipo.

Ignoro a qué especie conocida se pudiera asimilar la $D$. minor Lange (Prodr., II, pág. 590), que cita con seguridad en el valle de San Francisco, según planta recogida por F. Amor; cuando no existe en toda la cordillera mariánica, la $D$. lutea L. y la $D$. minor L. es igual a la $D$. purpurascens Roth $=D$. lutea $<$ purpurea.

Antirrhinum tortuosum Lange, Prodr., II, pág. 583.

Alrededores de Trespuentes y entre Córdoba y la Valanzona.

Planta glaberrima, alta, casi de la estatura humana; tallos derechos, rectos y muy ramosos; lacinias calicinales elipticas y aovadooblongas, nucronuladas, glaberrimas; corola rosada, de $3 \mathrm{~cm}$; cápsulas lampiñas por el lado superior, pubescente-glandulosas por su parte ventral y superiormente, estilo pelosillo.

Estos caracteres no convienen a las muestras de mi herbario procedentes de Roma. Difiere del A. siculum Ucria por los segmentos calicinales no agudos y aovado-lanceolados.

Miller, Dicc. núm. 5, publicó el A. siculum, que difiere del de UCRIA por ser anual y llevar flores solitarias sostenidas por largos pedúnculos. No pueden pertenecer, por consiguiente, ambas especies al mismo tipo específico.

Linaria Amoris Pat1, 11. sp.

Habitu complete L. filifoliae, sed seminibus angustissime marginatis ad L. Tournefortii et juxta eam collocanda. Fortasse L. difusan Lange, Prodr., II, pág. 568 (non Hffg. et Link) species diversissima. Vide praeterea, p. 569 in observatione.

Annua gracilis multicaulis et glabra, caulibus simplicibus 
surculis sterilibus numerosis, foliis anguste linearibus asperociliatis, pedicellis brevibus, laciniis calycis linearibus, corolla albido lutescenti palato glabro flavo, calcare tenui elongato subulato corolla duplo longiori, capsula ovali, seminibus triangulari reniformibus angustissime marginatis, disco convero acute tuberculato. Apex leviter glandulosa.

LANGE, con BoISSIER y otros autores extranjeros, afirmó que la $L$. glutinosa era una forma de la $L$. filifolia. Acudimos a la Flora portuguesa de HofFMmansEgG y Link, y vimos que tal asociación especifica no está apoyada en la descripción ni en la estampa. Dijeron los autores de la L. glutinosa: Caules plures, snepe ascendentes.... pilis clavatis, humoren viscidum evernentibus..... Folie angusta acuta..... hirta ut cuulis..... pedicellis..... hirtis. Cali.x laciniis lanceolatis..... Cap)sula ..... hirta. Perennis. Y en la página 239, en la observación a su L. saxatilis, añadieron: "vivaz como ésta». Precedenti (L. glutinosa) tamen affinis. Estos caracteres, evidentemente, no pueden convenir a ninguna forma de la $L$. filifolia.

Atendiendo ahora a la lámina 39 , vemos que dibujan una planta, al parecer, anual; tallos ascendentes o derechos; las hojas no son agudas, y únicamente la figura 7 basta para separarla especificamente por las lacinias calcinales lanceoladas y forma de la cápsula.

La estampa de BROTERo (Fit. port., tab. 13t) es un malísimo calco de la dada por Horfmmansega y LiNK; pero dice, sin contradecirles, "perennes (loc. cit., II, pág. 129). Y la L. filifolia de LAGASCA ni tiene raiz vivaz, ni destila esencia viscosa, ni los.pedicelos son erizados, ni su cápsula es hirsuta.

\section{Nepeta cordubensis Pan, I1. sp.}

Frecuente en las inmediaciones de Trespuentes.

Radix perennis, plus minusve villosa basi, superne villosa vel glabra, brachyalis, caulibus erectis stricte 't vix ramosis parcefoliatis, surculorum foliis villosis obtusis elipticis crenatis basi truncata viridilus, caulinis subcordatis crenaturis latioribus et lamina majori; verticillastris 10 in spicam basi latum; bracteis Ianceolatis herbaceis, bracteolis subulatis, calyjas villosis dentibus inaequalibus tubo constricto subaequantibus, corolla coerulea labio superiori bilobo, maculis..... Juxu N. Apuleji Ucria. 
Armeria capitella Pau, n. sp.

No es rara en la cuenca del Guadanuño y camino del cerro Muriano.

Caespitosa, foliis spathulato linearibus subtrinerviis longe et anguste in petiolum attenuatis, obtusis dense ciliatis, scapis elongatis, capitulis parvis, involucri plyyllis infimis triangulari-lanceolatis cuspidatis, interioribus obovatis late membraneceo-marginatis, calycis tubo ecalcarato ad costas tenuiter piloso tubo sesquiminori, lobis ovato-triangularibus in aristas sat longas attenuatis; corolla alba. - Circa A. plantagineam.

Difiere de la $A$. vestita Willk. (sec. descript., specimina non vidi) por las hojas sencillamente pestañosas, obtusas y generalmente de un solo nervio; escapos tenues, lampiños y leves; vaina alargada, pero no pubescente; invólucro con las escamas lampiñas y de color terroso; limbo más corto que el tubo y lóbulos aovado-triangulares.

De la $A$. plantaginea W. se distingue por las hojas elegantemente pestañosas, espatulado-lineales y obtusas, cabezuelas menores, escamas inferiores del invólucro doble menores que las corolas, limbo del tubo menor y corolas blancas.

La especie más parecida de mi colección es la $A$. undulata, de Grecia.

Serapias Lingua $>$ cordigera $=S$. ambigua Rouy, $\beta$ Laramberguei (Camus) Rouy.

Un solo pie en las praderas, en compañia de la $S$. Lingua.

Como no vi en el país la $S$. cordigera, dudo de que el híbrido lo sea realmente; nuestro ejemplar nos parece mejor una variedad, y conviene con el dibujo dado por CAmus.

Asphodelus cerasiferus $\times$ aestivus $=A$. Morisianus Parl., var. lusitanicus (Mariz?).

No vi más que un solo pie; sus padres son abundantes.

\section{Leucojum antumnale $\mathrm{L}$.}

Las cebollas que traje florecieron en casa en el mes de noviembre. También florecieron las del Narcissus serotinus L., pero un mes antes.

Todavía queda en observación otro narciso de las praderas elevadas del Toril. 
Agrostis salmantica (Lag.) Kth. (1833) = Trichodium salmanticum Lagasca $(1816)=A$ grostis pallida DC. (1s15) mun Wittlı. (Schkr. 181131

A. anemagrostoides Trin. (1821).

Airopsis tenella (Cav.) Cosson $=A$. globosa Desv. $=$ Miliun tenellun Cav. (1794) = Aira globosa Thoré (1808).

Muy rara, quizás por ser más primaveral, en las cercanías de Trespuentes.

Nardurus Marianus $=$ Lolium strictum $\times$ Nardurus tenellus.

Habitu Lolio stricto. Annuus, culmo 20-40 cm. solitario erecto ad nodus infimus geniculato, foliis elongatis anguste linearibus, spica simplici disticha erecta nitida, spiculis brevissime pedicellatis apertis patentibus 7 floris, glumis subulatis inaequalibus flosculis triplo brevioribus, glumelulis oblongo-linearibus, obtusis apice et margine membranaceis, terminalibus acutis. En compañia del Lolium strictum Presl., f. tenue Godr.

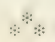

Lista de las especies recogidas, omitidas las vulgares y otras que no herboricé, como Ranunculus arvensis, Cistus albidus, C. crispus, etc., Echium plantagineum, Chrysanthemum Mi$c o i$, etc.

Sisymbrium asperum, Helianthemum umbellatum, Cleome violacea, Dianthus lusitanicus, Silene lasiostyla, Eudianthe laeta, Sagina maritima, Spergula arvensis var. laricina, Spergularia atheniensis, Malva althaeoides, Hypericum perfoliatum, Linum gallicum, Radiola linoides.

Genista hirsuta, Adenocarpus grandiflorus, Lupinus linifolius, Ononis reclinata, O. pubescens, Dorycnopsis heterophylla, Anthyllis cornicina, A. lotoides, Medicago orbicularis, M. hispida var. nigra, Trifolium hirtum, Tr. angustifolium, Tr. arvense, Tr. Bocconei, Tr. striatum, Tr. subterraneum, Tr. strictum, Tr. glomeratum, Lotus parviflorus, L. conimbricensis, Coronilla dura, Ornithopus pinnatus, O. compressus, Scorpiurus vermiculata, Astragalus lusitanicus, Biserrula P'elecinus, Poterium Masnoli, P. agrimoniaefolium, Montia fontana (f. rivularis), Illecebrum verticillatum, Corrigiola tele- 
phifolia, Cotyledon Muzizonia, Sedum tenuifolium, S. aureum, S. andegavense, S. arenarium, Saxifraga granulata forma, Eleoselinum foetidum, Thapsia villosa var. minor, Th. Transtagana, Daucus crinitus, D. setifolius, Ferula communis, Ferulago brachyloba, Oenanthe oligactis, Anthriscus vulgaris var. baetica, Conopodium subcarneum, Bifora testiculata, Lonicera implexa, Asperula repens, Crucianella angustifolia, Valerianella microcarpa, Pterocephalus diandrus, Senecio lividus var., Anthemis mixta, Matricaria Chamonilla, Filago spathulata, F. gallica, Phagnalon intermedium, Evax carpetana, Pulicaria hispanica, Carduus pycnocephalus, Andryala Rothia, Scorzonera angustifolia, Picris comosa, Thrincia hispida, $\mathrm{H}_{l}$ pochaeris glabra, Tolpis barbata, T. umbellata, Crepis virens, Campanula lusitanica, Jasione blepharodon.

Erica arborea, E. scoparia, Vincetoxicum nigrum, Centaurium minus Hill (1782) f. grandifloru (Biv. sp.), Cicendia filiformis, Myosotis stolonifera, Verbascum blattarioides, Scrophularia Scorodonia, Linaria spartea, Simbuleta bellidifolia, Orobanche gracilis, O. Spruneri, O. crenata, O. foetida, O. loricata var., Teucrium fruticans, T. Scorodonia, T. Haenselerii, Lavandula pedunculata, Cleonia lusitanica, Stachys lusitanica, Satureia Clinopodium, S. graeca, Asterolinum stellatum.

Rumex glaucus, R. Acetosella, Aristolochia longa, Securinega buxifolia, Helleborine latifolia, Serapias Lingua, Orchis fragrans, Iris Xiphium, Gladiolus illyricus, Tamus communis, Fritillaria hispanica (cápsulas), Allium neapolitanum, A. pallens var., Juncus capitatus, Carex divulsa, Anthoxanthum aristatum, Gastridium lendigerum, Chaeturus fasciculatus, Stipa gigantea Lk., Holcus annuus, Avena elatior, A. hispanica, Aira caryophyllea, Vulpia geniculata, V. sciuroides, V. Myurus, V. ciliata, Bromus tectorum, B. scoparius, B. macrostachys, Elymus Caput Medusae, Gaudinia fragilis, Lolium strictum.

Notochlaena vellea, Cheilanthes odora, Asplenium lanceoIatum, Ceterach officinarum, Gymnogramne leptophylla, Selaginella denticulata. 


\section{NOTAS SOBRE AFELININOS (HYMI. CHALC.)}

POR

RICARDO GARCIA MERCET

Desde el año 1912, en que publiqué la Monografía de los Afelininos, se han descrito una multitud de especies de esta subfamilia le microhimenópteros. Pero alonanas descritas con anterioridad a 1 , aparición de mi libro, dejaron de incluirse en éste por ignorar yo que se habian publicado.

He aquí una lista de los géneros y especies de afelininos descritos antes de 1912 y que no aparecen en mi monografía :

\section{Aphelinus japonicus Ashmead.}

Aphelinus japonicus Ashmead, Journ. N. Y. Ent. Soc., vol. XII, página 161 (1904).

Distribución GEOGRÁficA. - Japón: Atami.

\section{Género Aphytis Howard.}

Aphytis Howard, Rev. Chilena Hist. Nat., vol. VI, pág. 172 (1902).

TıPO. - Aphytis chilensis Howard.

OBservaciones. - Este género no tiene razón de existencia. Se caracteriza y diferencia de Ap/ıelinus nada más que por la pequeñez del primer artejo del funiculo y por presentar el oviscapto algo saliente. Su nombre tiene que pasar a sinonimia de Aphelinm. La especie a él atribuida por HowARD debe denominarse asf: 


\section{Aphelinus chilensis (Howard).}

Aphytis chilensis Howard, Rev. Chilena Hist. Nat., vol. VI, pág. 172 (1902).

DistribuCIÓN GEOGRÁFICA. - Chile.

Biología.-Parásito de Aspidiotus hederae, sobre presumible Hedera helix.

OBSERVACIONEs. - Esta especie tiene que ser extraordinariamente afín de Aphelinus longiclave Mercet. Es probable que sean lo mismo uno y otro insecto. En este caso mi especie tendría que pasar a sinonimia de Aphelinus chilensis.

\section{Género Mimatomus Cockerell.}

Mimatomus Cockerell, Entom. News, Philad., vol. XXII, pág. 464 (1911).

TiPo. - Mimatomus peltatus Cockerell.

OBSERVACIONEs. - Este género, según su autor, asesorado de Mr. Howard, participa de los caracteres de Encarsia y de Coccophagus. Se diferenciaría de ambos por presentar el nervio estigmático muy desarrollado. A pesar de ello, puede que sea muy difícil de separar de Encarsia.

\section{Mimatomus peltatus Cockerell.}

Mimatomus peltatus Cockerell, Entom. News, Philad., vol. XXII, página 464 (1911).

Distribución GEOGRÁFICA. - Estados Unidos.

Biología.-Parásito de Aleyrodes pruinosus subsp. euphorbiarım.

\section{Prospaltella brasiliensis (Hempel).}

Prospalta brasiliensis Hempel, Boletim da Agricultura, $5 .^{a}$ serie, núm. I, pág. 20, Sao Paulo (1904).

Distribución geográficA. - Brasil.

Biología. - Parásito endófago de Aleyrodes horridus Hempel, sobre ramas de naranjo. 
Aspidiotiphagus aleyrodis Ashmead.

Aspidiotiphagus aleyrodis Ashmead, Proc. U. S. Nat. Mus., vol. XXVIII. pág. 139 (1905).

Distribución GEOGRÁficA. - Islas Filipinas: Manila.

Biología. - Parásito de un Aleyrodes que ataca a la caña de azúcar (Sacharum officinarum).

\section{Eretmocerus paulistus Hempel.}

Eretmocerus paulistus Hempel, Boletim da Agricultura, $5 .^{\mathrm{a}}$ serie, núm. I, pág. 19, Sao Paulo (1904).

Distribución geOgRÁficA. - Brasil.

Biología. - Parásito de Aleyrodes horridus Hempel, sobre ramas de naranjo.

$$
*^{*} *
$$

Como adiciones a la fauna afelinina de España señalaré las siguientes :

\section{Physcus testaceus Masi.}

Physcus testaceus Masi, Boll. Lab. Zool. Gen. Agr. Portici, vol. IV, página 36 (1910).

Phy'scus testaceus Mercet, Trab. Mus. Cienc. Nat. Madrid, Ser. Zool., nimero 10, pág. 120 (1912).

PATria. - Italia, España.

Observaciones. - Esta especie no estaba señalada de Espaกิa. Recientemente hemos capturado una hembra en los alrededores de Madrid. La forma española difiere ligeramente de la italiana por la coloración, que es pardo-obscura, casi negra, en el tórax y amarilla en el abdomen. Las antenas presentan el escapo pardusco en casi toda su longitud; sólo el ápice de esta pieza es amarillo. Las patas son amarillas, con la base de los fémures ligeramente pardusca. Comparando estos detalles de coloración con los de la forma típica se observan algunas diferencias; pero la conformación de las antenas y de las alas parece ser idéntica en la forma italiana que en la española, y por este motivo no separo una de otra.

Physcus testaceus es parásito de Lepidosaphes ulmi. 


\section{Centrodora australiensis (Girault).}

Paraphelinus australiensis Girault, Arch. f. Naturg. Berlin, pág. 74 (1913). Aphelinus australiensis Girault, Mem. Queens. Mus., vol. II, página 180 (1913).

Aphelinus australiensis Girault, Mem. Queens. Mus., vol. IV, página 45 (1915).

Centrodora australiensis Mercet, Bol. Soc. Esp. Hist. Nat., vol. XVIII, pág. 106 (1918).

CARActeres. - Hembra: Cuerpo uniformemente de color amarillo de limón, incluso las antenas y las patas; alas hialinas, con una ligera nubécula extendida por el borde anterior de la línea calva.

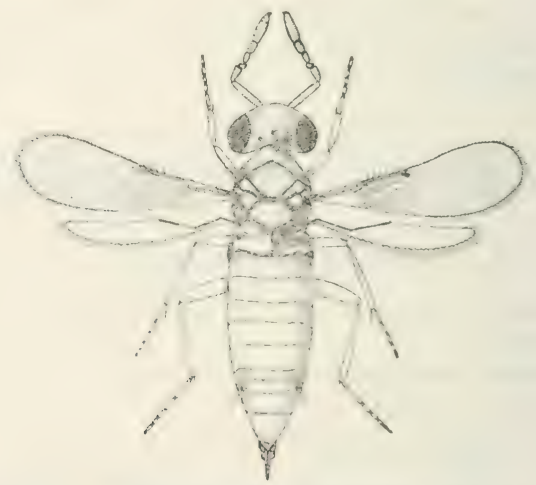

Fig. I. - Centrodora australiensis (Girault), hembra. $\times 4^{2}$.

Cabeza, vista de frente, casi tan ancha como larga; ojos redondeados, lampiños; estemas posteriores hastante próximos a las órbitas internas; mejillas casi tan largas como el diámetro longitudinal de los ojos; mandibulas tridentadas; palpos maxilares de dos artejos, labiales de uno. Antenas insertas cerca del borde de la boca; escapo cilindroideo, poco menor que el pedicelo y los tres artejos siguientes reunidos; pedicelo largo, mayor que cualquiera de los artejos del funículo; primero, segundo y tercer artejos del funículo sucesivamente mayores, todos más largos que anchos; el tercero como l.. 
tercera parte de la maza; ésta tan larga como el funículo, con dos sensorios en la mitad apical. Pronoto con una fila de pestañitas sohre el borde posterior; escudo del mesonoto tan largo como anchu. con seis pestañitas sohre el disco; escudete finisima y longitudinalmente estriado, con cuatro pestanitas en el dorso: segmento medin más finisimamente estriado que el escudete. Alas anteriores laras: nervio submarginal más corto que el marginal, con cuatro pextania sobre el borde superior; nervio marginal con seis pestañas; nervio postmarginal muy corto, pero visible, con una pestana en el ápice: disco profusamente pestanoso: seis filas de pestanitas más gruesas que las restantes entre la línea calva y la base del ala. Alas posteriores largas, estrechas: pestañas marcinales casi tan largas com; la anchura máxima del disco. Espolion de las tibias intermedias casi tan largo como el metatarso, éste un poco más largo que el de las patas posteriores; tibias del tercer par con un espolón pequeñisimo. Abdomen más largo que el tórax y la cabeza reunidos; lados de lus segmentos con dos o tres pestañitas muy cortas; espiráculos setiferos con tres pestanas, dos largas y una corta; oviscapto algo saliente.

\begin{tabular}{|c|c|c|}
\hline 8 & & $1,120 \mathrm{~mm}$ \\
\hline- & del escapo. & $0,162-$ \\
\hline - & del pedicelo.. & $0,081-$ \\
\hline - & del funiculo............... & $0,121-$ \\
\hline - & de la maza. ............ & $0,121-$ \\
\hline - & de las alas anteriores............. & $0,752-$ \\
\hline - & de las alas posteriores............ & $0,601-$ \\
\hline 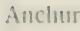 & láxima de las mismas. & 0,117 \\
\hline
\end{tabular}
drid),

Distribución geográficA.-Australia. España: El Pardo (Ma-

Haвттасіох. - Sobre plantas gramíneas silvestres.

Onservaciones. - La descripción del Paraphelinus austruliensis Girault se ajusta bastante bien a los caracteres del insecto encontrado por nosotros en Espana, y por este motivo aparece calificado del modo que aquil to ha sido un insecto de nuestro país. Parecerí a muchos chocante que una especie australiana se encuentre en Europa, pero esto en los calcididos no constituye un caso excepcional. El Aphelinus mytilaspidis Howard se encuentra en Europa y eni los Listados Unidos. Li Arrenophagus chionasplolis Aur. y el Aspidiotiphagus citrinus Craw son de Europa, Ceilan, América 
del Norte, Australia, etc. Muchos más ejemplos podría citar como demostración de que no constituye un fenómeno extraordinario el caso de una especie que viva en Europa y Australia.

\section{Prospaltella ilicis sp. nov.}

Caracteres. - Hembra: Cuerpo de color uniformemente negruzco; antenas negruzcas también, con el pedicelo ceniciento; alas hialinas, con un ligero ensombrecimiento debajo del nervio marginal; patas negruzcas; tibias anteriores e intermedias blancas, su base con un anillo negruzco; tibias posteriores

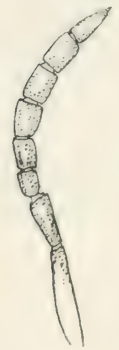

Fig. 2.-Antena de Prospaltella ilicis sp. nov., hembra. $\times 70$. obscuras en la mitad basilar y blanquecinas en la apical; tarsos blancos, con el último artejo ennegrecido.

Cabeza redondeada vista de frente; vértice reticulado-escamoso, con algunas pestañitas negras; ojos grandes, apenas pestañosos; mejillas un poco más largas que el diámetro longitudinal de los ojos; mandibulas tridentadas, dientes ligeramente obtusos; palpos maxilares de dos artejos, labiales de uno. Antenas insertas cerca del borde de la boca, separadas entre sí en la base por un espacio casi igual a la longitud del pedicelo; escapo un poco mayor que los tres artejos del funículo reunidos; pedicelo casi tan largo como los dos artejos siguientes; primer artejo del funículo un poco menor que los siguientes; segundo y tercero un poco más gruesos; primer artejo de la maza más grueso que el precedente; segundo artejo más estrecho; tercer artejo cónico, fuertemente estrechado; funículo y maza forman un conjunto fusiforme. Escudo del mesonoto con seis pestañitas negras, dispuestas en tres series; escudete con cuatro pestañitas, dos centra-

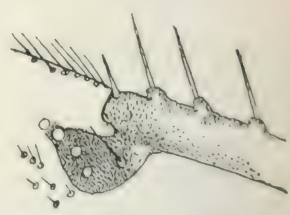

Fig. 3.-Nerviación alar de Prospaltella ilicis sp. nov., hembra. les y dos apicales. Alas anteriores grandes y anchas; nervio submarginal más largo que el marginal; nervio postmarginal rudimentario, obtuso; nervio estigmático sentado. triangular, su borde superior paralelo al borde del ala; pestañas marginales más bien largas; célula costal ancha: pestañas marginales 
de las alas posteriores tan largas como la anchura máxima del ala. Espolón de las tibias intermedias un poco mayor yue el metatarso: metatarsos intermedios y posteriores de casi igual longitud, algo menores que los dos artejos siguiente's reunidos. Abdomen finisima y loneritudinalmente reticulado-escamoso: lados del horde posterior de los sermentus segundo, tercero y cuarto con alerunas pestañitas blancas: (quinto sermento con aleunas pestañitas negras: pestañins de los espiráculos setiferos relativanente cortas; oviscapto oculto.

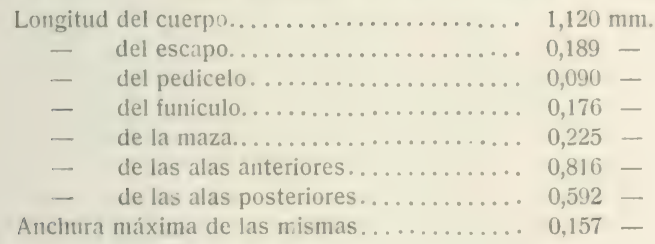

Macho: Desconocido.

Distribución geográfica.-Provincia de Madrid: Madrid.

HaBITACIÓn. - Sobre Quercus ilex.

Observaciones. - Especie próxima, sin duda, a $P$. quercicola How. y $P$. similis Masi. Pertenece al grupo de especies que ofrecen un rudimento de nervio postmarginal, como las dos citadas y otras: P. koebelei How. y P. perspicuipennis Girault. También pertenece al grupo de las que tienen antenas fusiformes, en el que figuran P. murtfeldtii How., P. berlesei How., P. similis Masi y algunas otras. Tal vez sea posible establecer algunos subgéneros fundándolos en la forma de las antenas, pues hay varias especies que ofrecen estos apéndices claramente engrosados en el ápice, y otras en que el funículo y maza forman un todo fusiforme.

\section{Prospaltella brunnea Howard.}

Prospaltella brunnea Howard, Ann. Ent. Soc. Amer., vol. I, página 243 (1004).

Prospallella brunnea Mercet, Trab. Mus. Cienc. Nat. Madrid, Ser. Zool., núm. 10, pág. 186 (1912).

Caracteres. - Hembra: Cabeza de color pardo, con una linea amarillentá contigua a las órbitas internas; ojos de color de carmin; tórax pardo obscuro, casi negro; abdomen blanquecino, negruzco 
en el ápice; antenas blanquecino-amarillentas; ápice de la maza ligeramente negruzco; alas hialinas; patas amarillentas, muy claras.

Cabeza tan ancha como el tórax; frente reticulado-escamosa, con algunas pestañitas blanquecinas; ojos casi lampiños, muy espar-

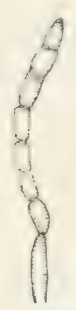
cida y muy cortamente pestañosos. Antenas insertas cerca del borde de la boca; pedicelo apenas más largo y más ancho que el artejo siguiente; primero, segundo y tercer artejos del funículo casi iguales en longitud y anchura; maza apenas más gruesa que el funículo, tan larga como los tres artejos precedentes reunidos; todos los artejos, a partir del segundo del funículo, con un sensorio longitudinal. Escudo del mesonoto, axilas y escudete reticuladoescamosos; en el escudete tiende la reticulación a

I'in. 4.-Anterth de Prosollithe irmonat l loward, liemima. $>-0$. formar finisimas estrias longitudinales; segmento medio transversalmente reticulado. Alas anteriores relativamente anchas y con pestañas marginales largas; nervio submarginal algo menor que el marginal, el primero con tres o cuatro pestañas sobre el borde superior, el segundo con ocho; nervio estigmático pediculado, terminado en forma de cabeza de pájaro, su borde superior recto o ligeramente convexo, casi paralelo al borde del ala. Alas posteriores triangulares, estrechas; pestañas marginales tan largas como la anchura máxima del disco. Espolón de las tibias intermedias un poco menor que el metatarso; éste más grue-

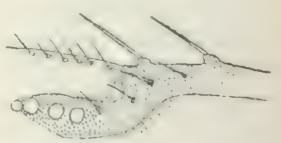

Fig. 5.-Nerviación alar de Fruspultella brumnea Howard. so, pero más corto que el de las patas posteriores; espolón de las tibias posteriores como la mitad del metatarso correspondiente. Abdomen oval, con una pestaña lateral en el borde posterior de los segmentos segundo y tercero; oviscapto poco saliente.

Longitud del cuerpo................... $0,800 \mathrm{~mm}$.

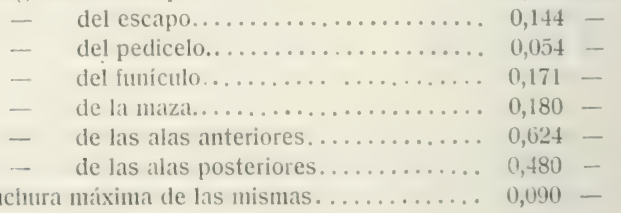


Hacho: Desconocido.

DistribucióN geográfica. - Isla de Puerto Rico. España: Madrid,

Biologia. - La forma antillana es parásita de un Aleyrodes.

Observaciones. - La descripción original de Prospaltellc brumnea Howard es brevisima, pero los caracteres que en ella s. uigman a la especie concuerdan exactamente con los que ofrecen tres individuos hembras cazados por nosotros sobre Pinus halepensis en los alrededores de Madrid. Sería necesario confrontar la forma madrileña con la antillana para poder apreciar si se trata de especies diversas o de una misma especie. Tal vez la descripción? un tanto minuciosa que doy yo de la forma española permita en Wáshington, cotejándola con el tipo de Howard, dilucidar estas dudas que a mí se me ocurren.

\section{Prospaltella (Doloresia) conjugata (Masi).}

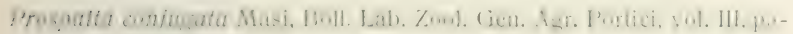
gina 146 (1909).

Prospultclla conjugata Mercet, Trab. Mus. Cienc. Nat. Madrid, Ser. Zool.. nimi. 10, píg. 187 (1912).

Distriblción geográfica, - Italia, España.

Orserviciones. - Los ejemplares españoles concuerdan exactamente con los italianos por todos sus caracteres. Proceden de Capellades (Barcelona), donde fueron obtenidos de Aleyrodes brassicae sobre Brassica oleracea. El Sr. Codina, del Museo de Barcelona, me envio hace tiempo una remesa de esta Prospaltella para su estudio y clasificación. Debe ser un parasito muy eficaz del Aleyrodes, pues la remesa del Sr. Codina la constituian más de un centenar de hembras de este afelinino.

ESPECIES EUROPEAS DEL GENERO IM(ISP.1I.T\%I.I.A

CLAVE DICOTÓMICA

IIembras.

1. Antenas engresatias hacia el ápice; la mazat hien diferenciandat del funiculr..................................

- Antenis fusifurmes; al antejo terminal de la maza fuertemente vinico.................................. 
2. Túrax amarillo o pardusco con porciones amarillas; abdomen amari-

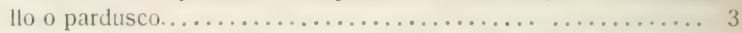

- Tórax negro; abdomen blanquecino en la mayor parte de su extensión, negruzco en el ápice mismo........... P. brunnea Howard.

3. Naza más larga que el funiculo .................. 4

- Maza a lo sumo tan larga como el funiculo.............. 5

4. Cuerpo de color amarillo; segundo artejo del funículo más largo que el primero........................ P. lutea Masi.

- Cuerpo de color amarillo con algunas manchas negruzcas; primero y segundo artejos del funículo de igual longitud................ ........................... P. leucaspidis Mercet.

5. Cabeza de color amarillo de limón; tórax amarillo o anaranjado; abdomen amarillo en la base y el ápice, pardo-negruzco en el centro; pedicelo más largo que el artejo siguiente..... P. olivina Masi.

- Cabeza de color amarillento obscuro; escudo del mesonoto pardo; escudete amarillo; abdomen negro-pardusco, amarillo en el ápice; pedicelo tan largo como el artejo siguiente. P. conjugata (Masi).

6. Nervio postmarginal nulo....................... 7

- Nervio postmarginal rudimentario.................. 8

7. Nervio marginal tan largo como el submarginal; abdomen de color pardo....................... P. berlesei Howard.

- Nervio marginal más largo que el submarginal; abdomen de color amarillo....................... P. fasciata Malenotti.

8. Nervio estigmático ligeramente pediculado, su borde superior curvo y dirigido hacia el borde del ala; cuerpo de color pardo; cabeza amarillento-pardusca; tórax con algunas porciones amarillas........... ............................. P. similis Masi.

- Nervio estigmático trianguliforme, sentado, su borde superior recto y paralelo al del ala; cuerpo de color pardo obscuro, casi negro......

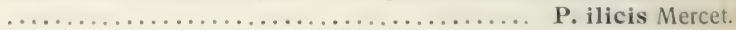

\section{Aspidiotiphagus citrinus (Craw).}

Coccophagus citrinus Craw, Destructive Insects, Sacramento, página 28 (1891).

Aspidiotiphagus citrinus Howard, Rev. Aphel. N. A., pág. 31 (1895).

Aspidiotiphagus citrinus Mercet, Trab. Mus. Cienc. Nat. Madrid, Ser. Zool., núm. 10, pág. 173 (1912).

Observaciones, - Esta especie está descrita en mi Monografia de los Afelininos. La incluyo, sin embargo, en la presente nota para consignar que la hemos obtenido como parásito endófago de Chionaspis evonymi Comst., sobre hojas de Evonymus japoni- 
cus. Este parasitismo de Aspidiotiphagus se señala ahora por primera vez en España.

\section{Archenomus bicolor Howard.}

Archenomus bicolor Howard, Proc. Ent. Soc. Washing., vol. IV, página 137 (1898).

Archenomus bicolor Masi, Boll. Lab. Zool. Gen. Agr. Portici, vol. III, paigina 115 (1909).

Árchenomus bicolor Mercet, Trab. Mus. Cienc. Nat. Madrid, Ser. Zool.. núm. 10, pág. 280 (1912).

DistribucióN GeográficA. - Estados Unidos, isla de Java, isla de Ceilán, Francia, Italia; España: Madrid, Bilbao.

ObServaciones. - La forma española se ajusta casi exactatamente a la descripción de la francesa e italiana. Un macho recogido por nosotros sobre Fraxinus excelsior ofrece la anomalia de presentar tres artejos en todos los tarsos. Una hembra difiere de los caracteres asignados a la especie por presentar el tórax casi completamente negro.

ESTUDIO CRITICO DE LA PUP.A MEOACHEMOS CRIST IIOTRI ET IAN, $Y$ DE ALCILNAS FORMAS DERIVADAS DE ELLA OLE VIVEX EY ESPAÑA

POR

FLORENTINO AZPEITIA MOROS

Profesor do la Escuela Espocial do Ingenieros do Minas.

(L.1́mina XIX.)

La Pupa megacheilos, como otras muchas especies antiguas, se fundó con una descripción brevisima y sin dar figrura de ella, y como se trata de un molusco sumamente variable en todos sus caracteres y se han creado demasiados nombres para designar sus variedades, nada tiene de particular que hoy resulte una especie litigriosa. 
Encuéntranse individuos grandes y pequeños, largos y cortos, de más o menos vueltas de espira, casi lisos y bastante estriados, con la abertura redondeada inferiormente o angulosa, con numero. sos pliegues y tubérculos dentiformes en la boca (entre 6 y más de 16) y color desde pardo rojizo más o menos obscuro hasta el córneo claro. A pesar de tales variaciones, presenta siempre un aspecto idéntico en su conjunto, que no permite desconocerla. Son muchas las combinaciones que admiten todos esos elementos, y no sé si se realizarăn todas ellas en la naturaleza. Desde luego, algunas son conocidas y han recibido nombres específicos; pero hay otras muchas, no descritas todavia, a las que no se les debe dar nuevo nombre, para no complicar más la ya embrollada sinonimia de esta concha.

Es muy difícil encointrar ejemplares que coincidan exactamente con todos los caracteres de una forma conocida y con nombre, porque como todos son inconstantes, casi siempre falta o sobra alguno para que la coincidencia sea absoluta. Consecuencia de esto es que la mayor parte de las veces no se sabe a qué variedad deben refrirse los ejemplares recogidos.

Aunque al fin y al cabo se ha de convenir en que todos los nombres que voy a citar corresponden a formas derivadas de un tronco común, o lo que es igual, son variedades de una especie única, daré las descripciones originales de todas separadamente, cual si fueran distintas, para que sirvan de base al estudio crítico que he de hacer de cada una de ellas, y al mismo tiempo se encontrarán asi reunidos los elementos necesarios para que cada cual pueda formar juicio independiente del valor específico de todas esas formas.

Para la distribución geográfica, además de los ejemplares de mi colección, en su mayor parte recogidos por mi mismo, he de servir me de las Obras malacológicas de mi maestro el Dr. Hidalgo (1). el cual ha compilado las citas de las especies de moluscos marinos y terrestres hispano-lusitanos contenidas en la casi totalidad de lo publicado en el mundo entero sobre esta rama de la Historia Natural. Como además da el juicio crítico de todas esas obras, puede vanagloriarse nuestro país de que ningún otro tiene una revisión bibliográfica que pueda compararse con ella. Es, pues, un libro yuw

(1) Publicadas en las Memorias de la Real Academia de Ciencias de: Madrid. La parte correspondiente a moluscos españoles comprende tres volumenes con 2431 páginas. 
forzosamente ha de servir de fundamento a cualquier trabajo serio que sobre Mlalacología española quiera emprenderse.

Pero téngase presente que las citas están hechas por multitud de autores, a veces con criterios muy diferentes, y que no siempre estará bien la determinación especifica de los moluscos de un lugar; por eso doy yo, además de la localidad, las páginas de HidALGO en que constan los datos, para que por sımediación se pueda llegar al origen de la cita y resolver las dudas que se presenten. Por otra parte, el mencionar todas esas páginas equivale a dar una bibliografía abreviada de la especie, en lo que a España se refiere.

Pupa megacheilos (Cristofori et Jan).

(Lím. XIX, flgs. 1 y 2.)

1832. Chondrus megacheilos Crist. et Jan.-Catalogus rerum naturalium in Museo exstantium, Sect. II, P. 1, Mantisa, pág. 3. .

1835. Pupa megacheilos Jan et De Crist. - Des Moulins, Description de quelques . Mollisques terrestres et fluviatiles de la France, nouveaux ou peu comus, in Soc. Linn. de Bordeaux, vol. VII, pág. 158 y sigs., pl. II, figs. A, B, C y D, que representan el tipo y tres variedades.

1837. P. megacheilos Crist. et Jan. - Rossm., Iconog., Heft V und VI, pág. 13, Tat. XXIII, fig. 318; III Bd., 17 Heft (Neue Folge), 1859, paig. 106, Taf. 85 (por error 84), fig. 938 (1).

1841. Torquilla tricolor Villa, A. y J. B.-Dispositio systematica Conchyliarum terrestrium et fluviatilium, etc. Mediolani, paig. 57.

1845. P. megracheilos Jan. - Kiister (Pupa und Vertigo), paig. 46, Taf. VI, figs, if a 8 y $8^{*}$.

1848. P. megacheilos (Chondrus) Jan. - Pfeiffer, Mon. Hel. viv., vol. II, pier. 346; vol. III, 1853, paig. 54i; vol. IV, 1859, piig. 673; vol. VI, 1868, pitg. 315; vol. VIII, 1977, pág. 384.

1855. P. megacheilos Crist. et Jan. - Moq.-Tand., Hist. Nat. des Moll. terr. et fluv. de France, t. 11, paig. 354, pl. 25, ligs. 23 a 32. (Estim comprendidas lia $P$. goniostoma y otras furmas.)

1881. P. megacheilos Jan. - Clessin et P'r., Nomencl. Hel. viv., pig. 347. 1887. P. megachilus Jan. - Westerl., Pauna Paliaarct., Reg., III, prig. 90.

1894. P. megachila Crist. et Jan. - Locard, Coq. terr. de France, paigina 299.

(1) Lat figura 937 la dit comu variedad, y P'ILSBzY la refiere a la Chondrina grigantea Moç.-Tand., m. s. in Rossum. 
1913. P. megacheila Crist. et Jan. - Germain, Moll. de la France, página 170 , fig. 229 en la pág. 172 (1).

1918. Chondrina megacheilos Crist. et Jan.-Pilsbry, Man. of Conchol., vol. XXV (cuad. 97), pág. 7, pl. 1, figs. 1 a 3, con las variedades: Torquilla tricolor Villa; f. minor Westerl; var. toscolana Schröder; var. Caziotana n. n. (2), y var. galloprovincialis Margier.

No P. Megacheilos var. Alb., que, según Pfeiffer, Hel, viv., es P. Arigonis Rossm.

No he tenido ocasión de consultar el Catálogo de CRISTOFORI y Jan, donde se publicó la primera descripción de la Pupa megacheilos, incluida en el género Chondrus, descripción que es brevísima y que PFeIfFer transcribe en su Mon. Hel. viv., t. II, nota (*), en la página 346 , de donde yo la copio:

"T. dextrorsa, conico-cylindrica, vertice obtusiusculo (alt., $4^{1} / 2$; lat., $11^{1} 2^{\prime \prime \prime}$ ), apertura septemplicata (alt., $1^{1} / 2$; lat., $1^{\prime \prime \prime)}$, perist. lato albo.» (Jan, Pfr.)

Tres años después, DEs Moulins, en la obra anteriormente citada, vuelve a tratar del mismo molusco y da descripciones y figuras del tipo y tres variedades.

Como se trata de diagnosis que han de servir de punto de partida para deslindar formas que viven en España, considero interesante reproducir lo dicho por este autor en la página 158 y siguientes:

«Pupa megacheilos Jan et De Cristofori. (Véase pl. II, figs. A, B, C, D.)

»Aunque esta bella y notable especie existe desde hace algunos años cn un gran número de colecciones francesas, hace, sin embargo, bien poco tiempo que ha sido reconocida y publicada como distinta; además, teniendo en cuenta que no existe ninguna figura, que yo sepa, he creido litil publicar los dibujos con la embrollada sinonimia con que la han recargado los diversos coleccionistas.

»Yo no sé que se haya encontrado la Pupa megacheilos en otra parte de Francia que en los Pirineos; pero en esta cadena parece esparcida sobre toda su extensión, porque $M$. N. Boubée, que acaba

(1) La figura muestra siete pliegues en la boca, que al mismo tiempo es algo angulosa en la base, como la goniostoma.

(2) A guisa de apéndice doy traducida la descripción de estas tres a continuación de la megacheilos. 
de publicarla por primera vez en Francia, bajo su verdadero nombre, en el Bull. d'Hist. Nat. de Fr., $3^{\mathrm{e}}$ sect., p. 29, n 70 , la cita de diez y seis localidades de los Pirineos franceses. Estas localidades están repartidas en los cinco departamentos (Pirin. orient., Ariège, Alto Garona, Altos Pirin., Bajos Pirin.); M. Boubée anunria igualmente que es abundante en los Pirineos espanoles; el doctor Jourdain la ha traido de Barcelona, y también habita la cade-na de los Apeninos.

„El célebre geólogo $M$. de Charpentier parece haberla descubierto el primero, hacia 1815, en las cercanias de Bagnères de Bigorre, donde es muy abundante; $M$. de Grateloup la recogió también en 1820 y la comunicó a $M$. de Charpentier, que le respondió que la consideraba especie nueva y le habia impuesto el nombre de Pupa Bigorriensis. Pero como este nombre no se ha publicado en ninguna parte, que nosotros sepamos, la prioridad corresponde a la primera publicación real, es decir, a la de los MM. Jan et de Cristofori, de Parma, asi como yo se lo he hecho observar a M. N. Boubée, que ha adoptado mis conclusiones. Insisto sobre esta observación, porque si no se admitiera la identidad de la especie apenina con la pirenaica, o por lo menos con alguna de sus variedades, sólo a mi habria que acusar de haberlas confundido; pero yo no creo que se ponga en duda esta identidad, a pesar de las notables diferencias que presentan diversos individuos.

¿Según los pocos ejemplares de Italia (ocho o nueve) que he podido examinar, ofrece diversas variaciones esta bella especie en su grado de alargamiento, en la fuerza de sus estrias, en su talla, en su coloración y también en el áıgulo inferior de su abertura. Variaciones análogas se encuentran en el gran número de ejemplares de los Pirineos que he tenido a la vista: los de los Pirineos orientales son más grandes, más obscuros y más agudos en la base que los de los Altos Pirineos; los que forman mi segunda variedad se distinguen por un alargamiento extremado que les aproxima a las Clausilia; pero todos, italianos y franceses, presentan igualmente este caracter saliente (la anchura del borde, blanco y dilatado del peristoma), de donde Jan y de Cristofori han sacado el excetente nombre. específico de Pupa megacheilos (gran borde).

„Llego a la sinonimia. En primer lugar debe colocarse el nombre dado por $M$. Charpentier, que si no estoy equivocado, ha quedado inédito, lo cual no es de sentir demasiado, puesto que la especie habita lugares tan alejados unos de otros, P. Bigorriensis Charp. 
"Luego me enviaron esta especie de los Pirineos y yo la confundi con la $P$. secale Drap.

„Fué mencionada en una Memoria leída ante una Sociedad cientifica de París, bajo el nombre de una especie considerablemente diferente, $P$. frumentum Drap., var. pyrenaica.

»Dos naturalistas, corresponsales míos, me la enviaron o me hablaron de ella en sus cartas, bajo los nombres sucesivos e igualmente erróneos de $P$. avena Drap., var. major, y de $P$. pyrenaearia Mich. (Compl.).

»M. Michaud tuvo la idea, que no ejecutó, de publicarla como nueva, bajo el nombre de $P$. Farinesi.

„Por su parte, M. Farines la proponía también como distinta, bajo el nombre de $P$. pyrenaica.

"Yo cometí la falta de descartarla, preocupado como entonces estaba con la identidad imaginaria de esta especie con la $P$. secale.

»Si alguno de los dos últimos naturalistas hubiera llevado a cabo entonces su proyecto, a él hubiera correspondido la prioridad sobre el nombre de megacheilos.

»Vino por fin la publicación de este último nombre, publicación consumada por los catálogos y los marbetes impresos que acompañaban las colecciones de moluscos italianos puestas en venta por el profesor Jan y M. de Cristofori, de Parma (Cat., sect. 2, fasc. I, Gen. 12, sp. 13).

»Considerada como nueva por cuatro naturalistas que todos han querido establecerla como tal, traqueteada sucesivamente y sin razón entre otras cuatro especies vecinas, pero distintas, la legitimidad, o por mejor decir, con la escuela moderna, la autonomía de esta especie, me parece indiscutible.

》Véase la descripción provisional que propongo para ella, comparándola a las especies vecinas:

"P. Testa fusiformi vel subpyramidata, oblique striata, corneo-fusca, anfatribus 7-10 conve-xiusculis, sutura profunda; apertura subovata 6-8 plicata, basi plus minus angulata; peristomate albo, patulo, late reflero; umbilico magno, profundo, subrotundato, carina eminentissima crassa cincto.

"Long., 7 -13 mm.; diám., 23/4-4 mm.

Dos de los dientes están sobre la uiltima vuelta, en lo alto de la abertura; otros dos sobre la columuilla; $2-4$ (ordinariamente 3 ) dentro del labro externo, y el más superior de estos últimos se liga al peristoma por una gibosidad más o menos saliente que completa 
el contorno testácéo, en el cual se desarrolla el orificio respiratorio. La longitud de la abertura es igual al diámetro mayor de la concha en todas las variedades.

»Esta especie, como todas sus congéneres, ofrece en primer lugar, en casi todas las localidades, una variación más alargada y otra más corta. Pero además presenta variedades muy notables (entre ellas dos o tres quizás fuesen susceptibles de considerarse como especies distintas), de las cuales he indicado anteriormente algunas. Voy a caracterizar más categóricamente las que me son conocidas :

„Var. a (typus). - Conchiı gruesa, sólida, de un pardo-rojizo, subfusiforme o subpiramidal, con estrias casi borradas. Vueltas de espira, 8-9. Peristoma grueso muy extendido. Long., 9-10 mm.: diám., $3^{1 / 2}-4$ mm. - Italia boreal. (Véase pl. 2, fig. A.)

- Var. b (elongatissima). - (La diagnosis integra, y todo lo dicho por Des Moulins sobre esta variedad, se transcribe más adelante.)

„Var. c (tenuimarginata). - Muy obscura, menos sólida y menos alargada que la precedente, más pequeña y más estriada que la var. $a, y$ que ofrece las mismas variaciones en cuanto al ángulo inferior de la abertura, pero que tiene el reborde del peristoma más delgado, más cortante y menos plano al reflejarse. Vueltas de espira, 7-8. Long., 8-9 mm.; diám., 3 mm. - Pirineos orientales, comunicada por M. Farines. Ésta es la que M. Michaud había querido publicar bajo el nombre de $P$. Farinesi, y $\mathbf{M}$. Farines, bajo el de P. plyrenaica. (Véase pl. '2, fig. C, 1-4.)

Ofrece una subvariedad de color córneo muy claro, transparente, frigil, muy estriada.--Barcelona. (Véase pl. 2, fig. C, 5-8.)

"Var. d (pusilla). - (Lo dicho por Des Moulins para esta variedad se copia más adelante en la P. Bigorriensis.)

Otros malacólogros posteriores (Küister, Pfr., IVesterl., etc.) están conformes en considerar la Pupa (Torquilla) tricolor Villa como sinónima de la megacheilos, y a continuación copio la descripción original, tomándola de PFEIFFER, Mon. Hel. viu., t. II, nota ( $\left.{ }^{3}\right)$, en la página 346:

Torquilla tricolor Villa. - T. dertrorsa, crassa, fusiformis, brunnea nel nigro-brunnea, vertice dilutiori, substriatu; anfracl. converiusculis; apertura obouata, basi subunerulata; s-plicata, plicis inaequalibus; perist. albo dilatato; umbilico masno, profundo. - Alt., 11-1.3; Iat., in mm.s (Villa, Pfr.)

Como se ve, en la descripción original sólo se citan 7 pliegues 
en la boca; Des Moulins indica un mínimo de 6 y un máximo de 8 , siendo éste el caso más frecuente; KÜSTER señala 9 (2 pariet., 2 colum. y 5 palat.); PFEIFFER hace la descripción por un ejemplar de su colección (indudablemente bastante adulto y robusto) y cuenta ya 10 ; y por fin, en la variedad toscolana Schröder pueden verse más de 16 entre pliegues y tubérculos dentiformes. A pesar de estas diferencias, los 7 pliegues señalados en el tipo ( 2 pariet., 2 colum. y 3 palat.) son los principales, pues se presentan en todas las variedades (salvo el caso de 6 en que se atrofia el palatal inferior) con la misma fuerza y en idéntica posición; todos los demás son accidentales, poco desarrollados y más o menos rudimentarios.

Respecto al ángulo inferior de la abertura, es indudable que existen individuos con ese ángulo bien definido (lo que dió lugar a que KÜSTER fundase su especie goniostoma), y en la misma localidad se ven otros en los que la boca es redondeada por abajo, quedando ligadas ambas formas por multitud de intermedias en las que el ángulo se va desvaneciendo por grados insensibles. Generalmente, en diferentes localidades, y aun en la misma en distintos puntos, se ven reuniones o grupos de individuos en que domina una u otra forma. La breve descripción de JAN nada dice de este ángu10, y las figuras A 1 y 2 de Des Moulins, lo mismo que la 318 de ROSSMÄSSLER, que son los primeros dibujos de la especie, tienen la base sin ángulo, y por lo tanto esta forma de abertura será la que debe considerarse como la del tipo verdadero de la megacheilos.

El color es igualmente variable tanto en el tipo como en sus distintas formas, desde el castaño o rojizo más o menos obscuro hasta el córneo claro. La Torquilla tricolor Villa debe su nombre a que el animal, desecado dentro de la concha, transmite a ésta por transparencia las tres variaciones de tono aludidas; pero si se extrae el animal, la concha queda unicolor. Generalmente, todos los individuos de la misma estación (no de la misma localidad) tienen idéntico color; es decir, no viven mezclados de los diferentes matices. La descripción original tampoco dice nada del color; pero los autores parecen conformes en asignar al tipo el color pardo rojizo más o menos obscuro.

De suerte que los caracteres distintivos del tipo de la megacheilos son: boca más o menos redondeada inferiormente (pero no angulosa), con 7 pliegues principales (casi siempre hay, además, un octavo, palatal superior), y color pardo rojizo más o menos obscuro. 
En las Obras malacológicas del Dr. Hidalgo se cita de las localidades siguientes con el nombre de megacheilos:

Barcelona, pág. 921. - Burgos, pág. 534 v.

Camprodón, págs. 534 v., 753. - Cataluña, págs. 650, 1538.

España, págs. 318,420 v., 471 v., 513, 564 v., 599, 685.

Montserrat, págs. 534 v., 1000, 1427, 1610.

Norte de España, pág. 2133.

Olot (Comarca de), Plataver, etc., págs. 627, 753.

Pirineos españoles, págs. 313, 921.

Ribas, págs. 307 v., 753.

Soria, pág. 534 v. - San Lloréns del Munt, pág. 1000.

Tagamanent (Cima del), pág. 2195 .

Valencia, págs. 275 v., 534 v. - Valle de Arán, pág. 306.

Con el nombre de $P$. pyrenaica Farines (n. Boubée):

Mlontaña de la Pinsa (Valle de Arán), pág. 306.

Como Torquilla megacheilos Jan:

Cataluña, Montserrat, pág. 393. - España, pág. 1074.

Poseo en mi colección tres ejemplares de Italia remitidos por los hermanos Villa a Pérez Arcas con el nombre de $P$. megacheilos Jan, que además de los dos parietales y dos columelares, tienen cinco palatales, los dos superiores muy pequeños y que fácilmente pasan inadvertidos (sobre todo el más alto). Uno de los individuos tiene la boca subangulosa inferiormente y el borde izquierdo rectilineo (como la leptocheilos).

Otro ejemplar de Italia, también remitido por Villa con el nombre de P. tricolor Villa, se diferencia de los anteriores solamente en ser un poquito mayor y otros insignificantes detalles; de todas las maneras es idéntico a muchos de los recogidos por mi en la Foz de Biniés (Huesca).

Es decir, que estos ejemplares que proceden anténticamente de Italia, pais originario de la especie, son absolutamente ignales a otros españoles, lo cual demuestra que no pueden considerarse especies distintas por la sola razón de vivir ell dos pafses que, después de todo, no están muy alejados entre sí, y que además tienen bastantes moluscos comunes en sus respectivas faunas. 
También he recogido esta Pupa en el valle de Canfranc desde Villanúa hasta las fuentes del río Aragón (mezclada con la leptocheilos y la goniostoma); en el valle de Tena desde Biescas hasta las fuentes del río Gállego y hasta Panticosa, y en el valle del río Ara desde Broto y Torla hasta Bujaruelo, asi como en el Parque nucional de Ordesa, por donde corre el rio Arazas, primer afluente por la izquierda del mencionado río Ara. Todas estas localidades de le provincia de Huesca.

Bien entendido que ni de éstas ni de ningún otro sitio de España he visto ejemplar alguno bien adulto que carezca del cuarto palatal (o sea el superior), siquiera sea rudimentario, pero siempre visible.

PlLsBry admite en la Chondrina megacheilos la forma minor Westerl. y las variedades toscolana y Caziotana. Menciona también la variedad galloprovincialis; pero como de ésta no hay descripción ni figura, debe prescindirse en absoluto de ella. Con el objeto de completar en lo posible el conocimiento de lo que afecta a la Pupa megacheilos, doy a continuación la descripción de las tres formas, aunque hasta ahora nadie, que yo sepa, las ha citado de España.

Forma minor Westerl._Fauna Paläarct., III, 1887, pág. 96.

Long., $5 \frac{1}{2}$ a a 6 ; diám., $2 \mathrm{~mm}$. - Difiere de la avenacea por lo comprimida que es la base aquillada de la última vuelta, el labio reflejado, la abertura angular inferiormente y el borde columelar recto, etc. WESTERLUND no da localidad para esta forma, pero SCHRÖDER la cita de cerca de Gargnano, Salo, etc., del lago de Garda (Nachrbl., 1913, pág. 174). CAZıot figura igualmente una var. minor del Norte de Grasse de cerca de 5,7 mm. (Pilsb., pág. 9.)

\section{Var. toscolana Schröder.}

Concha semejante al tipo, excepto que es corpulenta; vueltas, 8-9; abertura con muchos pliegues y tubérculos dentiformes (más de 16). Long., 11-14 ${ }^{1} / 2$; anch., 4-5 mm. - En los peñascos del valle de Toskolano, a poniente de las montañas del lago de Garda. (Modicella megacheilos Jan, var. toscolana Schrüder, Nachrbl. d. m. Ges., vol. XLV, 1913, pág. 174.) (Pilsb., pág. 9.) 
Var. Caziotana Pilsbry, n. n.

Más bien es variedad de la megacheila que de la avenacea; en la última especie los pliegues palatales están opuestos a los columelares y no llegan nunca al peristoma, mientras que en la megacheila los pliegues palatales más robustos alternan con los columelares, y uno a lo menos, o varios, alcanzan el peristoma; y éste es el caso de nuestra variedad, la cual es también muy afín a la variedad maritima. Forma el paso a la $P$. megacheila, pero no tiene abertura angular.-- Alpes marítimos, etc., a 1500-1600 metros. (P. megacheila var. labiosa Caziot, Etud. Moll. terr. et fluv., Mónaco, 1910, pág. 317, pl. 8, fig. 9.) Podría ser quizás equivalente a lì P. avenacea var. maritima Locard, según CAzIOT. (Texto cit., nota

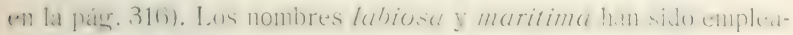
dos antes en el género Pupa. Las figuras de CAzıot son demasiado pequeñas para apreciar los caracteres distintivos. (Pilsb., pág. 10.)

La descripción de PILsBry es traducción literal de la de CAzIOT, y éste, en la explicación de la lámina, la da como variedad de la avenacea, y en el texto como variedad de la megacheila. La figura es una fototipia con la boca tan obscura, que no se ve ningún detalle. Está ampliada tres veces, y se pueden deducir las dimensiones que no indica la descripción. Long., $6 \frac{1}{3}$; diám., $2 \frac{1}{5}$. mm.

Al decir PILSBRy que el nombre de labiosa se habia usado ya, debe referirse a la $P$. multidentata Oliv., var. labiosa Moq.Tand., Moll. terr. et fluv. de France, II, 1855, pág. 375, variedad que más tarde fué considerada por Cl.essix et Pferrfare, Nomencl. Hel. viu., 1881, pág. 345, como sinónima de la Brauni Rossm.

En cuanto a la P. maritima Locard, publicadit por este autor el aino 1894 e'n Coy. terr. de France, paig. 208, existia ya otra P. maritima de la fauna de Cuba publicada por PFenfrer el año 1839. Esta uiltima concha figura hoy en el género Cerion.

\section{Pupá goniostoma Kiister.}

(1.ám. XIx, Hg. 3.)

1815, y segunda edicion 1852. Pupa goniostoma Kiist. - Pupa und Vertizo, in Systematiscles Conchylien Cahinet von Martini und Clemnitz, pigg. 53, Tiff. VII, figrs. 1-3. (Por erratit o transposicion de numero con la $P$. Moquiniana, dice: - figs. 4-5m.) 
1848. P. goniostoma Küst. - Pfr., Mon. Hel. viv., II, pảg. 345; vol. III, 1853, pág. 547; vol. IV, 1859, pág. 653; vol. VI, 1868, pág. 314; vol. VIII, 1877 , pág. 384 .

1859. P. goniostoma Küst. - Rossm., Iconog., III Bd., 17 Heft (Neue Folge), pág. 107, Taf. 85, fig. 939.

1863. P. goniostoma Küst.-Bourg., Moll. de San Juliá de Loria, pág. 22, y en la pág. 23 la var. Juliensis Bgt., representada en la lám. II, figs. 23-25, aunque sólo con el nombre de $P$. goniostoma.

El mismo año, Bourgignat, en Rev. et Mag. Zool., XV, pág. 151, pl. 14, figs. 23 a 25, según Pfeiffer., VI, pág. 314, nota (**), donde reproduce la descripción latina de Bourgignat.

1864. P. goniostoma Küst. - Bourg., Mal. Alg., II, pág. 83, pl. 5, figuras 35 a 38 .

1881. P. goniostoma Küst. - Clessin et Pfr., Nomencl. Hel. viv., página 347.

1887. P. goniostoma Küst. - Westerl., Fauna Paläarct., III, pág. 96.

1913. P. goniostoma Küst. - Germain, Moll. de la France, pág. 171.

1918. Chondrina goniostoma (Küster). - Pilsbry, Man. of Conchol., vol. XXV (cuad. 97), pág. 33, pl. 2, figs. 13 y 14 (cop. de K.).

No P. goniostoma Gray, que es el Plekocheilus goniostomus Fer. $($ Helix $)=$ Bulimus goniostoma Sow., del Brasil.

No P. goniostoma en Locard, Coq. terr. de France, pág. 299, figuras 420 y 421 , que es la var. Juliensis Bgt.

P. testa oblique rimata, cylindrico-conica, acutiuscula, elongata, subtilissime costulato-striata, nitida, diaphana, rufo-cornea; anfractibus convexiusculis; apertura magna, rotundato-trigona, basi angulata, fauce octoplicata, plicis binis in columella et in pariete aperturali, quator in palato, suprema minuta. - Long., $4^{\prime \prime \prime}$; diam., $1{ }^{1} / 2^{\prime \prime \prime}$. (Küst.)

El ángulo de la base que caracteriza esta Pupa es sumamente variable, y unas veces se hace muy pronunciado y agudo $(P$. angulata Fag.), otras se borra paulatinamente, aunque sin acabar de desaparecer ( $P$. leptocheilos Fag.); y como los demás caracteres virian también, resulta que pasa insensiblemente no solo a estas dos especies, sino también a la megacheilos y otras del grupo.

En España es bastante abundante, aunque generalmente domina la leptocheilos, que para mi es intermedia a la goniostoma y megacheilos; pero es muy. frecuente que en la misma localidad y aun adherida a la misma roca se hallen representantes de las tres formas, y asi la he recogido yo en las localidades que dejo apuntadas en la $P$. megacheilos. 
Hidalgo, Obras malacológicas, cita la $P$. goniostoma de las localidades siguientes :

De los baños de Benasque a Campo, págs. 361, 1583. - Barranco de San Carlos, Barbaruens, pág. 1583. - Basagoda, pág. 754. - Desde Biescas a Sallent, pág. 1118. - De Boucharo (Bujaruelo) a Bielsa, pág. 361.

Caldas, págs. 361, 620. - Camprodón, págs. 361, 626, 754.-Casa Falsa de Sitjar y Basegoda, pág. 626. - Cataluña, pág. 765.

España, págs. $315,317$.

Llobregat, pág. 2150.

Montgrony, pág. 2150. - Montserrat, págs. 361, 743, 1270, 1427, 1609 . Olot, págs. 361, 620.-Desfiladero de Organiá (Valle del Segre), pág. 1117.

Panticosa, págs. 356, 1583. - Pobla de Segur, págs. 1271, 2150.

Sallent, pág. 1583. - San Juliá de Loria, págs. 319, 361, 685, 1117. San Lloréns del Munt, págs. 999, 1000. - San Miguel de Fay, pág. 361.-

Ribas, págs. 361, 754, 2151.

Además de todas las localidades mencionadas, la poseo en mi colección de Collsacabra, Moyá, Roncesvalles y Valle del Roncal.

\section{Pupa leptocheilos Fagot.}

(Lám. XIX, fig. 4.)

1879. Pupa leptocheilos Fagot. - Note sur le véritable Pupa pyrenaica Farines, en Bull. Soc. d'Hist. Nat. de Toulouse. Treizième année,

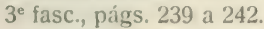

1887. P. leptochilus Fag. - Westerl., Fauna Paläarct., III, pág. 97.

1894. P. leptochila Fag. - Locard, Coq. terr. de France, pág. 300.

1913. P. leptochila Fag. - Germain, Moll. de la France, pág. 171 (como variedad pequeña de la megacheilos).

1918. Chondrina tenuimarginuta (1)es Muulins). - I'ilsbry, Man. of Conchol., vol. XXV (cuad. 97), paig. 31, pl. 2, figs. 4 y 5 (esta última cop. de Des Moul.). - En la sinonimia coloca la leptocheilos Fag.

"El tipo de la Pupa megacheilos (Cristofori et Jan, 1832) se encuentra en los Alpes de Lombardía, en la provincia de Como. Este tipo no vive en los Pirineos franceses; pero e's reemplazado por formas suficientemente distintas, que nos proponemos hacer conocer sucesivamente. Por hoy nos contentamos con estudiar una de estas formas, que es especial al departamento de los Pirineus 
orientales. Ninguna concha ha recibido tantos nombres ni ha sido tan desconocida, de lo cual es fácil convencerse por la sinonimia siguiente, que damos como cierta después de concienzudo estudio :

. Pupa irumentum Boubée. Bull. Hist. Nat. Fr., 3 sect., Holl. et Zooph., édit. in $18^{\circ}$, pp. 10 et 11, n. $18 ; 15$ février 1833 (1).

- Pupa frumentum var. Bubbee. Bull. Hist. Nat. Fr., 3 sect., .Holl. et Zooph., édit. in $8^{\circ}$, p. 30, n. $70 ; 1^{\text {er }}$ décembre 1834.

•Pupa megacheilos Boubée. Loc. cit.

Pupa frumentum var. pyrenaica Boubie et Des Moulins. Descript. Moll. terr. et fluv. (Extr. Act. Soc. Linn. Bordeaux, t. VII, $3^{\circ}$ livr.), p. 20, 1835 (2).

"Pupa secale Des Moulins. Loc. cit. (3).

»Pupa Farinesi Michaud, teste Boubée, loc. cit., édit. in $8^{\circ}$, p. 30, n. 70, 1834, y Des Moulins, loc. supra cit., pp. 20 et 22, 1835 (4).

„Pupa pyrenaica Farines, teste Boubée, loco citato (5).

Pupa pyrenacaria quorund Des Moulins, loco citato, p. 20 (6).

(1) Non P. frumentum Drap., Tabl. Moll., p. 59, n. 11, 1801.

(2) «Esta especie fué mencionada en una Memoria leida ante una Sociedad cientifica de Paris, con el nombre de otra; de la cual difiere considerablemente Pupa frumentum Drap., var. pyrenaica.» Esta Memoria 10 es otra que la de Boubée, señalada en nuestra Historia de los Pirineos orientales.

(3) Non P. secale Drap., Tabl. Moll., p. 59, n. 12, 1801.

(4) Non Pupa Farinesi Des Moulins, loc. cit., p. 16, pl. 11, fig. E., 1-3, especie diferente.

(5) Non $P$. pyrenaica Boubée, loc. cit., édit. in $18^{\circ}$, p. 9, nl. 18, 15 février 1833, sinónima de Pupa ringens Michaud.

(ii) Dos naturalistats corresponsales mios me enviaron, o me hathliron en sus cartas, bajo los nombres sucesivos e igualmente errúneos de Pupa avena Drap., var. major, y de Pupa pyrenacaria . Michaud, Complein.

Estos corresponsales debian ser muy probablemente Companyo y Aleron. Michand, en Pot. y Mich., Galer. Moll. Donai, píg. 167, t. I, 1838, se expresa asi: $₫ M$. Charles Des Moulins refiere a esta especie ( $P$. megacheilos) varias conchas de Francia que, aunque con un aspecto bien diferente al del tipo, pueden muy bien ser sus variedades; pero este naturalista comete un error al dar por sinónima la Pupa pyrenaearia Mich.. que en nuestra opinión constituye una especie perfectamente distinta. $\mathrm{No}$ es, en efecto, la Pupa pyrenaearia que M. Michaud tuvo en otro tiempo intención de publicar bajo la denominación específica de Pupa Farinesi: es una concha que por este autor ha sido considerada como una variedad major de la Pupa avena.» Las apreciaciones de M. Michaud son completa- 
-Pupa megacheilos var. tenuimarginata Des Moulins, loco citato, p. 22, pl. II, fig. C, 1-4.

Pupa badia Moquin-Tandon, Hist. Nat. Moll., t. 11, p. 354, 1855 (1).

A pesar de las muchas denominaciones que se le han impuesto. 1. hi: recibir un nombre nuevo nuestra especie, puesto que todus los que le han asignado habian sido ya usados para otras conchas. Tenuimarginata hubiera sido el único vocablo que hubiese podido tomar, a no impedirlo la regla de nomenclatura sesuuipedalic verba excludenda sunt. Por esta razón, proponemos denominarla Pupa leptocheila, traducción griega de tenuimarginata. Esta especie, aunque vecina de la Pupa megacheilos, es muy distinta, como lo haremos observar después de haber dado su diagnosis.

Dupa leptocheilos. - Testa subperforata, conica, corneorufa vel badia, vix nitida, subpellucida (3 primi laevigati ex-

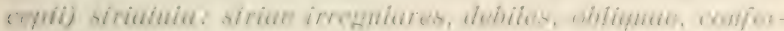
tissimae; spira parum elongata, regulariler acuminata, apice obtuso; anfractibus \& converis, sutura impressa separatis,

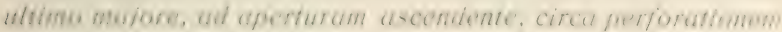
compresso et infra cristato; apertura vix obliqua, truncatosubrotundata, $s$ dentata scilicet: plicae parietales duae, qua-

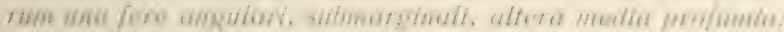
plicae columellares (2) duae in fauce remotae; t plicae pala-

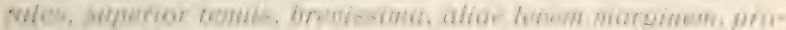
pe aperturam sium, attingentes; peristomate acuto, reflero; margine externo valde arcuato, expanso, margine columellari fere recto, reflewo, patente, rimam subtesente, marsinibus approximatis non callo junctis.

in Alt., 8 mm. (3); diám., 3 mm.

sLa Pupa leptocheilos no puede ser confundida mis que con

mente errineas. Des Moulins un ha dadu la Pupa pyrenuearia Mich. conn

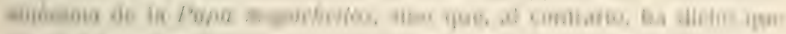
son dos especies distintas. Lo que laty que conservar de esta cita es que

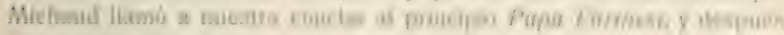
P'upa avena var. major.

(1) Non Pupa hadia Adiuns, in Boston Journ., t. III, p. 331, tah. III,

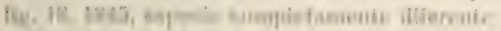

(2) J'or errata dice plicene pariclates.

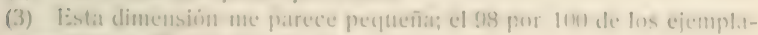
res espatmoles micten !) 10 iो 11 mum. 
la $P$. megacheilos y la Bigorriensis. Difiere de la primera por su forma más cónico-ventruda, por sus estrías más aparentes, sus vueltas más convexas, sus pliegues palatales reducidos a cuatro, de los cuales tres alcanzan un ligero bocel submarginal, mientras que en la especie de Cristofori y Jan uno solo de estos pliegues llega hasta el peristoma, por su borde externo más arqueado, por su peristoma, mucho más delgado y menos rebatido, etc.

"Se distingue de la segunda por su forma regularmente cónica y no cilindrácea, por sus estrías más finas y más regulares, su vértice menos rechoncho, sus pliegues palatales más acusados, su abertura menos oblonga, su borde externo más regularmente redondeado, etc.

„El tipo, tal como acabamos de describirlo, es muy común en la Preste (Pirineos orientales). Parece ser intermedio entre la Pupa megacheilos y la Bigorriensis, y probablemente por este motivo habrán sido desconocidos sus caracteres por todos los autores franceses. Nuestra Pupa leptocheilos y otra especie del mismo grupo, la Pupa goniostoma Küster, caracterizan la parte oriental de la vertiente francesa de los Pirineos.» (Fagot.)

Aunque FAGOT diga que es intermedia entre la megacheilos y la bigorriensis, analícese detenidamente la descripción, y se verá que es intermedia a la primera y a la goniostoma, pero muchísimo más próxima a esta última; y si no puede considerarse como ella misma, es porque algunos detalles la llevan hacia otras formas, como, por ejemplo, margine columellari fere recto, que la aproxima a la angulata, pero también se diferencia de ella por otros conceptos.

De todas suertes, como sus caracteres no se extreman en ningún sentido, resulta una forma verdaderamente intermedia a varias, y como lógicamente debe suceder, es la que más frecuentemente se encuentra en el Pirineo español.

FAGOT sólo cita como figura que representa su Pupa leptocheilos la de Des Mouliss, lám. II, fig. C, 1-4 (var. tenuimarginata Des Moul.).

Debe agregarse la figura 937 de RossuässLER, que la da como Pupa megacheilos var., pero que, además del mismo RossmässLeR en el texto, Pfeiffer, en su Mon. Hel. viv., VI, pág. 315, la refiere a la $P$. badia Moq.-Tand., que es igual a la tenuimarginata, y por lo tanto a la leptocheilos.

En mezcla con la megacheilos y la goniostoma, pero domi- 
nando en numero la leptocheilos, la he recosido en las localidader reseñadas para la primera, y en las Obras malacológicas del Dr. Hidalgo se cita de innumerables sitios, todos de la región pirenaica. El yue desee detalles puede con-ultar las páginas 320 .

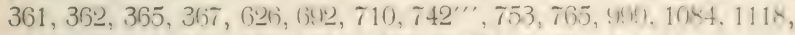
$12 \pi 0,1271,142 \pi, 1540,1583,1609,2150$ y 2151, advirtitadole que en alguna de esas páginas encontrará ocho o diez localliales, y, por otra parte, hay citas que se repiten cuatro o cinco veces.

\section{Pupa Adeodati Fagot.}

1906. Pupa Adeodati Fag. - Contribution à la Faune Malacologique de la Catalogne. I: Species novae Montserraticae, in Butll. Inst. Cat. d'Hist. Nat., pág. 134.

Esta nueva especie del grupo de la $P$. leptochilus no puede compararse más que a esta Pupa, de la cual se distingue, principalmente, por su espira más ovoidea, con la última vuelta ventruda. por su concha más clara y de color cúrneo pálido, por sus pliecrues palatales más delgados, menos largos, y por consiguiente mencs robustos, etc.

Cercanias del monasterio de Montserrat, sobre los peñascos, RRR. La ha encontrado el R. P. Adeodat Marcet. (Fagot, loc. cit.)

Indudablemente se ha fundado esta especie por poquisimos ejemplares, yuizá uno solo, y por lo que se deduce de la descripciun, se trata, más bien que de una variedad, de una anomalia, en la que por adquirir más desarrollo alguna vuelta se ha heclo el conturno más "voideo. Los pliegues palatales, menos robustos, son signo de juventud o de rayuitismo. En resumen, las diferencias senaladas creos que no purden tener más valor que el individual, y, jor consiguiente. la $P$. Adeodati no debe separarse de la leptocheilos.

HidAlgo, en sus Obras malacológicas, sólo la cita de la mencionada localidad de Montserrat, en las pácrimas 1427. 15-6 y 1600.

\section{Pupa leptocheilos Fag., var. microchilus Bofill.}

1909. Pupa leptochilus Fagr, var. microchilus Bof.-El Noguera Ribagorzana "Vallis clausa malacológicamente considerado, en Actas y Memorias del Primer Congreso de Naturalistas Españoles, celebrado en 1908, pais. 198. (Las Actas y Memorias se publicaron en I909.) 
1915. Pupa leptochilus var. microchilus Bof.-Iconocgrafia i descripció de formes malacologiques de les conques del Noguera Pallaresa i del Ribagorçana, en Treballs de l'Inst. Cat. d'Hist. Nat., vol. 1915, pág. 8, lám. 6, fig. 2.

En la primera obra citada dijo Bofill de su variedad: "Proponemos esta denominación para una curiosa forma que hemos descubierto en el Set de Fet, a la entrada del Congost de Sabinós. Difiere del tipo, sobre todo, por las reducidas dimensiones de su abertura.»

En el segundo trabajo mencionado dice:

A typo differt praecipue, apertura minori ac testa graciliori; dando una buena figura de la boca ampliada y dos vueltas de espira.

Mejor se hubiera apreciado la relación entre la abertura y el resto de la concha si el dibujo tuviese el contorno completo; pero no creo de gran importancia este detalle, por cuanto en todas las localidades en que vive la especie se ven ejemplares con la boca más o menos grande; y en este caso particular se ha elegido un individuo extremo, no sólo de boca pequeña, sino redondeada; es decir, corta en su dimensión longitudinal.

Hidalgo la cita, en la página 1546 de su obra, de la mencionada localidad.

Pupa Bigorriensis (Charpentier in sched., teste Des Moul.).

(Lám. XIX, fig. 5.)

1835. Pupa megacheilos Jan et de Cristof, var. $d$ (pusilla) Des Moul. (=Pupa bigorriensis Charp. in sched., según Des Moul.).-Des Moulins, Descript. de quelques Moll. terr. et fluv. de la France, nouveaux ou peu connus, in Soc. Linn. de Bordeaux, vol. VII, 1835, pág. 163, pl. 2, fig. D.

1812. I. mesacheilos var. gracilis Rossm. Iconog., vol. II, cuad. I' (XI), pág. 10, Taf. 53, fig. 728. (En la lámina dice $P$. avena, var.; corregido en el texto.) Westerlund la da como sinónima de la bigorriensis.

1881. P. bigorriensis Charp. - Clessin y Pfr., Nomencl. Hel. viv., página 347, en la sinonimia de la P. megacheilos.

1887. P. bigorriensis (Charp.) Des Moul. - Westerl., Fauna Paliarct., III, pág. 96. 
1890-92. P. bigorriensis Charp. in sched., teste Des Moul. - Fagot, Hist. malac. des Pyr. Fr. et Espag.; extrait du Bull. Soc. Ramond de Bagnères-de-Bigorre (Haut.-Pyr.), pág. 90 (1).

1894. P. bigorriensis Charp. - Locard, Coq. terr. de France, pág. 299.

1894. P. baregiensis Bourg. in Locard. - Locard, Coq. terr. de France, página 299.

1913. P. bigorriensis Charp. - Germain, Moll. de la France, pág. 171.

1918. Chondrina bigorriensis (Charp., Des Moul.). - Pilsbry, Man. of Conchol., vol. XXV (cuad. 97), pág. 29, pl. 2, figs. 1, 2, 3, 7.

No $P$. bigorriensis Rossm., Iconog., fig. 321 , que es la $P$. ringens (Caill.) .lich., segú Westerl., y Küster (en el indice altabéticu, pág. 190').

He aqui la diagnosis original de Des Moulins:

«Pupa megacheilos var. d (pusilla). - Esta concha es la que ha recibido de $M$. Charpentier el nombre de $P$. Bigorriensis. Es más pequeña que la variedad precedente (2); su peristoma es menos ensanchado, y su abertura es menus alargada, teniendo casi borrado el ángulo inferior. La desaparición de este ángulo inferior pierde toda la importancia verdaderamente caracteristica, por su mezcla con el tipo en las cuatro variedades. No constituye más que una variación individual que domina al tipo en Bagnères-de-Biçorre, mientras que el tipo es el que domina en la Preste (Pirin. orient.). Long., 7-8 mm.; diám., $2^{3} / \downarrow$ mm. Pirineos centrales. (Véase lám. 2, fig. D).

Aun cuando en la descripción nada se dice de él, se ve en la figura muy claramente que en la base de la abertura hay un tuberculito dentiforme. Algunos ejemplares no lo tienen, pero cuando

(1) No da descripción de la especie, pero sí interesantes noticias de ella. Dice que es abundante en la vertiente francesa, pero que no la ha encontrado en la española. Que CHARPENTIER la encontró el primero y la llamó bigorriensis (sin publicarla); que la comunicó a Des Mloulins, el cual la colocó en su baturrillo de variedades de la Pupa megacheilos. Y por fin, dice que ChaRPENTIER también la mandó a KUSTER, el cual eligió ejemplares de mayor número de pliegues como tipo de su Pupa moquiniana, que publicó con el nombre de la localidad equivocado.

Véase $P$. moguiniana, donde se copia integro lo dicho por FagoT respecto a este molusco.

(2) Se refiere a la variedad $c$ (tenuimarginata), a la cual asigna $8-9$ mun. de longitud y 3 mm. de dianetro. 
existe es muy característico. También se ve ese plieguecillo en la figura original de la $P$. Moquiniana dada por Küster. Ésta es únicamente otra forma idéntica a la Bigorriensis, con un pequeño pliegue más en la columnilla; en cambio, la Baregiensis que, siguiendo la opinión de GERMAIN, he incluido en la sinonimia de la Bigorriensis, tiene en esa región sólo un pliegue superior.

Hidalgo, Obras malacológicas, la cita como Pupa, de Artias, en el Valle de Arán, en la página 357, y de Miranda de Ebro en la página 745. Como Torquilla Bigorriensis está citada de Cataluña en la página 393.

Yo la poseo en mi colección de Saldes, provincia de Barcelona (R. P. Navás), con el tubérculo en la base de la abertura, como en la figura original de DEs Moulins; y de la misma localidad, sin el dentículo, unos individuos con la parte inferior de la boca redondeada y otros angulosa.

\section{Pupa Moquiniana Küster.}

(Lám, XIX, fìg. 6.)

1845. Pupa Moquiniana Küster.-Syst. Conch. Cabinet von Martini und Chemnitz. Pupa und Vertigo von Küster, pág. 52, Taf. VII, figs. 4-5. (Por errata o transposición de números con la goniostoma, dice: «figs, 1, 2, 3».)

1848. P. Moquiniana Küst. - Pfr., Mon. Hel. viv., II, pág. 347; III, 1853, pág. 548; IV, 1859, pág. 673; VI, 1868, pág. 315; VIII, 1877, pigina 384 .

1881. P. Moutuiniana Küst.-Clessin et Pfr., Nomencl. Hel. viv., pig. 347. 1887. P. bigorriensis (Ch.) D. M., var. Moquiniana Küst.-Westerl., Fatına Paläarct., III, pág. 97.

1918. Chondrina bigorriensis (Charp., Des Moul.), Var. Moquiniana Küst.-Pilsbry, Man. of Conchol., vol. XXV (cuad. 97), pág. 31), pl. 2, figs. 8 y 9 (deficientes).

P. testa subumbilicata, conico-cylindrica, elongata, obtusiuscula, costulato-striata, sericea, brunnea, anfractibus convexiusculis, sutura coarctata; apertura ampla, semiovata, ferruginea; peristomate reflexo, acuto, marginibus approximatis, albo; fauce non'emplicuta, quinque patalibus, binis in columella et in pariete aperturali.-Long., $3^{1} / 3^{-4^{\prime \prime \prime}}$; diam., $1^{1} / 4^{\prime \prime \prime}$. (Küster.)

FAGot, en su trabajo sobre los moluscos de los Pirineos france- 
ses y espanoles (1600-42). pág. 90, al tratur de la Pupa Bigurriensis Charp., dice :

«Por su parte Küster, que habia recibido ejemplares originales del mismo Charpentier, tomó como tipo individuos del monte Beclat. que poseian un columelar y un palatal más que el verdadero tipo, es decir, nueve denticulaciones, y los describió bajo el nombre de I'upa. Moquiniana con la estación de monte Beudar. curca de Pau. que no existe, y no es otro que el monte Bedat. No hay más que comparar las figuras de Küister y de Des. Moulins para convencerve de la veracidad de nuestro aserto. Bien es verdad que los autores no se han puesto de acuerdo sobre la $P$. Moquiniana, y cada cual la ha interpretado a su capricho. En el día, y con razón, es admitida como especie la Pupa bigorriensis."

No se ha expresado con exactitud FAGOT, aun cuando en el fondo sea en parte cierto lo dicho por él. Des Moulins, en su descripción de la Pupa megacheilos var. (pusilla), que según él mismo es la Pupa bigorriensis Charp., no indica taxativamente los dientes o pliegues de la columnilla, pero se sobrentiende que son los mismos que en el tipo, que tiene dos; y dos son también los asignados por KOSTER a la Moquiniana en el texto. Lo que sucede es que en la figura 5 de Kíster. suficientemente ampliada y que da idca bastante aceptable de la especie, aparece en la parte inferior de la columnilla un tercer plicgue, aunque pequeno, muy vi-ible. I clari es que a la fundación de la especie concurren a un tiempo y con igual valor la descripción y la figura, y por lo tanto hay que contar tres pliegues en la columnilla, sumados a los dos parietales y cinco palatales de la descripción.

En algunos valles de los Pirineos viven con extraordinaria profusión distintas formas d. la P. megucheilos meziladas en cabtic. confusión, lo cual de-mue-tra la poca importancra que tiencon las miltiples variaciones que esta concha presentat. Vim de estos puntus es la Foz de. Binis: provincia de. I luesca, donde recogi alemos centenares de individuos, elegidos un poco al azar, y he podido entresacar de ellos algunos que deben referirse a la $P$. Mloquiniana var. porque presentan los tres columelares como la figura de KCSTER, ademab de los dins parietales y thes palatulen principales. ma- otro superior profundo. Pero les falta el tubérculo dentiforme de la base. aunque no doy gran importancia a la ausencia de este dientecillo. por que en la bigorriensis también se observa que aun en la misma localidad unos ejemplares lo tienen y otros no. 
También de la Foz de Biniés he separado como subvariedad algunos individuos iguales a lus anteriores, pero con la boca angulosa en la base, y mezclado con la bigorriensis de Saldes he encontrado un ejemplar con el tercer columelar rudimentario y sin el dientecillo de la base, que igualmente debe referirse a la .loqu:niana como variedad.

Hidalgo, en sus Obras malacológicas, la cita de

España, págs. 318, 472, 587, 600.

San Juliá de Loria, pág. 319.

La $P$. . Hoyuminina podria unirse como variedad a la bigorriensis y constituir una subespecie.

Pupa elongatissima Des Mouliris.

(Lám. XIX, fig. 7.)

1835. Pupa megacheilos Crist. et Jan., var. elongatissima Des Moulins. -Descript. de quelques Moll. terr. et fluv. de la France, nouveaux ou peu connus, in Soc. Limn. de Bordeaux, vol. VII, pág. 362, pl. 2, fig. B.

1918. Chondrina tenuimarginata Des Moul., var. elongatissima Des Moulins.-1'ilsbry, Man. oi Conchul., vol. XXY'(cuad. 97), paig. 322, pl.2, fig. 6 (cop. de Des Moul., fig. B, 2).

«Notable por su alargamiento, su aspecto fusiforme, la estrechez de su ombligo (consecuencia de este alargamiento) y por la peypueñez de las vueltas de la punta, caracteres que la hacen semejante a una Clausilia. Su concha, más transparente que en la variedad de Italia, es más sólida que en las variedades siguientes. Su peristoma grueso y reflejado, casi plano, como en la de Italia, presenta las mismas variaciones en cuanto al ángulo inferior de la abertura; la magnitud de esta abertura es igual a la de la variedad $a$ (el tipo), de donde risulta una diferencia de proporcion muy caracteristica de la variedad. - -9-10 vueltas de espira; long., 12-13 mm.; diám., $3^{1 / 2} / 2-4$ milimetrus. - Pirineas, de donde el cilebre entomólugo y liquenólogo M. Leon Dufour ha traído cuatro individuos a M. Grateloup; pere lia lucalidad precisa nos es desconocida. léase pl. 22, fig. B. (Des Moul.)

Bofill, HaAs y Agullar-Amat, en su Estudi sobre la foumu 
malacológica de la Vall de l'Essera, publicado en la Institució Catalana d'Hist. Nat., vol. 1918, pág. 40, lám. IV, figs. 6 y 7 , tratan de la Pupa (Modicella) megacheilos goniostoma Küster, f. angulata Fagot.

En la serie derivada de la Pupa megacheilos, la $P$. angulata representa el último término, que tiene la boca más angulosa inferiormente. El ejemplar figurado por dichos tres autores es, por el contrario, un término diametralmente opuesto, con la boca completamente redondeada por abajo. En el texto, párrafo segundo de la pisina f), estain prefiectamente interpretadas las dif rencias de la $P$. angulata con sus afines, pero la lámina está en desacuerdo con entr parrafo. Las figuras en cuestion representan exatamente la variedad elongatissima de Des Moulins, con la menor de las dimensiones indicadas por su autor en el texto (12-13 $\mathrm{mm}$.), aunque en el atlas dibuja luego un individuo de tamaño natural (fig. B., 1) que mide $15,5 \mathrm{~mm}$.

Para la $P$. megacheilos var. elongatissima, procedente del Pirineo español lindante con el circo de Gavarnie, que MOQUINTANDon dibuja en su lámina 25, fig. 31, véase Pupa gigantea.

Conviene observar que las dimensiones de la figura de MoQun-T.ANm $(13.5$ mm. $\times 4)$ som muy aproximadamente las avigna-

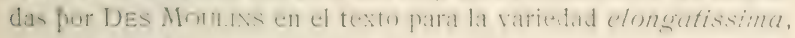
y quizás esto hiciera confundir a MOQUIN-TANDON; pero yo creo que en el diámetro (de $3^{1} / 2^{-4} \mathrm{~mm}$.) señalado por DEs Moulins hay exageración o se ha cometido error en la medición, pues esas mismas dimensiones da para el tipo de la megacheilos $(7-13$ imm. $\times 23 / 1,4)$, y sabido es que la variedad elongatissima se fundó por ejemplares más estrechos y alargados, y de haber sido de iguales medidas no lubiera tenido razón de ser. En apoyo de esto, las figuras originales dan también idea clara de que la variedad elongatissima es más estrecha que el tipo.

Poseo en mi colección muchos centenares de Pupa del grupo de

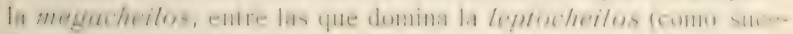

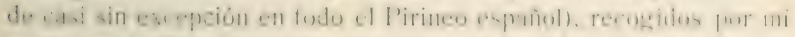
mismo en la Foz de Biniés, provincia de Huesca. En el tubo yue

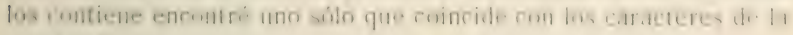
variedad elongatissima, pero en el que la abertura es algo angulo. sa por abajo, mientras que la figura original tiene su boca perfectilmente redondeada inferiormente; asi es que se trata de una subva. riedad respecto a la figura, si bien en el texto la indica ya su autor 
al decir que presenta las mismas variaciones en cuanto al angulo inferior de la abertura.

Mi ejemplar todavia exagera algo los caracteres. Mide $15^{i} / 2$ mi-

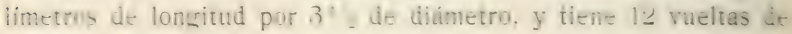
espira (1).

Pupa gigantea .lloq.-Tand., m. s, in Rossm.

(Lám. XIX, fig. S.)

1855. Pupa megacheilos Crist. et Jan, var. elongatissima (no Des Moul.) in Moq.-Tand., Hist. Nat. des Moll. terr. et fluv. de France, t. II, págs. 354 y 357 , pl. 25 , fig. 31 .

1859. P. badia var. gigantea Moq.-Tand., m. s. in Rossm. Iconog., III, pá-

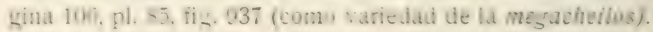

1918. Chondrina gigantea Moq., Rossm. - Pilsbry, Man. of Conde:... vol. XXV (cuad. 97), pág. 32, pl. 3, figs. 7 y 8.

Concha de color pardo córneo o rubio, con estrias finas más marcadas que en la megacheilos. El ombligo, que aunque estrech. está distintamente desarrollado en la megacheilos, se halla sólis débilmente indicado en la gigantea; la cresta del cuello es meno. fuertemente comprimida, y asi, la abertura resulta menos angular en la parte inferior. Es de notar especialmente que los dos pliegues palatales de en medio parecen adelgazados hacia dentro, mientraque en la megacheilos comienzan con un tubérculo. El peristomi. tiene el labro poco extendido y débil, y por lo tanto no es ancho y plano como en las otras especies afines. (Pilsbry.)

La figura que MOQUIN-TANDON da equirocadamente como veriedad elongatissima Des $\|_{10 u l}$, ya queda incluida en la sinonimia de la gigantea, y dicho autor la cita de dos localidades españolas:

Vertiente española del puerto de Gavamie (2).

Circo más allá del puente de Nieve (3).

(1) Con estus caracteres se aproxima mucho a la angulata, pero ts

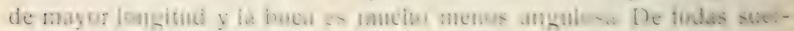
tes, es una variedad intermedia.

(2) Parte alta del valle del rio Ara, provincia de Huesca.

(3) En el valle de Astós, afluente del lado derecho del Esseric ar Nerre de Benasque. 
Yo he recogido individuos de esta forma en los que la boca es sublingulosa en la parte inferior, en lugar de ser bien redondeada. como marcadamente se ve en la figura $\overline{7}$ de PILSBRY; pero como en el texto dice menos angular...., se deduce que mis ejemplares concuerdan con la descripción, y además el sitio donde yo la encontré es el Parque nacional de Ordesa (en las rocas de las inmediaciones de la más hermosa cascada de este valle. llamada del estrecho del Arazas), que es afluente del río Ara, y como se ve coincide el punto casi en absoluto con la primera localididu de. IfoQUIN-TANDON.

En toda la parte alta del valle del Ara viven con asombrosa profusión diversas formas de la Pupa megacheilos, pero de la gigantea sólo hallé seis ejemplares diseminados por las rocas, a muchos metros de distancia unos de otros. Ninguna de las otras formas se mezclaba con ella.

\section{Pupa Juliensis Bourguignat.}

1863. Pupa goniostoma Küst., var. Juliensis Bgt. - Moll. de San Juliá de Loria, pág. 24, pl. 2, figs. 23 a 25.

1894. P. goniostoma Küst. - Locard, Coq. terr. de France, pág. 299, figu. ras 420 y 421 (1).

He aqui lo dicho por Bourguignat en la $P$. goniostoma var. Juliensis:

"Concha semejante al tipo, solamente que ofrece dos pliegues (en lugar de ino) hacia la inserción del borde derecho.»

Agrega Bourguignat que la $P$. goniostoma es rara en San Julia de Loria, mientras que, por el contrario, la variedad Juliensis es mucho más abundante.

\section{Pupa angulata (Fagot).}

1888. Pupa angulata Fagot. - Catálogo razonado de los moluscos del valle del Éssera, en Crónica científica, t. 11, pág. 104 (tirada aparte, pág. 16).

(1) En el texto dice que el pliegue angular es bifido, y las figuras son copiadas de las de Buurguignat en los Moll. de San Julia de Loria. 
1918. P. (Modicella) megacheilos goniostoma Kiist., f. ansulata Fagot.Bofill, Haas y Aguilar-Amat, Estudi sobre la fanna malacológica de la Vall de l'Êssera, en Treballs de l'Inst. Cat. d'Hist. Nat,, vol. 1918, pág. 40 (1).

1918. Chondrina angulata Fagot. - Pilsbry, Man. of Conchul., vol. XXY: (cuad. 97), pág. 34.

Testa vix perforato-rimata (perforatio margine columellari fere tecta), conico elongata, subnitida, pellucente, corneoInteola, striata (stricie obliquae, app)rovimatue subresulares. parum prominentes); spira elongato-fusiformi; apice laevigato, mamillato, luteo; anfractibus 12 primis convexis, medianis minus turgidis, caeteris subplanulatis, ultimo majore, subtus compresso, ac crista alba valida instructo, ad aperturam vix ascendente; apertura oblicua, infra angulata, longitudinaliter ovali-compressa, parva; 9 plicata, scillicet: columellares duae inferiore remota sed prominente, supera majore ad marginem columellarem fere provecta; parietalis 1 lamelliformis, angularis 1 ad marginem externum incurvata, dentiformis ac in pariete lamelliformis; palatales 5-6 supera et altera fere aequales, retrocedentes; tertia incurvata, ad peristomatem attingens, 4 et 5 punctiformis, plus minusve conspicuae; margine columellari a sinistra ad dextram recto, porcellaneo, margine externo subarcuato, ad plicam angularem valde incurvato, maxime incrassato, praecipue ad initium plicae palatalis tertiae.

Alt., 11; diám., 2; alt. ap., 2; lat., $11 / 4 \mathrm{~mm}$.

Salto del Caballo, entre Seira y Puente de Arunama.

Entre Chía y Seira se encuentra una variedad que difiere del tipo por su estriación más pronunciada, de modo que parece provista de verdaderas estrías.

La Pupa angulata difiere de la goniostoma, única especie a la cual puede aproximarse, por su espira mucho más adelgazada J fusiforme a causa de la última vuelta, por su abertura más estrech . y mucho más inclinada de izquierda a derecha, por sus pliegues columelares más robustos, los palatales más acentuados, especialmente el tercero, por su peristoma más grueso, etc. (Fagot.)

(1) El texto, en el párrafo de la página 40, diferencia perfectamente liw-

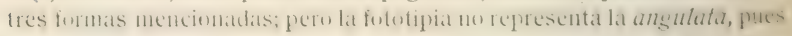
tiene la boca completamente redondeada inferiormente. (Véase P. clong..tissima.) 
En las Obras malacológicas del Dr. Hidalgo se cita de los valles de.1 Ara. Cinca, Éssera, Ezca. Isabena y Saluzar, con uma porción de localidades y sublocalidades que el que las quiera detalladas puede consultar las páginas 329, 361", 365, 367, 694, 710, 765 , 1546 y 1583.

También la cita con el nombre de Alodicella angulata, de España, sin puntualizar más la localidad, en la página 994.

\section{RESUMEN}

Sin tener en cuenta ciertos caracteres secundarios, y ateniéndo-

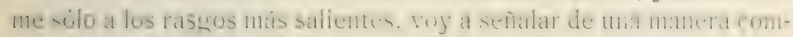
pundiada el distintivo de cada una de las formas estudiadas.

Mregaclieilos. - Peristona extendido, plano o más bien algo reflejado. Boca sin ángulo en la base y con 2 pariet., 2 colum. y 3 ó 4 palat. Color pardo rojizo más o menos obscuro. El tipo es muy raro en España, a pesar de las muchas citas.

Goniostoma.-Peristoma ensanchado, plano y francamente anguloso en la base. 2 pariet., 2 colum. y 4 palat. Concha un poco más estriada que la megacheilos. Frecuente en España, pero no el tipo exacto.

Leptocheilos. - Muy próxima a la goniostoma, con numerosos

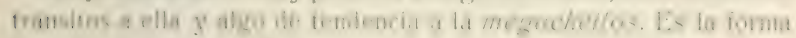
más abundante en el Pirineo español.

Adeodati. - Ligera anomalía de la leptocheilos.

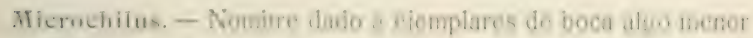
que ha del tipo de la leptocheilos.

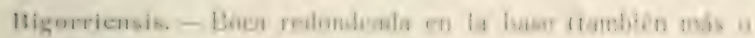
menos angulosa), pero la concha más pequeña y más estriada que la

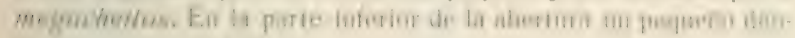
tículo, que puede faltar.

Tiene comn subvariedad la .Ioyuiniana, con tres columelares en lugar de dos; y la Baregiensis, con un solo colunelar. Esta biltima no se ha citado de Espana todavia. 
Elongatissima. - Es una megacheilos muy alargada.

Gigantea. - Ejemplares corpulentos de la megacheilos y la concha aún más estriada que la goniostoma.

Juliensis. - Variedad de la groniostoma, en la que el angular se duplica.

Angulata. - Variedad de la goniostoma, en la que el borde columelar se hace recto y oblicuo, el ángulo inferior de la boca más pronunciado, y con doce vueltas de espira.

Para terminar, sólo me resta insistir en la afirmación de que muchísimas veces es imposible decidir a qué forma debe referirse un determinado ejemplar, porque dentro del género seguramente no hay otro grupo que sea tan inconstante en todos sus caracteres.

\section{Explicación de la lámina XIX.}

(Las figuras están ampliadas cuatro veces aproximadamente.)

Figs. I y 2.-Pupa megacheilos Crist. et Jan. La figura I, ejemplar de Montsetrat. de $8 \mathrm{~mm}$. de longitud; la dificultad de iluminar el interior hace que no se vea $\mathrm{el}$ pa. rietal profundo, aunque lo tiene bien desarrollado. Tampoco se ve ese plieguc an la figura 2, hecha por un ejemplar de Torla, de $11 \mathrm{~mm}$. de longitud.

Fig. 3. - P. goniostoma Küst. Ejemplar de Torla, de $12,5 \mathrm{~mm}$. de longitud.

Fig. 4. - P. leptochcilos Fagot. Ejemplar de Los Arañones (Canfranc), de 9 mm. de longitud.

Fig. 5. - P. Bigorriensis Charp. Ejemplar de Saldes, de 7,5 mm. de longitud.

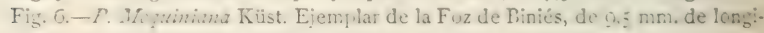
tud; en el retoque se ha exagerado un poquito el columelar inferior.

Fig. 7.-P. elongatissima Des Moul. Ejemplar de la Foz de Biniés, de I5,5 mm. de longitud.

Fig. S. - P. gigantea Moq.-Tand. Ejemplar del valle de Ordesa, de 12,5 mm. do longitud. 
R. Soc. Esp. de Hist. Nat. - T. del 50. aniv.

- LAM. XIX.

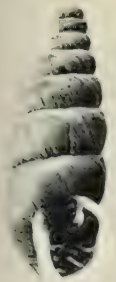

4

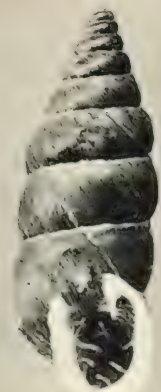

8

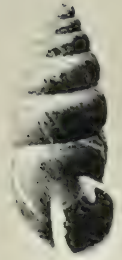

1

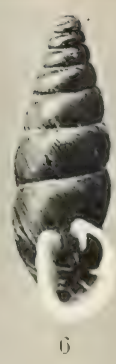

i)

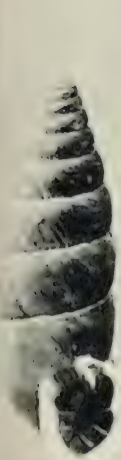

3

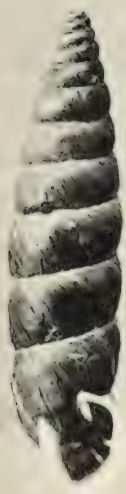

7

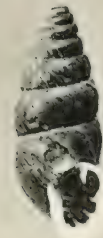

5

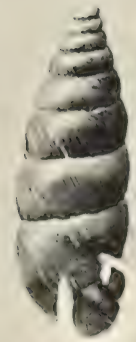



CONTRIBLCIÓY A LA BIOLOGIA DE LOS AYTROPOMORFOS AFRICAYOS

POP

EDUARD REICHENOW

(Líminas $\mathrm{XX}$ a $\mathrm{XXF}$.)

Al considerar los datos suministrados por los viajeros sobre las costumbres de los antropomortios africunos, tropezamos con numbrosas contradicciones y cun no pocas cosas inverosimiles. No es extraño, pues pocos exploradores refieren lo que vieron por si mismos; la mayor parte nos cuentan lo que, con más o menos crítica; han sacado de referencias de los indígenas. Valía, pues, la pena: cuando estuve año y medio en el Njong superior, en Camarones, en medio de una comarca en que abundan gorilas y chimpancés. que dedicara tiempo y esfuerzo a reunir algunos datos sobre el cénero de vida de seres tan notubles para la Ciencia. Resumiré en las sicuientes piginas las impresiones qu= he recogrito en mis numerosas cacerias a través de la selva virgen (1). Además de esto, haré alcunus indicaciones acerca de mis bbservaciones en urt gorila ioven que capturé cuando el animal tenía sólo muy pocos dias. Reservo para otro trabajo una exposición detallada de estas observaciones.

Los gorilas y chimpancés habitan frecuentemente el mismo territorio; sin embargo, no se los encuentra nunca reunidos en un mismo lugar, lo que es muy natural, pues son competidores, a causa de su predileocion pur lns misınis alimentos. Evhiontemente, el chimpanc⿺, mis debil, pero mis lierero, abandona el campo unte el corila. mas fuerte y pesidu; de chonde resulta poon venusimil yut wcurrar. en la naturaleza hibridos entre ambas especies, en los que se ha

(1) Pueden verse datos más extensos en mi trabajo Biologische Beobachtungen an Gorilla und Schimpanse. (Sitzungsber. Ges. Naturf. Freunde, 1920, pág. 1). En dicho trabajo aparece también indicada la bibliografia correspondiente. 
pensado algunas veces al no poder clasificar con precisión algún ejemplar de aspecto notablemente peculiar.

El que sea tan difícil a los europeos observar los antropomorfos en libertad no depende, en modo alguno, de que estos animales sean muy raros; algunas comarcas están llenas de chimpancés, y también el gorila es bastante numeroso en algunos sitios. El hecho se debe a que ninguna de las dos especies es sedentaria, sino que emigran constantemente de un lado a otro en la región donde viven. Hacia la caida de la tarde, como una hora antes de la puesta del Sol, es cuando algunas veces llegan a un sitio al alcance de la vista del hombre, cerca del borde de una plantación, en la proximidad de una aldea de negros. Alli pernoctan, y a menudo, ya muy de mañana, se van más lejos, para no volver a los mismos parajes hasta después de algunas semanas. El blanco ha de estar, pues, en buenas relaciones con los indigenas a fin de que éstos, ya durante la noche, le adviertan de la llegada de una banda; entonces puede, al salir el Sol, sorprender a los monos en los lugares donde durmieron.

En el sitio donde se proponen pernoctar construyen los antropomorfos ùnos lechoș con aspecto de nidos. La observación de estos lechos nos proporciona datos sobre diferentes costumbres de estos animales. Los nidos de los gorilas los he encontrado siempre en bajo, ya directamente en el suelo, ya sobre un arbusto vigoroso, a un metro o metro y medio de altura. Los lechos en el suelo los construyen del modo más sencillo, doblando, en parte hacia el centro y en parte hacia los lados, todas las plantas que se encuentran en un círculo de 2 ó 3 metros de diámetro, y entrelazando los troncos y ramas de tal modo que resulta un nido en forma de cesto. Si se deshace uno de estos nidos se observa que todas sus partes están arraigadas todavía en el suelo. No he observado que hayan sido agregadas hojas ni ramitas arrancadas para acolchonar algo el duro lecho.

Mucho más cómodamente se echan los monos en nidos construídos a cierta altura en un vigoroso arbusto. La construcción se hace del mismo modo que en los lechos del suelo: encorvando las ramas, parte hacia fuera y parte hacia el centro, y entrelazándolas unas con otras. Asi resulta un lecho extraordinariamente blando y flexible....., el prototipo de los colchones de muelles. La figura 1 de la lámina XX muestra en el borde derecho un nido de esta clase. Un segundo nido que se encuentra al lado, directamente en el suelo, a los pies del gorila muerto, está algo pisoteado. El gorila de esta figura (véase 
también la lámina XXIV, fig. 12) es un macho semiadulto; su dentadura presentaba los segundos molares precisamente rompiendo la encía, lo que en el hombre correspondería a una edad de trece a catorce años.

El sitio que elige el gorila para pernoctar ha de estar cubierto de matas espesas. También se fija en que no haya ninguna planta espinosa entre las que escoge para hacer su nido, lo que no es muy sencillo dada la frecuencia de éstas en la vegetación baja de la selva. Por lo demás, le es indiferente pernoctar en espesa selva virgen o a cielo abierto, en una antigua plantación frondosa, y no busca abrigo alguno especial contra las lluvias nocturnas.

Con excepción de algunos machos viejos, el gọila no vive solitario, como muchas veces se ha descrito, sino que, lo mismo que el chimpancé, es un animal sociable. Sin embargo, la banda de gorilas no suele ser muy numerosa. La mayor parte de las veces encontré de ocho a diez nidos reunidos en un mismo sitio; el número máximo fué trece. Debemos, sin embargo, tener en cuenta que, según lo revela el tamaño de los nidos, los individuos jóvenes no tienen lecho propio hasta bastante crecidos, quizá hasta los tres o cuatro años.

Los lechos de los miembros de una banda de gorilas no se encuentran agrupados sin orden, sino que los encontramos divididos por grupos de tres o cuatro, lo que nos permite reconocer que dentro de la banda existe una separación por familias. Los nidos de cada familia están muy próximos unos a otros y distan unos 8 a 15 metros del grupo vecino, de tal modo que los distintos grupos, gracias a lo enmarañado de la vegretación, parecen como diferentes viviendas separadas. Por el tamaño de los nidos vemos que entre los de una iamilia sólo dos nidos pertenecen a animales adultos: cuando hay más nidos, los restantes son siempre de menor tamaño, perteneciendo, pues, manifiestamente a jóvenes medio desarrollados. De esta observación se deduce el hecho muy notable de que ef gorila vive en monogamia.

Respecto a los nidos construidos en arbustos, del modo descrito anteriormente, llama la atención el que no los encontré en todos los sitios elegidos para pernoctar, y cuando los hay, no se ve nunca más que uno que tenga tal construcción, en el sitio ocupado por una familia. He observado también que los nidos de individuos que vagan solitarios - los cuales siempre son machos viejos - jamás se hallan construídos de esta manera, por lo cual me parece que úni- 
camente las hembras, y aun éstas sólo cuando tienen crias, se alojan en estas camas blandas, muelles y penosas de construir.

Hasta ahora no se habían conocido gorilas recién nacidos. En mis cacerías logré capturar uno de pocos días. Daré más adelante algunos datos sobre este gorila, que prosperó magníficamente al pecho de una nodriza negra (lám. XXI, fig. 4). Al ver a este pequeño ser en su desamparo y desnudez, forzosamente había que convencerse de que el pequeñuelo del gorila necesita el mayor cuidado y protección por parte de la madre. En los nidos blandos y elevados puede la madre cubrir bien con su pesado cuerpo a la cría pequeña, necesitada de calor, sin que corra ésta el peligro de ser aplastada.

Mis observaciones sobre el procedimiento seguido por el gorila al construir sus lechos no coinciden absolutamente en nada con lo que sobre este particular han referido del territorio del Gabón varios exploradores, entre ellos hombres como H. v. KopPENFELS, que se fundan en experiencia propia. KopPENFELs nos refiere del gorila lo siguiente: "Todas las tardes hace el gorila un nuevo nido, construyéndolo a una altura de 5 a 6 metros, sobre árboles sanos, esbeltos, de unos 0,3 metros de diámetro cuando más. Este nido, comparable al de las cigüeñas, está formado de ramitas verdes en las primeras ramificaciones de las ramas principales. Las crias, y también la madre cuando aquéllas necesitan todavía calor, descansan de noche en esos nidos, mientras el padre pasa la noche acurrucado al pie del tronco, con la espalda apoyada en él, protegiendo a los suyos contra los ataques de los leopardos. $\gg$ Estoy muy lejos de tener estos datos por inexactos y de pensar que pudiera haber en ellos una confusión con los nidos de los chimpancés, que a veces, como veremos, estản construidos de una manera semejante; creo más bien que en este respecto el gorila procede de modo distinto en los territorios del Norte de la selva virgen que en los del Sur. Confirman mi opinión las observaciones que hizo en el Sur de Camarones un observador digno de toda confianza, J. v. OERTzEN, que nos muestran, en cierto modo, una transición entre las costumbres de los monos en el Sur y en el Norte. Oertzen encontró una vez en las cercanias de Akoafim diez y seis nidos-camas juntos, nueve de ellos en el suelo y siete a una altura de 3 a 5 metros en las ramas de Musanga smithi. Finalmente, los nidos que yo señalé como situados a un metro o metro y medio del suelo, y que atribuí a las madres amamantando crías, parecen ser como una transición a los nidos de los árboles. 
Difícil es decir qué impulsa en el Sur a los gorilas hembras y las crías a ir a los árboles para el reposo nocturno. Es poco verosímil que busquen en ellos una protección contra los ataques de los leopardos, puesto que éstos abundan también en el territorio Norte de la selva virgen.

Sin duda alguna, el temor al leopardo es lo que determina al chimpancé a establecer su nido en las copas de los árbules. Nada pone tanto de manifiesto la inteligencia y habilidad de este antropomorfo como la gran diversidad que notamos en el modo de estar hechos sus nidos. Lo mismo que el gorila, necesita sólo unos pocos minutos para dejar acabada su obra. Elige de preferencia para construir su nido los árboles, bastante comunes, llamados en alemán "Schirmbaume» (Husanga smithi), que por sus grandes hojas son evidentemente muy adecuados para la construcción de nidos cómodos, y que constituyen además una fuente predilecta de alimentación. Sólo a falta de Musanga smithi se establece en árboles de otras especies.

Generalmente encontramos los nidos a 10 ó 20 metros del suelo - ya junto al tronco, en el sitio donde sale una rama fuerte, ya distantes del tronco - y tienen por base una ramificación (lám. XX, fig. 2). También pueden estar construídos sin base sólida, con ram:llas finas entrelazadas. Las construcciones más artísticas son aquellas que están constituídas por las ramas más externas de dos árboles próximos, y que se balancean libremente en el aire. La figura 3 de la lámina XX representa un nido de esta clase, tomado verticalmente desde el suelo. Para su construccion no sólo doblan y encorvan los chimpancés las ramas y ramitas que están directamente al alcance de la mano, sino que también, segun la necesidad, añaden ramas y hojas arrancadas.

También se encuentran nidos de chimpancés a menor altura, a veces sólo a 3 ó 4 metros del suelo. En la mayor parte de los casos se encuentran estos nidos aislados, y provienen, pues, de monos solitarios, machos viejos. Estos lechos son completamente accesibles para el leopardo, y nos prueban que ni aun el chimpancé viejo tiene que temer el ataque de esta fiera.

Nunca he visto nada del tejado protector especial contra la lluvia que, según los relatos del viajero Du CHAlLLU, debe construir cierta especie de chimpance; y aun la situación del nido, sóln en casos muy raros permite que el chimpancé busque, en los grandes aguaceros, refugio debajo de su nido, como me lo han asegu- 
rado los indigenas. Sin embargo, he observado en un individuo recién capturado que al empezar un chaparrón' acumulaba en sus espaldas hierbas y cañas que le habían dado como cama; parece, pues, en vista de esto, que también en libertad se protegen estos monos contra la lluvia, cubriéndose con ramas y hojas arrancadas.

En un mismo árbol no se encuentra generalmente más que un nido, rara vez dos. Dado que una banda de chimpancés es bastante numerosa - el número de los miembros oscila ordinariamente entre veinte y treinta-, estos animales, para pernoctar, se esparcen en un terreno bastante extenso. Por la situación de los nidos no podemos, pues, sacar conclusiones tan precisas sobre sus relaciones mutuas como para el gorila. Así, ha de quedar indeciso si la monogamia reina también entre los chimpancés. Puedo decir solamente que en mis cacerías nunca he sacado la impresión de que en una banda existan más individuos adultos hembras que machos.

Comio antes se ha dicho, los gorilas y chimpancés utilizan siempre su nido-cama para una sola noche, saliendo de nuevo para otra parte a la mañana siguiente. Sin embargo, evidentemente tienen en su comarca una serie de sitios preferidos, que vuelven a visitar con cierta regularidad. En efecto, en sitios en los cuales pasaron los monos una noche se observan ordinariamente, junto a los lechos recientemente abandonados, otros más o menos deshechos por el tiempo, que demuestran que estos animales ya antes habían establecido a menudo su vivienda en aquel mismo sitio.

En sus correrias, ambas especies de monos andan por el suelo, siendo el gorila mucho menos arborícola que el chimpancé, lo que deducimos ya por su diferente proceder en la elección del lugar donde establece su campamento nocturno. Cuando el gorila trepa a un árbol en busca de alimento, se baja siempre por el mismo tronco por donde ha subido. $\mathrm{Ni}$ aun al acercarse un peligro es capaz de pasar balanceándose de un árbol a otro, como to hace el chimpancé, el cual no prosigue su huída por el suelo hasta que se encuentra fuera de la vista del perseguidor.

Las distancias que los monos recorren en un día son bastante considerables. Pueden seguramente llegar, para el gorila, a 8 ó 10 kilómetros, pues algunas veces he seguido durante varias horas las huellas de estos monos en la selva virgen, sin llegar hasta su campamento. A los jóvenes aún no acostumbrados a las fatigas de las largas marchas, los llevan los adultos a la espalda.

Los antropomorfos son manifiestamente vegetarianos, y su ali- 
mentación principal está constituida por hojas y yemas foliares, asi como por la medula blanda del tallo de los vegetales, mientras que las frutas de todas clases les sirven más bien de aditamento. Cuando los monos caen sobre las plantaciones de los negros, se mantienen especialmente de spisangs y plátanos. No les atraen gran cosa los frutos, que por lo general son cortados antes de su completa madurez por los indigenas, sino que rompen las plantas y devoran los pecíolos blandos de dentro.

Al lado de la alimentación exclusivamente vegetal no puede representar papel alguno la ingestión, algo accidental. de alimentos de naturaleza animal. En todas las observaciones del contenido del intestino de gorilas y chimpancés matados, realizadas por anteriores investigadores y por mi mismo, faltaron por completo residuos de alimentación carnívora. Sin duda devoran a veces huevos de aves, pues un chimpancé cautivo demostró estar familiarizado con su manipulación práctica abriendo con los dientes un agujero en la punta de un huevo de gallina que se le había dado y sorbiéndolo después. En cautividad varian las necesidades de los antropomorfos. Entonces, una vez que se han acostumbrado, ingitren con gran predilección alimentos de origen animal. En un trabajo anterior (Arch.f. Protistenk., vol. XLI, 1920, pág. 1) he relacionado este hambre de carne que se despierta en los antropomorfos que viven en cautividad, con el hecho de desaparecer de su intestino ciertos infusorios que, como los del estómago de los rumiantes, son simbiontes presentes siempre en gran cantidad en el intestino de los antropomorfos salvajes.

Una planta alimenticia muy preferida por gorilas y chimpancés es el Schirmbaume (.Musanga smithi), de la cual devoran principalmente las cruesas yemas foliáceas y también los frutos, de sahor dulce. Como esta especie arbórea constituye casi por completo la Ilamada selva secundaria - es decir, la vegetación de selva que crece sobre antiguos terrenos de cultivo abandonados-, sucede que los antropomorfos buscan con predilección precisamente la selva secundaria, que se encuentra, naturalmente, muy desarrollada en regriones muy habitadas y en las cercanias de los pohlados. Asi, lleman los antropomorfos muy frecuentemente a la immediata proximidad del hombre, y ya no puede sorprender el encontrarnos muchas veces con campamentos del gorila y del chimpancé a pocos centenares de pasos de las cabañas de los negros.

A pesar de este atrevimiento, el chimpancé está en guardia 
ante el hombre. Lus indigenas le acechan de muchas maneras, pues entre las tribus que son antropófagas, la carne de los antropomorfos-que, según aseguran los conocedores, tiene un sabor parecido a la del hombre - es estimada como un bocado delicioso. Tan pronto como el chimpancé nota que uno se le acerca, huye y no vuelve a dejarse ver. Por esto, durante el día apenas si es posible al cazador llegar a tener a tiro a estos cautelosos animales. Como más fácilmente se matan es deslizándose, al amanecer, debajo de sus nidos. Se puede entonces esperar buena luz para el tiro, puesto que los monos no abandonan los lugares donde pernoctan hasta que es completamente claro.

De modo muy diferente que el chimpancé, se presenta el gorila frente al hombre. Seguramente, su modo de conducirse no es el mismo en todas partes y depende mucho de si el hombre se complace en atacarle o no en una comarca. En las regiones a que se extienden mis observaciones, por estar prohibida la importación de la pólvora en Camarones, no podían los negros hacer uso de las antiguas escopetas que se cargan por la boca y que todavía poseian. No osaban atacar al gorila con lanzas y flechas, y cuando un negro, yendo solo, le encontraba, más bien se apartaba del camino. Como, a consecuencia de esto, los inteligentes animales tenían la experiencia de que el hombre se apartaba de ellos, manifestaban por su parte poco miedo.

Durante el día, mientras el gorila está de camino, es muy difícil acercarse a él; pero cuando se le busca, al amanecer, en el sitio en que pernoctó, mientras está ocupado en su desayuno, entonces deja que el hombre se le aproxime hasta muy de cerca. Cuando un macho se ha dado cuenta de la presencia del recién venido, lanza un corto y ronco rugido dos o tres veces muy seguidas, pero quedándose al mismo tiempo tranquilo en su sitio. Este rugido debe evidentemente ser un aviso, y basta, por regla general, según la experiencia del gorila, para obligar al hombre a una rápida retirada; al mismo tiempo llama la atención de la hembra y de la cría sobre la proximidad de un ser sospechoso, pues éstos se retiran en seguida un poco.

De esta manera puede uno acercarse al macho hasta pocos pasos, y generalmente sin verle bien en la espesura del follaje de la vegetación baja de la selva. Rugiendo de nuevo, el gorila retrocede finalmente algunos pasos. Si se le sigue, se oye, al mismo tiempo que un rugido repetido, unos ruidos de palmoteo y como de. 
tambor. Estos ruidos, producidos en parte con las palmas de las manos y en parte con los puños, deben ser, según lo aseguran los negros, la señal del ataque. Sin embargo, no he tenido nunca ocasión de experimentar que un gorila se lanzase hacia mi; cuando yo me acercaba más a él, acababa por emprender la fuga, dando gritos continuos.

Pero el proceder de estos monos es algo diferente cuando al primer aviso se queda uno fijo en su sitio en actitud de espera. Entonces se envalentonan y ellos mismos se acercan. No avanzan. sin embarro, en linea recta, sino haciendo zigzag. para poder txaminar por todos lados al perturbador. En una de estas circunstancias, los individuos se me acercaron de tal manera que ya no dudé de que se hubieran echado sobre mi si yo no hubiese matado de un tiro a uno de ellos. haciendo con esto que los demás emprendiesen una retirada rápida.

Mis experiencias personales se extienden tan sólo a las costumbres de los gorilas que viven en bandas; desgraciadame ite no he podido ver nunca un gorila de los que vagan solitarios. Estos machos viejos que viven solos son, sin duda alguna, mucho más maliciosos. Hay entre ellos verdaderos salteadores de caminos, los cuales, sin ser excitados, se echan sobre el que viene desprevenido, hiriéndole o matándole, si no consigue ponerse a salvo huyendo rápidamente. Varios casos de éstos han llegado a mi conocimiento de un modo fidedigno. Algunos caminos solitarios, que son inseguros a causa de estos machos riejos, están desacreditados. y los negros no los utilizan sino yendo en grupos, y no sin llevar armas.

También en las plantaciones ocurren ataques de esta clase, y entonces aun los monos que viven en sociedad se sienten a veces con animo de atacar (uando, por la presencia de algún hombre, se encuentran molestados en su propúsito de tomar su cena en la plantacion. En este caso sun generalmente mujeres las que se ven atacadas, sencillamente por la razón de que los negros encarcan a las mujeres el trabajo de las plantaciones. Estos casos, al ser eonocidos por los europeos, pudieran constituir nuevos argumentos en favor de la leyenda de que los gorilas desean las mujeres. En real:dad, esta fábula carece de todo fundamento.

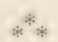

El gorila joven que llegó a mi poder y al que di el nombre de- 
Adán, tenía cuando le capturé, a juzgar por su ombligo recién cubierto de piel, unas dos semanas cuando más. Su longitud, echado y extendido, desde la parte superior de la cabeza hasta la planta de los pies, alcanzó 44 centimetros, desde la parte superior de la cabeza hasta la rabadilla, 30 centimetros, y su peso era exactamente de 2 kilogramos. Según las observaciones hechas en el hombre, de que al nacimiento sigue primero una disminución en el peso, que se recupera durante las dos primeras semanas, podemos admitir que el peso dicho corresponde con bastante exactitud al peso inicial. El gorila recién nacido pesa, pues, notablemente menos que el hombre recién nacido (término medio 3,35 kilogramos), lo que es muy digno de notarse, puesto que el peso del gorila adulto excede en mucho al peso normal del hombre.

Adán se desarrolló perfectamente hasta los diez meses, en que cayó enfermo a consecuencia del cambio de clima, al trasiadarle del territorio de la selva virgen a la región de las praderas y a una comarca muy elevada, muriendo poco después. A los diez meses medía desde la parte superior de la cabeza hasta la planta de los pies 60 centimetros, y desde la parte superior de la cabeza a la rabadilla, 405 milímetros, y pesaba 5,75 kilogramos.

Al comenzar la observación, su piel era de un color avellanado; la figura 4 (lám. XXI) nos muestra que Adán es notablemente 'más claro que su ama, de color de chocolate. Sin embargo, la piel se volvió rápidamente más obscura, y a la edad de tres meses era ya casi completamente negra.

Al principio todo el cuerpo estaba cubierto sólo por escasos pelos cortos y negros, de modo que la piel, por todas partes, se presentaba claramente a la vista. Es notable también que la frente no presentaba pelo; sólo en la parte superior de la cabeza se erguía un mechón de largos pelos de color castaño negro (lám. XXI, fig. 4, y lám. XXII, fig. 6). A la edad de dos meses (lám. XXI, fig. 5), el pelo habia aumentado notablemente por todo el cuerpo, y era bastante denso, especialmente en los brazos y piernas del lado externo. Durante el tercer mes empezó a salir también pelo por la cara, en las mejillas y barbilla, así como en la frente. Entonces el largo mechón de pelos de la parte superior de la cabeza se fué cayendo poco a poco, siendo reemplazado por pelo negro corto e igual que empezaba muy cerca de los arcos superciliares. A la edad de cinco meses hahia terminado el cambio de peto (lám. XXIII, figss. 10) y 11, y lám. XXII, fig. 9). 
El desarrollo de los dientes se efectuó muy pronto. Apenas de edad de dos meses rompieron ya la encia lus primeros incisivos de: la mandibula inferior, y quince dias después los de la superior. Hacia el final del sexto mes apareció el primer molar. La salida de nuevos dientes se anunciaba casi siempre porque Adcin se frotaba mucho las encias con el pulgar (lám. XXIII, fig. 11).

Por lo que se refiere al desarrolles intelectual, se ub-ervi que. Adcin, a la edad de umas tres semanas y mediat. empezi a remoionar al oír ruidos extranos, volviendo la cabeza. A las ocho somanas ya se fijaba manifiestamente, y seguía con los ojos un objeto en movimiento.

La facultad de distinguir pudo observarse hacia el final del tercer mes, cuando empezó a extender las manos hacia el biberón en cuanto éste aparecía en su campo visual; pero hasta los siete meses no se comprobó que distinguiese las personas.

A los cinco meses empezó Adcin a incorporarse por sí mismo, permane ciendo largo tiempo sentiado. Al mismo tiempo comenzaron los primeros ensayos de la locomoción, alargando Adain el brazo y acsarrando objetu, y acercándo-e a los que estaban fijos por medio de la flexión del brazo. En el séptimo mes tuvieron buen éxito sus primeros ensayos de tenerse en pie, sujetándose con las manos a apoyos laterales.

El desarrollo de la facultad de andar vino hacia el octavo mes (lám. XXII, figs. 7 y 8). Al principio la marcha se hacía doblando tan profundamente las rodillas, que el trasero tocaba casi en el suelo, y servian de apoyo las palmas de las manos. Luego empezó por doblar las dos últimas falanges de los dedos, mientras el resto de la palma de la mano tocaba todavía en el suelo (véase la figura 8 de la lámina XXII). Algunos días después las palmas de las manos dejaron de ponerse en contacto con el suelo, de modo que en adelante sirvió de punto de apoyo el dorso de los dedos, como ocurre en el animal adulto. Al mismo tiempo que la marcha, se desarrolló la facultad de trepar.

La traducción al castellano del presente trabajo ha sido hecha por D. Eduardo Surmely, y revisada, lo mismo que las pruebas de imprenta, por mi amigo D. Antonio de Zulueta, complaciéndome 


\section{en poder expresar aqui mi mayor agradecimiento por su estimable labor.}

\section{Explicación de las láminas $\mathrm{XX}$ a XXV.}

Lám. XX. - Fig. I. Gorila macho semiadulto (en su dentadura se encuentran los segundos molares rompiendo la encía). A sus pies, en el suelo, un nido de dormir algo deshecho; a derecha del mismo, otro nido en alto. - Fig. 2. Nido de chimpancé en una fuerte rama horizontal de Musanga smithi.-Fig. 3. Nido de chimpancé suspendido en el aire, formalo por las ramas más extcrnas de dos árboles prúximos (Musanga smithi) entretejidas. Tomado verticalmente desde el suelo.

Lám. XXI. - Fig. 4. El gorila Adán, de un mes aproximadamente, con su ama.Fig. 5. Adán a la edad de dos meses.

Lám. XXII. - Fig. 6. Busto de Adán a la edad de un mes. - Figs. 7 y 8 . Adán en sus primeros ensayos de marcha, a los siete meses y medio.-Fig. 9. Adán a los siete meses, junto a un pequeño chimpancé de dos meses.

Lám. XXlll. - Fig. Io. Adín a los cinco meses. - Fig. Ir. Adán a la misma edad. Molestias de la dentición.

Lám. XXIV. - Fig. I2. EI mismo gorila que en la figura I; matado en la orilla derecha del Njong superior, cerca de donde desemboca el Ajong (Gorilla affin. jacobi Matschie).-Fig. I3. Gorila macho desarrollado, pero todavia joven (no le har. salido aún los últumos molares); matado en la orilla izquierda del Njong, cerca de donde desemboca el Longmapfog (Gorilla jacobi Matschic).

Lám. XXV. - Fig. I4. Chimpancé macho adulto, del territorio del Njong superior (Troglodytes ochroleucus Matschie). - Fig. 15. Otro chimpancé macho adulto del territorio del Njong superior, especie o variedad conocida de la región de Yaunde, que todavia no está bien identificada. 
R. Soc. Esp. de Hist. Nat. - T. del 50. aniv. $\quad$ LAM. XX

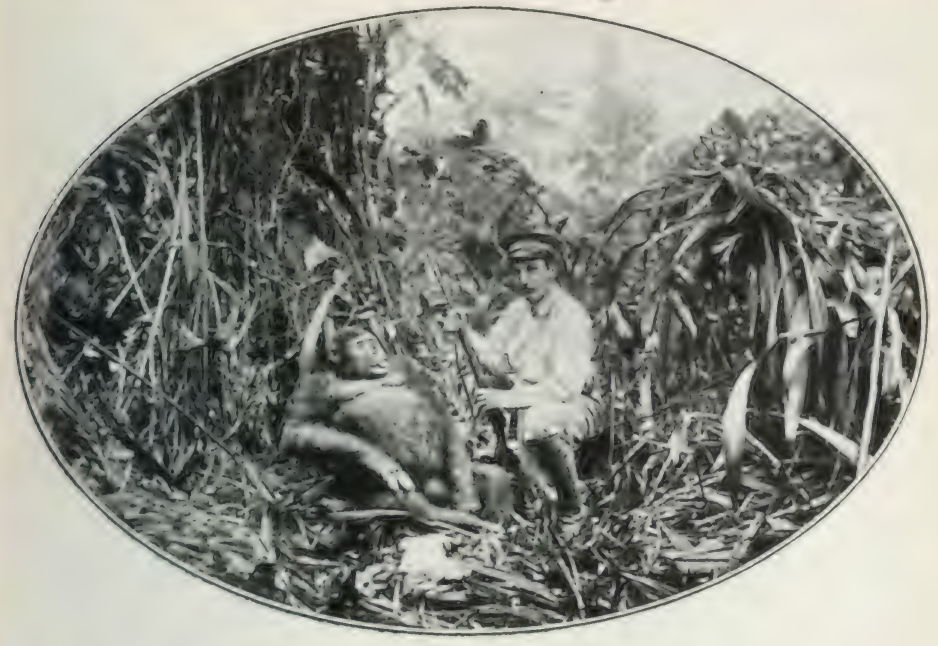

r.p. 1
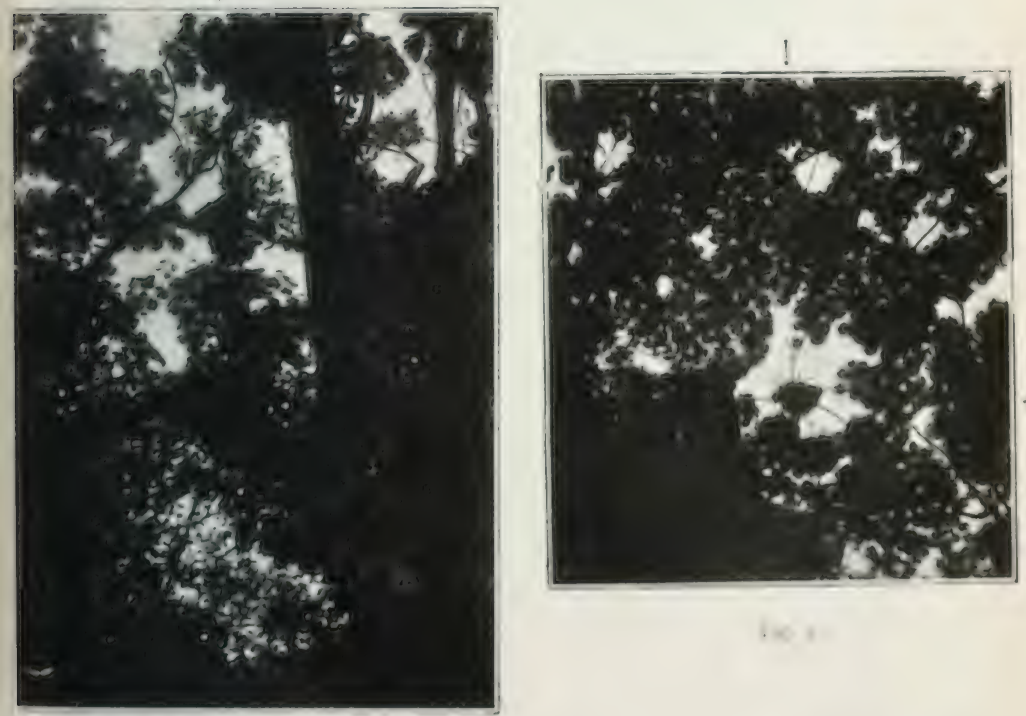




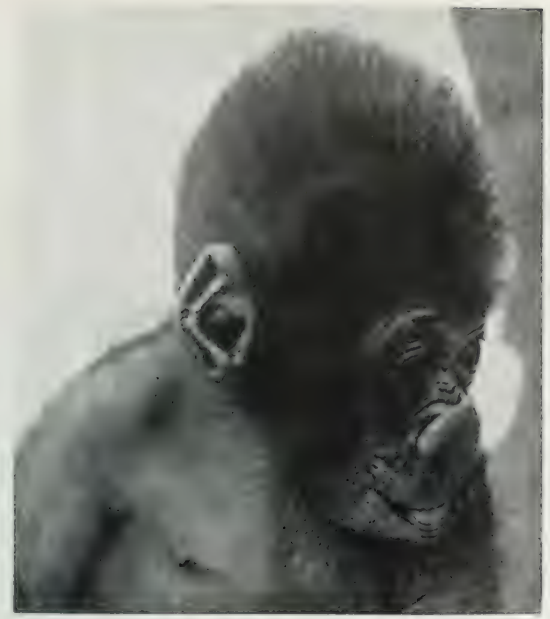

Fin. . .

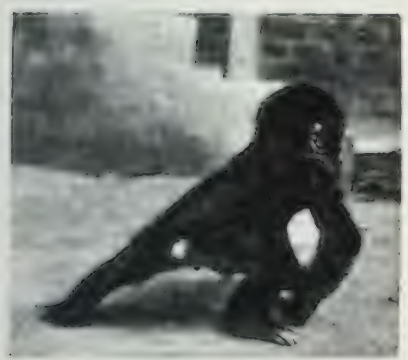

is

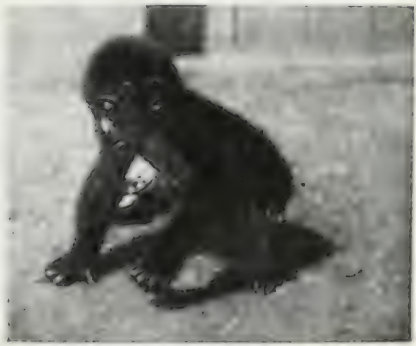

1. .

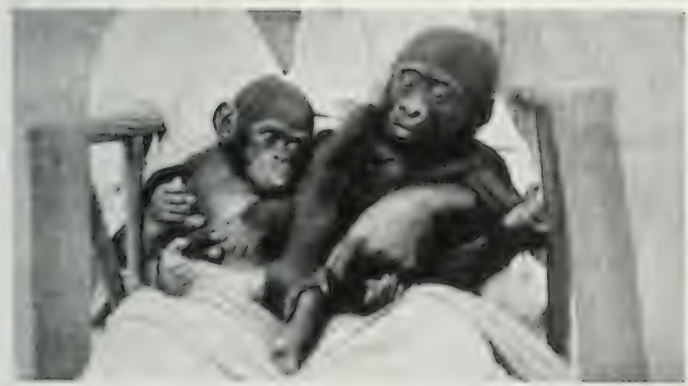

$\log 0$ 


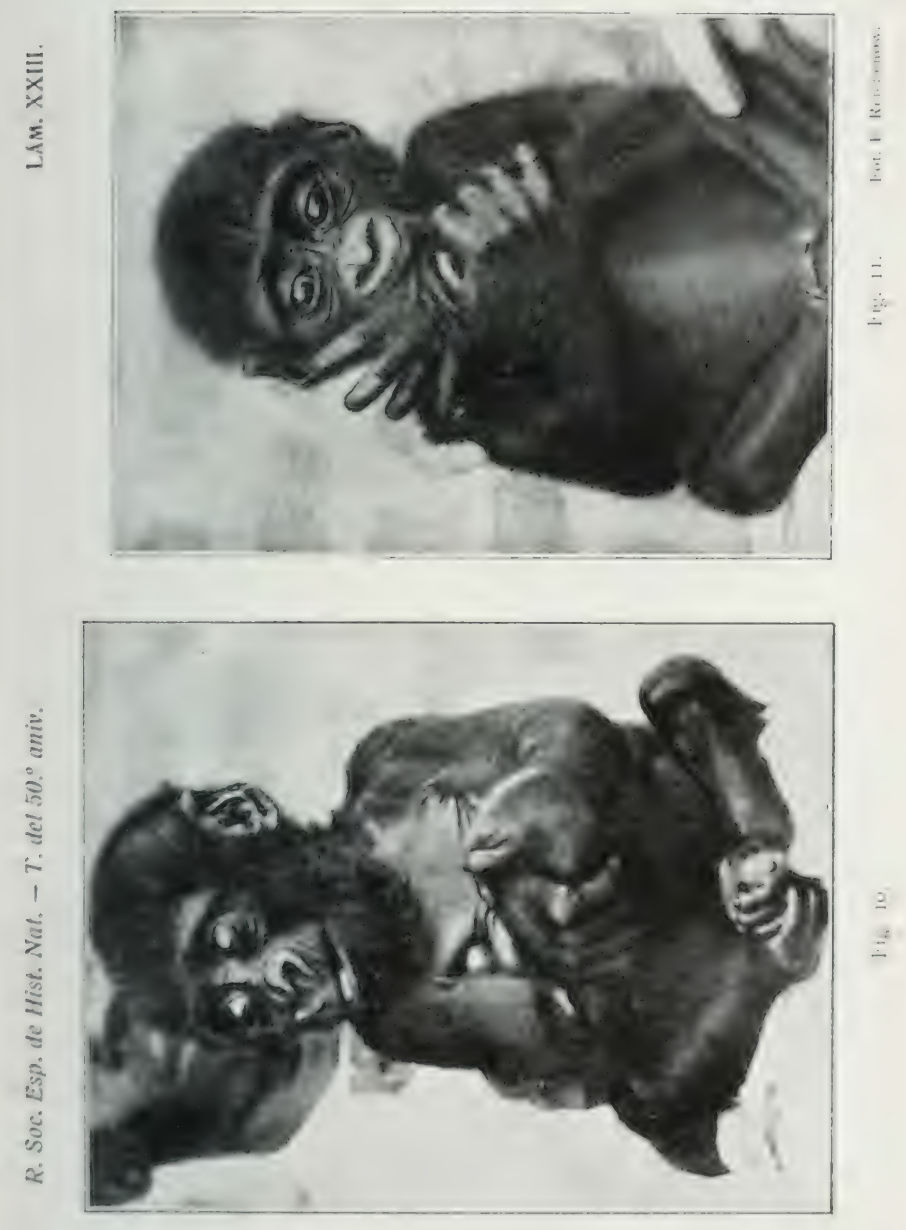


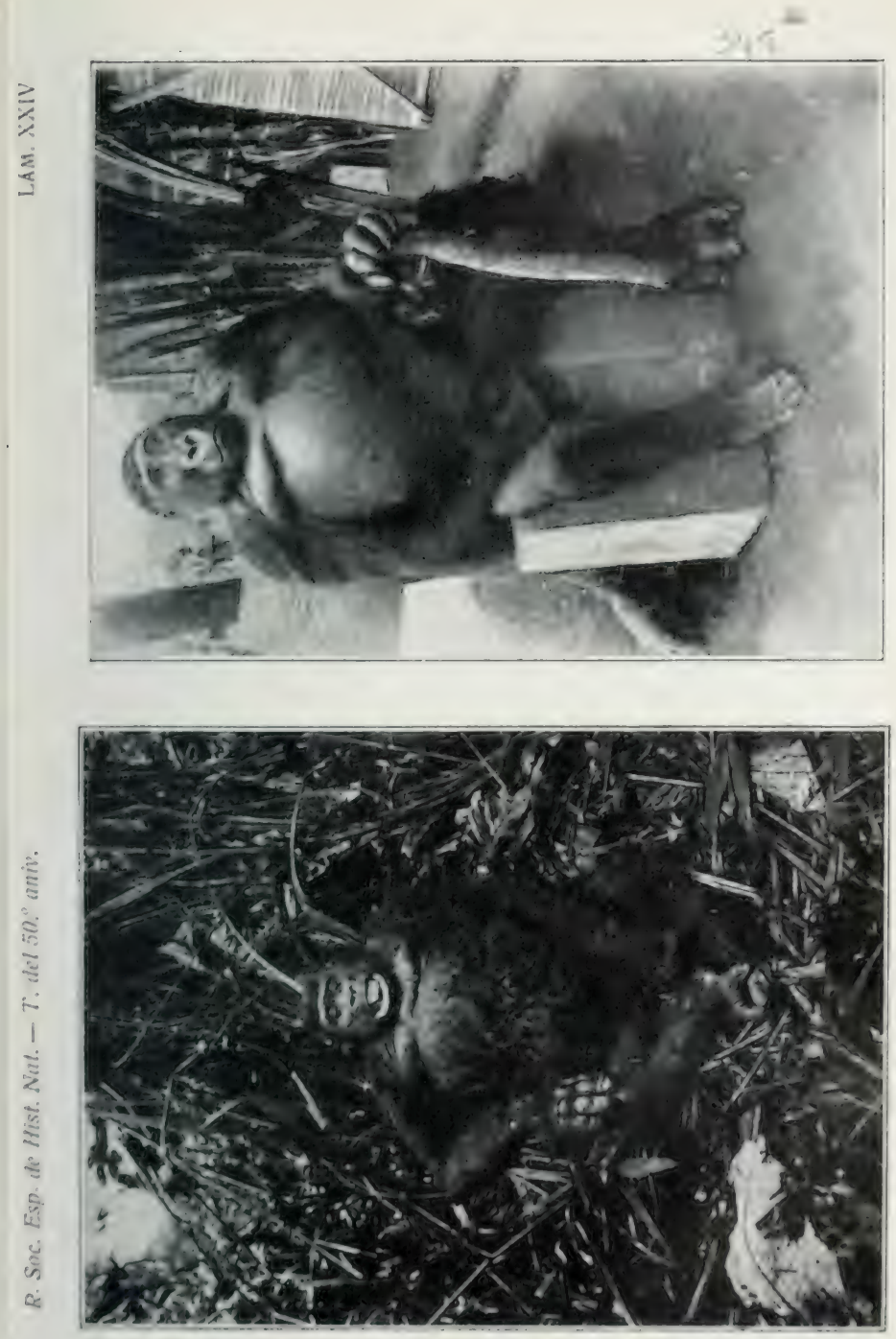




\section{LOS PROBLEMAS DE LA MODERNA SISMOLOGIA GEOLÓGICA EN RELACIÓN CON EL ESTUdIO DE LA TECTÓNICA DE LAS REGIONES SISMICAS DE ESPAÑA}

POR

\section{VICENTE INGLADA}

Director de la Estación Sismológica Central de Toledo.

Entre las concepciones más brillantes de la moderna Sismología geológica destacan dos por su importancia y fecundidad extramilinarias: las del gran geólogro norteamericano William Herbert HoBBS, que ataca la causa y naturaleza del temblor de tierra, y otra del ilustre sismólogo August. Sieberg, que se refiere a los efectos destructores del sismo, en intima relación, como parece natural y lógico, con la constitución geológica y estructura tectónica de la zona conmovida.

El primero, estudiando la repartición de dichos efectos en algunos temblores tectónicos importantes, ha podido observar el hecho de no haber relación alguna entre la intensidad sísmica, revelada por los efectos destructores sobre el terreno o en los edificios, y la distancia a uno o a varios puntos del área epicentral, y que los destrozos sísmicos parecen acumularse a lo largo de lineas rectas, con marcada tendencia al paralelismo, a las que HoBBs llama lineas sismotectónicas. Estas parecen ser la proyección sobre el suelo de las superficies de fractura que surcan las zonas de fallas de la corteza terrestre, y muy frecuentemente se acusan de manera indudable, pues coinciden con los accidentes tectónicos importantes de la región: líneas de contacto de formaciones geológicas distintas, aristas de hundimiento, líneas de costas abruptas, valles principales, etc.

Estas lineas caracteristicas del terreno que jalonan los destrozos sísmicos son los signos exteriores de los rasgos profundos de la corteza rocosa, ocuitos las más de las veces por el manto superfi- 
cial de aluviones, etc. que las cubre. El temblor de tierra sirve para descubrirlas y desempeña, en cierto modo, el papel de la radiogra. fía, que permite seguir la forma de los huesos ocultos a nuestra vista por la masa de los músculos.

HoBBs estudia los temblores de tierra acompañados de la formación de falla, especialmente el característico de San Francisco de California de 18 de abril de 1906, en que se abrió una grieta rectilinea de 300 kilómetros de longitud, de dirección aproximada N. $-35^{\circ}-W$. entre Puntas Arenas al N. y las cercanias de Mount Pinos en Ventura Country al S., y deduce que sólo por medio de terremotos se producen notables dislocaciones en la superficie terrestre, estando la magnitud del salto en relación directa con la intensidad del sismo; que las dislocaciones sísmicas son fallas normales de buzamiento aproximado a la vertical, y que un desplazamiento considerable de los labios de la falla ha sido observado en unos casos y es muy probable en otros.

El proceso del fenómeno sísmico es para HoBBs simple y preciso: la causa inmediata radicaría en los movimientos de compensación originados por el pasajero desequilibrio de los bloques de la corteza, que descansan sobre la zona plástica, y el sismo consistiría en desplazamientos verticales de uno o varios compartimientos contiguos, en resbalamientos a lo largo de la superficie de fractura, o en una combinación de ambos movimientos. Las componentes de éstos actuarían en el plano vertical o ligerísimamente inclinado que separa los bloques, pues un movimiento transversal a la línea de fractura no ha sido observado todavía, a menos de haber en la región considerada fallas concurrentes, en cuyo caso, en los puntos de intersección los efectos destructores del sismo se caracterizan por su intensidad máxima.

DAvison (1) cree que la fricción producida por el resbalamiento a 10 largo de una falla es la causa del fenómeno sísmico, y para demostrar que, en general, el temblor de tierra se deberá más bien a ese resbalamiento que a la producción de nuevas fallas o al desarrollo de las ya existentes, cita varios hechos: que el enorme número de sismos que se sienten en una región excede con mucho al de las fallas que la cruzan; que en los temblores importantes se

(1) Dr. Charles Davison, On the British Earlhquakes of the years 1889-1900. (Gerland's Beiträge zur Geophysik, Bd. V, 1902, páginas 242-312.) 
abren grietas y se forman escarpes en el suelo, a veces de extensión de muchos kilómetros, las cuales no son más que la manifestación, visible en la superficie, de dicho resbalamiento: que el epicentro d. los temblores que ocurren en una zona, ya pertenezcan al mismo o a distinto período sísmico, suele desplazarse a lo largo de lineas rectas determinadas, y que, por úitimo, más fácil que formar nuevas fallas, es originar o precipitar el resbalamiento a lo largo de las ya existentes.

La relación intima que existe entre las fallas y el temblor de tierra resulta demostrada frecuentemente por la forma alirmal i i.. área de sacudimiento, así como de las curvas isosistas, cuyos ejes mayores son ordinariamente paralelos a las líneas de fractura de la zona epicentral, por la migración ya citada del epicentro, en sismos sucesivos, a lo largo de líneas rectas, a veces paralelas a dichos ejes, y por la formación de grietas y fosas de extensión considerable en los temblores de importancia.

En cuanto a las demás fallas que no constituyen el accidente sismogénico, la opinión generalmente sustentada era que se oponían a la propagación del movimiento sísmico; mas a juicio del sismólogo SIEBERG, esto debe ocurrir únicamente si se trata de fallas próximas al epicentro y de profundidad superior a la det foco sismien. o bien de las que se hallan en los límites del área conmovida. Pero si el epicentro es bastante profundo, prodúcense refuerzos de intensidad sísmica en las superficies de fractura a causa de la facilidad con que a lo largo de ellas pueden moverse los bloques de la corteza y hasta puede resultar que las fallas se conviertan en focos secundarios.

Estas interesantes conclusiones se desprenden del estudio hecho por Sieberg y LAIS (1) del temblor de tierra de la Europa Central de 16 de noviembre de 1911, en el cual se presentan perfiles muy instructivos que muestran el aumento de la aceleración sismica en los puntos que corresponden a las fallas y prueban la importancia de esta clase de investigaciones, que pueden auxiliar al greólogro en el descubrimiento de los accidentes tectónicos ocultos.

En cuanto a la relación que existe entre los efectos destructores del sismo y la estructura geológica del suelo, Sieberci afirma que

(1) Das milteleuropäische Erdbeben vom 16 november l!) $1 /$ und sime Beziehungen zum geologischen Aufbau Süddeulschlumbs. (Girlund's l'citräge zur Geophysik, Bd. XII, Leipzig, 1912.) 
los mapas geológicos ordinarios apenas bastan para estudiarla, pues aquéllos, más que de la constitución geológica, dependen de la tectónica de la región conmovida, del grado de alteración más o menos avanzado de la roca y aun del espesor del depósito que se considere.

Las rocas cristalinas no alteradas ofrecen fundamento antisísmico a las construcciones, pero en estado de desagregación son muy peligrosas. En sus estudios sísmicos de las regiones italianas, SIEBERG ha podido encontrar puntos en que los destrozos sísmicos eran considerables y que estaban marcados en el mapa por gneis; pero examinada detenidamente la roca, pudo comprobar que el gneis estaba muy alterado y no era ya más que un material deleznable a causa de la lateritización producida.

La seguridad sísmica de las construcciones es tanto mayor cuanto más compacto es el suelo en que asientan, y crece en general con la edad de la roca, pues la sacudida sísmica produce en la roca firme, a causa de su elasticidad, movimientos vibratorios que se propagan a través de su masa, en tanto que en el material suelto, a causa de su falta de cohesión, originanse grandes desplazamientos relativos de las partículas y los subsiguientes efectos destructorès.

Las intrusiones de rocas eruptivas o hipogénicas amenazarian en algunas regiones la seguridad sísmica. También las pizarras cristalinas parecen actuar como acumuladores sísmicos. Las masas graníticas, en ciertos casos, se comprimirian a causa de la presión lateral de los macizos contiguos, en tanto que el gneis en igualdad de condiciones iria cediendo hasta llegar al limite de tensión y estallaría después produciendo vibraciones sísmicas.

Los efectos destructores del temblor de tierra manifiéstanse con extremada violencia en aquellos puntos donde materiales poco consistentes o sueltos (por ejemplo, depósitos terciarios hasta aluviales) descansan en delgada capa sobre roca firme, porque entonces las partículas se desplazan considerablemente unas con relación a otras, produciéndose análogo efecto al de las figuras sonoras de Chladni en las placas vibrantes. Como consecuencia de esto, en los puntos de contacto de dos formaciones distintas, especialmente si una de ellas es aluvial, los efectos destructores alcanzarán su máxima intensidad, no sólo por las razones expuestas, ya que el espesor del depósito será mínimo en la línea de contacto, sino porque el movimiento sísmico habrá tenido que salvar, al propagarse, la discordancia estratigráfica entre los dos terrenos y la diferencia de pro- 
piedades físicas, especialmente la de elasticidad en ambos medios. lo que hará transformar el movimiento vibratorio en otro desordenado y brusco que producirá los mayores destrozos.

Las consideraciones precedentes son de gran importancia y arrojan vivísima luz en el estudio geológico de los temblores de tierra. Para confirmar las vistas de HoBBS y Sieberg vamos a hacer un breve resumen de los hechos más importantes observados en dos sismos españoles, el famoso terremoto de Andalucia de 25 de diciembre de 1884, y el ocurrido en el bajo Segura el 10 de septiembre de 1919, como avance de un estudio que estamos efectuando acerca de tan interesantes temblores de tierra.

Del primero hay documentos y observaciones de un gran valor científico, pues fueron a estudiarlo sobre el terreno una Comisión de nuestro Instituto Geológico, presidida por su director, el ilustre geólogo D. Manuel FERnández dE CASTRO, y formada por ingenieros de tanto valer como D. Daniel de CORTÁzAR, D. Joaquín Gox-zalo TARín y D. Juan Pablo LAsala; otra, de la Academia de Ciencias de París, por geólogos tan eminentes como los señores Fouqué, Lévy, Bertrand, Barrois y Bréon, y los preparadores Sres. OfFret, Kilian y Bergeron, y por último una tercera, de la Real Academia dei Lincei de Roma, constituida por los sabios profesores Sres. Mercalli y TARAMELl, el primero arrebatado a la Ciencia por un accidente desgraciado, y el segundo, director en la actualidad del Instituto Geológico de la Universidad de Pavia, que a pesar de su avanzada edad conserva entusiasmo por esta clase de estudios y aun hace pocos meses nos comunicaba en afable escrito impresiones de su viaje a España con motivo del terremoto de Andalucia.

El eminente geólogo español D. José MAC-PHersoN, cuyos trabajos tanto han contribuido al estudio de los rasgos tectúnicos de la Península Ibérica, le dedica también atención especial en una notable conferencia: "Los terremotos de Andalucia, leida en (4) Ateneo de Madrid en febrero de 1885.

Después de describir en ella el sismo andaluz y exponer algunas consideraciones generales acerca de los temblores de tierra, MAC-PHerson apunta el hecho de que la región intensamente sacudida entre la Sierra Nevada y la serrania de Ronda está orientada en sentido transversal a la cordillera bética, dato importante si admitimos la naturaleza tectónica del terremoto de Andalucia, ya que la volcánica y la de hundimiento estin rechazadas por las razo- 
nes que se exponen en la notable Memoria de TARAMELli y MERCALLI (1).

Después observa el gran geólogo gaditano que en la región pleistosista los efectos destructores del sismo no se distribuyen de manera uniforme ni se agrupan alrededor de puntos fijos, siguiendo la ley del decrecimiento progresivo con la distancia, sino que los máximos efectos destructores preséntanse en zonas paralelas, separadas por otras en que los efectos son casi inapreciables. Este hecho importante alzábase en contra de la teoría focal, según la cual el centro de perturbación había de ser un punto o volumen de pequeñas dimensiones, del cual irradiaría la energía sísmica, decreciendo progresivamente con la distancia; mas la teoria focal estaba muy arraigada entonces a causa de las investigaciones de MALLET y sus sucesores, para que se prestara a la observación de MAC-PHERson la atención merecida.

Estas zonas paralelas en que se agrupaban los destrozos sísmicos eran cinco, distribuídas del siguiente modo: una al E. de Sierra Tejeda, en la provincia de Granada, y otra al W., en la de Málaga; una tercera, determinada por la recta que une los pueblos de Vélez-Málaga, Torrox y Frigiliana; otra a lo largo del valle del Guadalhorce, entre Málaga y Pizarra, y la uiltima en la parte inferior del valle del Guadiaro, correspondiente a los pueblos de Casares y Estepona, donde las sacudidas, aunque causaron daños, fueron menos sensibles que en las zonas precedentes.

- Dichas bandas paralelas de máxima intensidad sísmica siguen todas la dirección WNW.-ESE., que es precisamente la de las fallas o roturas que desde Galicia se extienden hasta el S. de España, por lo cual MAC-PHERson, con la admirable intuición en él característica, supone que los efectos destructores han sido máximos en dichas fallas, y deduce de ello una prueba más en favor de la tectónica de esta interesante región andaluza, tan afectada por el sistema de fallas WEW.-ESE., con lo cual el eminente geólogo español se vale de la observación de los efectos macrosísmicos para el descubrimiento de los rasgos tectónicos de la zona conmovida, aplicación importante que permite el estado actual de progreso de la Sismología geológica.

(1) Y terremoti Andalusi cominciati il 25 dicembre 1884. (Memoria di T. Taramelli e G. Mercalli, letta nelle sedute dei giorni 10 e 12 giugno 1885.) 
Como se ve, en la conferencia de Mac-Phersox hay dos observaciones fundamentales, de acuerdo con las actuales conclusiones de la Sismologia: una en contra de la teoria focal del temblor de tierra, que durante tantos años ha pesado como losa de plomo, impidiendo el progreso de esta ciencia, y otra que atañe a la relación de las fallas con los efectos destructores del sismo, a que corresponde la fecunda concepción de HoBBs sobre las líneas sismotectónicas.

Creemos se nos permitirá que pongamos de relieve estas interesantes observaciones del célebre geólogo español, como tributo de admiración a su memoria.

En cuanto a la relación intima entre los efectos destructores del terremoto de Andalucía y la constitución geológica del suelo conmovido y el manifestarse aquéllos con intensidad máxima en los puntos de contacto de dos formaciones distintas, la Comisión de la Academia de Ciencias dice en su informe textualmente (1):

"Las casas edificadas sobre terreno de aluvión fueron las que más sufrieron; las que descansaban sobre rocas sedimentarias poco resistentes, calizas friables, arcillas, etc., quedaron muy maltrechas. Por el contrario, las que tenian por base rocas sólidas, como calizas compactas y aun pizarras antiguas, resistieron mejor, sobre todo fuera de la región central. Las construcciones levantadas en las inmediaciones de dos suelos de naturaleza distinta, como una pizarra hojosa y una caliza cristalina, o una arcilla y una caliza compacta. sufrieron mucho.»

Si se echa una ojeada sobre el mapa geológico de la región conmovida, se verá que gran parte de las zonas en que se manifustaron los destr̃ozos sísmicos de mayor importancia están formadas por depósitos aluviales; por ejemplo: en el área pleistosista, la cuenca cuaternaria, cuyas aguas no tienen salida aparente, dentro de la cual están los pueblos de Zafarraya y Ventas de Zafarraya, el curso inferior del río Vélez y su zona immediata, a orillas del mar, çue se extiende desde Vélez-Málaga a Maro, y corresponde a ma de las bandas paralelas indicadas por MAC-PMEreson; las dos iltimis

(1) Estudios referentes al terremolo de Andaluciut ocurridu in 25 di diciembre de 1884 y a la constitución geolesgica del lerreno conmosidna hechos por la Comisión destinada al objeto por la deademiu de C'ientias de Paris, pág. 19. (Versión castellana publicada un el Boletin de lu Comisión del Mapa Geológico. Madrid, 189()-1893.) 
citadas por éste también, o sean la del valle del Guadalhorce, entre Málaga y Pizarra, y la de la parte inferior del valle del Guadiaro, etc.

Aun en las poblaciones que al examinar el mapa geológico parecen no estar comprendidas en los casos anteriores, existe alguna circunstancia local que explica perfectamente la intensidad sísmica con que el fenómeno se manifestó en ellas. He aquí algunos ejemplos, cuyos datos están tomados casi textualmente del informe ya citado de la Comisión de la Academia de Ciencias francesa.

En Vélez-Málaga, la parte de la ciudad edificada sobre terreno terciario sufrió más que los barrios situados sobre terrenos antiguos.

En Periana, que descansa sobre rocas cuaternarias atravesadas por un barranco, hubo 40 muertos y 18 heridos. El número de edificios en estado de inminente ruina fué de 158 , y de 146 el de simplemente resentidos.

Después de asentar que del estudio de la distribución de los efectos del terremoto andaluz resulta evidente la necesidad de no confundir la repartición de la intensidad sísmica con la de los efectos destructores, que varian entre límites muy amplios por circunstancias locales, aun en puntos muy próximos entre sí, anotan el hecho de haber ocasionado el terremoto pocos destrozos y ninguna victima en pueblos como Canillas de Albaida, Árchez, Columbela, Viñuela, Portugalejo, etc., a causa de asentar éstos sobre la roca antigua cristalina sin el intermedio de rocas superficiales modernas, y sintetizan del modo siguiente las relaciones entre la naturaleza del suelo y los efectos producidos en las edificaciones por el temblor de tierra, recordando de paso que Leopoldo PILla fué uno de los primeros que, con motivo del terremoto que asoló la costa toscana el 14 de agosto de 1846, estudió la relación entre los efectos dinámicos del sismo y la forma y naturaleza del suelo.

Resultaron muy damnificados los pueblos que asentaban sobre brechas, margas, travertinos, y en general sobre rocas poco consistentes y de débil espesor - especialmente si descansaban sobre formaciones antiguas de rocas compactas y homogéneas-, así como las construidas junto al borde de las depresiones producidas por los torrentes en los conglomerados y en las molasas terciarias. Sufrieron poco los pueblos edificados directamente sobre rocas calcáreas o cristalinas de gran espesor, y los destrozos fueron relativamente máximos en donde el suelo, a más de constituido por rocas no consistentes y de poco espesor, estaba en gran pendiente, como en 
Güevéjar. De aqui se deduce la conclusión que la transformación en desplazamientos relativos del movimiento molecular transmitido por las masas profundas y compactas fué tanto más desastrosa cuanto menores eran el espesor, la lomogeneidad y la continuidad de la capa superficial.

Como se ve, el acuerdo es perfecto entre estas deducciones y las que resultan de las investigaciones de SIEBERG enunciadas precedentemente.

Otra circunstancia importante que puede aumentar los efectos destructores del sismo es el tratarse de suelo pantanoso o de terreno empapado en agua a causa de recientes lluvias, pues las partículas adquieren movilidad extrema y los desplazamientos relativos pueden llegar a ser considerables.

En Guaro, no lejos de Periana, durante el terremoto de Andalucia, rel suelo arcilloso apoyado sobre las vertientes próximas de caliza y profundamente empapado por las aguas de lluvia, se separí del subsuelo y resbaló en masa, dejando en sus bordes una especie de foso ancho de 2 a 3 metros» (1). La Comisión española (2) atribuye el fenómeno al hundimiento de alguna de las cavernas subterráneas, tan abundantes en la caliza jurásica de aquella localidad.

En Cacín, edificado sobre aluviones, a más de un muerto y 6 heridos, hubo 21 casas destruidas y 72 quebrantadas. Los pueblos próximos de El Turro y Loja sufrieron menos.

Arenas del Rey, que fué convertido en un montón de ruinas por el terremoto, está edificado sobre molasa helvética. A cierta distancia, al SWV., esta molasa se apoya en caliza jurásica. Al N. y S. descansa sobre caliza antigua.

En Játar, pueblo inmediato al precedente, los daños fueron menores, lo que se explica por la gran cohesión del travertino y su adherencia a la caliza cristalina adyacente.

En Granada y Atarfe se sintió el terremoto con fuerza y muchas casas se agrietaron. Ambas poblaciones estan en el limite de la zona aluvial del Genil, que se extiende de W: a E. desde Loja a Granada y tiene focos sísmicos bien determinados, como son lus de dichas ciudades, Santafé, etc.

Los pueblos de Quéntar y Dúdar, aguas arribas del Cienil, estain ya separados de dicha zona aluvial, $y$ sin embarco sus casas suiric-

(1) Estudios referentes al terremoto de Andalucia, ete., piats. 22.

(2) Bol. de la Com. del Mapa Geol., t. XII, prig. 45. 
ron mucho durante el terremoto; mas hay que observar que ambos están sobre una falla terciaria, a media falda, cerca de la separación del mioceno y del terreno cristalino.

Albuñuelas y Saleres, pueblos en que un gran numero de casas quedaron arruinadas, están situados sobre molasa, inmediata a terrenos antiguos, el primero en contacto con calizas antiguas que 10 rodean por todas partes.

Murchas y Béznar, edificados sobre guijarral terciario, y Salar, situado en el borde de la cuenca terciaria, sufrieron también considerablemente. En el primero la mayor parte de las casas quedaron arruinadas, pero hay que añadir que estaban en general muy mal construidas. Fué uno de los pueblos que con relación a su vecindario sufrió más desgracias personales, pues tuvo 9 muerto’ y 13 heridos.

En Motril, edificado sobre terrenos de aluvión, quedaron muchas casas cuarteadas y otras amenazando ruina.

En Tablate y Talará, pueblos edificados sobre formación terciaria, próxima a terrenos antiguos, los daños fueron también importantes.

En Venta de las Angustias, cerca de Talará, la carretera quedó agrietada y hundida por el terremoto; está abierta en las capas de la formación de guijarros terciarios.

En la Memoria ya citada de TARAMELli y MERCALli hay también observaciones de gran interés que apoyan las vistas de SIEBERG, y que no citamos porque el objeto de este escrito es exponer rápidamente las ideas actualmente reinantes en el campo de la Sismología, y no hacer un estudio a fondo del terremoto de Andalucia, a que dedicaremos nuestra atención en otro trabajo; mas no podemos pasar en silencio ciertas consideraciones que tan ilustres sismólogos hacen en el capítulo VII, relativo a los efectos dinámicos del terremoto en los edificios y sobre el terreno, porque se pueden resumir fácilmente y son de importancia extraordinaria.

En Güevéjar, causas análogas produjeron una grieta semicircular de un kilómetro de largo. En medio del terreno por ella circunscrito, el pueblo, sin derrumbarse, experimentó todo él un movimiento de traslación, hecho que atribuyen a un resbalamiento, tanto la Comisión española como la francesa.

Si interesante parece el estudio del terremoto de Andalucia a la luz de las concepciones de la Sismología moderna, no lo es menos el del bajo Segura, del 10 de septiembre de 1919, cuyo epicentro, 
según los datos recogidos por la Comisión nombrada al efecto por el Instituto Geográfico y Estadístico, es un punto próximo a Bigastro y Jacarilla (provincia de Alicante), al SE. de ambos pueblos, a $38^{\circ} 4^{\prime} 30^{\prime \prime}$ de latitud y $2^{\circ} 49^{\prime} 30^{\prime \prime}$ de longitud E. (Madrid).

La región sísmica a que pertenece este temblor de tierra tiene importancia extraordinaria, pues está situada en la geosinclinal mediterránea, o sea en el círculo alpino-caucásico-malayo, donde, según las investigaciones del Conde MONTEssus de Ballore, fundador de la Geografía sismológica, ocurre el 53, 54 por 100 de los sismos terrestres.

La región sísmica del SE. de España, notable por sus periodos de actividad, y enclavada en la porción occidental del círculo mediterráneo, corresponde al extremo de la zona penibética, cuyo accidente principal es la gran falla diagonal del mismo nombre, que desde el Genil, por las depresiones granadina, lorquina y murciana, llega hasta el cabo de la Nao. Como directriz principal está el curso bajo del Segura, que por el Sangonera, afluente suyo, viene a enlazarse con la línea sismotectónica Lorca-Guadix-Granada.

Acrecienta aún más la actividad sísnica de esta región la circunstancia de que en ella interfieren en ángulo los plegamientos penibéticos con los del sistema ibérico en las proximidades del cabo de la Nao.

Los estudios de Nicklés han demostrado que la estructura estratigráfica de esta comarca presenta el sistema predominante y característico de la zona subbética, formado por pliegues paralelos a la dirección general de la sierra bética y de la gran falla del Guadalquivir, del cual participan, en la provincia de Alicante, la sierra de Crevillente y todas las alturas que rodean la comarca de Alcoy, y en la de Alurcia, las sierras de Caravaca y de las Cabras.

La zona sismica del bajo Segura, que comprende gran parte de las provincias de Alicante y Murcia, una de las mis accidentadas y montañosas de España, es de complicada estructura geológica, y' los terrenos que la forman aparecen muy trastormados y cruzados muy frecuentemente por abundantes plegamientos y fallas.

En el notable estudio correspondiente a los trabajos de rectificación del mapa geológico, titulado Réeseña geológica de la prór vincia de Alicante, que el distinguido ingeniero de Minas del Instituto Geológico de España D. Pedro de Novo y Chuchakmon hat publicado, se hace notar que los más importantes asomos ofiticos - únices eruptivos que hay en la provincia - se presentan en dos 
lineas principales, una orientada de NE. a SW., desde la mancha de Parcent hasta las de la Aparecida, en la sierra de Orihuela, y otra que desde las cercanías de Villena, por Pinoso, va a cortar en ángulo agudo a la anterior.

"Ahora bien-dice el Sr. Novo-: la primera linea se ajusta casi exactamente a la que marca el límite meridional de las formaciones secundarias y del terciario inferior, la que probablemente corresponde a una arista de hundimiento entre dichas formaciones y las antiguas de la provincia de Murcia, y la segunda línea se corresponde también con una falla que se acusa en las levantadas capas del eoceno de las sierras de la Horna, del Buaimi, del Boloni, etc., hasta la Peña Rubia.»

«Esto parece comprobar la gran relación de las ofitas con los trastornos que se observan en el suelo de Alicante, correspondiendo las zonas más trastornadas a las líneas donde se presentan las ofitas en la superficie.»

En cuanto a la provincia de Murcia, los terremotos en ella ocurridos en 1911 han dado lugar a un excelente estudio, hecho por los reputados geólogos D. Rafael SÁNCHEz LozAno, actual director del Instituto Geológico, y D. Agustín Marin (1), del que vamos a entresacar algunos datos interesantes acerca de la tectónica de esta importante zona sísmica.

A juicio de los autores de este trabajo, los temblores ocurridos en dicha provincia en 1911 son debidos probablemente a las últimas manifestaciones del volcanismo que tuvo lugar en esta región después de la época miocena, y para justificar esta creencia mencionan los principales asomos de rocas hipogénicas que alli se encuentran, cerca de los baños de Archena por el NW., en el extremo SW. de la sierra triásica de Carrascoy, a unos 8 kilómetros al E. de las aguas salinas termales de Alhama, en la misma sierra al SE. de Murcia, en la serrezuela triásica paralela a la de Carrascoy, cerca de Santomera, a unos 5 kilómetros al SE. de los baños termales de Fortuna, y, finalmente, en los alrededores de Albudeite y Campos, donde existen tres asomos de dichas rocas.

El epicentro de dichos temblores seria una zona de pequeña extensión, junto al curso del Segura, entre Ceuti y Lorqui, y situada en la intersección de dos grandes lineas de fractura: una real, la

(1) Estudio relativo a los terremotos en la provincia de Murcia de 1911. (Bol. del Inst. Geol., t. XII, segunda serie, págs. 179-214.) 
diel rio Segura, en la parte de su curso que se extiende desde Cieza a Murcia, y otra supuesta por dichos ingenieros de Minas, que es la indicada por la línea recta que une los asomos eruptivos de Fortuna con los de Mula, en atención a ser paralela a la dirección de la sierra de Carrascoy y a la de las principales cordilleras murcianas.

La existencia de esa línea de fractura, que actuaria como accidente sismogénico en los terremotos de 1911, es muy probable, no sólo por las razones apuntadas, sino por resultar paralela a la línea que forma el curso del Sangonera desde Lorca a Murcia y del Segura desde la capital hasta Orihuela, que constituye la prolongación de la importante línea sismotectónica Granada-Guadix-Lorca. Tampoco su dirección difiere mucho de la del eje mayor de la isosista máxima del terremoto de 10 de septiembre de 1919, como veremos más adelante, y esta coincidencia es de gran importancia, pues la profundidad hipocentral en ambos terremotos es sensiblemente la misma, de 4 kilómetros para las sacudidas sísmicas de 1911 , y de unos 4.750 metros para las de 1919, lo que induce a atribuir una comunidad de origen a ambos fenómenos.

Hay que notar también que la dirección de la repetida linea de fractura es la misma que la de los asomos ofíticos de la provincia de Alicante, que van en dirección NE. a SIV. desde la Aparecida, en la sierra de Orihuela, hasta Parcent, y hacen admitir al Sr. Noro la existencia de una arista de hundimiento.

La situación de dicha línea de menor resistencia estaria claramente definida en su mitad occidental por el curso inferior del rio Mula, y ello explicaría la frecuencia de las sacudidas sismicas en los pueblos situados en ella, como Albudeite, Campos, Cotillas y Alguazas, y el haberse observado en los terremotos de 1911 los destrozos máximos en Ceuti y Lorqui se explicaria perfectamente. no sólo por hallarse en la intersección de las dos lineas de fractura antes mencionada, circunstancia la más favorable secrin las teorias de HoBBs, sino también por encontrarse en la zona aluvial del Sigura y en el punto de contacto con los sedimentos miocenos, condición adecuada, según las ideas de Siemerici, para que los cfectos destructores se manifiesten con la mayor violencia.

En la región del bajo Segura las concepciones de Ilomis y Sieberg acerca de las lineas sismotectúnicas y la distribncion de. los efectos destructores del sismo aparecen confirmadas de hrillante modo, pues por lo que respecta a las lineas de fractura las conside- 
raciones precedentes muestran su propiedad sismogénica, ya que la región privilegiada de los temblores de tierra es el curso inferior del Segura desde Archena hasta casi su desembocadura y el del Sangonera, afluente suyo, que forman la prolongación de una línea sismotectónica de primer orden.

Por lo que atañe a la naturaleza del suelo, hay que observar que ambos ríos forman una zona alargada, en la que los depósitos aluviales están en contacto casi siempre con el mioceno o triásico.

En cuanto a los pueblos que están en el limite de ambas formaciones y han de sufrir, por lo tanto, los máximos efectos destructores, difícil resulta elegirlos a causa de su gran número; citemos, por ejemplo, Ceutí y Lorqui, tan castigados por los terremotos de 1911; Alguazas y Cotillas, en el área pleistosista del temblor de tierra de 28 de enero de 1917; Lorca, Albudeite, Campos, Molina, Archena, etc. Obsérvese también la pasición de Orihuela y Murcia, visitadas frecuentemente por el temblor de tierra; Ojós (en el contacto del mioceno y triásico), en donde se han sentido sacudidas sísmicas el 6 de octubre de 1920, y en el barranco de Tuna se ha abierto una grieta de 300 metros de longitud; y por último, por lo que respecta al terremoto de 10 de septiembre de 1919, no hay más que seguir la linea límite de los depósitos aluviales para encontrar los pueblos en que las sacudidas se sintieron con más intensidad: Almoradi, Daya Nueva y Vieja, Algorfa, Benejúzar, Jacarilla (en cuya rambla se abrieron grietas, una de las cuales alcanzaba un kilómetro de longitud), Bigastro, etc.

La adjunta figura muestra una parte del mapa de las isosistas correspondientes al terremoto de 10 de septiembre de 1919, que hemos trazado basándonos en los datos recogidos por la Comisión nombrada para su estudio por el Instituto Geográfico y Estadístico.

La marcha de las curvas es irregular y corresponde a la complicadísima estructura geológica de la zona conmovida. El área en que el fenómeno fué sensible es de reducida extensión, unos 5.000 km." (la del terremoto de Charleston de 31 de agosto de 1886 fué de $796.000 \mathrm{~km} .^{2}$, y la del sismo del Assam de 12 de junio de 1897 , de $3.970 .000 \mathrm{~km} .^{2}$ nada menos).

La isosista máxima-de grado VIII (escala Sieberg)-ocupa una extensión de $130,88 \mathrm{~km} .^{2}$, 10 que da una distancia media a su punto central de $6,45 \mathrm{~km}$. Su eje es, como ya hemos dicho, aproximadamente paralelo a la línea de fractura supuesta para la explicación de los terremotos de 1911, a la línea que forman el Sangonera y 
Segura en la última parte de su curso, a la dirección de las cordilleras principales, a la de los asomos ofiticos más importantes de la provincia de Alicante, que hacen suponer al Sr. Novo la existencia de una arista de hundimiento, etc.

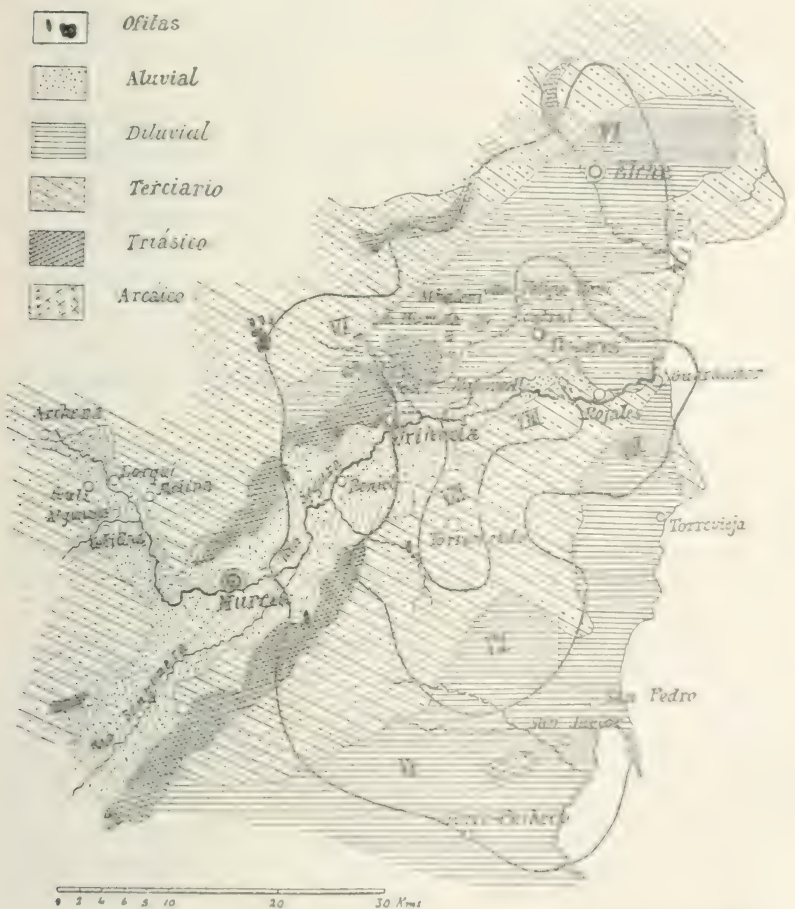

Croquis del área epicentral del terremoto de 10 de septiembre de Ioru en el bajo Segura, con la representación de las tres primeras isosistas.

Esta dirección fundamental, que juega tan importante papel en la tectónica de la región alicantino-murciana, es la que siguen aproximadamente los ejes mayores de todas las isosistas, acusando de 
manera evidente la íntima relación entre el fenómeno sísmico y el pasado geológico de la zona que visita.

El lector observará, sin duda, algunos interesantes pormenores de las inflexiones de las isosistas: la de grado VII, por ejemplo, destaca una lengua por la estrecha faja diluvial entre Orihuela y Callosa de Segura, por donde corre el río Dulce entre dos masas triásicas que se extienden al N. y a la inmediación del Segura, mostrando claramente la mayor violencia de los efectos del sismo en dicha faja.

La reducida extensión de la isosista máxima y la pequeña profundidad hipocentral (de unos 5 kilómetros) dan a este temblor un carácter marcadamente local, como el de los terremotos de 1911 y otros muchos ocurridos en esta interesante región levantina.

La hipótesis de atribuir el sismo a fenómenos expansivos causados por las descomposiciones químicas que el agua de infiltración pueda producir - principalmente por hidrocarburos que quedarian libres o se formarian en las margas salíferas del Keuper unidos a vapor de agua - , a lo que se presta la circunstancia favorabilísima de ser el trías el que acusa su presencia constante en el subsuelo de la provincia de Alicante, parece no explicar el carácter de este temblor de tierra que por espacio de dos o tres meses ha presentado numerosísimas réplicas en los pueblos del área pleistosista y el haberse transmitido el fenómeno a gran distancia, pues los sismógrafos de Hamburgo, y seguramente los de algunas otras estaciones cuyos datos no han llegado a nosotros, lo registraron en sus gráficas.

La delimitación del accidente sismogénico - ya sea el que sugiere la isosista de grado VIII u otro más amplio, si los mayores efectos destructores del sismo en ella se explican por circunstarcias locales: depósito aluvial del Segura, etc.- suscita un interesante problema que no podemos abordar por la falta de datos de tectónica local en que nos encontramos.

El sismólogo requiere a cada momento el concurso del geólogo para que éste le dé datos cada vez más precisos de los accidentes tectónicos de la región sísmica y del espesor y naturaleza de los depósitos superficiales, del mismo modo que el físico estudiando sus problemas plantea las ecuaciones y pide incesantemente al matemático que las resuelva, y el cálculo integral - fuerza es confesarlo-no siempre da la solución pedida, a pesar de los asombrosos progresos que ha realizado, de los cuales algunos han nacido por la imperiosa necesidad de satisfacer los requerimientos de la Física. 
Acaso la Sismologia, de un modo análogo, haga progresar los estudios tectónicos. En nuestra patria por lo menos, donde hay tanto que hacer en este campo, sería muy beneficiosa la estrecha colaboración de geólogos y sismólogos en esta importante clase de investigaciones, por lo cual nosotros hemos proclamado su necesidad e importancia en varias ocasiones. Acaso esta vez nuestra voz no se pierda en el vacío. De los amantes de la Geología queremos esperar una patriótica actividad en favor de estos interesantes problemas sismotectónicos, pues opinamos que el suelo español debe ser explorado por geólogos españoles, algunos tan eminentes que, al dedicar su esfuerzo a esta clase de trabajos, cosecharian resultados cientificos trascendentales y de una novedad extraordinaria, ya que nuestro país para algunas cuestiones es aún, por desgracia, una verdadera terra incognita.

\section{DESARROLLO DE LA THELEPROCTOPHYLLA (NEUROPT.)}

POR

\section{CAYETANO ESCRIBANO}

(Lámina XXVI.)

Habiendo tenido ocasión de seguir paso a paso todas las fases del desarrollo de una larva de neuróptero recogida en Montarco (Madrid), que resultó ser del género Theleproctophylla, hube de consultar con tal motivo las más importantes obras que sobre biologia de los insectos existen, suponiendo, desde luego, que alli encontraría tratado cuanto yo había visto, y que nada nuevo podría añadir con mis observaciones. Lejos de ser asi, pude convencerme di to contrario, pues, aparte de algunas generalidades morfolúgicas. apenas aparece tratado en el grupo que nos ocupa punto tan importante como el que motiva esta nota. Asimismo son muy deficientes las ilustraciones de dicho género, pues faltan en absoluto las referentes a sus larvas y ninfas, y son muy confusas las det animal adulto, por todo lo cual he creido conveniente recopilar ayui lus datos citados, acompañándolos de cuantos dibujos pude hacer de 
tan interesante neuróptero, creyendo de este modo contribuir a su conocimiento más completo.

El Dr. HAgen (1) describe una larva procedente de Asia Menor, que en principio parece atribuir a Th. barbara, ya que este nombre es el titulo de su trabajo, algunos de cuyos caracteres parecen coincidir con los que presenta la que nosotros estudiamos, tales como la forma general de la cabeza y de las mandíbulas, que tanto varían en los distintos géneros de este grupo de insectos; pero si nos fijamos cuidadosamente en detalles que hay que suponer también esenciales y característicos en los mismos, notaremos muy pronto que entre una y otra existen notables diferencias que nos llevan a suponer que era justificada la duda con que el autor citado termina su trabajo, no sabiendo, por fin, si la larva que empieza suponiendo de $T h$. barbara puede ser más bien propia del género Bubo, como nosotros desde luego suponemos.

En efecto, las colinas o tubérculos laterales de la cabeza, donde se implantan los ojos de estas larvas, son robustos, cilindrico-truncados y con una pequeña punta en el centro de la truncadura, en el ejemplar estudiado por el Dr. HAGEN; en el nuestro son evidentemente cilindro-cónicos (lám. XXVI, fig. 2). Las antenas del primero son poco más cortas que dichas colinas o tubérculos; las del nuestro apenas alcanzan la mitad de la longitud de los mismos; presenta aquél, dice HAGEN, toda la cabeza, como en general todo el animal y mitad basal de las mandibulas, espesamente cubiertos de pestañas muy cortas, blancas, planas y pegadas; son muy escasas, en grupos, discontinuas y apenas fuera de la cabeza en el nuestro. Por último, la forma general del abdomen, que en el primero parece ser oval, por cuanto su anchura máxima está detrás del primer segmento, es en el segundo marcadamente elíptica (lám. XXVI, fig. 1), y sobre todo las dimensiones que dicho autor asigna, longitud $15 \mathrm{~mm}$. y anchura 7,5 , contrastando con las que aproximadamente podemos dar nosotros, de $10 \mathrm{~mm}$. y $5 \mathrm{~mm}$. respectivamente, parecen estar en relación con el tamaño de los adultos de los géneros Bubo y Theleproctophylla, ya citados.

Sin prejuzgar por ahora cuál pueda ser la especie a que vamos refiriéndonos, diremos que dicha larva, de aspecto general şemejante a las de Myrmeleon, de todos conocidas, ofrecia, sin embargro, notables diferencias con éstas, no sólo morfoligicas, sino también

(1) Stett. ent. Zeit., t. XXXIV, 1873, paig. 40. 
en su género de vida, pues de igual modo que las de todos los ascaláfidos, no practica en la tierra las trampas cónicas de los Myrmeleon, sino que espera pacientemente a sus víctimas sobre la superficie, aprovechando con rapidez y precisión el paso de las mismas a su alcance para clavarles sus poderosas mandibulas, que las retienen como terrible tenaza mientras verifica la aborcion lenta y mompan de sus partes liquidas.

$\mathrm{Y}$ ahora, antes de proceder a su ligera descripción, véase en la lámina XXVI, figura 1, un aspecto de la larva antes de una nutrición abundante. Las arrugas que forman los segmentos abdominales, bien manifiestas, desaparecieron en absoluto después de haber dado cuenta de ocho o diez moscas, y el abdomen se tornó entonces globoso y de aspecto totalmente distinto del que aqui representamos.

Su cuerpo, en conjunto, es más o menos ovoideo, como en todos los ascaláfidos, de poco más de un centímetro de longitud máxima, prescindiendo de las mandibulas, esto es, desde la frente a la terminación del abdomen; su cabeza, de forma trapezoidal, pero más ancha en la parte posterior, al contrario de lo que ocurre en el género Ascalaphus, está armada de las poderosas mandibulas ya citadas, que son curvas y convergentes hacia el extremo, provistas de finos dientecitos próximamente iguales en su borde interno, entre los que se destacan tres mucho mayores situados hacia su parte media. A los lados y hacia la región anterior existen dos eminencias o tubérculos, donde están implantados los ojos, bien visibles, en dos series, y número de siete a cada lado. La parte posterior presenta ángulos entrantes y salientes, que corresponden con otros análogos de la parte anterior del tórax y que indican la existencia de fuertes músculos al servicio de tan perfecto engranaje, con lo que la cabeza disfruta de una movilidad y potencia notables.

El tórax, elíptico-redondeado, y cuyo eje mayor es el transverso, sólo presenta de notable dos enormes eminencias cónicas en su parte anterior, a que antes hicimos referencia, y una pequena escotadura en la posterior.

El abdomen, que es también elíptico-redondeado y con su eje mayor longitudinal, está constituido por ocho anillos que presentan a cada lado dos tubérculos digitiformes, y del seumento terminal, también de esta forma, pero de mayor tamaño.

Las patas son de regulares dimensiones y formadas de artejos más o menos cilindricos, con dos uñas terminales, curvas, de la forma de las de los felinos; otoservándose en las posteriores la particulari- 
dad ya citada por HAGEN, como característica de los ascaláfidos y mirmeleónidos, de presentar en una sola pieza, sin separación visible, la tibia y el tarso.

Por último, aun sin considerar como notable el detalle de que el ejemplar estudiado presente pelos abundantes en todo el cuerpo, más numerosos y largos en el abdomen y hacia sus tubérculos laterales, hacemos notar, por parecernos curiosa, la forma de los mismos (lám. XXVI, fig. 3), y sobre todo el que su extremidad sea asteriforme y sumamente variable, según indican los detalles representados en la figura citada.

Hemos hablado al principio del género de vida de esta larva, y sin poder precisar por ahora la duración de esta fase, sólo podemos afirmar que a los tres o cuatro días de empezar nuestras observaciones, y después de uno de sus más nutritivos banquetes a expensas de gran número de moscas, que fueron siempre su alimento, adoptó una posición sumamente extraña, colocándose patas arriba y apoyándose tan sólo en la cabeza y parte del tórax, ya que su abdomen, formando ángulo recto con aquélla, aparecia próximamente vertical. Esto nos hizo creer que, quizás debido a un exceso de nutrición, habia terminado su vida, pues, por otra parte, aun molestándola repetidas veces, no respondia con movimiento alguno.

En dicha posición, y después de segregar, al parecer por la terminación del abdomen, una substancia viscoso-algodonosa que aglutinaba moscas y otros residuos, formando un imperfecto capullo, aparece a los diez días transformada en ninfa con la forma indicada en la lámina XXVI, figura 4. De color blanquecino uniforme y aspecto de animal tierno, y dibujándose ya en él los detalles que con las consiguientes modificaciones de mayor tamaño, coloración, dureza, etc., han de ser definitivos en el adulto, sólo se observa un principio de coloración rojo-negruzca en los ojos y en las terminaciones de las uñas y mandíbulas, que progresivamente va invadiendo dichos órganos, hasta el extremo de ser totalmente rojizos al transcurrir doce días, como to son también los tarsos, cercos, etc., ell tanto que en las alas se inicia apenas esta diferenciación, que por último alcanza también al cuerpo del animal.

Por lo demás, y según puede verse en la lámina XXVI, figura 4, que la representa en el primer dia de esta fase, aparecen en ella bicn manifiestos la mayor parte de los órganos que subsisten en el animal adulto, como son los ojos, bien desarrollados; las antenas, que se aplican alrededor de éstos, sin tener diferenciada la maza final 
caracteristica de los adultos; las alas, pequ nas, adaptadas al cur.rpo y dirigidas hacia abajo; las patas, articuladas y lareas. pero blancis. e incapaces, como las alas, de servir para desempeñar sus funciones respectivas, y por último el abdomen, que es bastante grande $\mathrm{y}$ desde luego más alargado que en la larva, con los estigmas laterales bien visibles. En la ninfa las mandibulas son fuertes y quitinizadas, teniendo su borde interno armado de nueve denticulaciones muy marcadas.

Desde luego, mientras duró esta fase, la actividad fué nula. como de ordinario ocurre en todos los insectos en tal estado.

A los quince días justos la ninfa aparece súbitamente transformada en insecto perfecto, dejando abandonada la cubierta que antes le daba forma. Puede observarse perfectamente en ésta una hendidura longitudinal en la región cefálica superior, por la que seguramente pudo sacar primero la cabeza y tórax, y después desenfundar suavemente el abdomen, dejando intacta y sin detrimento la cubierta en esta región.

Desde este momento vemos ya al insecto con su forma y coloración definitivas, salvo pequeños detalles en los cercos y coloración de las alas, que necesitan dos o tres días para su total distensión. En la lámina XXVI, figuras 5, 6 y 7, pueden observarse las variaciones más notables a que aludimos, puesto que la figura 5 corresponde a un ejemplar macho de más de cuatro dias, la figura $\tau$ a una hembra de igual edad y la figura 6 a un ejemplar recién transiormado. El abdomen en este último caso termina de igual modo en los machos que en las hembras, pudiendo decirse que es inerme, mientras que presenta poderosos cercos el de los machos y unas láminas foliáceas el de las hembras, que varian según las especies, cuando se trata de ejemplares bien adultos. Las manchas y pterostigmas son mayores en los ejemplares jóvenes, que asimismo tienen más acentuada la coloración general de las alas.

Para terminar, creemos conveniente referir el ejemplar estudiado a alguna de las especies conocidas, y para ello hemos consultado la obra de VAN DER WEELE, Ascalaphiden, monographisch bearbeibet (1); la Sinopsis de los Ascalcifidos, del Rvdo. P. Longinos NavÁs (2), y la descripción por este mismo autor de un Asca-

(1) Cat. syst. el descr. (Coll. Zool. Sely's Longchamps, fasc. VIII. Bruselas, 1908.)

(2) Arxius de l'Instit. de Cienc, any I, num. 3. Barcelona, 1913. 
láfido nuevo de España (1), por considerar estos trabajos los más autorizados y recientes en la materia, y en su consecuencia, y muy especialmente por haber tenido ocasión de examinar las colecciones del Museo Nacional de Ciencias Naturales, donde se conservan varios ejemplares clasificados por este último autor, no dudamos en calificarla de Theleproctophylla dusmeti, con la que coincide desde luego en la forma de los cercos de los machos, que consideramos carácter fundamental en las distintas especies; pues si hubiéramos de atenernos a otros detalles que dicho Sr. NAvÁs consigna en sus descripciones, tales como la coloración y dibujos del tórax y abdomen, nos hubiera sido muy difícil llegar a clasificarla con seguridad.

De cualquier modo, queda cumplido nuestro único propósito, que no era sino dar a conocer nuestras observaciomes, hechas con toda la minuciosidad posible, suponiendo podrán interesar a los iniciados en estos estudios, y por creer que puede ser algo nuevo que añadir a la biología de los insectos.

\section{Explicación de la lámina XXVI.}

Fig. I. - Larva de 'Theleprocteplaylla dusmeti, aumentada cuatro veces próximamente.

Fig. 2,-Detalle de una colina lateral de la cabeza, para mostrar la implantación y distribución de los ojos.

Fig. 3. - Un pelo del abdomen, nuy aumentado, y varios detalles del extremo de algunos de ellos.

Fig. 4. - Ninfa de Theleproctopliylla dusmsti, aumentada unas cuatro veces.

Fig. 5. - Ejemplar macho adulto de 'Theleprectophy/la dusmeti, $\times$ I $1 / 2$.

Fig. 6. - Ejemplar hembra recién transformado, $X \quad 11 / 2$.

Iig. 7. - Ejemplar hembra adulto, $X$ I $^{1 / 2}$.

(1) Broteria, Ser. Zool., vol. XII, fasc. I, pág. 57. Túy, 1914. 

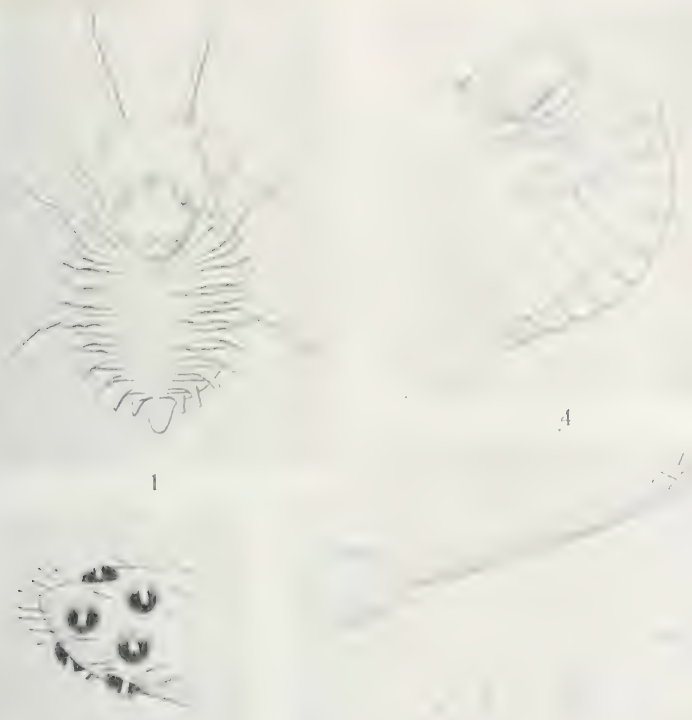

2

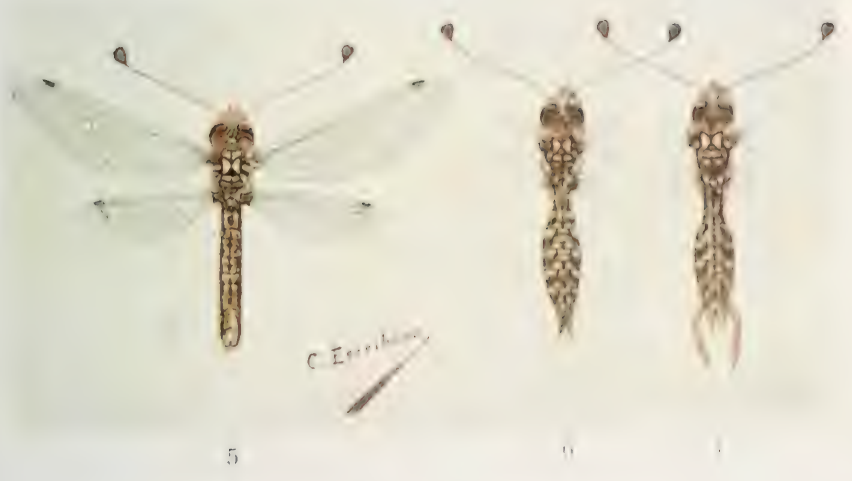

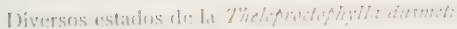





\title{
OBSERVACIONES SOBRE LOS GAMMMRIDAE IDE AIUA WUI.CL: DE ESPAÑA
}

\author{
POK \\ MANUEL FERRER GALDIANO
}

Estudiando los Gammarus de agua dulce de la colección carcinológica del Museo Nacional de Ciencias Naturales, he hallado algunos que no estaban citados y he creido conveniente publicar las observaciones que me ha sugerido su examen, confiando en reunir mayor número de ejemplares para hacer un estudio más completo de tan interesantes anfipodos del medio dulce ácueo. No quiero terminar estos cortos renglones sin manifestar mi agradecimiento a M. Edouard Chevreux, que ha tenido la atención de comprobar algunas de mis determinaciones.

Los dos géneros que existen en nuestra fauna, Gammarus y Echinogammarus, se diferencian fácilmente por el aspecto tan distinto que presenta la porción dorsal de su abdomen, pues en el Gammarus las pequeñas espinas y sedas están en muy corto mímero en el borde superior de la inserción de los tres últimos terguitos abdominales, mientras que en el Echinogammarus bordean toda la porción superior de los terguitos del abdomen.

Las especies estudiadas del género Gammarus son las sigruientes: pulex, pungens, Simoni y Delebecruci, siendo facil establecer su diferenciación fundándose en un corto mimero de caracteres. tales como la longitud y forma de las antenas superiores e initeriores, la forma y dimensión de los ojos compuestos, el tamano de los gnatópodos del primero y segundo par, la forma del quinto par de. patas torácicas, el tamaño tan distinto que presentan el exopodio y endopodio del tercer par de urópodos, el múmero y la disposicim de las espinas y sedas en la porción dorsal de los secrmentos det abdomen. Distinguiremos fácilmente las especies citadas con súlo observar los siguientes caracteres:

Gammarus pulex Limé,-Ojos pequeños, de forma oval y dis- 
puestos oblicuamente; las antenas superiores poco más largas que las inferiores; el artejo basilat del último par de patas torácicas es regularmente redondeado; los gnatópodos del primer par un poco más pequeños que los del segundo: el tercer par de urópodos alcanzando su rama interna las tres cuartas partes de la longitud de la externa.

Gammarus Delebecquei Chevreux et Guerne. - Ojos ligeramente arriñonados, siendo mucho más grandes que en la especie precedente, y su colocación es casi paralela al borde anterior de la cabeza; las antenas superiores son bastante más grandes que las inferiores; el artejo basilar del último par de patas torácicas se estrecha bruscamente en su porción inferior; el borde posterior presenta una curvatura cóncava bastante acentuada; la rama interna del tercer par de urópodos no sobrepasa la mitad de la longitud de la externa, no comprendido el pequeño artejo terminal.

Gammarus pungens Edwards.-Ojos grandes, de forma arriñonada; las antenas superiores generalmente son más largas que las inferiores; el artejo basilar del último par de patas torácicas se estrecha bruscamente en su porción inferior; los gnatópodos del primer par casi iguales a los del segundo, con el sexto artejo oblongo-oval; la porción palmar más hien oblicua, débilmente sinuosa: el tercer par de urópodos con su ranı interna muy corta, no alcanzando la cuarta parte de la longitud de la externa.

Gammarus Simoni Chevreux.-Ojos semejantes a los del pulex; las antenas inferiores están bordeadas de abundantes sedas; los guatipodos del primer par casi de igual tamaño que los del segundo; los urópodos del tercer par con su rama interna muy corta.

\section{Echinogammarus Berilloni (Catta).}

Es curiosa la variabilidad que presenta esta especie en las diferentes localidades en que ha sido capturada. Los ejemplares recolectados en Guetaria (Guipuzcoa) tienen las antenas superiores bastante mas largas que las inferiores, el pedúnculo de las primeras sobrepasa muy poco del segundo artejo de las inferiores, el flagelo accesorio compuesto de seis artejos; las antenas inferiores con su porción pedunculada mucho mis larga que la de las superiores, y su flagelo con diez y seis artejos que están bordeados de finas sedas; todos los anillos del abdomen están provistos de abundantes sedas y de pequeñas espinas, en mayor número en el $\sigma$ que en la $f$. Los 
ejemplares de Borja (Zaraguza) enviados por Fermindicz Navarm son los de mayor tamaño; las antenas superiores difieren, en cuanto a longitud, de las de los ejemplares de Guetaria. El flagelo accesorio con el sexto artejo de muy pequeño tamaño; las antenas inferiores con un número de sedas mucho más reducido que en los de dicha localidad; el primero y segundio terusuituo dial alidomen Hiwan sedas en corto número y los restantes en cantidad muy grande. Los recogidos por Breñosa en el Honasterio de Piedra, y que sirven de alimento a los peces de aquella piscifactoria, tienen las antenas superiores sobrepasando muy poco de las inferiores. En este carácter concuerdan con la descripción dada por Edouard CHEIRELX (1): el flagelo accesorio está compuesto de cinco artejos. Las antenas inferiores, en su porción flagelada tienen de diez y ocho a veinte artejos; en los terguitos del abdomen se observa una reducción en el número de espinas y sedas. Los ejemplares de Buñol (Valencia) y los de Olot (Gerona) son muy parecidos; ambos tienen las antenas superiores bastante más largas que las inferiores; el número de artejos varia de treinta a treinta y dos. Las patas torácicas con las sedas muy reducidas, asi como el primero y segundo terguitos del abdomen, cuyo borde superior es casi liso.

Esta especie estaba ya citada de Guetaria por I. Bolivar (2).

\section{Gammarus pulex Linmé}

Los ejemplares de Castroceniza (Burgos) tienen los ojos de forma oval, iniciándose el aspecto arriñonado; las antenas superiores con los tres artejos del pedúnculo adelgazándose gradualmente desde el de la inserción, que es el de mayor tamaño, hasta el tercero; su flagelo consta de veinticuatro a veintiséis artejos; el flagelo accesorio de sólo tres artejos, siendo el cuarto casi rudimentario; las antenas inferiores tienen su porción pedunculada casi tan larga como sus flagelos y compuesta de diez artejos. Los gniatópodos del primero y segundo par difieren en cuanto al tamaio del a la : Se observan muy bien estas diferencias en los dibujos publicados por C. SPENCE BAtE (3). Es variable de unos ejemplares a otros el

(1) Bull. Soc. Zool. de France, t. XXI, 1896 , pág. 2!!.

(2) Actas de la Soc. Esp. de Hist. Nat., t. XXI, 1812, piig. 137.

(3) A History of the British Sessile-cyed Crustacea, vul. I, phig. 3hit. 
número de espinas que se insertan en el borde superior de los tres últimos terguitos del abdomen, y la mayoria llevan cuatro espinas en el quinto y sexto segmentos. El tercer par de urópodos es distinto del $\sigma$ a la $q$, siendo en ésta de menor tamaño la rama interna, alcanzando las tres cuartas partes de la longitud de la rama externa. Los ejemplares de Gumiel de Izán (Burgos) difieren bastante de la descripción dada por T. R. R. SteBBing (1); siendo en ellos los ojos de forma oval; las antenas superiores de más de treinta artejos, y casi tan largas como la porción torácica; el flagelo accesorio de cuatro artejos; en el $\sigma$ las antenas inferiores tiene su flagelo de diez y seis artejos, y en la $q$ no pasa nunca de doce; en el último par de patas torácicas no tiene el artejo basilar la forma redondeada que se observa perfectamente en esta especie, estrechándose algo en su porción inferior; en el borde posterior se inicia una curvatura cóncava; el cuarto terguito del abdomen lleva en su porción dorsal algunas sedas, y el telson tiene en su parte inferior dos espinas.

I. Bolívar (loc. cit.) menciona esta especie de Segovia (Vila).

Gammarus pungens Edwards.

Los ejemplares recolectados en la Albufera (Valencia) han sido dibujados en vivo por el Sr. Simón, pudiendo observarse en ellos las diferencias entre el $\sigma$ y la . . En el anillo cefálico se ve el ojo compuesto de forma arriñonada. En el fo (fig. 1) las antenas superiores tienen su pedúnculo de tres artejos, el primero y segundo del mismo tamaño y el tercero muy pequeño; su flagelo consta de treinta y dos artejos, y el flagelo accesorio compuesto de cuatro; las antenas inferiores de menor tamaño que las superiores; su porción pedunculada un poco más pequeña que su flagelo, el cual está compuesto de diez y ocho a veinte artejos; en la $q$ (fig. 2) se observa en el pedúnculo de las antenas que sus artejos son más débiles y de menor tamaño, así como en número algo menor. El primero y segundo par de gnatópodos casi iguales, siendo mayores y más robustos en el $\delta$ que en la $f$; es curioso mencionar una pequeña hendidura que se observa en el cuarto segmento torácico en la $\uparrow$, que es el sitio por donde la agarra el $\delta$, valiéndose de la uña acerada de sus gnatópodos; los dos primeros pares de patas torácicas más cortos que los

(1) Das Tierreich, Amphipoda I Gammaridea, pág. 474. 


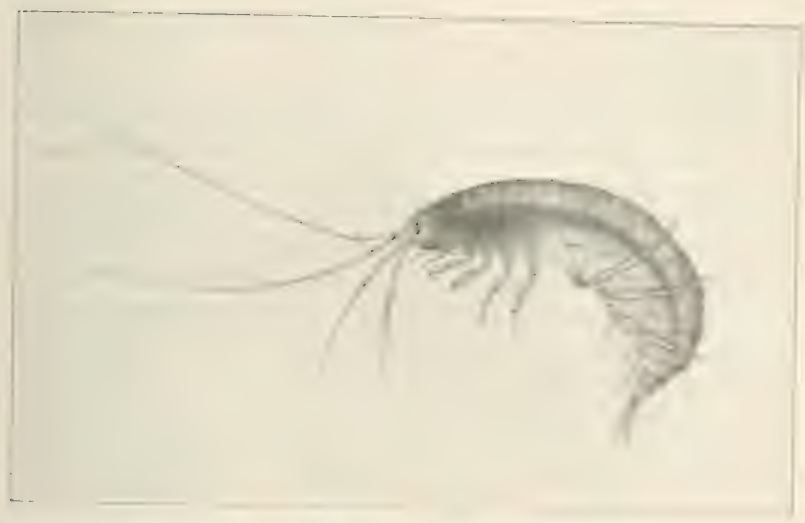

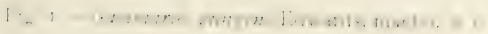

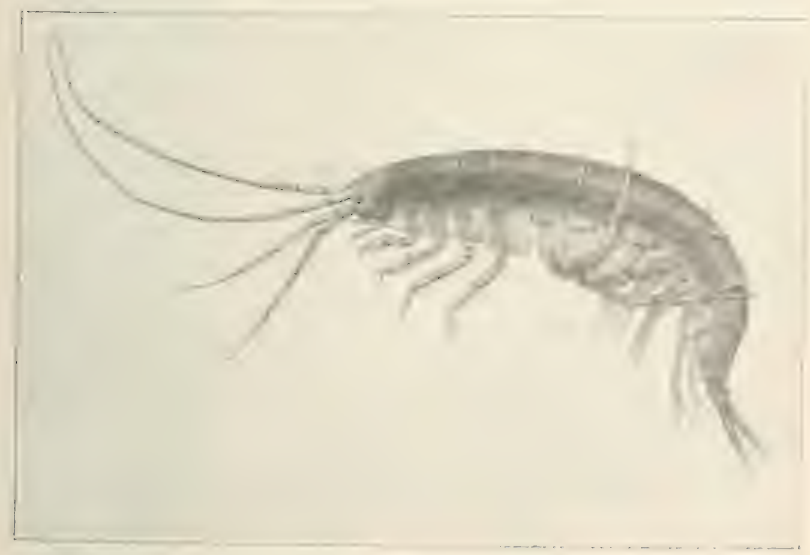

Fig. 2. - Gammarus pung Ems Eiwards, lembra, u. 
posteriores y con una fila de abundantes seilas; los tres pares siguientes casi dei mismo tamaño; los tres pares de pleópodos casi iguales y con el exopodio y endopodio provistos de abundantes sedas. Los tres pares de urópodos son mucho más grandes en el ō que en la $\$$; el último par de urópodos tiene su rama interna sumamente pequeña, y los segmentos abdominales llevan en el borde superior de dos a cuatro espinas y algunas sedas; el telson es corto y formado de dos pequeñas ramas. Los ejemplares de Cabra (Córdoba) recolectados por Carandell en la fuente de las Piedras (enero de 1921) se distinguen de los de Valencia por no llevar ninguna espina en los tres primeros terguitos del abdomen y solamente unas pequeñisimas en los tres últimos; es de notar la variabilidad en el número de artejos de las antenas superiores, que oscila de treinta a treinta y cuatro. En los ejemplares de Santander las antenas superiores están compuestas de veintiocho a treinta artejos, sin contar con los tres primeros del pedúnculo; las antenas inferiores son algo más pequeñas que las superiores; el flagelo accesorio está compuesto de cinco artejos, siendo el último casi rudimentario. En el ऽ los gnatópodos del primer par son de pequeño tamaño y de aspecto piriforme; los del segundo par de mayor tamaño y de la misma forma; ambos están bordeados de una ligera pubescencia; en la $q$ son de menor tamaño; el cuarto, quinto y sexto terguitos del abdomen llevan unas pequeñas espinas, cuyo número es variable de unos ejemplares a otros.

En un ejemplar estudiado de la laguna de Bañolas (C. Bolivar, mayo de 1917) se observan grandes variaciones: los ojos, de aspecto arriñonado; las antenas del primer par son casi tan largas como las del segundo y mucho menos consistentes que ellas; el primer artejo es ınás grueso y largo que el segundo, siendo éste mucho mayor que el tercero; el flagelo consta de veinte artejos, y el flagelo accesorio de cuatro, siendo el último rudimentario; las antenas del segundo par con el primer artejo más pequeño que el segundo y tercero; el flagelo de doce artejos y en todo el borde de la antena se distinguen pequeñas sedas; en el cuarto y quinto terguitos del abdomen se observan las siguientes espinas: cuatro en dos grupos en el cuarto segmento, y seis en la misma forma en el quinto.

Las localidades de Olot y Monasterio de Piedra, de que I. BoLIVAR menciona esta especie, han de ser referidas al Echinogammarus Berilloni. Los ejemplares que menciona este autor de Pote: (Cazurro) no los he podido revisar, por lo cual no puedo decir si corresponden al pungens o al Berilloni. 


\section{Gammarus Delebecquei Chevreux et Gueme.}

Los ejemplares han sido recogidos por Santo Domingo en Ávila (diciembre de 1895), siendo de notar las diferencias con la especie descrita por E. Chevreux y J. Guerne (1). Los ojos de forma oval, iniciándose el aspecto arriñonado, y situados algo oblicuamente al borde anterior de la cabeza; las antenas superiores tan largas como la porción torácica y cefálica juntas; su flagelo consta de veintiocho a treinta artejos; el flagelo accesorio está compuesto de tres artejos; las antenas internas son bastante más cortas que las anteriores, siendo su porción pedunculada mayor que el flagelo; en el cuarto y quinto terguitus del abdomen existen unas pequeñas espimss e: mimero de dos a cuatro; en las dos ramas del telson se observan dos espinas que están insertas en su borde inferior.

Esta especie no estaba citada de nuestro país.

\section{Gammarus Simoni Chevreux.}

A esta especie se refiere el Gammarus nov. sp. que cita I. BoLívar de Ciudad Real y Madrid. La especie entonces nueva fué descrita por E. Chevreux (2) dos años después sobre ejemplares de Argelia y Túnez.

También corresponde a esta especie la cita de Gammarus fluviatilis Roesel, de Ciudad Real y Madrid, duda pur (). de Huh ( W.

En los ejemplares de Ciudad Real la forma de los ojos se asemeja a los del $G$. pulex; las antenas superiores con el primer artejo mayor que el segundo y más corto que el segundo y tercero juntos; el flagelo consta en el $\delta$ de treinta y dos a treinta y seis artejos; en la $q$ el número de artejos no pasa de veinticinco; el flagelo accesorio consta de tres artejos; las antenas inferiores tienten su porción pedunculada mucho mayor que la de las antenas superiores; el flagelo con doce artejos; es muy característicu de esta especie el tener toda la antena bordeada de una pubescencia, que es mucho más ostensible en los $\sigma \sigma^{*}$ que en las $q$ f. Este caricter se observa

(1) Bull. Soc. Zool. de France, t. XVII, 1892, piig. 13ti.

(2) Bull. Soc. Zool. de France, t. XIX, 1894, pig. 171.

(3) Anales de la Soc. Esp. de Hist. Nat., t. XVI, 1887, pith 111. 
perfectamente en los dibujos realizados por el Sr. Simón, en los cuales pueden compararse la antena del $G$. pulex (fig. 4) y la de la especie de que tratamos (fig. 3). Los gnatópodos del primer par son casi de la misma forma que los del segundo; en la $q$ son de menor tamaño; el cuarto, quinto y sexto terguitos del abdomen con pequeñas espinas en número variable, y generalmente insertas dos en el cuarto terguito, cuatro en el quinto y seis en el sexto; los demás caracteres coinciden con la descripción dada por E. CHEvreux.
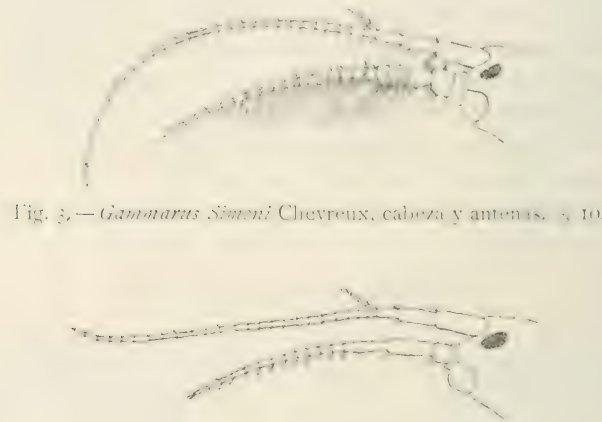

Fig. 4.- Gammarus pulex Linné, cabeza y antenas. $X$ ro.

Los ejemplares del camino de Puerta de Hierro (Madrid) fueron recolectados por D. Ignacio Bolívar en febrero de 1892 , siendo de notar algunas diferencias que presentan con los recogidos en Citldad Real. Las antenas superiores. son un poco más largas que las inferiores; el primer artejo casi tan largo como el segundo y tercero juntos; el flagelo accesorio compuesto de dos a tres artejos; las antenas inferiores muy pubescentes, teniendo el mismo aspecto que las de los ejemplares de Ciudad Real; los gnatópodos del primer par bien desarrollados y piriformes, con el propodio de gran tamaño y el dactilopodio en forma de uña encorvada en hoz; el segundo par de gnatipodos muy poco desarrollado, de consistencia muy dibil, y teniendo el dactilopodio forma de una, de pequeno tamano; en los ejemplares i estudiados los gratópodos son de menor tamaño. 


\title{
EL LABORATORIO DE GEOLOGIA DE LA FACUITAO DE CIRNCIAS DE LA UNIVERSIDAD DE LYON
}

\author{
POR \\ FEDERICO GJ́MEZ LLUECA
}

Conocer los laboratorios en que profesores eminentes o ricas colecciones permitan por sus enseñanzas profundizar en el conocimiento de la Geología y Paleontología, es una de las necesidades primeramente sentidas por aquellos que quieren dedicarse al estudio de estas ciencias.

La descripción que del Laboratorio de Geología de la Facultad de Ciencias de la Universidad de Lyon hacemos seguidamente, tiende a servir a aquéllos de orientación y dar a conocer un centro que por su importancia no debe ser ignorado.

En la orilla izquierda del Ródano y en el muelle de Claude-Bernard existen dos grandes edificios de sólida construcción y bello aspecto. El primero, más reducido, aunque más suntuoso, se halla ocupado por las Facultades de Derecho y Letras. El segundo, más extenso y severo, se lo reparten la Facultad de Medicina y la de Ciencias: La parte Noroeste del gran cuadrilátero que forma el edificio está destinada a esta última. El Laboratorio de Geología ocupa el primer piso del pabellón anterior, y en su conjunto forma un rectángulo de 39 metros de largo por 11,20 de ancho, con una superficie de 437 metros cuadrados próximamente. Los lados mayores corresponden a las dos fachadas, una orientada al Este, que da vistas a un gran patio, y otra al Oeste, que da frente al Rúdano. Estai dividido en once departamentos, entre salas y dependencias. [il vestibulo, que da acceso a la escalera, comunica de frente con cl cabinete particular del profesor; a la derecha, con una sala de preparacion de esqueletos y piezas anatómicas, y al fondo, con otra sala destinada a los alumnos y sus ejercicios prácticos. Tanto esta tiltima como la primera comunican con otra gran sala destinada a las colecciones de vertebrados y Paleontología humana. Desde ésta se pasa por un 
lado a otra más reducida, dedicada a las colecciones del Terciario, y por el otro a la biblioteca particular del Laboratorio. Estas dos últimas permiten la entrada en otra gran sala, que contiene las colecciones del Secundario. Por un extremo, ésta da acceso a otra de más reducidas dimensiones, que encierra pequenas colecciones de estudio, y por el opuesto del mismo lado comunica con otra sala de preparaciones y montaje de esqueletos como la ya conocida. La sala dedicada al Secundario, así como la biblioteca, están dotadas de galerías en donde numerosos armarios encierran colecciones estratigráficas. El vestíbulo, mediante una escalera pequeña, permite la subida a otra sala superior, dedicada exclusivamente a grandes mamíferos y colecciones del Paleozoico. La sala posterior e izquierda, mediante una escalera análoga, conduce a las galerías y al Laboratorio de Fotografía.

Hecha esta breve descripción del local, pasemos a la de las excelentes colecciones que encierra, que por su riqueza en algunos grupos, y muy especialmente el de los vertebrados, alcanzan extraordinario valor $y$ hacen de este Laboratorio uno de los primeros de Europa para el estudio de tan importante grupo de animales.

Una numerosa colección de rocas cristalinas y cristalofílicas permite el estudio de los terrenos anteriores a la era primaria.

El Paleozoico está representado por colecciones estratigráficas muy completas, sobresaliendo por su abundancia las especies vegetales, y por su mérito algunos ejemplares de peces placodermos. Merece especial mención una serie de los terrenos paleozoicos de la Montaigne Noire con grandes Asaphus.

El Secundario tiene una excelente representación, tanto estratigráfica como paleontológica. Ocupando todas las galerias existe una colección estratigráfica, en la que desde el Triásico al Cretácico superior encuentran representación todos los pisos establecidos, figurando en ella muy diversas regiones. Además existe otra especial del Jura meridional (col. Riche), y una rica colección del Mont d'Or Lyomnais, que abarca el Liásico y parte del Jurásico inferior (Bajociense). La paleontologia de este grupo de terrenos putede estudiarse en las varias series que existen perfectamente clasificadas y ordenadas, principalmente de equinidos, braquiópodos, gastrópodos, lamelibranquios y cefalópodos, mereciendo especial mención una preciosa colección de Ammonites. Además existe una serie de los tipos de Fontannes del Jurásico superior de Crusol, y otra de vegetales de distintos niveles. 
La sala dedicada al Terciario encierra valiosas series, que por su número e importancia permiten un acabado estudio de los terrenos que le forman. Es lo más importante una serie del Plioceno del Roussillon y de la Bresse. Otra de gastrópodos del Eoceno de Corbières. Otra, excelente, de pectínidos neógenos. Una serie de moluscos lacustres y continentales, desde (I Foneno al Cuatemariu. Otra del Plioceno y Cuaternario de Italia y Sicilia (col. Gignoux). Otra serie estratigrágica especial del valle del Rílano, y cura. también estratigráfica, del Terciario y Cuaternario marino de Francia, Italia, Austria, Rusia, Portugal, etc. Además existe una serie de vegetales correspondientes a pisos diversos, y otra de peces.

Pero, sobre todo los vertebrados, son los que gozan de la más brillante representación, que llega al máximum en los mamíferos. Sus ejemplares son en tal número, su preparación y conservación tan excelentes, su valor científico tan crecido en los más y la autoridad con que están clasificados tanta, que elevan esta colección a la categoría de única para el estudio de este grupo. Para que se pueda juzgar de ella trataremos de citar aunque sólo sea aquellas series y ejemplares que revisten mayor importancia. De las primeras tenemos las que siguen:

De huesos del Luteciense de la Levinière (Herault).

La más importante del Eoceno (Bartoniense) de Saint-Mammert (Gard).

Del Eoceno superior de Mormoiron (Vaucluse).

Del Eoceno superior de Euzet-les-Bains (Gard).

De Rhinoceros oligocenos de diversas localidades (Acerotherium Filholi Osborn, A. asphaltensis Depéret, A. gannatense Duvernoy).

De las arcillas stampienses de Marsella.

Del Aquitaniense de Saint-Gérand-le-Puy.

Del Aquitaniense de Pyrimont-Challonges (Haute-Savoie).

Del Mioceno medio siderolítico de la Grive-Saint-Alban (Isère).

Del Mioceno superior de Montredon (Aude).

Dentaria de Dinotherium del Pontiense de Montredon (Aude).

Del Plioceno medio de Perpignan (Pirineos orientales).

Del Plioceno medio de Montpellier (Herault).

Del Plioceno superior de Senc̀ze (Haute-Loire).

Dentaria de diversas especies de Elephas del Cnaternario.

Entre los ejemplares aislados existen bastantes de verdadero mérito, y algunos únicos, de los que merecen consigamens in isp. 
cial los signientes, esqueletos completos y montados la mayoría de ellos :

Palaeotherium magnum Cuv., del Eoceno superior de Mormoiron (Vaucluse), verdadera joya paleontológica.

Hipparion gracile Kaup., del Mioceno superior (Pontiense), de Mont Léberon.

Felsinotherium Serresi Gervais, del Plioceno medio de Montpellier.

Cervus Senezensis Depéret, del Plioceno superior de Senèze.

Rhinoceros leptorhinus Cuv., de la arcilla pliocena del Roussillon.

Elephas planifrons Falconer, procedente del Plioceno superior de Chagny (Saône-et-Loire).

Ursus spelaeus Blumb., de las grutas de Vallon (Ardèche).

En la actualidad se trabaja en el montaje de otros tres esqueletos completos pertenecientes a las especies Rhinoceros leptorhinus Cuvier, de Montpellier; Paleorix boodon Gervais, del Roussillon, y Bison priscus Bojanus, del Cuaternario de Villefranche.

Los cráneos forman hermosa serie, en la que figuran los preciosos y únicos ejemplares de

Lophiodon leptorhyncum Filhol, del Luteciense superior de la Levinière (Herault).

Acerotherium platyodon Meunier, del Burdigaliense de Royans (Drôme).

Acerotherium Filholi Osborn, del Stampiense medio de Pernes (Vaucluse).

Rhinoceros Schleiermacheri Kaup, del Pontiense de.Montredon (Aude).

Gacella deperdita Gervais, del Pontiense de Mont Léberon. Tragoceros amaltheus Wagn., del mismo.

Rhinoceros etruscus Falconer, del Plioceno superior de Senèze (Haute-Loire).

Equns stenonis Cocchi, del mismo.

Oryx sp., del mismo.

Diversos cráneos de cérvidos procedentes del mismo.

Elepas primigenins Blumb., del Cuaternario del valle del Oise (Noyon).

Las mandibulas sueltas son muchas, descollando una perteneciente al Elephas atlanticus Pomel, de Sedrata, provincia de Constantine (Argelia). Otra que, con la denticion superior, perte- 
nece a un Anthracotherium del Oligoceno de la Benisson-Dieu (Loire), y otra que, con la parte posterior del cráneo, corresponde al Mastodon Avernensis Cr. et Job., del Plioceno medio de SaintLaurent-des-Arbres (Gard).

No olvidaremos, para finalizar esta enumeración, una placa de arcilla, correspondiente al Ludiense inferior de Euzet-les-Bains (Gard), que contiene restos bien conservados de Hyenodon minor Gervais, Plagiolophus annectans Owen, Palceotherium crassum Cuvier, Lophiotherium cervulum Gervais, Dichodon cervinum Owen. Otra placa, del Triásico de Lodère (Herault), presenta abundantes y bien conservadas huellas de Chirotherium. Por uiltimo, citaremos un enorme caparazón de tortuga gigante, desgraciadamente incompleto en su parte superior, que mide metro y medio de longitud y que procede del Pontiense de Mont Léberon.

El Cuaternario, además de las representaciones ya indicadas, cuenta con otra de la fauna cuaternaria de Villefranche (Ródano).

Una excelente colección, y de gran valor cientifico (col. Genneraux), presenta toda la estratigrafía del Herault, desde el Paleozoico al Cuaternario. Existe además una colección de conchas actuales.

La Paleontología humana también cuenta con digna represent:1ción en el Laboratorio, y sus colecciones poseen algo de notable ý digno de estudio. Citaremos: 1. ${ }^{\circ}$ Serie de cráneos neolíticos dolicocéfalos, procedentes de la gruta-osario de Montouliers (Herault).

2. Serie de cráneos neolíticos, procedentes de la gruta-osario de Montelimar (Drôme). Uno de estos cráneos está trepanado.-3.. Industria del abrigo prehistórico de la Colombière, cerca de Poncin (Ain) : fin del Auriñaciense y Magdaleniense. Serie de cantos aurinacienses grabados. Figuras humanas grabadas sobre hueso de mamut. Varios centenares de silex tallados. Fauna abundante, sobre todo pequeños mamíferos. - 4." Fauna cuaternaria de las hendiduras rocosas de Villereversure (Ain), - 5." Fanna cuaternaria e industria musteriense de Villefranche-sur-Saone: silex musterienses asociados a una fauna cálida en la base de la Terraza de Villefranche. - 6. ${ }^{\circ}$ Numerosa serie de eolitos, seudosilex tallados, dul Puy Courny, de Thenay, de los yacimientos belgas, etc.

Una colección, hecha con fines pedagógricos, permite el estudio de razas prehistóricas mediante excelentes modelos de crineos cuilternarios: Néanderthal, Spy, La Chapelle-aux-Saints, etc. Homo heidelbergensis. Pithecanthropus erectus. Silex tallados de dife- 
rentes industrias paleolíticas. Paleontología marina y terrestre cuaternaria, etc.

Sería olvido imperdonable si antes de terminar esta relación dejáramos de citar las colecciones que, convenientemente dispuestas y ordenadas, sirven para estudio de los alumnos. Hay una de rocas; otra de los minerales que las integran, y otra paleontológica. Además aun hay otra, tan numerosa como bien elegida, que sirve para el estudio de las generalidades. En todas ellas se observa a primera vista la precisión y claridad con que cada ejemplar presenta aquellos caracteres de que es ejemplo. Sólo la labor de muchos años y una gran perseverancia han podido reunirlas.

Una serie de ejemplares aplicados a la Agronomía completa la enseñanza que de Geología agrícola se da en el Laboratorio.

Para terminar la reseña de cuanto importante encierra este centro, nos falta hablar de la biblioteca. Ocupa ésta una amplia sala, y los volúmenes que la forman la llenan en su totalidad. Muy numerosas son las obras de Geología y Paleontología que pueden consultarse, y algunas de mérito extraordinario por los estudios que encierran, y de gran valor por su rareza. En el mismo edificio está la biblioteca de la Universidad, la cual le tiene cedidas al Laboratorio, en calidad de depósito, gran número de obras de la mayor importancia. La biblioteca técnica de Antropología y Paleontologia humana es muy completa.

El Laboratorio de Geología, por circunstancias especiales, se aparta de la norma en cuanto al personal de los demás, y cuenta con un profesor y jefe del Laboratorio, $M$. Charles Depéret, decano de la Facultad y miembro del Instituto; un jefe de trabajos prácti$\cos$, que a la vez está encargado de un curso complementario de Geologiá, M. Attale Riche; un preparador de la Universidad y también encargado de un curso complementario de Geología, monsieur Frederic Roman; M. Louis Doncieux, encargado de otro curso complementario de Geología del P. C. N. superior (1); M. Lucien Mayet, encargado de un curso de Antropologia y Paleontología humana; M. J. Dareste de la Chavanne, ayudante de Paleontología, y por último, un mozo de laboratorio. El profesor y maitre de conferences corresponden al Estado. Los restantes profesores pertenecen a la Universidad.

Ya que conocemos cuanto integra el Laboratorio de Geología,

(1) Preparatorio de Ciencias y Medicina. 
vamos ahora a hablar de las funciones que le están encomendadas, empezando por la que se refiere a la enseñanza; pero como no es propio de este libro hablar de la organización de ésta en Francia, ni de las pruebas y estudios que se exigen para la agregación, que encajarán mejor en la Memoria que he de presentar a la Junta para Ampliación de Estudios, me limitaré a indicar aquí que la labor queda repartida en la forma siguiente: M. Depéret, profesor de la materia, da dos cursos semanales de una hora sobre Geología estratigráfica. Sus magistrales conferencias, que abarcan siempre los últimos descubrimientos en la parte que trata, van acompañadas de láminas, que representan, ampliados, los más clásicos cortes geológicos, y de cartas geológicas, asi como también de colecciones de ejemplares, debidamente seleccionados para cada caso.

M. Riche expone un curso complementario, que comprende la Petrografía y la Paleontologia, dedicando dos conterencia- - cun an les de una hora, y hora y media, por lo menos, de ejercicios prácticos una vez cada semana. Todas las explicaciones, que tienen el sello de la claridad y debida exposición, van acompañadas de la exhibición de los mejores materiales.

Por último, M. Mayet está encargado de un curso de Antropología y Paleontologia humana, que desarrolla en conferencias semanales de una hora. Las primerds están dedicadas al conocimiento de las faunas del Terciario y Cuaternario, preparando asi el posterior estudio de la Prehistoria. Como en los casos anteriores, sus excelentes explicaciones se acompañan de escogidos y bien conservatos ejemplares.

Esto forma lo que pudiéramos llamar cursos oficiales de Geologia; pero además, el profesor M. Depéret, dando un excelente ejemplo de laboriosidad y amur a la enserianza, todos los años mâtade varios cursos de más o menos duración, en los que desarrolla, mediante conferencias públicas, una parte de la Grología. Por lo que respecta a este curso, acaba de terminar uno trimestral sobre la formación de la primera corteza del globo y rocas primitivas, y continua otro curso, de conferencias senuanales, de (ieagrafia fisica. Cursos éstos que aprovechan sus alumnos para el mejor estudio de la materia, a cuyo certificado aspiran.

No se limita a esto la función docente del Laboratorio, sino que además participa esencialmente en el certificado que existe de Qutmica y Geologia agricola, correspondiendo a M. Riche un cunno de Geologia agricola, de conferencias semanales y una hora de tra- 
bajos prácticos durante el último trimestre, y otro curso semestral, de conferencias igualmente semanales, a M. Roman, de Geologia elemental. Por último, M. Doncieux está encargado de un curso quincenal de Geología general e Hidrología, para el certificado del P. C. N. superior.

Esta es la labor didáctica que compete al Laboratorio, y con ser tan extensa e intensa, aun sobra tiempo para realizar otra misión más trascendental, si cabe, más elevada y sin duda alguna la que ha contribuido con más intensidad a elevar la consideración de este Laboratorio a la primera categoría entre sus análogos. Nos referimos a la investigación y producción científica. Este grupo de profesores, todos ellos revalidados en los estudios superiores de las Ciencias Naturales, guiados con el entusiasmo y el ejemplo más digno de alabanza por su maestro, el eminente profesor M. Depéret, labora con ardor juvenil, sin que para ellos existan ni estatutos ni disciplina alguna. Sólo su conciencia les dicta el cumplimiento de un deber y en su espíritu reside el amor al trabajo. De este modo aumentan constantemente las colecciones y dan a la ciencia que les ocupa material que la robustece y nuevas ideas, que ponen su belleza más en relieve. Si hubiéramos de citar cuantas publicaciones salieron de alli, para extenderse sin limites hasta los lugares más apartados, necesitaríamos algunas páginas.

La brevedad a que me obligan las circunstancias me impide hacer la enumeración de los principales trabajos que se han producido en este Laboratorio y que más han contribuído al adelanto de la Ciencia, y muy especialmente de los del profesor $M$. Depéret, que se elevan a más de 125 , muchos de ellos de una importancia extraordinaria. Me reservo el dar cuenta de ellos para la Mlemoria que he de presentar a la Junta para Ampliación de Estudios, como pensionado por la misma. Esta falta no es, por otra parte, muy sensible en esta ocasión, por ir dirigida esta Memoria a nuestros consocios, que conocen perfectamente los trabajos del Laboratorio de Geología de la Universidad de Lyon.

Con ser, como vemos por lo que antecede, muy vasta la labor que a su cargo tiene el Laboratorio de Geología de la Facultad de Ciencias de la Universidad de Lyon, no hemos terminado todavia. Aún nos queda por señalar una última función. que cumple en digna competencia con las anteriores. Ésta es la de dar albergue y prestar ayuda a todo aquel que, laborando en la investigación cientifica. busca en él refugio y materia esencial para dar vida a su trabajo. 
¿Cómo decir que se realiza esta función? Nos es muy dificil, y el temor de no interpretar debidamente nuestro sentir nos aparta de tan delicada misión. Sólo dirumos que aquel que neceritido acuda a él, encontrará un grupo de maestros que viven en un ambiente de puro ideal, desconociendo el egoísmo y dispuestos, a la más simple demanda, a prestar solícitos, generosamente, cuanto atesoran su labor pasada y su experiencia. Alli se encontrará dueño de todas las riquezas que ansía, porque nada hay cerrado y nada se pierde. Lugar tranquilo en donde una sola vocación los.une a todos en la mejor armonía para rendir culto a las ciencias hermanas, Geologia y Paleontología:

Antes de cerrar estas lineas séame permitido expresar en ellas mi más profundo reconocimiento a los que hoy son mis maestros, y en cuanto a esta nota se refiere, no olvidaré los buenos deseos con que todos me han ayudado en la adquisición de los numeroios datw que precisaba, y muy especialmente a $M$. Roman, cuyas atenciones recordaré siempre con satisfacción.

\section{NUEVA ESPECIE DE PETROGNATHA DE FERNAIDU POO}

(COL. CERAMBYCIDAE)

POR

ÁNGEL ZARCO GARCIA

Petrognatha spinosissima nov. sp. (figs. $1,2,4,6$ a 9 ).

Tipo: o, de Santa Isabel (col. Museo de Madrid).

Cuerpo rugoso en su parte anterior, desde el tercio basal de los élitros más liso; éstos finamente aterciopelados. Cabeza leonadopardusca; epístoma y partes bucales más obscuros (de color café obscuro). Vértice liso; frente arrugada, con la sutura media bien marcada desde el borde posterior del occipucio. La porciún de la frente comprendida entre la parte inferior de los ojos, con tres arruguitas transversales a cada lado. Labro transverso, pero no doble de ancho que largo; mandibulas con perceptible concavidad en su cara anterior, rugosas en sus dos tercios basales y lisas en la extre- 


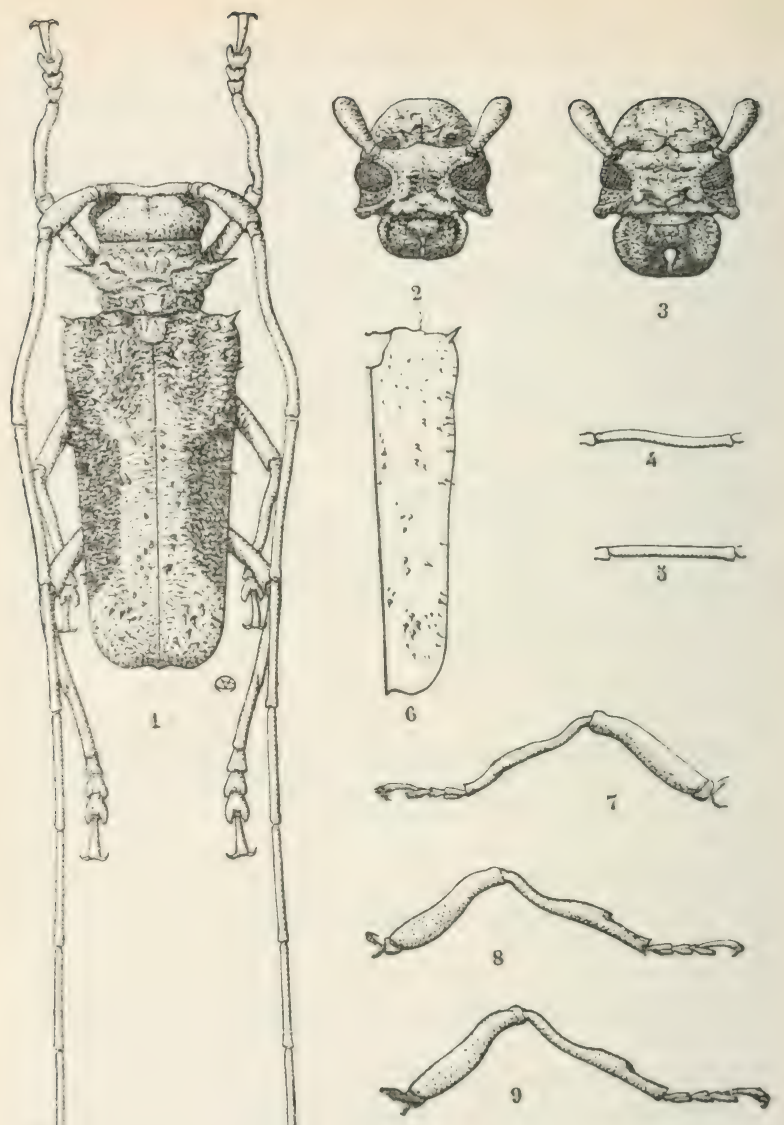

Fig. I, Petrugnatlua spinosissima nov. sp., tipo, tamaño natural.-Fig. 2. P. spinesissima, cabeza vista de frente. - Fig. 3. P. gigas, cabeza vista de frente. - Fig. 4. Cuar$g$ as, cabejo de las antenas de $P$. spinesissima. - Fig. 5. Cuarto artejo de las antenas ma. - Fig. 5. Fig. 6. Esquema del élitro de $P$. spinosissima. - Figs. 7,8 y 9 . Patas anterior, media y posterior, respectivamente, de $P$. spinosissima. 
midad, con el borde externo fuertemente saliente. Antenas con el primer artejo grueso y encorvado, más de tres veces más largo que ancho; segundo artejo muy corto: tercero doblemente sinuato; el cuarto más ligeramente curvado (fig. 4); los siguientes rectrs, decreciendo gradualmente en longitud, menos el último. quw es dos veces y media tan largo como el penúltimo.

Protórax toscamente arrugado, con un surco transverso justamente por detrás de la parte media superior, y dos espinas laterales agudas inclinadas de abajo a arriba y de atrás a adelante; escudete ancho en la base, gradualmente estrechado hacia atrás, truncado y redondeado en el ápice. Élitros (fig. 6) fucrtencente mensic, con tubérculos cónico-espinosos sobre las gibosidades basales; el resto de los élitros está cubierto de espinas grandes y muy agudas, irregularmente distribuídas, más abundantes a los lados de la sutura, a to largo del borde externo y en el tercio apical. El borde posterior de los élitros es algo escotado y su ángulo interno-posterior se prolonga agudamente hacia atrás.

El protórax es pardo, con brillo amarillento en las arrugas; los élitros más claros, amarillo tierra, con una gran mancha lateral alargada junto al borde, de color café obscuro, que ocupa los dos cuartos centrales y la mitad de la anchura; las espinitas son negras.

Fémures gruesos, comprimidos, sinuosos y algo estrechados en st tercio apical; las tibias muy sinuosas y tambien comprimidas: lis intermedias y posteriores con marcada escotadura en el borde superior, que forma a modo de un diente romo, más largas que los fémures; tarsos unos dos tercios de la longitud de las tibias y con los tres primeros artejos muy afelpados por debajo. Las patas son de la misma coloración pardo-grisácea de todo el cuerpo.

Abdomen con seis segmentos visibles, negro mate, con los bordes de los anillos brillantes.

Dimensiones:

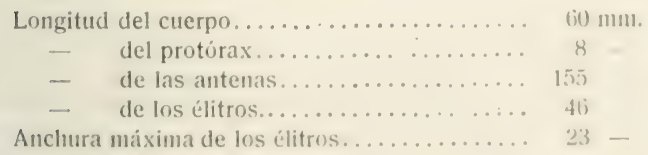

Esta descripción está hecha sobre un ejemplar macho recogido en Santa Isabel (Fernando Póo) por D. Manuel Hartinez de la Escalera en 11 agosto 1919. 
En su aspecto general es muy parecida a la única especie de este género conocida, Petrognatha gisas (Fabr.) Sin embargo, las diferencias que con ella presenta son, a mi juicio, suficientes para inclinarme a considerarla como especie diferente, y por tanto nueva. En primer lugar, la escultura de la parte anterior de la cabeza es muy diferente, estando las partes inferiores de los ojos más próximas en spinosissima que en gigas, y careciendo esta última de las arrugas transversales que existen en la cara de aqué1la. Tampoco tiene la nueva especie las dos arrugas divergentes tan marcadas que presenta la gigas en la frente, siendo el clípeo de ésta mucho más estrecho que el de la especie de Fernando Póo. La nueva especie tiene, además, las mandibulas con un fuerte reborde, lo que las hace ser algo cóncavas en su superficie anterior, y el labro mucho más largo y estrecho.

En las antenas difieren por ser el cuarto artejo recto en gigas y perceptiblemente sinuado en spinosissima. Respecto al tercer artejo también es más sensiblemente sinuoso en la primera que en la segunda.

La escultura rugosa del protórax es muy parecida en ambas. En los élitros ofrece las gibosidades basales menos marcadas que en gigas, y carece de las segundas gibosidades, más reducidas, que a los lados de la sutura, y por detrás de las anteriores, existen en dicha especie. Por último, las numerosas, fuertes y agudas espinas que recubren irregularmente los élitros dan a la especie de Fernando Póo un aspecto muy característico, siendo la diferencia que primero llama la atención al comparar las dos especies.

En ambas los élitros están algo comprimidos en su parte media, que corresponde a las zonas pardo-negruzcas que lateralmente presentan, y a cada lado de la base de los élitros queda delimitado un surco longitudinal entre la gibosidad grande basal y el ángulo externo-anterior; en este surco o canal imperfecto se acomodan las antenas cuando están dirigidas hacia atrás; este surco está desvanecido pasado el primer tercio de los élitros.

Las espinas de que están cubiertos los élitros son muy agudas y aceradas, muchas de ellas encorvadas en la extremidad, siendo más largas de lo que aparecen en la figura, por estar ésta tomada en proyección, pasando la mayoría de ellas de milimetro y medio y aun dos de longitud. 


\title{
ALGUNAS OBSERVACIONES \\ SOBRE LOS CROMOBLASTOS DE LA PIEL HUMANA
}

\author{
POR
}

\section{P. DEL RIO-HORTEGA}

Del Laboratorio de Histología normal y patologica do la Junta para Ampliación de Estudios.

(Láminas XXVII a XXX.)

Aunque forman legión los histólogos (Kölliker, AEBy, Cajal, List, Karg, Jarisch, Demieville, Gaspary, Unna, IVermanN, Fria, Beddoe, Bogolinsky, Carnot, Leydig, Müller, RoSENSTAdt, Retterer, Riehl, EHRMAnN, etc.) que se han ocupado de estudiar los caracteres morfológicos, microquímicos y fisiológicos de las células pigmentarias; aunque sus investigaciones han recaido en toda clase de seres superiores e inferiores, y en la copiosa literatura que nos han legado abundan las observaciones sobre los cromoblastos de la piel humana, no es todavía perfecto el conocimiento que se tiene de la manera de engendrarse el pigmento que da color a las células epidérmicas.

Al describir el tegumento externo, los tratadistas de Histologfa dan minuciosos detalles de todas las estructuras que en él existen; pero suelen olvidarse de la pigmentación propia de los estratos inferiores del cuerpo mucoso de Malpighi o, si la mencionan, omiten el dónde y el cómo de su producción y qué clase de elementos interviene en su génesis.

Quiere decir esto que, en general, no se concede la debida importancia a una estructura que, siendo constante en la piel humana; existiendo no sólo en las razas de color, sino en todos los individuos de la blanca, y ofreciendo considerable interés fisiológrico y' antropológico, es digna de mayor atención.

Quizá sea debido el abandono en que se tiene a estos estudios y la imprecisión de nuestros conocimientos actuales, en parte a dificultades técnicas y en parte a la confusión reinante hace alẹin 
tiempo acerca de la naturaleza de los corpúsculos diferentes del epitelio que han sido observados en la piel humana.

El estudio de las células intersticiales de forma estrellada descubiertas en el epidermis e interpretadas de varia manera por los autores, y el de los melanoblastos cutáneos, aunque sin conexiones aparentes, no pueden ir separados, puesto que es indudable que entre las especies celulares que habitan en los resquicios interepitélicos están incluídos los melanoblastos.

Desde que se conoce la existencia de melanina en las capas inferiores del epidermis está pendiente de resolución este importante problema: el pigmento de las células epiteliales malpighianas, ¿es elaborado dentro de ellas mismas o suministrado por corpúsculos de naturaleza mesenquimatosa?

Desde que KöLLIKER señaló !a existencia de corpúsculos intraepidérmicos libres, estudiados por LANGERHANS como elementos nerviosos, por EBERTH como leucocitos emigrados y por MERKEL como células pigmentarias, está sin resolver de una manera categórica si pertenecen exclusivamente a los leucocitos o si entre ellos existen cromatóforos destinados a proveer de pigmento al epidermis.

Estos problemas, cuyo interés parece evidente, pueden ser en gran parte resueltos aprovechando la singular propiedad que posee el carbonato de plata amoniacal de fijarse electivamente en los cromoblastos de la piel y de tenir todas las prolongaciones que envian entre las células epiteliales.

Tal apetencia muestran por la plata los citados corpúsculos ramificados, que ni una sola de sus expansiones deja de impregnarse ciando en la coloración se sigue las reglas indicadas por nosotros para efectuar la de los tejidos (1). La impregnación argéntica de las células melánicas de la piel resulta más fácil y constante que ninguna otra. Previa fijación rápida (doce a veinticuatro horas) en formol y seccionamiento por congelación, trátase los cortes uno a cinco minutos (según sea la temperatura) por la solución amoniacal de carbonato de plata (2) y después por formol al 1 por 100 hasta que la reducción se efectúa. El virado en solución de cloruro de oro,

(1) P. del RIo-Hortega, Coloración de tejidos normales y patológicos con carbonato de plata amoniacal. (Trab. del Lab. de Inv. Biol., 1919.)

(2) Aunque con resultados menos satisfactorios, puede substituirse el carbonato de plata por el óxido de plata de Bielschowsky y por la simple solución argéntica armoniacal. 
seguido de fijación en hiposulfito de sosa y a veces de coloración complementaria mediante picrofucsina o picruindigo, embellecen notablemente las preparaciones.

Las células pigmentarias son tan ávidas de plata, que se tiñen mucho más pronto que los núcleos, y son perfectamente visibles cuando en el tejido sólo existe una coloración difusa. Si abundan algo, como acontece en la piel de los órganos genitales y del periné, puede ser observada macroscópicamente su tinción con sólo poner el vaso que contiene la plata con los cortes sobre un fondo blanco. Entonces se ve aparecer en el límite inferior del epidermis una linea obscura correspondiente a los cromoblastos.

Según esto, es muy sencillo obtener preparaciones donde solamente las células pigmentarias aparecen tenidas, que son litil.- para el estudio de su morfología. Si se pretende conocer la situación interepitelial y la estructura, basta prolongar un poco la acción de. la plata, procurando, sin embargo, que la intensidad de la coloración general no haga desaparecer los contrastes. Debe tenerse en cuenta, además, que la excesiva permanencia de los cortes en la solución impregnadora produce efectos contrarios a los que fueran de esperar, pues las expansiones de los cromatóforos llegan a liacerse, en su mayor parte, invisibles cuando la plata actúa mucho tiempo. Estos resultados paradójicos, que no son exilurivos de lus cromoblastos, pues se los observa igualmente en la coloración de las células emigrantes del tejido conjuntivo (cuyo protoplasma préldopódico solamente es visible cuando la permanemcia de lus curtes en el licor argéntico es muy breve), pueden ser explicados suponiendo que la plata forma con las granulaciones intraprotoplanmicas un compuesto soluble en la propia solución argéntica.

Los cromatóforos de la piel se reparten desigualmente en las diferentes regiones $y$, aunque no llegan a faltar en ningmua de ell.h. escasean a veces mucho, encontrándoselos muy distanciatos on his cortes; en cambio, al nivel de los órganos genitales, margen del ano y areola del pezón, así como en los individuos de cutis moreno, abundan con frecuencia tanto, que se tocan y confunden, hasta el punto de resultar difícil el estudio de sus caracteres. En la piel del negro forman los cromoblastos y los células epiteliales carcad as de melanina tan espesa trama, que resulta casi imposible discernir los limites de entrambas especies celulares.

Es bien sabido, y huelga mencionar, que no sólo en las razas, en los individuos y en las diversas regiones tegumentarias exinten 
diferencias en la cantidad de pigmento, sino que éste aumenta o disminuye bajo distintas influencias físico-quimicas (calor, luz, etc), y en algunos procesos fisiolócricos (embarazo) y patológicos (influencias endocrino-simpáticas), haciéndolo en toda la extensión de la piel o solamente en pequeñas zonas. La melanosis estival, la enfermedad bronceada de Addison, la enfermedad de Recklinghausen y las efélides son ejemplos tan típicos como bien conocidos.

Se admite generalmente que el pigmento melánico existe en las células epiteliales de la capa germinal del epidermis, formando finisimas granulaciones perinucleares de color amarillento, y que en la piel obscura pueden estar melanizados todos los estratos del cuerpo de Malpighi y hasta la capa córnea, a semejanza de lo que ocurre en los cabellos negros, en las uñas de los monos antropoides y en la piel del gorila; pero no existe acuerdo entre los autores respecto al origen y formación de la melanina que da color a la piel y al cabello, que en algunos procesos patológicos aumenta considerablemente.

Según unos, se formaría en el interior de las células epiteliales; según otros, sería transportada a ellas por corpúsculos emigrantes del corion, y según algunos, ambas maneras serian posibles. La mayoría de los histólogos cree, con Ehrmann, Kerber, Riehl, AEBy, CAJAL, KARG, Kölliker, etc., que la substancia colorante de la piel y cabellos es conducida por células conjuntivas emigrantes (cromatóforos), que penetran en parte o totalmente en el epidermis, extendiendo sus finas ramificaciones por los espacios intercelulares. Según KöLliker, cuyas observaciones sobre la piel del gorila son muy demostrativas en cuanto a morfología y situación de los cromatóforos, las prolongaciones de estos corpúsculos penetrarían en las células epiteliales.

Aunque pudiera pensarse lo contrario, no es seguro que la cantidad de celulas pigmentarias intraepidirmicas guarde proporcion con el grado de melanosis de la piel, pues se dan casos, dentro y fuera de la normalidad, en que, estando el epidermis sobrecargado de melanina, apenas existe entre sus células algún corpúsculo ramificado portador de pigmento, y casos en que contrasta la ausencia de granulaciones melánicas en el epidermis con el número grande de cromatóforos interepiteliales.

No existe, por consiguiente - y más lejos insistiremos en esto-, una relación constante entre la melanización del epidermis y las celulas pigmentarias que habitan en $(\mathrm{l}$, las cuales pueden ser substi- 
tuidas en el trabajo de elaborar y conducir al epitelio materia cromógena por corpúsculos granulosos y ramificados, yacentes en la profundidad del dermis, que son tanto inás abundantes cuanto más obscura es la piel.

En relación con la hipótesis de los autores respecto a la existencia de un solo género de cromatóforos, habitante en el dermis y capaz de ascender y penetrar entre las células epidérmicas, no carecen de interés los hechos, fácilmente comprobables, de que jamás se encuentre en el corion corpúsculos ramificados morfológica ni estructuralmente parecidos a los del epidermis, y que nunca existan células pigmentarias con el cuerpo situado en el dermis y las prolongaciones en el epidermis.

Juzgamos indudable (el estudio del desarrollo lo demuestra) la procedencia dérmica de los corpúsculos ramificados interepiteliales, pero también que șus caracteres difieren de los que poseen en el adulto los melanóforos propios del dermis. Existen, pues, en el hombre adulto dos tipos de cromoblastos cutáneos, caracterizados por sus granulaciones gruesas o finas y por su situación dérmica o epidérmica, respectivamente.

Las observaciones que vamos a exponer se refieren a la topografia y caracteres morfológicos de los cromoblastos de la piel humana, y principalmente de los que habitan entre las células del epidermis y del bulbo piloso.

\section{CROMOBLASTOS PROPIOS DEL EPIDERMIS}

En la distribución cutánea de las células pigmentarias puede haber tres casos: que la pigmentación melánica de las células epiteliales coincida con la presencia en sus intersticios de células ramificadas; que abundando éstas células escasee la melanina en el epidermis, y que siendo crrande el yacimiento epidérmico de melanina, escaseen o sean invisibles las células pigmentarias.

Cuando los cromoblastos intraepidérmicos son muy abundantes, no puede apreciarse bien su forma ni sus relaciones con las cílulas epiteliales; de ahi que no convenga para su estudio la piel de los individuos morenos ni de recriones muy obscuras, y que deba elegrirse la de la cara, manos, muslo, etc., de sujetos de culor moderado o la del pene o escroto de sujetos rubios.

En la figura 6 (lám. XXVII) hemos reproducido los caracteres 
de las células melanóforas según se nos ofrecen en la piel de la cara de un hombre adulto. Los cromoblastos ocupan el estrato germinal del epidermis (A), distribuyéndose irregularmente entre las células epiteliales; su forma es variadísima, y aunque existen tipos bi o tripolares, predominan los estrellados. De su cuerpo, fusiforme, triangular o poligonal, emergen apéndices que, bifurcándose y ramificándose, ascienden en línea recta o quebrada por los resquicios que separan a las células epiteliales, acabando a variable altura en el stratum Malpighii (B) las más veces, o en el stratum granulosum (C). En su largo recorrido a través de la complicada trama epitelial, las prolongaciones cromoblásticas cambian a menudo de dirección, entrecruzándose unas con otras. Aunque las células pigmentarias bordean inferiormente al epidermis y no ascienden al cuerpo de Malphigi, no es raro hallar en éste corpusculos asteriformes, situados a diferente altura (D, E).

Tanto el cuerpo celular como las ramificaciones interepitélicas, aparecen sembrados de granulaciones de variable tamaño, pero generalmente muy finas. Las ramas se dibujan muchas veces como sartas de granos, cuyo volumen aumenta progresivamente a medida que se alejan del soma. No es raro que los apéndices terminen por gruesas bolas.

Contra lo que algunos autores piensan, jamás se observa la penetración de las ramificaciones cromatóforas en las células epiteliales, ni que los cromoblastos ocupen una situación intermedia con el cuerpo en el dermis y las prolongaciones en el epidermis.

Las células pigmentarias propias del dermis (fig. $6, \mathrm{~F}, \mathrm{G}, \mathrm{H}, \mathrm{I}, \mathrm{J}$ ) se caracterizan por tener escasas ramificaciones protoplásmicas y por encerrar en ellas, y sobre todo alrededor del núcleo, gruesos granos de melanina de forma redondeada $y$ de color natural amarillento.

Por el tamaño, la forma y el contenido granular de los melanoblastos del dermis se reconoce la existencia de tres tipos: el de granulaciones gruesas, cuya talla y expansiones ofrecen la mayor variedad $\left(F, G,\left(i^{\prime}\right)\right.$; el de granulaciones finas, que se ramifica más o menos $\left(I, I^{\prime}\right)$, y el de pequeña talla, fusiforme o redondeado, con granulaciones escasas $(\mathrm{J})$.

Obsérvese en la figura 1 (A) una de las células pigmentarias epidérmicas, considerablemente amplificada y ligeramente esquematizada. Su cuerpo ocupa un estrecho lugar entre los corpusculos epiteliales, que aparecen surcados y enlazados por epitelio-fibrillas; 
sus prolongaciones se elevan por los espacios intraepidérmicos, en los que terminan libremente. Las granulaciones protoplásmica- -imulan un delicado polvillo alrededor del núcleo, que destaca en claro,

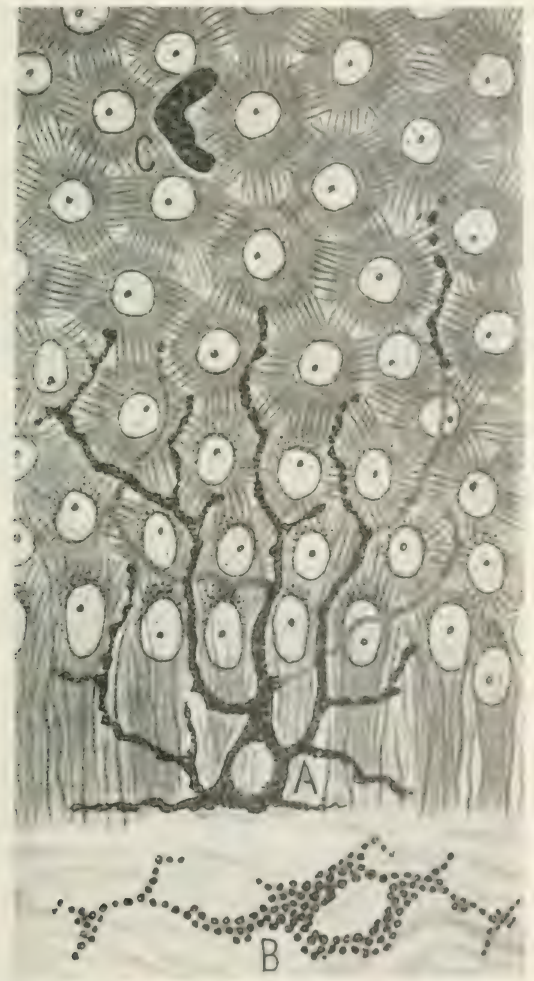

Fig. 1. - Piel de la cara de un hombre adulto: $A$, cromoblasto propie del epidermis; B, cromoblasto propio det termis; C, lencocito interepitelial. (Primera variante del método de Achúcarro.)

y son mucho más gruesas e irregulares en los apéndices, a los que dan aspecto moniliforme; con frecuencia se mur, stran bstos formation 
por gránulos discontinuos, indicio de fragmentación, no sabemos si real o aparente.

La misma figura 1 muestra una célula dérmica $(B)$ que emite algunas prolongaciones, apenas divididas, y encierra abundantes gránulos redondeados que, acumulándose junto al núcleo, trazan su silueta, y extendiéndose por los apéndices revelan su forma y su dirección.

No siempre siguen las prolongaciones de los cromoblastos epidérmicos una dirección ascendente, ni siempre son interepiteliales. Muchas de ellas, por el contrario, parten de la base del soma y se dirigen transversalmente.

Cuando las células pigmentarias son poco abundantes; sus ramificaciones basales acaban por debajo del epitelio sin entrecruzarse; pero cuando su número es considerable llegan a formar en la frontera dermoepidérmica una complicada red de prolongaciones. En las secciones tangenciales u oblicuas a las papilas del dermis es frecuente observar imágenes parecidas o iguales a la representada en la figura 8 (lám. XXVIII), que es copia de una preparación de piel del surco balano-prepucial. Los abundantes apéndices de los cromoblastos extendidos superficialmente se cruzan en diversos sentidos y constituyen un a modo de plexo subepidérmico donde no se aprecia que existan anastomosis. En los cortes perperidiculares a la superficie cutánea es tan grande a veces el número de prolongaciones ascendentes que envuelven a las células epidérmicas, que resulta tarea casi imposible averiguar si en el protoplasma de éstas existen granulaciones cromáticas.

En los individuos morenos y en las zonas del epidermis que encierran mucho pigmento llégase a percibir, si se observa con atención, que, en efecto, las células epiteliales encierran gránulos argentófilos muy abundantes repartidos por todo el protoplasma y acumulados especialmente en la parte superior del núcleo, donde se agrupan en masas conoideas o semilunares. En ocasiones el núcleo mismo parece contener melanina.

Mas si se compara la cantidad de pigmento visible en varios cortes de la misma piel, examinados uno sin teñir (fig. 2), otro teñido brevemente por la plata (fig. 3) y otro mantenido más tiempo en la solución argéntica (fig. 4), se aprecia una diferencia enorme en la cantidad de granulaciones intraprotoplásmicas, que es considerablemente mayor en el corte teñido con rapidez. Esto prueba que existen en las células epiteliales, además del pigmento ocráceo, 
granitos incoloros, tingibles por la plata, que corresponden vercsímilmente a melanina en formación.

Es de interés señalar la identidad de aspecto y de reacciones

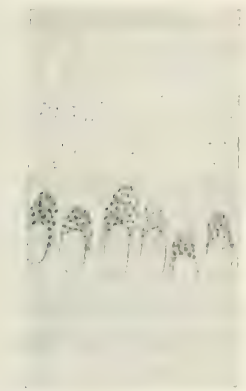

Fig. 2. - Piel del brazo de una mujer adulta, examinada sin coloración. (En el estrato germinal del epidermis abunda la melanina.)

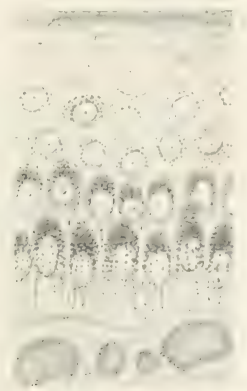

Fig. 3. - La misma piel de la figura 2, teñida un minuto por la plata amoniacal. (En las células epidérmicas abundan las granulaciones argentófilas. En cl dermis existe arcirosis.)

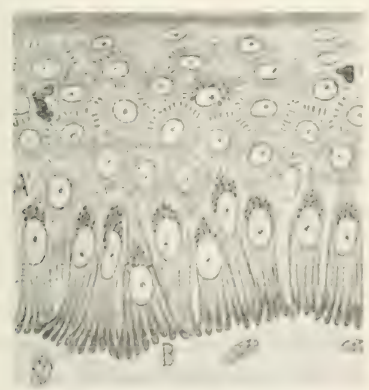

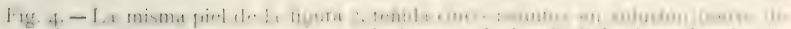
carbonato argéntico: $\mathrm{A}$, estrato germinal con melanina; $\mathrm{B}$, digitaciones bas bles de. las células epidérmicas.

colorantes de tales gránulos argentófilos y de los existentes en los cromoblastos interepiteliales, porque es un buen signo de que éstos no suministran a las células epidérmicas melanina ya formada, pero 
sí, verosimilmente, granulaciones de composición próxima a ella, que cambia en el protoplasma epitelial, aunque es posible que permanezca en él por tiempo ilimitado sin sufrir mutaciones químicas.

Así puede explicarse que, en ocasiones, abundando los cromoblastos y apareciendo el protoplasma de las células epiteliales sembrado de granulaciones argentófilas, no se comprueba la existencia đe pigmento melánico verdadero. Pero también podría suponerse que no incumbe a las células ramificadas intraepidérmicas la melanización de la piel, hipótesis ésta que hallaria apoyo en las observaciones de melanización intensa del epidermis, que no coincide con la presencia interepitelial de cromatóforos y que más bien parece relacionarse con la abundancia de corpúsculos pigmentados en el dermis.

De que la presencia de cromoblastos intraepidérmicos no lleva aparejada la melanización del epitelio, presentamos un ejemplo en la figura 7 (lám. XXVIII), que copia los caracteres de la piel en la vecindad de una neoplasia del cráneo. Los cromoblastos son, como se ve, muy numerosos y emiten multitud de apéndices ascendentes bastante ramificados; pero las células epiteliales - cuya falta de melanina se apreció al observarlas sin coloración - apenas encierran granulaciones argentófilas. Esta misma falta de pigmentacion se nota en el epitelio de muchas regiones cutáneas, así como en las mucosas vaginal, bucal y lingual, donde, aunque no siempre existen cromoblastos, no es difícil encontrarlos más o menos distanciados.

Asi como en estas regiones amelánicas las prolongaciones de las células pigmentarias suelen presentarse sin roturas aparentes, en las partes donde la piel es obscura no sólo se observa en aquéllas un aspecto varicoso, que es tanto más marcado cuanto más se asciende por el epidermis, sino una verdadera fragmentación en gránulos primeramente gruesos y después muy finos.

$\mathrm{Si}$ las granulaciones pulverulentas resultantes de la dendrorexis son acaparadas en tal estado por las células epiteliales para incorporarlas a su masa; si ulteriormente sufren en plena célula epitelial mutaciones de indole química, conducentes a la formación de productos melánicos o de otra naturaleza; si tras la fragmentación en grámulos viene su disolución (1) y su absorción por el protoplasma

(1) Según FREY (citado por CAJAL), el color moreno de la piel se debe a la existencia de melanina disuetta y esparcida tanto en el nicleo como en el protoplasma. 
epitelial, son fenómenos que no pueden ser averiguados con los métodos analíticos que poseemos. No parece, sin embargo, desatinado suponer que, sea cualquiera la forma de penetración de los materiales exógenos en el interior de las células epidérmicas, en el protoplasma de éstas se modifican más o menos sus caracteres.

De que la materia granulosa contenida en las células epiteliales y en los cromatóforos es semejante, a no ser idéntica, hay una buena prueba en los resultados de la impregnación argéntica, que si dura pocos minutos la descubre perfectamente, y si actúa más tiempo no la revela en ninguna de las dos especies celulares.

Juzgamos, pues, probable que las células mesodérmicas interepiteliales no encierran melanina verdadera, pero sí un compuesto especial próximo a ella y susceptible de formarla.

Inducen a discurrir de tal modo las siguientes consideraciones: a) que existen regiones de piel muy blanca en las que sorprende la abundancia de células ramificadas yacentes al nivel del estrato germinativo; b) que si se examina la piel de esas regiones sin previa coloración argéntica, no se aprecia granulación alguna de melanina ni el menor vestigio de prolongaciones amarillentas; c) que en los territorios muy melanizados no sólo existen granulaciones ocráceas en las células propias del epidermis, sino también en los espacios interepiteliales, donde las prolongaciones ascendentes de los corpúsculos ramificados se revelan como ristras de granulaciones de color amarillento; d) que hay epiteliomas melánicos en los que la coloración se debe principalmente a los corpúsculos ramificados que invaden los cordones epiteliales.

Esto parece indicar que las gramulaciones contenidas en las células estrelladas del epidermis, cuya naturaleza no es propiamente melánica, pueden convertirse en melanina. Conviene, no obstante, recordar que no existe una, sino muchas variedades de melanina.

Según la precedente interpretación, tratariase de elementos mosodérmicos encargados de suministrar eventualmente a las células epiteliales malpighianas los materiales que éstas requieren para claborar su pigmento. Los corpúsculos mesodérmicos encargados de tal misión pueden ser considerados como cromoblastos, y las células epiteliales, no como pigmentarias, sino como pigmentadas, en cel sentido en que Prenant emplea ambas acepciones. Creemos, sin embargo, que, de no considerar posible la procedencia endigena de la melanina epitelial, debe atribuirse el papel principal en lit melanización a los melanoblastos del dermis, amn(ue nu) es fácil com- 
prender la manera como se transmite la melanina de unos a otros elementos.

Mas no parece verosímil que las células epiteliales limiten su papel a recoger y almacenar pigmento de origen extraño, pues éste, en tal caso, no disminuiria en ellas a medida que ascienden a los planos superiores del cuerpo de Malpighi.

Ocurre preguntar si las células epidérmicas utilizarán el pigmento exógeno en su propio trofismo, y si los cromoblastos tendrán por único servicio el de proveer al epitelio de materiales pigmentarios; pues lo primero justificaria la desaparición progresiva del contenido granular del protoplasma de abajo a arriba de la piel, o sea de las partes mejor a las peor nutridas, y lo segundo explicaria satisfactoriamente la existencia de abundantes cromoblastos argentófilos en regiones no pigmentadas de la piel, y sobre todo en parajes, como las aberturas naturales, que requieren una vigilancia especial antitóxica y microbiana.

Pero la suposición de que los cromoblastos sean indispensables para realizar aquellos importantes menesteres presenta serias objeciones, de cuyas la principal es que cuando escasean o faltan totalmente no advienen evidentes trastornos orgánicos. Indudablemente el epidermis puede ser nutrido en sus primeras estratificaciones, a pesar de su falta de vasos, no sólo por los plasmas que imbiben los espacios intercelulares, sino también por los intimos enlaces de las células, que hacen del epidermis una asociación de elementos en simbiosis, casi un sincitium. No se precisa, por consiguiente, que los leucocitos, que van a todas las partes del cuerpo que los vasos no pueden alcanzar, transporten al epidermis materiales nutricios, como piensa RANiler, para quien el protoplasma leucocitario se disuelve y los materiales de que está formado se difunden en el plasma nutritivo en cuyo seno viven los órganos.

Además, para la defensa antimicrobiana cuenta el epidermis con densa estructura poliestratificada y con espesa trama fibrilar, que no impiden el acceso y ayuda de los leucocitos.

Es posible, a pesar de todo, que los cromoblastos unan a su función principal otras accesorias coadyuvantes a la nutrición y defensa del epidermis, al menos cuando su función melanógena se encuentra amortiguada, como parece acontecer en los territorios de piel alba, donde existen en singular abundancia. Según Sol.cier, los melanoblastos constituyen un medio de defensa contra los rayos ultravioleta. 
Estos cromoblastos en potencia, de cuyo pigmento no precisa el epidermis y que, no obstante el amiboidismo de que gozan. no encogen sus apéndices interepiteliales ni emigran de la capa germ:nativa, ¿qué papel desempeñan?

Aunque la facultad de emigrar de las células mesodérmicas interepiteliales ha sido reconocida por todos los autores y no es dudosa, ya que a ella se debe la situación eventual en que las sorprendemos, parece que sus movimientos no se realizan ron rapidez. puesto que en nuestras insistentes pesquisas en piel normal y patológica (1) jamás hemos podido observar su penetración ni su -alida del epidermis en el estado adulto.

Del estudio de sus caracteres infiérese que no provienen directamente de los melanoblastos propius del dermis, con los que tienan comunidad de origen.

Dichos cromoblastos, que están situados a variable distancia del epidermis (figs. 1, 6 y 7 ) y a veces inmediatamente subyacentes a él, encierran verdaderas granulaciones de melanina, de la que son, tal vez, los más activos proveedores de las células epiteliạles, a juzgar por su abundancia en los negros e individuos morenos y en los casos de melanosis patológica de la piel (enfermedud de Recklinghausen, argirosis, mal bronceado).

En la piel del negro, donde KöLLIKER no había logrado ver cromatóforos ramificados, hay en el dermis, según dicho autor, cantidad variable de células pigmentarias pequeñas, redondas, alargadas, que aquí y allá llegan hasta las células más profundas del epidermis y hasta penetran entre ellas. KaRri tampocio observó en la piel del negro corpúsculos pigmentarios asteriformes, pero si ramas intraepidérmicas de las células situadas en el dermis limitrofe; en cambio, en la piel de un blanco trasplantada a un negro observó abundantes cromatóforos ramificados entre las celuas epiteliales.

Con ocasión del estudio de un bello caso de argirosis cutánea, que debemos a la amabilidad del Dr. Marañun, hemus podido apreciar cuán difícil es fallar de una manera definitiva sobre el mecanismo de la pigmentación epidérmica. En dicho casos, que la fierura 3 reproduce, además del pigmento metálico de color rojizo exision-

(1) Nuestro material procede en gran parte de enfermos operados y está fijado, por consiguiente, en las mejores condiciones. 
te en el dermis, ora difusamente repartido sobre los haces colágenos, ora depositado en la superficie de las glándulas sudoríparas o en la basal conectiva del epidermis, ora acumulado en masas globulosas semejantes a células de núcleo incolorable, existe hipermelanosis del epidermis, que no parece depender de los escasos cromoblastos ramificados que habitan entre las células epiteliales, sino más bien de los abundantes corpúsculos melánicos yacentes en el dermis.

Mas si la melanosis fuese obra exclusiva de los corpúsculos dérmicos, no sabriamos qué papel atribuir a los que habitan en el epidermis. Descartada la suposición de que idénticos éstos, en principio, a las células melánicas del corion, se hallan agotados y atróficos, y admitiendo que realmente son vehículo de substancias especiales para las células del epidermis, ni siquiera podemos saber la manera cómo éstas las recogen y aprovechan.

$$
3 *
$$

Interésanos recordar las observaciones de los autores referentes a las estructuras nerviosas del epidermis y ver si algunas de ellas se relacionan con los melanoblastos, sabido que éstos y aquéllas se tiñen intensamente con las sales de plata y oro.

En 1868 señaló LANGERHANS la existencia de fibras nerviosas intraepidérmicas, extendidas por el cuerpo mucoso de Malpighi, y numerosos histólogos, entre los que figuran EBERTH, KROHN, KöLliker y RANVIER, ampliaron después el conocimiento de las terminaciones nerviosas del epidermis.

Según Ranvier, cuyas observaciones fueron confirmadas por Schul.tze, Van Gehuchten, CAJal, Retzius, etc., las fibras nerviosas que surcan el dermis envian al interior del epidermis ramas ascendentes que se dividen, incurvan y anastomosan y terminan por abultamientos entre las células malpighianas. De espesor uniforme en sus comienzos, las fibras nerviosas ofrecen después varicosidades cada vez más acusadas, y a menudo parecen estar constituídas en sus extremidades por bolitas aisladas dispuestas en serie.

La descripción, así como las ilustraciones del sabio francés, hacen pensar en la posible confusión de algunas prolongaciones ascendentes de los cromoblastos con fibras nerviosas terminales, y no es dificil, en efecto, que haya existido algún error de interpretación 
de las estructuras filamentosas intraepidérmicas, que poseen la propiedad de reducir el oro y la plata (1).

Mas si parece muy probable que una parte de las fibrillas ascendentes (las que aparecen nudosas y con bolas seriadas) pertenezca a los cromoblastos, tenemos por seguro que atañen a éstos las observaciones de células ramificadas intraepidérmicas, tingib!es por el oro, vistas primeramente por KöLliker y más tarde descritas por LANGERHANS con el carácter de células nerviosas emigradas al epidermis.

Aunque la opinión de LANGerhans no prevalece hoy dia, pues sólo escasos autores la compartieron al principio (PODCOPAIEW; Eimer), y LANGERHANS mismo la abandonó cuando los estudios de Eberth, Aristein; RANvier, Boninet, etc., trajeron la convicción de que los corpúsculos estrellados interepitélicos eran vulgares leucocitos emigrantes, no está de más volver sobre ese tema, ya que tampoco satisface por entero esta última interpretación.

No hemos de discutir la existencia, harto probada, de leucocitos verdaderos en el espesor de la trama epitelial, ni hemos de rebatir ideas que se rebaten solas, cual la de RETTERER, que considera a tales leucocitos como células epiteliales envejecidas, libres de conexiones con sus compañeras e incapaces de proliferación; queremos solamente probar que no sólo son capaces de penetrar (2) en el espesor del epidermis los glóbulos blancos de la sangre, que lo hacen en gran abundancia en los procesos inflamatorios de la piel, sino también los cromoblastos; pues aunque éstos no suelen ascender del

(1) Los estudios de Retzius, Eberth, Bunge, Sclavunos, Dogiel, VAN GeHuChTEN y CAJAL prueban de manera indudable la terminación intraepidérmica de fibrillas nerviosas que provienen del dermis ascienden flexuosamente entre las células epiteliales y acaban al llegar al estrato córneo.

(2) Si no hubiese suficientes pruebas listológricas contrarias a la existencia de la membrana basal de Tood y Bowmann, lie alii una mis: El paso de los leucocitos y de las células pigmentarias a los estratos germinal y de Malpighi, no seria fácil de existir aquella barrera dermoepidérmica diferenciada, tal como la describen RANvien, Hensen, TOOD y Bowmann, Prenant, Cajal, elc. Nuestras observaciones (véase la figura 4) son abiertamente contrarias a la existencia de una membrana refringente de origen epitelial, con dentellones en sus caras paral engranar por abajo con las fibras conjuntivas, y por arriba con las células epidermicas (P'RLNANT) o con el aspecto estriado que describe CANAL. 
estrato germinal, no es raro verlos en pleno cuerpo de Malpighi. La confusión con los leucocitos es imposible, porque las ramificaciones leucocitarias no son tan largas, abundantes y ramificadas, ni apetecen la plata y el oro como las de los cromoblastos, que por sílo este carácter pudieron ser interpretados como células nerviosas. Mas si la confusión de los cromoblastos con los leucocitos es imposible, no lo es menos la de aquéllos con las células epiteliales, contrariamente a la suposición de GRUND, de que existen transiciones entre ambas categorías de células.

Resulta, pues, que entre las células incluídas en el epidermis existen con frecuencia leucocitos emigrados, y que los corpúsculos estrellados de KÖLLIKER y LANGERHANS pertenecen a los cromoblastos. Ya Merkel los interpretó como células pigmentarias libres de pigmento (pigmentfreie Pigmentzellen), y KöLLIKER los consideró como células dérmicas que ascendian al epidermis y representaban, en ciertas condiciones, un escalón entre las células conectivas pigmentarias emigrantes y las células linfoides. Ulteriores investigaciones han permitido a KöLLIKER describir y representar con bastante acierto la morfología de los cromoblastos dermoepidérmicos (piel del gorila), a cuyo actual conocimiento han contribuído las descripciones de CaJAL, RieHL, KARG, AEBy y otros autores, cuya interpretación mesodérmica, emigrante y pigmentaria de las células ramificadas aceptamos. Nuestra discrepancia dimana de la observación de que los corpúsculos dérmicos y epidérmicos no son iguales.

\section{CROMOBLASTOS DEL BULBO PILOSO}

Dejaríamos incompletas estas notas si no hiciéramos mención de nuestras observaciones sobre las células pigmentarias del bulbo piloso seguidamente a las del epidermis, sus hermanas, teniendo en cuenta que, aunque han sido estudiadas ya en sus rasgos gentrales por los autores, no son aún suficientemente conocidas.

Las lagunas que existen en el conocimiento de los cromoblastos del pelo se relacionan con los caracteres morfoligicos y texturales y con la histogénesis, sin contar con lo que afecta al proceso de la canicie, de cuyo interesantísimo estudio no podemos prescindir en absoluto.

Los cromoblastos del bulbo piloso poseen caracteres casi idénticos a los que han sido descritos en los de la piel; pues las pe- 
queñisimas variaciones que en aquéllos sun visibles están ligadas a la forma especial del órgano donde habitan y carecen de importancia.

Sitúanse en la raiz del pelo, entre las células epiteliales que forman la concavidad del bulbo, por encima de la papila. Su numero, muy grande en los morenos, redúcese considerablemente en los rubios y es insignificante en los albinos; pero aunque de él dependa la intensidad de la coloración, los matices de color del pelo se relacionan con las variedades de melanina que contienen.

Sus caracteres de situación, forma y conexiones están representados en la figura 9 (lám. XXIX), que es una reproduccinn de la raiz de un pelo de barba de un hombre adulto, coloreada con la sulución amoniacal de carbonato arerentico. En ella son visibles las siguientes estructuras:

1. ${ }^{a} \quad$ La papila (A), que está constituída por haces colágenos flojos, entre los que moran abundantes corpúsculos conjuntivos de carácter embrionario, muchos de los cuales encierran en cantidad variable granulaciones pigmentarias. yue a veces envuelven al micleo. La forma de estas células puede ser adivinada obsérvando la disposición de las granulaciones. Se ve entonces que, aunque ovoideas o fusiformes por lo general, hay algunas irregularmente estrlladas.

En la parte alta del mamelón suelen existir algunos grandes corpúsculos, provistos de gruesas granulaciones melánicas que se amontonan alrededor del núcleo, impidiendo verle, y se extienden por los escasos apéndices del protoplanma. Ignoramos la significación de estas células, resultantes de la evolución de las otras más pequeñas y menos pigmentadas, e idénticas a las que habitan en el dermis, con respecto a los cromoblastos radiculares; mas podria pensarse que están destinadas a reemplazarlos o a servirles de reservorios de melanina.

2. ${ }^{a} \quad$ El bulbo piloso (C), que forma a manera de casco sobre la papila. Las células propias de la matriz del pelo, o sea los estratos inferiores del epitelio bulbar, no son visibles cuando abundan los cromoblastos, como ocurre en la preparación copiada en la figura 9, donde toda la superficie inferior del bulbo parece estar revestida de células pigmentarias (B). Estas células tienen una configuración muy variable (cilindroide, fusoidal o poligonal), en la que sobresalen los tipos bipolares, originados por un engrosaniento o vientre nuclear. De ambos polos, el inferior, tan pronto grueso como fino, 
simple por lo general y a veces bifurcado, se ensancha inferiormente y descansa sobre la papila mediante un pie más o menos ensanchado, unas veces liso y otras con asperezas o pequeños dentellones. El polo superior bifúrcase a menudo muy cerca del núcleo, y con igual frecuencia se prolonga un poco, antes de dividirse en horquilla. Cada una de sus ramas sufre numerosas dicotomias, y al alejarse del cuerpo celular se arboriza y resuelve en delicadas prolongaciones de curso flexuoso, repetidamente entrecruzadas en los resquicios interepiteliales, las cuales aparecen en su origen lisas, y después ásperas y nudosas, simulando sartas de granulaciones de desigual volumen, aqui reunidas por finos hilos, y alli discontinuas, como bolas libres, con frecuencia alejadas de las últimas ramillas. En ocasiones obsérvase en el extremo de la rama principal una especie de ramillete de gruesos granos (D).

Aunque la forma y disposición general de los cromoblastos del pelo es la referida, es de notar la existencia de tipos diferentes; verbigracia: los de forma estrellada, exentos, al parecer, de pies de implantación, que habitan en planos superiores; los fusiformes, situados transversal u oblicuamente a la superficie papilar; los aplanados, existentes en el reborde bulbar, que envían hacia arriba escasas ramillas granulosas, etc.

Respecto a la textura de los cromoblastos del pelo, sólo podemos decir que todo el protoplasma se encuentra sembrado de finísimas granulaciones, y que el núcleo, envuelto por ellas, aparece como un óvalo claro, sin vestigios estructurales. Idéntico aspecto ofrecen las células epiteliales del bulbo piloso situadas al nivel y por encima de los cromoblastos, que poseen un protoplasma fusiforme finamente granuloso y un núcleo ovoideo y anhisto.

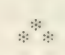

Las células pigmentarias del pelo han merecido desde hace tiempo el interés de los sabios, algunos de los cuales han hecho de ellas una descripción bastante exacta y segura. Sus vacilaciones surgen al interpretar la procedencia de los melanoblastos, que es para unos ectodérmica, y mesodérmica para otros.

Si todos los autores se hubiesen conformado con las descripciones antiguas de Riehl, Aeby, Kölliker, Cajal, Ehrmann, etc., creyendo, como ellos, que las células propias de los pelos son inca- 
paces de elaborar melanina, y atribuyendo esa función a las células ramificadas del dermis, que penetran entre las células epidérmicas del bulbo piloso para suministrar el pigmento a las células córneas. acaso fuera innecesario insistir sobre los caracteres de los cromoblastos del pelo; pero las discrepancias de POST, para quien tales células ramificadas no pertenecen al tejido conjuntivo, sino al propropio epidermis; las de JARISCH, SCHWALBE, KROMAYER, CARNOt, Retterer, Metschnikoff, etc., que opinan que el pigmento melánico se engendra de manera autóctona en el interior de las células epidérmicas, y la de MetschnikofF, que en sus investigaciones sobre la canicie hace entrever la posibilidad de que los

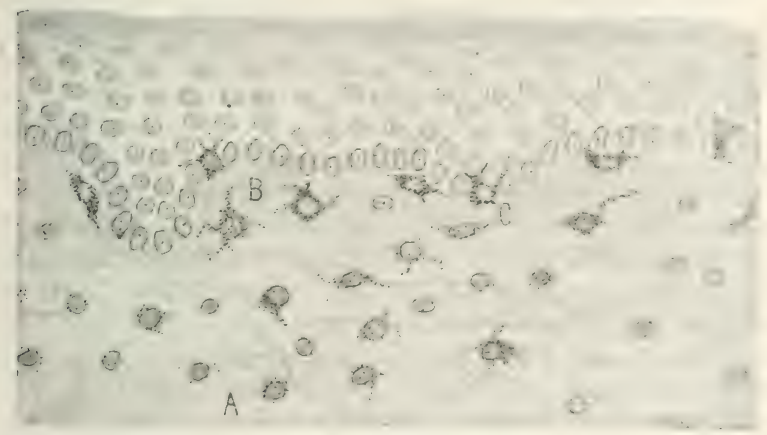

Fig. 5.-Piel de un embrión de conejo al final del clesarrollo: $\lambda$. perpueñas células pigmentadas; 3 , cromoblastos asteriformes, proximos al eppidermis; C, cromoblasto intracpidérmico.

melanoblastos descritos por los autores sean verdaderos melanófagos, obligan a insistir en estos estudios.

Para esclarecer el importante problema histogenético hemos acudido a los embriones de conejo, que por la facilidad con que pueden ser obtenidos en épocas diferentes, se prestan a ello mejor que los embriones humanos, siempre dificiles de adquirir en las condiciones deseables. Obsérvase en aquéllos que los cromoblastos de la piel ý anejos hacen su aparición en los viltimos periodos del desarrollo embrionario, evolucionando de la siguiente manera :

En un primer periodo, cuando los mamelones epidérnicus que 
constituyen el germen del pelo comienzan a esbozarse, y más tarde, cuando ya forman prolongaciones funiculares, hundidas en el dermis (fig. 5), obsérvase en éste, al lado de los hacecillos flojos del tejido conjuntivo, la presencia de pequeñas células (A) con núcleo redondo, muy parecido al de los leucocitos, en cuyo protoplasma se esboza la aparición de un fino polvillo argentófilo, que en fases más avanzadas del desarrollo se acumula junto al núcleo, pero sin llegar a envolverle por completo.

Las células con granulaciones argentófilas, cromoblastos en formación, poseen al principio una forma redondeada, ovoide o poligonal, que más tarde se modifica por la aparición de escasas prolongaciones.

Según puede verse en la figura 5 , se hallan situadas primeramente a cierta distancia del epidermis (A); pero ulteriormente (B) se acercan más a él y penetran entre las células epiteliales (C), insinuando por sus resquicios delicados apéndiçes granujientos.

Iníciase también en este período la penetración de los cromoblastos en el folículo piloso, que en el conejo comienza al final del desarrollo embrionario y prosigue después del nacimiento.

En los cortes verticales de la piel obsérvase la penetración de los cromoblastos a la vez en la parte superior y en la parte inferior del folículo, en la extremidad redondeada que constituye el germen del pelo. Los cortes horizontales, cual el representado en la figura 10 (lám. XXX), perteneciente a la oreja del conejo recién nacido, son más útiles para observar la penetración interepitelial.

En dicha figura 10 hállase multitud de foliculos seccionados transversalmente y formados por acúmulos de células epiteliales ordenadas en varias capas, envolviendo al pelo recién formado. En el tejido conjuntivo del dermis existen abundantes células granulosas, ramificadas, en las que por su forma y tamaño se reconoce hasta tres variedades:

A) Células grandes de forma irregularmente estrellada, con abundantes prolongaciones anchas, no muy largas y bastante ramificadas. Sólo excepcionalmente se aproximan a los folículos y envían apéndices a su interior.

B) Células de pequeñas o medianas dimensiones, que tienen un cuerpo redondeado o poligonal, provisto de escasas, cortas y poco ramificadas expansiones. Algunas de ellas (D) yacen en la proximidad de los folículos, extendidas sobre su superficie y enviando a su interior algunas prolongaciones dicotomizadas. Otras muchas (E) 
han logrado penetrar entre las células epiteliales, donde ocupan una situación marginal, y se extienden superficialmente contorneando al folículo; lisas por fuera, poseen interiormente muchas ramillas, qu se dividen varias veces al pasar por los resyuicios interepiteliales. Sólo algunas $(\mathrm{F})$, abandonando la superficie, se hallan libres en el espesor del folículo y ostentan una forma estrellada.

C) Corpúsculos diminutos, ovoideos, con finísimos apéndices largos, que rara vez se aproximan a los folículos, y con mayor rareza emiten prolongaciones a su interior. Entre este tipo pequeño y los otros más voluminosos existen todas las formas y tamaños de transición. Se asiste, pues, a todo el proceso de evolución morfológica de los cromoblastos y de emigración al interior del folículo piloso.

Como quiera que en la parte media y en la extremidad inferior del folículo son muy escasos al principio los cromoblastos, es de creer que el paso de las células pigmentarias a la matriz del pelo se efectúa en parte desde arriba, corriéndose a través de las células epiteliales.

Después del nacimiento aumenta considerablemente su número en el bulbo piloso, donde aparecen formando, primero, pequeñas agrupaciones sin orden; después, ordenadas en corona, y por último, grandes acúmulos en forma de cono.

Demuéstrase, por consiguiente, que los cromoblastos se originan en el dermis, emigran al epidermis y al pelo y viven en el estrato germinal de ambas formaciones. No tenemos datos secruros sobre la manera de multiplicarse y renovarse; sobre su permanencia, más o menos prolongada, en los tejidos ectodérmicos, ni sobre los estimulos que regulan su distribución. Resperto a tales problemas podriamos pensar, basándonos en la ontogenia y en la filogenia de los cromoblastos, que gozan de la propiedad de dividirse, que viven largo tiempo, que hacen una vida bastante sedentaria, y que en su reparto por el organismo, en su acrecentamiento y en sus cualida. des intervienen influencias nerviosas, todavía mal determinadas.

$\mathrm{Si}$, como parece indudable, los cromoblastos cutáneos de los mamiferos son los representantes de las grandes ciclular pigment arias existentes en los vertebrados inferiores, que a su vez son homólogas de las que poseen los invertebrados, es de presumir que, de manera semejante a lo que en estos últimos acontece, reciban estímulos nerviosos más o menos directos. Recuérdese a este propósito que en los invertebrados, singularmente en tos cefi- 
lópodos, han sido vistas terminaciones nerviosas alrededor de las células melánicas por BRÜCKE, BALLOWITZ y otros autores, y recuérdese también la contractilidad de las células pigmentarias en los seres inferiores y la propiedad que tienen de estirar y retraer sus apéndices bajo la acción de la luz y otros agentes irritantes.

De este modo podremos explicarnos la facultad que gozan de trasladarse de un sitio a otro, si bien lo hacen, al parecer, muy lentamente. A esta propiedad, y acaso también a su divisibilidad, deben ser atribuidos los resultados de aquellos experimentadores que, a ejemplo de KARG y CARNOT, injertaron piel blanca en individuos negros y piel negra en individuos blancos, sospechando que habria de conservar la piel trasplantada sus primitivos y naturales caracteres. Poco tiempo después de la experiencia, los cromoblastos del injerto de color habianse extendido por los territorios inmediatos, desapareciendo la mancha obscura, y los cromoblastos que rodeaban al injerto blanco habianle invadido y obscurecido.

Si se tiene en cuenta la lentitud con que se produce el proceso de pigmentación y despigmentación en condiciones normales y patológicas, precisa admitirse que los cromoblastos, una vez que se instalan en la trama del epidermis, donde quedan en cierto modo aprisionados, hacen vida bastante tórpida. Igualmente ocurre con los cromoblastos del pelo, que, salvo los casos de canicie rápida, tal vez explicables por emigración en masa de la matriz pilosa, parecen estar quietos en su alojamiento epitelial. Y aun en estos casos, no sabemos si son los corpúsculos interepiteliales o los papilares los que desaparecen. Según Ehrmann, en los casos de canicie precoz las células ramificadas dermoepidérmicas, cuyo pigmento no es transportado a las células córneas, se desarrollan de modo normal.

En algunas ocasiones podría pensarse en el ir y venir de los cromoblastos del dermis al epidermis y viceversa, o en la posibilidad de que los corpúsculos epidérmicos sean capaces de elaborar melanina circunstancialmente, sin ajeno concurso; tales son los casos de hipermelanosis epitelial, en que faltan los cromoblastos en el epidermis, abundando en el dermis.

En estos casos de pigmentación aparentemente autóctona del epidermis podria hallar apoyo la hipótesis de JARISCH; mas la existencia de melanoblastos situados ell el dermis quita a la suposición una gran parte de su verosimilitud.

Aunque esté probado que ciertas celulas epiteliales engendran 
melanina, como las que recubren a los conos y bastones retinianos (fucsina de Kühne), no basta esta observación para generalizar el origen endógeno de la melanina cutánea. Nuestra opinión en este punto va de acuerdo con los que admiten que el pigmento es transferido a las células epiteliales por cromoblastos mesenquimatosos; pero no negamos a aquéllas la capacidad de melanizarse autóctonamente en regiones y bajo influencias todavia mal determinadas. Hallámonos, sin embargo, un tanto perplejos respecto al papel que desempeñan las células ramificadas interepidérmicas, que sólo rara vez contienen melanina.

$\mathrm{Su}$ indudable naturaleza. pigmentaria hace sospechar que transmiten al epitelio una parte de las granulaciones que contienen, que luego se convierten en melanina; pero la apreciación de que sus prolongaciones remontan los lugares melanizados y se fragmentan en los linderos del estrato granuloso, induce a pensar en una hipotética y remota relación de esos fenómenos con la queratización. La melanogenia de las células intraepidérmicas se comprueba en los epiteliomas melánicos, en que su número aumenta considerablemente y. ofrecen granulaciones pigmentarias de color amarillento.

En todo caso, debemos confesar que aún no está resuelto definitivamente el problema de la pigmentación del epidermis, y que en nuestras observaciones las hay a favor y en contra de las diversas hipótesis que están en litigio.

Respecto a la histogénesis del pigmento, se admite generalmente que es un acto glandular a base de los gránulos de Altmann o plastosomas de Arnold; pero hay autores que admiten el origen hemático. Asi, List, que observa la existencia de células pigmentarias ramificadas en el dermis y epidermis, cree que el pigmento se engendra por transformación de los hematies, que son tomados como cuerpos extraños y llevados hacia la superficie, siendo en parte recogidos por las células epiteliales. EHRMa.x, que estudia el pigmento en los anfibios, piensa que se forma en las células del dermis próximas a los vasos y procede de la hemoglobina. Serún Post, para quien no concuerda la pigmentación de las cúlulas conjuntivas y epiteliales, pues la primera es granular y bacilar la segunda, el pigmento debe proceder de productos de recambio de los tejidos. Por nuestra parte, tenemos por segura la naturalezal crlandular de los cromoblastos. 
No hemos de terminar estas notas sin ocuparnos, siquiera sea brevemente, de la canicie, cuyo interesante mecanismo fisiológico y fisiopatológico está en tela de juicio, haciéndose intervenir modernamente influencias endocrinas. Como, al decir de WALDEYER, no existía ningún punto de apoyo para explicar la desaparición del pigmento del pelo, algunos autores se han interesado especialmente por encontrarlo.

Siendo suministrado el pigmento a las células córneas por corpúsculos ectodérmicos (POST, MEtschnikofF) o mesodérmicos (Riehl, Cajal, Kölliker, Ehrmann), bastaria suponer que éstos interrumpen su labor para explicar la canicie, al menos en su causa próxima, ya que la causa remota, o sea la influencia neurotrófica que paraliza la acción de los cromoblastos, es más difícil de comprender.

Pero si, como dice Metschnikoff en sus estudios sobre la vejez, la canicie sobreviene a consecuencia de un proceso fagocitario que hace desaparecer la melanina, será preciso, antes de tomar partido favorable o adverso a tal conjetura, el estudio de sus fundamentos histológicos.

Consideramos evidente que METSCHNikoff parte del error fundamental de creer que el pigmento localizado en las capas cortical y medular del pelo se forma seguramente en el interior de células de origen epidérmico, y de admitir que los corpúsculos ramificados, llenos de pigmento, visibles en los pelos blancos, no existen en los coloreados.

Ciertamente, cuando la cantidad de melanoblastos ramificados existente en el bulbo piloso es considerable y abunda el pigmento en las células epiteliales, no es fácil discernir el contorno ni las arborizaciones de aquéllos; pero cuando escasean, se diseñan con gran corrección. Por esto METSCHNikoff pudo verlos claramente en los pelos blanqueados. Esto no quiere decir, sin embargo, que solamente en ellos pueda evidenciarlos un examen atento, pues lo desmentirian las observaciones de muchos autores y las nuestras.

Estudiando el blanqueamiento de los pelos en el perro y en el hombre, MEtschnikorf creyó observar que ciertas células medulares provistas de nucleo redondo 11 oval y de expansiones de forma variada se movilizan y pasan a la capa cortical, cuyo pigmento absorben, descienden por la raiz del pelo y se extienden por el tejido conjuntivo. Según Metschnikofr, se trata de corpúsculos epidérmicos devoradores de pigmento. Estos pigmentófagos, que 
no se encuentran sobre los pelos blancos ni normalmente colureados, actuarian principalmente de noche.

Es indudable que los pigmentófagos de MetschaikOFF son, justamente, los cromoblastos que subsisten en los pelos blanqueados, incapaces ya de suministrar a las células epidérmicas el pigmento necesario para que aparezcan coloreadas.

El estudio de las propiedades inherentes a los cromoblastos nos enseña que son células mesodérmicas y emigrantes que, por razín del amiboidismo de que gozan, han penetrado entre las células epiteliales que forman la raiz del pelo, para suministrarles melanina o materiales susceptibles de formarla. La existencia de cromuhlastos en el bulbo piloso es, por consiguiente, un hecho fortuito y transitorio, a pesar de la constancia con que se efectúa en todos los individuos y con que conserva los caracteres raciales y familiares. Su accidentalidad hace posible que, llegado el momento oportuno, se alejen temporal o definitivamente de su residencia habitual (bulbo piloso) y emigren hacia otros lugares (1).

Como no nos consta con certeza, si bien está dentro de lo posible, si los cromoblastos son capaces de dividirse en el espesor de la raiz del pelo, no podemos fundar en base firme la conjetura de que la canicie sea una consecuencia natural del agotamiento del poder prolifico de los melanoblastos y de su progresiva reducción numérica. Siéndonos conocida, en cambio, la facultad de moverse y desplazarse que los melanoblastos poseen, es lígico que estimemos como causa directa de la canicie el abandono por apuéllos del bulbo piloso. Son, pues, cromoblastos ectópicos y emigrantes los pigmentófagos ectodérmicos de METSCHNiKOFF.

Pero por encima de todas las suposiciones está el hecho escueto y fundamental de que en los pelos obscuros abundan los cromoblastos en la raiz, y en los pelos blanqueados son escasísimos o no existen.

La causa inmediata de la canicie es, por consiguiente, la desaparición definitiva de las células mesenquimatosas que proveian al pelo de pigmento. La canicie transitoria observada por MAYER, LABORDE, Forel, Griffiths, Robius, etc., se explicaría por la emigración y retorno de los cromoblastos.

(1) La movilidad de los cromoblastos basta para explicar los casos de desplazamiento lento de las manchas pigmentarias, como el estudiato por ORLANDi en Riforma Medica, noviembre de 1895, pág. 506. 
La determinación de la clase de influencias que actúan sobre los cromoblastos cutáneos haciéndolos aumentar, disminuir o desplazarse, no es fácil de efectuar y requiere copiosas observaciones experimentales. Quienes atribuyen a desequilibrios hormónicos multitud de procesos fisiopatológicos, pueden buscar, y lo hacen, en efecto, en la intervención anómala de las glándulas endocrinas (tiroides, suprarrenal, ovario) la causa remota de la canicie y de la excesiva pigmentación parcial o general de la piel. La canicie precoz de algunos hipertiroideos, la melanosis de la enfermedad de Addison y del mal de Recklinghausen, la pigmentación circunstancial del abdomen, cara y areola del pezón (embarazo), etc., serían, pues, efecto de la influencia endocrina sobre los malanoblastos.

De la intervención de estos corpúsculos en ciertos procesos patológicos locales tenemos ejemplos en la gran hipertrofia que alcanzan a veces junto a tumores cutáneos y focos de dermitis, y en la hiperplasia que se observa en algunos epiteliomas pigmentados, donde los cordones epiteliales aparecen invadidos por melanoblastos que envuelven a las células neoplásicas en suș ramificaciones.

La índole no médica de la publicación a que está destinado este trabajo nos impide describir extensamente los detalles que hemos podido observar sobre las alteraciones de los cromoblastos en casos patológicos, y que serán objeto de un estudio separado.

\section{BIBLIOGRAFÍA}

AEBY. - Die Herkunft des Pigmentes im Epithel. (Zentralblat für die med. Wissench., núm. 16, 1885.)

IR:SHiv. Doe Nerwen des behaurten Haut. (Sitzungsher. der W'ien. Akad. d. Wiss., t. LXXIV, 1876.)

- Die Nerven der Sinushaare. (Anat. Anz., t. X, 1895.)

BEDDOE. - Observations on the nature, colour of the skin in certain oricntal races. (Jour. of Antluropolgy, 1870.)

CAJAL. - Manual de Histologia normal, 1885.

CARNOT. - Recherches sur le mecanisme de la pigmentation. (Thèse Doct. és sc., Paris, 1895.)

Ëhrmann. - Physiologie und Pathologie des Hautpigmentes. (Vierteljahrsschr. für Dermat. und Syphilis, 1886.)

EBERTH. - Die Endigung der Hautnerven. (Arch. für mikr. Anat., t. VI, 1870.) 


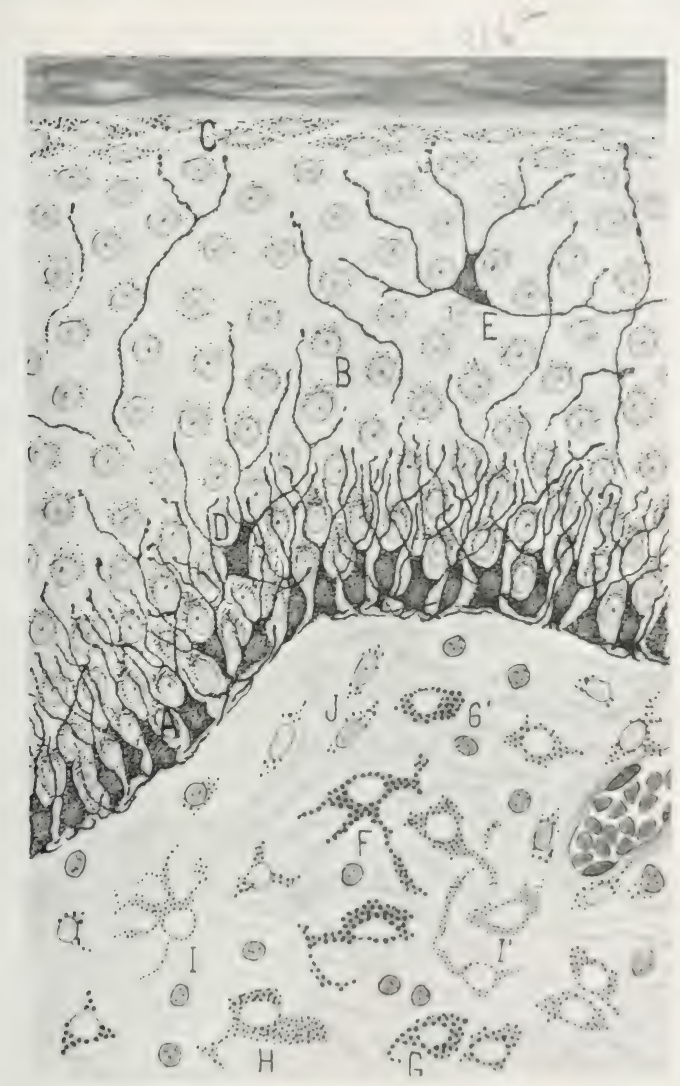

Fig. 6. - Piel de la cara de un hombre adulte: A, cromolilistos intracpiefermonos

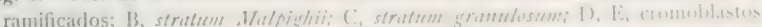

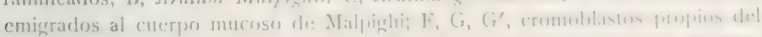

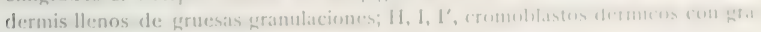

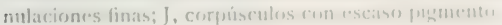





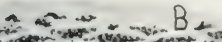

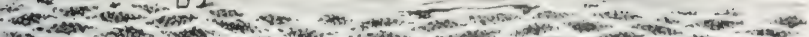

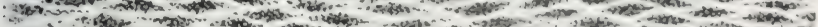

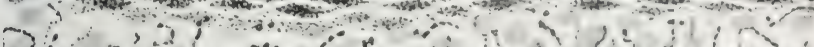
(2)

Fig. 7.-Piel del cráneo de un hombre adulto, seccionada verticalmente: A, cromoblastos intraepidérmicos ramificados; 13, stratum granulostum; C, cromoblastos dérmicos.

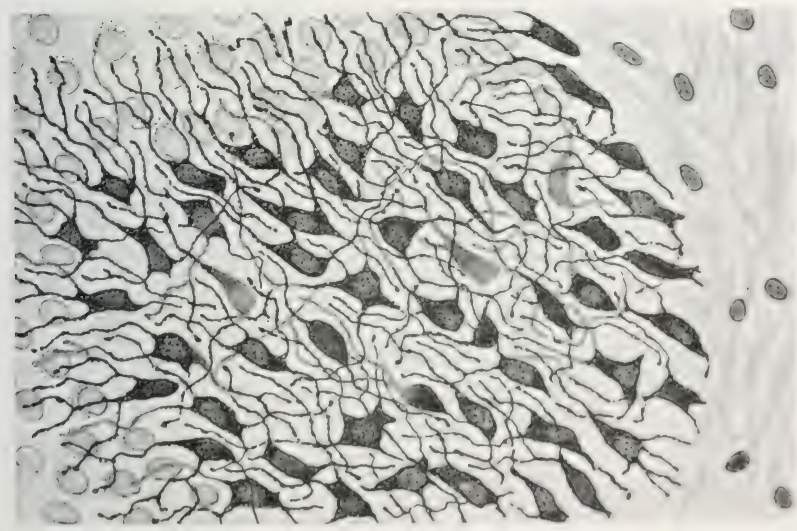

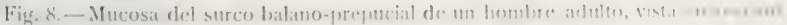

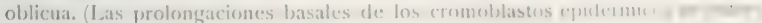
lazan en forma de plexor.) 



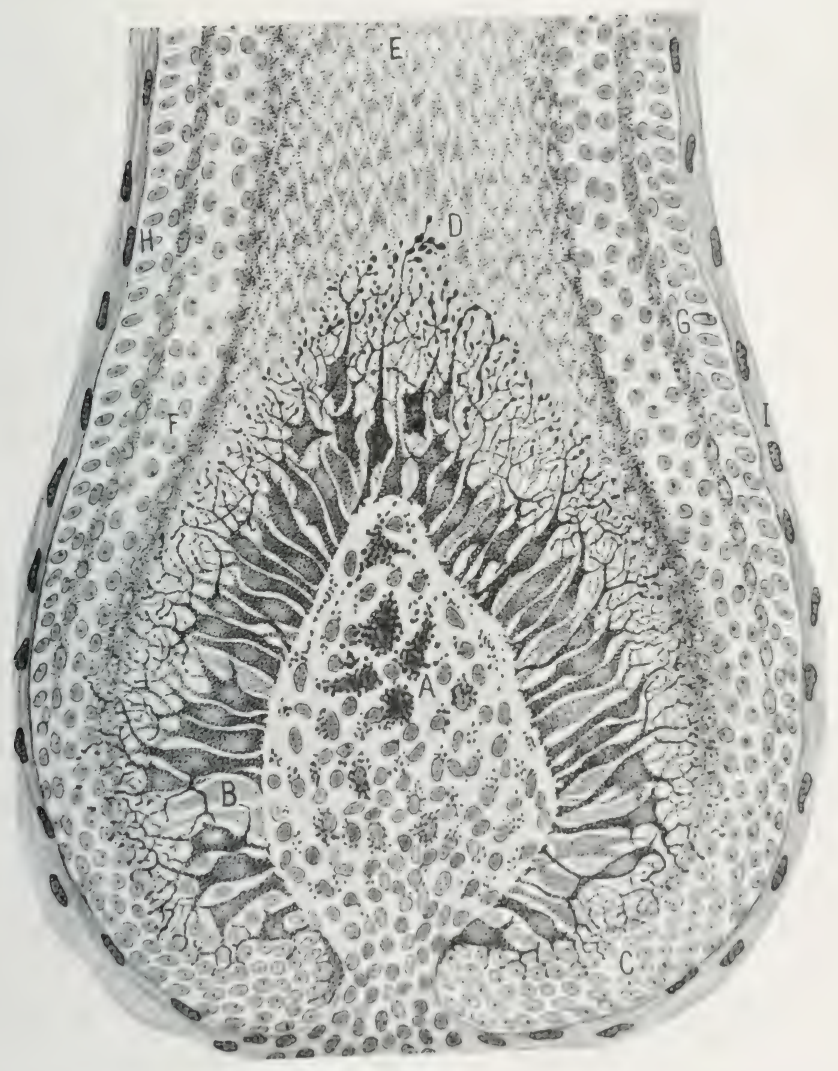

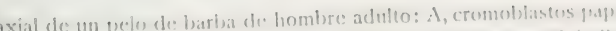

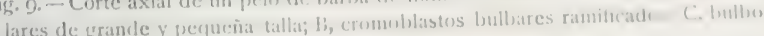
piloso; D, penacho terminal de: un cromoblasto. 



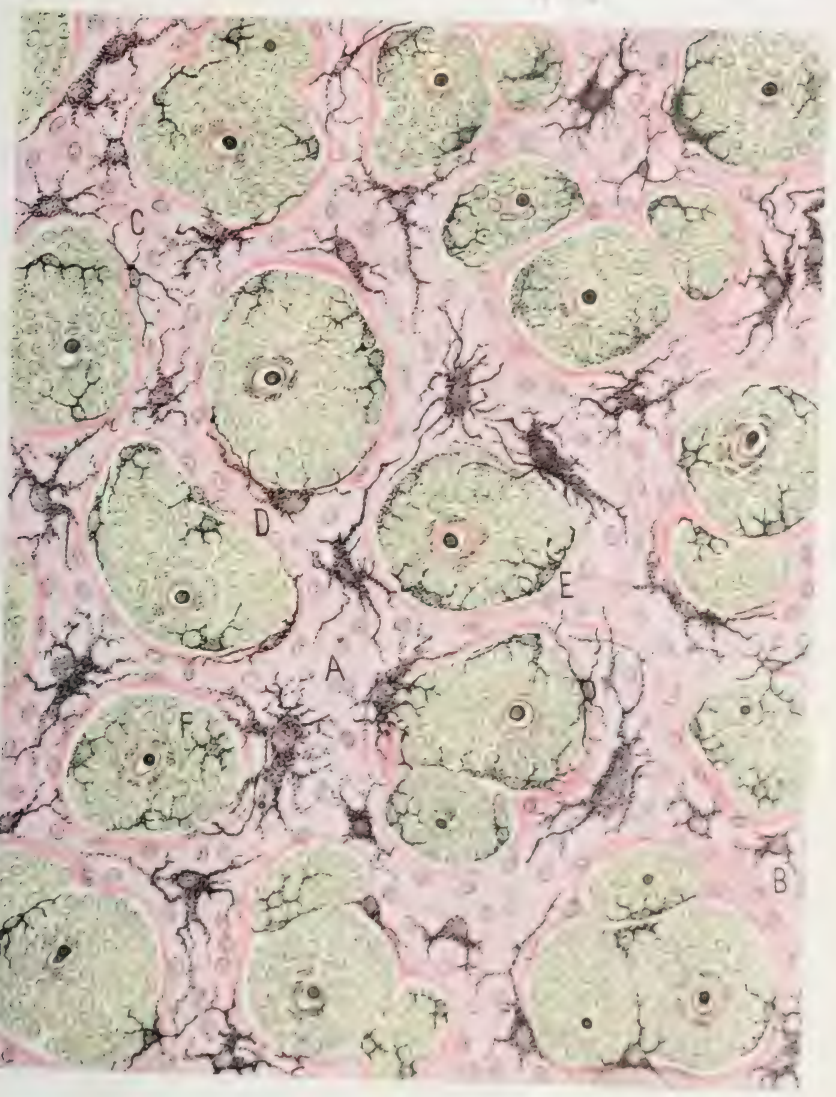

Fig. 10.-Corte horizontal de la piel de la oreja de un conejo recien natiden: 1, cromoblastos dérmicos, de gran tamaño; 13 , cromoblastos peepuenos, poco ramifica dos; C, cromoblasto con apéndices finos y larges; 1), (comoblaster que conternes a un folicule piloso $y$ le envia delgadas forolongaciones; E, folicule prituse on cromoblastos interepitélicos marginales; F, cromolulaste libre en el esperen di foliculo. (Coloración : carbonato argéntico-picro-luesina.) 

FRIA. - Recherches sur la peau du nègre. (Labori esseg. nell'Istit. Fisiol. di Napoli, 1888.)

GASPARY. - Ueber dem Ort der Bildung des Hautpigments. (Arch. für Dermat., 1892.)

JARISCH. - Ueber die Anatomie und Herkunft des Oberhaut und Haarpigmentes beim Menschen und $d$. Säugetieren. (Arch. für Dermat., 1891.)

- Ueber die Bildung des Pigmentes in den Oberhautzellen. (Arch. für Dermat., 1892.)

KöLlikeR. - Woher stammt das Pigment in den Epidermisgebilden? (Anat. Anz., t. II, 1887.)

- Ueber die Entstehung des Pigmentes in den Oberhautgebilden. (Zeitschr. für wissensch. Zool., t. XIV.)

- Handbuch de Geweblehre des Menschen. (6. ${ }^{a}$ edic., t. I, Leipzig, 1889.)

- Wurzbur. naturhist. Zeitschr, t. I, 1860.

KARG. - Studien über transplantierte Haut. Entwickelung und Bedeutung des Hautpigments. (Arch. für Anat. und Physiol., 1888.)

List. - Zur Herkunft des Pigmentes in der Oberhaut. (Anat. Anz., t. IV, 1889.)

LangerHans. - Ueber die Nerven der menschlichen Haut. (Virhow's Arch., t. XLIV, 1868.)

MERKEL. - Ueber die Endigung der sensiblen Nerven in der Haut der Wirbelthiere. (Rostock, 1880.)

METSCHNIKOFF.-Etudes biologiques sur la vieillese. I: Sur le blanchiment des cheveux et des poils. (Ann. de l'Inst. Pasteur, t. XV, !901.)

MERKEL. - Tastzellen und Tastkörperchen bei den Hausthieren und beim Menschen. (Arch. für mikr. Anat., t. XI, 1875.)

PRÉnANT. - Traité d'Histologie, t. I.

Post. - Normale und pathologische Hautpigmente. (Virchow's Arch.. t. CXXXIV.)

RANVIER. - Traité technique d'Histologie. (2. ${ }^{a}$ edic., I'aris, 1889.)

Retzius. - Ueber die Endigungsweise der Nerven an den Haaren des Menschen. (Biol. Untersuchungen, 1894.)

RIEHL. - Zur Kenntniss des Pigmentes im menschlichen Haare. (Vierteljalırsschr. fiir Dermatol. und Syphilis, 1884.)

RetTerer. - Soc. de Biologie, 1887 (citado por BranCA en Truilé d'Anatomie de POIRIER).

ROSENSTADT. - Studien ïber die Abstammung und die Bildung de's Hautpigments. (Arch. fiir mikr. Anat., t. L, 1897.)

UNNA. - Ueber das Pigment der menschlichen Haut. (Monatschr. fïr prakt. Dermat., t. IV, 1885.)

VAN GEHUCHTEN, - Les terminaisons nerveuses intraepidermiques chez quelques mammifères. (Lat Cellule, t. IX, 1893.) 
WALDEYER. - Atlas der menschlichen und thierischen Haare, Lahr, 1884. WERMANN. - Beitrage zur Lehere von Hautpigments. (Verhandl. d. deutsch. dermatol. Gesellsch., Congr. de Praga, 1890.)

Diciembre de 1920.

\title{
INTRODUCCIÓN AL ESTUDIO FISIOGRÁFICO Y GEOLÓGiCO \\ DE LA REGIÓN EGABRENSE (CÓRDOBA)
}

POR

\author{
JUAN CARANDELL
}

(Lámina XXXI.)

La region natural egabrense. - Cabra y su término municipal están situados en la falda occidental de una estribación del sistema penibético, denominada sierra de Cabra, la cual alimenta una interesante red hidrográfica tributaria de dos subcuencas: Salado-Guadajoz-Guadalquivir, y rio Cabra-Genil-Guadalquivir.

El río de Cabra es el modelador de los rasgos plásticos de la región egabrense, con el concurso de la diversa condición litológica del paisaje. El y sus numerosos tributarios, cuyos origenes en fuentes vauclusianas les aseguran gran constancia de caudal, excavan profundas hoces en la penillanura terciaria (margas eocenas plegadas que rápidamente pasan a arcillas), cuyos restos en alto perduran en los términos de Lucena, Moriles y Aguilar, y con caracteres más borrosos en Montilla, Espejo, etc.

Cabe definir, pues, la región egabrense como un bajo relieve labrado en un horizonte arcilloso-calcáreo, que se cierra al Este por un relieve abrupto de plegadas calizas mesozoicas.

Por tal circunstancia, más la orientación general abierta hacia el Sudoeste, a la vez que resguardada de los vientos fríos procedentes de Sierra Nevada, y con el concurso de una riqueza de aguas immensa, la región que nos ocupa contrasta en cultivos y en tem- 
peraturas con todos los términos municipales circundantes, y por sus huertas y por la policroma exuberancia de sus florestas, que desconocen el reposo invernal, se la considera como un jardin en medio de las tierras de pan llevar de la canıpiña cordobesa.

Hidrografia : las fuentes vanclusianas (figs. $1,2,3$ y 4). - Sea porque la transición entre la sierra calcárea y los materiales arcillosos de la vega egabrense (triásicos y eocenos) se efectúe mediante una falla - de la cual hay indicios en la llamada fuente del Río, con estrías de fricción-, o bien lo haga aprovechando la circunstancia de que la erosión regresiva de dicho río arrase las calizas que recubren a las arcillas triásicas y deje éstas a luz, es el caso que el contacto entre la sierra y la depresión. como ocurre en las sierras subpenibéticas cordobesas y jiennenses $\mathrm{y}$ las depresiones béticas y granadinas, es riquísimo siempre en aguas resurgentes o vauclusianas.

Citaremos aquí seis fuentes de esta clase, de las cuales dos radican en la misma vega de Cabra y alimentan sus huertas e industrias $y$ a la población: la fuente del río

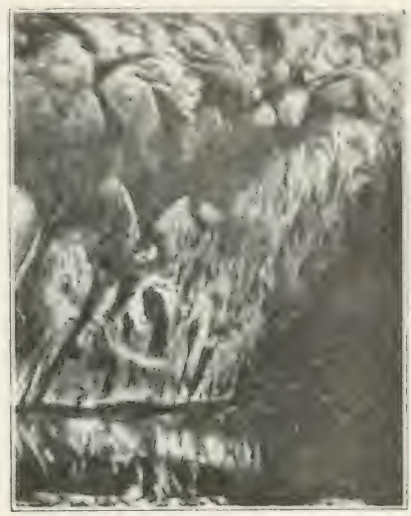

Fig. I. - Detalle de la fuente del Kío. Fot. Carandell.

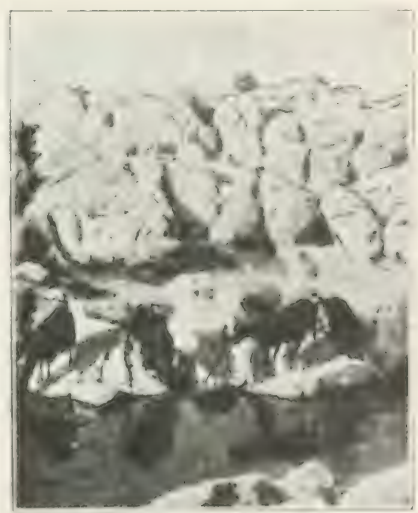

Fig. 2, - Fuente de las l'iedrat

Fot. $f$ ate de Cabra y la fuente de las Piedras; ot ras dos son la de la Sima 
y la de JJarcas; y las situadas cerca de la cumbre de la sierra, en

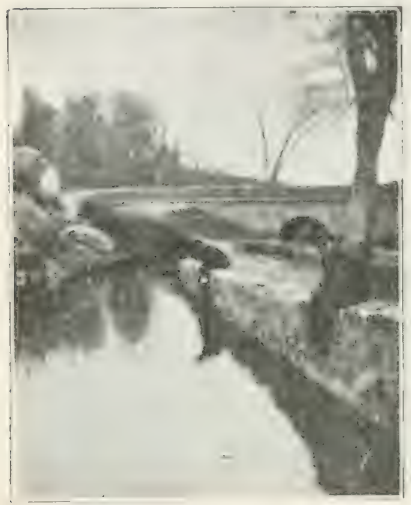

Fig. 3.-Detalle de la fuente del Río.

Fot. González.

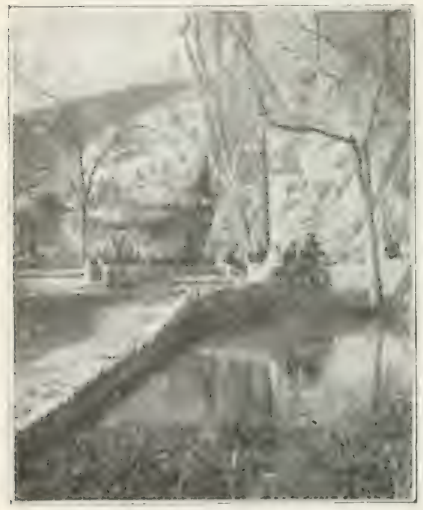

Fig. 4. - Fuente del Río.

Fot. González.

La Viñuela, constituyen las dos restantes.

La fuente del Río, cuyo rendimiento medio no baja de 2.000 litros por segundo, alumbra las aguas que se acumulan en el reservorio de $\mathrm{La}$ Viñuela, valle anticlinal amplio, bóveda arrasada del anticlinal de la sierra. Ella y la de las Piedras son las más importantes. Están situadas a unos 2 kilómetros de la población.

La sima de Cabra. - Popular en toda la Bética e inmortalizada por Cervantes, $y$ de unos 113 metros de profundidad por unos 7 de circunferencia en la boca, es la sima un pozo natural de rara verticalidad, que se abre en la vertiente occidental de $\mathrm{La}$ Camarena (sierra de Cabra).

Sería dificil su interpretación - y lo ha sido - si el observador, dejándose llevar de las generalizaciones, se atuviese solamente a la consideración del carácter calizo de la montaña y olvidase el factor tectónico, tan importante alli. Con ser importante en su génesis el proceso químico, es mayor, si cabe, la contribución de un agudisimo pliegue-falla de eje vertical que alli existe. Otras simas hay en varios lugares de La Nava 
(sierra de Cabra), y en ellas se da la misma doble circunstancia litológica y tectónica.

Los Hoyones: paisaje de avernos. - Son los dos embudos mayores entre los muchos extinguidos que aparecen al Sur de la carretera de Cabra a Priego y entre ésta y el cerro de la Camorra. Están abiertos en los potentes bancos calcarcus me sozoicon, los cuales están alli horizontales y poco plegadu. Miden unos 500 metrode perimetro por algo menos de un centenar de metros de profundidad, y son perfectamente circulares.

Sus paredes se yerguen verticalmente sobre el fondo plano, salpicado de canchales en el más oriental-a cuyo reborde se asoma un cortijo - y con señales de antigua laguna en el más occidental.

No es decir nada nuevo el que la evolución de aquel paisaje de avernos conduzca a un relieve arcilloso salpicado de isleos calcáreos, lo contrario de como hoy se presenta: calizas con ventanas, por las que asoman la arcilla subyacente y la derivada de la alteración química de aquéllas.

El anticlinal de la sierra de Cabra: La Viñuela y La Yava (lámina XXXI, fig. 1). - En apariencia cobíjase Cabra en la vertiente occidental de su sierra, mas.en realidad lo hace en el frente de ésta, que arranca rápidamente desde la vega egabrense y, una vez alcanzados los 1.221 metros de altura en el Picacho, se dirige hacia el Este, culminando en el Lobatejo, a los 1.300 metros, para desde alli caer otra vez con rapidez hacia la hondonada de Carcabuey. Desde Cabra no se ve, pues, una vertiente de la sierra, sino la perspectiva del eje de ésta.

Se trata de un anticlinal de calizas secundarias (jurisicas en su mayor parte); contrafuertes de esta sierra son los cerros de lit Atalaya y del Calvario, en los cuales no acertamos a ver huellas ciertas de corrimiento, a pesar de lo inexplicable de algunos cortes naturales.

En dos grandes extensiones aparece hundida la búvedia anticlinal, gracias a cuyo hecho se libra la sierra en ellas de la monotonia que de otro modo tuviera su paisaje calcáreo e inhospitilario. 1.a Viñuela es la depresión más próxima a Cabra, por cuyon fondu esta la vereda que conduce al Picachn: se trata de un valle invertido. a cuyos lados se yerguen los abruptos escarpes de calizal enl via de 
retrogradación, y su fondo margoso (las margas que constantemente se encuentran por debajo de las calizas) está surcado por los torrentes denominados del Chorrón y de Góngora, el primero de los cuales se precipita por una serie de cascadas y pilas a la vega egabrense y más tarde al río Cabra.

Separando La Viñuela de otra depresión más al Este, denominada La Nava, descuella el airoso y puntiagudo Picacho, en el cual se conserva un retazo del anticlinal.

La Nava es, sin duda, el producto lento de la anastomosis de antiguas torcas semejantes a los Hoyones. Su denominación no puede ser más toponímica. El fondo de La Nava, arcilloso, plano, contrasta, por los cultivos que la tierra obscura, negra, sustenta, con la desnudez de las descarnadas laderas de la sierra. Por él discurre el río Bailón, cuyos caprichosos meandros retienen el caudal inmenso con que luego ha de precipitarse en forma de pintoresca cascada por la lóbrega hoz de Zuheros en busca del río Guadajoz.

El yacimiento titónico de la fuente de los Frailes: los de La Vinnela: el género Nautilus en la fauna egahrense (lám. XXXI. fig. 2). - Seria inútil tarea intentar decir algo nuevo que no estuviera magistralmente estudiado por los KILIAN, los MALLADA, etc., a los cuales atrajo la asombrosa variedad de especies fósiles que encierra el notabilísimo titónico de Cabra. Bien contentos podemos quedar con añadir que la capa fosilifera se extiende desde la fuente de los Frailes hasta el Mojón, a lo largo y a ambos lados de la carretera de Cabra a Priego, y además desde ésta hasta los escarpes laterales de La Viñuela, en los cuales hemos visto los yacinientos de los Colchones y del cortijo de la Aulaguilla, junto al camino nuevo de la ermita de la Virgen, no consignados hasta el presente.

Tampoco hemos visto citado por aquellos autores el género Nautilus, que por dos veces ha sido hallado por nosotros, y cuya especie es la Geinitzii, de la fauna titónica de Stramberg (Moravia), clásica desde los estudios de PICTET, el memorable paleontólogo.

Manifestaciones hipogénicas. - Como apófisis de algún batolito profundo, o resultado de acciones metamórficas (epigénicas, al decir de CALDERón), hemos recogido en diversos parajes de la sierra de Cabra muestras de una roca eruptiva ofítica, de color verde 


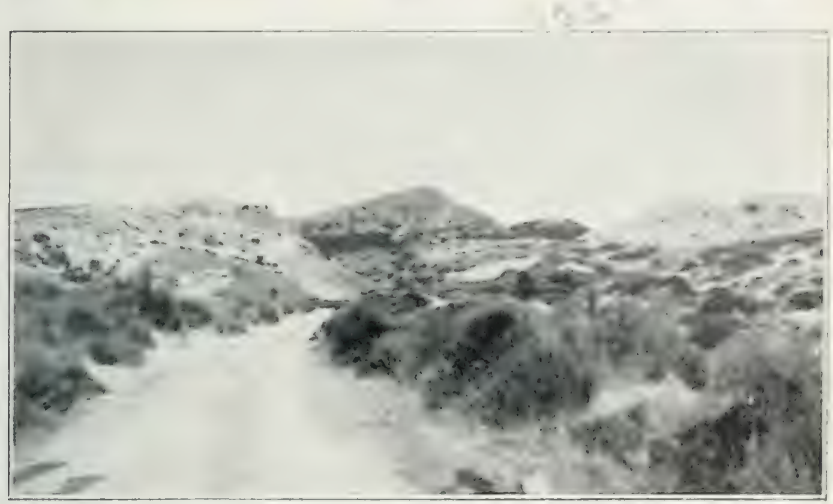

Fin. I. - Sirrra de Cabra: La Vinuelat y Pirachu de ha Viron.

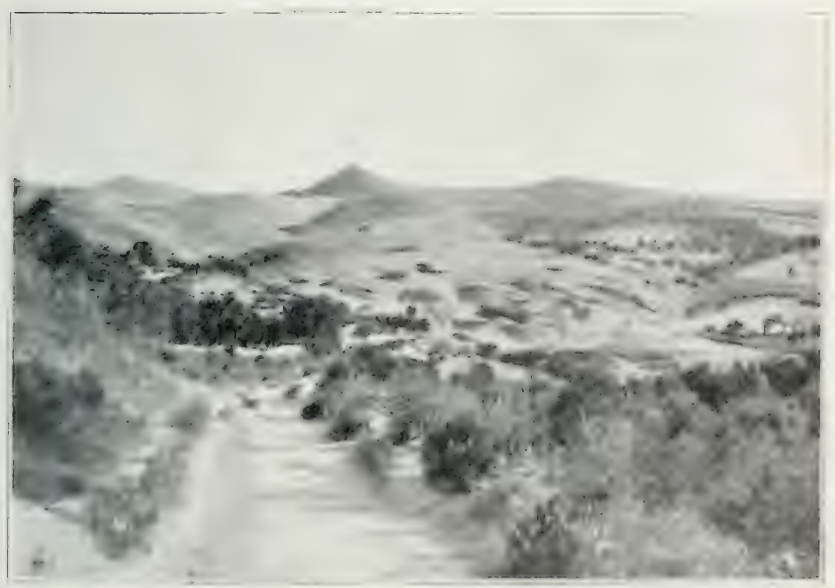

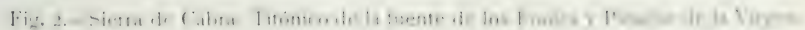

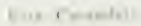



obscuro, que ha sido descrita por nosotros como un diabasa en el Boletín de la Real Sociedad Española de Historia Natural, 1920, págs. 199-201.

Mineralogia de la región egabrense. - No podía faltar en el triásico de Cabra el clásico aragonito, objeto de una nota anterior (año 1919), publicada en el citado Boletin. Acompáñanle lus cuarzos hematoideos, como es corriente. Tampoco deja de presentarse en dicho terreno la sal gema, en otro manchoncillo situado al Oeste de Cabra, a unos 7 kilómetros, y que tenemos en estudio en la actualidad. Abunda también la pirita, epigenizando a veces a Ammonites; pero sobre todo es frecuente la hematites roja con algo de magnetita, en vías de explotación en un cerro situado al Sudoeste de Cabra y a unos 5 kilómetros de dicha ciudad.

Huelga decir que en las numerosas resquebrajaduras de la caliza - la cueva de Jarcas entre ellas, que a nuestro juicio no es reputable como estación prehistórica - aparecen bellísimas cristalizaciones de calcita estalactítica.

Antropogengrafía. - El oasis (agua) crea una entidad biolegica y social absolutamente distinta de la que integra el desiertu f-equiah. en que aquél radica.

En el desierto domina la trashumancia, y a lo más, el cultivo extensivo. El oasis impone cultivo intensivo, tanto por la concentración de los pobladores como por el constante entretenimiento de energías cósmicas y humanas que brinda.

Podemos formular esta proporción: la campiña cordobesa es a la región egabrense tanto como el desierto lo es a uno de los oasis que en él radiquen, pues la comparación o urazón anterior sugiere ésta, sancionada por la ex́periencia de estos últimos anoos de ansias reformistas y por la Historia:

Campiña: secano; propiedad concentrada. Trashumancia de la mano de obra o irregularidad en su entretenimiento. El obrero vive largos periodos fuera de las poblaciones; lo cual, por otra parte, impone cierta austeridad en las costumbres (Lucena, Aguilar, Montilla, Baena, Castro, etc.).

Región egabrense: agua abundantisima. Nieblas invernales paréntesis al cielo rutilante del resto del ano-, procedentes del sindoeste, que imprimen al paisaje la penumbra propia de la faja cantibrica y gallega. La huerta es el cultivo típico. Propiedad pulverizada, 
aparcelada, arrendada y subarrendada. El obrero es fijo en la huerta; al lado de ella y de la fuerza motriz hidráulica crece la ciudad. En la aglomeración humana el movimiento es inusitado siempre; vida intensiva; resplandecen los oficios y las artes; fuerte arraigo de una clase menestral. La vida del individuo es plácida, decadente, sensual; la ciudad es una miniatura de una gran urbe con todos sus defectos, pero con todas las manifestaciones del progreso material y moral.

\section{Explicación de 1a lámina XXXI.}

Fig. I. - Sierra de Cabra: La Viñuela y Picacho de la Virgen.

Fiss. 2. - Sierra de Cabra: Titónico de la fuente de los Frailes y Picacho de la Virgen.

NOTES SUR LES FOURMIS PALÉARCTIQUES

I

\section{QUELQUES FOURMIS DU NORD DE L'AFRIQUE ET DES CANARIES}

PAR LE:

DR. F. SANTSCHI

Paraphacota Cabrerae Sants., st. obscuripes 11. st.

\%: long., 4,6-4,9 mm. Noir; antennes et pattes brunes; le scape et les cuisses presqute noirs; ailes enfumées à nervure jaune brunâtre. Sculpture et pilosité comme Cabrerae. Mandibules un peu moins larges, à dents apicales plus courtes. Antennes un peu moins épaisses. Le gastre et surtout les ailes plus courts. Pour le reste comme chez Cabrercie.

Canaries: Ténériffe, Bejairo, 20 septembre 1898, 1 б.

Bejamar, 10 octobre 1909, 1 (A. Cabrera leg.).

Monomorium (Paraholcomyrmex) destructor Jerd.

Canaries: Ténériffe, Santa Cruz, (Cabrera). 
Monomorium (Xeromyrmex) Salomonis Sm, var. Didonis n. var

ఫ: long., 2,8-3,4 mm. D'un jaune roussâtre faiblement brunâtre plus ou moins terne; la tête plus foncée que le thorax (tete thorax rouge vif chez le type). Le gastre brun noir; la base souvent plus claire (noire chez le type). Appendices comme le thorax. Scape de même couleur que la tête (plus foncé chez le typu). Pubencunce du scape plus rare et plus adjacente. Tête et pronotum mats ou submats (partie postérieure de la tête et pronotum luisants chez Salomonis). Tête plus courte et plus large. Thorax moins allongé et moins bas, surtout l'épinotum. Pas d'impression proménonutale (une légère chez le type). Pédicule à peine moins élevé. Incisure épinotale, et le reste, comme chez le type Salomonis.

Tunisie: Kairouan, Sousse, Tunis.

Algérie et Maroc: Très commune.

Cette variété a été confondue jusqu'ici avec le type qui provient de Syrie; elle en est cependant bien distincte. D'ailleurs, elle varie de taille et de couleur, pour passer aux variétés atrata Sants., Sommieri Em. et subopacum.

La var. atrata Sants. diffère de la var. Sommieri Em. par la sculpture plus mate de la tête et du thorax.

\section{Leptothorax Théryi n. sp. (fig. 1).}

₹: long., 2,4 mm. Thorax et pédicule rouge testacé passant au brun vers l'épinotum, les cuisses, la massue des antennes ut les dents des mandibules. Tête noirâtre; abdomen brun foncé avec la base du gastre plus claire. Tête finement striée en long. Ces stries, souvent interrompues, ont leurs intervalles luisants. Aire frontale luisante.

Thorax finement réticulé-ponctué devant, même lisse au milieu du pronotum tandis que la sculpture devient de plus en plus urossière vers l'épinotum où se forment des rides transversales. La face déclive et les côtés du thorax et du pédoncule réticulés-ponctués. Gastre lisse. Pilosité courte et espacée.

Tête un sixième plus longue que large; les coités un pu'u convexes et les angles arrondis. Les yeux ovales occupent le tiurs moyen des côtés. Sillon frontal très court. Aire frontale etroife. Épistome à bord antérieur arqué avec une stric médiane: plus mar- 
quée. Mandibules finement striées, mates, de cinq dents courtes. Thorax à sutures obsolètes, à profil faiblement convexe et continu. Il est environ le double plus large vers le pronotum dont les côtés sont arrondis que vers l'épinotum dont les épines sont divergentes, un peı plus longues que larges à leur base, et moins longues que l'intervalle de leur base. Le pédicule du pétiole est plus long que le
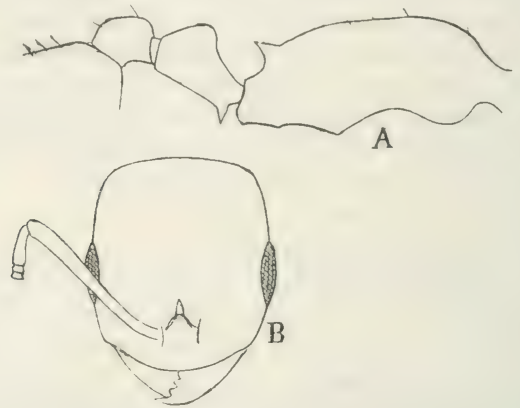

Fig. I. - Leptothorax Théryi n. sp: $A$, thorax et pédoncule vus de profil; $B$, tête de face.

nœud, avec une dent aiguë au-dessous. Le nœud est assez bas et arrondi au sommet. Vu de dessus, le postpétiole est un peu trapézoïdal, le devant plus large et un peu convexe, moitié plus large que le pétiole. Gastre court et tronqué.

Maroc: Rabat (Théry leg.) 1 ‘.

\section{Leptothorax Normandi Sants, st. Atlantis Sants.,} var. suturalis $\mathrm{n}$. v.

Diffère de la var. Atlantis par ses couleurs plus vives. Tête noire. Promésonotum rouge clair, passant au rouge sombre sur l'épinotum. Gastre, pédoncule et cuisses brun noirâtre. Reste des pattes, antennes, mandibules et épistome jaune plus ou moins brunâtre.

Maroc: Aïn Lench (Théry).

Facile à distinguer de l'espèce précédente par sa suture promésonotale disposée comme chez Normandi et Atlantis. 


\section{Leptothorax maurus $17 . \mathrm{Sp}$.}

そ: long., 2,7 mm. D'un rouge jaunâtre. Tête et milieu du gastre noirâtres; reste du gastre brunâtre. Épistome et appendices jaunâtres. La tête a des stries divergentes depuis l'aire frontale. D'abord assez fortes, elles vont s'effaçant peu à peu de façon à ce que le tiers postérieur de la tête soit à peu près lisse et luisant. Front, épistome et mandibules lisses, sauf quelques stries à la base de celles-ci, et une ride médiane sur le clypeus. Joues obliquement striées en dedans. Thorax et pédoncule réticulés-ponctués avec des rides irrégulières sur le dessus, mais espacées sur le milieu du mésonotum et de l'épinotum. Gastre lisse. Pilosité moyenne, subtronquée.

La tête est légèrement plus large que chez Théryi, mais de même contour. Les yeux, grands comme le quart des côtés, sont placés un peu en avant du milieu. Aire frontale imprimée et lisse. L'épistome, convexe entre les arêtes frontales, devient subcaréné devant avec un bord antérieur plus arqué sur les côtés qu'au tiers médian. Bord des mandibules de trois dents devant. denticule derrrière. Le scape atteint le bord postérieur de la tête. Articles 2 à 6 du funicule plus larges que longs; les 7 et 8 aussi larges que longs; 9 et 10 subégaux et le dernier aussi long que les deux précédents réunis. Thorax faiblement et régulièrement convexe, à sutures effacées, un peu moins convexe que chez Théryi. Les épines 2,5 fois aussi longues que la largeur de leur base et un peu plus longues que leur intervalle basal, obliquement relevées et recourbées en arrière et en dehors. Face déclive concave au milieu avec-les bords verticaux. Le pédoncule est plus large et plus robuste que chez Théryi avec un profil presque semblable sauf que le pédicule du pétiole est un peu plus court. Le postpétiole presque rectangulaire avec un bord antérieur rectiligne, à peine plus largre que le postérieur, les côtés presque droits formant des angles antérieurs bien marqués. Gastre plus large que chez Théryi.

Maroc: Arzou (Théry leg.)

C'est une forme apparentée à flevispinus André. Elle en diffire par son pétiole plus court à noeud plus haut. 
Le Tetramorium caespitum L., st. semilaeve André, et ses variétés.

Désirant classer quelques variétés inédites de cette race si variable, je me suis heurté à la difficulté de reconnaitre la forme type. EuERy (Deutsche Ent. Zeitschr., 1903, p. 703) et BoNDroIt (Ann. Soc. Ent. de France, 1918, p. 109) ont bien désigné comme type une variété brune, mais cette variété ne correspond pas, par la couleur tout au moins, à la description originale d'ANDRÉ ainsi formulée:

«D'un jaune rougeâtre plus foncé sur la tête et le dessus de l'abdomen qui passe au rouge brunâtre. Tête et thorax longitudinalement striés; pétiole et abdomen lisses et luisants. Dents du métanotum courtes. Taille petite $(2-2,5 \mathrm{~mm}$.).

„Cette variété, qui paraît méridionale, est répandue dans toute la région méditerranéenne de l'Europe, de l'Afrique et de l'Asie.»

Espérant éclaircir la question, je me suis adressé à M. Berland, assistant au Muséum de Paris, où se trouve la collection André, lequel m’a très obligeamment répondu par l'envoi de quelques exemplaires de cette collection et les renseignements suivants. La collection André contient deux séries de ces fourmis étiquetées itypes: une série de huit provenant des Pyrénées-Orientales, et une série de quatre provenant d'Alger. Cette désignation n'est pas due à ANDRÉ qui n'avait pas de ces étiquettes, mais à BONDROIT. La collection André contient en outre d'autres semilaeve provenant de Tunisie, de Dalmatie, de Palestine et de Syrie.

Ainsi BONDROIT a choisi comme type des fourmis provenant de deux localités bien différentes, dont plusieurs exemplaires mont été communiqués. Ceux d'Alger sont identiques à la race maura Sants. (Bull. Soc. Hist. Nat. Afrique du Nord, t. IX, p. 154, 1918), dont la femelle se distingue par son large pédoncule sculpté. L'ouvrière a également le pédoncule plus ou moins ridé dessus et légèrement plus large que chez semilaeve et les rides du thorax bien plus sinueuses. II n'y a donc pas lieu de tenir compte de ces exemplaires. Restent ceux des Pyrénées-Orientales. Ceux qui m'ont été communiqués sont un pẹ plus grands que ne l'indique ANDRÉ $(2,8 \mathrm{~mm}$. au lieu de 2,5$)$ et leur couleur beaucoup plus brunâtre, tandis que ce sont les exemplaires de Tunisie, Dalmatie, qui ont la couleur et la taille correspondant le mieux à ce que dit ANDRÉ et qui avaient dû être choisis comme types. Cependant ils ont le plus 
souvent le quart ou même la moitié (et plus) postérieure de la têt. lisse ou presque lisse, caractère assez apparent dont ne parle pas ANDRÉ. Ainsi donc, si l'on veut considérer la description de cet auteur comme générale et incomplète, ou peut admettre la prioriti. des types de BoNDroit (exemplaires des Pyrénies-orientales), et c'est pour cette dernière solution que je me suis ducide. Voici donc les caractères de ces diverses variétés, en tenant compte qu'ils offrent de fréquents passages les unes aux autres.

\section{Var. semilaeve André.}

ఫ: long., 2,8 mm. environ. D'un brun roussâtre plus ou moins clair sur le thorax. Les stries de la tête atteignent le bord postérieur et beaucoup même le bord cervical et s'effacent plus ou moins entre le front, les yeux et l'angle postérieur. Celles du thorax sont plus grossières mais assez régulières, leur intervalle assez espacé et relativement peu sculpté et luisant, souvent les rides medio-dorsales sont en partie effacées. La face basale de l'épinotum est réticulée-ponctuée, mais les rides longitudinales du mésonotum s'y prolongent parfois plus ou moins. Pédoncule et gastre lisses en dessus. La tête est distinctement plus longue que large. La suture promésonotale inégalement indiquée. Les bords du mésonotum arrondis. Les épines courtes. Le postpétiole distinctement plus large que le pétiole, et le double plus large que long.

f: Bondrolt indique 4,8-5,7 mm. de long. Je posséde une $q$ prise avec les dans le nid, au Canigou, Pyrénées-Orientales, qui mesure $6,5 \mathrm{~mm}$; ; elle a le pédoncule sculpté, le postpétiole bien plus large que chez Atlantis Sants. pes) $x$.

France: Pyrénées-Orientales, Banyuls (André, Bondroit, tyVar. depressa For., Bull. Soc. Ent. Belgique, t. XXXVI, p. 455, 1892.

Très voisin du type semilaeve. La couleur est parfois plus obscure, presque noire, rarement plus claire. La taille est la même, parfois un peu plus grande. Diffère surtout par la plus grande extension des espaces lisses de la tete. Forel dit que l'epicimma n'a pua trace de carène médiane, mais ce caractère est loin d'être constant: il en est de même de la sculpture de la face basale de l'épinotum généralement réticulée-ponctuée, et sur laquelle se prolongent parfois les rides du mésonotum. 
La $q$ a le mésonotum lisse et très luisant; l'épinotum finement réticulé-ponctué.

Chez le ơ l'impression postérieure du mésonotum est forte et finement striolée: le reste du segment est luisant. Le pédoncule est moins robuste que chez Atlantis Sants.

Canaries: Las Palmas (Ris) types ł̧ reçus de Forel. Ténériffe, Laguna, Monte Agua Gracia, Los Rodeos (Cabrera) ‡ $q$ б.

Maroc: Rabat (Théry) $\precsim$.

Tunisie: Dir el Kef (Santschi) $\curlyvee$; Kairouan, $\subsetneq \propto \sigma^{*}$; ces derniers sont plus petits que le type et passent à la var. Ernesti n. v. (voir plus bas).

Var. Atlantis Sants.

T. caespitum L., st. punicum Em., var. Atlantis Sants., Bull. Soc. Hist. $\mathrm{Na}^{+}$. Afrique du Nord., t. IX, p. 155, 1918.

Cette variété, comme la précédente, se rattache à la race semilaeve par le thorax sculpté et non à punicum, comme EMERY et moi nous !'avons dit.

Caractères de semilaeve, mais d'un brun souvent plus foncé et les appendices plus clairs; le thorax est un peu déprimé comme chez depressa. Stries de la tête aussi développées que chez semilaeve. Cette variété diffère surtout par le mésonotum presque entièrement strié de la .

Var. jugurtha n. v. (fig. $2, A, D$ ).

ફ̆: long., 2,2-2,5 mm. Jaune ou jaune roussâtre; le gastre un peu

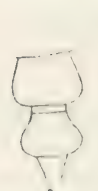

$\lambda$

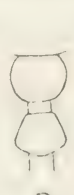

B
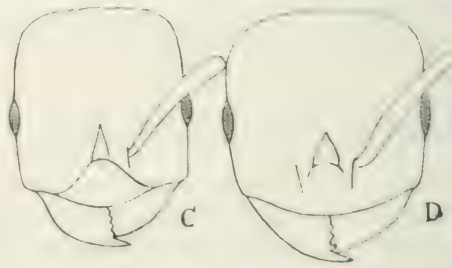

Fig 2.- Tetramorium catespitum L., st. semilacte André, var. jugurtha n. v. :

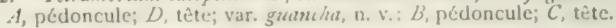

rembruni. La tête est luisante, souvent en grande partie lisse derrière depuis le quart à la moitié et plus. Les stries fines et plus ou 
moins effacées. Le thorax est submat, irrégulierement ride en lons avec de nombreuses anastomoses, les intervalles li sies ou réticules. Le col du pronotum, la face basale de l'épinotum et les côtés du thorax et du pédoncule réticulés-ponctués. Le dessur de ce dernier et le gastre lisses et luisants. La tête est relativensent un preu plus étroite qui chez semilaeve et le pétiole pas beaucoup plus étroit que le postpétiole, lequel n'est pas tout a fait le double plus large que long.

Tunisie: Kairouan (types) Sousse, Le Kef, Djmal (Santschi). Maroc: Rabat (Théry). Sicile: Palerme (coll. André).

Dalmatie (coll. André).

Var. Ernesti n. v.

ఫ: comme jugurtha, mais les stries de la tête en atteignent le bord postérieur. C'est la forme qui répond le mieux à la description d'Ernest ANDRÉ.

q: long., $5,5 \mathrm{~mm}$. Brun ou brun noir, tête noire, appendices brun jaunâtre. Mésonotum lisse avec deux aires triangulaires strices à base postérieure. Scutellum lisse au milieu, strié de cóté. Postpétiole presque deux fois plus large que long, à côtés arrondis. Pétiole large comme la longueur du postpétiole, les nouds non echancrés et lisses.

France: Hérault, Marsuliarque (Lavagne) $\subsetneq$ (type).

Algérie : Alger (Surcouf) q భ; Mascara (Dr. Cros) $q$ $\subsetneq$.

Var. guancha n. v. (fig. 2, B, C).

ఫ: long., $2 \mathrm{~mm}$. Jaune ou jaune roussâtre. Tête presque entièrement lisse el luisante avec quelques traces de riticulations effacés et quelques faibles stries devant. Thorax réticule ride en lomg. Pédoncule et gastre lisses. La tête et le pédoncule. sont beaucoup plus étroits que chez jusurtha, le postpétiole etant à peine. un yuart plus large que long.

Ténériffe: Medano (Cabrera).

Var. romana $\mathrm{n}, \mathrm{v}$.

Long., 2, 1-2,3 mm. D'un jaune brunatre terne (parfois foncé), les appendices un peu plus clairs. Stries de la tete fines. plus on molns effacies en arriitre (environ 12 entre les arites frontales), celles du 
thorax assez fortes, espacées, assez rectilignes, les médianes ne dépassant pas le pronotum. Côtés du thorax plus ou moins ridés. Mésopleure souvent ponctuée-réticulée. Pédoncule et gastre lisses. Tête presque aussi large que longue. Épistome très nettement caréné. Pétiole bien plus étroit que le postpétiole. Suture promésonotale effacée. Dents petites, aiguës.

Var. picta Karaw.

Cette variété est très apparentée aı type du semilaeve par sa taille, sa couleur et la sculpture de la tête. Elle en diffère par celle du thorax, qui est beaucoup plus irrégulière et généralement plus fine.

Crimée: Mejanoff.

Var. Sclumidti For.

Cette forme a le pédicule lisse (et non sculpté comme l'écrit FOREL); elle se rapproche beaucoup de la var. jugurtha, mais elle est plus robuste et les stries de la tête plus étendues.

Jérusalem (type). Les exemplaires d'Algérie qui s'y rapportent sont plus petits.

Var. splendens Ruzs.

Voisine de depressa, la tête en grande partie lisse, en général noire, les pâles font passage à jugurtha.

D'une façon générale la race semilaeve peut être caractérisée par son pédoncule lisse, son thorax toujours bien plus sculpté que la tête, les stries de celle-ci plus ou moins effacées surtout vers les angles postérieurs. BONDROIT en fait une espèce, mais il y a des passages au T. caespitum L. Ainsi, je possède des $q \nmid$ d'un nid provenant du ilont Canigou (Pyrénées-(Orientales) dont les $\$$ ont pour la plupart le pédoncule lisse, et je les avais déjà placées à côté du type semilueve, quand je me suis aperçu que la 7 et quelques $\$$ ? avaient le pédoncule sculpté. Ce sont des caespitum semilaeve.

Je possède une série semblable de Roumanie passant à la variété picta. D'autre part, la var. guancha est si distincte de T. caespitum, que si je n'avais sous les yeux toute l'échelle des intermé- 
diaires, j'en aurais fait une espèce. La var. Ernesti est le type moyen de la sous-espèce; la var. semilaeve, la plus proche de crespitum L.

Tetramorium caespitum, st. punicum Sm., var. Jarbas n. v.

§: long., 2,7-3 mm. Jaune roussâtre, parfois jaune brunâtre. Le gastre souvent plus foncé. La téte est généralement plus striée quu. chez le type de Syrie. Promésonotum lisse et luisant avec diverses stries devant. Col, côtés du thorax et épinotum réticulés-ponctués. Abdomen luisant et lisse. Le thorax est un peu moins convexe que chez punicum, mais bien plus que chez semilaeve, depressa. Les dents très petites.

Q : long., 6-6,5 mm. Brun roussâtre foncé, le gastre plus clair. Mésonotum lisse, sans stries. Les stries de la tête bien plus fortes que chez depressa, avec des points dans les intervalles. Le postpétiule un pe'u plus large que chez depressa, mais moins que chez. maura. Pédoncule finement rugueux.

$\sigma$ : long., $5 \mathrm{~mm}$. Noir; appendices et parfois le gastre bruns. Mésonotum finement strié. Pédicule échancré au sommet.

Tunisie : Kairouan ( $\ \Varangle$ $\left.\sigma^{\prime}\right)$ types. Le Kef, Maktar, Tunis.

Algérie : Région des Dayas (Lesne).

Ces derniers font passage à depressa par les stries plus accusées du thorax.

Cette nouvelle variété differe à première vue du type de Syrie par sa taille moindre et sa couleur d'un jaune moins roussâtre.

D'après une communication de $\mathrm{M}$. H. Donisthorpe, les types de T. punicum Sm. auraient disparu du British Museum et du Musée d'Oxford.

Tetramorium caespitum L., st. juda Wheel. et Mamn, var. juba II. v.

そ. long., 3,2-3,5 mm. Brun rouge sombre, tête et gastre brun noir. Appendices, bord de l'épistome et des jontes brun clair. Lisse et luisant sauf le devant de la tête et les mandibules qui sont striées. Mésopleure et épinotum fortement réticulés-ponctués, cótés du pédoncule plus finement. La tête a en outre quelques points épars mais pas les stries frontales atteignant le bord postérieur qui se voient chez juda. La tête est distinctement plus longrue yue large, 
convexe transversalement. Le thorax bien convexe devant, les dents médiocres.

Sahara algérien: El Golea (Surcouf) 4 ð̧

Tetramorium caespitum L., st. maura Sants., var. tingitana n. v. (fig. 3, o).

ఫ̧ long., 2,2-2,4 mm. Noire; le gastre brun avec le bout roussâtre. Appendices roux plus clairs aux extrémités et les cuisses rembrunies. Stries de la tête fines, serrées, luisantes et atteignant

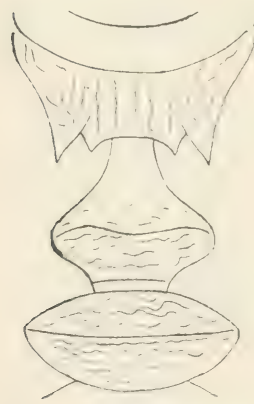

Fig. 3.- Tetranorium caespitum L., st. maura, var. tingituma n. v., lemelle. Epinotum et pédoncule vus de dessus. le bord cervical en divergeant. Elles sont parfois un peu effacées en dedans des yeux. Thorax et côtés du pédoncule densement réticulés-ponctués avec de fines rides longitudinales sur le promésonotum. Dessus des nouds lisses et luissants avec souvent quelques rides espacées. Gastre lisse. Tête déprimée, avec une impression frontale bien distincte. Épistome pas ou peu caréné. Dents épinotales petites. Du reste comme chez maura.

이 long., 5-6 mm. Noire; appendices bruns, tarses, articulations et mandibules brun clair. Tête et thorax densement striés, opaques. Les stries de l'épinotum bien plus grosses que celles du mésonotum, elles sont plus ou moins effacées au milieu du scutellum. Mandibules luisantes mais striées. Pédoncule rugueux. Gastre et appendices lisses. Pilosité fine, assez longue sur l'abdomen. Tête aussi large derrière que longue. Le sillon frontal atteint l'ocelle médian. Le scape atteint presque le bord postérieur. Face basale de l'épinotum convexe sur le profil, moins incline que chez caespitum. Epines un peu fortes. Les deux nouds sont un peu plus larges que chez maura et moins que chez ferox Ruzs.

Maroc : Rabat (Théry) $q$ ఫ.

Outre son pédoncule moins large, cette forme diffère de ferox par sa sculpture plus grossic̀re chez la f. Chez maura Sants. I la couleur est bien plus claire et les nouds pédonculaires moins larges. 
Crematogaster scutellaris Ol., var. corsica n. v.

ج: long., 4,5-6 mm. Tête et antennes rouges. Pronotum et pattes brun rouge, le reste sombre, y compris les cuisses. Stries de la tête bien indiquées. Les épines fortes. Le pétiole plus large devant que chez le type. Beaucoup plus robuste que le type et même que la var. ionia For.

Corse (Desanti leg.).

Camponotus (Myrmentoma) Gestroi Em., var. ponariensis n. v.

$\Varangle$ : long., 5-8,5 mm. Diffère du type par la couleur brun roussâtre clair des deux tiers de la base du scape, des tibias et des tarses. Cuisses et mandibules brunes, le reste noir. La tête est aussi mate que chez la st. creticus For. et les arêtes frontales aussi écartées. Profil thoracique comme chez le type de l'espèce. Ecaille très amincie au sommet.

Algérie: Tlemcen (Caseade).

Camponotus (Myrmentoma) Gestroi Em., st. tingitana n. st.

: long., 6 à $11 \mathrm{~mm}$. Tête et thorax seuls 4,7 mm. Le promésonotum forme une convexité plus accusée que chez le type, surtout la partie postérieure du mésonotum, ce qui rend le plan de la face basale de l'épinotum plus bas. Les arêtes frontales son beaucoup plus rapprochées, plus proches l'une de l'autre en arrière que des yeux. Côtés de la tête assez luisants. Appendices sombres.

Chez la ج" le profil du thorax est comme chez le type.

f: long., 15-16 mm. Côtés de la tête luisants; arêtes frontales écartées.

Maroc: Otigrigra: Azrou à Aïn Leuch (Théry).

Ponera Gyptis to nom. (= P. parva Bond. 1918, nom. pritoc. Forel, 1909).

Marseille.

Lasius (Formicina) flavus L., var. myops for.

Maroc : Aïn Leuch (Théry).

Variété un peu plus roussâtre que les types de Forel d'Algérie. 
Formica (Serviformica) fusca L., var, pyrenaea Bond.

Maroc: Ain Leuch (Théry).

Cette variété à écaille un peu mousse au sommet se trouve aussi en Espagne, d'où elle a dô être introduite au Maroc.

\title{
A PROPÓSITO DE UNA CAÍdA DE POLVO EN CANARIAS
}

\author{
POR
}

\section{LUCAS FERNÁNDEZ NAVARRO}

En febrero de 1919 dieron cuenta los periódicos de un fuerte temporal habido en Canarias, acompanado de! curioso fenómeno de una caída abundante de polvo. El estudio del material recogido y de las circunstancias que acompañaron a su depósito es el objeto de la presente nota (1).

Como preliminar a nuestro trabajo debemos, en primer término, hacer la conveniente distinción entre las lluvias de polvo propiamente dichas y las lluvias de arena, fenómenos análogos, pero de muy desigual importancia geológica. Sin embargo, se los confunde muy frecuentemente, y no se puede muchas veces saber con certeza a cuál de ellos se refieren los autores.

Las lluvias de arena son una agudización del conocido fenómeno de los médanos o dunas, que cambian de lugar por la acción de los vientos dominantes en una región. Son las «arenas voladoras», que cuando el viento es bastante fuerte pueden ser transportadas a considerable distancia. En los desiertos arenosos pueden originar las "tempestades de arena», que sepultan objetos voluminosos, hacen rodar sobre el suelo guijarros de varios centímetros, y volando a corta distancia del suelo producen sobre las rocas salientes el efecto conocido con el nombre de corrasión.

(1) Debo el material objeto de mi estudio, y muchas noticias acerca de las circunstancias que acompañaron a la caida, al celo del catedrático del Instituto de La Laguna, D. Agustin CABRERA, antiguo discipulo y querido amigo mio. 
Sólo en casos muy excepcionales estas arenas pueden ser transportadas a grandes distancias en cantidad comich rahle. dindu lugar a verdaderas «lluvias de arena», por lo cual el fenómeno carece de importancia como medio de formación de suelos. Donde parece que se observan con más frecuencia estas lluvias de arena es en el Atlántico Norte, al Oeste del Sahara, extendiéndose a veces hasta el centro de este océano en la región de los vientos alisios del Nordeste.

Mucho menos local y seguramente de más importancia geológica es la caída o lluvia de polvo. Acaso es hoy fenómeno poco frecuente o que escapa a la observación; pero tuvo sin duda una importancia extraordinaria en la época de la formación del loess y el lelım, que a veces con centenares de metros de espesor, recubren grandes extensiones en Europa Central, Persia y China, Turkestán (donde se forma actualmente), América del Norte, pampas de la República Argentina, etc.

En un estudio hecho por N. WINCHELL y R. MITLEX con motivo de una tempestad de nieve acaecida en 9 de marzo de 1918 en el Wisconsin, puede apreciarse la importancia que para la formación de terrenos llegan a alcanzar estas lluvias de polvo, o simplemente las precipitaciones acuosas acompañadas de polvo. Durante dicha tempestad vino a caer un gramo de materia terrosa por litro de nieve, o sean 5 gramos por metro cuadrado de terreno. El polvo, a juzgar por su composición mineralógica, procedía de las regiones desérticas del Arizona. Según el espacio cubierto por la nieve, los autores afirman que no bajaría de un millón de toneladas la cantidad de tierra transportada por el viento durante esta sola tempestad.

Aunque la mayoría de los geólogos convienen, para explicar la formación del loess, en considerarle como una acumulación de polvos resultantes de la desagregación de rocas diversas, transportados por el viento, falta mucho para conocer las circunstancias que han acompañado a este depósito. Al completo esclarecimiento de estas circunstancias no se podrá llegar sin la observacion minuciosa del fenomeno tal como hoy se realiza, y de ahi el interis yue tiene, en mi opinión, el estudio de las lluvias de polvo, fenómeno sobre el cual no se han hecho por los geológos trabajos sistemáticos. Sin que el presente tenga pretensiones de tal, acaso pueda servir para Ilamar la atención de los que se encuentran en localidades en que las lluvias de polvo son frecuentes, inclinándoles al estudio, yue esta por hacer, de este argente geológrico. Acaso también se contrihuya de 
este modo a esclarecer el problema de la circulación atmosférica, cuya importancia no es necesario ponderar.

$$
* *
$$

En este concepto, pocas regiones habrá de mayor interés que las islas Canarias. El fenómeno de las lluvias de polvo o de las precipitaciones acuosas acompañadas de residuos terrosos es muy frecuente en el archipiélago, coincidiendo siempre con vientos impetuosos del cuadrante Sudeste. Unas veces las nubes de polvo son sécas, y otras vienen acompañadas de temporales de agua, que producen la precipitación del polvo. Los meses en que principalmente suelen producirse estas lluvias son los de enero y febrero.

Cuando las materias acarreadas lo son en pequeña cantidad, el fenómeno pasa inadvertido. Pero si las tierras son abundantes, la opacidad producida en la atmósfera y el depósito del sedimento eólico sobre el suelo y los objetos llaman la atención de todas las personas, por poco observadoras que sean.

Don Veremundo CABRERA, hermano que fué del profesor que me ha proporcionado los datos de la actual lluvia de polvo, describe en estos términos la que sẹ observó en Tenerife el año 1902: «A fines de enero de este año, reinando viento Sur, se presentó en estas islas una neblina de tenue arena que duró unos seis dias, hasta que cambiando el tiempo con vientos del Norte, desapareció la nube en unas veinticuatro horas. Visto el sol a través de aquélla, lucía opaco y como si se le mirase a través de un vidrio de color..... El precipitado de la nube referida apareció claramente sobre las plantas en forma de polvo impalpable de color amarillo.... Una persona que aquí le observó al microscopio me ha dicho que aparecía como un agregado de cristales, a modo de polvo de azúcar, con pequeñísimas conchas calizas.»

De un fenómeno análogo, ocurrido en febrero de 1908, se conserva en Tenerife vivo recuerdo.

Durante este temporal de polvo llegó la densidad de la nube a ser tal, que podía mirarse el sol directamente sin la menor molestia. Los edificios eran invisibles a un centenar de metros y la costa se ocultaba a los barcos, que tenian que navegar con grandes precauciones y haciendo sonar constantemente sus sirenas. A pesar de todas las precauciones, el buque francés Flachat se perdió en un acantilado de la costa de Anaga. 
Seguramente que los que viven en Canarias, si revisan las colecciones de la prensa local y los archivos de los Municipios, vendrán en conocimiento de otras muchas caídas de polvo.

Nosotros tenemos noticia indirecta de otra anterior a las mencionadas. En efecto; entre los materiales traidos por mi malogrado maestro D. Francisco Quiroga cuando su excursión al Sahara occidental, figura una «tierra llovida en la noche del 22 de febrero de 1883 en Tenerife. Donativo del farmacéutico de Santa Cruz, Sr. SERRA».

Con las noticias recogidas de algunos periódicos, con las que particularmente nos ha comunicado el Sr. CABRERA y con una descripción del temporal coincidente publicada en la revista Iberica por el ingeniero gengrafo encargado del (Ohservatorio de Lzaña, Sr. Junco, podremos rehacer con bastante precisión las circunstancias en que se verificó el fenómeno (1).

El período de temporal abarca desde el 7 de febrero hasta el 10 de marzo, correspondiendo su mayor intensidad al 18 de febrero. En ese períndo llovieron en Izaña 562 milimetros, cifra supurior a la lluvia total de cualquiera de los dos años anteriores. El viento sopló constantemente del serrundo cuadrante. con velocidader de los últimos grados de la escala internacional telegráfica.

Las precipitaciones terrosas, al menos en cantidad importante, no parece que tuvieron lugar más que en los primeros días del temporal, especialmente del 8 al 11 de febrero. Acaso los materiales transportables se agotaron en el punto de origen con la deflación ejercida durante los primeros días, y aunque el viento siguió soplando impetuoso, no halló polvos suficientemente finos para ser transportados hasta Canarias.

El día 7 , desde por la mañana se empezó a observar en la atmósfera una especie de calina, que poco a poco fué laciéndose más espesa: era, sin duda, la nube de polvo, que iba acercíndose. Dicho dia el viento alcanzí una velocidad de 85 kilometros por hora. A primera hora de la noche hubo relámpagos por diversos puntos del horizonte, y más tarde la tormenta alcanzaba a

(1) Para detalles sobre el temporal concidente, véase firanciseo del - JunCo, Los últimos temporales en Canarias. (Ivérica, ano VII, num. 32!), 22 de mayo de 1920.) 
Izaña, en el centro de Tenerife. Cayó abundante granizo, acompañado de nieve en las regiones altas y de lluvia en los niveles inferiores. Ya estas precipitaciones acuosas de la noche del 7 al 8 arrastraron considerable cantidad de polvo, pues la capa de granizo que a la mañana siguiente cubría el suelo en Izaña era de color rojizo (1).

El temporal de lluvias iniciado en la noche del 7 continuó todo el día 8, yendo en aumento a medida que el día avanzaba; la lluvia caía acompañada de granizo y empujada por vientos del cuadrante Sudeste. Por la tarde arreció el viento, llegando a adquirir velocidades de hasta 200 kilómetros por hora. Entonces el cielo se obscureció con la opacidad típica que delata la presencia de las nubes de polvo.

Los fenómenos continuaron todios con gran intensidad los días 9 y 10 , especialmente las manifestaciones eléctricas el dia 9. En los periodos en que el viento amainaba, la tierrecilla descendia, aun sin lluvia, cubriéndolo todo, especialmente en los lugares abrigados del viento. El último día la nube era tan intensa, que impedía ver los objetos colocados a unos metros de distancia. La temperatura fué subiendo a la vez que disminuía el grado de humedad de la atmósfera. El suelo, los edificios y los objetos todos quedaron cubiertos por un polvillo de color rojizo claro, y los vegetales, que los dias anteriores denotaban vigor y lozanía, se demacraron y arrugaron, pareciendo que se acercaba su fin; éste era el cuadro que, iluminado por una luz difusa y opalina, se ofrecia a la vista.

El día 11 aun siguió soplando el viento con la intensidad y dirección de los anteriores, pero por la tarde cambió primero al Sudoeste y luego al Norte, con lo que desaparecieron las nubes de polvo.

El agua de lluvia de estos dias era cenagosa, especialmente en la mañana del 11, en que, arreciando el viento en forma huracanada, invadían la atmósfera nubes de polvo de tal densidad, que repentinamente se pasaba de la iluminación natural a una luz escasa de tono rojizo acaramelado. Parece, pues, que el polvo llegaba como por oleadas de viento que obscurecian el cielo; precipitados los materiales mediante la lluvia, la atmósfera se aclaraba, para

(1) El personal del Observatorio, que está muy lejos de poblado y en sitio abrupto, se vió en grave apuro por la persistencia del temporal. Faltándoles el agua, no podian recurrir a la fusión de la nieve, porque el líquido que obtenian ofrecia el aspecto de lodo. 
obscurecerse de nuevo cuando otro golpe de viento huracanado aportaba una nueva oleada de polvo.

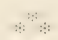

Al estudiar los materiales recogidos en estas lluvias de polvo, dos consideraciones nos importan más especialmente: la cantidad y la composición químico-mineralógica. Por la primera vendremos en conocimiento de la importancia que como agente geológico puede asignarse al fenómeno. La segunda consideración nos permitirá hacer deducciones acerca del lugar de origen de los materiales térreos.

En cuanto a la cantidad, en el caso de la caída que comentamos no puede afirmarse sino que fué excepcionalmente abundante. En primer término, nos falta el dato de la extensión del fenómeno, cuyos límites no se pueden fijar por tratarse de islas. Sabemos que también en Grain Canaria hubo lluvia de polvo, pero ignoramos si el fenómeno se extendió a las otras islas. Aun en la misma isla de Tenerife, por su accidentación extraordinaria, no es posible hacer un cálculo como cuando se trata de un territorio más o menos llano. Dificultaría además el cálculo la duracion del fenomeno (mis de curtro dias), su intermitencia y su coinplejidad. El polvo se depositaba unas veces por su propio peso, cuando el viento amainaba, mientras que en otras era arrastrado por la lluvia, la nieve o el granizo. Mucho de él sería transportado por las corrientes superficiales hacia los lugares bajos, donde se acumularía, o llevado al mar por los numerosos barrancos de la isla que en él desembocan.

El único dato positivo que poseemos es el que nos ha proporcionado D. Agustín CABRERA, quien por decantación de litro y medio de lluvia cenagosa obtuvo 2,24 gramos de polvo; es decir, próximamente 0,75 gramos por litro. Si este agua hubiera sido recogida directamente por un pluviómetro y la lluvia lubiera sido siempre igualmente cenagosa, calculando el agua caida det 8 al 11 de febrero, resulta una precipitación terrosa de no menos de 250 gramos por metro cuadrado. Y si bien es de suponer que el agua decantada correspondiese a una lluvia de las más abundantes ell polvo, también es cierto que hubo precipitaciones secas que 110 se han tenido en cuenta en el anterior cílculo.

De todos modos, se entrevé que la cantidad de polvo dopositada por este temporal es enorme, suguramente medible por bastantes 
millones de toneladas. Recuérdese lo que decimos anteriormente respecto a la tempestad de nieve del Wisconsin, en que la cantidad de polvo precipitado no es más que de 5 gramos por metro cuadrado. En el caso más notable de que tenemos noticia - una lluvia de polvo habida en Westfalia en 1855-, la tierra depositada llegó a 30 gramos por metro cuadrado, cifra muy inferior, de todos modos, a la de nuestro caso. Bien es verdad que en estos dos ejemplos del Wisconsin y Westfalia parece tratarse de una precipitación única, realizada de una vez, mientras que nuestro cálculo se refiere a un periodo de precipitaciones abundantes, de más de cuatro dias.

En cuanto a los caracteres del material precipitado, el sedimento que me remitió $\mathrm{D}$. Agustín CABRERA aparece como un polvo impalpable, de color canela (rojizo-amarillento), que tizna los dedos, ligero, insípido y que da un tenue olor de arcilla cuando se le humedece. El polvo obtenido decantando el agua de lluvia y el recogido directamente sobre el suelo no presentan al exterior diferencias apreciables. Únicamente que éste es un poco más obscuro y menos fino que aquél, diferencia que se explica por su mezcla inevitable, por mucho cuidado que se haya puesto en su recolección, con los materiales del suelo.

Los ensayos químicos realizados sobre una pequeña cantidad de la muestra denotan la presencia de silice abundante, pero no en exceso; en la porción soluble en clorhídrico hay hierro y potasio abundantes, alumina y cal en cantidad menor, sobre todo esta uiltima, e indicios de materia orgánica. La tierra ensayada es una mezcla del sedimento obtenido por decantación del agua de lluvia y el recogido en la superficie del suelo.

Aunque estos datos no permitan deducir una consecuencia precisa acerca de la roca de donde provenga el material ensayado, sí nos permiten excluir desde luego las arenas siliceas del Sahara, en que naturalmente se piensa de primera intención.

La presencia de la cal, la sílice y el hierro abundante, hacen pensar desde luego en una arcilla de decalcificación como las que se producen tan frecuentemente en los estratos superiores del terciario lacustre español. Pero, por otra parte, la abundancia de álcali pudiera admitir diversas interpretaciones: podria representar el resultado de la corrasión y deflación en una roca alcalina en masa del tipogranitico, como parecen abundar en el nicleo del continente africano; también se podría pensar en el resultado de la deflación simplemente sobre un suelo de tipo desértico abundante en eflores- 
cencias salinas, por más que entre éstas suelen predominar guneralmente las sales sódicas sobre las potásicas: la abundancia con que se presenta el álcali excluye la posibilidad de que procuda simplemente de la mezcla con los materiales del suelo canario, entre los que, en efecto, abundan las rocas alcalinas. A este último origen pudieran atribuirse los indicios de materia orgánica.

En resumen: el ensayo químico, sin permitir afirmar nada concreto acerca de la roca o rocas de cuya disgregación procede el polvo llovido en Canarias, hace pensar en los efectos de alteración química, corrasión y deflación, sobre una comarca de tipo decirtico calcáreo, y, lo que es más importante, lleva a excluir la posibilidad de que el material sea originado en un desierto arenoso silíceo como es el Sahara en la mayor parte de su extensión.

No es más concluyente que el ensayo químico el examen micrográfico. El polvo aparece formado por immumerables granillos notondeados, menudisimos, que a veces se aglomeran simulando foraminíferos; pero comprimiendo el cubreobjetos se ve disociarse los diversos granos que formaban el glomérulo. Entre nicoles cruzados la masa aparece ligeramente anisótropa, con menudísimos y escasos puntos fuertemente birrefringentes distribuidos sin regularidiul. en los que por su pequeñez no puede apreciarse forma ni otro carácter más que su extinción para ciertas posiciones durante el giro de la platina.

Me pareció que estos granillos pudieran ser de calcita y, en efecto, así lo he comprobado. Sometiendo el polvo a la acción del ácido clorhídrico diluido se aprecia la efervescencia poco abundante, y observando después al microscopio el polvo así tratado se comprueba que los puntos brillantes de gran birrefringencia han desaparecido en su mayor parte.

Hay también ciertas formaciones muy finas, cilindricas o aciculares, con indicios de estructura concéntrica, que se extinguen paralela y normalmente a su longitud. Algunas de estas formaciones, entre las cilindricas, parecen constituidas de segmentos uniformes diferenciados por tabiques transversales, percibiéndose también en ellas una especie de corteza o cutícula. Los cuerpecillos aciculares recuerdan ciertas espiculas calizas; y en cuanto a los cilindros segrmentados, parece indudable su origen orgánico, por más que 110 sepamos a qué organismos puedan referirse.

He de advertir que estos viltimos cuerpecillos no los he hallado más que en el polvo recogido del suelo. También en este polvo he 
observado un corpúsculo cuadrangular. isótropo, dividido en celdillas poligonales a modo de un minúsculo ludus helmontii, que bien podría ser el esqueleto silíceo (ópalo) de un pequeño radiolario. El Sr. Cabrera me dice que por su parte, habiendo puesto en el microscopio un poco del polvo, le parece haber observado algún fragmento de foraminífero.

Demuestra la impureza del polvo procedente del suelo la presencia de algunos trocillos de augita y de magnetita más o menos peroxidada, minerales tan abundantes en Tenerife, y que no he observado en las preparaciones hechas con polvo procedente de la decantación.

$$
4:
$$

Traídos estos polvos a Canarias siempre por los vientos del segundo cuadrante, es indudable que proceden de la región media del continente africano. Esta constancia en la dirección del viento que los transporta y la composición que el examen químico y micrográfico nos han delatado, excluye las hipótesis de que pudieran ser polvos volcánicos o meteóricos (cósmicos). Se trata, sin duda, de un polvo terrestre originado en una comarca de suelo sedimentario del continente inmediato, probablemente bajo un régimen desértico o por lo menos estepario. Cuál sea dentro de estas condiciones la región originaria, es imposible precisarlo con algún detalle. No hay que olvidar que estos vientos recorren enormes distancias y pueden, por consiguiente, ejercer sus efectos de corrasión y deflación sobre terrenos y rocas muy diversos.

Hay un fenómeno meteorológico muy conocido, el de las llamadas «nieblas'secas», que acaso guarda estrecha relación con el que estudiamos. Se presentan en el golfo de Guinea y costas ecuatoriales de África occidental, coincidiendo con vientos del Nordeste, que dominan del solsticio de invierno al de verano. Su altura no está medida, pero se cuenta por cientos de metros. Están constituidas exclusivamente por un polvo tenuisimo que parece proceder de las regiones desérticas del lago Tschad. Se presentan con una ráfaga de viento y persisten mientras la velocidad del mismo no pasa de 4 kilómetros por hora, pero desaparecen arrastradas por éste si su velocidad arrecia. $\mathrm{Si}$, por el contrario, el viento se calma, el polvo desciende, se deposita en el suelo y la atmósfera se aclara. Nada sabemos acerca de la composición del polvo que constituye estas 
nieblas secas africanas, dato que sería interesantísimo, acaso decisivo, para nuestras suposiciones.

Excluída, como hemos dicho, la posibilidad de que las lluvias de polvo en Canarias procedan de la región sahárica arenosa, y excluida también la probabilidad de su origen cósmico o volcánico, no parece aventurado suponer que son estas mismas nieblas secas del litoral Oeste africano, las que transportadas desde su punto de origen por los vientos del Sudeste. Hegan hasta $i \cdot 1$ urihinielago y en el se depositan, bien por una disminución de la velocidad del viento, bien arrastradas por los meteoros acuosos que casi siempre forman parte de estos temporales. Es decir, concretando, que el polvo que con tanta frecuencia cae en Canarias durante los temporales de invierno del Sudeste procede de las inmediaciones del lago Tschad, salvando, para llegar al archipiélago, toda la región interior de los grandes desiertos. Las regiones desérticas inmediatas al Tschad serian un centro formador de estos polvos, que los vientos del Nordeste llevan a las costas del golfo de Guinea y los del Sudeste al archipiélago canario.

Todas las circunstancias que hemos ido puntualizando parecen perfectamente concordantes con esta hipótesis, sin que sea óbice la enorme distancia que el polvo habria recorrido, no menor de 1.800 kilómetros en linea recta. Si los polvos son suficientemente tenues, pueden persistir flotando en la atmósfera y ser transportados por el viento durante mucho tiempo. Las cenizas más finas de la erupción de 1883 del Krakatoa se dispersaron por toda la tierra y permanecieron flotantes en la atmósfera varios meses, originando unos extraños fenómenos ópticos durante las puestas de sol. En la nieve caida sobre nuestro Guadarrama pudo MAC-PHERSON recoger polvo volcánico del Krakiatoa.

La conclusión a que llegamos acerca del origen de las lluvias de polvo de Canarias no puede considerarse todavia sino como una probabilidad; nos parece, sin embargo, bastante interesante para que merezca la pena de buscar las comprobaciones. Pasando los vientos del Sudeste, antes de llegar al archipiélago, por la costa comprendida entre el cabo Juby y Rio de Oro, bien se ve la conveniencia de establecer en estas colonias observatorios metenrologicos que pudieran darnos datos sobre los vientos del interior, sirviendo de estaciones intermedias para el estudio completo del fenómeno. 
EN MEMORIA DEL R. P. JOSEPH PANTEL, S. J.

\title{
OBSERVACIONES SOBRE ORTÓPTEROS ESPAÑOLES
}

\author{
POR \\ IGNACIO BOLIVAR
}

Pareciéndome un deber de justicia consagrar un recuerdo en las publicaciones de nuestra Sociedad a la memoria del que fué en vida el R. P. J. PAntel, he pensado dedicarle este trabajo, el primero que publico después de su fallecimiento, modesto, como corresponde a aquel justo varón, que tuvo la modestia por norma, por lo que sus méritos, sus vastos conocimientos científicos y su labor en pro de la Ciencia, y muy particularmente de la Entomología española, apenas si son conocidos de unos cuantos de nuestros consocios. Sin embargo, a él se deben, entre otros trabajos, dos Memorias publicadas en los Anales de esta Sociedad en un período de diez años, en los que residió en España, y que llevan por título «Contribution à l'Orthoptérologie de lEspagne centrale» (1) y "Notes orthoptérologiques» (2), que pueden considerarse como el modelo más acabado y perfecto de lo que deben ser esta clase de trabajos destinados a contribuir al estudio de un grupo de animales, en los que la enumeración de las especies va acompañada de interesantes observaciones sobre su habitat y biología. Entre ellas, merece citarse la que se refiere a la armadura de las patas y al abortamiento de las alas de los Nemobius, en las que descubre y describe un órgano nuevo, probablemente tactil, constituido por la espina primera de la arista interna de las tibias posteriores de los machos, que por ir acompañada de una modificación de la última espina de la misma serie, constituye el primer ejemplo, que habia pasado inadvertido

(1) Anales de la Soc. Esp. de Hist. Nat., t. XV, 1886.

(2) Ibid., t. XIX, 1890, y t. XXV, 1896. 
hasta entonces, de una diferenciación sexual en los referidos circanos de estos animales; las relativas al huevo del Ameles abjecta Cyr. (Spallanzanio Rossi), cuya dehiscencia no se verifica cumo en tos de los otros mántidos conocidos, así como la facultad de saltar de estos insectos, acerca de la que hace curiosas experiencias, y las no menos interesantes sobre la estridulación de los edipodinos; debiéndosele al propio tiempo el descubrimiento de notables génerin y especies de ortópteros de la Peninsula, tales cumm el frenero fornmantis, hallado por primera vez en Uclés, que hizo rectificar el área geográfica de la Fischeria baetica, relegándola a la región oriental y excluyéndola de la central, en la que había sido incluida por haberse tomado en un principio como larvas de esta especie las del Geomantis; la Discothera (Perlamantis), cuya descripción más completa, debida al P. PANTel, se publicó en nuestros Anales; mántido famoso, descrito por GUĖRIN MExEviLle bajo este último nombre y que constituyó durante muchos años un enigma para todos los naturalistas, descubierto después en Túnez por el Dr. Bonnet y a continuación en España por PANTEL, primero, y por otros exploradores después, gracias a lo que se ha podido llegar a la identificación de esta especie. El Dociostaurus crassiusculus (Stauronotus), Ephippigera Ortegai, Gryllomorpha Uclensis, Aeolopus platypygia (Epacromia), Scyrtobaenus grallatus, Leptynia attenuata, son todas formas de las más típicas y características de la fauna española. La misma descripción de la Oedipoda collina, identificada más tarde como Oedipoda Churpentieri Fieber, ha servido para el conocimiento de una especie de las mas frecuentes en algunas regiones de España, que no era fácil de reconocer por la breve descripción original, ni aun después de haber reforzado BRUNNer su característica, debiéndose a PANTEL un estudio comparativo tan claro y decisivo, que desde entonces se hat podido reconocer esta especie en distintos paises de Europa. En casos como éste, en el que el conocimiento de una especie se debe a un autor distinto del que la dió nombre y la hizo figurar en los catálogos por una descripción insuficiente, por lo que no puede decirse que la diera a conocer, deberian tener más flexibilidad las leyes de prioridad en gracia de la justicia. Su monografia del género Gryllomorpha y el estudio sobre los fásmidos de Europa son tan perfectos, que de ellos he tomado todos los datos para el tomo de los Ortópteros de la fanna ibérica, que tengo terminado, por profesar el principio de que cuando un estudio está bien 
hecho, ¿para qué intentar variarlo, exponiéndose a que no resulte tan bien?

Pero aunque fueran los ortópteros los insectos de su predilección, quizás por los mayores elementos de estudio que aquí encontró para el de estos insectos, no por esto dejó de ocuparse en el de otros órdenes, de lo que es prueba su "Catalogue des coléoptères carnassiers terrestres des environs d'Uclés avec la description de quelques espèces et variétés nouvelles»(1), en el que da a conocer el Harpalus ibericus y la Celia sollicita y algunas variedades de otras especies, y cuando su larga permanencia en España fué interrumpida, viéndose obligado a vivir en Bélgica, se inicia en los métodos prácticos de la Histología y la Biología bajo la dirección de Carnoy y de Gilson, y aplica aquellos conocimientos al estudio biológico de un diptero que había encontrado abundantemente en España como parásito de la Leptynia, acerca del que publica un estudio completísimo titulado Le Thrixion Halidayanum Rond., Essai monographique sur les caractères extérieurs, la biologie et l'anatomie d'une larve parasite du groupe des tachinajres» (2), Memoria que mereció ser premiada por el Instituto de Francia (premio Thore). En este estudio hace gala de su paciencia de observador y de toda la habilidad necesaria para seguir las metamorfosis de un díptero parásito que se introduce en el cuerpo del fásmido de un modo harto parecido al de ciertos crustáceos cirrópodos que viven sobre los cangrejos decápodos, haciéndolo a veces también por las patas del fásmido, como éstos por las del cangrejo, y que una vez dentro van a fijarse en las inmediaciones de determinados órganos, donde permanecen como parásitos internos; pero las del Thrixion, necesitando respirar el aire libre, establecen una comunicación con el exterior mediante un aparato estigmático en que termina su abdomen, y que forma unos tuberculillos de color negro, que con tanta frecuencia se ven a los lados del abdomen de las Leptynia, y sobre los que tantas veces me llamara la atención nuestro sabio colega.

Este trabajo y otros publicados más recientemente, y que no me detengo a examinar por no ser éste mi propósito, ni fuera tarea fácil darlos a conocer en estas breves líneas, acreditan al observador sagaz, y dan patente de verdadero sabio a este hombre bueno y

(1) Anales de la Soc. Esp. de Hist. Nat., t. XVII, 1888, págs. 143-245.

(2) La Cellule, t. XV, 1899. 
modesto en cuyo honor las escribo, que, si son harto breves y concisas para dar cuenta de la importancia de toda su labor, bastan para demostrar que su nombre debe figurar entre los de los más preclaros naturalistas que han contribuido al progreso de la Ciencia en general, y particularmente al de la Entomología española.

El R. P. Joseph PANTEL ha muerto en Toulouse el 7 de febrero de 1920 , a la edad de sesenta y siete años. Habia sido agregado al Instituto Católico, en el que daba un curso de Botánica.

Sus otros trabajos, además de los citados, son los siguientes:

Sur une anomalie de Timarcha tenebricusa (Col.). (Bull. Soc. Entom. de France, 1899, p. 174.)

Sur le vaisseau dorsal des larves de Tachinaires. (Ibid., 1900, p. 258.)

Sur quelques détails de l'appareil respiratoire et de ses annexes dans les larves des Muscides (Dipt.). (Ibid., 1901, p. 57.)

A propos de la vésicule anal chez les lavves de Diptères cyclorhaphes. (Ibid., 1901, p. 168.)

Sur la biologie de Meigenia fluralis Mg. (Dipt.). (Ibid., 1902, p. 56.)

Les cellules de la lignée mâle chez le Notonecta glauca L., avec des détails plus étendus sur la période d'accroissement et sur celle de transformation. (La Cellule, 1906, 217 pp. y 8 lams.)

Caloptenus italicus $L ., v$. Wattenwyliana Pant. n'est pas synonyme de Ciloptenus ictericus Serv. (Bol. Soc. Esp. de Hist. Nat., 1908, pp. 348-350.)

Notes de neuropathologie comparée. Ganglions de larves d'insectes parasitées par des larves d'insectes. (Le Neurax, 1909.)

Sur les organes rudimentaires des larves des Muscides. (C. R. Ac. Sc., Paris, 1909, pp. 107-110.)

Sur l'unification du nombre de segments dans les larves des Muscides. (Ibid., 1909), pp. 233-236.)

Recherches sur les Diptères ì larves entomobies. - I. Caracteres parasitulogiques aux points de vue biologrique, ètholonique et histologiume. (l.al Cellule, 1910.) - II. Les enveloppes de l'(2uf arec leurs dipendances. les dégats indirects du parasitisme. (Ibid., 1913.)

Précisions nouvelles sur la région postirieure du vaisseau dorsul des Muscides et particulurités remarquables de cette rigion chez la lurve de Ceromasia rufipes Mgy. (Lil Cellule, 19)14.)

Signification des rglandes annexes. inlestinules des larves des l'tyelupteridae et observations sur les tubes de Mulpighi de ce's Nimatucires (larves et adultes). (Ibid., 1914, pp. 3!13-42!!.)

Notes orthopterologiques. - VI. Le evemer sous-anal. n'est pus le -litillateur", élude des segments abdominaux et principalement du segment terminal des mâles, chez les Phasmides. (Am, Suc. Entom. de lranow, 1915, ip. 173-213.) 
Sur le genre Clonopsis, nov. gen. Orth. Phasm. (Bull. Soc. Entom. de France, 1915, p. 95.)

Note biologique sur Rhacodineura antiqua Fall. (et non Ceromasia rufipes B. B.), Tachinaire parasite des Forficules. (Ibid., 1916, p. 150.)

A propos d'un Anisolabis ailé. Contributions à l'étude des organes du vol et ses sclérites thoraciques chez les Dermaptères, données pour l'intelligence du macroptérisme exceptionnel. (Mem. R. Acad. de C. y A. de Barcelona, t. XIV, 1917, 3, 160 pp., pl. 1-6. Texto francés y español.) Description de Carausius nouveaux (Orth. Phasm.) et notes sur les Carausius de l'Inde méridionale. (Ann. Soc. Entom. de France, 1917, p. 267.)

Notes additionnelles sur les Carausius de l'Inde. (Ibid., 1917, p. 575.)

Sur le nombre des stades postembryonaires chez les Phasmides. (Tidskr. v. Ent., LXII, 1918.)

Le calcium dans la physiologie normale des Phasmides. (C. R. Ac. Sc., Paris, t. CLXVIII, 1919, p. 127.)

Le calcium, forme de réserve dans la femelle des Phasmides. (lbid., 1919.)

Rôle du calcium dans la minéralisation du noyau des cellules excrétrices chez les Phasmides (lbid., 1919, p. 318.)

J. PANTEl et E. LiCENT. - Remarques préliminaires sur le tube digestif et les tubes de Malpighi des Homoptères supérieurs. (Bull. Soc. Entom. de France, 1910, p. 36.)

J. PAntel et R. DE Sinéty. - Sur l'évolution de l'acrosome dans la spermatide du Notonecte. (C. R. Ac. Sc., Paris, t. CXXXV, pp. 1124-1126.)

Sur l'origine du Nebenkern et les mouvements nucléiniens dans la spermatide de Notonecta glauca. (Ibid., pp. 1359-1362.)

Sur l'apparition de mâles et d'hermaphrodites dans les pontes parthénogénétiques des Phasmes. (Ibid., 1908, pp 1358-1360.)

Réaction chromutique et non chromatique de quelque's Phasmides (Orih.) aux excitations dépendant de la lumière. (Bull. Biol., t. LH, 1918.)

\section{I.-IAS HOLOLAMPRAS DE ESPAÑA}

Las pequeñas blatas que forman este grupo viven en el campo entre la maleza o debajo de las piedras. De las especies españolas, la primera conocida fué la subaptera (Rb.), pues la sardea y la trivittata, descritas con anterioridad por SERVILLE, se han encontrado en España posteriormente. A ellas se han añadido más tarde la carpetana (1873), la virgulata (1878) y la baetica (1887), y recientemente ha venido a aumentar ef numero otra especie que denominaré Panteli, ya que la describo en esta ocasión.

Pero la descripción más completa de la $H$. subaptera se debe a PANTEL, que dió a conocer el macho y la ooteca. 
Hay entre las especies de Hololampra una que difiere notablemente de todas las demás, primero por la coloración, que es de otro tipo enteramente distinto, pues en vez del gris pizarroso, yue puede variar hasta el negro intenso, con diversas partes del cuerpo, como el pronoto y los segmentos abdominales, elegantemente marginadas de blanco o marfil, que es la coloración corriente en estos animales, rara vez degenerada en un amarillo pajizo uniforme; en la trivittuta (Serv.) el cuerpo es de un amarillo brillante y estáa adornado con
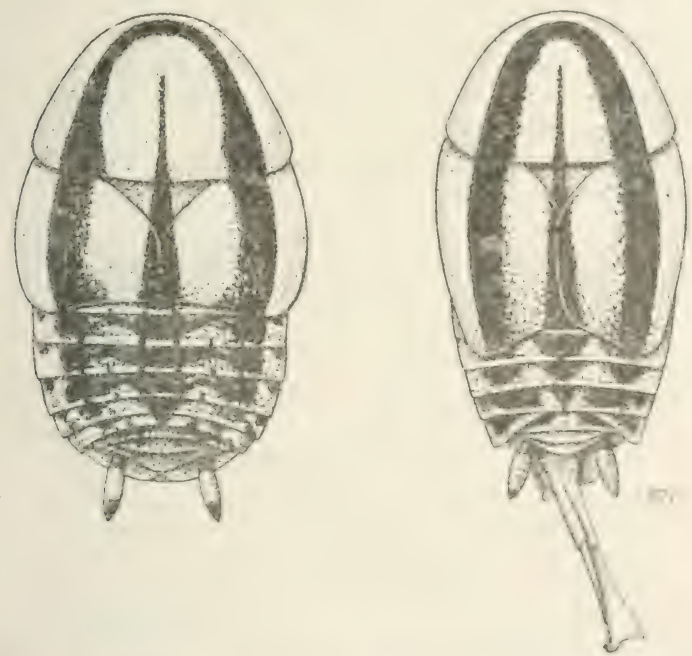

Figs. $x$ y 2.- Molulampra (Lamprella) triviltata (Serv.), hembra y macho. $\times 9$,

tres fajas de un negro intenso que recorren los lados y el centro del pronoto (figs. 1 y 2) y se extienden sobre los élitros. Diferencias de forma de varios de sus órganos concurren a determinar una caracteristica propia para esta especie que la separa de las restantes. Así, los élitros no sólo alcanzan en el macho el máximum de. desarrollo que pueden tener en el género, sino que se superponen el uno al otro por el borde interno, mientras que en las otras espe- 
cies son cuando más contiguos si están bien desarrollados (1), y en su extremo están truncados y escotados en arco de una manera bien visible. Son además córneos, con la superficie lisa y brillante, como pulimentada, de modo que no se distinguen eii ellos las nerviaciones como en los de las otras especies; y la placa subgenital es rectangular, más larga que ancha, y está provista de un solo estilo impar y tuberculiforme en el macho adulto. En la hembra el sexto segmento dorsal es entero. En atención a estas y otras diferencias de menor importancia, creo que la $H$. trivittata debe separarse de las restantes especies en 1 nn subgénero aparte, para el que propongo el nombre de Lamprella, en atención a la brillantez y lisura de sus tegumentos. La Lamprella trivittata es un insecto mediterráneo que hasta ahora ha sido hallado en Cerdeña, Argelia, Marruecos y en España, pero sólo en Sevilla, y que conserva cuando adulto una coloración que no deja de presentarse en algunas especies de otros géneros, sobre todo en estado de larva, como sucede en la Ectobia Panzeri Stephens, por lo que se ha citado varias veces del centro de España por el hallazgo de larvas de la Ectobia citada.

Por el siguiente cuadro podrán distinguirse las especies españolas:

Cuadro para la distinción de las especies españolas del género Hololampra.

A. Con élitros lisos y córneos, en los que no se distinguen las nerviaciones; truncados oblicuamente y algo escotados en el extremo; superpuestos por el borde interno, más cortos en la hembra, en la que queda al descubierto gran parte del abdomen. Coloración amarilla con tres fajas negras longitudinales. (Subgén. Lamprella nov. S. g.) ........................... H. trivittata (Serville).

AA. Con élitros coriáceos traslụcientes, en los que se distinguen más o menos las nerviaciones; diversamente desarrollados, pero a lo sumo contiguos por el borde interno. (Subgén. Hololampra s. str.)

B. Élitros contiguos por el borde interno en ambos sexos, extendidos sobre la base del abdomen.

C. Élitros lanceolados, cubriendo casi todo el abdomen............. ............................. sardea (Serville).

(1) Elytra cornea, abdomen tegentia, in margine interno haud incumbentia, vel abbreviata vel lobiformia, lateralia, venis vix indicatis, ha dicho BRUNNER caracterizando el género. (Véase Prodromus der Europäischen Orthopteren, pág. 37.) 
CC. Élitros subcuadriláteros, truncado-redondeados por detrís.........

BB. Élitros lobiformes, muy separados entre si, laterales.

H. baetica (Boliva!).

D. Élitros más anchos que la faja pálida del pronoto.

E. Disco del pronoto variado.

F. Pronoto con dos fajas y tres vírgulas negras; élitros con el borde interno recto en la base, anguloso y oblicuo después............ ........................... virgulata (Bulivar).

FF. Pronoto con el disco negro y con un rasgo pálido longitudinal en el medio; élitro con el borde interno oblicuo descle la base......... ............................ H. Panteli nov. sp.

EE. Disco del pronoto negro brillante, rodeado de la margen pálida.....

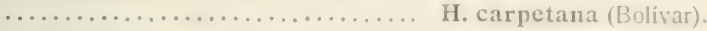

DD. Élitros tan anchos como la faja pálida del pronoto y no más largos que el mesonoto ................ H. subaptera (Rambur).

\section{Hololampra Panteli nov. sp.}

Coloración negra brillante, variada de blanco y gris. Cabeza y palpos negros; el vértex algo rojizo. Antenas negras. Pronoto con los lados estrechamente redondeados, así como los del meso- $y$ metanoto; el primero negro brillante, con una margen blanca muy ancha a los lados, estrechada hacia adelante y mucho más a lo largo del borde posterior, donde a veces llega a desaparecer; esta margen suele presentar a los lados algunos puntos pardos esparcidos; la gran mancha negra que ocupa casi todo el disco del pronoto no se redondea a cada lado, como en otras especies, sino que tiene sus ángulos bien aparentes, y en el medio presenta una línea blanca o de un gris blanquecino que no llega al borde anterior y que se ensancha algún tanto por detrás, incluyendo un pequeno rasgo negro y algunos puntos confundidos a veces en otro rasguitu en (4) tercio posterior. La coloración del meso- y metanoto es parecida a la del pronoto, pero más anchamente interrumpida en el medio la porción discal por un espacio blanquecino moteado de pardo, que suele desaparecer en el metanoto.

Élitros lobiformes en ambos sexus y laterales, de forma triangular; en el macho pasan ligeramente del borde posterior del metinoto, pero no en la hembra, en la que súlo llegran a tucar a dicho borde; en la base son más anchos que la faja blancil lateral del pronoto, y en el ápice están obtusamente redondeados; su borde externo es de un blanco de marfil, y en el resto son grisícuos y a vices 
punteados de pardo. Estos órganos están un poco extendidos horizontalmente a lo largo del borde externo, por lo que parecen algo acanalados longitudinalmente. Patas variadas de negro y gris amarillento, más claras en la hembra, y con el primer artejo de los tarsos pálido en la base.

Abdomen grisáceo, tirando a negro en los machos, y más claramente punteado de pardo en las hembras; en los primeros el borde posterior de los segmentos lleva una margen pálida, y lateralmente dan lugar a que aparezca continuada la margen pálida que rodea todo el cuerpo.

En los machos (fig. 3) el abdomen se estrecha rápidamente hacia atrás, y los cercos son negros por completo. Los tres últimos segmentos abdominales son más pequeños y de
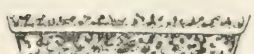

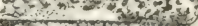

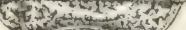

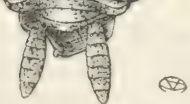

Fig. 3.- Extrenidarl (1, ab)domen de la Melalioutral Panteli nov. sp., visto por encima. (Bastante aumentado.) menor anchura que el resto; el séptimo está obtusamente escotado por detrás; el octavo tiene el borde recto, y el noveno es obtusamente anguloso y mucho más pequeño, asi como la placa supraanal, que, por el contrario, es ligeramente redondeada.

En las hembras el abdomen se ensancha hacia atris primero, para luero estrecharse rápidamente, resultando ovalado, con la mayor anchura al nivel del sexto segmento; el séptimo es semejante a los precedentes y escotado en arco por detrás; el octavo es muy pequeño y transverso, y el noveno, así como la placa supraanal, son ligeramente arqueados por detrás. Los cercos son pálidos, con la base y el ápice negruzcos.

La placa subgenital es asimétrica, truncada oblicuamente en el macho y provista de un solo estilo, y en la hembra, grande y redondeada por detrás, como en las restantes especies.

Longitud: $\sigma^{7}, 5,5 \mathrm{~mm}$; , , 6,2 mm.; de los élitros: ơ , 0,9 mm.; , $0,85 \mathrm{~mm}$.

Localidad: Cala!, en la provincia de Huelva; Badajoz (Uhagón!); Algeciras!, en la provincia de Cádiz.

El ejemplar procedente de Algeciras es un macho de tamaño algo mayor $(6,5 \mathrm{~mm}$.), con el mesonoto totalmente negro en el medio, y con el sexto segmento del abdomen algo elevado y ligeramente escotado por detrás; rugoso a los lados, lo que puede atribuirse al mayor tamaño y consiguiente robustez. 
II. - OBSERVACIONES SOBRE EL PRIONOTROPIS FLEXUOSA (SERV.)

KIRBY ha restablecido (1) el nombre genérico que encabeza estas líneas por su prioridad sobre el de Cuculligera, por lo que la única especie española que encierra deberá en lo sucesivo denominarse como queda indicado. Son insectos notables porque reunen a la vez dos clases de órganos productores de sonidos, como lo ha hecho observar el P. PANTEl en las publicaciones de esta Sociedad (2); pues además de la placa o escudete abdominal que DE SAUSSURE reconoce (3), como antes lo habian hecho Graber (4) y KraUSS (5), como el órgano cantor de los eremobinos existe en esta especie, como en algunas otras de la misma tribu, una disposición especial de las venas alares, en combinación con el borde dorsal de las tibias intermedias, que obran a manera de arco de violín sobre la cara inferior de la vena axilar posterior cuando el ala se halla extendida, y que por su disposición manifiesta bien el uso a que está destinada, como con más detalle puede verse consultando el trabajo de PANTEL ya citado, y también otro anterior del mismo autor (6), que conviene recordar para mejor conocimiento del asunto.

Esta especie, mimética como casi todos los edipodinos, presenta una coloración semejante a la del terreno en que vive, y que varía del gris ceniciento al ocráceo claro, por lo que respecta al tono general de ella, que no siempre es uniforme, puesto que las más de las veces es resultado de manchas diversas, unas pardas, otras claras y hasta de un blanco de cal, que contrasta con la coloración del fondo.

Pero no es sólo la coloración lo que varía de unos a otros ejemplares, sino también la forma y escultura de las diversas partes del

(1) Syn. Catal. of Orthopt., t. III, 1910, pig. 283.

(2) Notes orthoptérologiques. (Anales de la Soc. Esp. de' Hist. Nat., t. XXV, 1896, paig. 95.)

(3) Addit. ad Prodr. Oedipodiorun, paig. 114. (Lieneve, 1885.)

(4) Die tympanalen Sinnes apparate der Orthopteren, pigs. 37. (Wien., 1875.)

(5) Dic Orthopteren. Fauna Istriens. (Sitzun!bb, der Akad. der Wiss., pág. 491. Wien., 1879.)

(i) Contribution it l'Orthoplerologie de l'Espagne centrale'. (Anales de la Soc. Esp. de Hist. Nat., t. XV, Irsli, pigr. 273.) 
cuerpo, y muy principalmente de la cabeza y del protórax. Así, la primera puede tener liso o rugoso el escudete del vértex y hasta con granillos o tubérculos, y su prolongación anterior puede ser más o menos cóncava en la base, o rodeada de areolas o fositas impresas, hundidas, sin contar las temporales, cuya forma es también variable. Más polimorfo es aún el protórax, pues se extiende a ve-

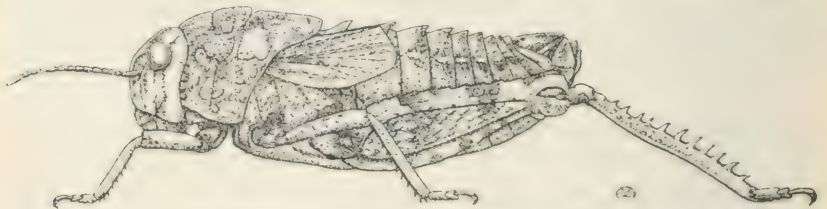

Fig. 4-Prionotropis flexuesa (Serv.), var. Peresi Bolivar; ejemplar hembra visto de lado. $\times \mathrm{I}^{1 / 2}$

ces por detrás considerablemente, terminando en ángulo agudo por encima de los élitros, mientras que otras termina en ángulo recto u obtuso, existiendo ejemplares en los que en realidad puede decirse que es redondeado. La quilla media, vista de lado, aparece recta en

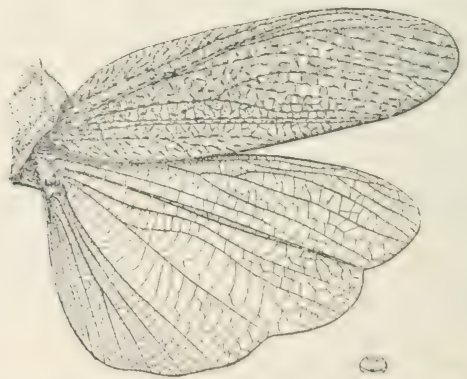

Fig. 5. - Ala del macho del Prionotropis fexuesa (Serv.), var. I'eresi Bolivar. $\times 2$.

unos y arqueada en otros, ya en toda su extensión o bien en una sola de las dos porciones en que está dividida. Un ejemplar macho de Montarco se distingue porque tiene la cresta de la prozona escotada, de modo que resulta dividida, la de todo el pronoto, en tres lóbulos, disposición excepcional que no he visto reproducida en ningún otro; y en cuanto a la escultura de estas diversas partes se ven 
análogas variaciones, pudiendo llevar a veces algunas series de granos tuberculiformes a lo largo del borde posterior del pronoto. Estas diferencias dan por resultado que si se examinan ejemplares sueltos procedentes de localidades lejanas entre sí, es casi seguro que han de encontrarse entre ellos diferencias más o menos manifiestas, que podrán conducirnos a la suposición de que pertenecen a especies diferentes, encontrándose a veces estas diferencias hasta en los que conviven en un mismo terreno.

No es de extrañar, por tanto, que asi haya sucedido y que yo haya descrito en 1873, con el nombre de Cuculligera Perezi, una variación en la que las patas posteriores presentaban un bello color purpúreo en los machos, que en las hembras se cambia en violeta. Verdad es que en aquella época era poco conocido este insecto, y que SERville habia dado como carácter específico del mismo la existencia de una gran mancha negra sobre la placa esternal, que no tenian mis ejemplares ni podian tenerla; pues según ha reconocido Brunner, la tal mancha era debida al mal estado del ejemplar típico por su defectuosa conservación. BRUNNER, en su obra (1), se sirvió de los ejemplares que yo le envié para la descripción de este insecto, sin que se le ocurriera sospechar que correspondiesen a una forma distinta del tipo, por lo que la coloración de la cara interna de los fémures posteriores sería, según él, purpúrea, y no azul como dice SERviLle (2). "Cuisses postérieures avec leur face interne presqu'entièrement noire; leur dessous bleuâtre au coté interne:, y luego "le dessus des jambes et la face interne bleuâtre», dando lugar esta confusión a que el P. L. NAvás haya creado su variedad azurea, que se confunde con el tipo, mientras que la de patas purpureas es la que constituiría variedad, o sea mi C. Perezi! Por iguales causas, o sea por la variabilidad extremada del insecto, este último autor ha considerado como de una nueva especie unos ejemplares, que ha descrito con el nombre de cupucina, cuyas diferencias con los demás entran dentro de las variaciones posibles de la especie, y aun pudiéramos anadir de las no extremas, como he podido comprobar por los ejemplares que generosamente me ha cedido el autor, asi como por el examen de los tipos.

Entre las variaciones más significadas por la coloración - pues por lo que respecta a la forma y al tamano son tantas las difuren-

(1) Prodromus der Europäischen Orthopteren. (Wien., 1852.)

(2) Insectes Orlhopt., 183!! 
cias, hasta entre los ejemplares de una misma localidad, que no hay medio de llegar a formar agrupaciones naturales - se encuentran las de los procedentes de Muela de San Juan y de Albarracín (Teruel), que a su coloración llamativa de flor de azufre, que a veces se extiende por todo el cuerpo, y que cuando menos forma una estrecha margen a lo largo del borde posterior del pronoto, unen otros caracteres, como el color de la cara interna de las patas posteriores, que es de un azul casi negro en la base, sobre el que destacan las espinas posteriores por su hermoso color de azufre. Estas espinas son además muy comprimidas, sobre todo las externas, que son muy anchas en la base, hasta el punto de que su longitud apenas llega a ser vez y media la de la anchura en aquélla. Esta variedad me parece que merecería ser designada con un nombre, y para ella propongo el de sulphurans, rẻcordando el que el P. PANTEL dió a una variedad semejante de la Oedipoda collina o Charpentieri.

Asi considerada esta especie, a la vez polimorfa y policlora, y dando nombre tan sólo a las variaciones más notables y constantes, podría establecerse así su sinonimia:

\section{Prionotropis flexuosa (Serville).}

Eremobia flexuosa Serville, Ins. Orth., 1839, pág. 709.

Thrinchus flexuosus Fischer, Orth. Europ., 1853, pág. 419.

Cuculligera flexuosa, var. azurea Navás, Bol. Soc. Arag., t. III, 1904, págs. 193-194.

\section{Var. Perezi Bolivar.}

Cuculligera Perezi Bolivar, Ort. Esp., 1876, pág. 159, lám. 3, f. 22-25; An. Soc. Esp. Hist. Nat., t. V, 1876, pág. 365, lám. 12, f. 22-25. Cuculligera flexuosa Brunner, Prodr. Eur. Ortlopt., 1882, páginas $178-179$.

Cuculligera capucina Navás, Loc. cit., 1904, paig. 193, fig. 194.

Var. sulphurans mihi, nov. var.

Las dos variedades se distinguen del tipo de este modo:

FORMA TíPICA. - Patas posteriores en su lado interno, de color azul cobalto en ambos sexos, casi negro en la base y espinas tibiales grisáceas. Del Sur de la provincia de Teruel.

Var. sulphurans. - Lado interno de las patas posteriores, de color azul muy obscuro, como en el tipo, con las espinas de las tibias amarillas de azufre y las del lado externo muy cortas y comprimi- 
das, anchas en la base; su longitud alcanza sólo vez y media la anchura basal. El cuerpo, más o menos amarillo de azufre. Muela de San Juan (Teruel). Esta forma podria decirse que era una variación amarilla del tipo.

Var. Perezi.-Patas posteriores en su lado interno, de color purpúreo en los machos y de un hermoso color violeta en las hembras, con las espinas tibiales de coloración grisácea y alargadas, las del lado externo dos o dos veces y media tan largas como anchas en la base, engrosadas liasta el tercio apical y ripidamente adelgazadak hasta el ápice, el que apenas es negro o lo es muy brevemente. Es la forma más esparcida en la Península.

\section{III. - LOS NEMOBINOS EUROPEOS}

Del interesante y minucioso estudio hecho por el P. PANTEL, que dejamos mencionado, acerca de estos insectos, resultó en evidencia, por lo que toca a la armadura de las patas posteriores, que el Nemobius sylvestris se separa de los otros por la carencia de toda especie de diferenciación sexual en las espinas de las tibias posteriores, así como por ser diclıas espinas lisas, y desprovistas, por tanto, de los dientecillos que tienen en sus aristas en las otras especies, observándose lo mismo en los espolones. Estas diferencias se acentúan si se observa que aquella especie pertenece a un tipo alar distinto, en el que el apterismo es un carácter de raza, diferencia que el P. PANTEL, después de un estudio muy interesante que revela la sagacidad de su autor para apreciar pequeñas diferencias y comprender su importancia, ha expresado brevemente, condensando sus observaciones diciendo que dicha especie y las que con ella convienen en los referidos caracteres son esencialmente ápteras», mientras que las otras dos especies europeas, / /e?deni Fischer y lineolatus Brullé, "son esencialmente aladas".

EI P. PANTEL dedujo de sus observaciones que aquella especie deberia colocarse en un género nuevo, pero su escasa afición a crear divisiones taxonómicas le llevi a aplazar el hacerlo para cuando pudiese revisar las especies exóticas del grénero. Yo he realizado después el pensamiento del P. PANTEL, por haber estudiado muchas especies exóticas y haber visto confirmadas las previsiones de acpuel ilustre sabio, y he designado con el nombre de Iromemolnius ol grupo del sylvestris, siquiera no le haya admitido sino como sul)- 
división del Nemobius; pero como la importancia de las observaciones referidas ha hecho camino en mi ánimo desde entonces, y haya llegado a creer que en realidad debe aceptarse por completo la proposición de PANTEL de separar aquella especie en un género distinto, propongo que a la nueva agrupación taxonómica se la designe con el nombre de Pantelinus, en recuerdo del que señaló los caracteres diferenciales, que justifican la creación de este género, debiendo añadir que este cambio de nombre está justificado porque el de Pronemobius que le di en un principio había sido ya empleado para un insecto fósil por SCCUDER, según me ha hecho observar M. CHOPARD, a fin de que lo cambiara, atención que, aunque natural y propia de la consideración que debe existir entre colegas, es siempre digna de agradecimiento. El Vemobius sylvestris pasará en lo sucesivo a denominarse Pantelinus sylvestris (Fabr.).

\section{LA SIGNIFICACIÓN MORFOLÓGICA DE LOS NESSELZELLSTIELE DE LAS MEDUSAS}

(NOTA PREVIA)

POR

\section{SALUSTIO ALVARADO}

La selectividad que el método tano-argéntico de AchúcarroRío Hortega muestra hacia determinadas estructuras protoplásmicas, nos ha permitido revelar la significación de ciertas formaciones vistas por los naturalistas desde hace mucho tiempo en las medusas, y cuyo valor morfológico había escapado a los numerosos autores que se preocuparon de la estructura de estos animales. Nos referimos a los llamados Nesselzellstiele, es decir, pedúnculos de las células urticantes.

Estos pedúnculos, que en muchas medusas se pueden observar con ayuda de los más vulgares y menos selectivos métodos histológicos, y aun en preparaciones sin teñir, a causa de su gran refrige- 
rancia, son en una especie observada por nosotros, la Olindias Mïlleri, gruesos bastones ( $h$ ), localizados en los montículos de los tentáculos del animal, que desde la región basilar del ectodermo, ocupada por los fascículos musculares (fig. 1, a), ascienden, siguiendo una trayectoria ligeramente ondulada y en ocasiones casi recta, hasta el tercio superior del epitelio, donde terminan, debajo de una

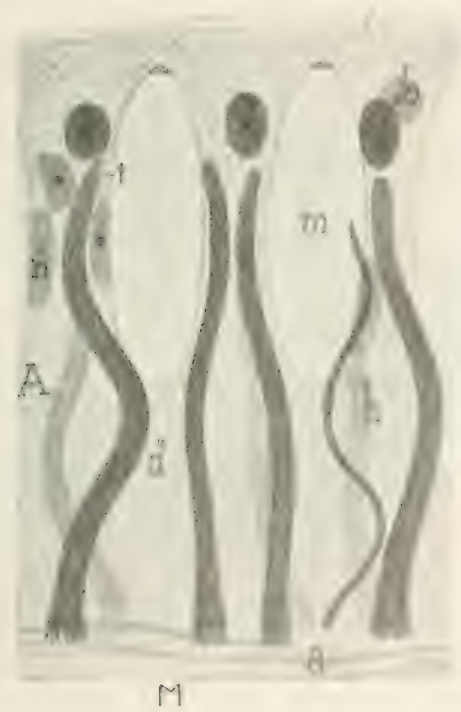

Fig. 1. - Corte de la región culminante, nematncistoria, de un monticulo de un tentáculo de Olindias Mïlleri: M, mesoglea; 1 , ectodermo; $d$, capa muscular; d. capa epitelial; $b$, núcleos de las células epiteliales; $c$, cuticula de las mismas; m, nematocistos; $t$, nematoblastos; $n$, núclen de los nematoblastos; h. pedinculos de los nematoblastos (Nesselacllstiele). (Método tano-argéntico.)

región puramente protoplasmatica ocupada por numerosos miclens ovoideos o redondeados (b), que son los nucleos de las ceihlas de revestimiento del ectodermo. Los pedinculos, en sil curso ascensional, pasan a los lados de las células urticintes $(t, m)$, a las yue se adhieren y abrazan intimamente.

Estos pedúnculos fueron considerados como especiales forma- 
ciones de sostén (Stiitzgebilde) por HAMANN (1882), LENDENFELD (1897), Iwanzoff (1896), K. C. Schneider (1897). En cambio, ChL'N (1891-92), Wille (1909), Murbach (1893-94), K. C. SCHNeIDER (1890-92), TOPPE (1910) y KRASINSKA (1912-14) les atribu-

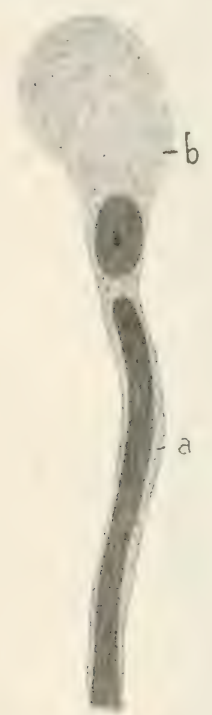

Fig. 2. - Una célula de sostén de los nematoblastos, exhibiendo su región apical de protoplasma indiferenciado (b), donde yace el núcleo y la región basal transformada en un grueso fasciculo de epiteliofibrillas, rodeado de una envuelta (a) de protoplasma normal. El fascículo epitelio-fibrilar es un Nesselzellsticle. (Método tanoargéntico.) con el objeto de mantener fijas en lo alto retrocedan y destrocen el epitelio. Cada pedúnculo va, en efecto, rodealo de una delgada vaina protoplásmica $(a)$, que es una prolonHADZI (1909) en ellos se hermanarian las propiedades elástica y muscular.

Nuestras investigaciones prueban que si en efecto los pedúnculos de las células urticantes son fisiológicamente formaciones de sostén, como creyeron los autores citados en primer lugar, a todos se les escapó por completo el valor morfológico que esos pedúnculos tienen, pues no lograron homologarlos con ninguna diferenciación protoplásmica conocida.

Mediante el método tano-argéntico, nosotros hemos podido confirmar en los pedúnculos una estriación longitudinal, ya apreciada por los autores que nos precedieron, y demostrar que ella es debida a que los pedúnculos están formados por la aglutinación en fascículo apretado de numerosas fibrillas elementales, fácilmente observables en la región basilar, donde los pedúnculos se descomponen en sus fibrillas integrantes, para insertarse en la mesoglea $(M)$ por una base más ancha.

En muchos cortes, en que la acción de los reactivos y la navaja operaron una delicada disociación de los elementos del epitelio (fig. 2), se aprecia que los Nesselzellstiele de Olindias no son otra cosa que las regiones basales de ciertas células de revestimiento del epitelio tentacular que han sufrido una curiosa diferenciación filar yen un carácter muscular. Finalmente, para 
gación del protoplasma apical indiferenciado (b) de la célulat. Estas células portadoras de los pedúnculos merecen, pues, el nombre de células de sostén de los cnidoblastos, y están alternando con otras de protoplasma normal, indiferenciadas, que son las verdaderas células de revestimiento. Los núcleos ( $b$, fig. 1) yacentes en el tercio superior del epitelio tentacular de Olindias Mülleri pertenecen, por lo tanto, a dos categorías de células: las de sostén de los

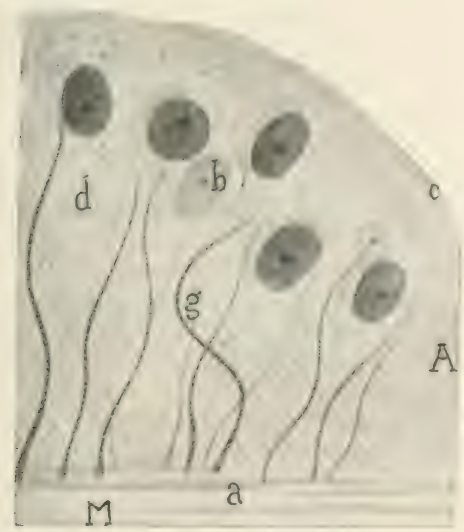

Fig. 3. - Corte de la regrión lateral, sin nematocistos, de un montículo de un zentáculo de Olindias Miilleri: $M$, mesnglea; $d$, ectodermo; $a$, capa muscular; $d$, jurotoplasma de las células de revestimiento; $b$, sus núcleos; $c$, cuticula; $g$. cjoituliofibrillas. (Método tano-arééntico.)

nematoblastos con sus vesiculas urticantes y las de revestimiento del ectodermo.

Por su aspecto y propiedades frente al método tano-argéntico, los Nesselzellstiele no son más que epitelio-fibrillas de tipo ascendente, homólogas a las que en tantas células epiteliales han sido objeto por parte de RIO-HORTEGA de un magristral estudio (1).

Nuestra opinión viene a ser apoyada por la observación de otras

(1) P. del RIo-llorteas, Contribución al conocimiento de las ipiteliofibrillas. (Trab. del Lab. de Inv. Biol. de la Universidad de Madrid, I. XV. 1917.) 
regiones del ectodermo donde los pedúnculos faltan. Asi, por ejemplo, en los bordes (fig. 3 ) de los citados montículos tentaculares se aprecia, mediante el método citado, la existencia en una masa protoplásmica granulosa (d) de epitelio-fibrillas ascententes $(g)$, de regular grosor, que por una parte recuerdan las epitelio-fibrillas de epitelios de otros animales, y por otra remedan en pequeño los pedúnculos. Un tránsito casi insensible entre estas epitelio-fibrillas y los pedúnculos es fácil de apreciar recorriendo un corte longitudinal de un tentáculo, y además no es raro encontrar en los montículos nematocísticos pedúnculos muy delgados que se parecen enormemente a las mais gruesas epitelio-fibrillas de la region normal. (Compárense las figuras 1 y 3.)

Por lo tanto, los Nesselzellstiele son fascículos epitelio-fibrilares enormemente desarrollados con objeto de formar un potente aparato de sostén a los cnidoblastos, que les mantenga fijos en lo alto del epitelio y evite que durante la descarga de la vesícula urticante la conmoción producida desgarre el epitelio.

Por estas razones constituyen dichas formaciones una elegante confirmación de las ideas de nuestro maestro Rio-HORTEGa sobre la fisiología de las epitelio-fibrillas.

Gerona, enero de 1921.

\section{ÍNDICES DE ALGUNOS CRÁNEOS PREHÍSTÓRICOS Y ANTIGUOS DE ANDALUCIÁ}

POR

\section{FRANCISCO DE LAS BARRAS DE ARAGÓN}

En el año de 1896, y en colaboración al principio con D. Manuel Medina Ranos, emprendimos en Sevilla la medición de varios cráneos prehistóricos en su mayor parte, y fuimos dando cuenta de los resultados de nuestros trabajos en forma de notas insertas en las Actas de esta Real Sociedad.

Despues hemns continuado midiendo y publicando, especialmente desde que, establecida la hoja craneométrica del Congreso de Mónaco en 1906, tuvieron las medidas una norma fija. 
Con arreglo a esta hoja hemos procurado recientemente revisar los cráneos medidos entonces, y de los que son muy pocos los que han desaparecido. También agregamos datus de alsunos de ciue hemos tenido conocimiento más tarde.

En esta revisión sólo nos proponemos dar los índices, acompañados del mayor número posible de noticias, sobre localidad, lugar en que actualmente se conservan, etc.

Agrupamos los cráneos en cuestión, por sus procedencias.

C'nera de la Mnjer, en Alhama de Gramada. - Sabido es que fué estudiada por D. Guillermo MAc-Pherson; quien publicó el resultado de sus exploraciones en Cádiz en 1870-1871. Una porción de restos humanos encontrados en ella fueron regalados por el mismo Sr. Mac-Pherson al Museo de Historia Natural de la Universidad de Sevilla, donde se conservan. Nuestra primera nota sobre ellos está en el tomo de Actas de la Sociedad Española de Historia Natural de 1896.

Don Carlos Cax̃al, en su Sevilla prehistórica (1894), se refiere a ellos en la página 205, considerándolos como una de las representaciones de la raza de Cro-Mlagnon en España. Nuestro maestro D. Manuel Antón, en su Programa razonado de Antropologia, página 26, considera como raza aparte, con el nombre de $<$ Raza de Alhaman, a la que dejó sus restos en la Cueva de la Mlujer, y de ello se hace eco el distinguido antropólogo D. Luis DE Hoýn en la página 123 de su Etnografia: clasificaciones, prehistoria y razas americanas. (Madrid, Romo y Fusel, 1900.)

Los indices que hemos obtenido nosotros son los siguientes:

Cráneo casi completo, marcado B. - Indices: cefilico, 75,28; cefálicovertical, 74,15 ; vérticotransversal, 98,50 ; frontal, 82,14 ; frontoparietal, $18,(15 ;$ agujero occipital, 85,71 ; nasal, 47,72 ; orbitario, 74,33 ; palatino, 75,55 ; maxiloalveolar, 101,88.

Calvaria incompleta. - Suturas empezando a usificarse. Un wormiano en la coronal. Marca A, núm. 1. Cefílico, 74,35; frontal, 80,95; rama mandibular (casi seguramente de este críneo), 55,55.

Calvaria muy incompleta. - Con las suturas casi osificadas. Esti par. tida en dos trozos por la región occipitoparietal derecla; la rotura es antigua. Marca 1: Cefalico, 78,39 .

Cráneo marcado num. 165. - Emppiezan a osificarse las suturats. Paltan el temporal, parte del parietal izquierdo y los maxilares. Tienc algnnos wormianos. Cefálico, 72,19 ; cefalicovertical, 83,99!; verticotransiele Sal, 114,81; frontal, 83,19; fronteparietal, 73,33 . 
Maxilares superiores con los nasales, marca núm. 5.- Nasal, 58,53 ?; palatino, 75,47; maxiloalveolar, 97,50.

Maxilar superior, marca a. - Palatino, 56,52; maxiloalveolar, 100,00. Maxilar superior, marca b. - Palatino, 60,41; maxiloalveolar, 98,33.

Mandibula inferior, marca $F$, núm. 14. - Indice de la rama ascendente, 55,73 .

Mandibula inferior, marca $F$, núm. 7. - Indice de la rama ascendente, 56,15 .

Mandibula inferior, marca a, núm. 13. - Dentición completa; molares bastante gastados, algunos con picaduras. Índice de la rama ascendente, 53,57 .

Ordenando en serie aquellos indices de que tenemos tres o más, resulta :

Índice cefálico, 72,$19 ; 74,35 ; 75,18 ; 78,39$.

Indice frontal, 80,$95 ; 82,14 ; 83,19$.

Índice palatino, 56,$52 ; 60,41 ; 75,47 ; 75,55$.

Índice maxiloalveolar, 97,5^; 98,33; 100,00; 101,88 .

Índice de la rama ascendente mandibular, 53,$57 ; 55,55 ; 55,73 ; 56,15$.

Yacimiento prehistórico de Carmona. - De él proceden los cráneos de la colección PELÁEz, que hoy se encuentran en el Museo Arqueológico Municipal de Sevilla. Estos cráneos, aunque en la colección no tienen indicaciones concretas de localidad, fueron exhumados de los túmulos que tan numerosos son cerca de la ciudad de Carmona. Si observamos un mapa de la región, como los que acompañan a las obras de los Sres. CAÑAL (citada) y CANDȦU, Prehistoria de la provincia de Sevilla (Madrid, Victoriano Suárez, 1894), pero principalmente la de este último, veremos que entre los rios Guadaira y Corbones existe una serie de alturas formadas por terreno terciario, que empieza en Alcalá de Guadaira y termina en Carmona. Estas alturas, llamadas alcores, fueron morada del hombre prehistórico, que dejó en ellas muchos depósitos de sus restos e industria.

En realidad, existen en Carmona restos de pueblos distintos, como puede comprobarse por los objetos que han dejado. Como dice D. Anatael CABRERA en su Memoria titulada Una excursión a los yacimientos prehistóricos de Carmona (1), los túmulos de los predios denominados Soldado y Acebuchal, que con algunos otros exploró el Sr. PELÁEZ, contienen unos restos francamente

(1) Anales de la Soc. Esp. de Hist. Nat., t. XXIII, 1894. 
paleolíticos, de tipo chelense y solutrense; otros son neoliticos, con objetos de piedra pulimentada, y por último, hay también tumulus de la edad del cobre.

Dice el Sr. Cañal (Sevilla prehistórica, pág. 52): «En unos túmulos, en los que no se han hallado más que objetos de piedra, los cadáveres están sentados o acurrucados con la cabeza junto a las rodillas. En otros, correspondientes al periodu de transicion de la piedra a los metales, pues en ellos se encuentran alerunos uhjeton de esta. última clase, los cadáveres se encuentran completamente tendidos en la misma dirección de la cavidad en que están colocados, y ellos siempre miran al Oriente. A medida que los túmulos contienen instrumentos de metal en vez de los de piedra, del mismo modo va desapareciendo la inhumación, que comienza a ser substituída por la cremación, la cual domina por completo en los que pertenecen fijamente al período del cobre.»Como vemos, se encuentran reunidas sepulturas de épocas diferentes, pudiendo esto explicar la mezcla de razas a que se refiere el Sr. Hoyos en la página 122 de su libro Clasificaciones, prehistoria y razas americanas.

No hemos de dar detalles que pueden verse, además de en las obras citadas de los Sres. Candáu y Cañal, en las Nuevas exploraciones de yacimientos prehistóricos de la provincia de Sevilla, de este último, inserta en los Anales de la Sociedad Española de Historia Natural, t. XXV.

El mismo Sr. CAÑal consigna en su libro dos indices cefálicos de 76,3 y 77,7 de otros tantos cráneos de la colección PELAEz.

Nosotros hemos procurado reunir la mayor cantidad posible de medidas en los cráneos que nos ha sido posible estudiar en el Ayuntamiento de Sevilla, si bien las numerosas roturas han impedido formar series completas :

Cräneo marcado núm. 4.- Suturas osificadas. fndices: cefálico, 74.86i; cefálicovertical, 72,72; vérticotransversal, 97,44; frontal, 77,96; frontopalrietal, 65,71; agujero occipital, 92,30; nasal, 62,22; orbitirio, 95,23.

Cráneo marcado núm. 8 (núm. 1 ant.). - Deformado post mortem por una presión que obró de lat parte izquierdat del frontal a la derecha del occipital. Indices : cefálico, 78,80; cefálicovertical, 70, ti5; vérticotransversal, 89,65; frontal, 84,06; frontoparietal, 74,78; agujero uccipital, $77,77$.

Cráneo marcado num. 5. - fndices: cefílico, 79,12; cefilicovertical, 76,92; vérticotransversal, 97,29; frontal, 75,42; agujero occipital, 822,14.

Cráneo marcado mum. 7 (X). - Mluy deformado post mortem peor presión lateral. Suturas no osificadas. W Wormianos en lat necipitoparictal. 
Índices : cefálico, 72,19; cefálicovertical, 74,86; vérticotransversal, 140,74?; frontal, 79,54; agujero occipital, 82,83.

Cráneo marcado núm. 1 (X). - Perforación en el parietal izquierdo. Gran deformación post mortem por presión lateral sobre los parietales. Índices : cefálico, 70,63; frontal, 82,60.

Cráneo marcado núm. 2. - Suturas en estado normal de adulto. Con mandíbula inferior. Índices : cefálico, 77,01; frontal, 73,21; rama mandibular, 45,70 .

Cráneo marcado núm. 3. - Suturas no osificadas. Índices: cefálico, 77,54; frontal, 73,77 .

Cráneo incompleto, marcado núm. 9 (núms. 7 y 8 ant.). - Parte de los lutesos de la cara con la mandibula inferior. Dientes algo gastados en las coronas. Índices: palatino, 75,00; maxiloalveolar, 95,77.

Cráneo marcado núm. 6. - Está completamente aplastado. Suturas no osificadas. Con mandibula inferior. Los dientes bien conservados, buen esmalte y coronas algo desgastadas. Índice de la rama mandibular, 74,91 .

Dispuestas en serie las medidas de que hay más de dos, resulta:

Índice cefálico, agregando las dos que inserta el Sr. CAÑAL, 70,63; 72,$19 ; 74,86 ; 76,30 ; 77,01 ; 77,54 ; 77,70 ; 78,80 ; 79,12$.

Índice cefálicovertical, 70,$65 ; 72,72 ; 74,86 ; 76,92$.

Índice vérticotransversal, 89,$65 ; 97,29 ; 97,44 ; 140,74$.

Indice frontal, 73,$21 ; 73,77 ; 75,42 ; 77,96 ; 79,54 ; 82,60 ; 84,06$.

Índice del agujero occipital, 77,$77 ; 82,14 ; 82,83 ; 94,30$.

Yacimiento de El Coronil. - Se verificó el primer descubrimiento de restos prehistóricos en 1888 , plantando una viña a tres kilómetros de esta villa, en el sitio llamado La Aguzadera. Fué el yacimiento estudiado por D. Manuel SALES y FERrÉ y D. Salvador CALDERÓN, nuestro querido maestro, quien dió cuenta de él en la Sociedad Española de Historia Natural (Actas, t. XVIII, 188!), pácinas 23, 24, 31 y 39). Los Sres. CAÑal y CANDÁU, en las obras citadas, se ocupan de él, especialmente el Sr. CANDÁU, quien en la página 99 dice: "Bastantes restos humanos han sido extraídos de las excavaciones, mas por desgracia ningún cráneo completo hemos podido obtener, siendo esto tanto más de lamentar, cuanto que solamente en este hallazgo habria de fundamentarse el conocimiento que pudiéramos tener de la raza a que pertenecian los primitivos pobladores de la comarca.» En la misma página trae el Sr. CANDÁu el fotograbado de "un frontal de bastante espesor que presenta arcos superciliares muy desarrollados; la mandibula de la figura 69 (pá- 
gina 100) es robusta, de poco prognatismo dental, muy ahierta en su parte superior y con el hueso de la barba rudimentario, y la tibia (fig. 70, pág. 191) es platicnémica, 10 mismo que un trozo de otra tibia, que no se dibuja. Como vemos, algunos de estos huesos ofrecen caracteres atávicos de la raza de Canstad, y a ella los referiríamos si otras consideraciones no lo impidieran, permitiéndonos, a lo sumo, este hecho deducir la existencia de una influencia, más fuerte aquí que en otras partes, de caracteres étnicos anteriores: .

Considera el Sr. CANDÁU «que se trata de una necrópolis», y la naturaleza de los objetos encontrados «indica que la edad a que pertenecen es a la del bronce, probablemente en sus comienzos, dada la abundancia de instrumentos neoliticos».

Luego, en la página 102, añade el Sr. CANDÁU: "Creemos que no cabe atribuir a otra raza que a la de Cro-Magnon la construcción de esta necrópolis, fundándose este juicio en los caracteres de los huesos encontrados, y principalmente en la forma platicnémica de las tibias».

Nosotros hemos podido medir solamente dos calvarias existentes en la Universidad de Sevilla, y el resultado es el siguiente:

Cráneo incompleto, marcado núm. 14. - Es muy incompleta. Conserva el frontal dividido por sutura. Indices: cefálico, 77,95 ; frontal, 78,12 ; frontoparietal, 86,96; palatino, 57,14; maxiloalveolar, 93,75; rama mandibular, 53,22 .

Calvaria incompleta, marcada núm. 14 bis. - Indices : cefálico, 79,48; frontal, 75,83; frontoparietal, 64,51 .

P'eñaflor, Mina Preciosa. - De ella procede un cráneo impregnado por sales de cobre que con otros huesos fué encontrado por el ingeniero D. Antonio Gonzílez y Garcia de Meneses, quien lo regaló al Museo de Historia Natural de la Universidad de SeviIla, juntamente con un mazo de piedra encontrado con ellos. El señor CANDÁU se ocupa de este descubrimiento en la página 43 de su obra citada. También lo hace el Sr. CAÑal en la $141 \mathrm{y}$ siguientes de la suya, trayendo además figuras que representan el craineo y el mazo.

Nosotros hemos obtenido los indices siguientes :

Cráneo marcado núm. 16\%. - Impregnado de sales de cobre. Suturas empezando a osificarse. Falta lat región occipital y la mandibula inferior. Indices: cefálico, 79,06; frontal, 77,27; frontoparietal, $(22,50)$; nasal, 47,(1), orbitario, 87,50; palatino, 90,24; maxilualveolar, 114,8!?. 
Hornachuelos. - Cráneo marcado $\mathrm{Br}$., recogido por el señor BRIOUDE, quien lo posee. Procede de una sepultura que, con otras, se halla excavada en roca granítica y cubierta con varias tejas de pizarra.

Suturas no osificadas. Índices: cefálico, 75,54; frontal, 79,50; frontoparietal, 69,13 .

\section{Andújar. - Calvaria incompleta encontrada por D. Enrique CONDE.}

Suturas de osificación muy avanzada. Índice cefálico, 81,60.

C'ádiz. - El descubrimiento del conocido sepulcro antropoide de la Punta de la Vaca y otras sepulturas no lejanas a Puerta de Tierra, continuado ordenadamente en estos últimos años por el notable arqueólogo D. Pelayo Quintero, ha dado por resultado el hallazgo de otras muchas sepulturas, y en ellas, de algunos cráneos en condiciones de ser medidos. Conocidos son los trabajos y publicaciones de tan distinguido investigador (de los que sólo citaremos aquí la Guia del turista, Cádiz, 1912), al cual debemos el haber podido publicar las notas insertas en el Buletin de la Real Sociedad Española de Historia Natural, t. XII, 1912, pág. 564; t. XIV, 1914, pág. 415, y t. XVII, 1917, pág. 574.

Cráneo correspondiente al esqueleto del sepulcro antropoide de la Punta de la Vaca, que se conserva en el Museo Arqueológico Provincial de Cádiz. - Falta la mandibula inferior. Indices : cefálico, 77,77; cefálicovertical, 77,72 , vérticotransversal, 99,28 ; frontal, 83,76 ; frontoparietal, 70,00 ; frontocigomático, 92,12; facial de Mónaco, 50,39; nasal, 51,92; orbitario, 80,00; palatino, 83,33; maxiloalveolar, 103,00; agujero occipital, 81,57 .

Esqueleto descubierto en octubre de 1912. - Suturas sin osificar. Indices : cefálico, 79,45 ; frontal, 88,88 ; frontoparietal, 70,74 ; nasal, 52,77 ; palatino, 82,00; maxiloalveolar, 106,89 .

Cráneo encontrado detrás de la cortina del glacis, junto al sitio llamado Los Corrales. - Índices : cefálico, 76,59 ; frontal, 76,85; frontoparietal, 64,68 .

Cráneo del grupo principal de sepulturas descubierto detrás de Puerta de Tierra. - Suturas osificadas. Dentición completa. findices : cefálico, 75,00 ; frontal, 80,73 ; nasal, 47,05 ; orbitario, 80,95 ; palatino, 76,59 ; maxiloalveolar, 105,40. 
Reuniendo en serie aquellos indices de que tenemos más de dur. resulta :

Cefálico, 75,00; 76,$59 ; 77,77 ; 79,45$.

Frontal, 76,$85 ; 80,73 ; 83,76 ; 88,88$.

Frontoparietal, 64,$68 ; 70,00 ; 70,74$.

Nasal, 47,05; 51,92; 52,77.

Palatino, 76,59; 82,00; 83,33.

Maxiloalveolar, 105,40;106,00; 106,89.

\section{EL PaRaíso de las ORquídeas OFRIDEAS EY ESPAÑa}

POR

\section{VICENTE MARTINEZ GÁMEZ}

La presente nota tiene por objeto dar a conocer a nuestra Sociedad las orquideas encontradas en las excursiones botánicas que durante los meses de febrero, marzo y abril del año pasado realizamos, con nuestros alumnos de Historia Natural del Instituto de Cádiz, al pintoresco y accidentado pinar de las canteras de Puerto Real, lindo y aseado pueblecito de esta provincia.

Por el número y diversidad de especies encontradas se verá con cuánta razón hemos bautizado esé deliciuso sitio con el simpático nombre de Paraiso de las Orquideas; porque polemos asegrurar, sin temor a ser desmentidos, que no existe región alguna en nuestra Península donde en un kilómetro cuadrado, escaso, de extensión superficial - que es lo que, calculando grosso modo, asignamos al referido pinar - existan tantas orquideas, no sólo por el número, sino, y principalmente, por su casi increfble variedad.

Júzguese por estos datos:

El género (Ophrys presenta en la totalidad del suelo iberico doce especies conocidas, y nosotros hemos encontrado mueve (speculum, fusca, iricolor, lutea, Bombyliflora, apifera, Arachnites, scolopax y tenthredinifera), y abrigamos fundadamente la esperanza de que en excursiones sucesivas hemos de encontrar tambion la arunifera, que recuerda la forma de una tarántula.

El género Serapias cuenta con cuatro especies (lingua, ocul- 
tata, longipetala y cordigera), y las cuatro las hemos encontrado alli; además hemos recogido el Aceras anthropophora y los Orchis papilionacea, morio, var. picta, saccata y longicruris.

En total, diez y ocho especies. ¿En qué región de España, en ana extensión igual, ocurre caso semejante? Por lo tanto, el calificativo de Paraiso de las Orquideas con que bautizamos ese pinar de Puerto Real, está bien justificado.

Téngase en cuenta, además, que sólo hemos herborizado cuatro veces durante unas horas en los meses de febrero, marzo y abril: tomábamos el tren mixto para Madrid, que sale de Cádiz a las trece y cinco minutos, y regresábamos en el correo descendente, que pasa por Puerto Real a las diez y nueve. De haber podido hacer excursiones de mayor duración, tal vez hubiésemos encontrado algunas especies más. Herborizando a principios de verano y después de las primeras aguas del otoño, quizás pudieran multiplicarse los hallazgos.

No hemos encontrado, ciertamente, ninguna especie nueva para la Ciencia; pero hemos dado con la Ophrys iricolor, citada hace un siglo por el botánico francés DesfonTAINES, en la serranía de Ronda, y que sin duda poquísimos de nuestros botánicos profesionales habrán visto viva jamás, y desde luego, que sepamos, nadie la ha citado en esta región por nosotros explorada. Es, por lo tanto, un hallazgo interesantísimo, que vale por una especie nueva. Sólo encontramos dos ejemplares.

El curiosísimo Orchis longicruris, espléndidamente representado en el pinar-cogimos unos veinte ejemplares -, y que nadie hasta la fecha lo habia citado de este punto, reproduce con tal perfección la silueta de un mico ahorcado, en alto la cabeza, como cubierta por los pétalos laterales, bien patente y manifiesto el cuello, y péndulos brazos y piernas, de entre las cuales arranca una colita ligeramente flexuosa, que de no verlo, difícilmente cabría sospechar que existan plantas con flores de esa indole.

De todas las especies encontradas, particularmente del género Ophrys, conservamos hermosos dibujos o láminas a la acuarela, para un trabajo que publicaremos en breve, donde aparecerá la descripción de las mismas con toda minuciosidad y lujo de detalles, y que si sale a medida de nuestros deseos, será, positivamente, del agrado de los aficionados al estudio de plantas tan singulares como las orquídeas. 


\section{NUEVOS FENÓMENOS DE FOTOTROPIA}

POK

JOSÉ RODRIGUEZ MOURELO

Aunque los hechos, objeto primordial del presente estudio, observados por mi mismo repetidas veces, no caigan de lleno dentro de los dilatados dominios de la Geoquímica, con ella guardan ciertas relaciones, no muy inmediatas ciertamente, pero si de analogia, por referirse a particulares acciones directas, muy poco estudiadas, no sobre cuerpos de composición constante y definida, sino sobre muy particulares disoluciones o diluciones, conteniendo, en una gran masa de contadas substancias, levísimas proporciones de otras calificadas de activas, al respecto del fenómeno aqui tratado. Conviene a mi propósito, primeramente, precisar su categoría y definirlo con toda la posible claridad.

Mucho tiempo hace que MARCKWALD señaló el hecho de varias substancias dotadas de la singular propiedad de cambiar su color mediante la sola influencia de la luz directa, y a tal hecho llamó fototropia. Eran cuerpos orgánicos y no muy numerosos, de complicada estructura molecular, pertenecientes a la serie quinoleica casi siempre. Al parecer, no significaba el cambio de color variaciones profundas de la estructura molecular, y en caso de haberlas, debian ser pasajeras y levísimas, por cuanto el hecho, a lo menos en la mayoria de los casos, era revertible. Apenas cesaban las acciones directas de la iluminación intensa, causa de la variente de color, cl cuerpo recobraba el suyo primitivo, quedando apto para volver a cambiarlo. Había algunos pocos, sin embargo, en los cuales el dicho cambio de coloración era seguro indicio de transformación más profunda de la molécula orgánica, y aun a las veeces de la destruccion del cuerpo fototrópico, como si sus enlaces se rompieran y los fragrmentos uniéranse luego de diferente manera. P'or de contado, el fenómeno representaba nueva acción quimica de la luz, concretadit al principio a los cuerpos en los cuales MARCKWM.D habialo obser- 
vado. Tales fueron los comienzos de un interesantísimo capítulo de la Fotoquímica, relacionado, conforme luego veremos, con los fenómenos de fluorescencia y de luminescencia, ahora tan estudiados.

Bastante después aparecieron los interesantes trabajos de STOBвE, con el descubrimiento de aquellas substancias denominadas fúlgidos. Son cuerpos orgánicos diversamente constituídos, con funciones variables, casi nunca sencillas, de complicada estructura molecular. Todos gozan la notable propiedad de cambiar de color mediante intensa y directa iluminación; pero distínguese unos de otros y se diferencian por la manera de producirse el fenómeno de la fototropia. En algunos de estos fúlgidos, como en el caso general de la fluorescencia, el cambio de color sólo es notado mientras actúa la luz directa del dia; pues en cuanto cesa, el cuerpo recobra la primitiva y propia coloración, quedando apto, por tiempo indefinido, para nuevos cambios, en apariencia a lo menos, independientes de su constitución química; es el mismo hecho observado por MARCKWALD con su característica de la revertibilidad. Otros fúlgidos, empero, sólo mudan su color una vez mediante las influencias de la luz, y ello implica modificaciones químicas más o menos intensas y cambios de estructura de su molécula; dícese entonces, y se demuestra, que su fototropia es irrevertible. Y existen varios en los cuales el hecho, con todas las apariencias de la reversión, preséntanlo irrevertible, y así, son llamados fúlgidos seudorrevertibles. Por donde resultan tres especies de fototropia características, de seguro relacionadas con la constitución de los cuerpos que las presentan.

No se ocultó a STOBBE, ya desde los comienzos de su copiosa labor, cuanto pudiera haber de análogo entre este fenómeno y otros muy conocidos relativos a la absorción de las radiaciones luminosas por substancias variadisimas, con producción de manifestaciones externas, a veces considerables, como las de la luminescencia o fosforescencia. Mas en el hecho de la fototropia, el cambio de color, como en la fluorescencia la emisión de luz, implica algo con justicia calificado de superficial y transitorio, en cuanto,"en uno y en otro caso, cesan los efectos en el momento de suprimir la radiación que los produjera, y ello era, por de pronto, una caracteristica para diferenciar la fototropia de la fosforescencia. Podía constituir otra la complicación molecular de las materias fototrópicas, y el ser todas de naturaleza orgánica.

Consecuencia del descubrimiento de los_fúlgidos, y aún mejor 
de sus variaciones en los modos de ser fototrúpicos, fué el estudio de la fototropia irrevertible y de su mecanismo, en cuanto implicaba un cambio quimico, a veces profundo y total. Prestabase a semejante estudio el fúlgido trifenílico, y se observú, en primer término, cómo las acciones de la luz, o mejor las acciones químicas a ella debidas, de las que el cambio de color es inherente, no son instantáneas, y la molécula del cuerpo no se altera y modifica de una vez, sino por fases, de las cuales se han determinado tres por lo menos. En la primera el fúlgido, muy sensible a las acciones de la luz, cambia de color sin aparentes alteraciones quimicas. Con nueva iluminación preséntase la segunda fase, en ciertos casos manifestada por cierto acrecentamiento de la sensibilidad. En la tercera sobreviene la inercia más absoluta y el fúlgido queda destruido, constituyendo así uno de los más claros ejemplos de fenomenos irrevertibles. Tal mecanismo presenta la singularidad de tornarse blanco, a su fin. el cuerpo que lo presenta, y blanco permanece luego indefinidamente en presencia de la luz.

Otros estudios de muy diversa indole y otras doctrinas ahora muy en boga asignan a la luz - mejor dijéramos a las radiaciones - papel muy primordial en lo tocante a las acciones quimicas, generalizando lo antes atribuido a particularisimas y especificas propiedades de las luminosas. Dentro del sentido modernisimo cabe pensar una forma especial de obrar en los fenúmenos irrevertibles en que intervienen, sean o no fototrúpicos: en ellos - y es ejemplo el fúlgido trifenílico - la luz es a modo de un explosivo; cuando menos provocan sus energías cierta explosión molecular, bastante para reducir a completa inercia aquella sincular sensibilidad delatada en los cambios de las coloraciones, generalmente sin relación con las peculiares de los cuerpos fototrópicos, en cuanto al tono y a la intensidad. Como en otros casos - el de la sintesis del aldehido fúrmico entre ellos - es la luz el agente que une firmemente los ele. mentos constitutivos de los cuerpos, aqui lus separa y disocia, acaso dándoles actividad para unirse luegro en formas nás catables, a expensas de su propia sensibilidad al respecto de las mismas radia. ciones.

Deduciase de los trabajos indicados, enlazados más o menos directamente con la polimerizacion del antrac eno - fenomeno revertible tipico debido a las directas acciones de la luz, de atris bien estudiado por L.UTHER y WriciekT -, la propiedad singular, al parecer inherente a su siempre complicada estructura molecular, que tuenen 
diversas substancias orgánicas de cambiar su color propio cuando se exponen a directa y enérgica iluminación. Y por la manera de presentarse semejante fenómeno admitianse tres especies de fototropia: la revertible, la irrevertible y la seudorrevertible. Refiérense a la primera los hechos que voy a relatar, observados en sistemas inorgánicos nada complicados, coexistiendo en algunos de ellos con otros fenómenos debidos a la luz, conocidos y estudiados desde muy antiguo; me refiero a la fosforescencia. Y he de indicar cómo casi todos los cuerpos capaces de ser impresionados por las radiaciones directas y emitir luego luz en la obscuridad, son fototrópicos, aunque algunos en grado mínimo, sin excluir la famosa blenda de Sidot, o sea la wurtzita sintética.

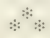

Por vez primera observé, hace algunos años, que al exponer a la luz un sulfuro de calcio, con intento de impresionarlo, cambiaba de color. Era blanco a la luz difusa, y en cuanto experimentó las acciones de fuerte y directa iluminación, sin insolación, adquirió marcado tinte rosado, cuya intensidad aumentaba y se acentuaba por momentos con tono violeta. Llevado el cuerpo a la obscuridad, lucía con intensa fosforescencia violada, y al volverlo a la luz difusa era ya blanco. Repetido el experimento varias veces, dió siempre idénticos resultados, sin observarse la menor disminución ni en la fosforescencia ni en el cambio de color; se trataba de una materia extraordinariamente sensible a las acciones de la luz, la cual manifestaba esta sensibilidad en dos formas distintas: la fotoluminescencia y la fototropia, coincidentes y con tal persistencia que se impresiona de la misma manera al cabo de veinte años de preparado el sulfuro de calcio objeto de mi primera observación, de la cual resultaba no ser privativa la fototropia de aquellas complicadas substancias orgánicas en las que primeramente habianla notado.

Entre la fototropia de MARCKivALD y de STOBBE y la por mí observada son de notar bastantes diferencias, aparte de la naturaleza orgánica y de la complicada constitución química de los cuerpos que la presentan. Primeramente la antes conocida producese, a la continua, en substancias de composición definida, función determinada e individualidad propia, y mi observación refiérese, no a una especie quimica concreta, sino al sistema de una disolución o dilución sólida singular, ejerciendo en ella de disolvente el sulfuro de 
calcio. En segundo término, yo parto siempre de cuerpos sólidos blancos, o mejor, de sistemas formados a temperatura elevada, lindante de los 1.000 grados, alterables en contacto directo y prolongado del aire húmedo, siendo muy favorable al fenómeno la oxidación incipiente y superficial del sistema, y los primeros cuerpos fototrópicos, particularmente los fúlgidos, son destructibles por el calor y a todos perjudica y transforma la elevación de temperatura.

Quise en seguida estudiar a fondo la fototropia de los sistemas inorgánicos, valiéndome de los muchos cuerpos obtenidos para mis investigaciones relativas a la fosforescencia de los sulfuros blancos, y para ello hube de emprender sistemáticas indagaciones, cuyos principales resultados pongo más adelante con los adecuados pormenores. Desde luego, procedi a experimentar con sulfuros de bario, de estroncio, de calcio y de cinc, preparados los tres primeros muy diversamente y con muy variados fosforógenos, conforme hacia tratándose de la fotoluminescencia. Todo se reducia, en substancia, a obtener la difusión de cantidades mínimas de materias metálicas, calificadas de activas, en una gran masa de los sulfuros blancos, en el acto de formarse éstos a temperatura muy elevada y con determinadas precauciones, operando siempre lo más posible fuera del contacto del aire. Resultaban masas blanquecinas por lo general, granujientas, poco duras, unas veces impresionables por la luz directa y fosforescentes en mayor o menor grado, y a la continua fototrópicas, influyendo en estas dos cualidades la naturaleza y las proporciones, siempre exiguas, del metal empleado como materia activa, el cual podia ser a la vez fototropo, conforme demuestran los experimentos más adelante relatados.

Fué siempre condición indispensable de los fenúmenos estudiados el operar con sulfuros blancos como diluyentes, y la razón está en la necesidad de tener un medio o un sistema dotado de cierta transparencia al respecto de determinadas radiaciones. Son las de mayor eficacia, tocante a la fotoluminescencia, las de menor longitud de onda, y ello se demuestra con someter una placa cubierta de sulfuro de cinc a la luz directa, poniendo encima de ella un vidrio azul o violeta, con lo cual, llevada luego a la obscuridad y separado el vidrio, fosforece con intensidad mucho mayor que no msando tal artificio y es más duradera la emisión de luz. Ademis, si cuando la fosforescencia de la placa alcanza la intensidad mixima es sumetida a las radiaciones rojas, al punto se extingue acpuilla, y en mis investigaciones he llegado a obtener sulfuros de cinc de ma sensi- 
bilidad tan extremada, que su espléndida fosforescencia se extinguia completamente en una décima de segundo por las radiaciones rojas no muy intensas. Sin esta transparencia del diluyente, exclusiva de los sulfuros blancos, no hay ni fosforescencia ni fototropia. Constituye la blancura un factor indispensable de la sensibilidad del sistema para las radiaciones en cuya virtud prodúcese el fenómeno, actuando los elementos del diluyente o de su sistema sobre los de la materia activa, que es otro sistema distinto, sea por la emisión rapidisima de electrones, como algunos quieren, en cuyo caso los de ésta reaccionarán a su vez, provocando acciones químicas nada complicadas y de carácter revertible, durante cuya reversión, nunca instantánea, emiten luz o cambian de color los conjuntos de los sistemas impresionados por ella.

Resulta siempre que en más o en menos puede decirse de las mezclas fosforescentes que todas son fototrópicas, sin ser cierta la recíproca; porque he preparado series numerosas de cuerpos fototrópicos no luminescentes, y otras en las cuales las dos cualidades aparecen a la vez bien determinadas y permanentes al cabo de bastantes años. De consiguiente, cabe admitir la fototropia como una cualidad de ciertos sistemas inorgánicos constituidos por un suliuro blanco, haciendo oficios de diluyente, y una pequeñisima cantidad de materia metálica, dicha activa o fosforógeno.

Grandemente influyen uno y otro en la fototropia, tratándose de los sulfuros de bario, de estroncio y de calcio; pero aquélla descúbrese menos cuando se estudia el sulfuro de cinc. Este cuerpo, obtenido siempre por vía húmeda y desecado a 300 grados, pues retiene fuertemente el agua y forma además numerosos hidratos definidos, tórnase en extremo sensible pará la luz luego de haberlo sometido durante algunas horas, y en crisol brascado, a la temperatura del blanco; y comparando el tono blanco del sulfuro de cinc simplemente desecado con el color del sometido al calor, vese cómo éste, sin dejar de ser blanco, ha adquirido ligerisimo tinte amarillo verdoso, el cual suele acentuarse exponiéndolo un solo minuto a la luz directa, sin insolación. Más se acentúa todavía experimentando con la blenda de Sidot, o sea el sulfuro de cinc cristalizado por vía seca, merced a un curioso y poco estudiado fenómeno de transporte. Naturalmente, mis indagaciones se dirigieron a los sulfuros de bario, de estroncio y de calcio, dejando para más tarde el de cinc, cuyo color de fosforescencia puede ser modificado, como en los otros, agregando distintos fosforógenos, todos de naturaleza metálica: cosa bien contra- 
ria a lo antes admitido, cuando se creía de absoluta necesidad y precisión, para lograr buena fosforescencia del sulfuro de cinc, su absoluta pureza química, no fácil siempre de conseguir.

Sabía por anteriores experimentos de la eficacia del bismuto en calidad de materia activa, singularmente para la fosforescencia de los sulfuros alcalino-terrosos, y muy repetidos análisis, practicados con el mayor esmero, me habían demostrado la constante presencia del manganeso en todos aquellos sulfuros de calcin dumte hathia mustow primeramente el cambio de color, cuando los exponía a la luz, que constituye la fototropia. Era preciso relacionar las proporciones mínimas eficaces con la temperatura a que obtenía los sistemas o disoluciones sólidas y al mismo tiempo apreciar, aun siendo de por sí independientes, cómo se podian afectar mutuamente la luminescencia y la fototropia. Así, logrado el determinar las condiciones del último fenómeno, podía establecerse una base o punto de partida experimental para nuevos y más concretos estudios, sin dar por definitivos cuantos he practicado.

Había que establecer el principio de la revertibilidad de cuantos fenómenos y casos - y son numerosísimos - de fotoluminescencia y de fototropia llevo hasta el presente estudiados. Ello tiene por sí mismo interés, en cuanto puede ser el fundamento de una cierta teoría química de ambos hechos, y también, respecto de la fototropia, por establecer la característica diferencial de la aquí estudiada con la observada por Marckiwald y STOBBE. Y ya dentro de Ins procedimientos experimentales, tenía sumo interés la temperatura, por cuanto, en cierta y muy amplia medida, de ella depende la sensibilidad para las radiaciones de todos los productos resultantes; y así como el calor genera la aptitud para la fosforescencia, la excesiva temperatura la anula e insensibiliza los sistemas de aquella cualidad dotados, lo cual se efectúa en el sulfuro de cinc, cuyar sensibilidad sólo se alcanza a la temperatura del blanco; pero si se sostiene demasiado tiempo, la masa del sulfuro se une, aglomera y endurece, como si experimentara un comienzo de fusión, y resulta inerte para la luz.

Tuve muy en cuenta, para preparar los sistemas fototrúpicos, cuantas enseñanzas habia adquirido en la larga práctica de mis estudios acerca de la fosforescencia, y he aqui lia manera de proceder tratándose del sulfuro de calcio : preparado el carbonato de calcio, en polvo fino, precipitando el cloruro de calcio con el carbonato de sodio, lavando muy bien y desecando a 200 grados, a cada 100 gra- 
mos de esta materia agregaba 0,1 gramo de cloruro de sodio y 0,03 de carbonato de sodio, incorporando las proporciones más abajo dichas de las materias activas. Y luego de haber mezclado algo de exceso de la proporción de azufre necesaria para formar el mono. sulfuro de calcio, calentaba, en crisoles de porcelana tapados, a temperatura variable de 700 a 1.000 grados durante cuatro horas seguidas, dejando enfriar los crisoles dentro del horno. Observaré que la temperatura está comprendida entre los límites dentro de los cuales, o no se forma el cuerpo dotado de luminescencia, aunque se genere el sulfuro, o por exceso se destruye la sensibilidad respecto de la luz y sólo la absorbe en proporciones mínimas y si fosforescescia resulta incipiente.

Inicié los experimentos partiendo, en calidad de materias activas, del manganeso y del bismuto, cuya eficacia en tal concepto teníala bien demostrada, y dispuse dos series de diez cuerpos cada una, conteniendo la primera cantidades variables y decrecientes del primero de estos fosforógenos, y asociando ambos en la segunda, con objeto de apreciar los límites de su sensibilidad. Pongo a continuación los resultados conseguidos:

\section{PRIMERA SERIE}

Un diluyente con un solo fosforógeno: el manganeso.

1. 0,1 gr. de $\mathrm{Mn}$ por $100 \mathrm{gr}$. de $\mathrm{CO}_{3} \mathrm{Ca}$. Producto blanco, en absoluto desprovisto de fosforescencia; fototropia de color rojo violáceo.

2. $0,05 \mathrm{gr}$. de $\mathrm{Mn}$ por $100 \mathrm{gr}$. de $\mathrm{CO}_{3} \mathrm{Ca}$. Producto blanco, sin fosforescencia; fototropia rosácea.

3. 0,025 gr. de $\mathrm{Mn}$ por $103 \mathrm{gr}$. de $\mathrm{CO}_{3} \mathrm{Ca}$. Producto blanco, sin fosforescencia; fototropia violácea.

4. 0,01 gr. de Mn por 100 gr. de $\mathrm{CO}_{3} \mathrm{Ca}$. Producto blanco, sin fosforescencia; intensa fototropia violácea.

5. 0,005 gr. de $\mathrm{Mn}$ por $100 \mathrm{gr}$. de $\mathrm{CO}_{3} \mathrm{Ca}$. Producto blanco, sin fosforescencia; fototropia intensísima y violácea.

6. $0,0025 \mathrm{gr}$. de $\mathrm{Mn}$ por $100 \mathrm{gr}$. de $\mathrm{CO}_{3} \mathrm{Ca}$. Producto blanco, sin fosforescencia; fototropia intensísima y violácea.

7. $0,001 \mathrm{gr}$. de $\mathrm{Mn}$ por $100 \mathrm{gr}$. de $\mathrm{CO}_{3} \mathrm{Ca}$. Producto blanco, sin fosforescencia; fototropia violácea más intensa que el anterior.

8. 0,0005 gr. de Mu por 100 gr. de $\mathrm{CO}_{3} \mathrm{Ca}$. Producto blanco, sinfosforescencia; fototropia violácea bastante más intensa que los anteriores. 
9. 0,00025 gr. de $\mathrm{Mn}$ por $100 \mathrm{gr}$. de $\mathrm{CO}_{3} \mathrm{Ca}$. Producto blanco, con fosforescencia incipiente; fototropia violáceo-amarillenta.

10. 0,0001 gr. de $\mathrm{Mn}$ por $100 \mathrm{gr}$. de $\mathrm{CO}_{3} \mathrm{Ca}$. Producto blanco, sin fosforescencia; fototropia violáceo-rojiza.

Una particularidad debe notarse, y es la persistencia de la fototropia y la ausencia de la fosforescencia, atribuible, conforme va indicado, a la temperatura a la cual los diferentes sistemas han sido generados.

Júzgolo así por haber logrado, a temperaturas convenientes, sulfuros de calcio, a la vez intensamente fosforescentes, con fosforescencia violeta y dotados de extremada sensibilidad para la luz, e intensamente fototrópicos. También se ha de notar cómo la coloración, siempre blanca, de los productos, cámbiase en rosada mediante las acciones de la luz, y adquiere tonos rojizos, y con mayror y más constante frecuencia violados, y una sola vez amarillentos. Aparece la fototropia en el preciso momento de someter los cuerpos a la influencia de intensa y directa iluminación y llega muy pronto al máximo de su intensidad, tornando al primitivo color blanco, en cuanto la iluminación intensa se suprime y se ponen a la luz difusa. Por término medio, el fenómeno, con las fases indicadas, sólo dura unos tres minutos. En cuanto a la ausencia de la fosforescencia, diré cómo viene a confirmar la independencia de ambos fenómenos, no su incompatibilidad, porque suelen presentarse juntos muchas veces.

Vese que comienza a ser sensible la fototropia cuando la proporción del manganeso es de 0,1 gr. por $100 \mathrm{gr}$. de carbonato de calcio, aumentando su intensidad, conforme disminuye la cantidad del fosforógeno, hasta la de 0,0001 gr. de manganeso por $100 \mathrm{gr}$. de carbonato de calcio, o sea hasta el último término de la serie. Disminuyendo la proporción de manganeso, la intensidad de la fototropia, lejos de aumentar, disminuye de modo muy sensible y gradual y pronto se extingue, lo cual parece indicar la existencia de unas ciertas proporciones óptimas para la producción del renóm nu a lo menos para el mismo diluyente, operando, al formar el sulfuro, en idénticas condiciones de temperatura. Cundo expmrimenus mus numerosos y precisos consientan practicar cierto linaje de medidas, será llegado el momento de enunciar la ley que ha de relacionar todos los elementos concurrentes en la fototropia y determinar. en virtud de ella, la intensidad del cambio de color y la sensibilidad 
de las materias fototrópicas en cada caso particular. Para ello, los experimentos aquí relatados pueden ser a modo de una primera aproximación. Por de contado, en ellos demuéstrase la influencia de las proporciones de la materia activa y la eficacia que en tal concepto ha de atribuirse al manganeso.

\section{SEGUNDA SERIE}

\section{Un diluyente y dos fosforógenos: el manganeso y el bismuto.}

1. 0,1 gr. de $\mathrm{Mn}$ y $0,1 \mathrm{gr}$. de $\mathrm{Bi}$ por $100 \mathrm{gr}$. de $\mathrm{CO}_{3} \mathrm{Ca}$. Producto blan$\mathrm{co}$, nada fosforescente; fototropia rojo-violácea.

2. 0,05 gr. de $M n$ y 0,05 gr. de $\mathrm{Bi}$ por 100 gr. de $\mathrm{CO}_{3} \mathrm{Ca}$. Producto blanco, sin fosforescencia; fototropia rosada.

3. 0,025 gr. de $\mathrm{Mn}$ y $0,025 \mathrm{gr}$. de $\mathrm{Bi}$ por $100 \mathrm{gr}$. de $\mathrm{CO}_{3} \mathrm{Ca}$. Producto blanco, sin fosforescencia; fototropia violácea.

4. 0,01 gr. de $\mathrm{Mn}$ y 0,01 gr. de $\mathrm{Bi}$ por $100 \mathrm{gr}$. de $\mathrm{CO}_{3} \mathrm{Ca}$. Producto blanco, sin fosforescencia; fototropia violácea.

5. 0,005 gr. de $\mathrm{Mn}$ y 0,005 gr. de $\mathrm{Bi}$ por 100 gr. de $\mathrm{CO}_{3} \mathrm{Ca}$. Producto blanco, sin fosforescencia; fototropia violácea intensa.

6. 0,0025 gr. de $\mathrm{Mn}$ y $0,0025 \mathrm{gr}$. de $\mathrm{Bi}$ por $100 \mathrm{gr}$. de $\mathrm{CO}_{3} \mathrm{Ca}$. Producto blanco, sin fosforescencia; fototropia violácea más intensa que la anterior.

7. 0,001 gr. de $\mathrm{Mn}$ y 0,001 gr. de $\mathrm{Bi}$ por 100 gr. de $\mathrm{CO}_{3} \mathrm{Ca}$. Producto blanco, sin fosforescencia; fototropia violácea más intensa que las anteriores.

8. 0,0005 gr. de $\mathrm{Mn}$ y 0,0005 gr. de Bi por 100 gr. de $\mathrm{CO}_{3} \mathrm{Ca}$. Producto blanco, sin fosforescencia; fototropia violácea más intensa que las anteriores.

9. 0,00025 gr. de $\mathrm{Mn}$ y 0,00025 gr. de $\mathrm{Bi}$ por 100 gr. de $\mathrm{CO}_{3} \mathrm{Ca}$. Producto blanco dotado de fosforescencia incipiente; fototropia amarillenta intensa.

10. 0,0001 gr. de Mn y 0,0001 gr. de $\mathrm{Bi}$ por 100 gr. de $\mathrm{CO}_{3} \mathrm{Ca}$. Producto blanco, sin fosforescencia; fototropia rojiza muy intensa.

Ya se pueden deducir algunas consecuencias de la observación de esta nueva serie. En todos los sulfuros, sin excepción blancos, hay un cierto paralelismo con los términos que ocupan el mismo lugar en la serie anterior; pero ha de notarse cómo la presencia y asociación de dos materias activas o fosforógenos parece sumarse, en cuanto contribuye a excitar la sensibilidad de los sistemas y a 
hacer más intenso el cambio de color, no pareciendo influir cosa alguna en su tonalidad. Algo análogo acontece tocante a la fosforescencia, sin embargo de notar la existencia de cierto hecho que pudiera decirse selectivo. Por ejemplo, el bismuto es el mejor fosforógeno para el sulfuro de estroncio.

Mientras todos los productos de las dos series son fototrópicos, con intensidades crecientes y presentando tonalidades muy marcadas rojizas y violáceas, sólo el noveno, en ambas, está dotado de fosforescencia tan débil e incipiente que no se puede apreciar su color, y tan poco sensibles resultan los dichos términos, que sólo al cabo de exponerlos tres minutos a intensa y directa iluminación manifiestan la cualidad de la luminescencia en su grado mínimo. Resulta asimismo ser excelente fototropo el manganeso, y lo es también en calidad de fosforógeno, conforme lo tengo bien demostrado. Asociándole el bismuto se ven exaltadas sus cualidades fototrópicas.

Al estudio de las influencias de las materias activas en la fototropia era preciso unir el de los diluyentes, a cuyo fin dispuse otras dos series de experimentos, empleando el sulfuro de estroncio, el cual fórmase a más elevada temperatura, y así fué menester calentar durante cuatro horas al rojo muy vivo, procediendo en el resto como en el caso del sulfuro de calcio.

\section{TERCERA SERIE}

Un diluyente con un solo fosforógeno: el manganeso.

1. $0,1 \mathrm{gr}$. de Mn por $100 \mathrm{gr}$. de $\mathrm{CO}_{3} \mathrm{Sr}$. Producto blanco, altgor agrisaldo, con intensa fosforescencia verde-amarillenta; leve fototropia rosícea.

2. 0,05 gr. de Min por $100 \mathrm{gr}$. de $\mathrm{CO}_{3} \mathrm{Sr}$. Producto blanco, con fusfurescencia verde-amarillenta; fototropia rosicea mis intensa que la anterior.

3. 0,025 gr. de Mn por $100 \mathrm{gr}$. de $\mathrm{CO}_{3} \mathrm{Sr}$. Producto blanco, con intensal fosforescencia; fototropia poco intensa y rojizal.

4. $0,01 \mathrm{gr}$. de $\mathrm{Mu}$ por $100 \mathrm{gr}$. de $\mathrm{CO}_{3} \mathrm{Sr}$. Producto blanco, muy fosforescente; fototropia verdosa poco intensa.

5. 0,005 gr. de $\mathrm{Mn}$ por $100 \mathrm{gr}$. de $\mathrm{CO}_{3} \mathrm{Sr}$. Producto blanco, con mury intensa y persistente fosforescencia; fototropia verdosi.

6. $0,0025 \mathrm{gr}$. de $\mathrm{Mn}$ por $100 \mathrm{gr}$. de $\mathrm{CO}_{3} \mathrm{Sr}$. P'roducte blance, poen fosforescente; fototropia verdosa, que a la luz directa se acentua $y$ anmenta. 
7. 0,001 gr. de $\mathrm{Mn}$ por $100 \mathrm{gr}$. de $\mathrm{CO}_{3} \mathrm{Sr}$. Producto amarillento, poco fosforescente; fototropia intensa rojo-amarillenta.

8. 0,0005 gr. de $\mathrm{Mn}$ por $100 \mathrm{gr}$. de $\mathrm{CO}_{3}$ Sr. Producto blanco, muy poco fosforescente; fototropia poco intensa, más acentuada por nueva iluminación.

9. 0,00025 gr. Mn por 100 gr. de $\mathrm{CO}_{3}$ Sr. Producto blanco, desprovisto de fosforescencia; fototropia rojiza poco intensa.

10. $0,0001 \mathrm{gr}$. de $\mathrm{Mn}$ por $100 \mathrm{gr}$. de $\mathrm{CO}_{3} \mathrm{Sr}$. Producto agrisado claro, sin fosforescencia; muy intensa fototropia verdosa.

No se observaron en esta serie los mismos resultados de la precedente; antes, por el contrario, las influencias progresivas de las proporciones de la materia activa no guardan relaciones de ninguna especie ni se puede deducir cosa alguna concreta y determinada, a no ser la marcada acción de la naturaleza del diluyente sulfuro de estroncio, procedente de un carbonato muy puro, obtenido tratando disoluciones de nitrato por carbonato de sodio. Al precipitado, blanco, muy bien desecado, se agregaban cloruro y carbonato de sodio en iguales proporciones que tratándose del carbonato de calcio, el fosforógeno y el azufre, y esta mezcla era calentada de la manera que queda dicho. Operando así conseguí los efectos apuntados, y como entre ellos no se veía la conexión notada operando y experimentando con el sulfuro de calcio, repetí hasta tres veces los experimentos de la serie en idénticas condiciones, y los resultados no cambiaron; por lo que infiero cómo en ellos participa la naturaleza del sulfuro de estroncio en su calidad de diluyente. Y desde luego afirmo, a la vista de cuantos experimentos acerca de la fototropia de los sistemas minerales llevo practicados - y son al presente muy numerosos -, que los más adecuados son aquellos formados por el sulfuro de calcio, resulten o no fosforescentes.

Bien se entiende la razón de preferir el manganeso, de continuo en estado de cloruro o de carbonato manganoso, en calidad de materia activa. Mis propios experimentos habian demostrado su excelencia en calidad de fosforógeno, y multiplicados ensayos me probaron su cualidad de fototropo en sumo grado y, conforme antes dije, en cuantos sulfuros de calcio observé primeramente la fototropia, encontré, sin excepción, trazas de manganeso, y los adrede exentos de tal cuerpo sólo cambian levísimamente de color cuando se les somete durante bastantes minutos a intensa iluminación directa.

Para dar por terminada esta parte de mi trabajo restaba ensayar la asociación de los dos fosforógenos, manganeso y bismuto, con el 
diluyente sulfuro de estroncio, operando en las mismas e idénticas condiciones del caso anterior del sulfuro de calcio, sólo persiguiendo el fin de apreciar los resultados inmediatos, comprobando de camino la supuesta influencia del diluyente asociado a las dos especies de materias activas difundidas en su masa.

\section{CUARTA SERIE}

Un diluyente con dos fosforógenos: el manganeso y el bismuto.

1. 0,1 gr. de $\mathrm{Mn}$ y 0,1 gr. de Bi por 100 gr. de $\mathrm{CO}_{2}$ Sr. Productı verdoso, con fosforescencia débil; fototropia rosácea muy poco intensa, que aumenta con la luz.

2. $0,5 \mathrm{gr}$. de $\mathrm{Min}$ y $0,05 \mathrm{gr}$. de $\mathrm{Bi}$ por $100 \mathrm{gr}$. de $\mathrm{CO}_{3} \mathrm{Sr}$. Producto verdoso, más claro que el precedente, muy poco fosforescente; fototropia como el anterior.

3. 0,025 gr. de Mn y 0,025 gr. de Bi por 100 gr. de $\mathrm{CO}_{3}$ Sr. Producto verdoso más claro, sin fosforescencia; fototropia como los anteriores.

4. 0,01 gr. de $M n$ y 0,01 gr. de Bi por 100 gr. de $\mathrm{CO}_{3}$ Sr. P'roductu casi blanco, con fosforescencia verde intensa; fototropia como los anteriores.

5. 0,005 gr. de $\mathrm{Mnn}$ y $0,025 \mathrm{gr}$. de Bi por $100 \mathrm{gr}$. de $\mathrm{CO}_{3} \mathrm{Sr}$. Producto blanco verdoso, con fosforescencia verde intensa; fototropia como lus anteriores.

6. 0,0025 gr. de Mn y 0,0025 gr. de Bi por $100 \mathrm{gr}$. de $\mathrm{CO}_{3}$ Sr. Producto blanco agrisado, con fosforescencia como los precedentes; fotutropia verdosa débil.

7. 0,001 gr. de $M$ n y 0,001 gr. de Bi por 100 gr. de $\mathrm{CO}_{3} \mathrm{Sr}$. Pruductn blanco, con fosforescencia verde-amarillenta; fototropia verdosa débil.

8. 0,0005 gr. de Mn y 0,0005 gr. de Bi por 10$)$ gr. de $\mathrm{CO}_{3} \mathrm{Sr}$. P'ruducten blanco, con fosforescencia como el precedente; fototropia rojiza no muy intensa.

9. 0,00025 gr. de Mn y 0,00025 gr. de Bi por 10x) gr. de Co() Sir. Producto blanco, con fosforescencia como el anterior; fototropia algo mis intensa.

10. $0,0001 \mathrm{gr}$. de $M 1 \mathrm{n}$ y $0,0001 \mathrm{gr}$. de 13i por $100 \mathrm{gr}$. de Č( $)_{3}$ Sr. P’ruducto casi blanco, con fosforescencia magnifica, verde y violeta; fotutrupia espléndida de color verde azulado muy intensal y persistente. Puede așugrtrarse alcanzado el óptimo del fenomemo, porpue repetide latsta tres veces el experimento en las mismas condiciones, los resultados fueron idemticos.

Comparando los resultados de estal serie con los de la precedente, resulta de ella algo más concreto y determinado. Tindos sus 
términos son fosforescentes con mayor o menor intensidad, siempre de color verde o verde amarillento, correspondiendo el máximo a los dos últimos, o sea a las menores proporciones de las materias activas. Es también constante la fototropia, verdosa unas veces y rojiza otras, siempre de escasa intensidad, hasta alcanzar los últimos términos, notándose el último como el más sensible e impresionable respecto de la luz, coincidiendo en él la fosforescencia máxima con la mayor fototropia, de hermoso color verde azulado, muy persistente. Parece cosa demostrada la influencia y la acción del bismuto en calidad de fosforógeno, exaltando la actividad antes manifestada del manganeso y aún diríase en cierto modo regularizándola, aunque la progresión del cambio de color y la sensibilidad para la luz no sea como la observada en el sistema del sulfuro de calcio. De todas suertes, aparecen ya bien ligadas y enlazadas las dos cualidades de fosforescencia y de fototropia; pero sin depender una de otra, antes bien, conservando su respectiva individualidad y todos sus caracteres.

Que los hechos relatados han menester mayores comprobaciones y ser objeto de investigaciones repetidas y variadas, téngolo por indudable; mas los resultados ya logrados me parece que son suficientes para admitir la existencia de la fototropia en sistemas inorgánicos sólidos, verdaderas diluciones de substancias metálicas activas, diluídas o difundidas en una gran masa de sulfuros blancos, en el acto de ser éstos formados a temperaturas relativamente elevadas. Coincide casi siempre la fototropia con la fosforescencia de tales sistemas, y la forma, color e intensidad de aquélla parecen depender, mejor que de la materia activa, de la naturaleza del diluyente. Resulta ser el manganeso el mejor fototropo; pero su actividad es exaltada por la concurrencia del bismuto, a su vez magnífico fosforógeno.

Tales son los resultados hasta el presente observados al respecto de los nuevos fenómenos de fototropia. 


\title{
LAS ESPECIES DEL GÉNERO SPIRIFERINA DEL LIAS MEDIO ESPAÑOL
}

POR

\author{
DANIEL JIMÉNEZ DE CISNEROS
}

(Lámina xxxır.)

Hasta hace algunos años no era conocida en España la facies alpina del Lías medio, siendo M. KiLIAN el primero que citó algunas especies en Salinas, Illora, etc. (1). En las colecciones de la Universidad de Sevilia hemos visto algunos fósiles procedentes de la sierra de Esparteros, recogidos por el Sr. CALDERón. Si las localidades visitadas por estos gerilogos huhiesen sido detenidannente exploradas, es seguro que se habría encontrado la fauna liásica alpina, que tantas especies encierra en España.

Tuve la suerte de encontrar, en 1912, el primer depósito de Lías medio alpino en la sierra de la Romana, cuyas canteras se habian considerado como del Titónico por pertenecer a este piso las canteras de Rambla Honda, situadas a corta distancia del primer punto. Sucesivamente hemos encontrado otros yacimientos fosiliferos, casi todos con abundancia de restos orgánicos, y la labor continua de estos ocho años ha dado por resultado un número tan grande de ejemplares, que permite el estudio de las especies comparando gran cantidad de individuos.

Cuando se lee en las obras clásicas la descripción de una forma nueva, es frecuente hallar que se ha establecido la especie a presencia de un corto múmero de ejemplares, a veces de uno solo, y esto expone a numerosos errores. Salvo casos especiales, ni la creación de una especie debe hacerse sólo por escaso número de

(1) M. KiLian, Estudio paleontológico acerca de los terremes secundarios y terciarios de Andalucia. Traducido al espantol por la Comision del Mapa Geológico, 1890-1893. 
individuos, ni deben darse como caracteres específicos las dimensiones ni la proporción entre éstas. Ciertamente que hay depósitos con escaso número de fósiles; pero es preferible no dar como caracteres exclusivos los de los ejemplares encontrados. Quien, como el que subscribe, puede disponer de muchos cientos de ejemplares, nota que nada hay tan variable como el tamaño y proporciones; así, para citar un ejemplo, diré que puedo en la actualidad disponer de unos trescientos individuos de la especie Zeilleria (v. Magellania) Hierlatzica Opp., de los que un centenar se encuentran en perfecto estado de conservación. Desde la forma de triángulo isósceles, en el que la base (borde frontal) es mayor que el borde lateral, hasta las que tienen la base muy reducida, es decir, desde las formas anchísimas hasta las más estrechas y alargadas, existen todas las proporciones (1).

Ya se ha dicho en otro lugar que en la descripción de las especies se suele prescindir de las formas que pudiéramos llamar intermedias, y se eligen, sin razón alguna, las que corresponden a la descripción que han dado de ella los autores clásicos. Es decir, que se busca la adaptación de ejemplares a las descripciones hechas, en lugar de seguir la marcha contraria. Toda forma intermedia queda sin significación alguna. Lo importante ha sido salvar la especie creada, cuando en rigor tienen más importancia esas formas de tránsito, que vienen a demostrar que algunas de las especies creadas son variedades llevadas al límite.

$$
\therefore:
$$

En las presentes lineas nos ocupamos sólo de las especies del género Spiriferina, reducido su número hasta hace poco tiempo a las cinco que cita el Catálogo del Sr. MALlada (2). Son éstas: Sp. rostrata Schlot., Sp. Münsteri Dav., Sp. Walcotti Sow., $S p$. pinguis Ziet. y $S p$. oxyptera Buv. La más frecuente en Es-

(1) Cuando se dice en algunas descripciones de nuevas formas, verbigracia, esta especie se parece a tal otra; pero es más ancha o más estrecha, o tiene una costilla más, o es de mucho menor tamaño", etc., debiera no aceptarse la especie así creada.

(2) Catálogo general de las especies fósiles encontradas en Espa$\tilde{n} a, 1892$. Las especies citadas llevan los numeros 854 a 858 inclusives. 
paña es la $S p$. rostrata, y de ella parecen derivar algunas otras. cuya distinción no es fácil.

Con el estudio de los depósitos liásicos del Sudeste de nuestra patria, la fauna ha tenido un considerable aumento. Creo que en la actualidad pueden citarse hasta diez y siete formas diversas; pero algunas de ellas deben aceptarse con reserva, porque comparando gran número de individuos, no encuentro tan marcadas las diferen-

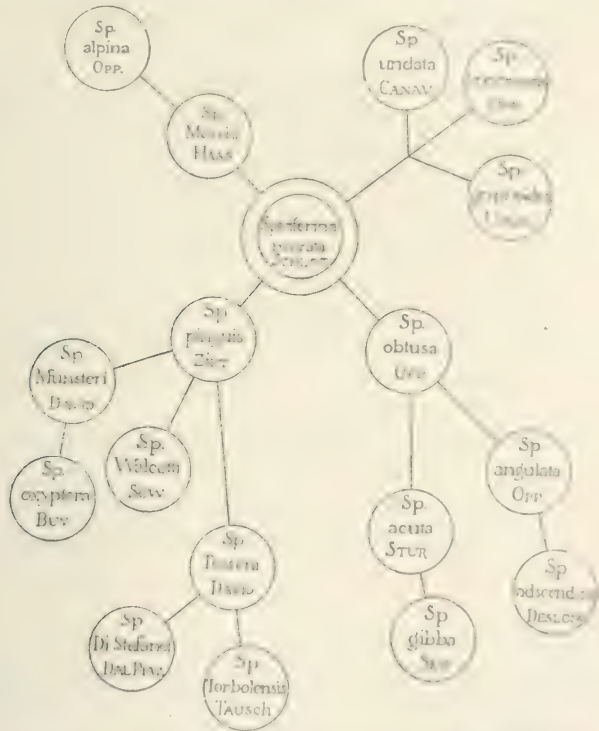

Agrupación sistemática de las especies clel ginero Sifirierim: encontradas en el Lias medio alpino.

cias que indican los autores. Las especies más frecuentes, además de la Sp. rostrata, son: la Sp. obtusa (Opp., la Sp. alpina ()pp. y la Sp. ansulata Opp. Las especies Sp. Sylviu (iemm. y Sp). D)i Stefanoi Dal Piaz., son sumamente raras.

Sistemáticamente agrupamos las especies atendiendo a la existencia o ausencia de costillas radiantes, a la presencia de un berel en la valva dorsal y, finalmente, a cue el mates este mis o menos 
arrollado o completamente derecho. Entiéndase bien que el adjunto dibujo no representa un árbol genealógico, siendo sólo una agmupación de algunas especies dispuestas asi para su más fácil estudio.

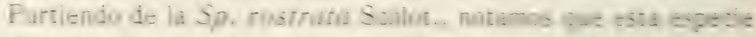
puede presentar caracteres variados. Ya es lisa. ya adornada de pequeñas costillas apenas marcadas; unas presentan un bocel muy aparente, que en otras apenas es perceptible; finalmente. el nates en unas está más arrollado que en otras. Tales variacionés forman como un lazo de unión, ya que a esta especie no se la consilere como origen de muchas otras.

I. El primer grupo lo forman especies lisas, de bocel escaso o nulo, nates poco arrollado o sólo arqueado, y a el pertenecen la Sp. Möschi Haas, considerada por su fundador como un tránsito a la $S p$. alpina Opp., fácil de distinguir esta última porque la linea del borde cardinal es casi recta, el nates de la valva dorsal apenas rebasa esa linea y el bocel es insignificante o no existe (rig. A, nimeros 4 a 7). Hay formas elegantísimas, circulares o de forma acorazonada. La especie es muy abundante en el Lias alpino que he recorrido: Algayat, Moleta de Togores, La Espada, Quivas, Fuente del Algarrobo, Algarejo, etc., etc. También la he encontrado uiltimamente en el Rincón de Egea.

II. El segundo grupo lo forman las especies de bocel escaso o nulo, concha lisa o marcada de estrias de crecimiento y de nates bastante retorcido. Las especies no se hacen notar por su tamaño. Su forma es más o menos ovoide: Sp. gryphoidea Uhlig, Sp. brevirostris Opp. y Sp. undata Canav. No son especies frecuentes en España.

III. El tercer grupo puede formarse con las especies que siempre presentan bocel en la valva dorsal y depresión, a veces muy profunda, en la valva ventral. El nates de ésta se encuentra poco arrollado o sólo ligeramente arqueado o completamente derecho. Las formas de este grupo no presentan costillas radiantes o sölo ligeramente indicadas. Unas presentan las valvas de dimensiones proporcionadas, mientras que en otras (Sp. angulata Opp., Sp. adscendens Deslong.) la valva ventral se alarga tanto que la corsal toma aspecto operculiforme. La asimetria es frecuente en la $S p$. angulata, Sp. acuta y Sp. adscendens.

De todas las especies de este grupo la más notable es la $S p . o b-$ tusa Opp., por su polimorfismo. La variedad que pudiéramos considerar como clásica tiene forma transversalmente oval, y colocada 
de manera que la recta que pasa por el gancho o nates de la valva ventral y el punto medio de la comisura frontal se conserve en posición vertical, el nates de la valva dorsal apenas sobresale de la línea de unión de las dos valvas. El área es muy manifiesta y con estrias paralelas. Es la forma que más se parece a la Sp. rostrata Schlot.

La forma cambia muchísimo, como puede verse en ios adjuntos dibujus. en lim que se lun copiedis los perfiles ile illyersua finiugnfías. En unos casos la valva ventral se prolonga en un seno profundisimo, en el que se notan muy bien las lineas de acrecentamien-
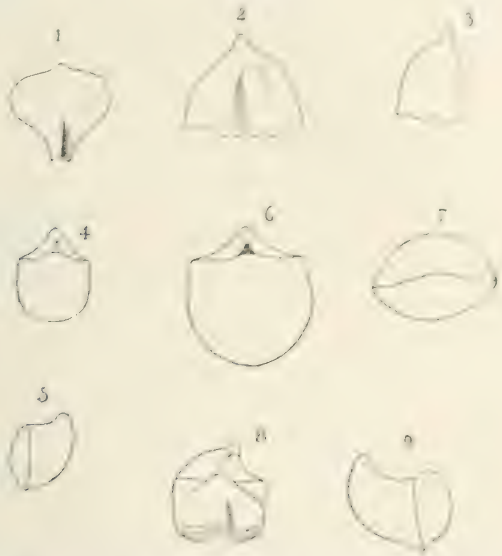

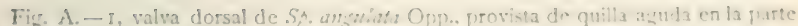

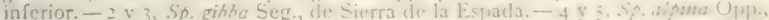

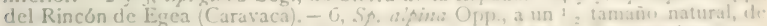
Sierra de la Espada. - 7 borde frontal de la misma. - 8 y g, Sp. angalan: Upp., con marcada asimetria, de Sierra de la Esprada.

to (fig. B, nums. 1 a 3), y la valva dorsal se inclina mucho a derecha e izquierda, pudiéndose decir que el bocel comprende toda la valva. Hay en otros casos formas ensanchadas y otras tan estrechas y recogidas que el grueso iguala al ancho, y el perfil lateral de la valva ventral forma un semicirculo (fig. B, nums, 4 y 5 ).

Las formas extremas, de sentido contrario a las anteriores, tienen la valva ventral con un seno tan pequeño que apenas se manifiesta como una ligera depresión, habiendo todos los trinsitos, como 
puede verse en los adjuntos dibujos. El seno (fig. B, núms. 6 y 7 ), como decimos, va disminuyendo; el nates de esta valva se recoge y retuerce, disminuyendo de altura, mientras que el de la valva dorsal va aumentando y elevándose sobre el otro, retorcido también, llegando a tocarse por sus superficies convexas (fig. B, núms. 8 a10), dándole aspecto de una nueva especie. Ya en la obra de GEYer (1) se representan variedades de este aspecto, aunque no de tan exage-
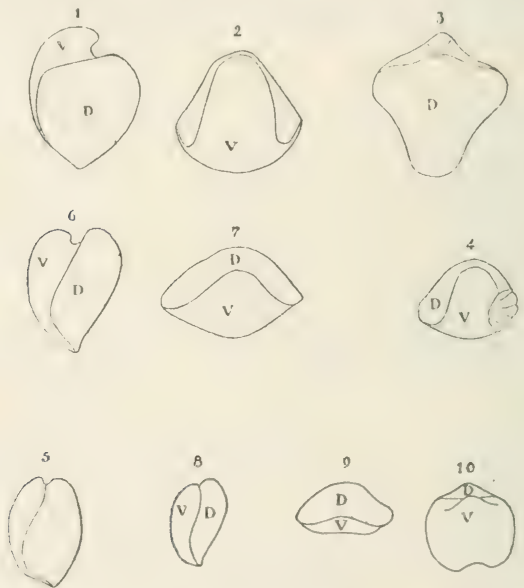

Iïg. B. - I a 3, Sp. obtusa Opp., variedad estrecha y abultada, del Rincón de Egea (Nurcia). -4 y $5, S p$. obtusa Opp., variedad con el nates de la valva ventral muy reducido, de Moleta de Togores (Murcia). -6 y 7 , Sp. obtusa Opp., variedad de escaso bocel y en la que el nates de la valva dorsal aumenta, de Moleta de Togores. -8 a io, Sp. obtusa Opp., de nates en contacto y bocel minimo, var. conclusa nov., de Sierra de la Espada.

radas proporciones como las que aqui presento. Propongo el nombre de conclusa para esta variedad, que he encontrado con relativa frecuencia.

Dos especies notables encierra además este grupo: la Sp. acuta Stur. y la $S p$. angulata Opp. En la primera el área está en un plano o superficie ligeramente curva, y termina en agudo vértice.

(1) Ueber die liasischen Brachyopoden des Hicrlatz bei Hallstatt. (Abandlungen der K. K. Geol. Reich., vol. XV, taf. VIII, fig. 13.) 
El seno es profundo y prolongado, y forma en la unión con la valva dorsal un ángulo agudo. Esta última valva es más reducida, y en los individuos adultos forma, por su unión con la ventral, una arista 0 reborde muy marcado.

Entre esta especie y la $S p$. angulata existen tránsitos; de manera que hay individuos de colocación muy dudosa. En esta última, en los ejemplares de bastante desarrollo, la valva ventral se alarga y aun se desvia ya a derecha, ya a izquierda, con asimetria muy manifiesta. La valva dorsal forma con frecuencia una aguda quilla, adonde viene a terminar la depresión o seno de la otra valva, y suele presentar, además, dos espacios casi planos en los bordes laterales próximos a la sutura cardinal, como puede verse en el adjunto dibujo (fig. A, núms. 1, 8 y 9).

La especie $S p$. gibba Seg. es forma vecina de la $S p$. acuta, en la que la valva ventral se ensancha bruscamente, formando una gibosidad que justifica el nombre (fig. A, núms. 2 y 3). Hay individuos de dudosa colocación.

La Sp. adscendens Deslong. (1) tiene mucha relación con las formas de la $S p$. angulata, en que la valva ventral ha crecido desmesuradamente. En ambas se nota asimetría con frecuencia.

IV. El cuarto grupo lo forman las especies provistas de bocel y costillas radiantes bien manifiestas. La forma de tránsito es la $S p$. pinguis Ziet., que algunos han considerado como una variedad de la $S p$. rostrata. Hay, sin embargo, formas muy extranias, en las que la valva ventral es poco convexa, y en cambio lo es mucho la dorsal. Las especies clásicas, tales como la Sp. Walcotti Sow., Sp. Münsteri Dav. y Sp. oxyptera Buv., presentan un bocel muy marcado en la valva dorsal, indiviso y a veces muy ancho, como en los individuos mayores de la primera, constituyendo formas muy elegantes entre los braquiópodos; no asi en otras tres especies encontradas en el Sudeste de España, en las que el bocel se divide en costillas en numero de dos a cuatro, apareciendo igualmente en el seno o depresión de la otra valva. La especie más frecuente la refiero a la Sp. Tessoni Dav. (2), notándose una asimetria muy marcada, tanto mayor cuanto más grande es el individuo, porque los más crecidos presentan inflexiones.

Refiero a otras dos especies irregulares (Sp). Di Stefunoi Dal

(1) Paleontograf., vol. IV, pl. XXIX, fig. 20.

(2) Loc. cit., pl. XXIX, fig. 21. 
Piaz y Sp. Torbolensis Tausch.) algunas de las encontradas. La primera de éstas se asemeja a la $S p$. Tessoni, con la valva ventral considerablemente alargada. La $S p$. Torbolensis es muy irregular. La Sp. Walcotti es de pequeño tamaño; las costillas y el bocel son poco aparentes. Posible es que sea una nueva especie; pero nos hemos abstenido de considerarla asi por no haber recogido suficiente número de ejemplares.

La $S p$. Tessoni Dav. presenta también formas variadas. Unas veces se alarga mucho la valva ventral, asimétrica y flexuosa, como en la lámina adjunta; en otras ocasiones se acorta y se ensancha, formando un área casi plana, y las costillas se combinan con las estrias de crecimiento, formando granulaciones y nudosidades. Esta especie corresponde principalmente a una zona de crinoides que forma una lumaquela, que sería beneficiable como mármol muy vistoso si tuviera más consistencia. En la zona de la Zeilleria Hierlatzica Opp. y de la Terebratula (Pygope) Aspasia Meng., var. Myrto, no se encuentran más especies del género que la $S p$. alpina Opp., la $S p$. obtusa Opp., la $S p$. rostrata Schlot. (?) y aun la $S p$. brevirostris Opp., y no he hallado hasta el presente esas formas irregulares, que creo deben pertenecer a horizontes superiores.

\section{Explicación de la lámina XXXII.}

Figs. i y 2.- Spiriferina acuta Stur. Vista de frente y por la parte dorsal. Rincón de Egrea.

Figs. 3 y 4 .-Spiriferina acuta Stur., tránsito a la $S p$. gibba s. Vista de perfil y de frente. Sierra de la Espada.

Fig. 5. - Spiriferina alpina Opp. Parte dorsal. Algayat.

Fig. 6. - Spiriferina alpina Opp. Parte dorsal. Sierra de la Espada.

Figs. 7 y 8. - Spiriferina alpina Opp. Vista por la parte dorsal y de perfil. Rincón de Egea.

Figs. 9 y 10. - Spiriferina obtusa Opp. Parte ventral y de perfil. Moleta.

Fig. II. - Spiriferina obtusa Opp. Gran ejemplar visto por la parte ventral. Rincón de Egea.

Figs. 12 a 14. - Spiriferina obtusa Opp., variedades afines a la conclusa. Parte dorsal (I2 y 13) y de perfil (I4). Sierra de la Espada.

Fig. 15. - Spiriferina gibba Seg. Vista de frente. Sierra de la Espada.

Figs. 16 y 17.-Spiriferina Tessoni Dav., forma alargada. Valva ventral y dorsal. Sierra de la Espada.

Figs. 18 y 19. - Spiriferina Tessoni Dav., forma corta. Valva dorsal y ventral. Sicra de la Espada.

Figs. 20 y 21 . - Spiriferina angulatı Opp., forma asimétrica. Parte ventral y de frente. Sierra de la Espada. 
R. Soc. Esp. de Hist. Nat. - T. del 50. aniv.

LAM. XXXII.
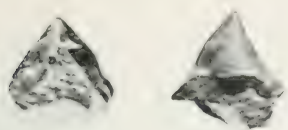

2
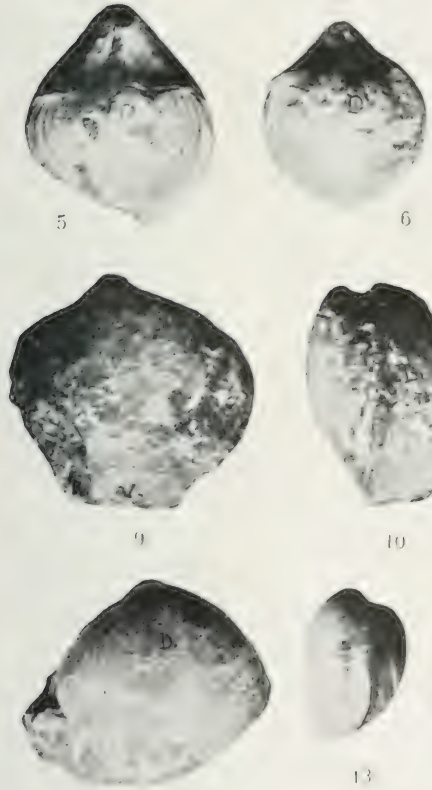

12

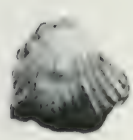

11,
6
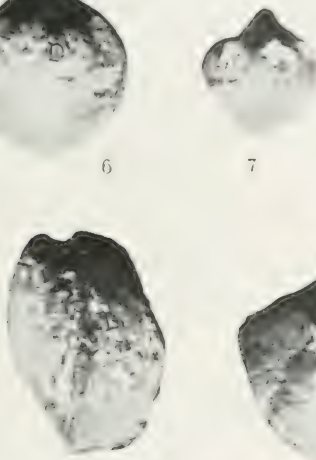

7

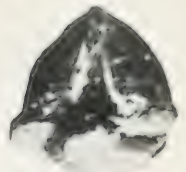

$\div$
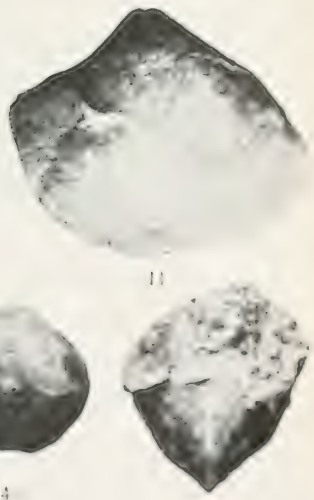

15

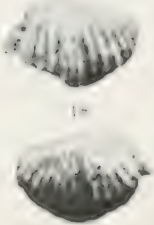

1'

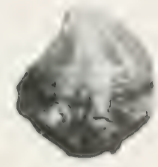

N

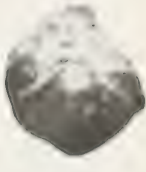

I

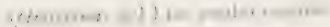



EXPERIENCIAS SOBRE EL AVIVAMIENTO EXIEUPORANEO DE LOS huEVOS DE LA MARIPOSA DEL (iUSANO IDE LA SEDA

POR

ANTONIO DE ZULUETA

Los huevos de la mariposa del gusano de la seda de las razas que ordinariamente se crian en Europa presentan, como es sabido, normalmente y de modo muy ostensible, el fenómeno de la diapausa embrionaria, o interrupción del desarrollo del embrión, la cual dura muchos meses. Los huevos empiezan a desarrollarse inmediatamente después de la fecundación y siguen haciéndolo durante tres o cuatro días, lo que se manifiesta porque su color amarillo se cambia en color de ceniza. En este breve espacio de tiempo se han formado en el embrión diez y seis metámeros y se han desarrollado las membranas embrionarias, siendo debido al color de la serosa el cambio que se observa en la coloración. Llegado el huevo a este estado, en lo que, como digo, se invierte sólo unos tres o cuatro dias, el desarrollo cesa, pasando en reposo casi absoluto el verano, otoño e invierno, y no se reanuda hasta la primavera siguiente, en la que, a una temperatura conveniente, se termina, invirtiendo en ello unos quince dias.

Lo notable de esta diapausa es que no hay causa externa que la determine, pues el desarrollo se para invariablemente, cuando hat llegado al punto antes indicado, cualesquiera que sean las condiciones de ambiente, naturales o artificiales, en que se encuentre el huevo. Y llama aún más la atención este fenómeno si se tiene en cuenta que las condiciones del ambiente, en el momento en que se detiene el desarrollo, son naturalmente muy parecidas - y pueden artificialmente hacerse iguales - a las que en primavera determinan el que el desarrollo se reanude; aparte de que, como luego veremos, en casos extraordinarios los huevos se desarrollan sin diapausa en condiciones muy varias, mostrándose nada exigentes. Además, otras razas de gusanos de la seda tienen maturalmente dos 
o más generaciones cada año (razas bivoltinas y multivoltinas), en vez de la generación sola que estamos acostumbrados a ver en nuestras razas ordinarias (univoltinas).

La larga diapausa de estas últimas debe ser una adaptación admirable a la vida en climas de verano caluroso, en los cuales las orugas, que de otro modo nacerían en verano (segunda generación), perecerían probablemente en estado natural por el rigor del calor o por escasez de alimento, lo que acarrearía la destrucción de la raza. Pero no me parece fácil averiguar de qué modo se produjo esta adaptación, ni qué causa determina la detención que vemos en el desarrollo.

Desde hace ya bastante tiempo se han ensayado, con fines económicos o puramente científicos, medios artificiales de reducir la duración de la diapausa, o de suprimirla por completo, como podrá ver el lector a quien este asunto interese, en el conocido Manual de Entomología de Henneguy (1), y más extensamente en la reciente obra de VERSON sobre el gusano de la seda y su cria (2).

Tienden unos métodos a abreviar el periodo invernal, por ejemplo, sometiendo los huevos, unos dias después de puestos, a baja temperatura, y elevando ésta al cabo de cierto tiempo (cuarenta y cinco días como mínimum), simulando así un breve invierno, seguido de primavera. Pero, aparte de estos métodos, que no son sino un remedo de lo que ocurre en la Naturaleza, hay otros quizás más interesantes desde el punto de vista biológico. Sometiendo los huevos, poco tiempo después de puestos, a ciertas acciones violentas, adquieren la facultad de desarrollarse sin diapausa, saliendo de ellos orugas a los pocos días, en lugar de hacerlo al cabo de meses. Entre estos medios violentos - fricción, electricidad, acción de los ácidos clorhídrico y sulfúrico - existe uno sencillísimo y al alcance de todo el mundo, señalado por BELLATI y QUAJAT (3), que parecia estar olvidado. Acerca de él tuvo la amabilidad de darme una breve indicación por carta el profesor UDA, del Laboratorio de Nakano (Tokío), y aplicándolo, aun en condiciones poco favorables, logré resultados que, al presentarlos a la Sociedad, en la sesión de noviembre último, tuvieron los consocios la extrema bondad de juzgar

(1) L. F. Henneguy, Les Insectes. (Paris, Masson et $\left.C^{1 e}, 1904.\right)$

(2) E. VERSON, Il filugello e l'arte di governarlo. (Milano, Società Editrice Libraria, 1917.)

(3) No he podido procurarme sus trabajos, pero aparecen indicados ell Henneguy. 
interesante el conocimiento y divulgación del modo como habian sido conseguidos.

Consiste fundamentalmente este método en sumergir los huevecillos, a las pocas horas de puestos, en agua a la temperatura de $52^{\circ}$ a $54^{\circ}$ durante algunos segundos (1), y abandonarlos luegro a la temperatura del ambiente - siempre que ista no sea sumamente fria -, hasta que se ven salir oruguitas al cabo de doce o catorce días. Cuando se hace esto por vez primera, resulta sorprendente que operación tan simple pueda modificar el huevo de tal mantera que éste, en vez de detenerse fatalmente en su desarrollo, lo verifique de un modo continuo hasta salir la oruga. Es de notar que la acción del agua caliente no es igual en todos los huevos: aun siendo de una misma puesta, y sometidos a idéntico tratamiento, unos toman el color de ceniza y terminan sin interrupción su desarrollo dando las orugas; otros mueren - lo que se conoce porque se arrugan, se secan y toman irregularmente color amarillo-rojizo-, y otros, finalmente, aunque toman el color de ceniza y presentan en todo el aspecto normal, no dan por el momento oruga, lo que hace presumir que han entrado en diapausa y que terminará su desarrollo a la primavera siguiente, como si nada artificial se hubiese hecho en ellos (2).

Mediante la aplicación reiterada de este procedimiento, con las variantes que se indicarán, he visto en el transcurso del año 1920 cuatro generaciones de gusanos de la seda:

Primera generación. (La normal de 1920.) - De ésta, obtenida naturalmente, sólo he tenido las mariposas que salieron de los capmllos que me fueron amablemente remitidos por la Estacion Suricicola de Murcia, a cuyo ingeniero director, D. Adolfo Virgili, me complazco en reiterar las gracias. Estas mariposas pusieron a mediado de julio, o sea muy tarde con relación a lo habitual en nuestro clima.

Segunda generación. (La que naturalmente hubiese nacido en la primavera de 1921.) - Los huevecillos puestos por las mariposas de la creneración anterior fueron tratados signiendo exar 1.4nente el procedimiento que me indicó el profesor UDA, o sea inmersión de los huevos, a las cinco horas de puestos, en agua a $54^{\circ}$ durante $5^{\prime \prime}$. De estos huevos salieron orugas en los últimos dias de

(1) Facilita la inmersión de los huevos el hacer que las mariposas los depositen sobre papeles, a los que quedan adheridos.

(2) En efecto, estando ya en prensa este trabajo (mes de marzo), han salido algunas orugas de estos huevos puestos en sitio caliente. 
julio y primeros de agosto.. No conservo nota del número de oruguitas obtenidas, aunque recuerdo que pasaron de un centenar. No hubo dificultad para procurarles alimento, pues las moreras jóvenes tenían aún hojas muy tiernas; pero, a pesar de ello, en los primeros días la mortandad fué enorme, lo que al pronto atribuí a debilidad de las oruguitas, aun cuando, en realidad, la muerte fué debida a que las hojas tiernas de morera se secaban muy pronto con el calor de agosto. Bastó para hacer cesar totalmente la mortandąd poner las pocas oruguitas supervivientes sobre un papel de filtro húmedo, cubierto con una campana de cristal. Las orugas, a pesar del calor, siguieron desarrollándose bien y empezaron a hacer sus capullos del 23 al 31 de agosto. Éstos fueron bastante pequeños, sobre todo si se compara su tamaño con el que tenían los hermosos capullos de sus padres. No obstante, la metamorfosis se verificó sin dificultad, empezando a salir las mariposas el 8 de septiembre y continuando la salida en los dos o tres días siguientes. Estas mariposas, realizada la cópula, pusieron huevos en los días 10 , 11 y 12 .

T'ercera generación. (La correspondiente a 1922.) - Los huevecillos de que se acaba de hablar fueron tratados también por el agua caliente, pero este método se aplicó con algunas varientes. Unos los sumergí simplemente $5^{\prime \prime}$ en agua a $54^{\circ}, 10$ mismo que la vez anterior; pero otros los sumergi alternativamente en agua caliente $\left(54^{\circ}\right)$ y en agua fría $\left(21^{\circ}\right)$, repitiendo esta doble operación dos, cinco o diez veces. Aunque el número de experiencias no fué muy grande (23 lotes pertenecientes a 8 puestas) se pudo ver que el resultado mejor era el conseguido sumergiendo dos veces en agua caliente y dos en agua fría, durante 2 ó $5^{\prime \prime}$ cada vez, huevecillos que llevaban cinco horas o menos de puestos, ya que más del 50 por 100 de los tratados así se desarrollaron dando las correspondientes orugas. permaneciendo vivos, aunque en diapausa, los restantes huevos de los lotes tratados de este modo. También salieron orugas de algunos de los huevos sumergidos cinco veces en agua caliente y cinco en agua fria, durante $5^{\prime \prime}$ cada vez, y el mismo resultado dieron los que lo fueron diez veces en agua caliente y diez en agua fría, I" cada vez; pero de los sumergidos diez veces en agua caliente y diez en agua fria, $5^{\prime \prime}$ cada vez, no salió absolutamente ninguna oruga y quedaron todos muertos.

Las oruguitas nacieron en los días 23 de septiembre a 2 de octubre, observándose que de huevos puestos por una misma mariposa 
y tratados idénticamente salieron orugas durante varios dias consecutivos, lo que prueba que el desarrollo no se habia verificado con igual velocidad en todos los huevos; así, en los puestos y tratados el día 11, empezó la salida de orugas el 23 y se prolongó hasta el día 1 , tardando, por consiguiente, en desarrollarse doce dias unos huevos y otros veinte.

Como en octubre las hojas de morera estản ya muy duras, no hubiera sido posible alimentar las oruguitas si tres o cuatro semanas antes de nacer éstas no hubiese tenido la precaución de podar una morera que, habiendo retoñado bien, proporcionó hojas tiernas en el momento oportuno.

Empezaron a desarrollarse las orugas a la temperatura del ambiente; pero como ésta descendiese notablemente, las coloqué, después que hicieron la segunda muda, en una estufa de cultivo, que mantuve a unos $20^{\circ}$ hasta el final de las experiencias. Estas orugas, en número de unas doscientas cincuenta, se desarrollaron bien-murieron tan sólo tres o cuatro individuos-, y fueron las que presenté en la sesión de la Sociedad de 3 de noviembre. En este mismo dia empezó una a hacer el capullo, continuando todas las demás en los dias siguientes. Los capullos fueron algo mayores y de más seda que los de la generación anterior, aunque sin llegar al tamaño y consistencia de los hermosos capullos de la primera generación. Empezaron a salir las mariposas el dia 20 , continuando la salida hasta el dia 17 de diciembre. Estas mariposas, continuando siempre er: la estufa de cultivo a unos $20^{\circ}$, verificaron la cópula y pusieron huevecillos normalmente.

Cuarta generacion. (La correspondiente a 1923.) - Aunque ya con el propósito de dejar morir las oruguitas que saliesen, por la absoluta imposibilidad de alimentarlas, someti los huevecillos al tratamiento del agua caliente, obteniendo el mismo resultado que las veces anteriores, y ensayé además la acción que sobre ellos pudiesen tener los rayos X, la luz ultravioleta y el radio, lo que no creo haya sido ènsayado hasta ahora (1).

(1) Para estos experimentos se han utilizado los medios de que disponen el lnstituto de Radioactividad de la Universidad Central y el Laburatorio de Investigaciones fisicas de la Junta para Ampliacion de Estudios, debiendo hacer constar mi sincero agradecimiento al personal de ambos centros por haber puesto a mi disposicion el material necesario y. más aun, por las amables instrucciones con que me hat favorecido. 
Se sometieron 24 lotes de huevos recién puestos (de dos a nueve horas) a la acción de los rayos $\mathrm{X}$ de dureza media, emitidos por un tubo de Coolidge, durando el tratamiento en los diferentes experimentos, $1^{\prime \prime}, 2^{\prime \prime}, 5^{\prime \prime}, 15^{\prime \prime}, 30^{\prime \prime}, 1^{\prime}, 2^{\prime}, 5^{\prime}, 15^{\prime}, 20^{\prime}, 25^{\prime}, 30^{\prime}$ y una hora. El resultado fué siempre negativo; los huevecillos no dieron orugas, aunque adquirieron el color de ceniza normal, como si nada se hubiese hecho. Los rayos X parecen, pues, no tener acción sobre ellos.

El mismo resultado negativo obtuve con los huevos sometidos a la acción de los rayos ultravioletas procedentes de un arco voltaico entre eléctrodos de hierro; aun cuando en este caso el número de experiencias fué menor y no permite sacar conclusiones.

Para estudiar la acción del radio utilicé un tubito de 11,7 miligramos de radio elemento, equivalentes a 21,85 de bromuro de radio hidratado, y otro de 5,5 miligramos. Los huevecillos fueron dejados en las diferentes experiencias dos, seis, siete y doce dias en contacto con los tubitos. Todos los huevecillos murieron, mientras que los testigos siguen vivos. Me propongo ampliar este experimento disminuyendo el tiempo de tratamiento, pues hemos visto que la acción del agua caliente, que produce la supresión de la diapausa, es mortal si se prolonga, y lo mismo pudiera ocurrir con la del radio.

$$
4
$$

Los experimentos de avivamiento extemporáneo sugieren inmediatamente la idea de la posibilidad de obtener cada año varias cosechas de seda, como se hace con muy buen éxito en el Japón.

Desgraciadamente, en Italia, la aplicación de algunos de los diversos métodos de avivamiento extemporáneo ya indicados no ha dado, en general, el resultado económico apetecido.

Tampoco han sido hasta ahora felices - según ha tenido la amabilidad de manifestarme detalladamente el Sr. VIRGill - algunos ensayos hechos en Murcia mediante el empleo de razas bivoltinas o retrasando simplemente hasta junio o julio el avivamiento de los huevecillos de la generación normal, manteniéndolos en cámara frigorifica; pues si se utilizan las mismas moreras que sirvieron para la primera crianza, los árboles se perjudican, por privarles con insistencia de las hojas; y si se emplean moreras no defoliadas, resulta costoso el elegir las hojitas tiernas para las orugas pequenas. Además, las orugas nacidas de huevos conservados en cámara frigori- 
fica no se criaron bien, hasta el punto de que en experimentos verificados hace tres anos por algumos sederm, ningunn de los lotes avivados llegó a terminar su crianza.

Como quiera que este último inconveniente no se ha presentado aplicando el método del agua caliente, quizás pudi-ra - útil en`ayar la cria extemporánea por este procedimicnto en alsunas localidades en que las condiciones económicas y de clima parezcan ser favorables para ello.

Laboratorio de Biología Experimental del Museo Nacional de Ciencias Naturales, Madrid.

CALYPOGEIA ARGUTA NEES ET MONT., VAR. SPINULOSA v. II.

POK

\section{ANNTONIO CASARES-GIL}

Hace poco tiempo, el profesor F. Bescansa, de la Coruña, me

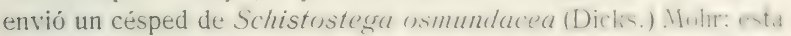
vez era, en efecto, el musgo luminoso de las cuevas, con su característico protonema de reflejos de esmeralda a ciertas incidencias de luz y algunos tallitos estériles; no habia, pues, error, como tantas otras veces que tomaron algunos por Schistostega algún Fissidens, y hasta algas y líquenes, que en las cuevas suelen reflejar la luz de un modo semejante, y por la misma causa, que el protonema de la Schistostega. Fué cogido este césped en la cueva de las Choyas, cerca del balneario del Incio (provincia de Orense).

Entre los pies de la Schistostega, y sobre su protonuma, habia una hepática de tallos postrados, de hojas incumbentes y anfigastrios bífidos con un gran diente agudo en cada lóbulo; el extremo erguido de algunos ramos con hojas y anfigastrios de tamano decreciente y con propágulos hasta terminar ef tallo en un accimulo de estas células, me dió la certeza de que se trataba de una especic del género Calypogeia, porque tales ramas propagulfferas sólo las presentan este género y el Odon/oschisma, cuyas especies tienen aspecto muy diferente del de las Calypogerio. Pero lo que desde el primer examen me llamó la atención fué el extremo de las hojas 
con muchos dientes desiguales, como no se presentan en ninguna especie del género; algunas hojas, las menos, sólo tienen dos dientes triangulares separados por una escotadura redondeada como en la Calypogeia arguta, y esta particularidad, unida a la de que en muchas de las hojas pluridentadas se advierte una tendencia a

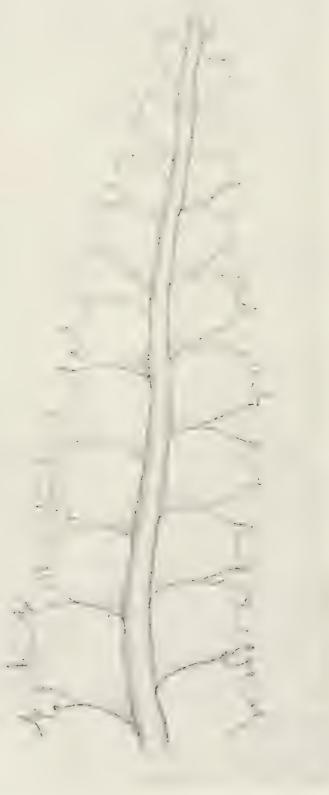

Una rama de Calypogeia arguta var. spinulosit. $\times 25$. la bilobulación y a que las células tienen un diámetro de unas $55 \mu$, me induce a considerar esta planta como una variedad de la especie antes dicha. Excepto en el extremo de las hojas, dentadoespinoso, en los demás caracteres coincide en un todo con la Calypogeia arguta.

Es notable el parecido de la gametófita en los géneros Lophocolea y Calypogeia; puede decirse que forman series paralelas y de términos tan semejantes, que el mejor criterio para diferenciar los dos géneros (en ejemplares estériles) es la decumbencia de las hojas en el primero, y la incumbencia en el segundo; entre las especies europeas, la Calypogeia arguta tiene mucho parecido con la Lophocolea cuspidata o con las formas pequeñas de la Lophocolea bidentata, y en esta última especie hay una variedad ciliata ( $L O-$ phocolea ciliata Warnst.), que tiene los bordes de las hojas con dientes, por el estilo de la variedad de Calypogeia aquí descrita. Ambas variedades son esquiofilas, $y$ sabido es que en muchas especies la disminución de luz determina una más fuerte denticulación y un alargamiento de algunas células del borde de las hojas. La causa de este fenómeno es muy obscura. 
NOTA ACERCA DE LA BACTROPHORA DOWINAN WESTWUII)

(ORTH. LOCUST.)

POR

SERAPIO MARTINEZ

Fué descrito este notable insecto por WESTIOOD en 1842 (1), por un ejemplar hembra de localidad desconocida, por lo que se ignoraba su procedencia; y como en las colecciones del Museo de Madrid existe un macho, de Santa Fe de Bogotá, me ha parecido interesante señalar las diferencias sexuales y describir con mås amplitud este insecto, ya que la descripción que IVESTWOOD diú es tan breve que resulta insuficiente para reconocer la especie, haciendo de paso algunas indicaciones que creo necesarias sobre su sinonimia y colocación en el sistema.

Es de advertir que BRUNER dió a conocer en 1905 (2) como nuevo el género Scolocephalus con una especie que Hamó mirabilis, procedente de Costa Rica, y que más tarde (3) reconoció como sinónimo de Bractrophora, y que KirBy, en su Catcilogo (4), ha rechazado esta sinonimia, considerando el género Scolecocephalus (sic) como distinto de Bactrophora, manifestándolo así expresamente al decir Bactrophora dominans Brun. (nec Westwood) (5).

Por esta causa la primera cuestión que se me presentaba al estudiar este insecto era la de saber si pertenecia al primero o al segundo de los dos géneros citados, para lo que era preciso encontrar las diferencias que entre ellos pudieran existir; pareciéndome más bien que pudiera pertenecer a Scolocephalus por las que observaba al compararlo con la figura que ha dado WEstwonot) en

(1) Arcana Entomologica, t. I, pig. 64, lium. 17, fig. 2 (1812).

(2) Entom. News, t. XVI, pig, 315, läm. XI (1905).

(3) Biol. Centr. Amer., Orth., t. II, paigr. 250 (19(1).

(4) A Synonymic Catalogue of Orthopter., t. 111, (1!111).

(5) Loc. cit., pits. 406i. 
la obra citada; pero no satisfecho del resultado de este examen, pareció conveniente comparar directamente nuestro insecto con el tipo que se conserva en la colección del Museo Británico, y aprovechando la estancia en Londres de Mr. Urarov, cuya amabilidad es bien conocida en el Museo de Madrid, se le envió el ejemplar en cuestión para que pudiera hacer la comparación necesaria con el género Bactrophora, resultando, en opinión de Mr. Uvarov, que las diferencias a que nos referiamos y que nosotros encontrábamos son debidas a que la figura dada por WESTWOOD no es completamente exacta, y que por lo tanto no existen caracteres diferenciales entre los géneros en cuestión, los que, como BRUNER supuso, deben reunirse, no pudiendo asegurar, por no existir en Londres la especie de BRUNer, si realmente es diferente de Bactrophora dominans.

Mr. Uvarov añade que existe también en aquella colección un macho, procedente de la Guayana inglesa, mejor coloreado que el nuestro, y en el que el cuerpo es más obscuro y los fémures posteriores están teñidos en su cara interna de un verde casi negro. Tenemos, por tanto, como resultado de este examen comparativo, que Scolocephalus es sinónimo de Bactrophora, y que este género es propio de la América Central y del Norte de la Meridional, extendiéndose desde Costa Rica hasta la Guayana inglesa, faltando sólo saber si todos los ejemplares conocidos pertenecen a una misma especie, o si, por el contrario, los de Costa Rica corresponderían a otra distinta, que sería la mirabilis (Brun.).

Resuelta esta primera cuestión, queda por examinar la relativa a la colocación del género en el sistema de los Locústidos. WESTWOOD se limita a decir que pertenece a la sección de los Conophori de Serville, y su descripción es tan breve que ni Stål ni BRLNER han hecho mención de él, sin duda por no encontrar en ella caracteres para decidir acerca de su colocación; Bri...er, en Entom. Velus, lo coloca en la familia Proscopidae, lo que evidentemente es un error, y después en Biol. Centr. Amer., y por fin, KIrBy, en su Catalosue of Orthoptera, lo coloca entre Rhamphacrida Karsch y Acanthoxia Bol., esto es, en el grupo Opomalae de BRUNner, con lo que no podemos estar conformes, porque en este grupo, lo mismo que en el Carsulae y Mesopes, los lóbulos mesosternales están unidos formando una larga sutura en medio de la placa esternal, lo que no sucede en Bactrophora, como tampoco en Escalera Bol. ni en Pristocorypha Karsch, que pone a continuación. 
Todos estos géneros, lo mismo el americano que las africanns. tienen, en opinión del Sr. Bolivar (I.), mayor analogía con los del grupo Mazaeae, por la separación de los lóbulos mesosternales y por la forma de la frente, en la que la quilla media se borra y desaparece antes del epistoma, caracteres de suficiente importancia para justificar la aproximación indicada. Desgraciadamente. Brounnem se ha limitado a dividir los géneros que pertenecen a la división 6 de su cuadro por la procedencia en africanos, asiáticos y americanos, y el Bactrophora, como de este último origen, habría de llevarse al grupo Mezentiae, colocación que no le corresponde.

Creemos que el género que estudiamos debe figurar a continuación de Pristocorypha Karsch, siquiera el uno sea americano y el otro africano, pudiendo formarse dos grupas, Bectrophurae y Pristocoryphae, y en este último podría incluirse el Escalera Bol., género también africano.

Y ahora, como la Bactrophora dominans.Westwood, no ha sido suficientemente descrita, nos parece ocasión oportuna para hacer at descripción y señalar los caracteres del macho, que no eran conocidos.

El insecto, que parece haber permanecido alguin tiempo en alcohol y está evidentemente decolorado, es de un ocráceo obscuro y está recorrido a uno y otro lado, desde las mejillas hasta el extremo de los fémures posteriores, por una ancha faja de un amarillo claro, algo rojizo, que se extiende por debajo de los ojos, siguiendo luego por el borde inferior del pronoto y los lados del resto del tórax, y se continúa después por la mitad superior del área externomedia de los fémures posteriores hasta su extremo.

La cabeza es casi lisa, convexa por encima, con una impresión dorsal arqueada, que pasa de uno a otro ojo y separa el vértex del grueso tubérculo en que se prolonga por delante, que es dos veces y media tan largo como el resto de la cabeza vista por encima: detrás de la impresión de que hablamos se distinguen unos gránulos poco elevados, que forman una línea paralela al borde posterior de los ojos. El fastigio es cilindro-cónico, obtusamente anguloso en el ápice, y en el medio tiene, a cada lado, una pequeña tumefacción que le hace parecer como anguloso; por debajo está recorrido por la quilla media, obtusamente cremulada y que se extiende hasta el ápice, donde se halla bordeada a cada lado por una fosita o depresión; en la base se bifurca y no pasa del nivel de las antenas, por lo que la frente, cuya superficie es desigual, no presenta surco ni 
quilla media alguna. Esta parte de la cabeza es fuertemente transversa, y las pequeñas quillas que la separan de las mejillas son poco aparentes. Los ojos son grandes, convexos, oblongos y oblicuos y están bastante separados por encima. Las antenas, incompletas en

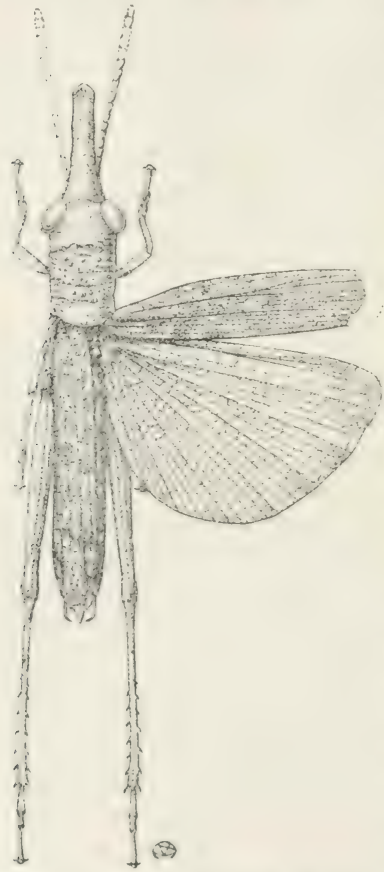

Fig. 1. - biactrophora dominans TVestw.. macho, visto por encima. $\times 1,5$. el ejemplar que describo, están figuradas en la lámina de la $A r-$ cana Entomologica, que antes cité; son negruzcas y mucho más largas que el tubérculo cefálico.

El protórax es rugoso y está cubierto por encima de numerosos tubérculos redondeados, lisos y brillantes, entre los que se destacan por su mayor tamaño dos colocados en el borde anterior, próximos a la línea media; entre los tubérculos la superficie aparece con algunos puntos hundidos; los surcos transversos son superficiales y dividen el pronoto en tres por. ciones, de las que la anterior es la mayor y lleva otro surco próximo al borde cefálico, que se percibe sólo lateralmente; por efecto de esta distribución la metazona mide escasamente el tercio o tal vez menos de la longitud total de la región. El borde posterior es redondeado y estrechamente rebordeado; los lóbulos laterales son rugosos, con el borde inferior hori-

zontal y sinuado en la mitad anterior; el ángulo anterior es recto y el posterior redondeado.

Los élitros, amarillentos en el fondo, están cubiertos de manchas pardo-rojizas que les dan un tono obscuro. Las nerviaciones longitudinales están muy aproximadas, y las transversas son en general de color más claro, siendo todas ellas salientes. (En el ejemplar 
del Museo están incompletos en su terminación, por lo que el lector debe consultar sobre este particular la lámina de W'ESTWOOI) y también la del Entom. News, de BruYer.) Las alas son poco extensas, de color claro, decoloradas, con una faja negruzca a lo largo del borde externo, que va estrechando rápidamente de delante a atrás, no prolongándose por el borde posterior; la porción anterior correspondiente a los dos primeros campos no es saliente en su extremo, por lo que la sinuosidad que la separa del resto del ala es insignificante.

El pecho ofrece algunos pelos grises, no muy abundantes; el tubérculo prosternal es pequeño, recto y obtuso; la placa esternal más larga que ancha, con el borde anterior separado del resto por un surco transverso; los lóbulos mesosternales, redondeados interiormente, están separados entre si por un espacio en forma de X, que lleva en el centro una fosita alargada y se ensancha por delante,

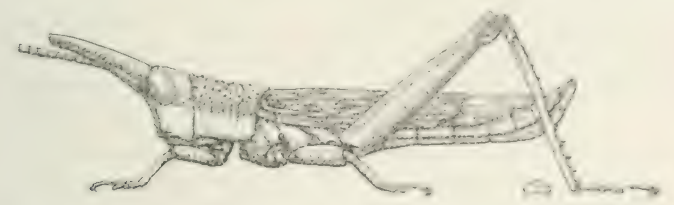

Fig. 2.-Bactrophora dominans WVestw., macho, visto de lado, $\cdots$ i,,.

formando a cada lado un ángulo agudo que en su vértice lleva otra fosita; los metasternales se reunen por detrás de las fositas correspondientes en una corta sutura.

Las cuatro patas anteriores son cortas, pero fuertes, con los tarsos de las dos primeras más largos que las tibias, y un poco más cortos que ellas los del segundo par; los dos primeros artejos son cortisimos y el tercero muy largo y muy delgado en la hase; el arolio es muy grande. Los fémures posteriores no alcanzan a la extremidad del abdomen, estrechos y apenas adelgazados hacia el ápice, con el borde superior algo arqueado, el inferior recto, la superficie externa convexa, lisa y angulosamente pennada; por dehajo son cóncavos; los lóbulos geniculares romos, no salientes, y la yuilla dorsal de la rodilla inerme, no prolongada en espina. Las tihias de este último par, que llevan por encima una fila de largos pelos grises, son rojizas, con los bordes redondeados, sin aristas, hastante: 
comprimidas en la mitad basal y cilindráceas en el resto; las espinas de que están armadas son fuertes, pero cortas, de color negro, en número de siete las externas y de diez las internas, existiendo espina apical en ambos bordes. Las tibias están algo aplanadas inferiormente, sobre todo hacia la base. Los tarsos posteriores, provistos también de largos pelos, son delgados y prolongados, con el primer artejo más largo que el segundo, y el tercero más que el primero; los dos de la base se prolongan por debajo en el ápice en dos lobulillos agudos.

El abdomen es ancho y deprimido, sobre todo hacia el ápice; muy obtusamente aquillado en la línea media superior. Los ocho primeros tergitos son normales, truncados en su borde posterior; noveno y décimo fusionados, escotados en la parte media de su borde posterior, y a cada lado de la escotadura con dos lobulillos agudos y deprimidos. Lámina supraanal subtriangular, formada por una porción basal trapezoidal que hacia atrás está continuada por un lóbulo agudo y largo; por encima obtusamente biaquillada, y en la parte media con un surco oblicuo a cada lado. Cercos muy finos y largos, adelgazando paulatinamente hacia el ápice, en el cual son agudos, rectos en sus dos tercios basilares y encorvados hacia adentro en el apical. Esternitos primero a quinto normales; en este último se perciben ya vestigios de la zona media deprimida, que en los tres siguientes esternitos está más marcada y delimitada a cada lado por una fila de fuertes cerdas, dirigidas hacia la línea media esternal. La lámina subgenital, vista por debajo, es cónica, con una pequeña excavación en su parte media central, por detrás de la cual la lámina parece estar constituída por dos valvas soldadas.

Longitud total del macho, $45 \mathrm{~mm}$; ; de la prolongación cefálica, 10; del pronoto, 7; de los élitros, 23?; anchura de los élitros, 5,3; longritud de las alas, 22; anchura máxima de las alas, 14,5; longitud de los fémures anteriores, 4 ; de los intermedios, 4,3; de los posteriores, 17 ; de las tibias anteriores, 3,5; de las intermedias, 4,3; de las posteriores, 15,5 .

Localidad: Santa Fe de Bogotá (Colombia) (ejemplar del Museo de Madrid). - Guayana inglesa (ejemplar del Museo de Londres, según Uvarov). 


\title{
COLEÓPTEROS CAVERNICOLAS NUEVOS DE LAS PROVINCIAS VASCAS
}

POH

\author{
C. BOLIVAR Y PIELTAIN $Y$ R. JEANNEL
}

El abate Breuil fué el primero que, durante el verano de 1917, exploró las cuevas de los alrededores de Tolosa, en Guipúzcoa, y las de la meseta de Martinchurito, cerca de Larraun (Lecumberri), en Navarra. Los resultados de aquellas primeras exploraciones han sido consignados en Biospeologica, en la Enumeración de cuevas visitadas (1), 6. ${ }^{a}$ serie, págs. 397 y siguientes; los tipos nuevos y muy notables de coleópteros cavernícolas que descubrió han sido ya publicados en notas preliminares (2).

Hemos querido visitar personalmente estas cuevas tan interesantes, cuyo conocimiento se debe a H. Breuil, y mucho celebramos el haberlo podido hacer en su compañía. En efecto, nuestro amigo tuvo la amabilidad de consagrar un mes del verano de 1919) a servirnos de guia. Gracias a su perfecto conocimiento de la región, pudimos, sin pérdida alguna de tiempo, explorar unas treinta cuevas, ya conocidas algunas de ellas, y otras nuevas. Como podrá verse en las páginas siguientes, nuestra campana fué fructifera. Recogimos en cantidad y observamos in situ todas las hermosas especies cavernicolas anteriormente descubiertas por H. Breuil,

(1) R. Jeannel et E. G. Racovitza, Biospeologica, XXXIX. Liumération des grottes visitées, 1913-1917 (6 série), en Arch. Zool. Exp. đl Gén., Paris, t. 57, págs. 203-470.

(2) R. JEANNEL, Troglorites Breuili, nouveau Carabigute camernicole des Pyrénées espagnoles, en Bull. Soc. Ent. France, Paris, 1918, páginas 273-276, fig.

R. Jeannel, Bathysciinae nouveaux des Pyrénées espagnoles, en Bol. de la R. Soc. Esp. de Hist. Nat., Madrid, XIX, 1919, pígs. 129-137, figs. 
y además tuvimos la suerte de encontrar aún bastantes formas nuevas.

Las descripciones de las cuevas exploradas en el transcurso de nuestra expedición serán publicadas más adelante en la 7. a serie de Enumeración de cuevas visitadas, de Biospeologica, por lo que nos limitaremos ahora a dar una breve reseña de las características de las diferentes regiones calizas en que se abren las cuevas.

La meseta de Martinchurito, cerca de Larraun, en Navarra, es una amplia meseta cársica situada en la extremidad oriental de la sierra de Aralar, y de aguas vertientes hacia el valle del Araquil; está cubierta de bosque y en ella se abren numerosas cuevas, simas y dolinas. Su fauna cavernícola es uniforme y se caracteriza especialmente por el Troglorites Breuili y el Euryspeonomus Brenili.

En los alrededores de Tolosa, en Guipúzcoa, se abren numerosas cuevas en diferentes montañas: en el monte de Mendicute, en el Hernio, etc., dependiendo todas ellas de la cuenca hidrográfica del río Oria. En esta región caliza, bien separada y de aspecto muy diferente de la primera, se encuentra un Troglorites especial. Los Bathysciinae pertenecen a la serie filética de los Speonomus, y están representados por una notable especie de Speonomus y por el género Speocharidius Jeann. La segregación de las colonias en cuevas aisladas ha podido producir un cierto número de especies distintas de este último género.

En el valle alto del río Araquil, en la peña Aratz y en el valle del río Deva, exploramos un cierto número de cuevas situadas en los confines de la cuenca del Ebro, de las cuales unas dependen de la cuenca de este último, y otras se abren en la vertiente atlántica. Todas estas cuevas están habitadas por las especies más occidentales del género Speonomus.

Es sabido que el área de distribución geográfica de los Speonomus españoles corresponde en su conjunto a los valles tributarios del Ebro, pero extendiéndose sobre la vertiente atlántica en las provincias vascas; esta sobreposición parece ser el resultado de un desplazamiento de la linea divisoria de aguas, posterior a la época de colonización de las cuevas. Las observaciones de los geólogos indican como probable que las cuevas situadas en la parte alta de los valles de los ríos costeros cantibricos hayan pertenecido en otro tiempo a la cuenca del Ebro.

Según M. MEngaud, cuya competencia sobre la geologia de 
la provincia de Santander es bien conocida, el litoral cantäbrico se hunde bajo el Océano desde el final del Terciario (1), y por otra parte, la erosión por el curso superior de estos rios costeros opera poco a poco la captura de la cuenca alta del Ebro. Algunos centenares de metros separan las fuentes del torrente Besaya del alto valle del Ebro, de curso tranquilo y sinuoso y pendiente suave y regular. Es posible prever que llegará un día en que todo el curso superior del Ebro sea capturado por la vertiente atlántica. Estas observaciones del estado actual de la cresta de partición de aguas hacen ver claramente que desde el Plioceno la cadena cantábrica ha debido sufrir profundas modificaciones en su morfología. Cuando se haya hecho con precisión el estudio de estas modificaciones, será posible explicar con certeza la repartición, anormal en apariencia, de los Speonomus vascos.

En el limite Norte de la provincia de Alava hemos explorado. finalmente, las cuevas de la peña de Gorbea, y en particular la inmensa caverna de Mairuelegorreta, una de las más grandes de toda la Peninsula Ibérica. No hemos podido encontrar Bathysciincae en las cuevas de esta peña de Gorbea, de modo que nos es imposible decir si esta importante región espeológica pertenece al área de distribución de los Speonomus, o bien a la de los Speocharis. Sin embargo, el hecho de que vivan Bathysciola entre las hojas caidas en los bosques del Gorbea, permite suponer que si algín dia llegan a descubrirse Bathysciinae cavernicolas en este macizo, seri lo más probable que pertenezcan a la serie de los Speonomus.

Antes de entrar en el detalle de las descripciones de las especies nuevas, séanos permitido dar las cracias a los Sres. D. Isaac López Mendizábal y al Dr. D. Doroteo Ciaurriz por la aỹuda que nos prestaron en Tolosa y los valiosos datos que nos proporcionaron. Cumplimos también con el mayor gusto el deber de expresar nuestra gratitud a los profesores D. Pedro Ruiz de Azuia, dun Marcelo Alonso y Bronchal, D. Marcos Ruiz de Apodaca (del Colegio Santa Maria, de Vitoria), asi como a D. Félix (iarcia, D). Jenaro Fernández Santa Maria y D. Constantino Marcos (del Cole-

(1) El Sr. MEngaud ha observado que en San Vicente de la barquera existen turberas submarinas con troncus de árboles, que a veces quedan a descubierto en las fuertes tempestades, cuando las olas arrastrun la arena que los recubre. Se trata de depositos lorizontales indudablemente posteriores al Mioceno. 
gio de Escoriaza), por el celo y solicitud con que nos ayudaron en la exploración de las cuevas de Mondragón, Oñate y de la peña de Gorbea.

\section{Carabidae}

pon

R. Jeannel.

\section{Gén. Troglorites Jeannel.}

Bull. Soc. Ent. Fr., 1918, pág. 273.

He podido examinar un macho de la Platysma nodicorne Fairm. y comprobar que esta feronia endógena del Jura tiene próximamente la misma quetotaxia aberrante e idénticas antenas nudosas que el Troglorites. Pero en $P$. nodicorne existe una pequeña estriola yuxtaescutelar entre la primera y segunda estrías, y además el oniquium lleva dos series ventrales de varias sedas, como ocurre en los verdaderos Pterostichus.

Troglorites Breuili Jeannel.

Loc. cit., paig. 274, fig. 1.

Hemos recogido varios ejemplares en la cueva de Akelar y en las dos cuevas de Martinchurito (término municipal de Larraun, partido de Pamplona, provincia de Navarra) en agosto de 1919. Se encuentra este hermoso carábido andando por el suelo o trepando por las estalagmitas y tratando de esconderse en las grietas. Sus costumbres son más bien las de un Aphaenops que las de un Ceuthosphodrus. El Troglorites Breuili pertenece a la fauna de las paredes estalagmíticas, no siendo lapidícola.

Troglorites Breuili, subsp. Mendizabali nov. (fig. 1).

Tipos: tres ejemplares hembras de la cueva de Hernialde (colección Biospeologica y Museo de Madrid).

El T. Brenili típico está localizado en las cuevas de la meseta de 
Martinchurito, cerca de Larraun. En las cuevas de los macizos calizos que se extienden al Oeste de Tolosa, sobre la margen izquierda del río Oria, en Guipúzcoa, encontramos Troglorites que, aunque indudablemente pertenecen a la especie Breuili, tienen caracteres diferenciales constantes que permiten considerarlos como una raza geográfica aislada.

En ellos (fig. 1) la cabeza es siempre mucho más voluminosa,
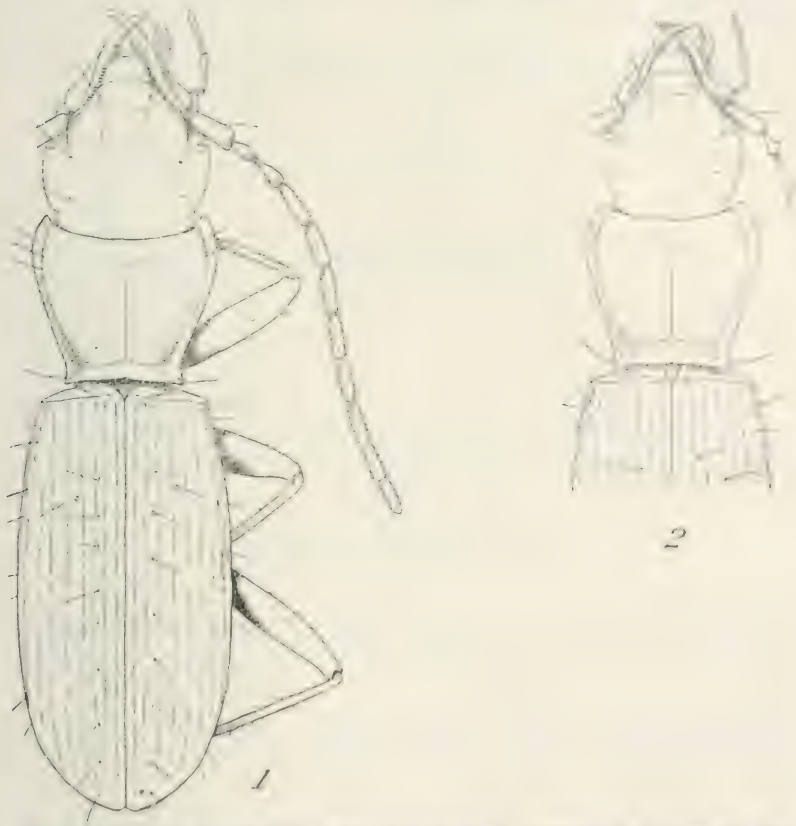

Fig. 1. Troglorites Brewili, subsp. Mentisabali Jeann., hembra, de la cueva de Hernialde; $\times$ 8. - Fig. 2. Cabeza y pronoto de Tregloribs lirenili Jeann., tipico, macho, de la cueva de $\mathrm{Akelar} ; \times 8$.

orbicular, tan ancha como la base de los ditros. P'or consecuencia, el pronoto está mucho más ensanchado hacia adelante que en los T. Brenili típicos (fig. 2). Ademas, las estrias de los élitros son mas regulares, y no se anastomosan entre si, como ocurre muy fre- 
cuentemente, o quizás de un modo general, en los T. Breuili de Martinchurito.

Habitat.-El abate Breuil había recogido en septiembre de 1917 élitros de un Troglorites de gran talla en la cueva de Mendicute (término municipal de Albistur, partido de Tolosa, provincia de Guipúzcoa). Se trata probablemente del T. Mendizabali. Nosotros recogimos, en agosto de 1919, tres ejemplares vivos en la cueva de Hernialde (término municipal de Hernialde, partido de Tolosa), debajo de piedras, en la gran galería de la izquierda (1).

Las dos cuevas de Mendicute y de Hernialde se abren en montañas distintas, pero están poco distantes una de otra.

\section{Laemostenus (Ceuthosphodrus) navaricus Vuillefroy.}

Un ejemplar de pequeña talla, notable por su forma alargada y su pronoto muy estrecho hacia adelante, recogido por el abate H. Breuil, en julio de 1917, en la cueva de Landarbaso (término municipal de Rentería, partido de San Sebastián, provincia de Guipúzcoa).

Esta especie es común en las cuevas del macizo de las Arbailles, en el departamento francés de los Bajos Pirineos. De España había sido señalada, de San Sebastián, por uno de nosotros (2).

\section{Trechus distigma Kiesenwetter.}

Varios ejemplares encontrados en la ladera de la peña Aratz (altura, 1.100 metros aproximadamente), cerca de la cueva de San Adrián (término municipal de Cegama, partido de Azpeitia), en 1 septiembre 1919. Esta especie no había sido encontrada hasta ahora sino en la vertiente francesa de los Pirineos occidentales.

(1) En septiembre de 1917 el abate H. Breuil habia encontrado también restos del Troglorites Mendizabali en el fondo de la pequeña galeria que desemboca en el vestibulo de la cueva de Hernialde.

(2) C. Bolivar y PIeltain, Estudio de un nucvo acuthosphodrus * de España. (Bol. de la R. Soc. Esp. de Hist. Nat., t. XIX, 1919, paig. 156.) (El ejemplar citado de San Sebastián procedia igualmente de la cueva de Landarbaso |C. B. I'.|). 
Trechus Pieltaini Jeannel (figs. 3 a 5).

Bull. Soc. Ent. Fr., 1920, pág. 155.

Tipos : varios ejemplares de ia cueva de Mairuelegorreta (colección Biospeologica y Museo de Madrid).

Longitud, 4-4,5 mm.

Forma alargada, elíptica, deprimida. Coloración testácea brillante. Glabra.

Cabeza oval, más estrecha que el pronoto, con las mejillas poco abultadas, los surcos frontales bien marcados, poco separados, regularmente arqueados y poco divergentes hacia atrás; los ojos
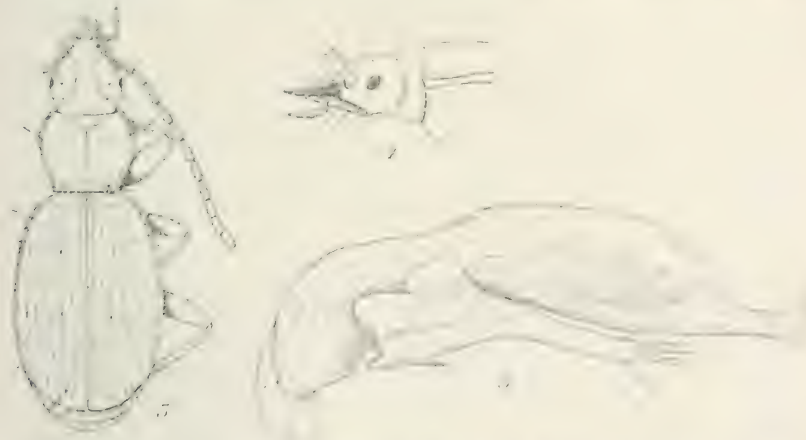

Fig. 3. Trechus Piellaini Jeann., macho, de la cuewa de Mairnelegerreta; $\therefore$ is.-

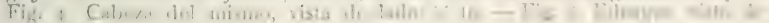
lado; : 56 .

(fig. 4) pigmentados, pequeños, planos, próximamente de la longitud de un tercio de las sienes. Piezas bucales sin caracteres especiales.

Antenas bastante gruesas, alcanzando el tercio basilar de los ćlitros; el artejo II es tan largo como el 1, más corto que el uI; los artejos apicales están claramente engrosados.

Pronoto de forma bastante variable, pero siempre un poco mis ancho que largo, apenas estrechado en la base; sus márgenes son poco arqueadas y presentan su anchura máxima un poco antes del medio; los ángulos anteriores son poco salientes; los posteriores, 
obtusos, vivos, más o menos grandes; la base es rectilínea. El disco, poco convexo, lleva una línea media superficial y fositas basales bien hundidas, separadas de los ángulos posteriores; la canal marginal estrecha y regular.

Élitros ovales, regulares, próximamente vez y media tan largos como anchos, no ensanchados hacia atrás; los hombros redondeados; la canal marginal regular, estrecha, lisa, no ensanchada en los hombros; el borde marginal cortante, saliente. Todas las estrias son visibles, aunque finas y superficiales, pero las tres primeras estân más profundamente trazadas que las otras; todas finamente punteadas. Los dos últimos segmentos del abdomen sobrepasan ampliamente la extremidad de los élitros.

Patas robustas; los fémures muy engrosados; las tibias anteriores lampiñas en su cara dorsal, brillantes, con un profundo surco longitudinal externo.

Edeagus (fig. 5) muy grande, del mismo tipo que el del T. Beusti Schauf. El lóbulo interno está muy engrosado en su mitad apical, estrechado y fuertemente acodado en su mitad basal, que lleva una aleta sagital muy desarrollada. La extremidad del lóbulo está fuertemente quitinizada, aguzada en pico, que termina por un gancho dorsal; todo el pico terminal está cubierto de dentículos sensoriales. Los estilos laterales son grandes, bastante delgados, y llevan en su extremidad seis sedas, de las cuales cuatro son apicales, una dorsal y ventral la otra. El saco interno con una fuerte armadura quitinosa, constituída por dos piezas en forma de y que ocupan la parte dilatada de la extremidad apical del lóbulo interno.

Este edeagus, de gran tamaño y muy diferenciado, es de tipo muy diferente del de $T$. fulvus; estableciendo más bien las afinidades de los T. Beusti y Pieltaini con los Trechus lucícolas de los Pirineos, como T. Grenieri Pand. y T. Uhagoni Crotch.

Quetotaxia normal; lineas orbitarias divergentes hacia adelante; poros del pronoto y series discoidales de los élitros normales; serie umbilicada regular.

Habitat. - Cueva de Mairuelegorreta, en la peña de Gorbea (término municipal de Cigoitia, partido de Vitoria, provincia de Álava), varios ejemplares, recogidos en 28 agosto 1919), entre detritus leñosos.

Cueva del Manantial, próxima a la precedente, un ejemplar y restos de otro, encontrados hacia el fondo de la parte accesible del arroyo subterráneo. 
El T. Pieltaini es próximo del T. Beusti Schauf., pero es más pequeño, más corto y más ancho, más rechoncho proporcionalmente; su pronoto está menos estrechado en la base, sus élitros son más cortos, sus antenas más gruesas. Las dos especies tienen indudablemente el mismo origen: derivan del mismo tronco, siendo dos formas claramente diferentes producidas por desigualdad en la rapidez de evolución de dos colonias bien aisladas.

\section{Pselaphidae}

POK

\section{R. Jeannel.}

Macrobythus armatus Schaufuss (figs. 6 at 10).

Verh. Zool.-bot. Ges. Wien, XIIl, 1863, pág. 1247.

Sinonimia : M. Alluaudi Jeannel, Bull. Soc. Ent. Fr., 1914, pig. \&0, fig. 4 .

Habitat.-Cueva de San Valerio (término municipal de Mondragón, partido de Vergara, provincia de Guipuizcoa), tres machos y’ varias hembras, recogidos en agosto de 1919, hacia el fondo de la cueva, hajo los pedazos del piso estalagmítico roto.

M. Alluaudi Jeann. no es sino el sexo hembra, hasta entonces desconocido, del M. armatus Schauf. descrito de una cueva de Vizcaya; en efecto, nosotros recogimos, en unión de varios individuos perfectamente semejantes a los tipos de 11 . Allucaudi, tres machos típicos de la especie de Schnuruss. Al describir el M. Alluamali crei tener a la vista los dos sexos de una especie de machos teleomorfos; pero en realidad no tenia sino hembras, siendo dehida esta equivocación a las grandes diferencias individuales del tamano de los ojos en estas uiltimas. Lo que tomaba como machos no sumi sino dos hembras con ojos particularmente desarrolladus.

El macho del M. armatus (figr. (i) es alado. Sus ojos son hastante grandes y salientes. El primer artejo de las antenas (fignras 7 y 8) lleva un grueso diente dirigido hacia atris en el amgulo apical del borde interno; el secrundo artejo es ancho, aplanado hacia adentro y aquillado en la extremidad apical de su borke interno. I.ns 
palpos tienen sus artejos II y III granulosos, el artejo apical grande, cultriforme, engrosado en la extremidad, sin curvatura alguna.

Por el contrario, la hembra es áptera. Sus ojos son puntiformes,
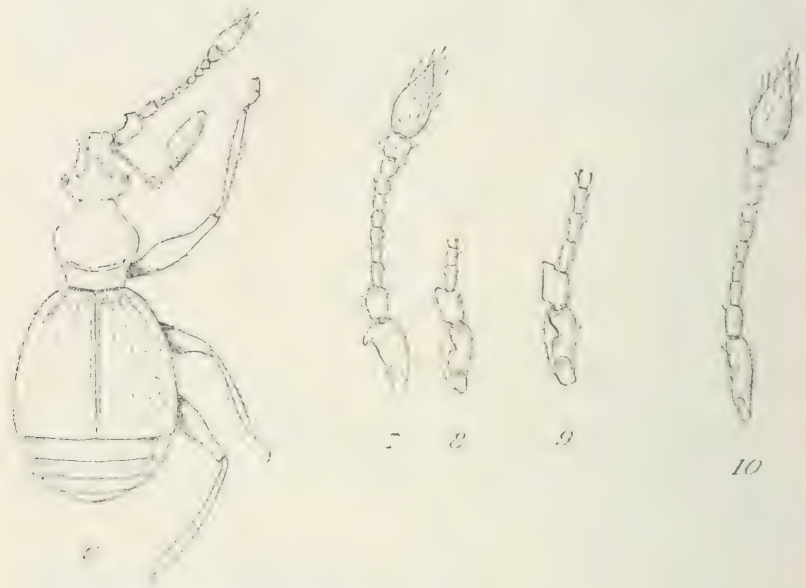

Fig. 6. Aacrobythus armatus Schauf., macho, de la cueva de San Valerio; $\times 20 .-$ Fig. 7. Antena derecha del macho, cara dorsal; $\times$ 50. - Fig. S. Base de la antena derecha del macho, cara anterior; $\times 50 .-$ Fig. 0 . Base de la antena derecha.del macho de la raza Fugniezi Ab., de la cueva de Espezel; $\times$ 50. - Fig. Io. Intena derecha de la licmbra tipica de la cueva de San Valerio (M. Alluaudi Jeann.); X 50.

suts antenas sencillas (fig. 10), pero un poco más finas y alargadas que las del macho.

Machacrites Breuili nov. sp. (figs. 11 a 13).

Tipos: cinco ejemplares (hembras?) de la cueva de Aitzquirri (col. Biospeologica y Museo de Madrid).

Longitud, 1,5 $\mathrm{mm}$.

Coloración testácea pálida. Pubescencia dorada, muy fina, esparcida, sentada en el pronoto, más fuerte y levantada sobre los élitros y el abdomen; un mechón de pelos erizados sobre las sienes.

Cabeza más larga que ancha, triangular, estrechada con regula- 
ridad hacia adelante, desde los ángulos temporales hasta los tubérculos antenales; éstos salientes, separados por una ancha canal frontal lisa y brillante. Card dorsal de la frente con dos fositas, por detrás de las cuales el vértex está levantado en una gibosidaci triangular, sobre la cual corre una pequeña quilla longitudinal mediana muy fina. Sin vestigios de ojos.

Antenas (fig. 13) finas y largas; el artejo I es cilindrico, próximamente cinco veces tan largo como ancho; el II es ovalado, asimé-

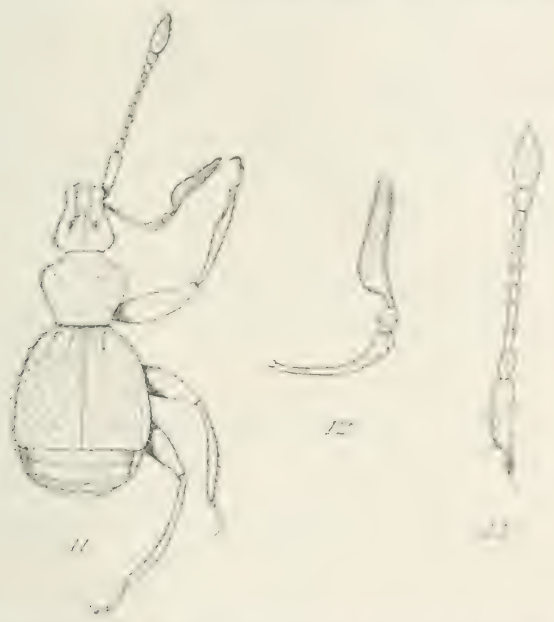

Fig. Ir. Alachaerites Brenili Jeann., hembra ( $)$, de la cueva de Aitzquirri; $\times 20 .-$ I. ig. 12. Palpo derecho, cara dorsal; $X$ 50. - Fig. 13. Antena derecha, cara dorsal; $\times 50$.

trico, pareciendo ligeramente inclinado hacia afuera; los artejos III a vil son finos, cilindricos, un poco mas largos que anchos; el artejo vin es oval, muy pequeño; (el Ix, globuloso, un poco mis ancho que el precedente; el $x$, globuloso, tan ancho como el 11 ; 4.11 , por uiltimo, muy grande y piriforme. Palpos (iig. 12) muy erandes y imos: sus artejos 11 y un estain cubiertos de gruesas granulaciones deprimidas, el III es apenas mís larro que ancho, el IV muy grande y falciforme, fuertemente arqueado hacia afura y cubierto de pequetios pulos erizados más o menos dispuestos en series longitudinale's. 
Pronoto amplio, convexo, próximamente tan largo como ancho; sus lados forman dos ángulos redondeados muy salientes. El disco es brillante, punteado superficialmente; a los lados existen dos fositas superficiales, y entre ellas la base sólo presenta vestigios de un surco transversal.

Élitros amplios, abombados, ensanchados hacia atrás. Su superficie está toscamente punteada. La sutura es saliente; sobre la base se encuentran a cada lado dos profundas fositas prolongadas hacia atrás por débiles impresiones longitudinales que se borran sobre el disco. Abdomen muy declive, punteado como los élitros.

Prosternón y mesosternón no aquillados.

Patas muy robustas y grandes, sobre todo las anteriores. Los fémures son fusiformes, muy engrosados; las tibias anteriores muy largas, aplanadas, llevando una espina hacia el cuarto apical de su borde interno; las tibias posteriores están fuertemente arqueadas hacia adentro.

Habitat. - Cueva de Aitzquirri (término municipal de Oñate, partido de Vergara, provincia de Guipúzcoa), varios ejemplares recogidos en 31 agosto 1919, debajo de grandes piedras, hacia el fondo de la caverna.

El M. Breuili es indudablemente próximo del M. Clarae Schauf. (Verh. Zool.-bot. Ges. Wien, XIII, 1863, pág. 1248, pl. XXV, figs. 12-16), que habita «una cueva de la provincia de Burgos». Pero en $M$. Clarae los lados de la cabeza estarian profundamente sinuados por delante de los ángulos temporales, la impresión transversa de la base del pronoto sería profunda y existiría, entre ella y el escudete, una quilla media longitudinal saliente sobre la base del pronoto, la cual falta totalmente en el M. Breuili.

A. Rafrray, en su Genera de los Pselaphidae (Wytsm. Genera Insect., fasc. $64 .^{\circ}, 1908$, pág. 286), coloca, si bien es verdad que con duda, la especie Clarae Schauf. en su género Apobythus (tipo A. gladiator Reitt.), del cual ciertamente no tiene los caracteres. Es realmente en el género Machaerites L. Mill. (tipo M. spelaeus L. Mill.), tal como está definido por RAFreRAY (loc. cit., página 288), donde deben ser colocadas las formas ibéricas, al lado de M. Lucantei Saulcy, de los Bajos Pirineos. Todos los caracteres de la diagnosis del género, y en particular la escultura y la forma muy especial de los palpos, se aplican tanto a las especies españolas como a los Machaerites de Carniolia y de Córcega. 
Sin embargo, son necesarias algunas observaciones respecto al género Machaerites, tal como RAFFrAy lo define.

El subgénero Bythoxenus Motsch. (tipo B. subterraneus Motsch.), caracterizado por la sola presencia de un surco transverso completo sobre la base del pronoto, no puede ser conservado. Vemos, en efecto, que este surco existe o está borrado en el grupo muy homogéneo de los Machaerites occidentales, existe en M. Clarae. se borra en M. Breuili y falta en M. Lucantei.

Si fuese necesario dividir el género Machaerites, seria mucho más natural hacerlo del modo siguiente:

1. ${ }^{\circ}$ Grupo de las especies orientales, que tienen en maza el primer artejo de las antenas, y la pubescencia del último artejo de los palpos dispuesta con regularidad en lineas longitudinales (Machaerites s. str., Bythoxenus Motsch., Facetus Schauf.), con las especies M. spelaeus L. Mill. y M. subterraneus Motsch., de Carniolia, y M. Revelieri Reitt., de Córcega.

2. ${ }^{\circ}$ Grupo de las especies occidentales, que tienen el primer artejo de las antenas cilíndrico, y la pubescencia del artejo apical de los palpos indistintamente dispuesta en líneas longitudinales; a este grupo corresponden el M. Clarae Schauf., M. Brenili Jeann., de España, y M. Lucantei Saulcy, de los Bajos Pirineos.

Añadamos que la mayoría de las especies de Machaerites 110 están descritas sino por las hembras, y que sin embargo parece que tanto los machos como aquéllas están privados de ojos (véase l’. de Peyerimhoff, Bull. Soc. Ent. Fr., 1901, pág. 298). Como no parece existir en este género ningún carácter sexual secundario, haria falta poder disecar los ejemplares para determinar su sexo con seguridad. Y sin embargo, icuánta tinta han empleado los teorizantes de la Biospeología a propósito de los machos oculados y de las hembras ciegas de los Machaerites! La verdad es que en los pselaifidos oculados de ias cuevas, los ojos son siempre más pequenos en las hembras que en los machos.

Gén. Prionobythus nox:

Especie tipo: P. Bolivari nov. sp.

Este género posee la mayoria de los caracteres del género. Machaerites L. Mill., pero se distingue perfectanente por lal forma y la ornamentación de los palpos. 
Coloración pálida. Forma general fina. Cabeza muy alargada, muy estrechada hacia adelante, sin vestigios de ojos en el macho; frente triangular, bordeada lateraimente por una quilla; vértex muy poco convexo.

Antenas finas y largas, con el artejo I en maza (fig. 15), sin denticulaciones ni artejos de forma especial en el macho. Palpos (figs. 16 y 17) muy finos y muy largos. El artejo I es muy pequeño, el II está aplanado a los lados, muy fuertemente encorvado, perfectamente liso, sin tubérculos ni granulaciones, pero su borde ventral está como dentado en forma de sierra, provisto de una serie regular de una decena de fuertes dientes quitinosos agudos. El artejo III es corto, cilíndrico, armado también de tres dientes ventrales en la prolongación de la serie de dientes del artejo II. Por último, el artejo terminal del palpo es grande, largo, falciforme, fuertemente encorvado sobre șu borde externo y simultáneamente arqueado sobre su cara ventral; todo él está cubierto de una pubescencia indistintamente dispuesta en series longitudinales.

Pronoto muy convexo, liso. Élitros sin fositas basales profundas; sin quillas ni surcos. Abdomen muy poco declive, de manera que el pigidio es bien visible mirado el insecto por encima.

Patas muy finas; los fémures fusiformes; las tibias largas, finas, comprimidas, sin dientes; los tarsos finos y largos.

Estando basada principalmente en la forma de los palpos la clasificación actual de los Bythinini, el Prionobythus se encuentra, por tanto, completamente aislado de los otros géneros; ninguno de los cuales, que yo sepa, tiene una denticulación en sierra semejante en el segundo artejo.

Prionobythus Bolivari nov. sp. (figs. 14 a 17).

Tipo: un macho de la cueva de Martinchurito (Museo de Madrid). Longitud, $1,5 \mathrm{~mm}$.

Forma general fina y alargada. Coloración testácea pardusca, brillante, con las antenas, los palpos y las patas más pálidos. $\mathrm{Pu}$ bescencia dorada, corta, bastante densa, levantada, sobre todo el cuerpo.

Cabeza (fig. 15) más de vez y media tan larga como ancha, con los ángulos temporales salientes, los lados de la frente rectilíneos, estrechándose con regularidad hacia adelante desde los ángulos 
temporales hasta los tubérculos antenales; éstos son pequeños, separados por una estrecha canal frontal. Frente plana, con dos fositas; vértex apenas convexo. Sin ojos.

Antenas (fig. 15) muy largas y delgadas. El artejo I forma el tercio de la longitud de la antena, siendo fino, en maza, seis o siete veces tan largo como ancho; el artejo II es ovalado, un poco más estrecho que el I; el III es cónico, pequeño, un poco más largo que ancho; los artejos IV a x son globulosos, los IV a viI muy pequeños,
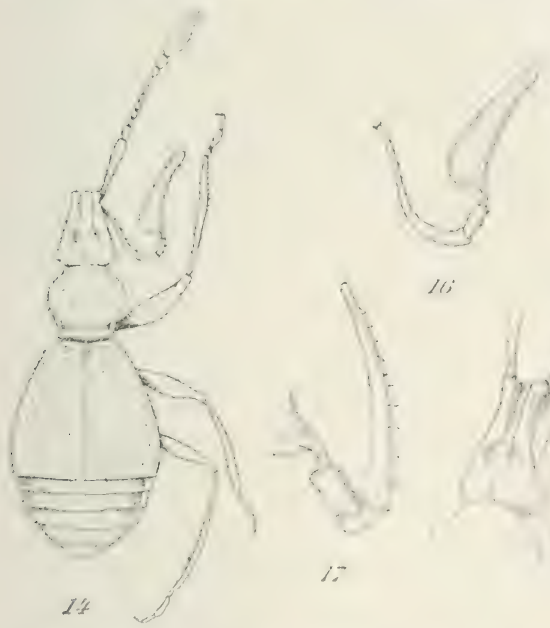

$1 / ;$

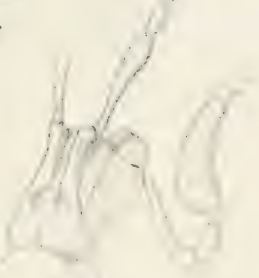

Fig. 14. Prionobythus Bolivari Jeann, macho, de la cuevai de .llartinclurito; $X 20$.

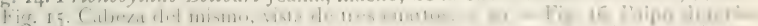
cara dorsal; $X$ 50.-Fig. 17. Artcjos in y 111 del palpo derenche, vistos por la cin. inferior; $\times 80$.

el ix un poco más ancho que el vin, el $x$ bastante grueso, mais que el II; el artejo XI es muy grande, piriforme, largamente penicilado. Palpos (figs. 16 y 17) con el artejo II fino, muy curvado, bastante más largo que la cabeza; el artejo m cilíndrico, un poco mis largo que ancho; el artejo IV muy grande, alargide, falciforme, sustenido por un fino pedúnculo encorvado hacia adentro y el mismo fuertemente arqueado sobre su borde externo y sobre: su cara ventral. 
Pronoto apenas más ancho que largo, convexo con regularidad, con los ángulos laterales relativamente poco salientes, las fositas laterales superficiales, el surco transverso poco profundo, la base rebordeada. Disco finamente punteado.

Élitros amplios, muy convexos, muy estrechados en la base; la sutura saliente cerca del escudete, las fositas poco visibles; disco liso, sin surcos, punteado superficialmente.

Prosternón y mesosternón sin quillas.

Patas finas y largas; las tibias están ligeramente ensanchadas hacia la extremidad y poco arqueadas hacia adentro.

El ejemplar descrito es un macho, según puede verse, porque la extremidad del edeagus aparece saliente en el extremo del pigidio.

Habitat. - Cueva de Martinchurito (término municipal de Larraun, partido de Pamplona, provincia de Navarra), un solo ejemplar macho, recogido por C. Bolívar y Pieltain en 22 agosto 1919, bajo una piedra, en una sala obscura. A pesar de buscar perseverantemente durante varias horas en el mismo sitio, no nos fué posible encontrar un segundo ejemplar.

\section{Silphidae}

rot:

\section{Bolivar y Pieltain.}

Batlysciola (s. str.) azuai nov. sp.

Tipo: macho del Gorbea (col. Museo de Madrid).

Longitud, $2-2,1 \mathrm{~mm}$.

Forma ovalada, estrechada hacia atrás, convexa. Coloración pardo-testácea obscura. Pubescencia finísima, no muy densa. Punttuación protorácica fina; en los élitros formando estriolas transversales muy marcadas. Ojos nulos. Antenas cortas, no, alcanzando a los ángulos posteriores del pronoto. El artejo II doble de grueso que el III; artejos III a vi alargados, de ellos los tres primeros casi iguales en longitud, el último más corto; artejo vI ensanchado desde la base; vilı muy pequeño, globular; ix y x transversos; xi ovalalargado, vez y media tan largo como ancho. Pronoto no más ancho que los élitros, muy convexo, de lados arqueados con regularidad. Élitros no paralelos, anchamente redondeados en el extremo; sin 
estría sutural. Quilla mesosternal formando un ángulo recto, algo redondeado en el ápice; borde anterior nada arqueado. Tarsos anteriores del macho un poco más estrechos que la extremidad de las tibias correspondientes. Tibias posteriores rectas en ambos sexos. Tarsos posteriores tan largos como los cuatro quintos de las tibias correspondientes.

Edeagus tan largo como el tercio de la longitud del cuerpo, fuertemente arqueado en la parte media y con su borde superior bisinuado en la mitad basal. Los estilos laterales presentan tres inflexiones: la primera, muy fuerte, los dobla en ángulo obtuso; en la extremidad llevan cuatro largas sedas, todas ellas de longitud próximamente igual, muy aproximadas en la base y colocadas sobre el borde terminal del estilo, estando dirigidas hacia adentro y normalmente al eje de aquél.

Habitat. - Especie lucicola que vive entre las hojas caidas en el bosque en que se abre la gran caverna de Mairtelegorreta y no lejos de la entrada de ésta.

Provincia de Álava: vertiente Este de la peña de Gorbea, en la ladera de la montaña entre la cueva del Manantial y la de Mairuelegorreta (término municipal de Cigoitia, partido de Amurrio). Recogimos tres ejemplares de esta especie (col. Museo de Madrid y Biospeologica) en 28 agosto 1919.

Observaciones. - Ofrece la misma forma, coloración y estriolado de los élitros que B. schiödtei (Kiesenw.), pero se diferencia fácilmente de esta especie tan polimorfa porque los estilos laterales de su edeagus están provistos de cuatro largas sedas en la extremidad, en vez de las tres sedas cortas que presentan en dicha especie. De rugosa (Sharp) se diferencia principalmente por los caracteres que la aproximan a schiödtei, y de parallela (Jeann.) por estos mismos caracteres y por su coloración obscura.

Bathysciola (s. str.) breuili nov. sp). (fig. 18).

Tipo: macho de la cueva de Landarbaso (col. Biospeologica). Longitud, 2,3-2,5.

Forma ancha, deprimida, apenas estrechada hacia atrás. Coloración testácea pálida. Pubescencia fina, bastante larga y poco densa. Puntuación muy fina y superficial sobre el pronoto; en lus étitros formando estriolas transversales bien marcadas, aunque 110 muy 
apretadas. Ojos nulos. Antenas cortas, no alcanzando a los ángulos posteriores del pronoto, finas, con la maza gruesa y algo comprimida. El artejo II doble de grueso que el III; artejos III a VI alargados, el III el más largo de ellos; artejo vil engrosado desde la base; VIII muy pequeño, globular; IX y x casi tan largos como anchos; xI oval-alargado. Pronoto muy convexo en su parte anterior, no más ancho que los élitros, de lados arqueados con regularidad. Élitros de lados no paralelos, estrechados hacia atrás muy poco a poco, en la extremidad anchamente redondeados por separado; estría sutural nula. Quilla. mesosternal muy elevada; su borde anterior curvo y formando un angulito agudo en su unión con el borde inferior. Tarsos anteriores del macho próxima-

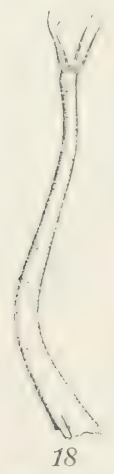

Fig. I8.-Estilo lateral del edeagus de bathy'sciola brenili C. Bol.; $\times 90$. mente tan anchos como las tibias correspondientes en su' extremidad. Tibias posteriores rectas en ambos sexos. Tarsos posteriores tan largos como los cuatro quintos de las tibias correspondientes.

Edeagus tan largo como el tercio de la longitud del cuerpo, bastante arqueado después del medio, su borde superior bisinuado en la porción basal. Estilos laterales (fig. 18) con la curvatura ventral muy pronunciada, y más adelante dirigidos levemente hacia arriba; en la extremidad ligerísimamente adelgazados y provistos sobre el ápice mismo de cuatro sedas, juntas en la base, las cuatro muy largas y de longitud semejante, dirigidas hacia adentro e insertas normalmente al eje del estilo.

Habitat. - Especie cavernícola que vive debajo de las piedras en la primera parte de la gran caverna de Landarbaso.

Provincia de Guipúzcoa: cueva de Landarbaso (término municipal de Rentería, partido de San Sebastián). Varios ejemplares (colección IBiospeologica y Museo de Madrid), recugidos por II. Breuil y R. Jeannel en 18 agosto 1919.

Observaciones. - Esta especie es, indudablemente, muy próxima de rugosa (Sharp), de la cual parece ser una rama que en época reciente ha colonizado la cueva, adaptándose a la vida cavernícola. Difiere de aquélla por su coloración pálida, su forma menos ancha y deprimida, sobre todo en los élitros, los cuales están cubiertos de pubescencia algo más larga; sus tarsos anteriores son 
proporcionalmente más anchos, y su quilla mesosternal más alta y angulosa, formando un dientecito agudo muy pronunciado. Su coloración y su aspecto son más bien de parallela (Jeann.), pero el conjunto de sus caracteres la aproximan a rugosa.

Aprovecho esta ocasión para consignar que los estilos laterales del edeagus de rugosa llevan en su extremidad cuatro largas sedas de longitud semejante, lo mismo que la nueva especie, y no dos largas y dos cortas, como se creía.

Bathysciola (s. str.) rugosa (Sharp).

En nuestra excursión encontramos tres veces esta especie: en la región de Tolosa, en la entrada de la cueva del Chorrote, debajo de las piedras; en la vertiente de la peña Aratz (provincia de Guipúzcoa), no lejos del San Adrián, entre las hojas caídas, en unión del Trechus distigma Kiesenw., y en la cueva de Orobe, cerca de Alsasua (provincia de Pamplona), entre los montones de hojas podridas almacenadas en el fondo de la gran dolina, en donde vive también el Trechus uhagoni Crotch.

Parece ser una especie poco frecuente, aunque ampliamente extendida. Había sido recogida anteriormente en las siguientes localidades :

Provincia de Pamplona: Alsasua (Uhagún!, Crotch); entradil de l.l cueva de Daran-Daran, frente al puerto de Olozagoitia, en el valle de Alsasua (Uhagón); entre Alsasua y Zumárraga (R. Oberthur et L. Bileuse).

Provincia de Alava: Zuazo, partido de Vitoria (Escilera!).

Provincia de Guipúzcoa: Zumaya (Escalera).

\section{Speonomus (Liuryspeonomus) breuili Jeannel.}

Bol. Soc. Esp. Hist. Nat., 1919, piigs. 135-137, fig. 2.

Este interesante Speonomus, que ha merecido la creación de 111 subgénero independiente, labita en fodas las curvas que hasta ahora han sido exploradas en la regrión de Martinchurito; habicindolo recogido nosotros en las dos cuevas de Martinchurito y' e.t1 la de Akelar (término municipal de Larraun, partido de l'annplona, provincia de Navarra). Se le encuentra andando sobre el suefo e paredes estalagmíticas. 
Speonomus mendizabali nov. sp. (figs. 19 y 20).

Tipo: hembra de la cueva de Mendicute (col. Biospeologica).

Longitud, $3,5 \mathrm{~mm}$.

Forma general oval-alargada, poco convexa. Coloración testácea rojiza. Escultura formada de puntıación fina y superficial sobre la cabeza y el pronoto, y de estriolas transversales muy bien

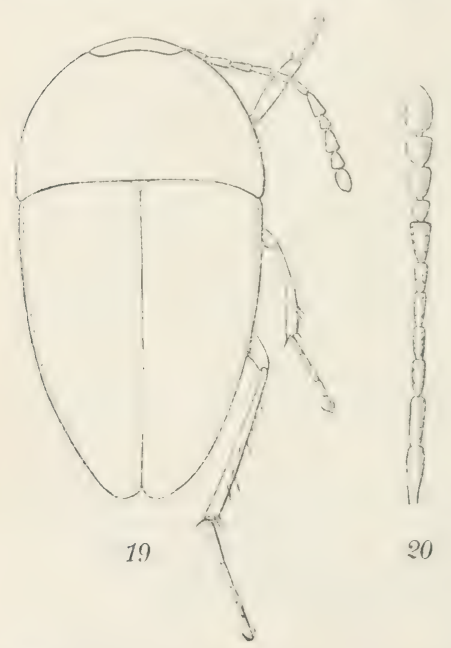

Fig. I9. Speonomus mendizabali C. Bol, silueta de la hembra, de la cueva de Mendicute; $\times$ 16. - Fig. 20. Antena derecha, vista de lutu; $\times 2$; marcadas sobre los élitros, pero menos densas que en E. brenili. Pubescencia dorada, sentada, corta.

Antenas (fig. 20) cortas, pasando poco de los ángulos posteriores del pronoto, y $n$ alcanzando en modo alguno a la mitad de la longitud del cuerpo. Los seis primeros artejos son completamente cilindricos; a partir del vil son gruesos; el vII doble de largo que ancho en su ápice, hacia el cual está ensanchado; el vill muy pequeño, mitad menor que el anterior; $\mathrm{IX}$ y $\mathrm{x}$ casi iguales, un poquito más corto el $\mathrm{x}$ que el $\mathrm{Ix}$, ambos subtrapezoidales, más largos que anchos en el ápice; xi oblongado, vez y media más largo que ancho.

Pronoto transverso, corto, bastante convexo, de lados arquesdos con regularidad; presentando su mayor anchura en la base, en la que es casi doble de ancho que largo y ligeramente más ancho que los élitros.

Élitros casi vez y media tan largos como anchos en conjunto en la base, muy poco convexos; en la extremidad redondeados por separado. La sutura está deprimida, sobre todo hacia la base, y no existe estria sutural. 
Quilla mesosternal alta, su borde anterior arqueado y formando en su unión con el inferior un diente agudo.

Tibias intermedias y posteriores armadas de espinas en su cara externa, no más largas que la anchura de las tibias. Las tibias intermedias están algo dobladas antes del medio y con la mitad apical bastante engrosada; las posteriores son completamente rectas, un poco comprimidas. Tarsos posteriores tan largos como los cuatro quintos de la longitud de las tibias correspondientes; oniquium con las uñas de longitud normal.

Habitat. - No conozco de esta especie sino el tipo que fué recogido por R. Jeannel, en 20 agosto 1919, en la cueva de Mendicute (término municipal de Albistur, partido de Tolosa, provincia de Guipúzcoa).

En la misma cueva vive el Speocharidius breuili Jeann., habiendo sido recogido el Speonomas mendizabali entre varios ejemplares de dicha especie, sin que nos fijáramos al recogerla, por lo cual no puedo precisar nada del sitio en que vive.

Observaciones. - No conociendo el macho de esta especie me es casi imposible colocarla con exactitud dentro del género Speonomus. A mi juicio, no pertenece a los Speonomus s. str., con los cuales no concuerda por su forma ni por sus antenas gruesas y muy cortas, con los artejos apicales ensanchados; ademis, carece aún de vestigios de estría sutural en los élitros, lo que la aproximaria a las especies del grupo V, con las que no tiene la menor relación.

Tampoco pertenece al subgénero Phacomorphus, pues no ofrece la forma ni el aspecto de las especies mascaran.xi y alexinae, las cuales, por otra parte, tienen antenas largas, filiformes y muy delgadas.

Por tanto, sólo podria referirse esta especie al subrénero Ėurıspeonomus, que habita las cuevas de la meseta de Martinchurito, en Navarra. Sin embargo, resulta muy aventurado el hacerlo no habiendo podido estudiar el edeacrus del macho y ver si sus estilos laterales carecen de las tres sedas divergentes o del penacho de pestañas característicos de los Speonomus s. str., pues presenta grandes diferencias con esta especie, siendo sus antenas mucho más cortas y gruesas y de otra conformación, sus tibias mucho menos espinosas y la pubescencia general y estriolado transversal de los élitros diferente. 
Speonomus (s. str.) ciaurrizi nov. sp. (figs. 21 a 24 ).

Tipo: macho de la cueva de Malkorraundi (col. Museo de Madrid).

Longitud, 2,3-2,6 mm.

Forma oval-alargada, poco convexa. Coloración testácea pálida. Puntuación protorácica muy fina; en los élitros formando estriolas apretadas, pero muy superficiales. Pubescencia muy corta y fina, bastante densa.

Antenas alcanzando la mitad de la longitud del cuerpo, muy en-
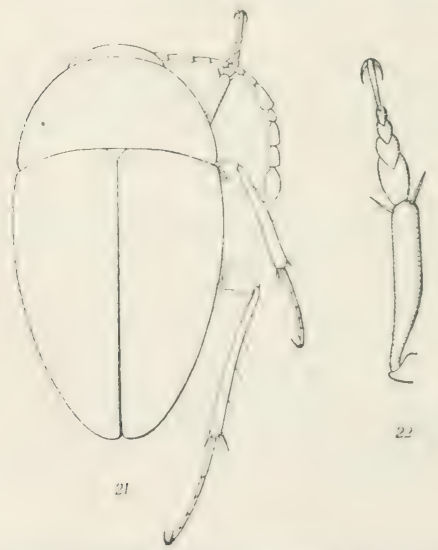

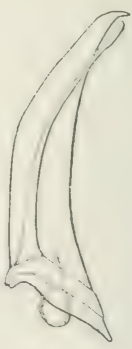

23

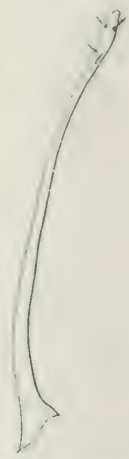

26

Fig. 2I. Speonomus (s. str.) cianrriai C. Bol., silueta del macho, de la cueva de MalRorraundi; $\times 20$. -Fig. 22 . Tibia y tarso anteriores del macho; $\times 44 .-$ Fig. 23 . licleasus, cara izquierda; $\times 50 .-$ Fig. 24 . Estilo lateral izquicrdo del edeagus; $\times 8_{4}$.

grosadas a partir del VII artejo; el artejo II vez y media más largo que el III y casi doble de ancho que él; artejos III a v casi iguales, cilindráceos; artejo vı un poco más corto y algo engrosado; vir muy grueso, engrosado desde el tercio basal; vin corto, algo más largo que ancho, globoso; $\mathrm{x}$ y $\mathrm{x}$ doble de largos que anchos, gruesos desde la base; xi oval-piriforme, mitad más largo que el anterior; a partir del artejo IX las antenas son algo comprimidas.

Pronoto corto, casi doble de ancho en la base que largo en la 
línea media, de lados arqueados con regularidad, presentando su anchura máxima en la base; sus ángulos posteriores son agudo-redondeados, nada prolongados hacia atris. Flitros en sunjuntu menms de vez y media tan largos como anchos; sin depresión ni estría sutural. Quilla mesosternal alta, en ángulo obtuso; su borde anterior arqueado, formando un dientecito agudo en su unión con el borde inferior, que es recto.

Tibias anteriores (fig. 22) muy finas, de bordes paralelos en sus dos tercios apicales. Los tarsos correspondientes poco dilatados en los machos, no más anchos que las tibias en su extremidad; primer artejo más corto que los dos siguientes reunidos. Tibias intermedias ligeramente arqueadas, armadas en su parte externa de tres o cuatro espinas más largas que la anchura de la tibia. Tibias posteriores rectas en los dos sexos, comprimidas, provistas también de varias largas espinas. Los tarsos posteriores tan largos como los cuatro quintos de las tibias correspondientes.

Edeagus (fig. 23) tan largo como el tercio de la longitud del cuerpo, grueso, en sus dos tercios basales completamente recto $y$ de lados paralelos, seguidamente un poco arqueado, en la extremidad en punta aguda fuertemente encorvada; la lámina basal es corta. El saco interno presenta una pieza en $Y$ muy bien desarrollada, siendo las ramas superiores largas y en su extremidad dilatadas en ůna ancha laminita quitinizada; las bandas longitudinales quitinosas de la mitad terminal del saco están bien desarrolladas. Los estilos laterales (fig. 24) 110 alcanzan a la extremidad del edeacrus, son extraordinariamente finos, y terminan por una porción oblongrada, ligeramente más ancha, que lleva cuatro sedas cortas, situadas dos antes de la porción más ancha y las otras dos cerca del ápice, una sobre cada margen del estilo; no existen pelos esparcidos ni brocha de sedas.

Habitat. - Vive esta especie en la cueva de Malkorraundi, situada cerca de Gorriti (término municipal de Larram, partido de Pamplona, provincia de Navarra). Recogimos mumerosos ejemplares de ella en 23 agosto 1919.

Obseruaciones, - El carecer de estria sutural lleva a estat especie al grupo $\mathrm{V}$ de los que hace R. Jisantr, y en el que estiu incluidas las especies mís occidentales de Speonomus. P’(ro sm mumerosos los caracteres que la separan de las otrus esperies que comprende este grupo, siendo Ios mis importantes la forma de su cuerpo más deprimida; sus élitros alego más anchus en su halse yue 
el pronoto, por lo cual las márgenes laterales de éste no se continúan seguidamente con las de los élitros; sus antenas muy gruesas en la mitad apical, con los artejos vir, Ix y x engrosados casi desde la base; sus tibias anteriores muy finas y largas, con los tarsos correspondientes muy poco dilatados, en los machos de la misma anchura que las tibias en la extremidad, pero como éstas muy estrechos; sus tibias intermedias y posteriores provistas de espinas finas y largas, de longitud superior a la anchura de la tibia. Por último, el edeagus ofrece caracteres muy notables que separan a esta especie con facilidad, no sólo de las restantes del grupo $\mathrm{V}$, sino de todas las demás especies de Speonomus.

Speonomus (s. str.) mazarredoi (Uhagón).

Recogimos numerosos ejemplares de esta especie en la cueva de San Valerio, cerca de Mondragón, donde fué descubierta en 1879 por C. de Mazarredo, y vuelta recoger recientemente por Ch. Alluaud y H. Breuil.

El edeagus de este insecto concuerda en un todo con el de la siguiente especie.

Speonomus (s. str.) aitzquirrensis nov. sp. (figs. 25 a 27 ).

Tipo: macho de la cueva de Aitzquirri (col. Museo de Madrid). Longitud, 2,3-2,5 mm.

Forma general oblongo-alargada, poco estrechada hacia atrás, bastante convexa. Coloración testácea obscura. Estriolas elitrales densas y muy finas. Pubescencia finísima, corta y no muy densa.

Antenas alcanzando a la mitad del cuerpo, poco engrosadas en la mitad apical; artejos III a vi cilíndricos, semejantes; vII un tercio más largo que el precedente, hacia la extremidad engrosado; vil corto, grueso, poco más largo que ancho; ix y x ensanchados hacia el ápice; xi casi doble de largo que ancho, muy poco comprimido, alargado-piriforme.

Pronoto tan ancho como los élitros; sus ángulos posteriores son agudos, pero poco salientes. Élitros en conjunto vez y cuarto más largos que anchos; estría sutural nula. Quilla mesosternal alta, en ángulo recto, su borde anterior ligerisimamente arqueado.

Tibias anteriores del macho (fig. 26) moderadamente ensancha- 
das en su mitad apical. Los tarsos correspondientes poco dilatados. de igual anchura que la tibia en su extremidad; primer artejo un poco más corto que los dos siguientes reunidos. Tibias intermedias un poquito arqueadas, armadas en su borde externo de espinitas muy cortas. Tibias posteriores rectas en los dos sexos, comprimidas. Los tarsos posteriores tan largos como los tres cuartos de las tibias correspondientes.

Edeagus (fig. 27) menos de un tercio de la longitud del cuerpo. muy fino, fuertemente encorvado en su parte media; la lámina basal muy larga y recta. La mitad apical del edeagus es muy estrecha y
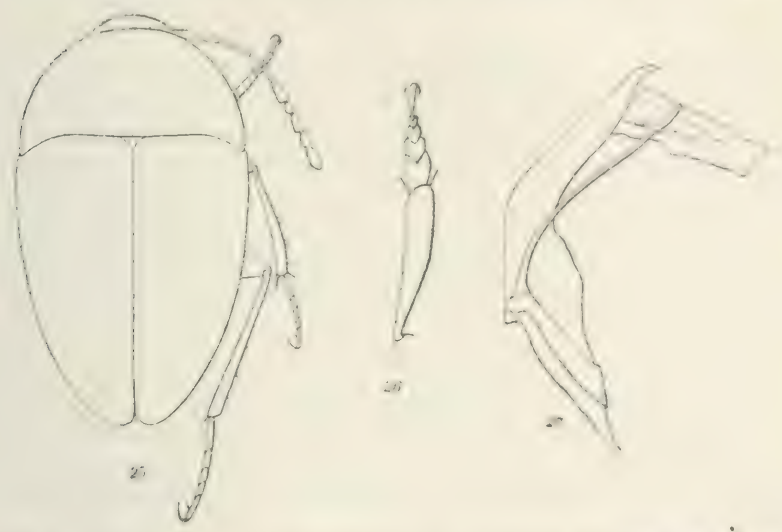

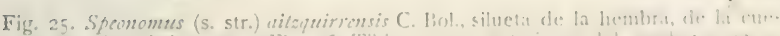
va de Aitzquirri; $X$ 20. - Fig. 26. Tilsia y tarso anteriones del macho; $2+2$ Fig. 27. Edeagus, cara izquierda; $\times 70$.

recta, con la punta encorvada. Los estilos laterales no alcanzan a la extremidad del edeagus, son finos, ligrerisimamente ensanchados en la extremidad, en la que llevan muchos pelos cortus y hacia ut burde. inferior dos sedas de longitud mucho mayor.

Habitat. - Cueva de Aitzunirri (términu municipal de: ()nate, partido de Vergara, provincia de (iuipuzcoa). ('inco e jemplares (colección Biospeologrica y Museo de Madrid), recorridos en 31 agrosto 1919 .

Observaciones. - Pertenece al grupo V de los syemmomms por carecer de estria sutural, siendes sus mayores analogian ion 
mazarredoi, de la cual se distingue principalmente por su forma más alargada y paralela, mucho menos estrechada hacia atrás; sus antenas menos comprimidas en la extremidad, con el último artejo alargado-piriforme y no ovalado y comprimido.

Quizás no deba considerarse a este Speonomus como una especie diferente, sino más bien como una raza local del mazarredoi, lo que no puedo resolver hasta que disponga de un mayor número de ejemplares.

Speonomus (s. str.) oberthuri Jeannel (fig. 28).

De esta especie se conocia un solo ejemplar hembra, recogido en la cueva de San Adrián por R. Oberthür y L. Bleuse en 1879; posteriormente no se había vuelto a encontrar a pesar de haber visitado la cueva en 1913 cazadores tan hábiles como Ch. Alluaud y H. Breuil. En nuestra excursión fuimos más afortunados, y aunque la especie parece ser rara, encontramos cuatro ejemplares en una de las galerias obscuras del paso del San Adrian (término municipal de Cegama, partido de Azpeitia, provincia de Guipúzcoa), en 1 septiembre 1919.

Además tuvimos la suerte de descubrir, a poca distanicia del San Adrián, una nueva localidad de esta especie, en una cueva llamada "Partchancovia», en la que parece ser más abundante.

Señalo a continuación los principales caracteres de esta especie, que pueden servir para completar la descripción dada por R. JEANNEL.

Longitud, 2,2-2,6 mm.

Forma oval-alargada, muy convexa. Coloración testácea obscura. Estriolas elitrales densas y muy finas. Antenas, no alcanzando a la mitad del cuerpo, poco engrosadas en la mitad apical; artejos III a vı cilindricos, iguales; viı un tercio más largo que el anterior, engrosado hacia el ápice; vill pequeño, cilindráceo, casi doble de largo que ancho; $x$ y $x$ sensiblemente iguales, ensanchados hacia el ápice; xi vez y media más largo que el anterior.

Pronoto tan ancho como los élitros, con sus ángulos posteriores poco salientes. Élitros, en conjunto, una vez y un tercio más largos que anchos; sin estria sutural. Quilla mesosternal alta, en ángulo recto, el borde anterior licerisimamente arqueado, y formando en su unión con el inferior un dientecito. 
Tibias anteriores del macho (fig. 28) cortas y anchas en los dos tercios apicales. Los tarsos correspondientes muy dilatados, siendo mucho más anchos que la tibia en su extremidad; su primer artejo distintamente más corto que los dos siguientes reunidos. Tibias intermedias y posteriores armadas de espinitas muy cortas y finas.

Edeagus semejante al del aitzquirrensis; bastante arqueado en su porción media. Los estilos laterales llevan en su extremidad muchos pelos, de los cuales se destacan dos por su longitud mucho mayor.

Observaciones. - Especie bien distinta de las otras, y que presenta en cierto modo caracteres intermedios entre el crotchi de un lado, y el mazarredoi y aitzquirrensis de otro. Tiene, como el primero, unos tarsos anteriores muy dilatados en el macho, más anchos que las tibias correspondientes en su extremidad; pero el artejo

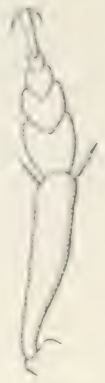

28

Fig. 2x. Tibia y tarso anteriores ilel macho de sifconimu: (s. str. 1 efierthuri Jeann.; $\therefore 50$.

VIII de las antenas no es tan cilíndrico ni alargado como en dicha especie, si bien lo es algo más que en mazarredoi y aitzquirrensis.

\section{Speonomus (s. str.) crotchi (Sliarp).}

En la cueva de Orobe, situada cerca de la via férrea, entre las estaciones de Alsasua y Cegama, encontramos esta especie en el sitio indicado exactamente por UnAciùx (1), e's decir en una de las cuevas laterales (en la que se abre a ha izquierda bajando a la gran dolina). Parece ser una de las especies mas escasas.

\section{(iin. Speocharidius Jeannel.}

Bol. Suc. Esp. Ilist. Nat., 1919, paigs. 1301-131.

La descripción de este genero está hecha casi exclusivamente. sobre ejemplares hembras, pues en ayuel momento su autor mo disponia sino de los restos de un macho. Por esta razin, creo conve-

(i) S. Umagos, Anules Soc. Espr. llist. Nat., t. I, 1872. paig. 272. 
niente añadir algunas particularidades a la descripción genérica, especialmente por lo que se refiere a la conformación del edeagus, que es muy característico. La preparación del saco interno de éste resulta bastante difícil, dado lo estrecho y curvo que es, no siendo fácil, por otra parte, estudiarlo por transparencia. Habiendo logrado disecarlo, doy los caracteres de las piezas quitinosas, siendo lo más notable el que la pieza en $y$ presente dobles sus dos ramas superiores y muy ancha su rama infero-posterior.

Cuerpo de forma general muy alargada en los machos, más elíptica en las hembras. El protórax siempre más estrecho que los

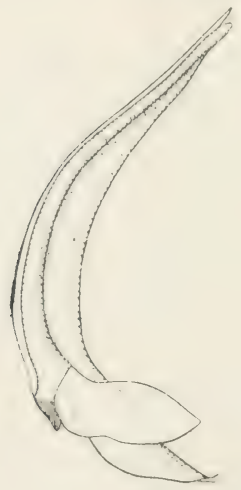

29

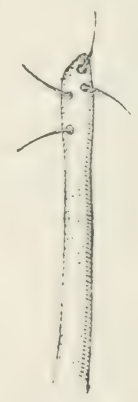

3()

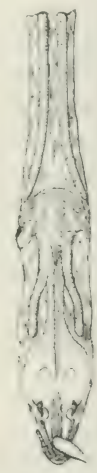

$\because 1$

Fig. 29. Edeagus de Spzocharidius bolizari Jeann., cara izquicrda; $\times$ 55. -Fig 30. Extremidad de un estilo lateral del edeagus; $\times 160 .-$ Fig. 31 . Saco interno del cdeagus, cara dorsal; $\times 86$.

élitros, cuadrangular en los machos, transverso en las hembras; sus lados son sinuosos, mucho más fuertemente en los machos. Ángulos posteriores del pronoto agudos y salientes hacia atrás, a veces agudísimos; la base más o menos sinuosa. Élitros oblongados, de dos a tres veces más largos que anchos. Las tibias intermedias están doblado-arqueadas hacia adentro, débilmente en las hembras, muy marcadamente en los machos, en los cuales están además ensanchadas hacia adentro en su porción apical, siendo igualmente la pubescencia en esta parte muy densa y levantada, formando a veces 
una especie de cepillo, y continuándose más o menos esta misma pubescencia por la parte inferior de los tarsos correspondientes.

El edeagus (fig. 29) es muy fino, arqueado con resularidad, muy deprimido en la porción apical, en la que es muy agudo. El saco interno (fig. 31) lleva en la región donde desemboca el canal eyaculador una pieza en $Y$, cuyas ramas superiores son dobles, las internas un poco más largas que las externas y unidas por un filamento encorvado a un corpúsculo quitinoso; la parte infero-posterior de la pieza en $Y$ es ancha; en la parte media del saco hay dos fuertes bandas quitinosas, entre las cuales quedan unas porciones menos quitinizadas, y más hacia adelante se prolongan en un vástago quitinoso, de extremidad libre, dirigida hacia la base del saco; los dos tercios apicales del saco están recorridos' a cada lado por una fuerte banda quitinosa. Los estilos laterales están insertos dorso-lateralmente, son anchos en la porción basal y adelgazados paulatinamente hacia el ápice (fig. 30), en el cual llevan cuatro cerditas muy cortas, aproximadas y dirigidas hacia adentro, normalmente al estilo.

Observaciones. - El género Speocharidius pertenece a la serie filética de los Speonomus, y no a la de los Speocharis, como se dice en la descripción original. Esta es la opinión, tanto del doctor R. JEANNEL conio mía, y si en un principio pudo creerse que tendria relación más bien con los Speocharis, el estudio detenido del edeagus nos ha demostrado que pertenece al grupo de los Speonomus, pues el saco interno carece del estilete o de los dientes esparcidos propios de los Speocharis, y en cambio presenta una pieza en $Y$, si bien de tipo especial.

Speocharidius se diferencia de los demis géneros de la seric de los Speonomus por presentar cuatro sedas en-la extremiclad de los estilos laterales del edeagus, mientras que éstos no tienen sino tres como máximum, excepción hecha del Eur!speonomus bremili Jeann., que igualmente lleva cuatro sedas cortals y espaciadas. Lis curioso que los dos géneros propios del pais vasco temgan los estilos laterales provistos de igual mumero de sedas en la extremidad.

Se diferencia también de los otros géneros porque sus ilitros ofrecen densa y tosca puntuación, que no forma cestriolas transversales, $y$ además por no presentar penachos de seclas en la extremidad de los estilos laterales del edearrus.

El edeagus varia muy poco en las diferentes especies de uste género, no habiendo podido encontrar diferencias especificas de importancia, aplicándose los caracteres que se senalan anteriormente 
a todas las especies. Las piezas del saco interno no las he estudiado en breuili y filicornis sino de un modo deficiente por transparencia, pero parecen presentar la misma disposición que describo refiriéndome a bolivari.

Dimorfismo sexual. - Como se deduce de los caracteres que doy anteriormente, el dimorfismo sexual es muy marcado en las especies de este género. Los machos son de forma mucho más alargada y paralela, sus antenas y patas mucho más finas y largas, su protórax tan largo como ancho y sus tibias intermedias más arqueadas hacia adentro y en la extremidad ensanchadas. Quizás sea el género de la serie de los Speonomus en que el dimorfismo sexual esté más acusado.

Speocharidius breuili Jeamel.

Bol. Soc. Esp. Hist. Nat., 1919, paigs. 131-133, fig. 1.

Recogimos varios ejemplares de esta especie en la cueva de Mendicute (localidad típica) y en la del Chorrote, situada próxima a la anterior, y ambas en el término municipal de Albistur, partido de Tolosa, provincia de Guipúzcoa.

Los ejemplares de la cueva del Chorrote presentan ligerísimas diferencias con los de Mendicute, siendo en ellos el pronoto menos sinuado lateralmente, los últimos artejos de las antenas menos engrosados en la extremidad y la talla general ligerisimamente menor; pero estas variaciones no justifican, a juicio mio, el que se les designe con un nombre especial.

Speocharidius filicornis Jeannel.

Loc. cit., 1919, pág. 134.

De esta especie, de la que se conocia tan sólo la hembra que sirvió para hacer la descripción, recogimos unos cuantos ejemplares en la misma localidad en que fué encontrada aquélla, o sea en la cueva die Hernialde, situada sobre el pueblo de Hernialde, en el partido de Tolosa, provincia de Guipúzcoa.

Por el conjunto de sus caracteres se aproxima más a breuili que a bolivari, concordando con la primera en la coloración obscura y en la finura de sus antenas. Su talla es intermedia entre ambas. Su 
cuerpo está más ensanchado en la parte media que en las otras. siendo también más fuertemente arqueado el borde externo de sus élitros. La pubescencia es finisima y bajo ella aparece la escultura, también muy fina, y formada por puntos dispuestos sin ningún orden. El pronoto del macho es poco transverso, estando sus bordes escotados en la mitad posterior (algo menos que en breuili), y los ángulos posteriores son muy agudos y salientes. En la hembra. el pronoto es bastante transverso y nada escotadas sus márgenes en la mitad posterior, por lo cual resulta, en conjunto, campanuliforme. Las tibias intermedias de los machos están bastante ensanchadas en la porción terminal, teniendo su borde interno bastante curvo.

Speocharidius bolivari Jeannel (figs. 29 a 32).

Bol. Soc. Esp. Hist. Nat., 1919, pág. 133.

Recogimos, en 19 agosto 1919, abundantes ejemplares de esta interesante especie en la cueva de Arrobieta, situada cerca del caserio de Bideondo (término municipal de Anoeta, partido de Tolosa, provincia de Guipuzcoa), localidad donde fué descubierta por el abate H. Breuil dos años antes.

Es la especie de tamaño más pequeño, diferenciándose además de las otras dos por su coloración mucho más pálida, de un testáceo claro, y por sus antenas cuyos artejos no son tan extraordinariamente delgados como en las otras especies, sobre todo los terminales, que además son casi del mismo grosor desde la base al ápice, y no engrosados tan súlo en tercio o cuarto apical, como ocurre en las otras especies.

El edeagrus de este insecto

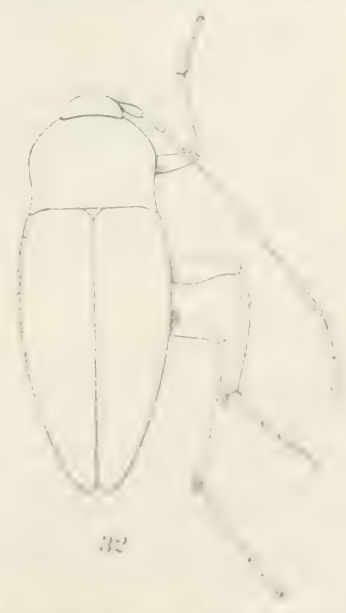

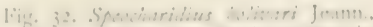

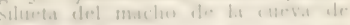
Arrolsiet.1; $\therefore$ it. mide próximamente un tercio de la longitud total del cuerpon. 


\section{SOBRE LA HISTOLOGÍA DE LOS CORAZONES BRANQUIALES $Y$ DE SUS APÉNDICES EN ALGUNOS CEFALÓPODOS (LOLIGO, ROSSIA, ELEDONE)}

POR

\section{E. FERNÁNDEZ GALIANO}

No hace mucho tiempo que publicamos en esta misma Sociedad un estudio acerca de la estructura fina de los corazones branquiales y sus apéndices del cefalópodo Sepia officinalis L. (1); en él poniamos de relieve ciertos pormenores histológicos inadvertidos por los autores que anteriormente habian trabajado sobre el mismo tema y aclarábamos la significación de algunos otros que habian sido entrevistos de manera confusa.

E1 presente trabajo está principalmente dedicado a averiguar si aquellas disposiciones anatómicas que hemos sorprendido en Sepia tienen su representación en los demás cefalópodos, habiendo, al efecto, elegido tres tipos entre estos animales: Loligo vulgaris Lam., Rossia macrosoma D'Orb. y Eledone moschata Lam.

En cierto sentido, pues, es este estudio una continuación del trabajo citado, el cual deberá ser consultado por el lector, no sólo porque en él se expone el estado actual de la cuestión y se pasa revista a la bibliografía sobre el asunto, sino porque contiene también la descripción de ciertos detalles anatónicos cuyo conocimiento es indispensable para entender e interpretar las formaciones histológicas y que, en obsequio a la brevedad, omitimos en las páginas que siguen.

(1) Fernandez Galiano, Estudio histológico de los corazones branquiales de sepia officinalis» L. y de sus apéndices. (Bol. de la R. Soc. Esp. de Hist. Nat., t. XIX, 1919.) 
Corazón branquial de Loligo. - Está cubierto exteriormente este órgano, como ya había advertido MARCEAU (1), por un epitelio compuesto de células bajas, intimamente soldadas entre si y provistas de una delgada cutícula apenas visible. En nuestras preparaciones, teñidas por la primera variante de Rio-HorTEGA al método de ACHúcARro (2), hemos sorprendido en tales células, comu antes lo habiamos hecho en las análogas de Sepia (3), la presencia de numerosas epitelio-fibrillas. Muéstranse éstas bajo la forma de finísimas hebras teñidas en violeta, que se asientan por su pie sobre las fibras de la basal conectiva, y después de seguir un curso más o menos tortuoso, se desvanecen antes de alcanzar la cuticula superficial. El aspecto que presenta el sistema de epitelio-fibrillas es variado, dependiendo en gran manera del ángulo que forma el plano de la sección con el eje mayor de las células; puede, no obstante, decirse en general que rara vez conservan las epitelio-fibrillas su independencia hasta el final, sino que casi siempre se anastomosan entre sí las contiguas para dibujar una red que evidentemente representa el retículo protoplásmico de las células a que aquéllas pertenecen (4).

La masa del corazón branquial, envuelta por la membrana epitelial de que acabamos de hablar, está compuesta, como ya observú MARCEAU (5), de una red de haces musculares de amplias mallas, en las cuales se encuentran las que podemos llamar células propias, caracterizadas por poseer un núcleo pobre en cromatina y' un protoplasma vacuolar con granulaciones, a veces de considerable tamaño, tingibles en rojo por la eosina. Una observación atenta de las granulaciones eosinófilas nos conduce a establecer para ellas los siguientes caracteres (fig. 1) :

1. Su tamaño es extraordinariamente variable, pues se encuentran todas las gradaciones imaginables entre las granulaciones casi imperceptibles por su escaso volumen y las formadas por una masa

(1) MARCEAU, Recherches sur la structure du curur chez les Mullusques. (Arch. d'Anat. Microsc., t. VII, 1!414-1!(15.)

(2) Rlo-HORTEGa, Varias modificaciones al mitodo de Achicarro. (Bol. de la Soc. Esp. de Biol., 19l(i.)

(3) Vúase íernanitez (ialiano, loce, cit., fig. 3."

(4) RIO-Hortega, Contribución al conocimiento de las cpilitio-fibrillas. (Trab. del Lab. de Inv. Biol. de la Univers. de Madrid, 1. XI. I!17.)

(5) MIARCEAU, loc: cit. 
que ocupa gran parte de la célula. Su forma es también variable, esférica u ovoidea en la mayoría de los casos.

2. No se encuentran jamás incluídas en el espesor del protoplasma, sino constantemente en el seno de vacuolas.

$3 .^{\circ}$ La masa eosinófila, que constituye una granulación, tiene una estructura finamente esponjosa, exhibiendo en ocasiones alguna que otra vacuola.

Al hablar de formaciones análogas a éstas en el corazón branquial de Eledone diremos algo acerca de la probable significación fisiológica de las granulaciones.

El empleo de la segunda variante de Rio-HORTEGA al método de
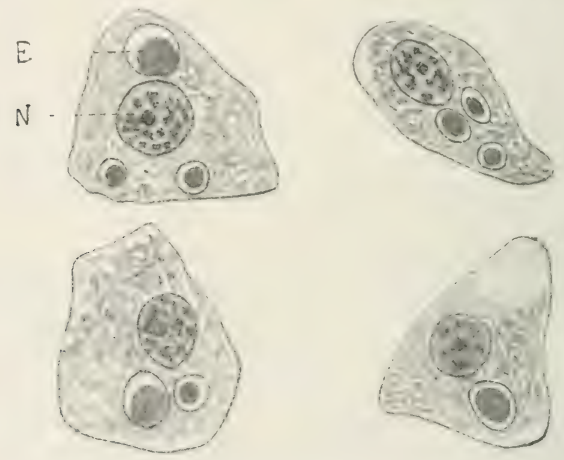

Fig. I. - Células propias del corazón branquial de Loligo: $N$, núcleo;

$E$, granulaciones eosinófilas en el interior de vacuolas.

ACH CARRo permite poner de manifiesto la presencia de numerosisimas fibras conjuntivas de reticulina relativamente gruesas, teñidas en negro intenso, que serpentean sobre los haces musculares, abundantes en el corazón branquial, se anastomosan unas con otras y forman en conjunto una complicada red, de la cual parten fibras más finas; éstas, insinuándose por los resquicios existentes entre las fibras musculares, constituyen elementos aisladores de las diversas fibras componentes de cada paquete muscular. La dirección de las susodichas fibras conjuntivas es variada, pues no sólo corren paralelas al eje de los haces musculares, sino también en planos perpendiculares a él; de modo que el sistema fibrilar es tan aparente en 
los cortes longitudinales de paquetes musculares comm en lis transversales. La disposición de las fibras de reticulina es, en el fondo, la misma que hemos sorprendido en otros objetos de estudio (1).

Las fibras de reticulina no se limitan a separar unas de otras las fibras musculares, sino que, saliendo de los haces de miofibras y extendiéndose entre las células propias, separan también éstas entre si. Cosa semejante hemos observado anteriormente en Sepia (2).

La región periférica del corazón branquial, por debajo de la membrana epitelial limitante, está ocupada por un sistema de fibras conjuntivas gruesas, onduladas, paralelas a la superficie, que se continúan con las de reticulina y cuyo carácter colágeno denuncia la coloración rojiza que les presta la segunda variante al método de ACHÚCARRo y el tono violeta que les imprime la tercera.

Corazón branquial de Rossia. - Las células propias de este órgano poseen un protoplasma muy claramente vacuolar, semejante al de las células análogas de Loligo, si bien se diferencian de ellas en que las de Rossia poseen muy escasas granulaciones eosinófilas. Por lo demás, en este molusco, lo mismo que en Loligo, las granulaciones eosinófilas se encuentran constantemente en el interior de vacuolas.

Los hacecillos musculares muestran en las secciones tratadas por la segunda variante al método de ACHic ARro copioso numero de fibras de reticulina, gruesas y finas, las cuales, formando una inextricable red, envuelven el fascículo muscular y se insinuian y serpentean entre las fibras integrantes de aquél. Las lrebras de reticulina asaltan asimismo los intersticios existentes entre las cielu. las propias, y ramificándose y anastomosándose mutuamente de mil maneras, componen una especie de fieltro flojo, cuyos hilos aislan y separan unas células de otras.

El epitelio envolvente del corazion branquial esta compuesto por células más o menos altas, seguin la regrión a que pertenezcan, de limites indiscernibles, con núcleo inmediato a la extremidad periférica del corpusculo. Aparecen surcadas tales cilulas por epitelio-

(1) Fernande\% Galdano, Sobre la fina estructura del corazin de

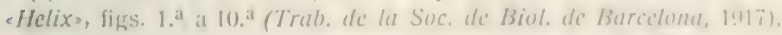

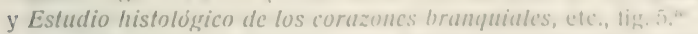

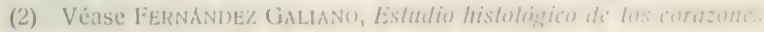
branquiales, etc., fig. 1i." 
fibrillas, a las cuales se puede aplicar la descripción hecha para las del epitelio externo del corazón branquial de Loligo. Por debajo de este.epitelio se extiende una espesa formación fibrilar colágena. cuyos elementos se continúan con los hilos de reticulina pericelulares e intramusculares de que antes hemos hecho mención.

Corazón branquial de Eledone.-MARCEAU, que en su trabajo citado estudia la estructura del corazón branquial de Eledone, caracteriza las células propias del mencionado órgano por ser voluminosas, de protoplasma muy vacuolar, núcleo redondeado, muy pobre en granulaciones cromáticas, y por contener diferentes clases de inclusiones; a saber :

1. Granulaciones esféricas, a menudo voluminosas, de un pigmento violáceo, en el interior de las cuales existen a veces pequeños cristales cuboides dispuestos con regularidad alrededor del centro. Este pigmento es dicroico y parece amarillo por transparencia; no se tiñe por la hematoxilina férrica ni por la eosina.

2. Granulaciones figuradas, más pequeñas, que se tiñen enérgicamente por la laca férrica.

3. ${ }^{\circ}$ Granulaciones redondeadas, eosinófilas y finamente granulosas.

4. Granulaciones análogas, un poco más voluminosas y que contienen, ya granulaciones hematoxilinófilas, ya granos de pigmento, ya ambas cosas a la vez.

En material teñido por hematoxilina férrica y eosina hemos podido confirmar en todas sus partes lo observado por MARCEAU. Sin embargo, un examen minucioso de las preparaciones nos permite añadir que tanto los granos de pigmento como las granulaciones eosinófilas, ocupan constantemente el interior de vacuolas protcplásmicas (fig. 2), observación que consideramos de cierta importancia por lo que luego diremos para conjeturar acerca del origen de los productos de inclusión.

Las formaciones pigmentarias se hacen particularmente visibles con la impregnación de carbonato argéntico, según Rio-HoRTEGA (1), pues los granos de pigmento resultan coloreados en negro o en violeta obscuro. Como en los cortes tratados por este

(1) Rio-Hortegs, Notas técnicas. Noticia de un nuevo y fácil método para la coloración de la neuroglia y del tejido conjuntivo. (Trab. del Lab. de Inv. Biol. de la Univers, de Madrid, t. XV, 1917.) 
proceder se tiñen únicamente los núcleos (en violeta claro) y los granos de pigmento, estos últimos se destacan con suma limpieza sobre un fondo absolutamente transparente, apureciendo en mimern mayor que el que se descubre cuando no están teñidos, pues los hay pequeñísimos que en las preparaciones coloreadas con hematoxilina pasan inadvertidos.

Además de los granos de pigmento descritos por MARCEAU, hemos observado la presencia de formaciones aciculares n en forma de bastoncito, que en número de una o dos, rara vez más, yacen junto a aquéllos (fig. 2. B). La situación de tales ba-toncitus al lado
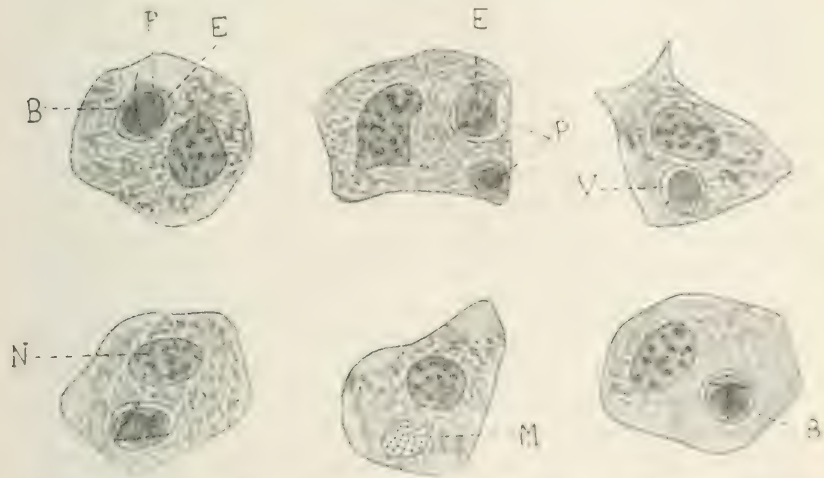

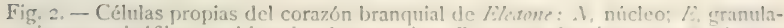
ciones eosinófilas en el interior de vacuolas; $P$. granos de pigmento en el sem de granulaciones eosinófilas; $V$, vacuola con un voluminoso grano de pigmento y muchos pequeños; $M$, vacuola con muchos $v$ diminutos granos pizmentarios; b, bastoncitos de pigmento.

de los granos de pigmento y su color pardo-amarillento hacen pensar que su composición química es la misma que la del pigmento.

MARCEAU, en su mencionada Memoria, sugiere la hipótesis de que las granulaciones eosinófilas son verdaderos plastidios (p) / (1:tos) capaces de elaborar en un seno, a la manera de Ios lencitos vegetales, granos de pigmento y cranulaciones lematoxilinofilas, opinión a la que nos adherimos, si bien provisionalmente, en mes-

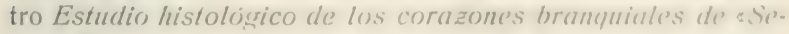
pia». Una observacion atenta de cortes de corazones brancuiates 
de los cuatro cefalópodos sometidos a nuestra investigación (Sepica, Loligo, Rossia, Eledone), nos induce a modificar nuestro criterio respecto del asunto. En los cuatro moluscos, en efecto, se muestran los cuerpos eosinófilos constantemente en el interior de vacuolas, siendo así que el concepto que generalmente se tiene acerca de los plastidios o plastos es el de considerarlos como meras diferenciaciones protoplásmicas, yacentes, por tanto, en el espesor del citoplasma. Por otra parte, son muy abundantes los granos de pigmento en Eledone completamente aislados e independientes, por consiguiente, de las formaciones eosinófilas, como el propio MARCEAU los representa en las figuras que ilustran su trabajo. También hemos observado siempre los granos de pigmento residentes en el seno de vacuolas protoplásmicas.

Estas consideraciones, unidas a la de la forma irregular de los cuerpos eosinófilos y a la de la gran variabilidad de su tamaño, nos conducen a suponer que no representan otra cosa que masas líquidas segregadas por el citoplasma y ulteriormente coaguladas, ya de una manera espontánea, por decirlo así, ya por influencia de los reactivos; al coagularse aprisionarian en su seno los granos de pigmento formados con prioridad. Se desarrollaria aquí, en suma, un proceso semejante hasta cierto punto al que da origen a los granos de aleurona de ciertos vegetales (semilla del ricino, por ejemplo); sabido es que los botánicos consideran estos granos como resultado de la coagulación en el interior de una vacuola preexistente de un liquido que contiene el material albuminoide (aleurona) en disolución, en cuyo seno se concretan los cristaloides y globoides que indefectiblemente acompanan en muchas plantas a las formaciones de esta naturaleza.

En cuanto a las granulaciones hematoxilinófilas, que son poco abundantes, no podemos saber, a causa de su exiguo tamaño, si yacen en vacuolas (pues éstas pueden ser pequeñisimas) o en el espesor del citoplasma; más bien parece que están esparcidas indistintamente. Por consiguiente, sin más dato positivo que el de su colorabilidad por la hematoxilina férrica, toda conjetura acerca de su origen y significación sería aventuradísima.

En el corazón branquial de Eledone las miofibras están separadas entre sí, en los haces musculares, por hebras conectivas de diverso grosor, de modo semejante al observado en Sepia, Loligo y Rossia. Y, al igual que acontece en los otros casos estudiados, se desparraman, a partir de los paquetes musculares, finas fibrillas de 
reticulina, las cuales, después de serpentear entre las células propias, dividiéndose y anastomosándose unas con otras, cambian sus caracteres químicos al final de su trayecto, para convertirse en fibras colágenas, que entran a formar parte de la robusta formación conjuntiva que envuelve la masa del corazón branquial por debajo del epitelio externo.

Apéndice del corazón branquial de Loliçes. Fispe Grgano, rum ya observó MARCEAU, está recubierto por una capa de células epiteliales altas y provistas de una fina cutícula. Esta membrana epitelial penetra en la masa del apéndice, tapizando ciertas cavidades tubiformes que proceden de la ramificación de un canal comunicante con el exterior por un orificio situado en el centro de la cara externa del órgano; pero, a pesar de que esta membrana epitelial interna es simplemente continuación del epitelio externo, sus células difieren de las de aquél, principalmente, por ser bastante más bajas y porque sus núcleos no son tan ricos en cromatina.

En cambio, no exhiben las células del epitelio interno ningún carácter que las diferencie de las situadas por debajo de ellas y que forman la masa principal del órgano (células propias), pues unas y otras muestran un protoplasma finamente granuloso y un núcleo que se tiñe débilmente por la hematoxilina férrica. Esta escasa apetencia para los colorantes distingue los nucleos de que hablamos de los pertenecientes a las células conjuntivas, entremezcladas con las propias, cuyo retículo cromático se tiñe intensamente.

Destacándose por su gran tamaño de la maraña conjuntiva y. muscular, hemos sorprendido la existencia, en determinados parijes del corazón branquial, de unos corpusculos que por su considerable talla merecen ser llamados células grigantes. Su volumen, en efecto, es doble, triple o cuádruple que el de las células propias, y están formados por un protoplasma finamente uranular. provisto de grandes vacuolas, que alberga un micleo robusto regularmente rico en cromatina; también suelen exhibir granulaciones enéricicamente teñidas en negro por la laca férrica. Lals células gigantes nu aparecen aisladas, sino remidas en islotes o grupos mas o menos numerosos, cuya situacion con respecto a los demais componentes del órgano de que forman parte no hemos consegruido de-terminar: tinicamente podemos decir que, de ordinario, las ciłulas crimanter que integran un islote estan dispuestas en series lineales. (Yamo está que con tan escasos efementos de juicio es imposible fundir- 
mentar ninguna conjetura tocante al origen y significación de los citados corpúsculos.

Por debajo del epitelio externo existe una serie de láminas conjuntivas más o menos paralelas entre sí y a la superficie, si bien alterado este paralelismo por numerosas anastomosis mutuas y curvaturas. De esta serie de láminas y perpendicularmente a ellas arrancan muchos grupos de láminas idénticas que invaden todo el espesor del órgano, subdividiéndose y fusionándose unas con otras y constituyendo a manera de un esqueleto cuyas partes o miembros están revestidos de una membrana epitelial, la cual no representa otra cosa que la continuación en el interior del órgano del epitelio externo, envolvente de aquél. En los huecos que dejan entre sí las láminas conjuntivas se albergan las células propias de que antes hemos hecho mención. La formación laminar, que nos parece de naturaleza elástica, a causa de su fácil teñido por la orceína clorhídrica y por el método de WEIGERT de la resorcina-fucsina, muéstrase particularmente desarrollada en torno de los vasos, análogamente a lo que sucede en Sepia (1).

Apéndice del corazón branquial de Rossic.-De modo parecido al que acabamos de describir se halla dispuesto el sistema laminar conjuntivo en el apéndice de Rossia; la imagen del conjunto resulta, sin embargo, más clara aquí que en Loligo, a causa de que la masa del órgano es más suelta, menos compacta.

El epitelio externo del órgano en cuestión está compuesto de células altas cuyos límites de contacto es imposible discernir, las cuales contienen un protoplasma vacuolar y un núcleo muy próximo a la cutícula estriada que remata el corpúsculo por su extremidad distal, intensamente coloreable por la laca férrica. En estas células resaltan con gran claridad numerosas epitelio-fibrillas que, apoyándose en la basal conectiva, siguen un curso más o menos tortuoso paralelamente a la dimensión mayor del corpúsculo, para desvanecerse en la región citoplásmica en que se asienta el nícleo. En todas las células epiteliales, pero en unas con más profusión que (n) otras, se observan anastomosis entre las distintas epitelio-fibrilias para dibujar un reticulo irregular. Las epitelio-fibrillas, que nosotros hemos observado a favor de la primera variante de Rio-HoR-

(1) Véase Fernandez Galiano, Estudio histológico de los corazones branquiales, etc., fig. $10 .^{\mathrm{a}}$ del texto y fig. $2 .^{\mathrm{a}}$ de la lámina XII. 
TEGA al método de AcHúCARRO, se tiñen incompletamente con la hematoxilina férrica, apareciendo coloreadas por este reactivo bajo la forma de lineas de puntos. Indudathlemente, este arpecto hat sugerido a MARCEAU la idea de que tales formaciones son estrías discontinuas que, como tales, representa en los dibujos que acompañan a su trabajo anteriormente mencionado.

Las células propias, alojadas en las mallas del sistema laminar, son corpúsculos dotados de un protoplasma escaso y vacuolar, y no difieren grandemente de las células propias de ios apendices de lim otros cefalópodos.

El empleo del método de AchúcARRo descubre la presencia, debajo del epitelio externo, de una potente formación colágena ondulada, cuyas fibras dan numerosas ramas hacia el interior, las cuales, subdividiéndose y reuniéndose unas con otras, determinan la formación de un plexo, integrado por finas hebras de reticulina, que constantemente acompaña a las trabéculas componentes del sistema laminar.

Apéndice del corazón branı̣ial de Eledone. - Caracterizase el epitelio externo de este órgano por estar compuesto de células no muy altas cuyo protoplasma posee vacuolas grandes: los núcleos aparecen frecuentemente deformados por la presión que sobre ellos ejerce el líquido vacuolar. Las epitelio-fibrillas, que se anastomosan entre sí para constituir el retículo protoplásmico, se distinguen con gran claridad, sobre todo en la parte inferior de las células.

También en este órgano, como en sus análogos de Sepia, Loligo y Rossia, ponen en evidencia la orceina clorhidrica y la resorcina-fucsina un sistema de láminas conjuntivas que no difiere en lo fundamental de los que anteriormente hemos descrito en Ios otros cefalópodos. Rellenando las mallas formadas por el sistema laminar se encuentran células menudas, de escaso protoplasma, que Hlamaremos células propias.

Mientras que en las células del epitelio externo no se ven inclusiones de ningún género, son fácilmente observables en las células epiteliales de los repliegues, como ya habia notado Makcisur, minúsculos granos redondos de pigmento, situados tanto por debajo como por encima del núcleo. Nos parece que estos granes son idénticos a los que hemos tenido ocasión de observar en el corazín hramquial del mismo molusco, puesto que presentan el mismor colur qune aquéllos, y además se tiñen también en violeta obscuro por el car- 
bonato argéntico de Rio-Hortega. Pero no sólo aqui existen los diminutos granos de pigmento, sino que también los hemos observado en las células propias. Aunque la escasa talla de la mayoría de estos granos impide determinar con precisión su posición dentro del protoplasma, hemos podido notar que los más voluminosos de entre ellos se alojan en el seno de vacuolas, de igual modo que anteriormente dejamos dicho para los granos de pigmento en el corazón branquial.

Con auxilio del método de AcHúCARRo se distinguen en el órgano que nos ocupa, lo mismo que en su análogo de los demás cefalópodos estudiados, fibrillas de reticulina dispuestas en todas direcciones y acompañando constantemente a las láminas conjuntivas. El sistema de las fibras de reticulina se convierte en la periferia del órgano en un rodete colágeno subepitelial, de fibras onduladas. También alrededor de los vasos se muestra una espesa formación colágena, cuyas fibras, onduladas, se prolongan a veces hasta parajes bastante alejados del conducto sanguíneo.

Laboratorio de Histología de la Facultad de Ciencias, Universidad de Barcelona.

\title{
CATÁlOGO ABREVIADO dE LA COLECCIÓN PALEONTOLÓGICA SUDAMERICANA EXISTENTE EN VALENCIA
}

\author{
POR \\ E. BOSCÁ Y CASANOVES
}

El que esto escribe tuvo el honor de presentar a esta Sociedad (sesión de 1 de marzo de 1899) una nota titulada: "Noticias de una colección paleontológica regalada al Excmo. Ayuntamiento de Valencia». Tratábase de un espléndido donativo sin precedentes, al menos en nuestros dias, hecho a su patria chica por D. José Rodrigo Botet, formado por gran número de huesos fósiles recogidos en la Argentina, provincia de Buenos Aires, por D. Enrique de Carles en distintas localidades, cuyos yacimientos corresponden a la formación pampeana en sus distintos estratos. 
Esta colección, por su importancia, merecía haber sido sometida al estudio de un especialista, ya que, aparte de los valiosos ejemplares que encierra, de especies más o menos conocidas, contiene también formas anotadas como nuevas y un remanente de materiales que atestiguan el entusiasmo de su experto colector, y demues-

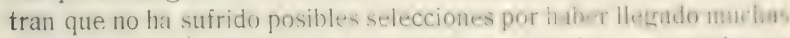
de las cajas en que estaban contenidos tal como fueron cerradas en el mismo campo explorado.

Los aludidos fósiles pertenecen al grupo de los mamiferos monodelfos, y casi todos, incluso el esqueleto humano, representan formas extinguidas, circunstancia que avalora las colecciones de su indole, por modestas que sean.

La falta de ambiente para esta sección de conocimientos histórico-naturales, cuya primera materia depende de circunstancias fortuitas, y por otro lado el estado precario en que generalmente se halla la hacienda de los Municipios, han retardado el ideal cientifico, no sólo de exponer la colección de un modo decoroso, como se merece, si que de llevar al público las notas pertinentes a una atractiva vulgarización, propia de los países de elevada cultura. No obstante, han podido darse a conocer algunos hechos concretos (1), y habiendo mejorado algunas circunstancias de carácter técnico, y disponiendo de mayor cantidad de tiempo para el estudio de la colección, se ha llegado a preparar un segundo catálogo anotado, en cl que se han incluído los datos adquiridos con posterioridad al Catciígo-Guia, publicado en 1909, opúsculo dedicado al próximo Con-

(1) Al efecto pueden verse: J. VILAnova y PIERA, Las Provincius, diario de Valencia, números correspondientes al 5 y 8 de enero de 18011 . E. BoscA, Notas sobre un megaterio existente cn Valencia. (Bol. Soc. Esp. Hist. Nat., marzo 1902.) - Crónica del IV centenario de la Universidad de Valencia, apéndice 13, 19uli. - E. Bosci, El esqueleto humanu fósil del arroyo de Samborombon (Argentini). (Asoc. Esp. P'rogrr. Cienc., Congreso de Zaragoza, 19u3.) - Catcilogro-Guia de la Coleccion paleuntológica de J. Rodrigo Botet, etc.. Valencia, 1909). - E. Rouscí, Los Muséos de Paris, Londres, Amsterdam y Bruselas. (Anales de la Junla para dmpliación de Estudios, Madrid, 1911.) - E. Bosci y A. Buscil Si:YTRli, Los Museos nacionales de Buenos Aires y de La Plata (Ibid., 7 agnistu, Mildrid.) - E. Bosci, Restos pertenecientes al ginero . Sictidolherium. Ow. (Asoc. Esp., etc., Congresu de Sevilla, 1917.) - L. Busci, El essumilite) inédito de -Eutatus punchalus. Amegh. (Asoc. Esp. etc., Congresto de Bilbato, 1919.) 
greso de la Asociación Española para el Progreso de las Ciencias, que se celebrará en Oporto en el corriente año.

La presente comunicación, destinada a conmemorar el primer cincuentenario de nuestra Sociedad Española, puede considerarse como un avance en cuanto a la enumeración de especies reconocidas hasta la fecha, o simple lista ordenada según la monumental obra del Dr. J. Ameghino titulada Contribución al conocimiento de los mamiferos fósiles de la República Argentina (1), como la más adecuada, por reunir el historiado de las diferentes agrupaciones y especies entonces conocidas, mereciendo especial mención la procedencia de los restos fósiles en cuanto a su yacimiento geológicamente considerado. Estas observaciones se imponen para la filiación de las especies entre sí, siquiera resulte como un ensayo sintético de trascendental porvenir para la Ciencia.

Y a propósito de la nomenclatura generalmente adoptada para el concepto de terrenos en series, sistemas, etc., no hay que olvidar que el movimiento del globo, llamado de cabeceo, por la mayor acumulación de tierras en el hemisferio Norte, no ha afectado de igual manera al otro hemisferio, ni mucho menos en el periodo posterciario, en el que aquí se han interpuesto los diluvios, resultando allá periodos de sedimentación más largos y menos accidentados. entre los que se cuentan la extensa formación pampeana, asi llamada al mismo tiempo por D'Orbigny y Darivin, como observa J. AME(iHiNo, quien añade que es una de las más vastas regiones del territorio argentino, así como la más accesible a la observación, y por consiguiente, la más conocida de todas las formaciones cenozoicas de la República, añadiendo que su espesor varía de 4 () a 100 metros en determinados puntos.

Los sistemas sedimentarios de la serie terciaria han sido reconocidos por los autores que han tratado del asunto, aunque con discrepancias de segundo orden, admitiendo los tres pisos análogos en la pampa, o sea piso inferior, otro piso intermedio y otro piso superior, seguido de la capa llamada cuaternaria y actual, con los respectivos horizontes. En cuanto a sus faunas, al lado de especies residenciadas exclusivamente en determinado piso, como, por ejemplo, Scelidodon Capellini Amegh., en el piso mis profundo, hay otras que se extienden al piso medio, como Typotherium cristatum Se-

(1) Tomo en folio de 1027 páginas y atlas con 86 láminas. Buenos Aires, 1889. 
vres, habiéndolas también que se hallan indistintamente un nisu: en el piso medio como en el superior y aun hasta en horizontes postterciarios, como el megaterio. Finalmente, tenemos en la colección algunas especies hoy vivientes, como el Myopotamus coypus fossilis Amegh.

Resumiendo: la colección la forma un núcleo de treinta especies cuyas partes esqueléticas, por su importancia, están ya montadas casi todas, existiendo, además, cuarenta y nueve especies con restos menos numerosos.

\section{CUADRO DE LOS GRUPOS DE MAMIFEROS MONODELFOS REPRESENTADOS EN LA COLECCION}

\section{Unguiculados.}

Orden PRIMATES : Familia Hominidos.

Order: ROEdORES : Familias Lagostómidos, Equinúmidos, Oetodúntidos, Cávidos.

Orden CaRnivoros: Familias Úrsidos, Félidos.

\section{Ungulados.}

Orden Toxodovres : Familias Toxodóntidos, Tipotéridos.

Orden PERISODÁ́ctilos : Familias Équidos, Macrauquénidos.

Orden Rumiantes : Familias Camélidos, Cérvidos.

Orden PROBOSCIDEOS: Familia Elefántidos.

Orden Desdentados GravlgRados: Familias Megratéridos, Lestudúntidos, Escelidotéridos, Milodóntidus.

Orden DESDENTADos GLIPTODONTES: Fannilias Giliptodóntidos, Huplofóridos, Dodicúridos.

Orden DESDEnTAdos DASIPODOS: Familias Clamidutéridus, I’ropaópidos, Dasipódidos.

\section{ENUMERACIÓN DE LAS ESPECIES}

\section{Antropoideos.}

Homo sapiens L., arroyo de Samborombon.

\section{Roedores.}

Myopotamus coypus fossilis Amegh. - Lagustomus sp). ? - L. tri.hudactylus fossilis Amegh. - L. debilis Amegh. - L. spricalus Amegh. L. incisus Amegh. - Orlhomyctera ringens Amegh. - O. lata Amegh. - Dolichotis minor H. Gers. y Amegh. - Lute de 38 mimerns de rocedures indeterminados. 


\section{Carnivoros.}

Arcthotherium bonaerense P. Gerv. - A. vetustum? Amegh. - Smilodon populator Lund. - Machairodus (pendiente de estudio), río Plata. - Lote de 41 números referentes a este grupo.

\section{Ungulados anfidáctilos.}

Toxodon platensis Amegh. - T. Burmeisteri Gieb.-Xotodon Amegh.Entelomorphus rotundatus Amegh. - Typotherium cristatum Serre. $T$. cristatum (joven). - Idem id: $-T$. exiguum Amegl. - Lote de 121 restos dentarios, mandibulares, etc., de la familia Tipotéridos. - Restos mayores de algunas regiones esqueléticas de un individuo pendiente de estudio.

\section{Ungulados perisodáctilos.}

Equts curvidens Ow. - E. rectidens Amegh. - Hyppidium neogeus Lund. - Lote de 24 números de la familia Équidos. - Macrauchenia patachonica Ow., arroyo de Samborombon.-Palaeolama P. Gerv. - Auchenia gracilis $\mathrm{H}$. Gerv. y Amegh. - A. cordubensis? Amegh. - A. lujanensis Amegh. - Eulaops parallelus? Amegh. - Cervus L. - Paraceros vulneratus Amegh. - Mastoceros Gray. - Lote de 15 restos mandibulares de rumiante.

\section{Proboscideos.}

Mastodon andium Cuv. (1). - Mastodon platensis Amegh., rio Samborombon.

\section{Desdentados gravigrados.}

Megatherium americanum Cuv., rio Samborombon. - Lote de huesos pertenecientes a otros dos individuos. - Diodomus Copei Amegh. Scelidotherium leptocephalum Ow. - S. Bravardi Lund., rio Plata. S. Carlesi Boscí, rio Salado. - Idem id., restos de otro individuo. S. Floweri? Amegh.-Scelidodon Capellini Amegh., rio Plata.-Idem id., restos de otro individuo. - S. tarigensis Amegh. - S. patrius? Amegh.Lote de 69 piezas esqueléticas de un animal joven de la familia Escelidotéridos. - Otro lote de 63 piezas de idem id. id. - Otro lote de 21 huesos, incluso la calavera, de idem id. id. - Otro lote de 47 , procedentes de varios individuos adultos y jóvenes de distintas regiones esqueléticas, de especies de Escelidotéridos.-Mylodon robustum Ow.-Pseu-

(1) Procedente del lote Bolivia. 
dolestodon myloides (P. Gerv.) - P. debilis H. Gerv. y Amegl. - Lote de 2 pelvis de distintas especies de Milodonte.

\section{Desdentados gliptodontes.}

Glyptodon clavipes Ow., río Salado. - G. reticulatus Ow., rio Samborombon. - G. Muñizii Amegh. - G. elongatus Burm. - Neothoracophorus? - Hoplophorus ornatus Burm., rio Platil. - idem id., wtro individuo. - Idem $i d$., restos de otros dos individuos. - H. pseudornatus Amegh. - Idem id., otro individuo. $-H$. migoy'anus Amegh., rio Samborombon. - Idem id., otro individuo. - H. paranensis Amegh. - H. scrobiculatus Ow., río Plata. - H. perforatus Amegh. - Lamaphorus compressus Ameglı. - Panochtus tuberculatus Ow.-Doedicurus clavicaudatus Ow., rio Samborombon. - Idem id., otro individuo jusen. - Clamydotherium typus Amegh. - Praopus grandis Amegh. - Eutatus seguini P. Gerv, rio Plata. - E. punctatus Amegh., rio Plata. - Tolypeutes conurus fossilis Amegh. - Lote de gran número de partes esqueléticas de varias regiones y de distintas especies de animales desdentados de coraza.

\section{LAS SENSACIONES DE LAS HORMIGAS}

POR

\section{S. RAMÓN CAJAL}

Requerido bondadosamente por D. Ignacio Bolivar, el sabio y venerado maestro de todos los naturalistas espunoles - aprartado por tirania de la ley y en plena lozania intelectual del aula universitaria, aunque no por fortuna de su vocación docente-, escribo las presentes cuartillas, pobrísima ofrenda con que intento colaborar a lia celebración del cincuentenario de la Sociedad Espanola de Historia Natural, una de las Corporaciones cientificas mis patriciticas, lahoriosas y desinteresadas con que se enormullece muestru pais.

Esta breve y descosida contribución constituy: - lumelesa decirlo-fruto en agraz, prematuramente arrancado del árbol, todavia en vivero, de mis investigaciones sobre la psicologia de las homigas.

Las cuestiones tocantes a los tropismos, datos sensoriales, percepciones, memoria asociativa, actos reflejos, instintos superio- 
res, etc., de esta atrayente categoria de himenópteros, han sido estudiadas por numerosa falange de esclarecidos investigadores, entre los cuales - y no cito sino los más modernos - es de justicia recordar los nombres de LUBBOck, FABRE, Forel, ANDRÉ, Turner, Bethe, Ziegler, Santschi, Bonnier, Bohm, Piéron, CorNETZ, BOUVIER, etc.

Todo observador recién venido a un dominio muy explorado, antes de hacer obra personal, se ve forzado a repetir, comprobar y discutir los datos y experimentos recogidos por sus predecesores. Yo me encuentro aun, por desgracia, en la primera fase de este proceso. En vez de añadir cosas nuevas a lo publicado por tantos sabios ilustres, véome obligado a señalar, según mi humilde entender, lo que haya de cierto en lo diputado por nuevo. Por donde mi labor, harto ingrata, consistirá, no en apurar, sino en depurar; y esto $\sin$ la certidumbre de conseguirlo: tantas y tan variadas son las causas de error que falsean el juicio al discurrir sobre tan delicados problemas.

Careciendo de tiempo para dar cuenta de la totalidad de mis observaciones, me contraeré en esta primera nota a decir algo sobre las sensaciones de las hormigas. En otro trabajo más extenso me ocuparé de las cautivadoras y controvertidas cuestiones relativas al supuesto lenguaje gesticular, construcción de nidos, expediciones de recolección y caza, y sobre todo del magno problema de la orientación y del regreso al nido.

Convienen todos los mirmecólogos en que los citados insectos poseen cuatro sentidos fundamentales, base de su vida psíquica: el visual, el olfativo, el tactil y el gustativo. De ellos se conoce más o menos bien la porción receptora y muy poco los centros del ganglio cerebroide, donde la impresión se convierte en sensación.

A estos sentidos habria que añadir el acistico, ya señalado por LUBBOCK y descrito recientemente por JANET en el interior de la primera pata. Mas a juzgar por la sordera, bien comprobada, de estos himenópteros, trátase quizás de un ircrano rudimentario y de dudosa utilidad. Por lo que toca al Ilamado organo de Johnston, diversos indicios inclinan a estimarlo como la estación periférica del sentido olfativo.

Los demás sentidos adjudicados a las hormigas, tales como el muscular de PIéron, y el de la dirección de CORNETz, parécennos muy problemáticos.

A nuestro entender, el sentido de la dirección de CORnEtz y 
los diversos actos que lo traducen - recuérdense las expresiones favoritas de este autor: sentido de los angulos, ley del contrapié, la vuelta es función de la ida, etc.-, podrian interpretarse simplemente como manifestaciones de la memoria de la dirección inicial o accidental, y de los principales incidentes ocurridos en el camino. Al mismo proceso psicológico de retentiva de lugares y rutas pertenece sin duda la memoria muscular de PIÉRON, a que este sabio otorga capital importancia para la dilucidación del problema del regreso al nido. Aun en el hombre, donde tal linaje de memoria inconsciente alcanza su plenitud y aparece servida por aparatos receptores complicados, jamás es poderosa a orientarnos eficazmente. Sólo nos permite la medición automática y no siempre exacta de la cantidad de movimiento necesaria para remontar en la obscuridad una escalera, reconocer la posición de un mueble o el sitio aproximado de un timbre. Y si esto ocurre en los animales superiores, ecómu admitir vicho sentido, con fines de infilible orientación hasta por terrenos desconocidos, en la hormiga, en cuyos músculos y tendones nadie ha lourado encontrar algo comparable. los husos de hühne (estación del sentido mu-cular) o a los irquanes músculo-tendineos de Golgi?

\section{CLASIFICACION SENSORIAL IDI LAS HORMIGAS}

Para la comodidad expositiva importa clasificar dichos himenópteros atendiendo a la preponderancia de alguno de sus sentidos. Asi ha procedido PIÉRON al distribuir dichos insectos en tres tipos sensoriales: el visual, olfativo y muscular. Este tiltimo, en que se alude al referido sentido muscular, podría substituirse, sin falsear demasiado el pensamiento del autor, por el tipo tactil.

De buen grado adoptaríamos la agrupación de P’IER()x, algo modificada, si no fuera porque la admisión de tres géneros sensoriales choca en la práctica con serias dificultades. Preciso es convenir en que casi todas las hormigas disponen de aparatos tactiles y uffativos bien desarrollados, cualquiera que sea el grado de perfección de su sentido visual; por ejemplo : el Myrmecocystus viaticus y el Polyergus rufescens, pertenecientes sin duda al tipu risuml, están dotados de tacto y olfato exquisitos, tan buenos o mejores que las diversas especies de Aphanenogaster inchudas habitualmente en el grupo olfativo. 
Por consiguiente, parécenos más sencillo y menos comprometido repartir las hormigas en sólo dos grupos: las que ven bien o regularmente (poliopsicas), cuyos ojos poseen ochocientas o más facetas, y las que ven poquísimo o medianamente (oligopsicas), cuyas facetas corneales oscilan entre setenta y quinientas.

Contamos entre las primeras el Polyergus rufescens, el Lasitus niger, la Formica rufibarbis, el Myrmecocystus viaticus, la Formica rufa, etc., cuyas obreras, además de ojos saltones y laterales ricos en corneolas, poseen tres ocelos característicos; y entre las segundas incluímos las diversas especies de Camponotus, la Pheidole megacephala, la Tapimoma erraticum, la Aphaenogaster barbara, la Aphaenogaster testaceopilosa, etc., cuyas obreras están desprovistas de ocelos y ofrecen ojos pequeñisimos y como rudimentarios (1).

Salvo la Formica rufa, que hemos estudiado en La Grania, todas las citadas abundan en Madrid y han sido objeto preferente de nuestras observaciones y experimentos.

Cuando se comparan las descripciones hechas por diversos sabios acerca de las reacciones de las hormigas en conflicto con estimulos naturales o artificiales, adviértense notables diferencias y desacuerdos relativos no sólo a la interpretación de los fenómenos, sino también sobre la realidad de los mismos. Séanos lícito manifestar, aun a riesgo de repetir ajenos juicios, que las aludidas contradicciones provienen casi siempre de no haber tenido en cuenta 0 justipreciado suficientemente la influencia perturbadora de ciertos estados psicológicos actuales o preexistentes, que modifican mucho los resultados obtenidos.

a) En primer término, cada hormiga posee cierta individualidad psiquica más o menos acusada; por donde, en igualdad de condiciones experimentales, las respuestas motrices difieren bastante. Sin duda que en el comportamiento influyen, como en los animales superiores, residuos y asociaciones sensoriales generados por acontecimientos anteriores ignorados del observador; pero además pudiera ocurrir que, aun en obreras de la misma comunidad, y con

(1) Para la determinación sistemática de las lıormigas de Madrid, nos han aprovechado mucho los consejos de los sabios entomólogos D. Ignacio y C. Bolivar, y muy singularmente las atinadas indicaciones de nuestros expertos y fervientes mirmecólogos Sres. Dusmet y Mercet. A todos ellos les rendimos aqui la expresión de nuestra cordial gratitud. 
mayor razón entre obreras y soldados, existieran pequeñas divergencias de aptitud sensorial y de capacidad asociativa.

b) Mencionemos en segundo lugar el fenómeno del ensimismamiento o distracción, comunisimo tanto en las obreras cargadas de botín como en las absorbidas en la construcción del nido: distracción observada también en otros insectos sociales y sobre la cual llamaron ya la atención hace tiempo LUBBOCk, FABRE y FOREL.

c) Recordemos además el estado emocional producido por las rudezas y violencias de la experimentación, o por la imposición de condiciones artificiales en pugna con hábitos arraigados. Todo insecto que se siente perseguido cae en el aturdimiento, la ofuscación y el pavor, que llegan en ocasiones en las hormigas hasta el punto de abandonar la presa, huir a campo traviesa, esconderse bajo las hierbas y desconocer, como atacadas de inhibición olfativa y visual, su propia pista, las cercanias del nido y hasta las aberturas de éste. Según es de presumir, semejante estado emocional comprende grados y matices, disipándose con más o menos rapidez. según las especies y los individuos. Hemos notado que las hormigas de tipo visual son las que se emocionan más fácilmente.

En fin, para la justa interpretación de algunos hechos negativos, que a primera vista parecen implicar extremada penuria de ciertos sentidos, conviene tener presente que la hormiga strele guiarse en sus labores y pesquisas por la impresion sensorial dominante. Este comportamiento representa un ahorro de esfuerzo nervioso. Condúcese, pues, como nosotros, que para orientarnos bien lo fiamos todo a la vista, desdeñando o inadvirtiendo las impresiones tactiles, olfativas y la sensibilidad a las vibraciones mecinicas; impresiones de capital importancia, secrín es notorio, en la marcha de los ciegos.

Previas las precedentes reservas, pasemus a formular las principales conclusiones desprendidas de nuestras observaciones y experimentos; conclusiones - huelga repetirlo - sujetas todavia a contraste y revisión. Comencemos por la aptitud visual.

\section{Sensaciones visuales.}

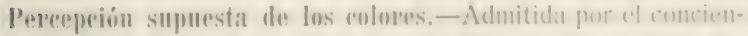
zudo Sir Lembeck y otros observadores, dista mucho de estar demostrada. En rigor, lo que se deduce de los pactentes e ingeniomens 
experimentos del sabio inglés, no es que la $F$. fusca y el Lasius niger discriminen cualitativamente los colores, sino que tales hormigas son afectadas, al modo de la placa fotográfica, por las radiaciones más breves del espectro, o sea por las dotadas de mayor poder fotoquímico.

Por otra parte, la anatomía del ojo de las hormigas de vista escasa no habla en pro del parecer de LuBBock. Aun cuando nuestros estudios sobre este punto disten de tocar a su fin, a causa de la enorme dificultad con que se lucha para obtener cortes finos bien teñidos del aparato ocular, todas nuestras preparaciones del ojo de los soldados del Aphaenogaster, Camponotus cruentatus, etc., muestran inmediatamente detrás de corneolas fuertemente biconvexas una capa compacta y continua de pigmento pardo-negruzco, que absorbe totalmente las radiaciones espectrales (1). En vano hemos buscado en esta pantalla obscurísima un resquicio por donde asomen a la luz los rabdomas o elementos nerviosos fotoreceptores. Por lo cual resulta dificilisimo comprender cómo una imagen coloreada podria impresionar cualitativamente las citadas células receptoras, y producir, según debe ocurrir con toda probabilidad en los insectos de visión lúcida (abejas, avispas, tábanos, mariposas, mosca azul, etc.), fenómenos fotoquímicos específicos generadores de corrientes nerviosas, igualmente especificas. En ojos tan impermeables a la luz coloreada, el mecanismo de la impresión luminosa sólo puede concebirse suponiendo que cada pantalla pigmentaria postcorneal absorbe y transmite la energía química de las vibraciones (energía tanto mayor cuanto más breve es la longitud de onda), y que por tanto los rabdomas, al modo de la placa fotográfica, traducen por grados de intensidad luminica los diversos ritmos ondulatorios del éter. Esta explicación, necesariamente vaga, dada nuestra ignorancia del verdadero papel desempeñado por el pigmento y los rabdomas ęn los fenómenos de recepción y transformación de la energía cinética de la luz, tiene la ventaja de concordar bastante bien con lo más esencial de los resultados experimentales de LUBBOCK y de otros autores.

(1) Detrás de las corneolas existen, en verdad, unos cristalinos aplastados y como rudimentarios (Aphacnogaster, etc.), sobre los que adhiere la costra compacta de pigmento. En cuanto a las vias visuales, preséntanse como atrofiadas. Falta un verdadero perióptico o retina intermediaria, y la retina profunda o cpióptico se muestra muy delgada y pequeña. 
Sea de ello lo que quiera, es para nosotros sumamente probable que las hormigas no disciernen los colores. Todos muestros experimentos lo persuaden. El espacio visual percibido por estos himenópteros podría imaginarse, pues, como un panorama nebuloso donde destacan solamente algunos objetos prúximos de gran tamaño $\mathrm{y}$ de contornos indecisos.

Citemos ahora algunos experimentos, a nuestro juicio, probatorios de que las hormigas oligovisuales carecen de la visión de los colores.

Comencemos por declarar que tales himenópteros no revelan el menor signo de sorpresa o de extrañeza cuando, de regreso de sus excursiones, encuentran las pistas o las aberturas del nido teniida: intensamente con diversos colores de anilina, a condición de que la desecación de éstos sea completa. Igual indiferencia se advierte cuando delante de las obreras en marcha son proyectadas las radiaciones del prisma o la luz solar tamizada por cristales coloreados. Tampoco demuestran preferencias cromáticas si son encerradas en cajas obscuras, uno de cuyos extremos, relleno de provisiones, se divide en compartimientos o pequeños comedores iluminados por sendas láminas de talco intensamente coloreadas de rojo, naranja. amarillo, verde, azul y violado. Es más: ni aun les cxtrañan los cebos agradables artificialmente teñidos, tales como terrones de azúcar, pedazos de pan o de plátano y diversas semillas (hormisus cosecheras).

Hasta en las hormigas de tipo visual, como el Lasius niger. produce apenas repulsión la presencia de una gota de miel o de mermelada pintadas con eosina o azul de metileno. Ën materia de. alimentos el criterio supremo de la hormiga es el sahor, por cierto no muy delicado.

Las hormigas oligovisuales, ėson sensibles a los rayos ultraviolados, conforme afirmaron LUBBock y lForet, para ciertos tipos de estos himenópteros terrestres?

Mucho lo dudamos. Reproducidas por nosotros las experienciats de estos sabios haciendo uso del aparato de líbler (electrodos de. magnesio) y de cubetas cubiertas con portaobjetos de cuar/an, hemos sacado la impresión de que Camponotus, Tapinoma, Aplacumogaster, etc., evitan (no siempre) la acción de las radiaciomes ultravioladas, no a causa de la pereepción cromatica (efecto cualitativo de ondas brevísimas), sino de resultas de su accion irritimte subre el cuerpo del animal y quizis sobre los pelos tactiles. Notemos, sin 
embargo, que nuestras experiencias no han recaido sobre las especies utilizadas por LuBBock ( $F$. fusca, Lasius niger).

Distinción de la luz y de la sombra. - Mas si las hormigas olfativo-tactiles (Tapinoma erraticum, Aphaenogaster barbara, A. testaceo-pilosa, Pheidole megacephala, etc.) son incapaces de distinguir cualitativamente las diversas longitudes de onda del espectro, diferencian bastante bien la luz de la sombra, con tal de que el contraste sea bastante acentuado.

Por ejemplo : si a una hormiga de pista se la obliga a pasar por un largo túnel de cartón dispuesto en forma de bóveda, no vacila cuando el trayecto sombrío es corto; pero muchas se asustan, retroceden o flanquean cuando éste mide de 8 a 10 centímetros de longitud. Con todo, en virtud del fenómeno de la distracción, algunas obreras cargadas siguen impertérritas su camino. Claro es que un puente breve, tal como el formado por un bastón, aunque diste sólo 3 ó 4 milimetros del suelo, no produce el menor efecto. Tampoco perciben un cristal puesto a dicha distancia sobre la ruta: casi todas las hormigas pasan por debajo hasta llegar a un punto en que por la exigüidad del espacio vertical chocan con el vidrio; entonces viran casi siempre en ángulo recto en busca de los bordes, para emerger al fin y bordear el obstáculo.

Que diferencian lo tenebroso de lo muy claro lo persuade también la curiosidad con que las obreras exploradoras (Aphaenogaster testaceo-pilosa, A. barbara, Pheidole, etc.), se acercan a un terrón de azúcar puesto en la vecindad de la ruta, a condición de que el insecto pase a menos de medio centímetro de la golosina.

Con todo, este hecho perceptivo, no siempre fácil de comprobar en las hormigas oligópsicas, exige una restricción aclaratoria. Toda hormiga que regresa cargada o que trajina tierra arrancada del nido, suele ser indiferente a los cebos más apetitosos, en virtud del mencionado fenómeno del ensimismamiento. Esta inhibición sensorial es tan radical en ocasiones, que hemos sorprendido Aphaenosaster testaceo-pilosa y A. barbara, enardecidas en la tarea de agrandar sus madrigueras, tocar impasibles y hasta enterrar completamente trozos de azúcar, para los cuales, sin embargo, en condiciones ordinarias, son singularmente golosas.

Otra prueba de la impresionabilidad a la luz nos la ofrece el fenómeno del deslumbramiento, que nos parece haber sido algo inadvertido por SANTSCH y FERTON en sus tentativas de despistar 
a las hormigas proyectando sobre ellas la luz del sol. En realidad, la reflexión de las radiaciones solares por los espejos no perturba casi nada la marcha y penetración en el nido de las Pheidole, Camponotus, Tapinoma, Aphaenogaster, etc. Mas si a favor de una lente se concentra la luz sobre la pista-sin llegar, naturalmente, a elevar demasiado la temperatura-, las obreras se asustan; muchas retruceden después de penetrar en el foco; algunas dan un rodeo, acabando por orientarse, y sólo las abrumadoramente cargadas, y por tanto en estado de profunda distracción, cruzan impasibles el foco luminosn.

En cambio las hormigas poliópsicas, como la F. rufibarbis, el Myrmecocystus viaticus, el Lasius niger, etc., reaccionan mucho más vivamente a los focos lenticulares y en ocasiones a distancia de medio a un centímetro. En ellas, pues, según era de presumir, el fenómeno del deslumbramiento se desarrolla más fácil y rápidamente. Con la $F$. rufibarbis y el $L$. niger adviértense ya titubeos e inquietudes hasta en presencia de la luz solar reflejada por espejos. A pesar de lo cual no se despistan, sino que, cruzando cautelosamente el pincel luminoso o bordeándolo con precaución, acaban por incorporarse a sus compañeras y ganar la madriguera. Pero de la posible influencia de la luz en la orientación de las hormigas trataremos en otro trabajo.

Acuidad usual de las hormiugs. - Por punto greneral, y salvando excepciones, los objetos muy delgados plantados verticalmente en la pista (de medio a un centimetro) y separados por espacios variables no son percibidos ni poco ni mucho. Todas las obreras de tipo oligópsico se enteran del obstáculo imprevisto súlo despué: de tocarlo con las antenas. Naturalmente, la mayor o menor facilidad de la travesía de vallas y enrejados depende de la amplitud de: los espacios. Con enrejados cuyos alambres estin separados mos 4 milimetros pasan la mayoria de las Tapinorma y Aphaenogaster (exceptuados los soldados); con enrejados de 3 milimetros disminuye ya notablemente el mimero, salvando la alambradia solamente las obreras medianas y pequeñas; en fin, un enrejato de. 2 milimetros constituye obstáculo infranqueable. Al topar con il Casi todas se desvian o corren en ángulo recto, bordean la tela metálica y ensayan el paso por parajes más o menos alejados de la misma; algumas retroceden descorazonadas; $y$, en fin, las hay yue. después de trazar ziszís, flanyuean lateralmente el cmrejado, incorporándose a la pista, no sin dar antes gran redeos. 
Este espectáculo sugiere, más que la idea de una visión confusa de las vallas, la de una filtración o tamización, exclusivamente regulada por el tamaño de las obreras y la envergadura de la antenas; envergadura variable, naturalmente, en cada hormiga, a causa del diverso grado de aducción o de inclinación hacia adentro de tales apéndices. Semejantes tentativas, reveladoras de la penuria visual de las hormigas, evocan algo la conocida teoria de los ensayos y errores de MORGan, comprobada en los infusorios por JENnings.

No obstante, en presencia de recias empalizadas (palitos blancos de cerca de 4 milímetros) nos ha parecido que desempeña algún papel la visión, aunque a brevísima distancia ( 5 a 6 milimetros).

Prácticamente, pues, las Tapinoma, Pheidole y Aphaenogaster barbara se comportan casi como si estuvieran totalmente ciegas y se guiaran exclusivamente por el tacto y el olfato. Con todo, ciertas hormigas oligovisuales, tales como el Camponotus cruentatus (cuyos ojos poseen ya de 400 a 600 facetas) y la Aphaenogaster testaceo-pilosa, nos parecen ver menos mal.

Naturalmente, la acuidad visual es mucho mayor en las hormigas poliópsicas. Así, el Myrmecocystus viaticus suele ya atisbar los enrejados puestos verticalmente delante del nido, a distancia de uno y hasta 2 centimetros. Es frecuente sorprender a obreras regresadas de sus cacerías rodear el obstáculo sin tocarlo, para incorporarse al hormiguero, y a las atareadas con la labor de la extracción de escombros evitar en sus excursiones la empalizada, marchando siempre en otra dirección. En fin, cuando el retículo se coloca sobre el nido, ocurre una de dos cosas: o las obreras retroceden antes de tocarlo, o se encaraman a él, pugnando por insinuarse por sus mallas, para lo cual aproximan las antenas y ofrecen la menor superficie posible. Claro es que no faltan aquí actos de obcecación debidos, en parte, al fetiómeno del ensimismamiento o del vis a tergo. En general, se saca la impresión de que el $M$. viaticus percibe a distancia el obstáculo, y cuando no puede evitarlo, como en los casos en que se coloca horizontalmente sobre el nido, trata de salvarlo infiltrándose en sus mallas.

Parecidas y, en ocasiones, mayores pruebas de acuidad visual revelan también, en condiciones semejantes, el Lasius niger, la F. rufibarbis y el Polyergus rufescens.

Nuestras observaciones revelan también que las hormigas se impresionan muy especialmente del color negro, con tal de que 
despida reflejos brillantes. En tales circunstancias, la acuidad visual se acrece notablemente. Citemos dos ejemplos:

Una comunidad de Lasius niger (variedad provista de ocelos y de ojos de finas facetas) invadió nuestra casita de campo, haciendo nido en las grietas del embaldosado. A distancia de varios metros. y no lejos de amplia pista recorrida por obreras exploradoras, pusimos sobre un cristal negro tres pequeñas gotas de materias mucilaginosas de brillantes reflejos marginales: una de las gotas era de miel, otra de goma arábiga y, en fin, otra de cola del comercio. Todas tres mostraban sensiblemente igual matiz amarillento, casi imperceptible sobre el fondo obscuro. A los pocos minutos, algunas obreras repararon en el botin, estableciéndose una pista muy trillada desde el nido a las gotas. Con sorpresa advertimos que las tres atrajeron por igual a las hormigas. Conforme era de presumir, las posadas en el borde de la miel aumentaron progresivamente: engolosina-

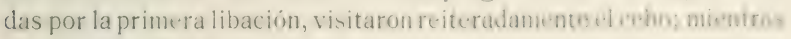
que las empeñadas en saborear la goma arábiga y la cola antiséptica quedaban prendidas, no pudiendo, por tanto, repetir sus expediciones. Parece indudable que lo que sedujo imperiosamente al Lasius no fué el olor ni el color, sino el vivo reflejo luminoso de las substancias mucilaginosas, percibido de uno a medio centimetro de distancia.

Otro ejemplo de la capacidad de distinguir objetos diminutos obscuros con tal de que brillen mucho, nos ofrecen corrientemente las hormigas cazadoras, aun cuando pertenezcan al tipo oligovisual.

Varias obreras de Aphaenogaster barbara fueron asfixiadas por el cloroformo, tratadas subsiguientemente, primero por el alcohol y el éter y después por diversos agentes alcalinos, a fin de eliminar en lo posible el olor fórmico; finalmente se desecaron al sol durante una semana. En tal estado de momificación, abandonaronse en las inmediaciones de nidos del splucenogaster testaceopilosa y del Myrmecocystus viaticus. Incontinenti fueron atisbadas por obreras exploradoras que, considerandolas como excelente. botin, las condujeron a sus silos subterrineos.

Mas si antes de ser emplazadas en la vecindad de los hormigueros se las pintaba de blanco, pasaban las cazadoras a su lado sin reconocerlas. Prueba inequivoca de que el color negro brillante. propio de muchos insectos las impresiona harto más yue la forma y el olor, y de que aun las hormigas de escasa vista aciertan a distinguir de cerca un objeto de 2 i) 3 milimetros de diametro.

Iguales resultados se obtuvieron con los cadiveres de hormigas 
que sus compañeras de comunidad extrajercn del nido, guiadas por una suerte de instinto higiénico. Pintados de varios colores, fueron inadvertidos.

En todo caso - lo hemos dicho ya - las percepciones visuales influyen muy poco en la vida psiquica de las hormigas oligópsicas. No sólo los experimentos efectuados con retículos y empalizadas, sino otros muchos que fuera prolijo describir aqui, lo persuaden con evidencia. Citemos solamente el hecho bien conocido, y repetidamente comprobado por nosotros, de que el Camponotus aethiops y la Aphaenogaster barbara trabajan lo mismo de día que de noche, y con igual diligencia y brio durante las noches tenebrosas y bajo la sombra de los árboles, que en las noches claras del estio. Con lo cual no pretendemos significar que todas las hormigas de vista deficiente sean indiferentemente diurnas o nocturnas: muchas de ellas, por ejemplo, la Aphaenogaster testaceo-pilosa, la Tapinoma erraticum y el Camponotus cruentatus, etc., se recluyen en el nido al anochecer.

Un experimento, muchas veces practicado, consiste en la obstrucción de los ojos mediante barnices opacos o a favor de la cauterización de las corneolas. Nosotros lo hemos reproducido también; empero la interpretación de los resultados parécenos sumamente ardua. Por punto general, todo insecto cegado se desconcierta y queda como desmoralizado y alocado. Por exigua que sea la ventana cerrada al mundo exterior, constituye para la hormiga fuente preciosa de informaciones, complementarias de las aportadas por los sentidos olfativo y tactil. Además, según hemos apuntado, es dificil señalar la parte que en tal desorientación toman, respectivamente, la mera supresión de la imagen luminosa y el deterioro, coarrugación o empaste de algunos pelos tactiles cefálicos y, más que nada, la emoción del animal al sentirse primeramente amarrado y después libre sobre una pista cuya dirección ha olvidado, por consecuencia del eclipse, durante las manipulaciones operatorias, de la memoria de los ángulos y de la trayectoria inicial. De todas maneras, si hemos de dar crédito a nuestras observaciones, el atolondramiento de obreras y soldados ciegos es mucho menor que el producido por la sección de las antenas. Con un poco de paciencia consiguese sorprender algunos Camponotus, Tapinoma y Aphaenogaster, de ojos ennegrecidos con betun de Judea, retornar al nido a tientas después de mucho tiempo de estupor y extravio y de reiteradas tentativas para limpiarse las corneolas. 


\section{Impresiones oliativas.}

Con razón se admite en las hormigas un sentido olfativo exquisito. En este punto, aun cuando para ciertos efectos parízcanos exagerada la capacidad de oler atribuida a dichos himenúpteros, nuestras observaciones confirman en principio las de todos los mirmecólogos, a excepción quizás de FABRE, que priva al Polyersus y a otros insectos de la percepción de los olores.

Preciso es confesar que, de negar dicha sensibilidad olfativa, resultaría singularmente embarazosa la comprensión de algunos actos de las hormigas oligópsicas, y con mayor motivo de las hormigas ciegas de Tejas y Árica (Eciton vastator, E. erratica, Anomma arcens Wersl., etc., etc.), estudiadas cuidadosamente por BATES y otros mirmecólogos.

Los puntos a examinar y establecer acerca de esta materia conciernen a la distancia a que las hormigas poliópsicas y oligópsicas huelen; a si su escala odorífera corresponde exactamente a la nuestra y a la de los mamíferos superiores, y, en fin, a averiguar si en sus faenas, cacerias y expediciones goza el sentido olfativo de alguin privilegio o decisiva preponderancia sobre los demás.

Comencemos por sentar, de acuerdo con muchos sabios, que la mayoría de los olores fuertes, agradables o nauseabundos, percibidos por nosotros, lo son también por las obreras oligrovisuales. El olor a alcanfor, el del amoniaco, de la trementina, de la asufitida, de la piridina, del timol, del creosol, de las esencias de' clavo, bergamota, de anis y de origano, del iter, del alcolus amilico y alilico, etc., las impresiona enérricamente, produciéndoles una repugnancia invencible. Regla greneral: la hormiga huye alarmada de toda emanación odorifera al que no está habituada.

La distancia de impresion, como si dijeramos el dintel de la excitación, varia para cada especie. De ordinario es muy corta, lo que se explica bien por la ausencia de aparato colector y conserviador de las emanaciones olfativas. Por ejemplo, lat ilphumegraster barbara, la A. testaceo-pilosa, la Pheidole, la Taprinoma, ete.. retroceden ante una mancha de piridina, de esencia de clavo o de bergamota situada entre uno y medio centimetro, Con todo, en virtud del fenómeno de la distracción y de la velocidad adyuirida, sorpréndense obreras sobrecargadas que llegan hasta el horde de la mancha. Poquisimas veces el impetu del retormo las lleval a perte - 
trar en el trozo de pista empapada en la esencia; y si lo hacen, es para huir rápidamente. Por excepción, hemos visto al Camponotus cruentatus que, en fuga alocada, cruza extensas manchas de bergamota y de clavo situadas cerca del nido. En los referidos actos de repulsión no suele intervenir el tacto antenario, es decir, el olfato tactil de FOREL. Trátase, por consiguiente, de una acción a distancia provocada por efluvios materiales.

Hay hormigas de tipo visual (el Myrmecocystus viaticus, por ejemplo) que reconocen los olores desagradables a mayor distancia todavia que la Aphaenogaster barbara y la Tapinoma. Derramadas varias gotas de bergamota en torno del nido, ninguna de las obreras cargadas de escombros se atrevió a salir de aquél, no obstante mediar entre la abertura y el círculo oloroso más de 2 centimetros. Del mismo modo, las regresadas de sus expediciones rétrocedieron a distancias variables entre uno y medio y 3 centímetros. Sólo al siguiente día restablecióse la circulación, ya porque el olor se disipara, ya a causa de su atenuación artificial, mediante el depósito de escombros. En fin, olores demasiado persistentes, como el de la esencia de clavo arrojada en la pista, obligan a ciertas especies de hormigas a abandonar el antiguo camino y a trazar otro nuevo paralelo al anterior.

Pero en los experimentos anteriores se trata de la acción de olores insólitos y desagradables o incómodos para las hormigas. Y pudiera ocurrir que las emanaciones que excitan su sensibilidad y motivan sus reacciones fueran totalmente inaccesibles para nosotros. En otros términos: la escala olfativa por la cual se guian en sus actos pudiera coincidir sólo parcialmente con la nuestra. Ello nos parece indudable si consideramos la seguridad y el tino con que recolectan semillas y renuevos de plantas que por lo pequeños no pueden ver, y sobre todo cuando se entregan a expediciones encaminadas a la captura de pulgones o de esclavos. Por lo demás, esta lisparidad de escalas olorosas se advierte ya entre los mamiferos. Así, como afirma PASsY, el perro percibe olores absolutamente imperceptibles para nosotros.

Vaya sólo un ejemplo referente a la hormiga amazona, de la que poseo populoso nido. He observado muchas veces, durante las razzias estivales, que la cabeza de la columna del Polyergus detiénese bruscamente al llegar a un montón de escombros, de sarmientos o de broza; una vez allí, sin la menor vacilación, precipitanse todas las asaltantes en los intersticios y recovecos del laberinto de 
ladrillos y malezas, de donde emergen, a los pocos minutos, prendidas en los garfios mandibulares, larvas y crisálidas pertenecientes a la tímida $F$. rufibarbis. Ahora bien: la exploración escrupulosa del montón de escombros donde penetraron las feroces amazonas no permitió observar el menor indicio de hormiguero, ni descubrir tampoco obreras dispersas en busca de botin. Súlo al final del desastre asomó tal cual rufibarbis, con intención, sin duda, de salvar algún hijuelo, por azar abandonado de los invasores.

Se ha exagerado mucho por BETHE y otros observadores la importancia que en la orientación de las hormigas oligópsicas posee el sentido olfativo. Contentémonos por ahora con anticipar que en el reconocimiento de pistas colaboran también, conforme notaron TuRner, PIÉron y otros observadores, diversos datos sensoriales, y muy especialmente la impresión de los pelos tactiles. En apoyu de este aserto recordemos no más que cuando las hormigas cargadas se desvian por accidente imprevisto (golpe de viento, etc.), muchas de ellas cruzan su pista o se acercan al nido sin reconocerlo, por lo menos durante el primer cuarto de hora. Las revueltas descritas por estos himenópteros alrededor de la madriguera (revueltas de TURNER) antes de adentrarse en ella, prueban también la escasa eficacia orientadora de las emanaciones olfativas, proce. dentes tanto de hormigas congéneres como de las pistas y de las bocas del nido. Ni hay que olvidar que muchas hormigas se orientan bien, aun cuando el viento haya barrido las emanaciones olorosas.

\section{Impresiones tactiles.}

Uno de los sentidos cuyas informaciones son más preciosas para las hormigas oligópsicas es el tactil, según han notado algunos mirmecólogos, y singularmente Pléron. La importancia de estas impresiones se impone ya con sólo examinar la cantidad prodigriosa de pelos largos y cortos que erizan las antenas, la cabezal y sobre todo las patas de dichos himenópteros. En el bulbo terminal de las antenas de la Tapinoma y Aphaenogaster burbura dichos apuindices son tan abundantes, que en algunos parajes casi se tocin las criptas de que emergen. Estimamos, sin embargo, yne para lus efectos de la marcha las impresiones tactiles dominantes son recogidas por los garfios córneos y pelos de las patas.

Nada más fácil que demostrar experimentalmente la sensibilidaut tactil de las hormigas. Basta para ello alisar o cambiar ligreramente. 
por medios mecánicos, el suelo de las pistas, o mejor aún, cubrirlas con tules o enrejados que, dejando a salvo las emanaciones olfativas, transformen el relieve.

En presencia, tanto de los enrejados finos como de los de anchas mallas emplazados horizontalmente sobre las pistas, casi todas las obreras sufren grandes perturbaciones, no obstante percibir el olor específico. Ciertamente, algunas, las más audaces y por lo común cargadas, avanzan titubeando y deteniéndose a cada paso; pero la mayoría rehusan atravesar el inesperado obstáculo, o si lo recorren, es sólo en brevísima extensión, para torcer en seguida en ángulo recto y ganar la orilla; algunas, en fin, retroceden despavoridas. Por punto general: cuanto más fino es el retículo, mayor es la sorpresa y desorientación.

Los remolinos y desviaciones observados en las hormigas mediante la colocación de retículos, gasas, etc., sobre las pistas o junto al nido, suelen ser harto mayores que los sufridos por los experimentos de barrido, irrigación o deformación de los caminos mediante erosiones o colocación de tierra (1), hierbas, etc.; experimentos repetidamente efectuados por los autores con la mira de demostrar el papel orientador de las emanaciones odoríferas. Asi es que nosotros, sin negar que en los resultados obtenidos por numerosos sabios influya algo la atenuación o descarte de tales efluvios, juzgamos que la causa desorientadora principal consiste en la modificación del relieve del suelo, de que la hormiga conserva memoria fidelisima. Y aun seríamos más afirmativos y categóricos si no fuera notorio que sobre la corteza de los árboles siguen fidelisimamente ciertas pistas preestablecidas (Lasius y Tapinoma). Así y todo, en estos mismos cjemplos no parece desdenable el papel desempenado por las impresiones tactiles, conforme lo prueba la preferencia de las hormigas por ciertas resquebrajaduras profundas de la corteza, muy ricas en referencias estereotópicas, y la desorientación e inquietud que sufren al cruzar por un segmento cortical suavizado y como pulido por un cuerpo duro (mango de bastón, espátula de marfil, etc.) o ligerísimamente empastado por un color transparente. Pero de la influencia de las impresiones tactiles en la

(1) Si sobre un pequeño trozo de pista se superpone tierra superficial tomada mediante delgada espátula de otro segmento de la misma pista, la desorientación es completa, no obstante la persistencia del mismo olor (Aphaenogaster barbara). 
orientación de estos himenópteros trataremos detalladimente en otro trabajo.

Como anejos del sentido tactil cabe considerar la capacidad bien conocida de las hormigas de apreciar contrastes de temperatura (sentido térmico) y las excitaciones dolorosas (sentido del dolor). Es muy posible que, al modo de lo que sucede en los mamiferos, la piel de dichos himenópteros disponga de nervios especificos térmicos, dolorosos y tactiles, distribuídos en distritos diferentes, o sea en sendos apéndices pilosos. Pero nuestros experimentos acerca de este punto distan mucho de estar acabados.

En conclusión: las hormigas oligovisuales, a las que muy particularmente hemos aludido en las precedentes observaciones, adolecen de gran penuria sensorial. Salvo el tacto y el olfato, que en ellas alcanzan desusado desarrollo, los demás sentidos aportan al animal confusas y fragmentarias informaciones del mundo exterior. Insensibles a los colores, incapaces de la percepción del relieve, distinguen solamente, a pequenisimas distancias y sin detalles, objetos de gran tamaño relativo; olfatean, comúnmente desde muy cerca, faltas de aparato colector de los olores; carecen casi enteramente de oido y, en fin, aprecian exclusivamente variaciones termicas de? muchos grados.

Como en todas las especies animales, el mundo exterior percibido por la hormiga es un mundo aparte, especifico, fundamentalmente diverso del nuestro, salvo la comunidad de ciertas propiedades geométricas y de determinadas emanaciones materiales.

$\mathrm{Y}$, no obstante esta pobreza sensorial, dichos insectos despliegan, por compensación, un lujo prodigrioso de reacciones motrices y de instintos de finalidad maravillosia. Y' es yue los sentidus no son lo mis importante de la vida psiyuica: por encima de ellos, courdinander sus datos e interpretándolos a la luz de las milenarias adyuisiciones de la especie, impera el cerebro, riyuisimo en potencialidades.

Yo compararia de buen grado las hormigas a los ciegos y sordo. mudos de nacimiento, de yue son ejemplos admirables laura Bridgman - que además de ciena y sorda carecia de guster y ulfato - y la célebre leten Keller. Ambas, y simgularmente la tiltima, sin mis recurso sensorial que el tacto, sabia y' metedicamente educadn, lograron desarrollar prodigiosas aptitudes intelectuales innatas, dur- 
mientes y como en estado potencial. Helen Keller, auxiliada por el alfabeto tactil, aprendió a leer, siguió brillantemente una carrera, dominó varios idiomas y escribió libros admirables, donde campean, con la más selecta y copiosa erudición, el más sano y elevado criterio. Al leer sus obras, como las de otros ciegos ilustres, acude a la memoria la frase gráfica de Villey: «La vista es el sentido de las distracciones.»

Prueba elocuente de que si nuestros sentidos aportan noticias preciosas acerca del mundo exterior, su misión principal consiste en obrar como despertadores de nuestro maravilloso mundo interior. Ellos ponen en marcha los instintos superiores, así como los innatos y complicados mecanismos mnemómicos, sentimentales, representativos y lógicos, valiosísimo legado de la raza y de la evolución filogénica. Muy clarividente y acertado mostróse, por consiguiente, LEIBNITZ cuando, corrigiendo el escueto e incompleto aforismo de LOCKE, nihil est in intellectus quod non ante fuerit in sensu, añadió: nisi intellectus ipse. Cabe, pues, disponer de un cerebro poderoso y hasta genial, asistido de mezquinos e incompletos sentidos.

Claro está que no pretendemos identificar el magnífico cerebro humano con el precario ganglio cerebroide de las hormigas, aun cuando nuestros estudios sobre el sistema nervioso central de los himenópteros y múscidos nos hayan revelado la existencia de una máquina asociativa prodigiosamente compleja y sutil. Séanos lícito, empero, afirmar que en las hormigas se da en pequeño algo de lo ocurrido con ciertos ciegos-sordomudos: compensan la miseria sensorial con una rica y finísima organización del órgano encefálico. Muy instructivo es comparar, bajo este aspecto, los lúcidos y complejos instintos industriales de la hormiga, casi ciega, con la precaria mentalidad de aquellos insectos que, cuales la mosca, la libélula o la mariposa, están dotados de ojos magníficos, de olfato y tacto exquisitos y de vuelo poderoso. Diriase que la Naturaleza, como si tuviera conciencia de sus propias injusticias, se complace a menudo en prodigar todos los dones del espíritu a los más humildes seres, por igual abandonados de la fuerza, de la belleza y de la gracia. 


\section{ÍNDICE}

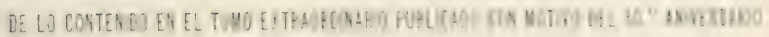

DE LA FUNDACIÓN DE LA SOCIEDHO

ACTA Y DISCURSOS :

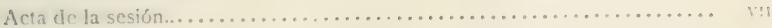

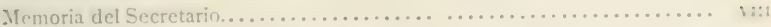

Discurso del Presidente de la Sociedad......................... xm

- del Excmo. Sr. Presidente del Conscjo de Ministros............. xwn

\section{MEMORIAS :}

C.1ster.t.urxule (Joan̨uin Maria). - Alger neerea de la historia de las dus leyes

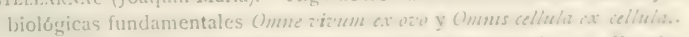

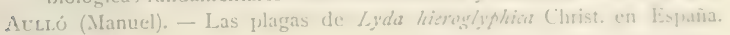

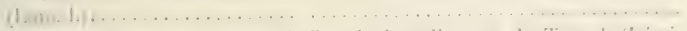

Rovo Gósuz (T.) - I.os peces fúsiles de los aljuzares de Teruel. (L.imi-

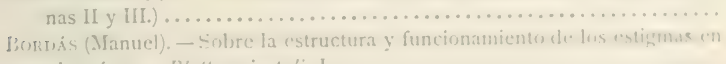

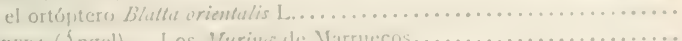

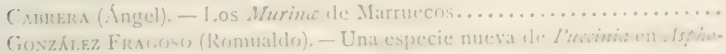

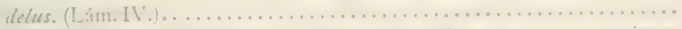

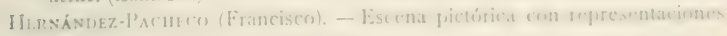

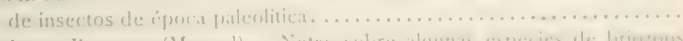

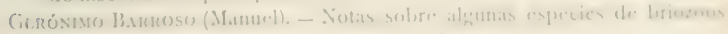

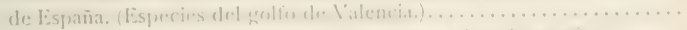

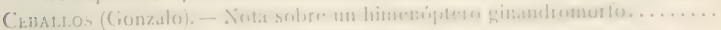

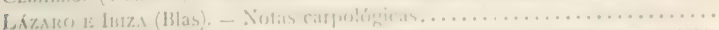

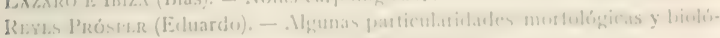

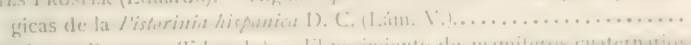

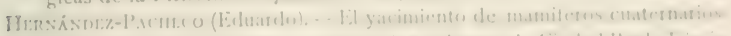

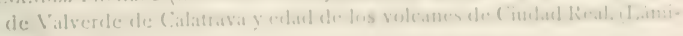

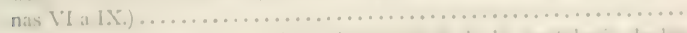

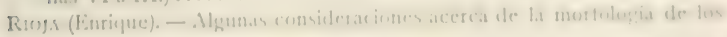

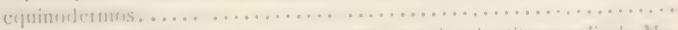

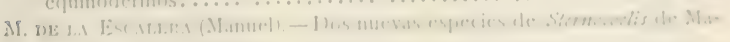

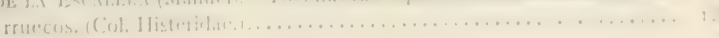


Sánchez y Sánchez (Domingo). - Sobre la evolución de las neuronas retinianas en los lepidópteros................................

Unamuno (Luis M. de).-Algunos datos nuevos para el estudio de la llora micológica de la provincia de Oviedo.........................

ARÉvilo (Celso). - Notas hidrobiológicas. Larvas planktónicas de arquípteros de la laguna de Peñalara.

D.wintix Cereceda (J.). - Levantamiento reciente de la MLeseta central de la

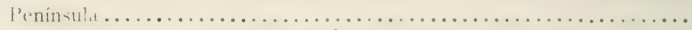

Dismet y Alonso (José M. ${ }^{2}$ ). - Los 'Ápidos de España. V. Géneros Stelis Panz., Dioxys Lep., Ammobates Latr., Phiarus Gerst., I'asites Jur. y Bias-

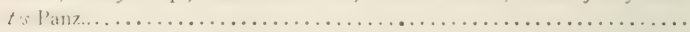

LozANo y Rey (Luis). - Algunas consideraciones sobre la representación gráfica de los seres naturales, y descripción de un aparato especial destinado a hacer fotografias de los mismos, especialmente de los peces....

Font Quer (P.). - Las Sideritis híbridas españolas. (Láms. X a XIII.)......

Beltrán (F.).-Uredales (royas) de las provincias de Castellón y Valencia..

Cendrero (Orestes). - Generalidades sobre los tómbolos y descripción de dos de ellos situados en la provincia de Santander. (Láms. XIV a X'I'I.)

Carré Aguiló (Juan) y Pérez Temprado (Lorenzo). - Nuevos hallazgos de arte rupestre en el Bajo Aragón. (Láms. XVII y XVIIL.)..............

PAU (C.). - Diez días en Sierra Morena. (Del 12 al 22 de mayo de 1920.)....

Garcí Mercet (Ricardo). - Notas sobre Afelininos (Hym. Chalc.) ........

Azpertia Moros (Florentino). - Estudio critico de la Pupa megacheiles Cristofori et Jan, y de algunas formas derivadas de ella que viven en Es-

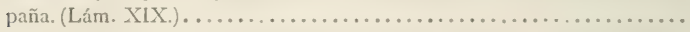

Reichenow (Eduard). - Contribución a la biología de los antropomorfos

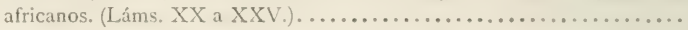

INcilada (Vicente). - Los problemas de la moderna Sismologia geológica en relación con el estudio de la tectónicit de las regriones sismicas de

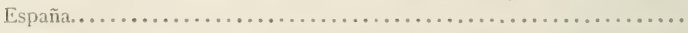

Escrib.1no (Cayetano).-Desarrollo de Ja Theltproctopliylla (Neuropt.). (Lá-

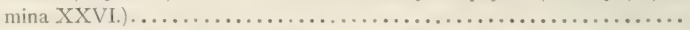

ferrer Galdi.ino (Manuel). - Observaciones sobre los Gammaridae de

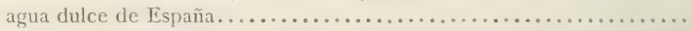

Gómez Llueca (Federico). - El Laboratorio de Geología de la Facultad de Ciencias de la Universidad de Lyon........................

Z.ırco Gircí. (Ángel). - Nueva especic de Petrıgnatha de Fernando Póo.

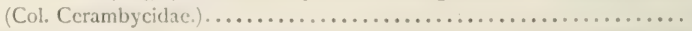

Rí-Horteg. (P. del). - Algunas observaciones sobre los cromoblastos de la piel humana. (I_áms. XXVII a XXX.).......................

C.Ir.ingetr. (Juan). - Introducción al estudio fisiográfico y geológico de la región egabrense, Córdoba. (Lám. XXXI.).......................

Saxtscui (F.). - Quelques fourmis du Nord de l'Afrique et des Canaries...

Ferxismez Nivirno (Lucas). $-A$ propósito de una caida de polvo en Ca-

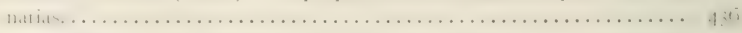

Borírir (Ignacio). - En memoria del R. P. Joseph Pantel, S. J. Observacio-

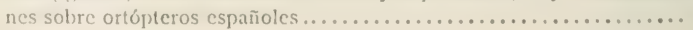


Alvir.ido (Salustio). - La significación morfolúgica de los . lissela:klicle de las Medusas. (Nota previa.). . . . . . . . . . . . . . . . . . . . . irn

Batr.is dE ARAgóx (Francisco de las). - Indices de algunos crineos mm his-

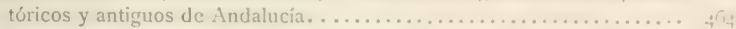

Martínez Gámez (Vicente).-El Paraiso de las orquideas ofrikleas en Fspana. qï

Rodríguez Motrelo (José). - Nuevos fenómenos de fototrofiat. . . . . . . . . 4i:

Jiméxez dE Cișeros (Daniel). - Las especies del género SAirifurinz del Lias medio español. (Lám. XXXII) . . . . . . . . . . . . . . . . .

Zuleetı (Antonio de). - Experiencias sobre el avivamiento extumporáneo de los huevos de la mariposa del gusano de la seda............... fok

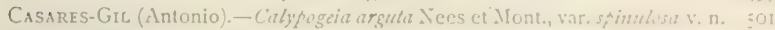

MIntisez (Serapio). - Nota acerca de la Badropherd domimms Wiestworul.

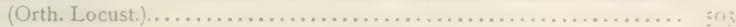

Bolívar y Pieltais (C.) y Jeisael (R.). - ColeGpteros cavernicolas nuevos de las provincias vascas.......................... $5 \ldots \ldots$

Fersixdez Giltuxo (E.). - Sobre la histología de los corazones loranquiales y de sus apéndices en algunos cefalópodos..................

Boscí y Cis.ıxoves (F.). - Catáloro abreviado de la coleccion paleonectiogica sudamericana existente en Valencia.................... $5: 0$

Rasóx C.yjal (S.). - Las sensaciones de las liormigas...............

\section{ERRATAS IMPORTANTIS}

Pág. 18. - En la explicaciún de la lámina, en vez de Tam. nat., debe leerse: $1 / 5$ tam. nat.

Págs. 356 a 358 . - La parte de texto comprendidat deste la linea lit de la pagina 356 hasta la linea 20 de la pigina 357 , debe leerse a contimuación de la linea 32 de la paigina 358.

Pág. 375. - Las explicaciones de has figuras estan cambiadals, corres. pondiendo la 1 a lat hembra y la 2 al macho. 




QH

Sociedad Española de Historia

364 Natural

Real Sociedad Española de Historia Natural

BioMed

\author{
PLEASE DO NOT REMOVE \\ CARDS OR SLIPS FROM THIS POCKET
}

UNIVERSITY OF TORONTO LIBRARY 
36)

by

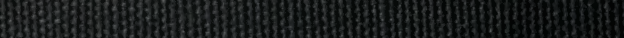

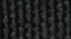

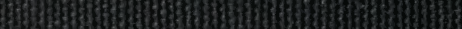

(15)

IIt)

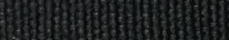

65:

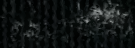

